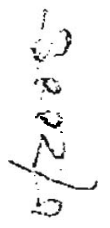

\section{Geochemical Characterization of Endmember Mantle Components}

By

\author{
RHEA K. WORKMAN \\ at the \\ MASSACHUSETTS INSTITUTE OF TECHNOLOGY \\ and the \\ WOODS HOLE OCEANOGRAPHIC INSTITUTION
}

June 2005

(C) 2005 Rhea K. Workman

All Rights reserved.

The Author hereby grants to MIT and WHOI permission to reproduce and distribute publicly paper and electronic copies of this thesis document in whole or in part.

Author

Joint Program in Oceanography Massachusetts Institute of Technology and

Woods Hole Oceanographic Institution

Jane 2005

Certified by

$D r$. Stanley $R$. Hart

Thesis Supervisor, WHOI

Accepted by

Dr. Greg Hirth

Chair, Joint Committee for Marine Geology and Geophysics

Woods Hole Oceanographic Institution 


\title{
Geochemical Characterization of Endmember Mantle Components
}

\author{
by \\ RHEA K. WORKMAN \\ Submitted in partial fulfillment for the requirements for the \\ degree of Doctor of Philosophy \\ at the Massachusetts Institute of Technology \\ and the Woods Hole oceanographic Institution \\ June 2005
}

\begin{abstract}
This thesis uses trace elements and radiogenic isotope tracers to define elemental abundances in reservoirs of the Earth's mantle, including EM2 (the Enriched Mantle 2), as seen in the Samoan hotspot track, and DMM (the depleted upper mantle), which is sampled at mid-ocean ridges. Together these components comprise up to $-50 \%$ of the total mantle mass. Much of the mantle's chemical heterogeneities are suspected to originate by either the removal of mass from the mantle (in the case of DMM) or the addition of mass to the mantle through subduction zones (in the case of EM2). We show that DMM represents mantle that 1) has been previously depleted by $\mathbf{2 - 3 \%}$ melt removal, 2) mass-balances well with the continental crust, 3 ) has only $15 \%$ of the radiogenic heat production in primitive upper mantle and 4) can generate present-day ocean crust by $\mathbf{6 \%}$ aggregated fractional melting. EM2 is classically interpreted as mantle material enriched in trace elements through the ancient, subduction-zone recycling of terrigenous sediments; here we show this model is unlikely and provide two other working hypotheses. The first is recycling of meltimpregnated oceanic lithosphere; the second is recycling of a mantle wedge impregnated with melt from a subducting oceanic plate.
\end{abstract}


Thesis Advisor: Dr. Stanley Hart, Woods Hole Oceanographic Institution

Thesis Chair: Dr. Nobu Shimizu, Woods Hole Oceanographic Institution

Committee:

Dr. Henry Dick, Woods Hole Oceanographic Institution

Prof. Fred Frey, Massachusetts Institute of Technology

Dr. Erik Hauri, Dept. of Terrestrial Magnetism, Carnegie Inst. of Washington

Dr. Jian Lin, Woods Hole Oceanographic Institution 


\section{Acknowledgments}

Each of us have come to where we are today upon separate, unique and intricate pathways. Everyone we have encountered along the way has, in some form, shaped us into who we are and how we interact with our world. In this way, it is impossible to acknowledge them all, but there are a few who have done more shaping than the rest; and there are a few who believed in me before I did.

I met Stan during a summer student internship at WHOI and he quickly became the first reason I ever had for seeking a graduate degree. I'm nearly certain he has a sixth sense - knowing when to push, when to guide, when to teach and when to be a friend. Mantle geochemistry has been a medium for us to discuss the greater lessons of life, with "shoptalk" often ending in "life-talk". With thanks to Stan, I've learned much about science as well as much about myself.

Nobu has been a constant source of knowledge, support and great discussions. My experience here would not have been as vibrant or full without him. Fred taught me the first think I ever knew about trace element geochemistry and since then has been a reminder that 'the devil is in the details'. Erik has a wonderful and sincere way of seeing the world as a whole, but also the holes in our science - I hope it's rubbed off a little. Jian inspired me venture outside the realm of geochemistry; in doing so, I gained a great appreciation for geophysicists! Henry finally remembered my name after I finally saw the beauty of abyssal peridotites; we have since had great discussions about mantle rocks and life in general. Jurek taught me how to work in the clean lab, how to have patience, and how to perk up when things get a little dim. I have received nothing but unwaivering encouragement and support from Jurek, and I am forever grateful.

There is a very long list of very remarkable people from EAPS, Geology and Geophysics, and Marine Chemistry and Geochemistry who have contributed to my growth and overwhelmingly positive experience in the Joint Program: Peter K., Greg H., Glenn G., Mark K., Josh C., Wolfgang B., Bernhard P.-E., Wen-Lu Z., Rob R.-S., Peter C., Karen B., Jerry M., Bill C., Ken S., Susan H., Karen H., Jeff M., John H., Laurent M., Hans S., Dan F., Lary B., Graham L., Pete L., Dan M., Bob D., Jack W., Adam S., Andrew D., Grotz, Grove, and Bowring. I very much enjoyed our interactions and learned something important from each of them. Many of the same people regularly attended Geochemistry Seminar and prepared me for the piranhas. 
I would like to thank those students who have gone before and who showed me the way of companionship, cooperation and comradery: Alberto, Ken K., Debbie H., Mark B., Amy D., Jen G., Robyn K., Mike B., and Astri. My fellow students are a wonderful and earthy group of people: Jeff, Margaret, Linda, Matt J., Cara, Jessica, Brian, Emily, Trish, Clare, Lynn, Sharon, Heidi, Mea, Fabian, Oscar, Chris, Janelle, Rose, Dave, Matt M., Steve DB and Kristy, my world-class officemate. May we meet many times and in many places! Special thanks go to the Ta'u Island Field Team - Jeff, Margaret and Matt - who put up with miles and miles of machete work, but got a great view! If it weren't for Kaeo, I likely never would have come to the east coast at all. The Geodynamics Seminar field trips were invaluable for solidifying an intuition for the world of geology.

Julia, Marsha, John and Judy from the Academic Programs Office care for us beyond their duty and always create an environment of true warmth and support. Pam, K., Maryanne, Elaine and Lynn from the G\&G Administration are endlessly helpful, friendly and giving. To the Graphics Department - You guys are incredible!

I've had the fortune of living with people over the last two years who made our house feel like a home, filled with love and support, like a second family; thank you Margaret, Linda, and Cara! I also had the fortune of Living with Emily, Charlie and Joe - they offered a very wide spectrum of personality, and were each great fun! Rose, you were always a shoulder, a kick or laugh right when I needed it - you will not be forgotten. Astri and Chanda made Life exciting and always had something to talk about! Andy, thank you for the shelter and for showing me more patience than I thought was humanly possible.

I couldn't have been more fortunate with the wonderful family I have. If I had to live this life 100 times, I would pick each of them every time!

Very generous financial support for this thesis has been provided by WHOI's Academic Programs Office, NSF grants 81903800,80489100 and 82591700 to Stan Hart and the Cole Ocean Ventures Fund. 
To Boa, Patty, Marcie, Adam and Michael 


\section{Contents}

Chapter 1: Introduction............................................................................... 13

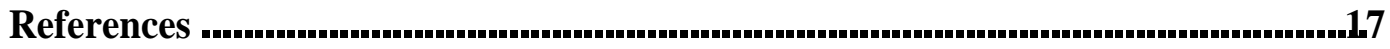

\section{Chapter 2: Recycled metasomatized lithosphere as the origin of the} Enriched Mantle II (EM2) Endmember: Evidence from the Samoan Volcanic Chain .......................................................... 19

Abstract ...................................................................................................................... 19

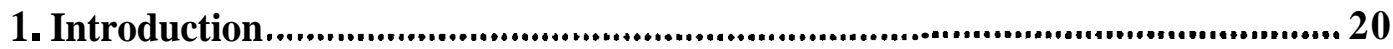

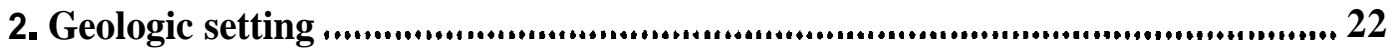

3. Samples and Analytical Details........................................................................ 24

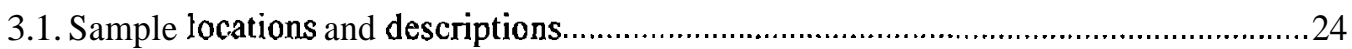

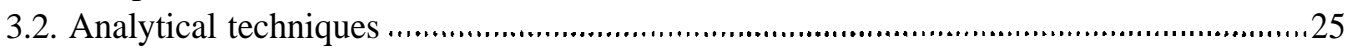

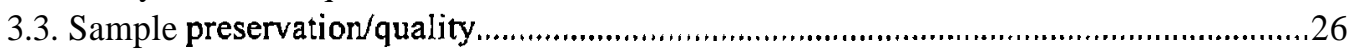

4. Age Relationships and Age-Progression............................................................... 27

5. Magma Generation and Crystal Fractionation .................................................... 28

6. Isotopes and Trace Elements .............................................................................. 30

6.1 The Global Context ……......................................................................................30

6.2 Shield vs. Post Erosional...............................................................................................33

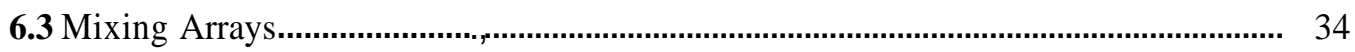

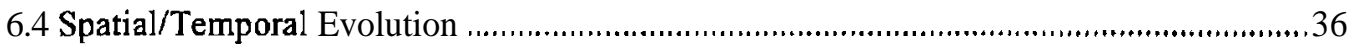

7. Calculation of a "Pure" EM2 Lava ....................................................................38

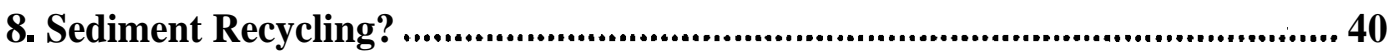

9. Metasomatic Origin of EM2 ….............................................................................. 44

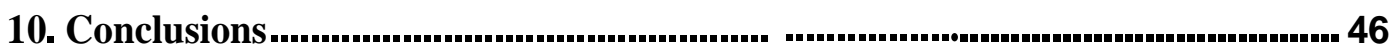

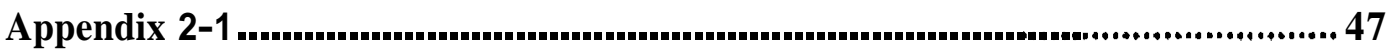

References .................................................................................................................. 49

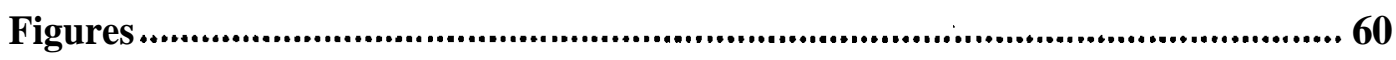

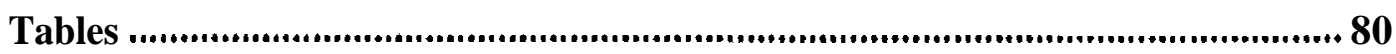

Table 2-1. 40/39 Argon Ages from Upolu and Savai'i. Western Samoa.................................80

Table 22 . Sample information and chemical data for Samoan basalts .................................81

Table 23 . Major element electron probe data on submarine glasses from Samoa...............91

Table 2.4 . Isotopic compositions of Samoan lavas. .........................................................94

Table 2-5. Sample information and chemical data for Samoan basalts collected by M. 


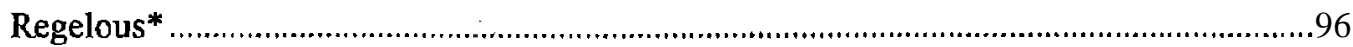

Table 2-6. Isotopic compositions of samples previously collected by KAF** , ...................103

Table 2-7. Calculated trace element composition of a "pure" EM2 melt.............................. 104

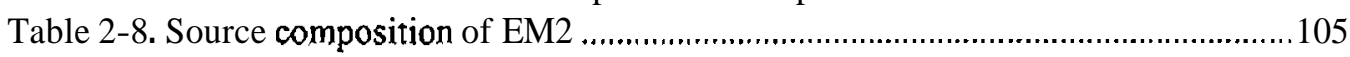

\section{Chapter 3: Major and Trace Element Composition of the Depleted} MORB Mantle (DMM) ......................................................... 107

Abstract .............................................................................................................. 107

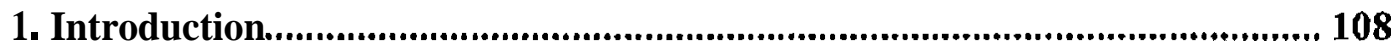

2. Trace Element Composition of DMM .......................................................... 109

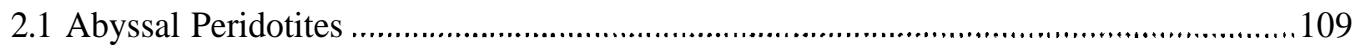

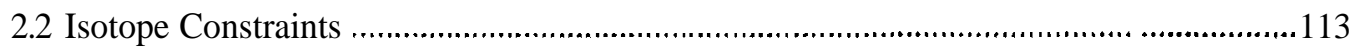

2.3 Canonical Ratios and Volatile Contents.....................................................................115

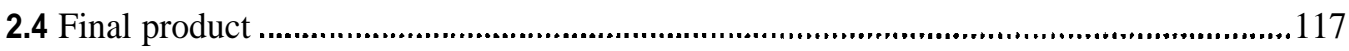

3. Physical and Chemical Properties of DMM ............................................... 118

3.1 Modal abundances \& major elements ................................................................118

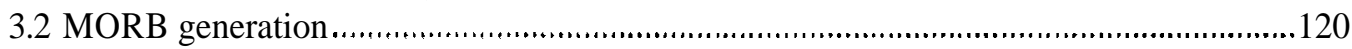

4. Crust-Mantle Mass Balance................................................................ 122

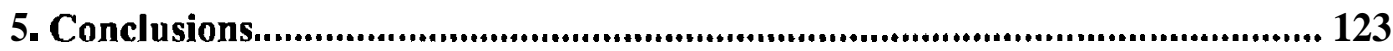

Acknowledgements.............................................................................................. 124

Appendix 3.1 . ............................................................................................ 125

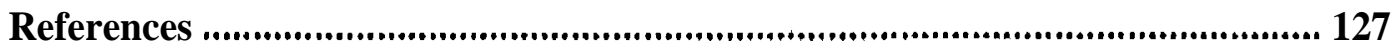

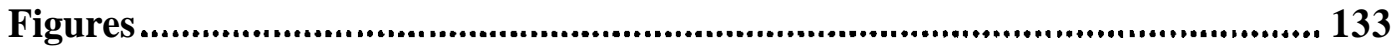

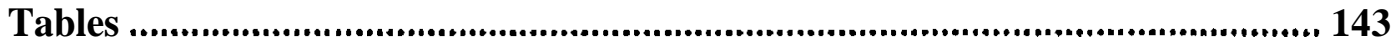

Table 3.1 . Isotopic constraints on the depleted MORB mantle (DMM)...............................143

Table 32 . Trace element composition of DMM................................................................144

Table 33 . Modal abundances and major element composition of DMM............................145

Supplementary Data Table 3-1. Abyssal peridotite modes and compositions .......................146

Supplementary Data Table 32 . Mineral compositions in average DMM........................... 155

\section{Chapter 4: Volatile and Trace Elements in Basaltic Glasses from Samoa:} Implications for Water Distribution in the Mantle............... 157

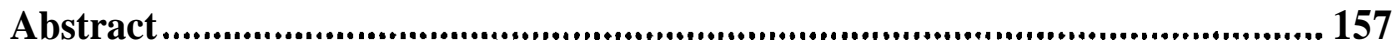

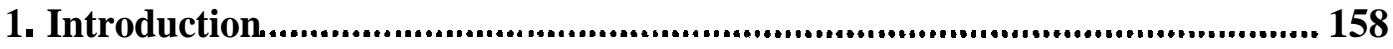

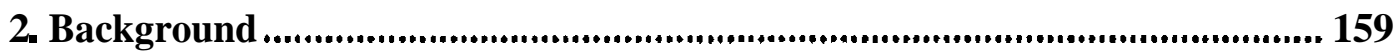

2.1. Geological and Geochemical Setting ............................................................... 159

2.2. Samples and Volcano ages................................................................................ 160

3. Analytical Techniques.............................................................................. 161

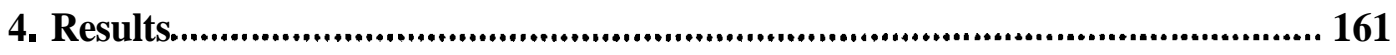


4.1. Trace elements and fractionation correction ................................................................162

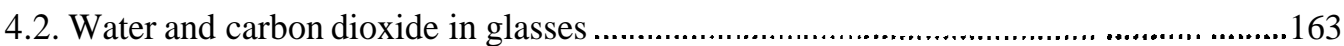

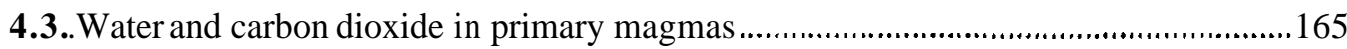

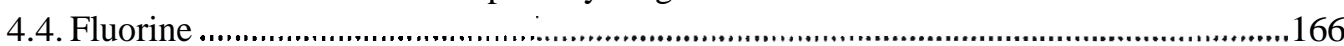

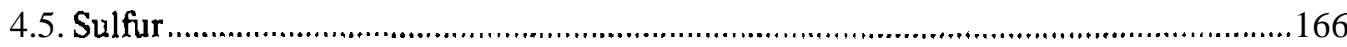

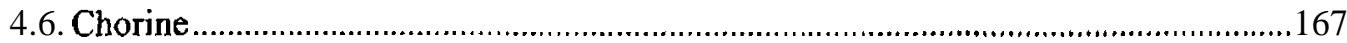

5. Source Variations In Water Enrichment ..................................................... 169

6. Origin Of EM2's "Dehydration" "................................................................... 170

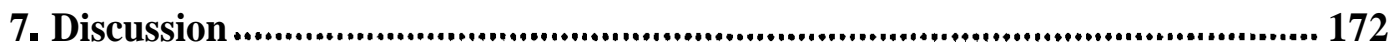

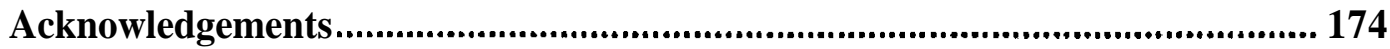

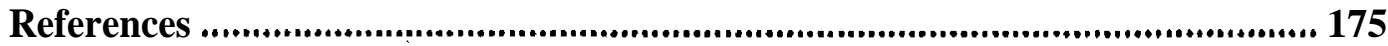

Figures.................................................................................................181

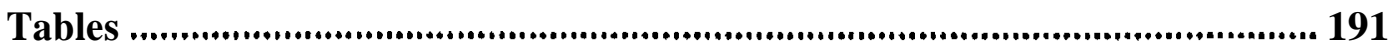

Table 4.1 . Chemical data for Samoan Glasses. .................................................................191

Table 42 . Volatile Composition of Olivine-Hosted Melt Inclusions ...................................199

Chapter 5: Assessment of recycled. slab-derived material in enriched lavas from Samoa: evidence from oxygen isotopes........... 201

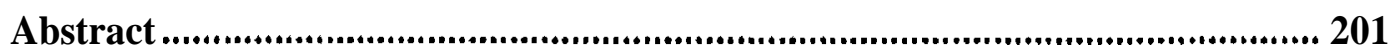

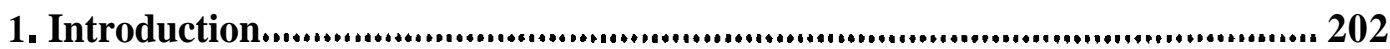

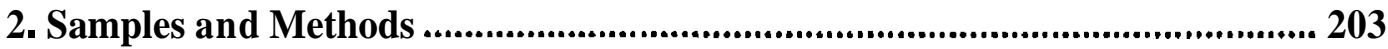

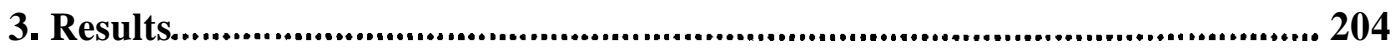

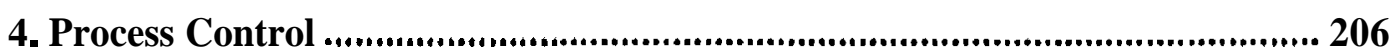

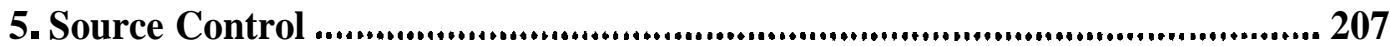

5.1. Test for a sediment source of enrichment ...............................................................209

5.2. Test for an eclogite melt source of enrichment........................................................211

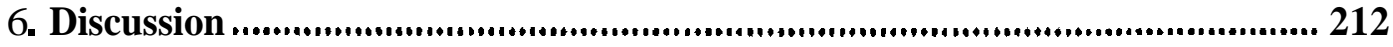

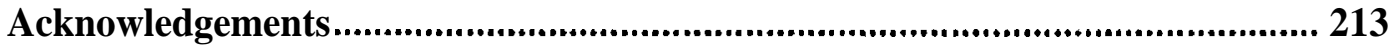

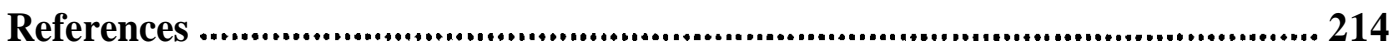

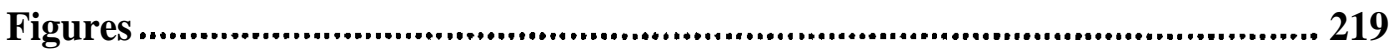

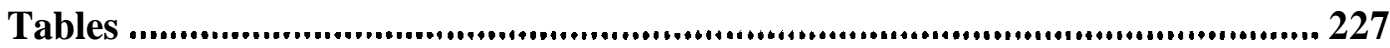

Table 5.1 . Oxygen isotope compositions of phenocrysts from Samoan lavas .....................227

Table 5-2. Compositions and mineral/melt partition coefficients (D's) used in the

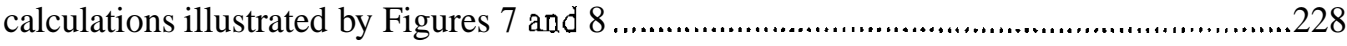

\section{Chapter 6: Gravity-based calculation of crustal flux from the Samoan} hotspot and its correlation with Pb-isotopes: a brief overview 


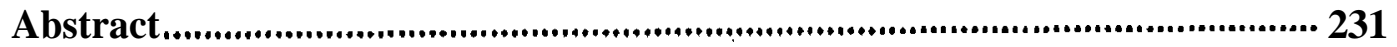

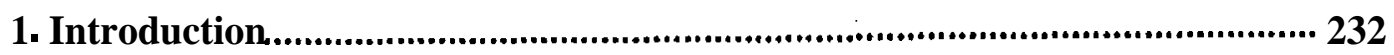

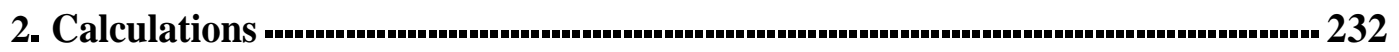

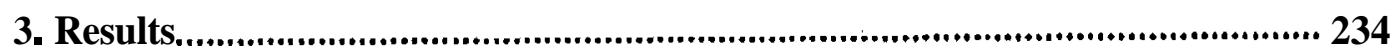

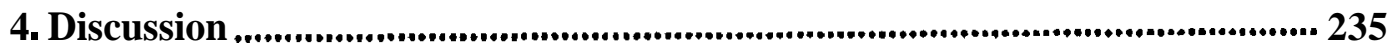

References ........................................................................................... 237

Figures 


\section{Chapter 1:}

\section{Introduction}

The field of mantle geochemistry is fundamentally concerned with the processes and history of Earth's differentiation. How has Earth developed its inner and outer cores, mantle, continental crust, oceanic crust, ocean and atmosphere? Can we track the growth and evolution of these reservoirs through the 4.56 billion years of Earth history - and can we project into the future? Though we are concerned with all these reservoirs, our field is selfnamed 'mantle' geochemistry since the Earth's mantle is the primary driver of differentiation. It mediates convective transfer of materials from deep to shallow Earth, resulting in the formation of crust, oceans and the atmosphere. It also returns bits of shallow, differentiated materials back to the deep Earth in places where the mantle is downwelling at subduction zones. The mantle essentially turns the Earth inside-out, trying to purge it of unwanted, incompatible elements (such as hydrogen, carbon, potassium and uranium) and retain in it the wanted, refractory elements (such as .magnesium, iron and chromium). It is fascinating to think our human bodies are made of carbon once contained within the very deep, very hot inner Earth.

The Earth was born of materials condensed from our solar system about 4.56 billion years ago (Patterson, 1956; Birck and Allegre, 1978); it almost certainly had some small initial variations in chemical composition, but is thought to be, on average, similar in elemental and isotopic abundances to the class of meteorites called $\mathrm{Cl}$ carbonaceous chondrites (Anders and Ebihara, 1982; Anders and Grevesse, 1989). From its mess of agglomerated materials, Earth formed (very early.in its history) a dense, Fe-Ni metallic core, leaving the remaining lithophile materials to form the Bulk Silicate Earth (BSE); BSE is about $84 \%$ the volume of the Earth, but only $68 \%$ the mass of the Earth because its density is lower than that of the core. Knowing the approximate mass and composition of the core from seismic surveys through the Earth allows for a fairly good estimate of the chemical composition of the Bulk Silicate Earth (by subtracting the core from the CI composition; Fet and Zindler, 1986; McDonough and Sun, 1995); this simple estimate is inaccurate for 
those elements, such as hydrogen, helium, sulfur and lead, that are strongly volatile and lost to space before the formation of Earth's atmosphere.

The BSE has further differentiated, or fractionated, into distinct chemical reservoirs some of which are obvious at the surface of the Earth (like the oceans and continental crust) and some of which are held within the Earth's mantle. The focus of this thesis is on the compositional variations within the mantle, as determined from mantle melts erupted at both mid-ocean ridges and hotspots (i.e. mantle plumes). Zindier and (1986) noted that there are 4 unique end-member mantle components based on ${ }^{87} \mathrm{Sr} /{ }^{86} \mathrm{Sr},{ }^{143} \mathrm{Nd} /{ }^{144} \mathrm{Nd}$, ${ }^{206} \mathrm{~Pb} /{ }^{204} \mathrm{~Pb},{ }^{207} \mathrm{~Pb} /{ }^{204} \mathrm{~Pb}$, and ${ }^{208} \mathrm{~Pb} /{ }^{204} \mathrm{~Pb}$ radiogenic isotope compositions of a global database of oceanic lavas. They described how most mid-ocean ridge basalts (MORBs) are isotopically similar and represent an upper mantle previously depleted of melt (i.e. oceanic and continental crust); this reservoir is termed the Depleted MORB Mantle (DMM). On the other hand, ocean island basalts (OIBs), erupted by hotspot volcanism, are isotopically heterogeneous in terms of most radiogenic isotope systems. Each hotspot chain is unique in radiogenic isotope space and represents a unique mixture of the Zindler and mantle components. From parent isotope half-lives and parent-daughter ratios, it is inferred that end-member mantle sources for OIBs and MORBs must have been chemically isolated for billions of years in order to develop the observed differences in the abundance of daughter isotopes. Because isotopes of heavy elements are so little fractionated in the melting process, isotopic compositions of oceanic basalt are not only "clocks" for ancient reservoir development, but also "fingerprints" of a melt's solid source. The goal of mantle geochemistry in general and this thesis specifically is to determine the origins, ages and chemical compositions of these mantle components.

Although there have been many ideas regarding the origins of the classic mantle endmembers seen in OIB chains, one model has been relied upon most commonly and received the most attention from a modeling point of view. We are in effect "outside looking in", so major differentiation processes occurring at the solid Earth's uppermost layers, namely the formation of continental and oceanic crust, are the most obvious explanations for the creation of volumetrically significant heterogeneities in composition. Return of these differentiated materials to the mantle through return flow at subduction zones creates mantle heterogeneity. Geochemical models attempting to accurately quantify the compositions of deeply-subducted materials need precise knowledge regarding: 1) hydrothermal alteration of the oceanic crust, 2) partition coefficients for both the dehydration and melting of crust and sediments, 3) the thermal structure of mantle wedges, 4) tbe compositions of subducting 
sediments, and 5) the lifespan of a subducted slab in the deep mantle. Although much progress has been made in each of these topics, many parameters are not well defined through space and time. making it difficult to formulate a completely accurate model for any one of the OIB end-members.

In this thesis, I focus on describing the chemical character of 2 out of the 4 mantle reservoirs that were identified and 'fingerprinted' by Zindler and Hart (1986). The first is DMM; it is ubiquitously sampled along the global system of mid-ocean ridges and represents the largest accessible reservoir on Earth (at least $30 \%$ the BSE). It is called 'depleted' because we know from its isotopic fingerprint that melts were removed from this mantle a very long time ago ( 2 to $3 \mathrm{Ga}$ ), in a process we speculate to be much like the oceanic and continental crust formation that occurs today. We use the following constraints in deriving an average trace element composition of DMM: 1) trace element content of clinopyroxenes from abyssal peridotites, 2) isotopic evolution from primitive upper mantle (PUM) and 3) canonical trace element ratios in MORBs. The average trace element content of DMM, as deduced here, generally shows a very smooth pattern with increasing trace element compatibility, which to furst order mass-balances with the continental crust. The degree of depletion indicated in DMM represents 2-3\% melt removal from the primitive upper mantle; this means that DMM has only $15 \%$ the radiogenic heat production of PUM (from $K, U$ and $T h$ ). Present-day ocean crust (i.e. average MORB) can be modeled with $6 \%$ aggregated fractional melting of the deduced DMM.

The second mantle reservoir studied in this thesis is nearly opposite in character from the depleted upper mantle - it is called the Enriched Mantle 2 (EM2) and is sampled from the inner Earth by the Samoan hotspot. EM2 has the highest ${ }^{87} \mathrm{Sr} /{ }^{86} \mathrm{Sr}$ of all oceanic lavas, whereas the depleted upper mantle has the lowest. Although EM2 may not be a volumetrically significant reservoir, its rare and unique composition is very significant because it allows us to eventually understand the details of BSE differentiation (for example, the growth rate of continental crust).

Chapters 2, 4 and 5 of this thesis address the geochemistry of the Samoan islands and seamounts in great detail. In Chapter 2, we use trace element abundances and radiogenic isotope tracers to establish the geochemical variability, character, and habits of the Samoan lavas, including the ones that are more extreme in their EM2 signature than any other lavas sampled on Earth. In Chapter 2, we establish that a model involving the recycling of only marine sediments will not successfully explain the origin of EM2, Instead, an alternative model is offered in which an oceanic lithosphere is impregnated with an upper mantle melt, 
recycled through a subduction zone and stored for $2.5 \mathrm{Ga}$ in the mantle - to be sampled 'today by the Samoan mantle plume.

In Chapter 4, we use volatile element abundances (water, carbon dioxide, fluorine, sulfur and chlorine) from Samoan glasses to comment on the general properties of these elements in igneous systems and the specific properties of water in the EM2 mantle reservoir. We find that absolute water contents are high for Samoan lavas $(0.63-1.50 \mathrm{wt} \%)$, but relative enrichment of water compared to trace element enrichment is low. $\mathrm{H}_{2} \mathrm{O} / \mathrm{Ce}(58-157)$ and $\mathrm{H}_{2} \mathrm{O} / \mathrm{La}\left(120\right.$ - 350) correlate inversely with ${ }^{87} \mathrm{Sr} /{ }^{86} \mathrm{Sr}$ compositions $(0.7045-0.7089)$. This leads us to believe that, because of very fast diffusion of hydrogen in olivine, recycled lithospheric material with high initial water content will lose water to the drier ambient mantle during storage within the inner Earth. This concept implies that water may be one of the few (if only) elements in the mantle that is close to chemical equilibrium over great distances.

Chapter 5 presents oxygen isotope data for Samoan olivine phenocrysts as a means to identify the presence of recycled material that was once at or near Earth's; oxygen isotope variations occur not because of production of a radiogenic oxygen isotope, but because oxygen's isotopes, ${ }^{16} \mathrm{O}$ and ${ }^{18} \mathrm{O}$, have slightly different chemical behavior during low temperature reactions. Here we test two models for the generation of EM2. The first is (once-again) the standard sediment-recycling model. The second expands upon the metasomatic model of Chapter 2 by identifying a location for the metasomatism (the mantle wedge), and more accurately defining what the metasomatising agent is (an eclogite melt). Each model shows some major misfits to characteristics of end-member Samoan lavas, although the metasomatic model requires less 'special pleading'.

Chapter 6 investigates the correlation between geochemical and geophysical properties of Samoa. Excess crustal flux along the Samoan volcanic lineament decreases nearly monotonically approaching Vailulu'u Seamount, the easternmost and youngest volcano. This trend shows excellent correspondence to increasing ${ }^{206} \mathrm{~Pb} /{ }^{204} \mathrm{~Pb}$ compositions of the lavas with decreasing age along the hotspot track. We speculate this con-elation could be due to either a lithosphere thickening toward the east or decreasing potential temperature of the mantle plume, and that the geochemical signatures observed in the lavas are partly a function of how mantle materials with differing solidus temperatures are sampled from the Earth. 


\section{References}

Anders, E. and M. Ebihara, Solar-system abundances of the elements, Geochim.

Cosmochim. Acta, 46,2363-2380,1982.

Anders, E. and N. Grevesse, Abundances of the elements: meteoritic and solar, Geochim. Cosmochim. Acta, 53,197-214,1989.

Birck, J.L. and C.J. Allegre, Chronology and chemical history of the parent body of basaltic achondrites studied by the ${ }^{87} \mathrm{Rb}-{ }^{87} \mathrm{Sr}$ method, Earth Planet. Sci. Lett., 39, 37-5 I, 1978.

Patterson, C.C., Age of meteorites and the Earth, Geochim. Cosmochim. Acta, 10,230-237, 1956.

Fut, S.R. and A. Zindler, In search of a bulk-Earth composition, Chemical Geology, 57, 247-267,1986.

McDonough, W.F. and S:-s. Sun, The composition of the Earth, Chemical Geology, 120, 223-253,1995.

Zindler, A., and , S.R., Chemical Geodynamics, Ann. Rev. Earth Planet. Sci., 14,493$571,1986$. 


\title{
Chapter 2:
}

\section{Recycled metasomatized lithosphere as the origin of the Enriched Mantle II (EM2) Endmember: Evidence from the Samoan Volcanic Chain*}

\begin{abstract}
An in-depth $\mathrm{Sr}-\mathrm{Nd}-\mathrm{Pb}-\mathrm{He}-0 \mathrm{~s}$ isotope and trace element study of the EMII-defining Samoan hotspot lavas leads to a new working hypothesis for the origin of this high ${ }^{87} \mathrm{Sr} /{ }^{86} \mathrm{Sr}$ mantle endmember. Systematics of the Samoan fingerprint include 1) increasing ${ }^{206} \mathrm{~Pb} /{ }^{204} \mathrm{~Pb}$ with time - from 18.6 at the older, western volcanoes to 19.4 at the present day hotspot center, Vailulu'u Seamount, 2) en-echelon arrays in ${ }^{206} \mathrm{~Pb} /{ }^{204} \mathrm{~Pb}-{ }^{208} \mathrm{~Pb} /{ }^{204} \mathrm{~Pb}$ space which correspond to the two topographic lineaments of the $375 \mathrm{~km}$ long volcanic chain this is much like the Kea and Loa Trends in Hawai'i, 3) the highest ${ }^{87} \mathrm{Sr} /{ }^{86} \mathrm{Sr}(0.7089)$ of all oceanic basalts, 4) an asymptotic decrease in ${ }^{3} \mathrm{He} /{ }^{4} \mathrm{He}$ from $24 \mathrm{R}_{\mathrm{A}}$ (Farley et al., 1992) to the MORB value of $8 \mathrm{R}_{\mathrm{A}}$ with increasing ${ }^{87} \mathrm{Sr} /{ }^{86} \mathrm{Sr}$, and 5) mixing among four components which are best described as the "enriched mantle", the depleted FOZO mantle, the (even more depleted) MORB Mantle, and a mild HIMU (high ${ }^{238} \mathrm{U} /{ }^{204} \mathrm{~Pb}$ ) mantle component. A theoretical, "pure" EMII lava composition has been calculated and indicates an extremely smooth trace element pattern of this endmember mantle reservoir. The standard recycling model (of ocean crust/sediment) fails as an'explanation for producing Samoan EM2, due to these smooth spidergrams for EM2 lavas, low ${ }^{187} \mathrm{Os} /{ }^{188}$. Os ratios and high ${ }^{3} \mathrm{He} /{ }^{4} \mathrm{He}\left(>8 \mathrm{R}_{A}\right)$. Instead, the origin of EM2 has been modeled with the ancient formation of metasomatised oceanic lithosphere, followed by storage in the deep mantle and return to the surface in the Samoan plume.
\end{abstract}

\footnotetext{
- Published in $G^{3}$ Volume 5, No. 4, April 2004.
} 


\section{Introduction}

Although intra-plate ocean island volcanism accounts for only a few percent of the total volcanism on Earth, these volcanic piles may be the surface manifestations of the deepest known samplings of the interior of the planet. The relative stationarity of mantle plumes with respect to upper mantle plate flow (Molnar and Stock, 1987; Steinberger and O'Connell, 1998; Wang and Wang, 2001; Koppers et al., 2001), and a growing catalogue of seismic evidence and tomographic images showing velocity anomalies beneath hot spots extending well into the mid-mantle and sometimes to the core-mantle boundary (Russell et al., 1998; Shen et al., 1998; Zhao, 2001; Montelli et al., 2003), all support the idea that mantle plumes sample the inner Earth at a much deeper level than do mid-ocean ridge spreading centers. Ocean island chains may thus provide some of the best clues to the chemical character of the lower mantle and the nature of convective interactions between the deep and shallow mantle.

Unlike mid-ocean ridge basalts (MORBs), which derive from a fairly uniform meltdepleted upper mantle, ocean island basalts (OIBs) are isotopically heterogeneous in terms of most radiogenic isotope systems (e.g. Zindler and Hut, 1986; Hat, 1988; Hofmann, 1997). Isotopic arrays from ocean island chains often extend from a "common" mantle. termed FOZO (i.e. Focus Zone; Hart et al., 1992), and tend toward one of three "endmember" mantle components: HIMU, the high time-integrated U/Pb mantle, EM1 or EM2, the Enriched Mantles 1 and 2 (Zindler and 1986). From parent isotope half-lives and parent-daughter ratios, it is inferred that mantle sources for OIBs and MORBs must have been chemically isolated for billions of years in order to develop the observed differences in the abundance of daughter isotopes. Because isotopes of heavy elements are so little fractionated in the melting process, isotopic compositions of oceanic basalt are not only "clocks" for ancient reservoir development, but also "fingerprints" of a melt's solid source. We are left, through geochemical interrogation and theoretical ingenuity, to reverse the processes by which mantle melts were generated and brought to Earth's surface. Ultimately, with some indication for source compositions, the origins and ages of chemically distinct, isolated mantle reservoirs can be deduced.

Although there have been many ideas regarding the origins of the classic mantle end members, one model has been relied upon most commonly and received the most attention from a modeling point of view. We are in effect "outside looking in", so major 
differentiation processes occurring at the solid Earth's uppermost layers, namely the formation of continental and oceanic crust, are the most obvious explanations for the creation of volumetrically significant heterogeneities in composition. Many workers have applied this perspective and contributed to what is here referred to as the Standard Model for the origin of mantle components (Armstrong, 1968; Chase, 1981; Hofmann and White, 1982; Cohen and O'Nions, 1982; White, 1985; Zindler and Hent, 1986; Weaver, 1991; Hart et al., 1992). In summary, oceanic crust is subducted at convergent margins, dehydrated (increasing $\mathrm{U} / \mathrm{Pb}, \mathrm{Th} / \mathrm{Pb}$, and $\mathrm{Sr} / \mathrm{Rb}$ ratios) and put into long term storage in the deep mantle to evolve to HIMU. EM1 and EM2 are generated when trace-element-enriched pelagic (i.e. deep-sea) and terrigenous (i.e. continental) sediment, respectively, accompany the subducted and stored oceanic crust (Fig. 1). Geochemical models attempting to accurately quantify the compositions of these deeply-subducted materials (Hart and Staudigel, 1989; Weaver, 1991; Stracke et al., 2003) are greatly hindered by a Jack of knowledge regarding: I) hydrothermal alteration of the oceanic crust, 2) partition coefficients for both the dehydration of crust and sediments and the melting of sediments, 3 ) the thermal structure of mantle wedges, 4) the variable compositions of sediments in space and time, and 5) the lifespan of a subducted slab in the deep mantle. Although much progress has been made in each of these topics, the constraints are not strong enough to provide the needed resolution in parent/daughter ratios. Ironically, it may be exactly the lack of constraints that ultimately makes the Standard Model nonviable. By all indications from today's geodynamical systems, sediments and the subduction zone processing of crust and sediments all display such variability that a specific composition (which evolves to HIMU, EM1 or EM2) almost certainly would not be produced twice, and there would be no discrete or recognizable "endmember" reservoirs. On the other hand, and often the strongest criticism of the Standard Model (e.g. Hawkesworth et al., 1984; Barling and Goldstein, 1990; Morgan, 2000), is that there may be no such things as mantle endmembers. Each ocean island array could consist of its own unique isotopic composition, which represents a unique subducted slab from a unique recycling time.

In the present study, we specifically deal with the origin of the Enriched Mantle II (EM2) endmember. Lavas from the Samoan Islands have long been recognized as holding the most extreme signal of EM2 (Zindler and Hart, 1986; Wright and White, 1986; Farley et al., 1992, Hauri and Hart, 1993). Here we use a new comprehensive geochemical study to assess possible origins of the EM2 reservoir. This paper outlines why the recycling of sediment/slab cannot be the origin of EM2, and offers an alternative model which will 
generally result in consistent trace element compositions, and hence isotopic signatures, through time. We assume that mantle endmembers do, in fact, exist, and that one process, acting to varying degrees at a variety of times, will produce a fairly homogeneous endmember reservoir, which is available for mixing with other mantle components during upwelling of mantle plumes.

The working model introduced here for the origin of EM2 involves metasomatism (i.e. fluid/melt infiltration) of oceanic lithosphere, followed by subduction zone recycling and long-term storage of this lithosphere. As a process for creating trace-elementenriched mantle, metasomatism is not a new idea and has been invoked both for continental lithosphere (Frey and Green, 1974; .Brooks et al., 1976; Menzies and Murthy, 1980; Menzies, 1983) and oceanic lithosphere (Zindler et al., 1979; Kay, 1979; Hawkesworth et al., 1979, 1984; Richardson et al., 1982; Roden et al., 1984; Hart et al., 1986; Halliday et al., 1992; Class and Goldstein, 1997; Niu et al., 19\%; 1999; Niu and O'Hara, 2003). The process we envision is much like the SYS model of Zindler et al. (1979), and the autometasomatic model of Roden et al. (1984). We envision it operating on newly formed lithosphere close to spreading centers, as illustrated by Niu et al. (1999) and Niu and O'Hara (2003).

We show that a lithosphere impregnated $2.5 \mathrm{Ga}$ with a small-degree upper mantle melt can evolve to the present day isotopic composition of EM2. This model provides an EM reservoir with much greater volume than that of oceanic crust and sediment. A more voluminous "package" will have greater resistance to mixing within the convecting mantle and therefore have greater possibility of staying an isolated body for the required $2.5 \mathrm{Ga}$ evolution time. Another benefit of this model is that the lithosphere will be isolated and protected from subduction zone processing (such as elemental fractionations that occur within the subducted oceanic crust and sediments during metamorphism and devolatilization).

\section{Geologic setting}

The Samoan islands and seamounts are centered on $14^{\circ} \mathrm{S}$ latitude and stretch from 169$173^{\circ} \mathrm{W}$ longitude (Fig. 2). They sit $-100 \mathrm{~km}$ north of the northern termination of the Tonga Trench, on -110 Ma oceanic crust of the Pacific Plate which is moving $25.8^{\circ} \mathrm{WNW}$ at 7 $\mathrm{cm} / \mathrm{yr}$ (Sella et al., 2002). The Samoan volcanoes separate into two topographic ridges, both sub-parallel to the direction of plate motion: the Savai'i - Upolu - Tutuila - Malumalu 
group define the southwestern (and generally older) lineament, and the Muli - Ofu/Olosega - Ta'u - Vailulu'u group define the northeastern (and younger) lineament. We will designate these the "Malu" and "Vai" Trends, respectively. The recently mapped leadingedge seamount, Vailulu'u, rises from 5000 meter seafloor to a summit depth of 590m (Hart et al., 2000). Recent volcanic activity at Vailulu'u has been documented with the following observations: elevated water temperatures and particulatecontents within the summit crater, a halo of intense particulate matter surrounding the summit in the depth range of 600-800 meters, high $\mathrm{Mn}$ concentrations and ${ }^{3} \mathrm{He} /{ }^{4} \mathrm{He}$ ratios (up to $9 \mathrm{R}_{\mathrm{A}}$ ) in the crater water, swarms of seismicity, and dredged rock samples with U-series ages of 5-50 years (Hart et al., 2000). The age-progression heading west from this present-day hot spot location approximately follows the plate velocity of $7 \mathrm{~cm} / \mathrm{yr}$ and includes the seamounts Lalla Rookh, Combe, and Alexa, which is 1750 krn west of Vailulu'u (Duncan, 1985; Natland and Turner, 1985; McDougall, 1985; Hart et al., 2000; Hart et al., unpubl. data). Malulu seamount and Rose Atoll to the east of Vailulu'u do not have Samoan isotopic signatures (Hart et al., unpubl. data), and are most likely associated with the Cook-Austral lineament.

As if burning the candle at both ends, post-erosional volcanism has been extensive on the westernmost island of Savai'i (with the most recent eruptive episode taking place from 1905-1911) as well as being documented on the islands of Upolu and Tutuila (but here, all pre-historic, and much less extensive) (Kear and Wood, 1959; Keating, 1992). Although the pervasive post-erosional veneer on Savaii has disrupted the age-progression model (Savai'i should be $-5 \mathrm{Ma}$ based on the plate velocity model) and has lead to debates about the origin of the Samoan volcanoes (e.g. Natland, 1980), we believe there is little doubt about the chain originating from hot spot volcanism. The atypical volume of post-erosional volcanism on Savai'i is possibly due to the complicated tectonic setting of the volcanic chain. Since Savai'i is closest to the Tonga Trench, it is reasonable that bending stresses are facilitating additional melt extraction from the upper mantle (e.g. Hawkins and Natland, 1975; Natland, submitted 2003).

Tectonic reconstruction of the region (Brocher, 1985; Pelletier et al., 1998; Zellmer and Taylor, 2001) show that the transform-fault bounding the northern Tonga Trench evolved $-6-8$ million years ago from the fossil Vitiaz Trench in response to opening of the Lau back-arc basin. Studies of the chemical characteristics of the northern Lau back-arc basin seamounts and seismic profiling beneath the basin collectively suggest leakage of Samoan plume material into the northern Lau Basin through a tear, or window, in the paleo-slab of the Pacific Plate subducted at the Vitiaz Trench. Geochemical evidence includes high 
${ }^{3} \mathrm{He} /{ }^{4} \mathrm{He}$ lavas of some Lau Basin seamounts (Poreda and Craig, 1992; Turner and Hawksworth, 1998), with trace element and isotopic compositions which are more characteristic of OIBs than MORBs or IABs (Ewart et al, 1998; Danyushevsky et al, 1995; Wendt et al., 1997). Seismic studies by Millen and Hamburger (1998) and Chen and Brudzinski (2001) illustrate a remnant slab of the Vitiaz subduction that has detached from the warped Pacific Plate, thereby providing an unobstructed path for melt/mantle migration from the Samoan plume into the Lau Basin. By speculation, this suggests that the Samoan plume beneath the Pacific Plate is much more widespread than the discrete lineament of volcanoes would indicate. Also, the exact location of the Samoan volcanoes may not necessarily be where the plume upwelling is "strongest", but instead where the plume fortuitously intersects a structural weakness imparted to the lithosphere by tectonic stresses of the local area. The en-echelon nature of the volcanic edifices may provide witness to this structural control (see Natland, submitted 2003, for a full discussion of this idea).

\section{Samples and Analytical Details}

\subsection{Sample locations and descriptions}

Rock samples utilized in this study have been collected from both land and sea. The seamounts Vailulu'u, Muli, and Malumalu, along with submarine portions of Ta'u, were dredged during the 1999 AVON2/3 cruise of the R $N$ Melville. Land-based sampling of Savai' $i$ and Upolu, conducted in 2001, was aimed at expanding the coverage of "old shield" (namely, the Fagaloa Volcanic Series; Kear and Wood, 1959), and thereby establishing a greater temporal coverage of the Samoan plume. On Upolu, we sampled the southwestern exposure of the Fagaloa Volcanics; this is a topographic massif with welldeveloped river valleys, referred to as A'ana by the local inhabitants. Our Upolu samples primarily come from along or near the Matafa'a coastline and Fagalei Bay. Samples from Savai'i were collected from the north-central shore, where exposures of Fagaloa Volcanics were mapped over a $20 \mathrm{~km}^{2}$ relative topographic high (Kear and Wood, 1959). This area is bound to the east by the village of Vaipouli, contains the Muliolo and Eatelele Streams, and is bound to the west by an escarpment that leads down to the village Paia.

Subaerial sampling of Ta' $u$, the youngest island of the chain, was conducted in 1999 and was principally concentrated along the coastline. The sampling was temporally diverse, in that all five of the volcanic series mapped by Stice and McCoy (1968) are represented. 
Unlike the older and larger islands of Savai'i and Upolu, Ta'u Island manifests from only one main shield volcano; this simplified structure is reflected in the isotopic homogeneity observed for Ta'u, as will be discussed in following sections.

Phenocryst abundances in Samoan lavas range from $0 \%$ to $50 \%$ and include the following minerals in decreasing modal abundance: olivine, clinopyroxene, plagioclase, orthopyroxene, and Ti-augite. Phenocrysts are most common in samples from Vailulu'u and least common in samples from Savai'i and Upolu. In thin section, some samples show two populations of olivine in which a coarse-grained population $(2-10 \mathrm{~mm})$ shows resorption boundaries and a smaller-grained population $(1-2 \mathrm{~mm})$ shows almost no embayed crystal boundaries. However, for most samples, olivine major element compositions (Jackson et al., unpubl.) show that phenocrystic olivines are in $\mathrm{Mg}-\mathrm{Fe}$ equilibrium with the coexisting liquids. Some samples (especially T14) have glomerocrysts of olivine (+spinel). Plagioclase, clinopyroxene, and oxides are the most common matrix minerals. Hand-samples can generally be classified as aphanitic basalt, olivine basalt, picrite or (rarely) ankaramite. Alteration, in the form of iron-oxide, is most prevalent in the Savai'i and Upolu samples. Sample 63-I 1 from Vailulu'u crater shows hydrothermally-precipitated quartz rinds along some cracks and grain boundaries.

\subsection{Analytical techniques}

Techniques reported here are for samples described above. Additional subaerial samples from Savai'i, Upolu, Tutuila and Ta'u have been collected by K.A. Farley and J.H. Natland over the last two decades and analyzed by K.A. Farley for $\mathrm{Sr}-\mathrm{Nd}-\mathrm{Pb}-\mathrm{He}$ isotopic compositions. Additional subaerial samples from Savai'i and Upolu have been collected and analysed for major and trace elements and $\mathrm{Sr}-\mathrm{Nd}-\mathrm{Pb}$ isotopes by $\mathrm{M}$. Regelous. We include these data in the present manuscript, as they are previously unpublished; any differences in analytical techniques are reported in the corresponding data tables.

$\mathrm{Sr}, \mathrm{Nd}$, and $\mathrm{Pb}$ isotopic analyses were carried out with conventional ion exchange procedures (references in Taras and 1987), using whole rock powders, prepared in an agate shatterbox, and leached for 1 hour in warm $6.2 \mathrm{~N} \mathrm{HCl}$. The TIMS techniques are described by Hauri and Hart (1993). Sr and Nd isotope data carry 20 precisions of \pm 35 ppm and $+40 \mathrm{ppm}$, and are reported relative to 0.71024 (NBS 987) and 0.511847 (La Jolla), respectively. Some samples run for $\mathrm{Sr}$ and $\mathrm{Nd}$ by NEPTUNE multi-collector ICP/MS at W.H.O.I. are of comparable precision to TIMS anaylses. The precision of TIMS $\mathrm{Pb}$ data is taken to be $0.05 \%$ per mass unit after fractionation-correcting to the NBS 
981 values given by Todt et al. (1996). Pb isotopic compositions of some samples were also 'determined on the P54 multi-collector ICP/MS in Lyon, with $2 \sigma$ precisions of all ratios of -200 ppm. Additionally, the Upolu and Savai'i sample suite was analyzed on the NEPTUNE multi-collector ICP/MS at W.H.O.I.; using a $\mathrm{Tl}$ internal standard, the 20 external reproducibility for these samples was \pm 100 pprn or better for all ratios (see Hart et al., 2002). Helium isotopic compositions $\left({ }^{3} \mathrm{He} /{ }^{4} \mathrm{He} \mathrm{R}_{\mathrm{A}}\right.$, relative to atmospheric standard) of olivine and/or fresh glass separates $(-1-3 \mathrm{~mm})$ were determined at W.H.O.I. by in vacuo crushing, using methods described in Kurz et al. (1996). Analytical errors average $\pm 0.2 \mathrm{Ra}$ at $2 \sigma$, for helium concentrations ranging from $\sim 10^{-8}$ to $10^{-6}$ cc/gram. Os isotopic compositions on a select group of olivine-rich samples were determined by sparging of $\mathrm{OsO}_{4}$ into W.H.O.I.'s Finnigan Element Magnetic Sector ICP-MS, following a flux fusion sample preparation (see Hassler et al., 2000 for a detailed Os analytical technique). Fusion blank corrections resulted in $0.06-1.22 \%$ corrections to the ${ }^{187} \mathrm{Os} /{ }^{188} \mathrm{Os}$ ratios. Major elements and some trace elements $(\mathrm{Ni}, \mathrm{Cr}, \mathrm{Sc}, \mathrm{V}, \mathrm{Ga}, \mathrm{Cu}, \mathrm{Zn})$ in unleached whole rock powders were measured by XRF, and all other trace elements by ICP/MS at Washington State University (Hooper et al, 1993). Submarine glasses have been analyzed for major elements by electron microprobe at Massachusetts Institute of Technology.

\subsection{Sample preservation/quality}

Despite sampling of lavas from older shield and submarine settings, the quality of preservation is generally very good. The Th/U ratios of the sample suite fall entirely within $4.5 \pm 1.5$ (with the exception of sample $\mathrm{S} 15$ at $\mathrm{Th} / \mathrm{U}=6.7$ ) and show a slight (although rough) positive correlation with Th concentrations. The $\mathrm{Ba} / \mathrm{Rb}$ ratios have an average of 9.3 \pm 1.8 at 10 (near the canonical value of -12 for fresh ocean island basalts; Hofmann \& White, 1983) and are inversely correlated with Rb concentrations; significantexceptions to this correlation are samples 79-4, S15, and S25, with $\mathrm{Ba} / \mathrm{Rb}$ ratios of $17.2,14.0$, and 3.7, respectively. We take these two proxies of alteration as indications that elements as or less mobile than $\mathrm{Rb}$ and $\mathrm{U}$ are very nearly pristine for most samples. However, elevated $\mathrm{Rb} / \mathrm{Cs}$ ratios (176 \pm 70 at 10$)$ in the subaerial Upolu and Ta'u samples are most likely explained by chemical weathering and contrast strongly with the roughly canonical values (85-95; Hofrnann \& White, 1983) represented by the remaining suite (97 \pm 30 at $1 \sigma$ ). 


\section{Age Relationships and Age-Progression}

Vailulu'u seamount, the most easterly volcano in the Samoan chain, is currently active and belived to be the present day hotspot center (Hart et al,, 2000). U-series data constrain two samples from Vailulu'u's summit region to be less than 50 years old; 7 other samples from six dredge locations show excess ${ }^{230} \mathrm{Th} /{ }^{238} \mathrm{U}$, evidence of ages less than a few hundred thousand years (Sims and to be submitted). The oldest $\mathrm{K}-\mathrm{Ar}$ age from Tau Island is 0.3 Ma (McDougall, 1985). The youngest volcanic series on Tau (Faleasao) is probably younger than 37,000 years, based on ${ }^{14} \mathrm{C}$ ages of coral inclusions in these volcanics unpublished). Additionally, there was an underwater eruption just west of Tau in 1866 (see description in Keating, 1992), evidence that Tau is still in an active shield-building stage. As yet, we have no age constraints on Muli seamount, though the samples dredged from there appear "older" than those dredged from Vailulu'u or Tau. Samples from three dredges on Malumalu show ${ }^{230} \mathrm{Th} /{ }^{238} \mathrm{U}$ excesses similar to those on Vailulu' $\mathrm{u}$ (Sims and Hart, to be submitted), suggesting that Malumalu is not significantly older than Vailulu'u. K-Ar ages for the Pago and Masefau shields on Tutuila range from 1.0-1.9 Ma (McDougall, 1985; Natland and Turner, 1985), somewhat younger than the 2.3-2.7 Ma expected from plate motion considerations.

New high-quality ${ }^{40} \mathrm{Ar} /{ }^{39} \mathrm{Ar}$ step-release plateau ages are given in Table I for the northern shield on Savai'i and the SW shield on Upolu, along with an earlier 40/39 total fusion age for the Vanu River shield on Savai'i. Previous K-Ar ages on the eastern Upolu shield range from 1:54-2.74 Ma (Natland and Turner, 1985); our western shield ages are 0.93 and 2.65 Ma. The older age agrees with the older ages of the eastern shield, though both shields appear younger than the expected plate model age range of 3.9-4.5 Ma. The $0.93 \mathrm{Ma}$ ' sample (U10) was collected from well within the interior of the eroded SW shield massif, and appears to be reliable evidence for an extended ( $-2 \mathrm{Ma}$ ) period of shield building on Upolu.

There are no published radiometric ages from Savai'i. Based on a plate velocity of 7 $\mathrm{cm} /$ year, the age expected for shield initiation on Savai'i is about 5.2 Ma; the two ages reported in Table 1 for the northern (Manase) shield, 0.24 and $0.39 \mathrm{Ma}$, are far younger than this expected plate age. Kear and Wood (1959) mapped this northern area as shield largely on the basis of abundant surface streamflow. However, we found no obvious evidence of unconformable erosional morphology in this area, and the geochemical evidence discussed below strongly suggests that this map unit is akin to the post-erosional basalts on 
Savai'i and Upolu, and unlike the Upolu shield basalts. The young ${ }^{40} \mathrm{Ar} /{ }^{39} \mathrm{Ar}$ ages are consistent with a re-assignment of this unit to post-erosional status. In the southern interior of Savai'i, Kear and Wood (1959) mapped a small exposure of shield in a gorge on the upper Vanu River. This area is virtually inaccessible, but a trachyte cobble was collected from the lower Vanu River by one of us (KAF) in 1991, and the 40139 total fusion age of this trachyte is $2.05 \mathrm{Ma}$ (Table 1). While still significantly younger than a plate-model age, this trachyte age is nevertheless very important as it shows that not all of the volcanism on this island can be related to proximity to the Tonga trench, as suggested by Natland (1980); at $2 \mathrm{Ma}$, the corner of the Tonga trench was almost $400 \mathrm{~km}$ west of Savai'i (Bevis et al., 1995). On the other hand, there can be little doubt that Savai'i has been massively resurfaced with post-erosionalvolcanism as proposed by Natland (1980). The early history of this island will probably only be accessed by dredging on the deeper flanks, where slope failure provides an exposed record.

All in all, the radiometric ages of shield lavas in Samoa are broadly consistent with $\mathbf{a}$ simple age-progressive hotspot track, in that ages generally increase from east to west. However, it is clear that shield ages are overall younger than those predicted by plate motion, most likely because the oldest incipient shield lavas are not sampled at the surface of present day volcanoes. While the earliest stages of shield building on Tutuila, Upolu and Savai 'i are thus far missing from the 'sampled record, it would be premature to use this as evidence against a simple hotspot model for Samoa.

\section{Magma Generation and Crystal Fractionation}

In major element composition, the Samoan basalts and trachybasalts analyzed for this study are clustered just above the alkali-tholeiite line (MacDonald and Katsura, 1964) at 44$49 \mathrm{wt} \% \mathrm{SiO}_{2}$ (Fig. 3; Tables 2 and 5). Samples that fall into the tholeiitic field are, for the most part, from Vailulu'u Seamount, and three of these are highly picritic. Post-erosional lavas (on Savai'i, Upolu and Tutuila) overlap with the shield volcanics, but extend to much greater silica-undersaturation (basanites and nephelinites down to $36 \mathrm{wt} \% \mathrm{SiO}_{2}$; Hawkins and Natland 1975; Johnson, 1983; Hauri and Hart, 1997). Mg\#'s (molar percent $\mathrm{Mg} / \mathrm{Mg}+\mathrm{Fe}^{2+}$ ) range from 40 in the differentiated Muli samples to 85 in the Vailulu'u picrites. The low $\mathrm{MgO} /$ high $\mathrm{SiO}_{2}$ end of the suite is (vaguely) dominated by samples from Vailulu'u, Malumalu, and Upolu; on the other hand, high $\mathrm{MgO} /$ low $\mathrm{SiO}_{2}$ samples are mainly from Savai'i, Tutuila, and Ta'u. Also plotted on some co-variation plots of Figure 3 
are trajectories of near-solidus primary melt compositions at varying pressures of melting in the garnet stability field, using algorithms defined by Herzberg and Zhang (1996) through experiments on KLB-1 peddotite. Recent experiments on another fertile peridotite (KR4003 starting material; Walter, 1998) show primary melt compositions with a general shift to higher $\mathrm{MgO}$ at a given pressure (by $-5 \%$ in the $4-5 \mathrm{kbar}$ pressure range). Most of the Samoan Iavas have undergone some amount of crystal fractionation, as indicated by the fact that they have significantly lower Mg\#'s than any estimated primary mantle melts.

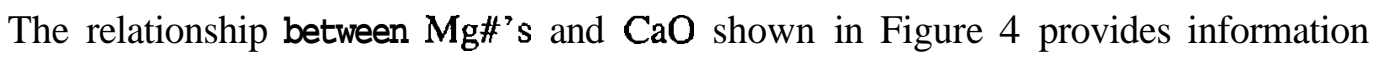
regarding both magma generation and crystal fractionation. Plotted along with lava compositions is the trajectory of primary mantle melt compositions (Herzberg and Zhang; 1996). To assess the extent of differentiation and the minerals involved, we have used the pMELTS program (Ghiorso et al., 2002) to model anhydrous fractional crystallization (at a best-fit pressure of 3-4 kbar) of some of the more primitive lavas (Ta'u samples T14 and T48, Vailulu'u sample 63-3, and Malumalu sample 78-1). PMELTS trajectories calculated with $1 \mathrm{wt} \% \mathrm{H}_{2} \mathrm{O}$, at a given pressure, are nearly identical to anhydrous runs at $1 \mathrm{kbar}$ lower pressure (not shown). All starting compositions have olivine as the second liquidus phase (after spinel), leading to a negative slope for the liquid.path on $\mathrm{Mg \#}$ against $\mathrm{CaO}$ (Fig. 4). The kink to positive slopes on the liquid lines of descent marks the crystallization of cpxtolivine \pm plagioclase. As $\mathrm{CaO}$ content of the starting magma decreases, clinopyroxene (cpx) saturation occurs at lower Mg\#'s. A suite of submarine Samoan glasses (Table 3) has also been plotted on Figure 4 and shows that true liquids follow the lines of crystal fractionation predicted by pMELTS.

Suites of lavas from each volcano cluster along fairly distinct $\mathrm{Mg} \#-\mathrm{CaO}$ fractionation trends. By projecting the olivine fractionation trends for the different volcanoes back to the primary mantle melt trajectory, we can interpret that the Samoan lavas were generated in the pressure range of 2.5-6 GPa; the order of increasing pressure of melting would be Vailulu'u < Ta'u/Malumalu < Tutuila/Upolu/Savai'i. The extrapolated primary magmas in this model have an extensive range in $\mathrm{MgO}$, from $11 \mathrm{wt} \%$ a lowest pressure to $22 \mathrm{wt} \%$ at 6 $\mathrm{GPa}$. To get integrated pressures of melting as high as $6 \mathrm{GPa}$, melting would have to initiate at depths exceeding $180 \mathrm{~km}$ and terminate at depths much deeper than the thickness of the lithosphere $(-100 \mathrm{~km})$. Given estimates for potential temperatures of plumes $\left(-1550^{\circ} \mathrm{C}\right.$; Watson and McKenzie, 1991) and water-undersaturated solidi (Hirth and Kohlstedt, 1996), the depth of initial melting is close to $180 \mathrm{~km}$ and therefore cannot be the integrated depth of melting. The above approach is strictly valid only if the lavas from each 
volcano are derived from a constant source composition. We conclude that this $\mathrm{CaO}$ index for pressure of melting is rather rickety, given the isotopic variations between volcanoes that will be discussed further into the paper, and that the order of "increasing pressure of melting" is clouded by the extent to which melts were generated from a depleted (low $\mathrm{CaO}$ ) material.

The Vailulu'u samples are not only high in $\mathrm{CaO}$ (also $\mathrm{Ca} /(\mathrm{Ca}+\mathrm{Na})$ and $\mathrm{CaO} / \mathrm{Al}_{2} \mathrm{O}_{3}$ ) \& a given $\mathrm{MgO}$ value, but they are also low in $\mathrm{Na}_{2} \mathrm{O}, \mathrm{TiO}_{2}$, and $\mathrm{FeO}$. This suggests they have the most promise in being interpreted as the shallowest, highest degree partial melts in the whole sample suite (Kinzler and Grove, 1992; Herzberg and Zhang, 1996; Walter, 1998). Melting beneath the other volcanoes may be initiated deeper in the mantle, possibly due to (1) differences in source composition (required by isotopic variations), (2) higher potential temperatures and mantle flow rates, or (3) mantle flow paths which affect melt-solid segregation. The Vailulu'u suite is fit fairly well by a crystal fractionation trend at a pressure of $\mathbf{3} \mathbf{k b a r}$, and indicates cpx fractionation has likely occurred for most samples.

For Ta'u and Malumalu, olivine fractionation clearly dominates the spread in lava compositions. A few samples with Mg\#'s greater than $\mathbf{- 7 3}$ have obviously accumulated olivine (they are phenocryst-rich), but most samples lie along olivine fractionation lines or at the intersection of the olivine control line and cpx saturation (Fig. 4). Three Ta'u samples have compositions close to those of the Muli samples and have surely undergone cpx fractionation; these samples also have the lowest concentrations of the cpx-compatible elements vanadium and scandium in the whole suite (not shown). If parental magmas for all the Ta'u and Muli samples were of nearly the same composition, liquid lines of descent indicate that these low Mg\# lavas have undergone about $15 \%$ more olivine fractionation than samples T14 and T48, along with $25 \% \mathrm{cpx}$ fractionation.

\section{Isotopes and Trace Elements}

\subsection{The Global Context}

Plotted on the three-dimensional axes of Figure 5 is the mantle tetrahedron of Hart et al. (1992), with data from the ocean island chains which quintessentially define the coordinates for each of the mantle components, EM1, EM2, and HIMU. Data arrays for individual island chains, as well as groups of taxonomically similar island chains, quasi-linearly extend from one of the three OIB endmember components toward FOZO, the common mantle; 
very notable is the serious lack of elongation of arrays along tie-lines between the three OIB components. It is clear that EM2 lavas in general, and Samoan lavas in particular, dominate the range in oceanic ${ }^{87} \mathrm{Sr} /{ }^{86} \mathrm{Sr}$ values, but are much less variable in ${ }^{143} \mathrm{Nd} /{ }^{144} \mathrm{Nd}$ than EM1. The variation in ${ }^{206} \mathrm{~Pb} /{ }^{204} \mathrm{~Pb}$ found in EM2 basalts is small relative to the composite oceanic suite.

Strontium, neodymium, lead, helium, and osmium isotope ratios for Samoan basalts are given in Tables 4 through 6. Isotope plots (Figs. 6-9) show this new data along with data reported in previous studies (Wright and White, 1986; Farley et al., 1992; Hauri and Hart, 1993). The wide range in ${ }^{87} \mathrm{Sr} /{ }^{86} \mathrm{Sr}$ values, $0.7044-0.7089$, is correlated with the more narrow range of $0.51293-0.51251$ for ${ }^{143} \mathrm{Nd} /{ }^{144} \mathrm{Nd}$ (Fig. 6). Each island or seamount tends to show a unique field of isotopic compositions that, as will be shown, evolve systematically through space and time. Malumalu Seamount contributes the furthest afield EM2 signature and now defines the most radiogenic ${ }^{87} \mathrm{Sr} /{ }^{86} \mathrm{Sr}$ value (0.7089) of all oceanic lavas. At lower ${ }^{87} \mathrm{Sr} /{ }^{86} \mathrm{Sr}$ (0.7044), near estimates for Bulk Silicate Earth (BSE), the Samoan array is split into two prongs - the "serpent's tongue". Both prongs, one comprised of lavas from Ta'u Island and the other, at higher ${ }^{143} \mathrm{Nd} /{ }^{144} \mathrm{Nd}$, comprised of lavas from Upolu and Tutuila, are significantly elevated (at $\varepsilon_{\mathrm{Nd}}$ of +3 and +5 , respectively) over the BSE value of 0.512638 (Hamilton et al., 1983). The other notable EM2 hotspot, the Societies, overlaps the lower prong of the "serpents tongue", and is generally shifted to less-enriched $\mathrm{Sr}$ and $\mathrm{Nd}$ values. The classic EM1 array (Pitcairn) lies well below the Samoa array.

The sample group on the high ${ }^{143} \mathrm{Nd} /{ }^{144} \mathrm{Nd}$ prong is also the lowest in ${ }^{206} \mathrm{~Pb} /{ }^{204} \mathrm{~Pb}$ and ${ }^{207} \mathrm{~Pb} /{ }^{204} \mathrm{~Pb}$ of all the shield lavas (Fig. 7). All Samoan lavas lie to the right (high ${ }^{206} \mathrm{~Pb} /{ }^{204} \mathrm{~Pb}$ side) of the terrestrial $\mathrm{Pb}$ Geochron and are in the mid-range of the elongate, worldwide OIB cluster; they are situated entirely above the Northern Hemisphere Reference Line (NHRL; Hart, 1984) in both ${ }^{207} \mathrm{~Pb} /{ }^{204} \mathrm{~Pb}$ and ${ }^{208} \mathrm{~Pb} /{ }^{204} \mathrm{~Pb}$ (Figs. 7 and 8). The most radiogenic ${ }^{206} \mathrm{~Pb} /{ }^{204} \mathrm{~Pb}$ compositions (19.4) are found not in the highest ${ }^{87} \mathrm{Sr} /{ }^{86} \mathrm{Sr}$ samples, but in samples from Vailulu'u Seamount (of moderate ${ }^{87} \mathrm{Sr} /{ }^{86} \mathrm{Sr} \sim 0.7055$ ). On the other hand, the highest ${ }^{207} \mathrm{~Pb} /{ }^{204} \mathrm{~Pb}(15.65)$ and ${ }^{208} \mathrm{~Pb} /{ }^{204} \mathrm{~Pb}$ (39.8) correspond to the EM2defining Malurnalu lavas, implying that EM2 is an old reservoir of high time-integrated Th/U.

The Society array (not shown in Fig. 7) is much steeper, falling below the NHRL at low ${ }^{206} \mathrm{~Pb} /{ }^{204} \mathrm{~Pb}$ and crossing above it, to overlap the' Malu trend data from Samoa. Interestingly, the highest ${ }^{87} \mathrm{Sr} /{ }^{86} \mathrm{Sr}$ sample from Tahaa (Societies) lies very close to our extreme ${ }^{87} \mathrm{Sr} /{ }^{86} \mathrm{Sr}$ 
sample in ${ }^{207} \mathrm{~Pb} /{ }^{204} \mathrm{~Pb}-{ }^{206} \mathrm{~Pb} /{ }^{204} \mathrm{~Pb}$, but is far lower than it in ${ }^{208} \mathrm{~Pb} /{ }^{204} \mathrm{~Pb}$. Note in Figure 8 that the Society array lies close to the NHRL, and is totally distinct from the Samoa field.

The ${ }^{3} \mathrm{He} /{ }^{4} \mathrm{He}$ ratios of Samoan lavas range from $8 \mathrm{R}_{\mathrm{A}}$ at high ${ }^{87} \mathrm{Sr} /{ }^{86} \mathrm{Sr}$ to a maximum of $26 \mathrm{R}_{\mathrm{A}}$ at generally' lower ${ }^{87} \mathrm{Sr} /{ }^{86} \mathrm{Sr}$ (Fig. 9). New data support the existence a primitive helium mantle (i.e. PHEM of Farley et al., 1992) but with depleted $\mathrm{Sr}$ and $\mathrm{Nd}$ isotopic compositions (i.e. FOZO of Hart et al., 1992). With increasing ${ }^{87} \mathrm{Sr} /{ }^{86} \mathrm{Sr}$, values of ${ }^{3} \mathrm{He} /{ }^{4} \mathrm{He}$ asymptotically approach $-8 \mathrm{R}$, showing that the helium isotopic composition of EM2 is approximately equivalent to that of MORB and much higher than the atmospheric values of recycled crustal materials (see discussion by Farley et al., 1992). This low ${ }^{3} \mathrm{He} /{ }^{4} \mathrm{He}$ value of EM2 is either inherent to the EM2 source, or is a product of diffusive equilibrium with the upper mantle over long timescales (see section 9).

The trace element character of the Samoan lavas display typical OIB features (Hofmann, 1988; Weaver, 1991), with trace element enrichments up to 100 times primitive upper mantle (PUM), the highest normalized concentrations at the highly incompatible elements, and negative anomalies at $\mathrm{Cs}, \mathrm{K}$ and $\mathrm{Pb}$ (Fig. 10). The largest inter-volcano differences are at $\mathrm{Pb}, \mathrm{Rb}, \mathrm{Ba}$, and Th. Weaver (1991) employed the trace element ratios $\mathrm{Rb} / \mathrm{Nb}, \mathrm{Ba} / \mathrm{Nb}, \mathrm{Ba} / \mathrm{Th}$, and $\mathrm{Ba} / \mathrm{La}$ to distinguish between the EM1 and EM2 species. He used these trace elements to argue for a recycled sedimentary component as the cause for the EM signature, and ascribed the difference between EM1 and EM2 to a pelagic versus terrigenous sedimentary provenance. Therefore, a comparison between the Samoan lavas (extreme EM2) and those from Pitcairn (extreme EM1) should theoretically show the greatest differences in these ratios. However, recent studies on Pitcairn lavas (Dostal et al., 1998; Eisele et al., 2002) show nearly complete overlap with the Samoan lavas for Weaver's classification ratios, unlike the clear distinction between EM1 and EM2 previously reported for lavas with less extreme endmember signatures (Fig. 11). This result makes the trace element differences between EM1 and EM2 very difficult to resolve and discourages the description of EM1 and EM2 as having "pelagic" and' "terrigenous" components, respectively. Furthermore, the Plank and Langmuir (1998) study of the compositions of sediment being subducted at today's convergent margins shows that pelagic and terrigenous sediments are: (1) not notably different in trace element ratios such as $\mathrm{Ba} / \mathrm{Th}$, and (2) not typically occurring alone in subducted sedimentary sections, but are instead components of the whole, mixed sedimentary package. Hence, generating mantle endmembers by recycling of only pelagic or only terrigenous sediment seems physically unlikely. 


\subsection{Shield vs. Post Erosional}

As initially observed by Wright and White (1986), post-erosional (PE) lavas are isotopically distinct from all shield lavas. There is a commonality among the PE lavas from all along the chain (Savai'i, Upolu and Tutuila), in contrast to the observation that each island displays a unique isotopic birthmark in its shield lavas. The PE lavas show restricted ${ }^{87} \mathrm{Sr} /{ }^{86} \mathrm{Sr}$ values that plot mid-range in the Samoan field, have the lowest ${ }^{206} \mathrm{~Pb} /{ }^{204} \mathrm{~Pb}$ values and some of the lowest ${ }^{208} \mathrm{~Pb} /{ }^{204} \mathrm{~Pb}$ values of the whole sample suite (Figs. 6 and 8 ). The $\mathrm{PE}$ field on the ${ }^{206} \mathrm{~Pb} /{ }^{204} \mathrm{~Pb}$ versus ${ }^{207} \mathrm{~Pb} /{ }^{204} \mathrm{~Pb}$ plot (Fig- 7) is unusual, as it is elongate in an almost inverse direction to the shield trend (Wright and White, 1986).

Overall, the new Savaiian lavas are all of the same chemical nature as the post-erosionals, even though many are samples of the oldest-mapped flow series on the island (Fagaloa Series; Kear and Wood, 1959). These Savai'i lavas, as well as most other PE lavas, are clearly distinguishablefrom shield lavas by having the highest $\mathrm{Nb} / \mathrm{U}$ and $\mathrm{Ba} /(\mathrm{La}, \mathrm{Sm}, \mathrm{Nb}, \mathrm{Th})$ ratios of the whole sample suite (Fig. 12). Given the earlier discussion of the young radiometric ages for this "shield" series, we believe this sequence is in fact post-erosional, and not shield. The alternative explanation, that all of Savai'i is young and not part of an age-progressive Samoan hotspot track, is belied by the 2.05 my age for a trachyte cobble from the Vanu River valley (see above). Either way, we cannot rule out the possibility that PE lavas and shield lavas are geochemically the same on Savai'i, but nowhere else in Samoa.

What accounts for the distinct trace element and isotopic differences between shield and PE lavas? The commonality among Samoan PE lavas possibly derives from a similar history of being brewed and aged in the crust and lithosphere, unlike shield lavas that may have a shorter residence time in this shallow environment. Local Tongan sediments (from DSDP Site 5951596, about $1000 \mathrm{~km}$ southeast of Samoa) have Pb isotopic compositions (Plank and Langmuir, 1998) with the general characteristics of PE lavas (Figs. 7 and 8). Pb isotopic compositions of marine sediments are highly variable over short distances and other sediments could likely be found nearer to Samoa that provide closer fits to the Samoa post-erosional $\mathrm{Pb}$ field (which lies near the lower end of the general marine sediment array; Abouchami and Goldstein, 1995: O'Nions et al., 1998; Plank and Langmuir, 1998; Jones et al., 2000). In support of a sediment component in the PE lavas are values for $\delta^{18} \mathrm{O}$ of olivine (5.5-5.7\%; Eiler et al., 1997) which are elevated over upper mantle values and can be interpreted to reflect the heavy values documented for marine sediments (also see discussion 
below), In other words, we cannot rule out the late-stage incorporation of modernmarine sediments in PE lavas based solely on isotopic compositions. Trace element ratios may provide a stronger constraint on the presence or absence of a modern sediment component; one would expect the PE lavas to inherit the high $\mathrm{Pb} / \mathrm{Ce}$, high REE/HFSE, low Sm/Yb, and Ba-enriched ratios characteristic of both local and globally averaged marine sediments (see Fig. 17; Plank and Langmuir, 1998). This is not the case for the PEs, which have, of all suspected traits, only notably high Ba (Figs. 11 and 12).

\subsection{Mixing Arrays}

The spread of isotopic compositions in the Samoan lavas can be attributed to either (1) processes that generate an infinite number of chemical (i.e. parent/daughter) heterogeneities within the mantle that, upon long-term storage, evolve into an infinite number of isotopic heterogeneities or (2) processes that produce a small number of unique chemical compositions that, upon long-term storage, result in a limited number of "end-member" isotopic compositions available for mixing. In order for the first option to produce sublinear arrays in 2-D and 3-D isotope space, there must be a single process which acts systematically to varying degrees or at various times. Hence, talk of or modeling of the most extreme values (i.e. endmember mantle components) is the same in either case.

The lavas from Malumalu undeniably establish the existence of a reservoir with high ${ }^{87} \mathrm{Sr} /{ }^{86} \mathrm{Sr}$ (at least 0.7089 ), low ${ }^{143} \mathrm{Nd} /{ }^{144} \mathrm{Nd}$ (at most 0.5125 ), and ${ }^{206} \mathrm{~Pb} /{ }^{204} \mathrm{~Pb},{ }^{207} \mathrm{~Pb} /{ }^{204} \mathrm{~Pb}$, and ${ }^{208} \mathrm{~Pb} /{ }^{204} \mathrm{~Pb}$ values near $19.3,15.65$ and 39.9 , respectively. An unaltered sediment reservoir can be immediately ruled out as the cause of the EM2 component in Samoan shield lavas: although Global Subducting Sediment (GLOSS; Plank and Langmuir, 1998) and local Tongan sediment (Site 5951596; flank and Langrnuir, 1998) each have convincing ${ }^{87} \mathrm{Sr} /{ }^{86} \mathrm{Sr}$ and ${ }^{207} \mathrm{~Pb} /{ }^{204} \mathrm{~Pb}$ compositions (Figs. 6 and 7), they are severely inadequate(low) in ${ }^{206} \mathrm{~Pb} /{ }^{204} \mathrm{~Pb}$ and ${ }^{208} \mathrm{~Pb} /{ }^{204} \mathrm{~Pb}$ to generate tbe isotopic signatures displayed by the shield lavas (Fig. 8). Therefore, for recycled sediment to have evolved to the EM2 coordinate in Sr-Nd$\mathrm{Pb}$ isotope space, subduction zone'alteration of ancient sedimentary packages needed to be very specific: $\mathrm{U} / \mathrm{Pb}$ and $\mathrm{Th} / \mathrm{Pb}$ must increase, while $\mathrm{Rb} / \mathrm{Sr}$ and $\mathrm{Sm} / \mathrm{Nd}$ remain very much the same. In the dehydration of subducted oceanic crust, this is shown to be the case for all systems except $\mathrm{Rb} / \mathrm{Sr}$ : $\mathrm{Rb}$ is about 5 times more mobile than $\mathrm{Sr}$ (Ayers, 1998), so the final dehydrated product has significantly lowered $\mathrm{Rb} / \mathrm{Sr}$ ratios. Experiments on the dehydration and melting of sediments (Johnson and Plank, 1999) give rather inconclusive results for relative trace element partitioning of these parent/daughter ratios, and suggest that 
partitioning can be extremely variable depending on the minerals present and the degree of dehydration.

Although the Samoan lavas are isotopically extreme, the "pure" EM2 signature may be even more extreme. For example, clinopyroxene and glass separates from peridotite xenoliths from Savai 'i studied by Hauri et al. (1993) yield ${ }^{87} \mathrm{Sr} /{ }^{86} \mathrm{Sr}$ values up to $\mathbf{0 . 7 1 2 8}$ and have been interpreted to represent metasomatism of oceanic lithosphere by a small degree carbonatitic melt (not diluted by mixing with depleted mantle) from the same source as that which provides melts for Samoan volcanism. However, the $\mathrm{Pb}$ isotopes in these rare xenoliths $\left({ }^{201} \mathrm{~Pb} /{ }^{204} \mathrm{~Pb} \sim 18.86 ;{ }^{208} \mathrm{~Pb} /{ }^{204} \mathrm{~Pb} \sim 39.76\right)$ lie well outside the isotopic array set by the Samoan lavas (Fig. 8); this suggests an origin for the enriched component in these xenoliths from a smaller, unique reservoir, unrelated to extant Samoan lavas.

Clearly, though, EM2-rich samples are more rare than samples of a less-enriched nature. On a plot of ${ }^{206} \mathrm{~Pb} /{ }^{204} \mathrm{~Pb}$ against ${ }^{87} \mathrm{Sr} /{ }^{86} \mathrm{Sr}$ (Fig. 13), the Samoan samples can be enclosed in a triangle where the high ${ }^{87} \mathrm{Sr} /{ }^{86} \mathrm{Sr}$ apex is defined by EM2. At lower ${ }^{87} \mathrm{Sr} /{ }^{86} \mathrm{Sr}$, there are two components, one with higher ${ }^{206} \mathrm{~Pb} /{ }^{204} \mathrm{~Pb}$ than EM2 and one with lower ${ }^{206} \mathrm{~Pb} /{ }^{204} \mathrm{~Pb}$, but both assuredly depleted according to their high ${ }^{143} \mathrm{Nd} /{ }^{144} \mathrm{Nd}$ values (Fig. 6). The low ${ }^{206} \mathrm{~Pb} /{ }^{204} \mathrm{~Pb}$, low ${ }^{87} \mathrm{Sr} /{ }^{86} \mathrm{Sr}$ apex (note the Upolu data cluster) has a signature tending toward DMM, but the smct use of the most depleted MORB/DMM isotopic values is not necessarily the only option for describing this component. The sub-Samoan upper mantle has been punctured by multiple mantle plumes in its 110 Myr lifespan, so may no longer be strictly, or homogeneously, pure DMM (see the South Pacific Isotopic and Thermal Anomaly; Staudigel et al., 1991). Also, we do not absolutely require the low ${ }^{206} \mathrm{~Pb} /{ }^{204} \mathrm{~Pb}$ depleted component to reside in the upper mantle (i.e. it could be part of the plume), although it's most easily visualized as.being there given current notions of mantle dynamics. Regardless of these disclaimers, the use of anything but a generic DMM isotopic composition is arbitrary, and ultimately only compromises the generality of our observations and conclusions.

The high ${ }^{206} \mathrm{~Pb} /{ }^{204} \mathrm{~Pb}$, low ${ }^{87} \mathrm{Sr} /{ }^{86} \mathrm{Sr}$ component (obvious in the Ta'u and Vailulu'u lavas; Fig. 13) is suggestive of mixing with a HIMU mantle component. This component may also be present in the Samoan plume, but there is reason to believe HIMU material has under-plated the Samoan lithosphere in the past. Calculated hotspot tracks show that 20-25 million years ago, the Cook-Austral plume was located beneath the lithosphere on which the Samoan Islands presently sit (Norton, 2000). The Cook-Austral chain shows great variation in isotopic compositions (Fig. 14), not all of which would fit the Samoan data in multi- 
isotope space, However, there is one volcano, Raivavae, which has the isotopic compositions .appropriate to be a significant component in the Vai Trend lavas (Fig. 14; data from GEOROC database); we are not suggesting that Raivavae itself is contributing to the Samoan lavas, but that isotopically similar material may be underplating the Samoan island chain.

A fourth mixing component must be acknowledged when considering ${ }^{3} \mathrm{He} /{ }^{4} \mathrm{He}$ values. Figure 9 shows the inverse relationship between ${ }^{87} \mathrm{Sr} /{ }^{86} \mathrm{Sr}$ and ${ }^{3} \mathrm{He} /{ }^{4} \mathrm{He}$. The EM2 component can be classified as having a ${ }^{3} \mathrm{He} /{ }^{4} \mathrm{He}$ signal which asymptotically approaches the average DMM value of $-8 \mathbf{R}_{\mathrm{A}}$ (Kurz et al, 1982) at high ${ }^{87} \mathrm{Sr}{ }^{86} \mathrm{Sr}$. HIMU has also been shown to have low ${ }^{3} \mathrm{He} /{ }^{4} \mathrm{He}$ values (Graham et al., 1993; Hanyu and Kaneoka, 1997; Hilton et al., 2000) and likely explains why Vailulu'u (with the largest HIMU component) is in parallel with Malumalu on Figure 9. Therefore, all three endmember components discussed above have low ${ }^{3} \mathrm{He} /{ }^{4} \mathrm{He}$, thus requiring an additional reservoir to account for high ${ }^{3} \mathrm{He} /{ }^{4} \mathrm{He}$. High ${ }^{3} \mathrm{He}{ }^{4} \mathrm{He}$ values are found in the center of the Samoan $\mathrm{Sr}-\mathrm{Pb}$ data array, at Ta'u and Tutuila, and generally decrease towards the outer fringes (Fig. 13). Farley et al. (1992) named this component the primitive helium mantle (PHEM) but new data suggest this reservoir has depleted ${ }^{87} \mathrm{Sr} /{ }^{86} \mathrm{Sr}$ and ${ }^{143} \mathrm{Nd} /{ }^{144} \mathrm{Nd}$ (like FOZO of tat et al., 1992), and not bulk-earth-like values assigned to PHEM.

All four mantle components are in the Samoan plume from a magmatic standpoint. But what material is coming from the deep mantle is another story. We can make a good case for the depleted component coming from entrainment of the widely documented depleted upper mantle and the radiogenic $\mathrm{Pb}$ component (HIMU-ish) coming from entrainment of under-plated lithosphere from the HIMU Cook-Austral chain. This means the deep mantle material within the Samoan plume is dominantly EM2 and PHEM/FOZO. The sequence of mixing these components is difficult to ascertain, as the length scale of compositional heterogeneity and differences in solidus temperatures (i.e. solid vs. melt mixing) are unknown.

\subsection{Spatial/Temporal Evolution}

Samoan shield samples on the ${ }^{206} \mathrm{~Pb} /{ }^{204} \mathrm{~Pb}-{ }^{208} \mathrm{~Pb} /{ }^{204} \mathrm{~Pb}$ plot form two en echelon trends of positive slope (Fig. 8) which are most distinctly separated at high ${ }^{206} \mathrm{~Pb} /{ }^{204} \mathrm{~Pb}$, and converge at lower ${ }^{206} \mathrm{~Pb} /{ }^{204} \mathrm{~Pb}$. The isotopic trends correspond to the two topographic ridges of the Samoan islands (Fig. 2); for a given ${ }^{206} \mathrm{~Pb} /{ }^{204} \mathrm{~Pb}$, the southern Malu Trend has higher ${ }^{208} \mathrm{~Pb} /{ }^{204} \mathrm{~Pb}$ than the northern Vai Trend. Within each of the two trends, isotopic enrichment 
increases with decreasing age along the volcanic ridge. This relationship, shown clearly in a plot of distance versus ${ }^{206} \mathrm{~Pb} /{ }^{204} \mathrm{~Pb}$ (Fig. 15), has remarkablecorrelation and is striking in its implication of a systematic evolution of plume material or mantle processes. Figure 15 also shows how the Malu and Vai Trends form a continuum though time: even though each ridge independently displays isotopic enrichment with distance/time, the younger Vai Trend is generally higher in ${ }^{206} \mathrm{~Pb} /{ }^{204} \mathrm{~Pb}$ than the older Malu Trend (note that Malumalu may overlap in age with Ta'u and Vailulu' $u$ ). Of the four mixing components, low ${ }^{206} \mathrm{~Pb} /{ }^{204} \mathrm{~Pb}$ values are found only in the DMM reservoir (-18.0; Fig. 14). Therefore, the increase in ${ }^{206} \mathrm{~Pb} /{ }^{204} \mathrm{~Pb}$ with younging of volcanoes is interpreted to be a waning of the DMM component in the Samoan lavas, with a resulting increase in the abundance of EM2 and HIMU components. The separation of the Vai and Malu Trends in Pb-isotopic space indicates a higher HIMU/EM2 ratio in the Vai Trend.

Moving east along each of the two Trends, there are systematic increases in $\mathrm{K} / \mathrm{Na}$, $\mathrm{Rb} / \mathrm{Sr}, \mathrm{La} / \mathrm{Sm}, \mathrm{La} / \mathrm{Y}$ b $\mathrm{Ba} / \mathrm{Sm}, \mathrm{Th} / \mathrm{Nb}, \mathrm{Th} / \mathrm{Zr}, \mathrm{Nb} / \mathrm{Y}, \mathrm{Nd} / \mathrm{Sm}, \mathrm{Nb} / \mathrm{Zr}$, and $\mathrm{U} / \mathrm{Nb}$ (Fig. 16); in other words, incompatible-element-enrichment increases with $\mathrm{Pb}$ isotopic enrichment distance, and decreasing age. Due to correlations between isotopes and trace elements like those seen in Figure 16, variations in trace element ratios are easily attributed to differences in composition between the low ${ }^{206} \mathrm{~Pb} /{ }^{204} \mathrm{~Pb}$ source and the high ${ }^{206} \mathrm{~Pb} /{ }^{204} \mathrm{~Pb}$ sources. However, we are witness not to the source compositions, but to the products of "source processing". Because the process of melt generation has maintained (or not overly obscured) trace element correlations with isotopic compositions, we can infer some characteristics of the sub-Samoan mantle.

Possible explanations for the systematic chemical evolution of the Samoan plume include:

1. Horizontal zonation of plume material, implying a length-scale of heterogeneity on the order of volcano spacing, as has been suggested for the Hawaiian Islands (see below). In this case, trace element variations are truly source variations.

2. A lithologically-homogeneous mantle in which peridotite components of variable composition occur in the same proportions beneath all Samoa, but exist on a length-scale large enough to allow preservation of disequilibrium between the components. In this case, variable potential temperature of the plume would result in preferential sampling of components based on their respective solidus temperatures. Enriched materials would be sampled at small degrees of melting and trace element enrichment is partly a function of degree of melting. 
3. A vertically-stratified plume, changing composition and/or physical properties as upwelling proceeds, and affecting the degree of entrainment of ambient upper mantle and lithospheric assimilation.

In the Hawaiian Islands (an EM1 plume), isotopically distinct, topographic en echelons, named the "Kea" and "Loa" Trends, have also been documented (Tatsumoto, 1978; Staudigel et al., 1984; Abouchami et al., 2000). The Society Islands (another EM2 archipelago) display similar sub-parallel trends in both geographic and $\mathrm{Pb}$ isotopic space (using data compiled in the GEOROC database). However, nothing so temporally systematic as that in Samoa has been previously reported. Chemical zonation of a mantle plume (e.g. Kurz et al., 1995; Hauri et al., 1996; Lassiter et al., 1996; DePaolo et al., 2001) may explain isotopic lineaments within island chains, but fails to address how this chemical heterogeneity may translate into topographic features. On the other band, creation of topographic Lineation as a consequence of either 1) the lithosphere's structural response to loading (e.g. Hieronymus and Bercovici, 1999; Hieronymus and Bercovici, 2000) or 2) magma rising in "plumlets" instead of a continuous stream (Ihinger, 1995) ignores the fact of correlative chemical variations. Even so, some common dynamic feature clearly exists, independent of mantle taxonomy, for the way in which plumes forge through the mantle/crust, melt, and arrive at Earth's surface.

\section{Calculation of a "Pure ${ }^{\text {ss }}$ EM2 Lava}

The following calculation is aimed at defogging the trace element pattern for lavas of the enriched endmember, through "un-mixing" (subtracting) Ta'u lavas (average ${ }^{87} \mathrm{Sr} /{ }^{86} \mathrm{Sr}=$ 0.7046) from the most EM2-rich Malumalu lavas, under the assumption that the highest ${ }^{87} \mathrm{Sr} /{ }^{86} \mathrm{Sr}$ lavas are, instead of pure EM2 melts, still somewhat contaminated by melts from a depleted/less enriched mantle. As a group, Ta'u lavas are closest to the PHEM mixing component (Figs. 13 and 14). By this calculation, trace element differences between unenriched and enriched mantles are accentuated, and help to clarify the trace element characteristics of the EM2 source.

We extrapolate to the end-member trace element pattern of an EM2 melt in effect by subtracting the averaged trace element composition of Ta'u lavas from the Malumalu lavas until the ${ }^{87} \mathrm{Sr} /{ }^{86} \mathrm{Sr}$ composition equals 0.7128 ; . this value derives from an analysis of cpx contained in a metasomatized peridotite xenolith from Savai'i (Hauri et al., 1993). Although 
these xenoliths are not an extension of the Samoan $\mathrm{Pb}$ isotope array (Figs. 7 and 8), for lack of a better stopping point, they do place an upper limit on oceanic mantle Sr isotopic ratios.

Mixing between Ta'u and a "pure" EM2 component to make the most enriched Samoan samples (Malumalu samples 78-1 and 78-3) is calculated with the following two equations:

$$
\begin{aligned}
& \left({ }^{87} S r / 86 S r\right)_{78-1}=\frac{F[S r]_{E M 2}\left({ }^{87} S r / 86 S r\right)_{E M 2}+(1-F)[S r]_{T a u}\left({ }^{87} S r / 86 S r\right)_{T a u}}{F[S r]_{E M 2}+(1-F)[S r]_{\text {Tau }}} \\
& {[S r]_{78-1}=F[S r]_{E M 2}+(1-F)[S r]_{\text {rau }}}
\end{aligned}
$$

The concentration of $\mathrm{Sr}([\mathrm{Sr}])$ in EM2 and the fraction of the EM2 melt, F, are solved simultaneously so that the right hand of equation (1) equals the ${ }^{87} \mathrm{Sr} /{ }^{86} \mathrm{Sr}$ composition of the two extreme Malumalu lavas (0.70889). With the value for $F$, concentrations of all trace elements can be calculated for the EM2 melt by using the structure of equation (2) and are reported in Table 7. Lava compositions used in this calculation have been corrected for crystal fractionation by incremental addition of olivine (or subtraction in the case of 78-1, 78-3 and 74-1) until the melt compositions reaches a $\mathrm{Mg \#}$ of 73 (olivine addition ranges from $10-51 \%$; olivine subtractions are $10 \%, 7 \%$ and $23 \%$, respectively). Note from Figure 4 that Ta'u and Malumalu have very similar crystal fractionation trajectories with minimal cpx loss. All Ta'u samples have been utilized except for T21 which is plagioclase-rich and T44 which is an ankaramite.

The resulting fraction of EM2 "melt" in the Malumalu "mixture" is 51\%, and the resulting ${ }^{143} \mathrm{Nd} /{ }^{144} \mathrm{Nd}$ ratio for the EM2 component equals 0.51235 . Figure 17 shows the trace element pattern for the calculated "pure" EM2 melt component; note enrichments at $\mathrm{Rb}$ and Th that are almost 120 times PUM, negative anomalies at $\mathrm{Cs}$ and $\mathrm{Ba}$, and an .almost non-existent $\mathrm{Pb}$ anomaly. The REE slope of the calculated EM2 melt is steeper than both Malumalu and Vailulu'u, and the overall trace element pattern from $U$ to the right is remarkably smoother than either the Malumalu or Vailulu'u pattern, save for dips at $\mathrm{Sr}$ and Ti. In general, the degree of enrichment in the EM2 melt is greatest for the highly incompatible.elements.

The calculated trace element pattern of the "pure" EM2 melt is compared to: 1) an estimate of global subducting sediment [GLOSS; Plank and Langmuir, 1998) and 2) a local 
sediment from DSDP Hole 595/596 analyzed for the GLOSS compilation (Fig. 17). Clearly, the sediment trace element patterns are very different from the calculated EM2 component. In particular, the sediment spidergrams are marked by large negative anomalies of the high-field-strength elements (HFSE; $\mathrm{Nb}, \mathrm{Ta}, \mathrm{Zr}$, and $\mathrm{Hf}$ ), and large positive $\mathrm{Pb}$ and $\mathrm{Ba}$ anomalies, whereas the calculated Samoan enriched component has no such features; in fact, the Ba anomaly becomes more negative in the EM2 melt. Also, the heavy rare-earthelement slope of the EM2 melt is significantly steeper than the sediment patterns: $\mathrm{Sm} / \mathrm{Yb}$ for the sediments is 2.1 whereas for the EM2 melt is 7.2. The only argument in favor of sediment addition is the significantly decreased $\mathrm{Pb}$ anomaly in the EM2 melt. However, we (1) do not believe this alone lends credence to the sediment theory, and (2) show in our nonsediment model below how $\mathrm{Pb}$ in the EM2 source does not have a negative anomaly.

Ultimately, the calculated EM2 spidergram is inconsistent with standard models invoking ancient sediment recycling to explain the enrichment of the EM2 mantle source. As discussed below, it is unlikely that any chemical processing during subduction would so effectively "smooth out" the typically jagged spidergram of oceanic sediment. Alternatively, if the enriched plume material is argued to derive from addition of present-day sediments, the trace element patterns of local sediments should be directly reflected in the EM2 melt and they are not. Therefore, late-stage contamination of plume material with local sediment is also an unsatisfactory explanation for the observed chemical characteristics of the enriched Samoan basalts (and this point is strongly supported by the $\mathrm{Pb}$ isotope evidence shown in Figs. $7 \& 8$ ). Production of the EM component by deep mantle fractionations involving high-pressure phases such as $\mathrm{Ca}$ or $\mathrm{Mg}$ perovskite likewise will lead to jagged, not smooth, spidergrams (Hirose et al., 2004). Segregation of carbonatitic melts from mantle assemblages has been used to explain elevated trace element concentrations in oceanic lavas (see Zindler and Hart, 1986), but this process also causes

irregular trace element patterns (e.g. Klemme et al., 1995; Sweeney et al., 1995; Hoernle et al., 2002). Instead, the remarkably smooth EM2 melt spidergram gives the uncanny impression of having originated from nothing but "unadulterated" melting processes within the upper mantle.

\section{Sediment Recycling?}

Osmium and oxygen isotopes are thought to be "smoking guns" for sediment/slab recycling (Eiler et al., 1997; Shirey and Walker, 1998; van Keken et al., 2002). Due to the 
incompatibility of Re (Righter and Hauri, 1998) and compatibility of Os (Hart and Ravizza, 1996) in mantle melting, elevated Re/Os ratios in crustal materials should evolve to radiogenic osmium during long-term storage within the mantle. Altered upper MORB crust and marine sediments are enriched in heavy oxygen $\left(\delta^{18} \mathrm{O}\right.$ of $\sim 15-25 \%$; Savin and Epstein, 1970; Lawrence et al., 1979; Staudigel et al., 1995; Alt, 2003) by low-temperature fractionation processes at the Earth's surface. This is high above the $\delta^{18} \mathrm{O}$ value of $5.2 \%$ for upper mantle olivine (Ito et al, 1987; Mattey et al., 1994; Eiler et al., 1997). Therefore, the standard theory for the origin of EM2 involving recycling of mafic crust plus temgenous sediment would suppose Samoan lavas to have both elevated $\delta^{18} \mathrm{O}$ and ${ }^{187} \mathrm{Os} /{ }^{188}$ Os compositions.

Eiler et al. (1997) demonstrated that EM2 basalts from Samoa (Savai'i post-erosional) and the Societies do have the highest $\delta^{18} \mathrm{O}$ of all OIB's $\left(\delta^{18} \mathrm{O}\right.$ of olivine up to $6.1 \%$ ), explainable by the incorporation of $-5 \%$ terrigenous sediment addition to DMM. Using values chosen by Eiler et al. (1997) for the concentrations of $\mathrm{Sr}, \mathrm{Nd}$, and $\mathrm{Pb}$ in $\mathrm{DMM}$ and sediments, the sediment contribution to the trace element budget in the EM2 source will be $50 \%, 68 \%$ and $96 \%$, respectively, for these elements. Clearly then, the trace element pattern of EM2 lavas should reflect the trace element patterns of sediment, but they do not (see Fig. 17). Eiler et al. (1997) also mention the possibility that metasomatism can elevate $\delta^{18} \mathrm{O}$ values in magmas, and the present work recommends this idea be further explored.

Osmium isotopic compositions are likewise not so "smoking" of a sediment component. Combining data presented here (Table 4) with those from Hauri and Hart (1993), Samoan basalt samples with $>80$ ppt Os (ranging in ${ }^{87} \mathrm{Sr} /{ }^{86} \mathrm{Sr}$ from 0.7046 to 0.7089 ) reveal ${ }^{187} \mathrm{Os} /{ }^{188} \mathrm{Os}$ ratios of $0.124-0.130$ which do not correlate with any other isotope system. Samples with $<80 \mathrm{ppt}$ Os ( 5 out of 21 in total) have elevated ${ }^{187} \mathrm{Os} /{ }^{188} \mathrm{Os}$ ratios and are interpreted to be contaminated with seawater (see Shirey and Walker, 1998). The small range in ${ }^{187} \mathrm{Os} /{ }^{188} \mathrm{Os}$ compositions of pristine samples spans values estimated for the primitive upper mantle (0.129; Meisel et al., 1996) and DMM (-0.125; Standish et al., 2002), and is much lower than the upper limit of 0.16 displayed in HIMU and EM1 lavas (Hauri and Hart, 1993; Reisberg et al., 1993; Eisele et al., 2002).

The unradiogenic ${ }^{187} \mathrm{Os} /{ }^{188} \mathrm{Os}$ values for these Samoan lavas represent either (1) a similarly unradiogenic mantle source, or (2) re-equilibration of more radiogenic Os components with unradiogenic upper/lower mantle through special processes that are not active beneath HIMU or EM1 hotspots. With regard to the former option, and to test the standard model, low Os concentrations in sediments may prevent a sediment component 
from significantly elevating ${ }^{187} \mathrm{Os} /{ }^{188} \mathrm{Os}$ ratios in the EM2 source. In a simple case, if DMM with ${ }^{187} \mathrm{Os} /{ }^{188} \mathrm{Os}=0.125$ and [Os] $=3000 \mathrm{ppt}$ is mixed with sediment having ${ }^{187} \mathrm{Os} /{ }^{188} \mathrm{Os}=$ 1.0 and [Os] $=30$ ppt (Peucker-Ehrenbrink and Jahn, 2001), then 35\% of sediment is needed to change ${ }^{187} \mathrm{Os} /{ }^{188} \mathrm{O}$ s from 0.125 to 0.130 . Here we are again left with an EM2 source whose trace element budget would be dominated by sediment, but do not observe such trace element patterns in the EM2 lavas nor see the implied correlations with other isotope systems. The second option, suggesting the Os budget derives from reequilibration, can be ruled out since olivine phenocrysts are in approximateequilibrium with coexisting liquids (Jackson et al., unpubl.) and have high ${ }^{3} \mathrm{He} /{ }^{4} \mathrm{He}$ ratios (i.e. are not xenocrystic, but rather truly phenocrystic). We conclude that the mantle sources for Samoan lavas all have inherently unradiogenic ${ }^{187} \mathrm{Os} /{ }^{188} \mathrm{Os}$ values and are not influenced by a sediment/crustal component.

Although slab/sediment recycling has been a common theory for the origin of EM2 for over two decades (see Introduction), there are major flaws in this train of thought. The Standard Model for generating the EM2 reservoir involves the introduction into the deep mantle of 1) oceanic crust which has been depleted of fluid-mobile elements, such as the large-ion-lithophile elements (LJLE; e.g. $\mathrm{Cs}, \mathrm{Rb}, \mathrm{K}$ and $\mathrm{Pb}$ ), by dehydration and 2) a relatively pristine (i.e. elementally unfractionated) continental crust component (i.e. terrigenous sediments). Although not typically considered in the Standard Model, it seems logical that trace elements of subducted sediments (pelagic and/or temgenous) must be fractionated by the same process by which the subducted ocean crust is fractionated (dehydration)-especially since sediments are closer to the mantle wedge and likely to have greater water contents than the altered ocean crust. Whereas there have been experimental studies showing high trace element mobility during dehydration of subducted ocean crust (especially for the isotopically important elements $\mathrm{Rb}$ and $\mathrm{Pb}$; see Ayers [1998] and Stracke et al. [2003] for overviews), very little similar work has been done on dehydration of subducted sediments (i.e. Johnson and Plank, 1999). Actually, there is growing geochemical evidence that not only a fluid component, but also partial melts of subducted sediments contribute to arc magmas. The high recycling efficiencies (up to 40\%) of elements which are not particularly fluid mobile, such as Be, Th and $\mathrm{Nd}$ (see discussion by Johnson and Plank, 1999), suggest sediment melting is a reality, even though many thermal models predict subsolidus temperatures within the subducted sediment column (e.g. Peacock, 1996). Regardless of the mechanism of trace element fractionations in subducted .sediments, it is.clear that fractionations will occur and will result in significant loss of incompatible 
elements, and a decrease in the mass of a possible future EM2 reservoir. Ultimately, it is grossly inconsistent to use modern, surface sediment as an approximation of the trace element and isotopic composition of a "sediment" component in the mantle - once subducted, the sediment will never look the same, especially for parent/daughter ratios like $\mathrm{Rb} / \mathrm{Sr}$ and $\mathrm{Th} / \mathrm{Pb}$.

Additionally, since today's surface, temgeneous sediments represent what has been extracted by convergent margin volcanism and/or continental crust formation, it is the residue, or complement, to surface sediments which should be our concern for what material is actually recycled deep into the mantle. For example, depletion of the fluid immobile elements $\mathrm{Na}$ and Ta in arc volcanics (Pearce and Peate, 1995), and hence sediments (Plank and Langmuir, 1998), will be matched by $\mathrm{Nb}$-Ta enrichments in the material that is ultimately introduced to the deep mantle. Experiments on partitioning between dehydration fluids and eclogite mineral assemblages (garnet, clinopyroxene and rutile) suggest that depletion of high field-strength elements (including $\mathrm{Nb}$-Ta) in arc volcanics is due to their high compatibility in residual rutile (Stalder et al., 1998) and is therefore not a sediment signature. Enrichment of HFSE in the subducted slab will offset HFSE depletions in the subducted sediment. This is why decreasing $\mathrm{Nb}$ anomalies with increasing ${ }^{87} \mathrm{Sr} /{ }^{86} \mathrm{Sr}$ ratios, as documented for EM1 and EM2 lavas by Eisele et al. (2002), are not supporting evidence for sediment recycling.

We believe there is an alternative explanation for correlation between $\mathrm{Nb}$ anomalies and isotopic compositions. Figure 18 shows $\mathrm{Nb} / \mathrm{Nb}^{*}$ (calculated as $\mathrm{Nb}_{\mathrm{N}} / \sqrt{ }\left(\mathrm{Th}_{\mathrm{N}} \times \mathrm{La}_{\mathrm{N}}\right)$; Eisele et al., 2002) plotted with ${ }^{208} \mathrm{~Pb} /{ }^{204} \mathrm{~Pb}$ and $\mathrm{La} / \mathrm{Sm}$ ratios of lavas from Samoa and Pitcairn. We have used ${ }^{208} \mathrm{~Pb} /{ }^{204} \mathrm{~Pb}$ as a measure of EM2 abundance instead of ${ }^{87} \mathrm{Sr} /{ }^{86} \mathrm{Sr}$ only because it provides better correlations. Samoan lavas show inverse relationships between $\mathrm{Nb} / \mathrm{Nb}^{*}$ and ${ }^{208} \mathrm{~Pb} /{ }^{204} \mathrm{~Pb}$ as well as $\mathrm{La} / \mathrm{Sm}$. Pitcairm lavas (from Eisele et al., 2003) show a negative correlation between $\mathrm{Nb} / \mathrm{Nb}^{*}$ and $\mathrm{La} / \mathrm{Sm}$, which overlaps with the Samoan lavas, and a more shallow slope than Samoa for $\mathrm{Nb} / \mathrm{Nb}^{*}$ against ${ }^{208} \mathrm{~Pb} /{ }^{204} \mathrm{~Pb}$ (the greatest isotopic variation in the Pitcairn lavas is in ${ }^{143} \mathrm{Nd} /{ }^{144} \mathrm{Nd}$ ). Pitcairn and Samoa samples have almost an identical range in both $\mathrm{La} / \mathrm{Sm}$ and $\mathrm{Nb} / \mathrm{Nb}^{*}$, even though the isotopic variability is greater in Samoa. Also plotted in Figure 18 is a trajectory for variable degree of melting of a depleted mantle, showing that small changes in $\mathrm{F}$ can produce large changes in both $\mathrm{La} / \mathrm{Sm}$ and $\mathrm{Nb} / \mathrm{Nb} *$. Therefore, variable $\mathrm{Nb} / \mathrm{Nb}^{*}$ (previously interpreted as only a source effect) can be produced by recent variations in melt production, and is most likely what causes (1) scatter in the plots of Figure 18 and (2) the same $\mathbf{N b} / \mathrm{Nb}^{*}$ variation in Pitcairn as Samoa given less isotopic 
'variation. The correlation of ${ }^{208} \mathrm{~Pb} /{ }^{204} \mathrm{~Pb}$ (and ${ }^{87} \mathrm{Sr} /{ }^{86} \mathrm{Sr}$ ) with $\mathrm{Nb} / \mathrm{Nb} *$ can be interpreted as .an ancient enrichment of mantle by a small degree (low $\mathrm{Nb} / \mathrm{Nb}^{*}$ ) melt, as suggested by the calculated EM2 melt and modeled below.

\section{Metasomatic Origin of EM2}

Given the many failures of the "sediment recycling" model for EM2, as enumerated above, we propose here a new model that invokes rnetasomatic enrichment of ancient oceanic lithosphere, followed by long-term storage in the deep mantle and recent return to the surface as the Samoa plume. Conceptually, this model derives from the autometasomatic process proposed by Zindler et al. (1979) and Roden et al. (1984). Numerous authors have appealed to metasomatism of oceanic plates to generate chemical heterogeneities that can be tapped prior to plate subduction (Hawkesworth et al., 1979, 1984; Halliday et al., 1992; Class and Goldstein, 1997; Niu et al., 1996). Recycling of such metasomatized lithosphere,

after long-term storage in the mantle, has been advocated by Richardson et al. (1982) and Niu and O'Hara (2003) as a source for enriched OIB.

If we start with the assumption that EM2 is a two-stage differentiate of bulk-earth, the slope on the ${ }^{206} \mathrm{~Pb} /{ }^{204} \mathrm{~Pb}-{ }^{207} \mathrm{~Pb} /{ }^{204} \mathrm{~Pb}$ plot (Fig. 7) yields an age of $2.5 \mathrm{Ga}$. This is an age older than the commonly quoted average mantle differentiation age of 1.8 Byr (Hart, 1984). At that time, the composition of the mantle would have been more similar to primitive upper mantle than to the depleted mantle observed today (i.e. DMM). Assuming plate tectonics was operating 2.5 billion years ago in much the same way as it is today, this more primitive mantle material would have undergone depletion by melt extraction during upwelling under spreading ridges, then "turned the corner" and solidified to become depleted lithospheric mantle.

In the following calculations, we model the case in which small degree, deep melts not extracted at the ridge crest percolate up through the asthenosphere and impregnate the overlying lithosphere that had just undergone melt extraction on the ridge crest. This is essentially a metasomatic process. This metasomatized lithosphere then is recycled and stored in the mantle to become today's EM2 reservoir (Fig. 19). The melt fraction, amount of melt impregnation, and ratio of garnet to spinel peridotite melting are calculated so as to match parent/daughter ratios of EM2 for the $\mathrm{Rb}-\mathrm{Sr}, \mathrm{Sm}-\mathrm{Nd}, \mathrm{U}-\mathrm{Pb}$, Th- $\mathrm{Pb}$ and $\mathrm{Lu}-\mathrm{Hf}$ systems, based' on evolution from bulk earth 2.5 billion years ago. Bulk partition coefficients used for melting a primitive mantle source (McDonough and Sun, 1995) are 
based on a compilation of D's from Kelemen et al. (2003) for melting of garnet and spinel peridotite, with the few exceptions listed in Figure 20. Bulk partition coefficients are weighted $72 \%$ garnet peridotite to $28 \%$ spinel peridotite. The best match to parent/daughter ratios is with a $1.1 \%$ impregnation of a depleted lithosphere by a $0.5 \%$ batch melt of a primitive mantle. The lithosphere represents a mantle depleted by $2 \%$ melt extraction, as calculated using the method of Workman and Hart (2003) and as reported in Table 8. Figure 20 shows the resulting trace element pattern of the EM2 source (also see Table 8). $\mathrm{Rb} / \mathrm{Sr}$ has been fit to within $<1 \%, \mathrm{Sm} / \mathrm{Nd}$ and $\mathrm{Lu} / \mathrm{Hf}$ have been fit to within $3 \%$, and $\mathrm{Th} / \mathrm{U}$ has been fit to within $4 \%$. The "unfortunate fits" are for $\mathrm{U} / \mathrm{Pb}$ and $\mathrm{Th} / \mathrm{Pb}$, which are $53 \%$ and $58 \%$ too high respectively in the calculated EM2 source. This is clearly more a $\mathrm{Pb}$ problem than anything else. If the compatibility of $\mathrm{Pb}$ is lower by about a factor of two, as suggested by experimental partitioning data (Hauri et al., 1994; Salters et al., 2002), the $\mathrm{U} / \mathrm{Pb}$ and $\mathrm{Th} / \mathrm{Pb}$ ratios may be more precisely modeled. Because the mass fraction of melt added to the FOZO lithosphere $(\mathbf{1 . 1 \%})$ is twice the degree of melting $(0.5 \%)$ required to generate that impregnating melt, the mass of the mantle which melts must be twice as large as the mass of the metasomatized lithosphere.

Does this source lead to the observed ${ }^{3} \mathrm{He} /{ }^{4} \mathrm{He}$ values of $8 \mathrm{R}_{\mathrm{A}}$ for EM2? Given the general trace element enrichment in the impregnating melt, and making the standard assumption of extreme incompatibility of $\mathrm{He}$, it is likely that the calculated EM2 source would have high $\mathrm{He} / \mathrm{U}$ ratios and hence evolve to ${ }^{3} \mathrm{He} /{ }^{4} \mathrm{He}$ values higher than $8 \mathrm{R}$. There are two possible solutions. One concerns the relative compatibility of $\mathrm{He}$ and $\mathrm{U}$; if at high pressure and low degree of melting $\mathrm{He}$ is more compatible than $\mathrm{U}$ (this has not been proven nor disproven), then the impregnating melt will have low $\mathrm{He} / \mathrm{U}$ and potentially evolve to DMM-like ${ }^{3} \mathrm{He} /{ }^{4} \mathrm{He}$ values (by coincidence). The second option is that the EM2 "package" has had a residence time in the upper mantle long enough $(-1-2 \mathrm{Ga})$ to result in diffusive equilibrium of He (see model by Moreira and Kurz, 2001, for example); this option has obvious implications for the primary home of recycled lithosphere.

Although the above model leaves several questions unanswered, such as the scale-length of the heterogeneities created by the metasomatism, and the resulting lithologies (mafic veins or enriched peridotite), it is successful in producing the observed isotopic and trace element characteristics of the Samoan mantle source. It does not require ad hoc chemical manipulations in the subduction zone, as does the standard crust/sediment-recycling model. In fact, as the enrichment zone is limited to the lower parts of the lithosphere, it will be nearly invulnerable to subduction zone processing. It calls on a process for which there is 
abundant evidence, particularly in the sub-continental lithosphere (Frey and Green, 1974; Menzies and Murthy, 1980; Menzies, 1983; Menzies and Hawkesworth, 1987). And insofar as small-degree melts are ubiquitous in the upper oceanic asthenosphere, the process is virtually guaranteed. We note also that the small-scale convection usually invoked for this part of the mantle (i.e. Richter rolls) provides an efficient means of upward advection of standing melt fractions, as well as the consequent decompression that will augment the melt fractions and facilitate melt/solid segregation.

\section{Conclusions}

A large suite of recently collected basalts from the Samoa hotspot chain have been analyzed for $\mathrm{Sr}, \mathrm{Nd}, \mathrm{Pb}, \mathrm{Os}$ and $\mathrm{He}$ isotopes, and major and trace elements. Localities include the sub-aerial islands of Savai'i, Upolu and Ta'u, and the submarine seamounts Muli, Malumalu and Vailulu'u.

1. Samoan basalts are isotopically $(\mathrm{Sr}-\mathrm{Nd}-\mathrm{Pb})$ the most extreme EM2 lavas in the oceanic database $\left({ }^{87} \mathrm{Sr} /{ }^{86} \mathrm{Sr}\right.$ up to 0.7089$)$. The. Samoan isotopic arrays can be explained by mixing among four mantle components: DMM, EM2, HIMU and PHEM/FOZO. The deep plume material is most likely composed of EM2 and PHEM/FOZO, whereas the HIMU and DMM components are entrained into the plume in the upper mantle.

2. Systematic temporal and spatial variations in lava chemistry occur while going from west (older) to east (younger) along the chain: e.g. ${ }^{206} \mathrm{~Pb} /{ }^{204} \mathrm{~Pb}, \mathrm{La} / \mathrm{Sm}, \mathrm{Rb} / \mathrm{Sr}, \mathrm{Th} / \mathrm{Zr}$. This indicates a waning of the DMM component and waxing of the EM2 and HIMU components in Samoan volcanoes over the last few million years.

3. The standard recycling model (ocean crust plus terrigenous sediment) fails as an explanation for producing Samoan EM2, as witnessed by the smooth spidergrams for EM2 lavas with negative $\mathrm{Ba}$ anomalies, low ${ }^{187} \mathrm{Os} /{ }^{188} \mathrm{Os}$ ratios, high ${ }^{3} \mathrm{He} /{ }^{4} \mathrm{He}$ (>8Ra) and mismatched $\mathrm{Pb}$ isotopic compositions.

4. The EM2 mantle source can be successfully modeled with the ancient $(2.5 \mathrm{Ga})$ formation of metasomatised oceanic lithosphere, followed by storage in the deep mantle and return to the surface in the Samoan plume. 


\section{Appendix 2-1}

Samples analyzed by M. Regelous were crushed in a steel jaw crusher to 3-5 mm sized chips, .washed in deionised water, dried and handpicked in order to avoid chips which were visibly altered, or which contained vesicles. A portion of these chips was set aside for isotope analysis, the rest was powdered in an agate swing mill. Major element analyses were carried out by X-ray fluoresence at the Universität Mainz, Germany, using a Phillips PW 1404 instrument. Trace element concentrations were determined by JCPMS using a Fisons Plasrnaquad II instrument at the University of Queensland, Australia. Full details of the procedure are given in Niu and Batiza (1997). The external precision on the concentrations of most of the trace elements measured is $<3 \%$. The long-term average values for the BHVO-1 rock standard are reported in Table 5. Pb isotope measurements were carried out at the Max Planck Institut fiu Chemie, Mainz, following the procedure outlined by Abouchami et al. (2000). Between 50 and $100 \mathrm{mg}$ of rock chips were washed in deionised water in an ultrasonic bath, then ultrasonicated in $6 \mathrm{M} \mathrm{HCl}$ for 15 minutes, before being leached in hot $6 \mathrm{M} \mathrm{HCl}$ for I hour. The HCI leachate was pipetted off, and the residue was rinsed, soaked in deionised water for 15 minutes, rinsed again and dried. This leaching procedure appears to remove much of the non-magmatic $\mathrm{Pb}$ that is contained in lessresistant components (surface contamination or alteration products), as discussed by Abouchami et al. (2000) and Eisele et al. (2003). The leached residues were dissolved in $\mathrm{HF}-\mathrm{HN} 03$, treated repeatedly with $\mathrm{HNO}$, and HCI until completely in solution, and $\mathrm{Pb}$ separated on anion exchange resin using $\mathrm{HBr}-\mathrm{HNO}$, mixtures (Abouchami et al., 2000). All reagents used were double-distilled, and total precedural blanks for the $\mathrm{Pb}$ chemistry were below 50pg. The eluent from the Pb columns was twice evaporated to dryness with $15 \mathrm{M}$ $\mathrm{HNO}_{3}$, and redissolved in $3 \mathrm{M} \mathrm{HNO}_{3}$. Sr and $\mathrm{Nd}$ were separated from this fraction at the University of Bristol, U.K., using methods adapted from Pin et al. (1994). The sample in $3 \mathrm{M} \mathrm{HNO}_{3}$ was loaded onto columns containing $0.15 \mathrm{ml}$ of TRU spec resin, positioned so as to drip directly into a second column containing $0.1 \mathrm{ml}$ of $\mathrm{Sr}$ spec resin. After rinsing with $3 \mathrm{M}$ HNO, the columns were separated, and $\mathrm{Sr}$ was eluted from the $\mathrm{Sr}$ spec column in $\mathrm{H}_{2} \mathrm{O}$. The light- and middle-rare earth elements were recovered from the TRU spec resin by rinsing with 2.5M HCI. Nd was separated from this fraction using conventional HDEHP columns and $0.3 \mathrm{M} \mathrm{HCl}$. Pb isotope analyses were carried out using a triple spike technique to correct for instrumental mass fractionation. About $5 \%$ of the purified $\mathrm{Pb}$ fraction was transferred to a second beaker and spiked with a ${ }^{204} \mathrm{~Pb}^{206}{ }^{206}-{ }^{207} \mathrm{~Pb}$ triple spike. The spiked and unspiked fractions were loaded onto separate Re filaments with silica gel- $\mathrm{H}_{3} \mathrm{PO}_{4}$. Isotope compositions were measured using a Finnigan MAT-261 multicollector mass spectrometer (M.P.I. Mainz) in static mode, and the data for spiked and unspiked fractions were combined off-line to obtain the fractionation-corrected $\mathrm{Pb}$ isotope composition of the sample (Galer, 1999). During this study, the NBS981 Pb standard gave ${ }^{206} \mathrm{~Pb} /{ }^{204} \mathrm{~Pb}$, ${ }^{207} \mathrm{~Pb} /{ }^{204} \mathrm{~Pb}$ and ${ }^{208} \mathrm{~Pb} /{ }^{204} \mathrm{~Pb}$ ratios of $16.9403 \pm 0.0022,15.4974 \pm 0.0020$ and $36.7246 \pm 0.0058$ respectively $(2 \mathrm{~s}, \mathrm{n}=19)$. $\mathrm{Sr}$ and $\mathrm{Nd}$ isotope measurements were carried out on a Finnigan Triton multicollector mass spectrometer (University of Bristol) in static 
mode, and within-run exponential fractionation corrections applied using ${ }^{86} \mathrm{Sr} /{ }^{88} \mathrm{Sr}=0.1194$ and ${ }^{146} \mathrm{Nd} /{ }^{144} \mathrm{Nd}=0.7219$. The NBS987 $\mathrm{Sr}$ and $\mathbf{J} \& \mathbf{M} \mathbf{N d}$ standards gave ${ }^{87} \mathrm{Sr} /{ }^{86} \mathrm{Sr}$ and ${ }^{143} \mathrm{Nd} /{ }^{144} \mathrm{Nd}$ ratios of $0.710247 \pm 0.000008$ (2 sigma, $\mathrm{n}=15$ ) and $0.511113 \pm 0.000004$ $(n=12)$ respectively, during the period of the sample measurements. 


\section{References}

Abouchami, W. and S. L. Goldstein, A lead isotopic study of Circum-Antarctic manganese nodules, Geochim. Cosmochim. Acta, 59. 1809-1820,1995.

Abouchami, W., Galer, S.J.G., and Hofmann, A.W., High precision lead isotope systematics of lavas from the Hawaiian Scientific Drilling Project, Chemical Geology, 169, 187-209, 2000.

Alt, J. C., Stable isotopic composition of the upper oceanic crust formed at a fast spreading ridge, ODP Site 801, Geochemistry, Geophysics, Geosystems, 4(5), 10.1029/2002GC000400, 2003.

Armstrong, R. L., A model for the evolution of strontium and lead isotopes in a dynamic Earth, Reviews of Geophysics 6, 175-199, 1968.

Ayers, J., Trace element modeling of aqueous fluid - peridotite interaction in the mantle wedge of subduction zones, Contributions to Mineralogy and Petrology 132,390-404, 1998.

Barling, J., and Goldstein, S.L., Extreme isotopic variations in Heard Island lavas and the nature of mantle reservoirs, Nature, 348(6296), 59-62, 1990.

Bevis, F. W. Taylor, B. E. Schutz, J. Recy, B. L. Isacks, S. Helu, R. Singh, E. Kendrick, J. Stowell, B. Taylor and S. Calmant, Geodetic observations of very rapid convergence and back-arc extension at the Tonga arc, Nature, 374, 249-251, 1995.

Brocher, T. M. and R. Holmes, Tectonic and Geochemical Framework of the Northern Melanesian Borderland: An Overview of the KK820316 Leg 2 Objectives and Results. In Investigations of the Northern Melanesian Borderland, Circum-Pacific Councilfor Energy and Mineral Resources Earth Science Series 3, edited by T. M. Brocher, Vol. 3, pp. 1-12, 1985.

Brooks, C., James, D.E., and Hart, S.R., Ancient lithosphere: its role in young continental volcanism, Science, 193, 1086-1094, 1976.

Chase, C. G., Ocean island Pb: two-stage histories and mantle evolution, Earth Planet. Sci. Lett., 52,277-284, 1981.

Chen, W., and Brudzinski, M. R., Evidence for a Large-Scale Remnant of Subducted Lithosphere Beneath Fiji, Science, 292,2475-2479,2001-

Class, $\boldsymbol{C}$., and S.L. Goldstein, Plume-lithosphere interactions in the ocean basins: constraints from the source mineralogy,Earth Planet. Sci. Lett., I50, 245-260, 1997. 
Cohen, R. S., and O'Nions, R.K., Identification of recycled continental material in the mantle from $\mathrm{Sr}, \mathrm{Nd}$ and $\mathrm{Pb}$ isotope investigations, Earth Planet. Sci. Lett., 61, 73-84, 1982.

Danyushevsky,L. V., Sobolev, A.V., and Falloon, T.J., Northern Tongan high-Ca boninite petrogenesis: the role of Samoan plume and subduction zone-transform fault transition, Journal of Geodynamics, 20(3), 219-241,1995.

DePaolo, D. J., and Manga, M., Deep Origins of Hotspots - the Mantle Plume Model, Science, 300,920-921,2003.

Dostal, J., B. L. Cousins and C. Dupuy, The incompatibleelement characteristics of an ancient subducted sedimentary component in ocean island basalts from French Polynesia, J. Petrol. 39,937-952,1998.

Duncan, R. A., Radiometric ages from volcanic rocks along the New Hebrides-Samoa lineament, in Geological investigations of the Northern Melanesian Borderland, Circum-Pacific Council for Energy and Mineral Resources Earth Science Series 3, edited by T.M. Brocher, pp. 67-76, 1985.

Eiler, J. M., Farley, K.A., Valley, J.W., Hauri, E.H., Craig, H., Hart, S.R., and Stolper, E.M., Oxygen isotope variations in ocean island basalt phenocrysts, Geochim. Cosmochim. Acta, 61(11), 2281-2293,1997.

Eisele, J., W. Abouchami, S. J. G. Galer, and A. W. Hofmann, The 320kyr Pb isotope evolution of Mauna Kea lavas recorded in the HSDP-2 drill core, Geochemistry, Geophysics, Geosystems, 4(5), doi:10.1029/2002GC000339, 2003.

Eisele, J., Sharma, M., Galer, S.J.G., Blichert-Toft, J., Devey, C.W., and Hofmann, A.W., The role of sediment recycling in EM-1 inferred from $\mathrm{Os}, \mathrm{Pb}, \mathrm{Hf}, \mathrm{Nd}, \mathrm{Sr}$ isotope and trace element systematics of the Pitcairn hotspot, Earth Planet. Sci. Lett., 196, 197-212, 2002.

Ewart, A., Collerson, K.D., Regelous, M., Wendt, J.I., and Niu, Y., Geochemical Evolution within the Tonga-Kermedec-Lau Arc-Back-arc Systems: the Role of Varying Mantle Wedge Composition in Space and Time, J. Petrol., 39(3), 331-368, 1998.

Farley, K. A., Natland, J.H., and Craig, H., Binary mixing of enriched and undegassed (primitive?) mantle components $(\mathrm{He}, \mathrm{Sr}, \mathrm{Nd}, \mathrm{Pb})$ in Samoan lavas, Earth Planet. Sci. Lett., I11, 183-199, 1992.

Frey, F. A, and Green, D.H, The mineralogy, geochemistry, and origin of Iherzolite inclusions in Victorian basanites, Geochim. Cosmochim. Acta, 38, 1023-1059, 1974.

Galer, S. J. G., Optimal double and triple spiking for high precision lead isotopic 
measurement, Chem. Geol., 157, 255-274, 1999.

Ghiorso, M. S., Hirschmann, M.M., Reiners, P.W., and Kress, V.C. III, The pMELTS: A revision of MELTS for improved calculation of phase relations and major element partitioning related to partial melting of the mantle to $3 \mathrm{GPa}$, Geochemistry, Geophysics, Geosystems, 3(5), 10.102912001GC000217, 2002.

Graham, D. W., S. E. Humphris, W. J. Jenkins, M. D. Kurz, Helium isotope geochemistry of some volcanic rocks from Saint Helena, Earth Planet. Sci. Lett., I10, 121-131, 1993.

Halliday, A. N., G. R. Davies, D-C. Iee, S. Tommasini, C. R. Paslick, J. G. Fitton, D. E. James, Iead Isotope Evidence for Young Trace Element Enrichment in the Oceanic Upper Mantle, Nature 359,623-627,1992.

Hamilton, P.J., R.K. O'Nions, D. Bridgewater, and A. Nutman, Sm-Nd studies of Archean metasediments and metavolcanics from West Greenland and their implications for the Earth's early history, Earth Planet. Sci. Lett., 38, 26-43, 1983.

Hanyu, T. and Kanoeka, I, The uniform and low ${ }^{3} \mathrm{He} /{ }^{4} \mathrm{He}$ ratios of HIMU basalts as evidence for their origin as recycled materials, Nature, 390,2730376,1997.

Fut, S. R., A large-scale isotope anomaly in the Southern Hemisphere mantle, Nature, 309(5971), 753-757,1984.

Hat, S. R., Heterogeneous mantle domains: signatures, genesis and mixing chronologies, Earth Planet. Sci. Lett., 90,273-296, 1988.

Fat, S. R., and H. Staudigel, Isotopic characterization and identification of recycled components, 15-28. In Crust/Mantle Recycling at Convergence Zones, edited by S. R. Hart and L. Gulen, NATO ASI Series, Vol. 258, Series $\boldsymbol{C}$, Kluwer Academic Publishers, Dordrecht, The Netherlands, 1989.

Hart, S. R., and Ravizza, G.E., Os Partitioning Between Phases in Lherzolite and Basalt, in Earth Processes: Reading the Isotopic Code, edited by R. Basu and S.R. Hart, Geophysical Monograph Series 95, AGU, Washington, D:C., 1996.

Hart, S. R., Gerlach, D.C., and White, W.M., A possible new Sr-Nd-Pb mantle array and consequences for mantle mixing, Geochim. Cosmochim. Acta, 50, 1551-1557,1986.

Hart, S. R., Hauri, E.H., Oschmann,L.A., and Whitehead, J.A., Mantle Plumes and Entrainment: Isotopic Evidence, Science, 256, 517-520, 1992.

Hart, S. R., Staudigel, H., Koppers, A.A.P., Blusztajn, J., Baker, E.T., Workman, R., Jackson, M., Hauri, E., Kurz, M., Sims, K., Fornari, D., Saal, A., and Lyons, S., Vailulu'u undersea volcano: The New Samoa,Geochemistry, Geophysics, Geosystems, l, 2000GC000108, 2000 . 
Hart, S.R. R K. Workman, M. Coetzee, J. Blusztajn, L. Ball and K. T. M. Johnson, The Pb Isotope Pedigree of Western Samoan Volcanics: New Insights From High-Precision Analysis by NEPTUNE ICP/MS, EOS, 83, F20, 2002.

Hassler, D. R., B. Peucker-Ehrenbrink and $\boldsymbol{G}$. E. Ravizza, Rapid determination of Os isotopic composition by sparging $\mathrm{OsO}_{4}$ into a magnetic-sectorICP-MS, Chem. Geol., $166,1-14,2000$.

Hauri, E. H., and Hart, S.R., Re-Os isotope systematics of HIMU and EMII oceanic island basalts from the south Pacific Ocean, Earth Planet. Sci. Lett., 114,353-371,1993.

Hauri,E. H., and Chemical Geology, 139,185-205,1997.

Hauri, E. H., Shimizu, N., Dieu, J.J., and Hart, S.R, Evidence for hotspot-related carbonatite metasomatism in the oceanic upper mantle, Nature, 365,221-227,1993.

Hauri, E. H., Wagner, T.P., and Grove, T.L., Experimental and natural partitioning of Th, U, $\mathrm{Pb}$ and other trace element between garnet, clinopyroxeneand basaltic melts, Chemical Geology, 117,149-166,1994.

Hauri, E. H., Lassiter, J.C., and DePaolo, D.J., Osmium isotope systematics of drilled lavas from Mauna Loa, Hawaii, J. Geophys. Res., I01, 11793-11806,1996.

Hawkesworth, C. J., Norry, M.J., Roddick, J.C., and Vollmer, R., ${ }^{143} \mathrm{Nd} /{ }^{144} \mathrm{Nd}$ and ${ }^{87} \mathrm{Sr} /{ }^{86} \mathrm{Sr}$ ratios from the Azores and their significance in LL-element enriched mantle, Nature, $280,28,1979$.

Hawkesworth, C. J., Rogers, N.W., van Calsteren, P.C.W., Menzies, M.A., Mantle enrichment processes, Nature, 311,331-335, 1984.

Hawkins, J. W., and Natland, J.H., Nephelinites and Basanites of the Samoan linear volcanic chain: their possible tectonic significance, Earth Planet. Sci. Lett., 24,427-439, 1975.

Herzberg, C., and Zhang, J., Melting experiments on anhydrous peridotite KLB-1:

Compositions of magmas in the upper mantle and transition zone,J.Geophys. Res., 101, 8271-8295,1996.

Hieronymus, C. F., and Bercovici, D., Discrete alternating hotspot islands formed by interaction of magma transport and lithospheric flexure, Nature, 397,604607,1999.

Hieronymus, $\boldsymbol{C}$. F., and Bercovici, D., Non-hotspot formation of volcanic chains: control of tectonic and flexural stresses on magma transport, Earth Planet. Sci. Lett., 181,539554,2000 .

Hilton, D.R., C.G. Macpherson, and T.R. Elliott, Helium isotope ratios in mafic phenocrysts 
and geothermal fluids from La Palma, the Canary Islands (Spain): Implications for HIMU mantle sources, Geochim. Cosmochim. Acta, 64,2119-2132,2000.

Hirose, K., Shimizu, N., van Westrenen, W., and Fei, Y., Trace element partitioning in Earth's lower mantle, Physics of the Earth and Planetary Interiors, in press, 2004.

Hirth, G., and Kohlstedt, D.L., Water in the oceanic upper mantle: implications for rheology, melt extraction and the evolution of the lithosphere, Earth Planet. Sci. Lett., 144, 93-108, 1996.

Hoernle, Kaj, G. Tilton, M. J. LeBas, S. Duggen and D. Garbe-Schönberg, Geochemistry of oceanic carbonatites compared with continental carbonatites: mantle recycling of oceanic crustal carbonate, Contrib. Mineral Petrol., 142,520-542,2002.

Hofrnann, A. W., Chemical differentiation of the Earth: the relationship between mantle, continental crust and oceanic crust, Earth Planet. Sci. Lett., 90,297-314, 1988.

Hofmann, A. W., Mantle geochemistry: the message from oceanic volcanism, Nature 385, 219-229, 1997.

Hofmann, A. E., and White, W.M., Mantle plumes from ancient oceanic crust, Earth Planet. Sci. Lett., 57, 421-436, 1982.

Hofmann, A. W., and White, W.M., Ba, Rb and Cs in the Earth's Mantle, Z. Naturforsch, 38(a), 256-266, 1983.

Hooper, P. R., Johnson, D.M., and Conrey, R.M., Major and trace element analyses of rocks and minerals by automated $x$-ray spectrometry, Washington State University, Geology Dept., 1993.

Ihinger, P.D., Mantle flow beneath the Pacific Plate: evidence from seamount segments in the Hawaiian-EmperorChain, Amer. J. Science, 295, 1035-1057, 1995.

Ito, E., White, W.M., and Gopel, C., The $\mathrm{O}, \mathrm{Sr}, \mathrm{Nd}$, and $\mathrm{Pb}$ isotope geochemistry of MORB, Chemical Geology, 62, 157-176, 1987.

Johnson, K. T. M., The petrology and tectonic evolution ofseamounts and banks of the Northern Melanesian Borderland, southwest Pacific. Thesis, University of Hawaii, 1983.

Johnson, M. C., and Plank, T., Dehydration and Melting Experiments Constrain the Fate of Subducted Sediments, Geochemistry, Geophysics, Geosystems, 1, 1999GC000014, 1999.

Jones, C. E., A. N. Halliday, D. K. Rea, R. M. Owen, Eolian inputs of lead in the North Pacific, Geochim. Cosmochim. Acta, 64, 1405-1416,2000.

Kay, R.W., Zone refining at the base of lithospheric plates: A model for a steady-state 
asthenosphere, In Processes at Mid-Ocean Ridges, ed. J. Francheteau, Tectonophysics, $55,1-6,1979$.

Kear, D. and B. L. Wood, The geology and hydrology of Western Samoa: New Zealand Geological Survey Bulletin, 63, 1-90, 1959.

Keating, B. H., The geology of the Samoan Islands. In Geology and offshore mineral resources of the Central Pacific basin, edited by B. H. Keating and B. R. Bolton, Circum-pacific Council for Energy and Mineral Resources Earth Science Series, 14, 127-178, 1992.

Kelemen, P.B., G.M.Yogodzinski and D.W. Scholl, Along-strike variation in the Aleutian island arc: Genesis of high Mg\# andesite and implications for continental crust, in Inside the Subduction Factory, Geophysical Monograph 139, John Eiler, editor, American Geophysical Union, Washington DC, 223-276,2003.

Kinzler, R. J., and Grove, T.L., Primary Magmas of Mid-Ocean Ridge Basalts I. Experiments and Methods, J. Geophys. Res., 97,6885-6906,1992.

Klernme, S., S. R. van der Laan, S. F. Foley and D. Günther, Experimentally determined trace and minor element partitioning between clinopyroxene and carbonatite melt under upper mantle conditions, Earth, Planet. Sci. Letts., 133,439-448, 1995.

Koppers, A. A. P., Morgan, J.P., Morgan, J.W., and Staudigel, H., Testing the fixed hotspot hypothesis using ${ }^{40} \mathrm{Ar} /{ }^{39} \mathrm{Ar}$ age progressions along seamount trails, Earth Planet. Sci. Lett., 185, 237-252, 2001.

Kurzz, M. D., T.C. Kenna, J.C. Lassiter, D.J. Depaolo, Helium isotopic evolution of Mauna Kea: First results from the I-km drill core, J. Geophys. Res., 101 (B5), 11,781-11-791, 1996.

Kurz, M. D., Jenkins, W.J., Shilling, J.G., and Hart, S.R., Helium isotopic variations in the mantle beneath the central North Atlantic Ocean, Earth Planet. Sci. Lett., 58, 1-14, 1982.

Kurz, M. D., Kenna, T.C., Kammer, D.P., Rhodes, J.M., and Garcia, M.O., Isotopic evolution of Mauna Loa volcano: A view from the submarine southwest rift, in Mauna Loa Revealed: Structure, Composition, History and Hazards, edited by J.M. Rhodes, and Lockwood, J.P., Geophysical Monograph Series 92, pp. 289-306, AGU, Washington, 1995.

Lassiter, J. C., DePaolo, D.J., and Tatsumoto, M., Isotopic evidence of Mauna Kea volcano: Results from the initial phase of the Hawaiian Scientific Drilling Project, J. Geophys. Res., 101,11769-11780, 1996.

Lawrence, J. R., Drever, J., Anderson, T.F., and Brueckner, H.K., Importance of alteration of 
volcanic material in the sediments of Deep Sea Drilling Site $323,{ }^{18} \mathrm{O} /{ }^{16} \mathrm{O}$ and ${ }^{87} \mathrm{Sr} /{ }^{86} \mathrm{Sr}$, Geochirn. Cosmochim. Acta, 43,537-588,1979.

MacDonald, G. A. and T. Katsura, Chemical composition of the Hawaiian lavas, J. Petrol., 5, 83-133, 1964.

Moreira, M., and M.D. Kurz, Subducted oceanic lithosphere and the origin of the 'high $\mu$ ' basalt helium isotopic signature, Earth Planet. Sci. Lett., 189, 49-57,2001.

Mattey, D., Lowry, D., and Macpherson, C., Oxygen isotope composition of mantle peridotite, Earth Planer. Sci. Lett., 128, 231-241,1994.

McDonough, W. F. and S.-s. Sun, The composition of the Earth, Chemical Geology, 120, 223-253,1995.

McDougall, I., Age and Evolution of the Volcanoes of Tutuila, American Samoa, Pacific Science, 39, 311-320, 1985.

Meisel, T., R. J. Walker and J. W. Morgan, The osmium isotopic composition of the Earth's primitive upper mantle, Nature, 383, 517-520, 1996.

Menzies, M., Mantle ultramafic xenoliths in alkaline magmas: evidence for mantle heterogeneity modified by magmatic activity, in Continental Basalts and Mantle Xenoliths, edited by C.J. Hawkesworth, and Norry, M.J., pp. 92-110, Shiva, Cheshire, 1983.

Menzies, M., and Murthy, V.R., Nd and Sr isotope geochemistry of hydrous mantle nodules and their host alkali basalts: implications for local heterogeneities in metasomatically veined mantle, Earth Planet. Sci. Lett., 46,323-334, 1980.

Menzies, M. A. and C. J. Hawkesworth, Editors, Mantle Metasomatism, Academic Press, London, 1987.

Millen, D. W., and Hamburger, M.W, Seismological evidence for tearing of the Pacific plate at the northern termination of the Tonga subduction zone, Geology, 26(7), 659-662, 1998.

Molnar, P., and Stock, J., Relative motions of hotspots in the Pacific, Atlantic and Indian Oceans since late Cretaceous time, Nature, 327(6123), 587-591,1987.

Montelli, R., G. Nolet, F.A. Dahlen, G. Masters, E.R. Engdahl, S-H. Hung, FiniteFrequency Tomography Reveals a Variety of Plumes in the Mantle, Science, 10.1126/science. 1092485,2003.

Morgan, J. P., Isotope Topology of Individual Hoptspot Basalt Arrays: Mixing curves or Melt Extraction Trajectories, Geochemistry, Geophysics, Geosystems, I, 1999GC000004, 2000. 
Natland, J., H. The progression of volcanism in the Samoan linear volcanic chain, American Journal of Science, 280-A, 709-735, 1980.

Natland, J. H., The Samoan Chain: A shallow lithospheric fracture system, 2003, in prep.

Natland, J. H. and D. L. Turner, Age Progression and Petrological Development of Samoan Shield Volcanoes: Evidence from K-Ar Ages, Lava compositions, and mineral studies, Investigations of the Northern Melanesian Borderland Circum-Pacific Councilfor Energy and Mineral Resources Earth Science Series 3, edited by T. M. Brocher, Vol. 3, pp. 139-171, 1985.

Niu, Y., and R. Batiza, Trace element evidence from seamounts for recycled oceanic crust in the Eastern Pacific mantle, Earth Planet. Sci. Lett., 148, 471-483,1997.

Niu, Y. K., D. Collerson, R. Batiza, J. I. Wendt and M. Regelous, The origin of E-type MORB at ridges far from mantle plumes: The East Pacific Rise at $11^{\circ} 20^{\prime}$, J. Geophys. Res., 104,7067-7087,1999.

Niu, Y. and M. J. O'Hara, Origin of ocean island basalts: A new perspectivefrom petrology, geochemistry, and mineral physics considerations, J. of Geophys. Res., 108, 2209, doi:I0.1029/2002JB002048, 2003.

Niu, Y., G. Waggoner, J.M. Sinton, J.J. Mahoney, Mantle source heterogeneity and melting processes beneath seafloor spreading centers: The East Pacific Rise $18^{\circ}-19^{\circ} \mathrm{S}, J$. Geophys. Res., 101, 27,711-27,733, 1996.

Norton, I. O., Global Hotspot Reference Frames and Plate Motion, pp. 339-357, in The History and Dynamics of Global Plate Motions, eds. M. A. Richards, R. G. Gordon and R. D. van de Hilsf Geophysical Monograph 121, American Geophysical Union, 2000.

Peacock, S. M, Thermal and petrologic structure of subduction zones, in Subduction Top to Bottom, Geophys. Monogr. Ser., 96, edited by G. E. Bebout et al., 119-133, AGU Washington, D.C., 1996.

Pearce, J.A. and D.W. Peate, Tectonic implications of the composition of volcanic arc magmas, Ann,.Rev. Earth Planet..Sci., 23, 251-285, 1995.

Pelletier, B., Calmant, S., and Pillet, R., Current tectonics of the Tonga-Hebrides region, Earth Planet. Sci. Lett., 164,263-276, 1998.

Peucker-Ehrenbrink, B., and B.-m. Jahn, Rhenium-osmiumisotope systernatics and platinum group element concentrations: Loess and the upper continental crust, Geochem. Geophys. Geosyst., 2,2001GC000172, 2001.

Pin, C., D. Briot, C. Bassin, and F. Poitrasson, Concomitant separation of strontium and 
samarium-neodymiumfor isotopic analysis in silicate samples, based on specific extraction chromatography, Anal. Chim. Acta, 298,209-217,1994.

Plank, T. and C. H. Langmuir, The chemical compositions of subducting sediments and its consequences for the crust and mantle, Chem. Geol., 145,325-394,1998.

Poreda, R. J., and Craig, H., He and Sr isotopes in the Lau Basin mantle: Depleted and primitive mantle components, Earth Planet. Sci. Lett., 113,487-493, 1992.

Reisberg,L., Zindler, A., Marcantonio, F., White, W., Wyman, D., and Weaver, B., Os isotope systematics in ocean island basalts, Earth Planet. Sci. Len., 120, 149-167, 1993.

Richardson, S. H., Erlank, A.J., Duncan A.R., and Reid, D.L., Correlated Nd, Sr and Pb isotope variation in Walvis Ridge basalts and implications for their mantle source, Earth Planet. Sci. Lett., 59,327-342, 1982.

Righter, K., and Hauri, E.H., Compatibility of Rhenium in Garnet During Mantle Melting and Magma Genesis, Science, 280,1737-1741,1998.

Roden, M. F., Het, S.R., Frey, F.A., and Melson, W.G., Sr, Nd and Pb isotopic and REE geochemistry of St. Paul's Rocks: the metamorphic and metasomatic development of an alkali basalt mantle source, Contributions to Mineralogy and Petrology, 85,376-390, 1984.

Russell, S. A., Lay, T., and Garnero, E.J., Seismic evidence for small-scale dynamics in the lowermost mantle at the root of the Hawaiian hotspot, Nature, 396,255-258, 1998.

Salters, V. J. M., Longhi, J.E., and Bizimis, M., Near mantle solidus trace element partitioning at pressures up to $3.4 \mathrm{GPa}$, Geochemistry, Geophysics, Geosystems, 3(7), 10.1029/2001GC000148, 2002.

Savin, S. M., and Epstein, S., The oxygen and hydrogen isotope geochemistry of ocean sediments and shales, Geochim. Cosmochim. Acta, 34, 43-63, 1970.

Sella, G. F., Dixon, T.H., and Mao, A., REVEL: A model for recent plate velocities from space geodesy, J. Geophys. Res., 107, EGT 11-1 to 11-32,2002.

Shen, Y., Solomon, S.C., Bjarnason, I.T., and Wolfe, C.J., Seismic evidence for a lowermantle origin of the Iceland plume, Nature, 395(6697), 62-65, 1998.

Shirey, S. B., and Walker, R.J., The Re-0s isotope system in cosmochemistry and hightemperature geochemistry, Annual Reviews in Earth and Planetary Science, 26, 423500,1998 .

Smith, W. H. F. and D. T. Sandwell, Sea floor topography predicted from satellite altimetry and ship depth measurements, Rep. MGG-09. World Data Cent. A for Mar. Geol. and Geophys., Natl. Geophys. Data Cent., U. S. Dep. Comer., Boulder, Colo., 
1994.

Standish, J. J., Hart, S.R., Blusztajn, J., Dick, H.J.B., and Lee, K.L., Abyssal peridotite osmium isotopic compositions from Cr-spinel, Geochemistry, Geophysics, Geosystems, 3(1), 10.102912001GC000161,2002.

Staudigel, H., Zindler, A., St, S.R. ,Leslie, T., Chen, C.-Y., and Clague, D., The isotope systematics of a juvenile intraplate volcano: $\mathrm{Pb}, \mathrm{Nd}$, and $\mathrm{Sr}$ isotope ratios from Loihi Seamount, Hawaii, Earth Planet. Sci. Lett., 69, 13-29, 1984.

Staudigel, H. K.-H. Park, M. Pringle, J. L. Rubenstone, W.H.F. Smith and A. Zindler, The longevity of the south Pacific isotopic and thermal anomaly, Earth Planet. Sci. Lett., 102, 24-44, 1991.

Staudigel, H., Davies, G.R., S.r, S., Marchant, K.M., and Smith, B.M., Large scale isotopic $\mathrm{Sr}, \mathrm{Nd}$, and $\mathrm{O}$ isotopic anatomy of altered oceanic crust: DSDP/ODP sites 417/418, Earth Planet. Sci. Lett., 130, 169-185, 1995.

Steinberger, B., and O'Connell, R.J., Advection of plumes in the mantle flow: implications for hotspot motion, mantle viscosity and plume distribution, Geophys. J. Int., 132(412434), 1998.

Stice, G. C. and F. W. McCoy, Jr., The Geology of the Manu'a Islands, Samoa, Pacific Science, 22,427-457,1968.

Stracke, A., Bizimis, M., and Salters, V.J.M., Recycling oceanic crust: Quantitative constraints, Geochemistry, Geophysics, Geosystems, 4(3), 10.1029/2001GC000223, 2003.

Sweeney, R. J., V. Prozesky and W. Przybylowicz, Selected trace and minor element partitioning between peridotite minerals and carbonatite melts at $18-46 \mathrm{~kb}$ pressure, Geochim. Cosmochim. Acta, 59, 3671-3683, 1995.

Taras, B.D., and S.R. Hart, Geochemical evolution of the New England seamount chain: isotopic and trace-element constraints, Chemical Geology, 64, 35-54, 1987.

Tatsumoto, M., Isotopic composition of lead in oceanic basalts and its implication to mantle evolution, Earth Planet. Sci. Lett., 38, 63-87, 1978.

Todt, W., R.A. Cliff, A. Hanser, A.W. Hofmann, ${ }^{202} \mathrm{~Pb}+{ }^{205} \mathrm{~Pb}$ double spike for lead isotopic analyses, Terra Cognita, 4,209, 1984.

Turner, S., and Hawkesworth,C., Using geochemistry to map flow beneath the Lau Basin, Geology, 26(11), 1019-1022,1998.

van Keken, P. E., E. H. Hauri, and C. J. Ballentine, Mantle Mixing: The Generation, Preservation, and Destruction of Chemical Heterogeneity, Annu. Rev. Earth Plant. Sci., 
30,493-525,2002.

Walter, M. J., Melting of Garnet Peridotite and the Origin of Komatiite and Depleted Lithosphere, J. Petrol., 39, 29-60, 1998.

Wang, S., and Wang, R., Current plate velocities relative to hotspots: implications for hotspot motion, mantle viscosity and the global reference frame, Earth Planet. Sci. Lett., 189, 133-140, 2001.

Watson, S. and D. McKenzie, Melt Generation by Plumes: A Study of Hawaiian Volcanism, J. Petrology, 32,501-537, 1991.

Weaver, B. L., The origin of ocean island basalt end-member compositions: trace element and isotopic constraints, Earth Planet. Sci. Lett., 104, 381-397, 1991.

Wendt, J. I., Regelous, M., Collerson, K.D., and Ewart, A., Evidence for a contribution from two mantle plumes to island-arc lavas from northern Tonga, Geology, 25(7), 611-614, 1997.

White, W. M., Source of oceanic basalts: Radiogenic isotopic evidence, Geology, 13, 115118,1985 .

Workman, R.K., and S.R Hart, Trace element composition of the depleted upper mantle, Eos Trans. AGU, 84(46), Fall Meet. Suppl., Abstract V52D-02, 2003.

Wright,E., and White, W.M., The origin of Samoa: new evidence from $\mathrm{Sr}, \mathrm{Nd}$, and $\mathrm{Pb}$ isotopes, Earth Planet. Sci. Len., 81, 151-162,1986187.

Zellmer, K. E., and Taylor, B., A three-plate kinematic model for Lau Basin opening, Geochemistry, Geophysics, Geosystems, 2, 2000GC000106, 2001.

Zhao, D., Seismic structure and origin of hotspots and mantle plumes, Earth Planet. Sci. Lett., 192, 251-265,2001.

Zindler, A., and Sciences, 14,493-571, 1986.

Zindler, A, S. R. Hart, F. A. Frey and S. Jakobsson, Nd and Sr isotope ratios and REE abundances in Reykjanes peninsula basalts: Evidence for mantle heterogeneity beneath Iceland, Earth Planet. Sci. Lett., 45,249-262, 1979. 


\section{Figures}

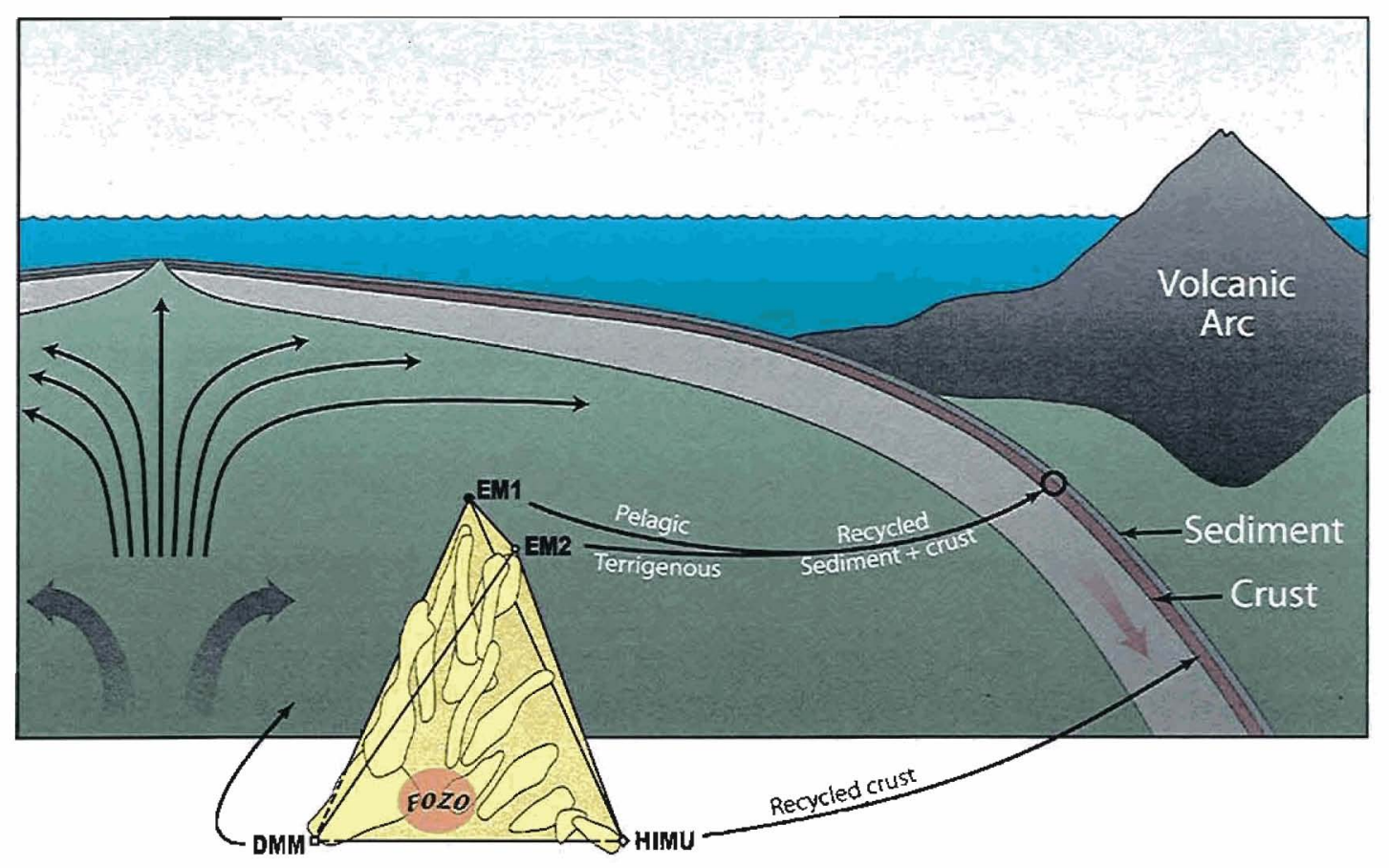

Figure 2-1. Schematic diagram of the Standard Model for the origin of isotopically defined mantle components. DMM (the Depleted MORB Mantle) is the melt-depleted upper mantle that supplies melts to mid-ocean ridges; HIMU (bigh U/Pb mantle) is a reservoir derived from recycling and long-term storage (billions of years) of oceanic crust; EM1 and EM2 are derived from recycling and long-term storage of oceanic crust along with pelagic or temgenous sediment, respectively. Major contributions to the model have been from Armstrong (1968), Chase (1981), Hofmann and White (1982), Cohen and O'Nions (1982), White (1985), Zindler and Hart (1986), Weaver (I 991), and Hart et al. (1992). 


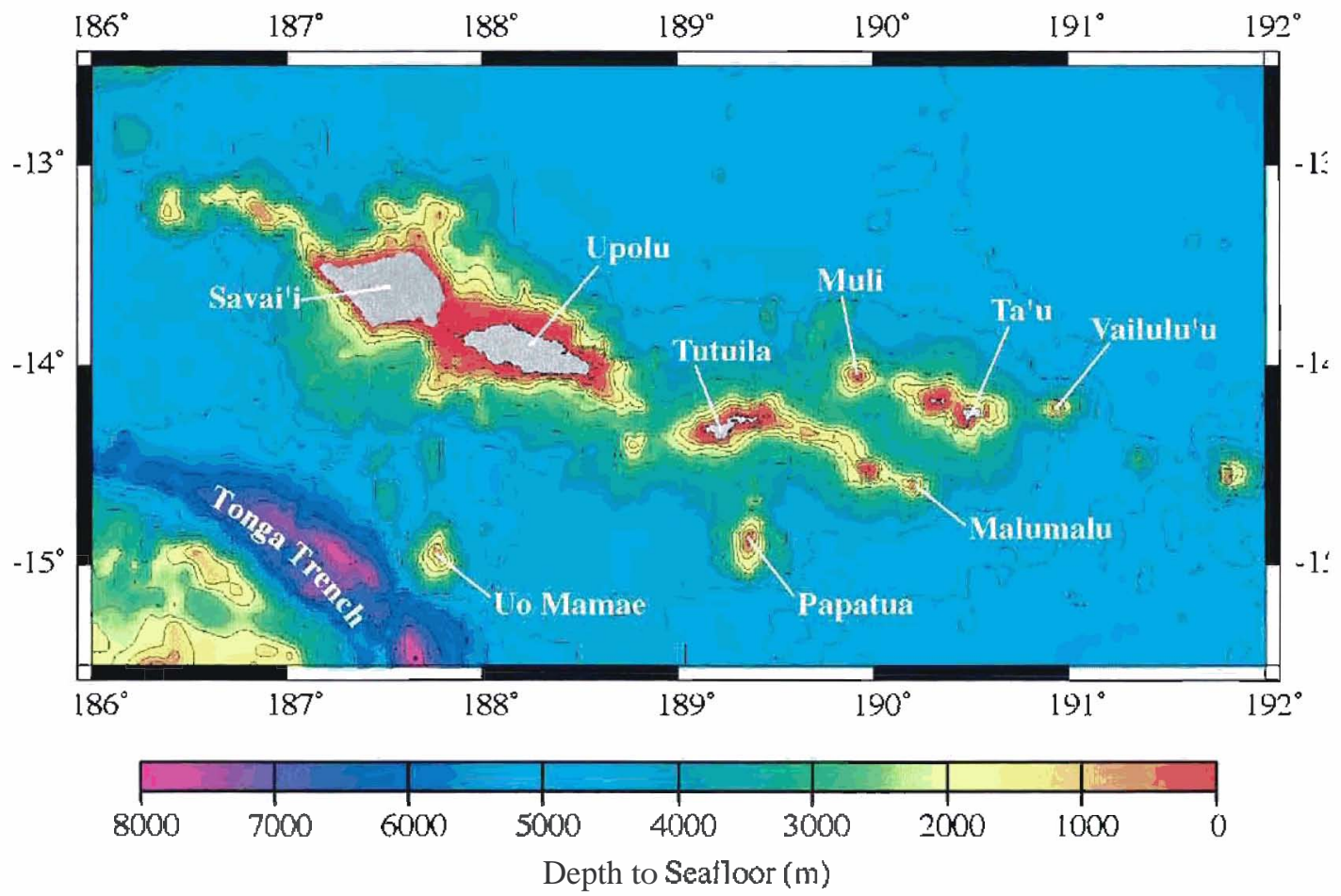

Figure 2-2. Bathymetric map of the Samoan volcanic chain made from merging inferred bathymetry from Smith and Sandwell (1994) with ship-track data from both the AVON 2/3 cruise (see Hart et al,, 2000) and the GEODAS track-line database. Western Samoa is comprised of the two western islands, Savai'i and Upolu; American Samoa is comprised on Tutuila, Otu, Olosega, and Ta'u. In the southwest corner of the map, where depths are down to $8000 \mathrm{~m}$, is the northern termination of the Tonga Trench. Just off to the west at about $14.5^{\circ} \mathrm{S}$ is a transform fault bounding the Lau Backarc Basin to the south. 

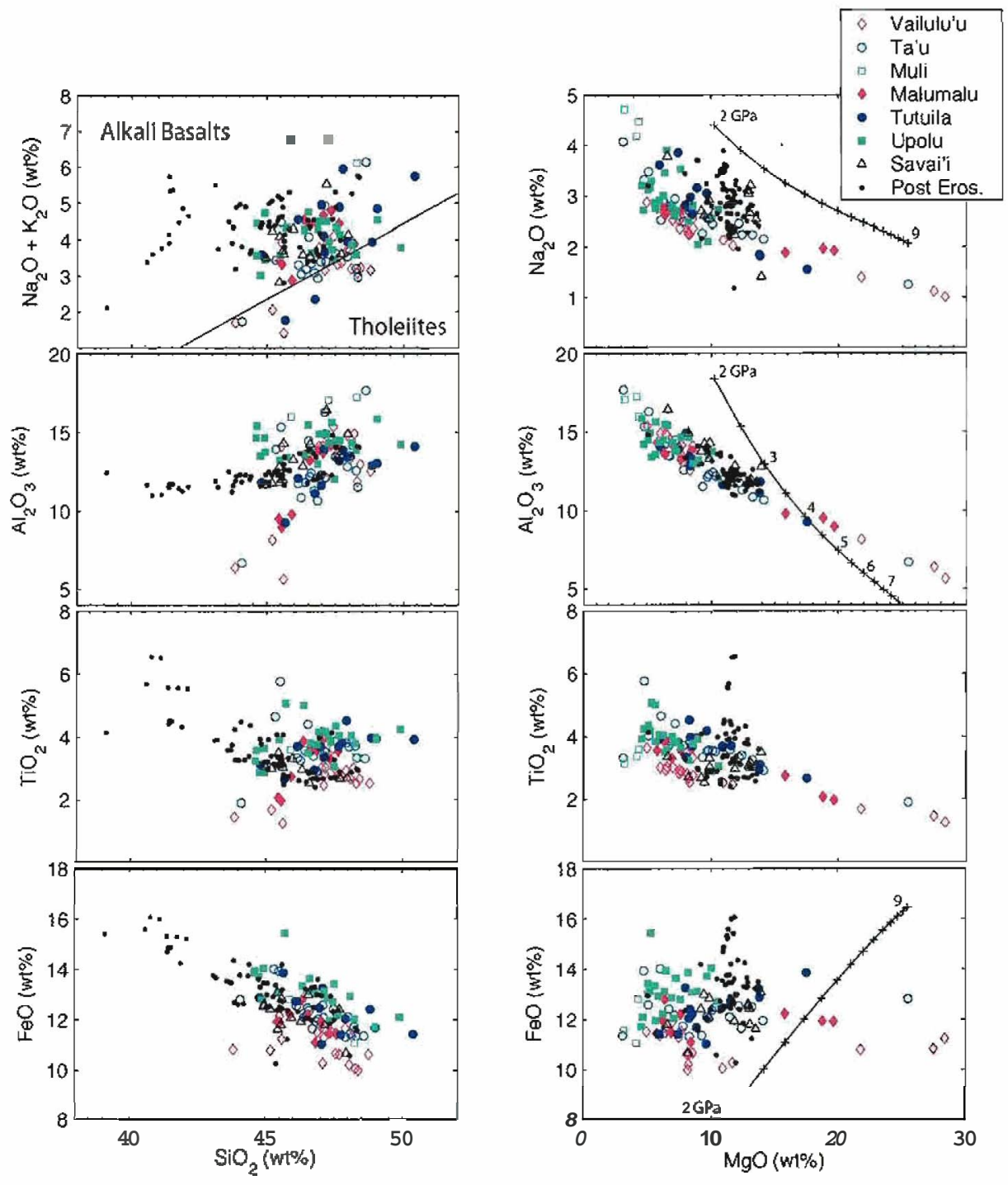

Figure 2-3. Major element compositions of Samoan basalts. Plots include data from Hauri and Hart (1997) for Savai'i lavas. Alkali-tholeiite line is from MacDonald and Katsura (1964). Trajectories of compositions for primary melts from fertile peridotites are plotted on some of the $\mathrm{MgO}$ diagrams, using the algorithms of Herzberg and Zhang (1996) in the pressure range of 2-8 GPa (tick marks every $0.5 \mathrm{GPa}$ ). 


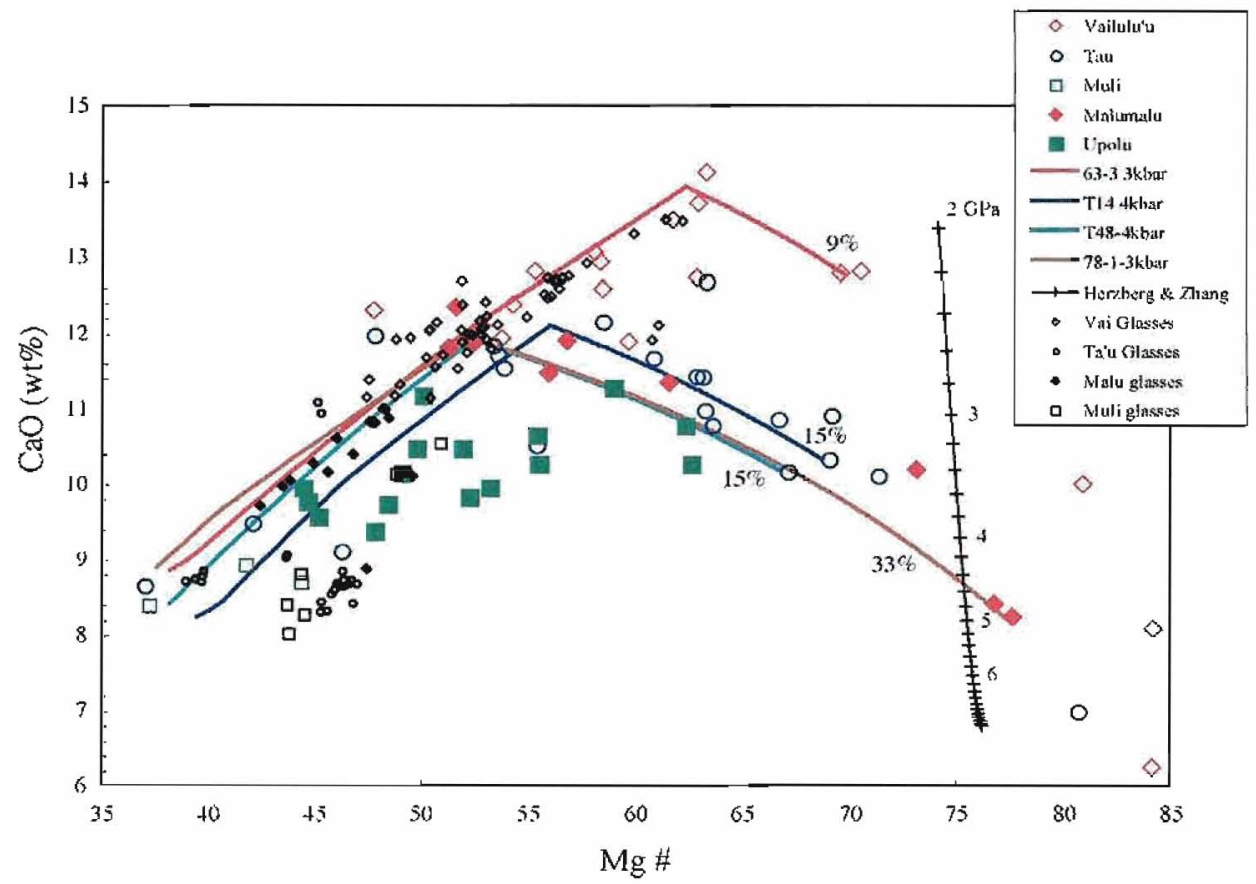

Figure 2-4. CaO plotted with Mg\#'s for Samoan lavas. Mg\# is calculated as molar percentage of $\mathrm{Mg} /\left(\mathrm{Mg}+\mathrm{Fe}^{2+}\right)$ where $\mathrm{Fe}^{2+}$ is taken to be $85 \%$ of reported $\mathrm{FeO}$. Compositions of primary melts from fertile peridotite are plotted using algoritbms from Herzberg and Zhang (1996) in the pressure range of 2-8 GPa; tic marks are every $0.2 \mathrm{GPa}$. Crystal fractionation trends have been calculated using pMELTS at pressures of 3 and $4 \mathrm{kbar}$ for best fits to compositional trends starting with some of the most MgO-rich lavas. Mass of olivine crystallized (expressed as a percent of the total initial mass) before clinopyroxene saturation is noted at the high $\mathrm{Mg \#}$ end of the liquid Iines of descent. Primary melts can be interpreted to have integrated depths of melting from $2.5-6 \mathrm{GPa}$, but $\mathrm{CaO}$ variations in the lavas more likely represent $\mathrm{CaO}$ contents of a heterogeneous mantle source. Plot includes data from Hauri and Hart (1997) for Savai'i lavas. 


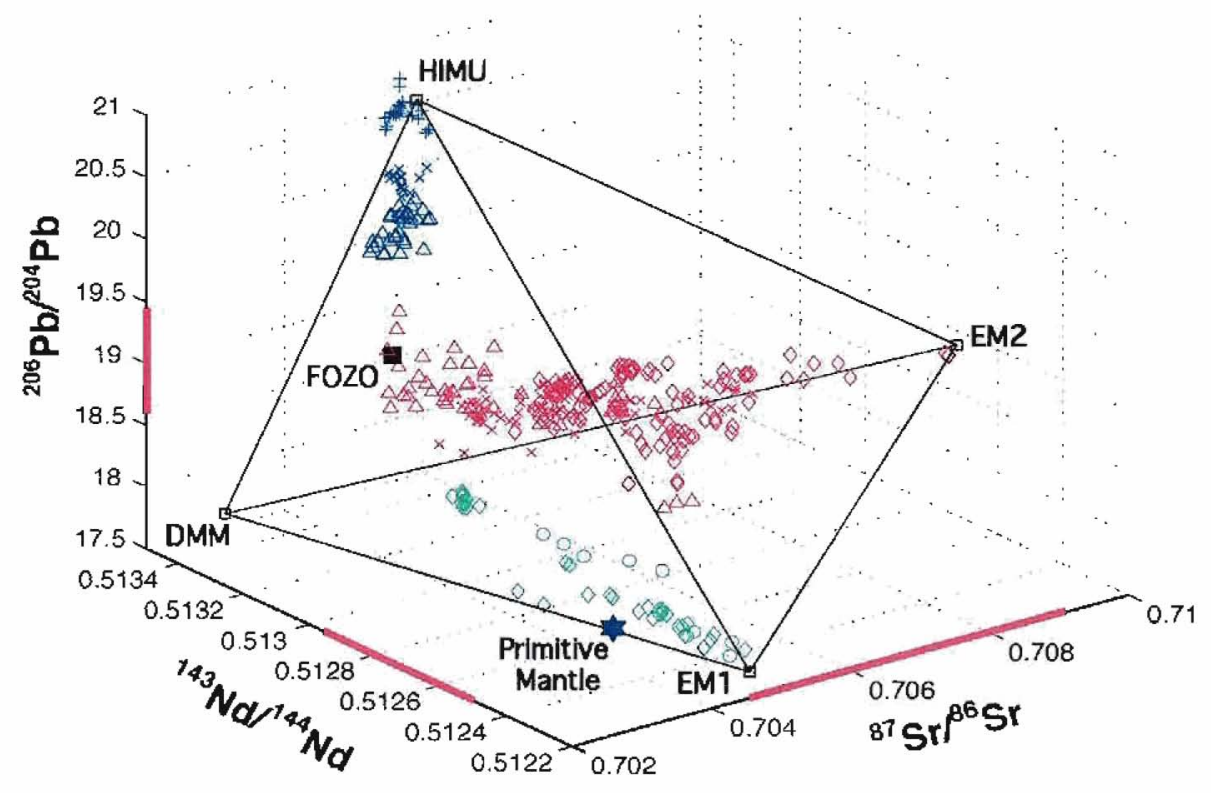

Figure 2-5, Mantle tetrahedron of Hart et al. (1992). Arrays from endmember defining island chains have been plotted using the GEOROC database and data presented in this manuscript. Island chains plotted for HIMU are in blue and include Tubuaii ( $\times$ ), Mangaia (+) and St. Helena (A). EM1 islands are in green and include Pitcairn (0) and Walvis Ridge (O). EM2 islands are in red and include Samoa (0), Societies (x), and the Marquesas $(\triangle)$. Red bars along the axes mark the range of values for the Samoan Islands. EM2 has been exrended from its previous coordinate (Zindler and Hart, 1986) to values for ${ }^{87} \mathrm{Sr}{ }^{86} \mathrm{Sr},{ }^{143} \mathrm{Nd} /{ }^{144} \mathrm{Nd}$, and ${ }^{206} \mathrm{~Pb} /{ }^{204} \mathrm{~Pb}$ at $0.7090,0.5125$, and 19.3 , respectively. 


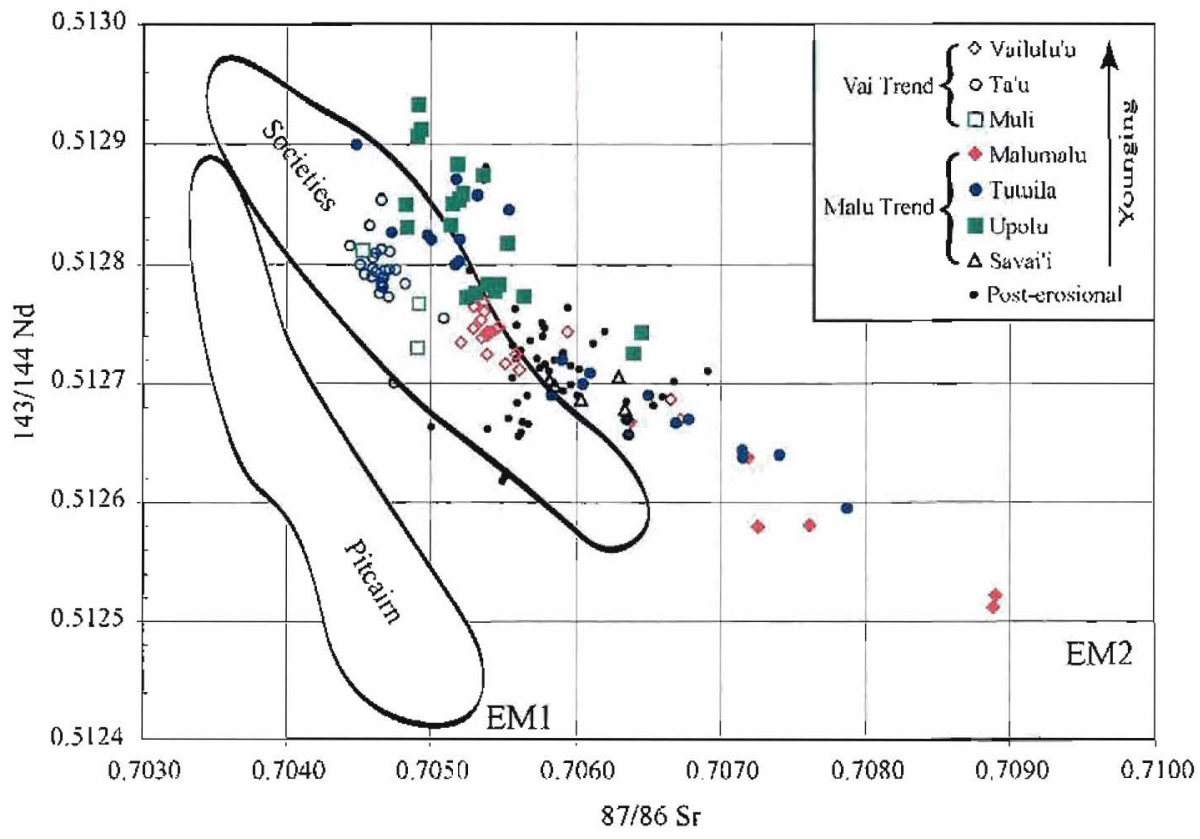

Figure 2-6. Sr and Nd isotopes for Samoan lavas. This as well as other isotope plots includes data from Wright and White (1987), Farley et al. (1992), and Hauri and Hart (1993). The legend here applies to all other isotope plots. The Vai Trend and Malu Trend correspond to topographic ridges of the volcanic chain (see Fig. 2). Savai'i samples marked with triangles are all from the Fagaloa Volcanic series. Post-erosional lavas include samples from Upolu and Savai'i. Fields for the Societies and Pitcairn were obtained from the GEOROC database. Coordinates for Globally Subducting Sediment (GLOSS) and local Tongan sediment are from Plank and Langmuir (1998). 


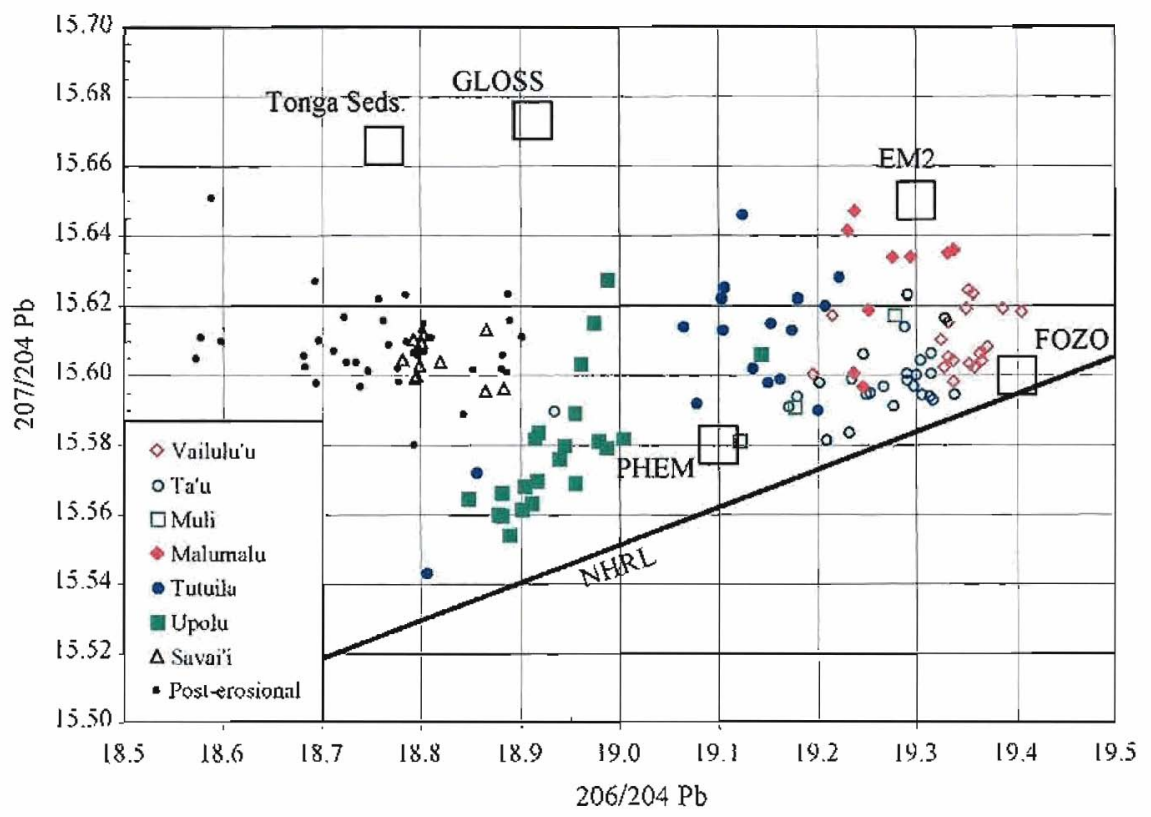

Figure 2-7. Plot of ${ }^{206} \mathrm{~Pb} /{ }^{204} \mathrm{~Pb}$ with ${ }^{207} \mathrm{~Pb} /{ }^{204} \mathrm{~Pb}$ of Samoan lavas. The Northern Hemisphere Reference Line (NHRL) Lies significantly below the EM2 coordinate. Here, the Vai and Malu topographic lineaments can be distinguished as separate isotopic trends. Note how the post-erosional lavas are askew to the overall array of shield lavas. GLOSS = Globally Subducting Sediment (Plank and Langmuir, 1998); PHEM = Primtive Helium Mantle (Farley et al., 1992). Hauri et al. (1993) xenolith data derives from cpx and glass separates from Savaiian xenoliths. See Figure 6 for other references. 


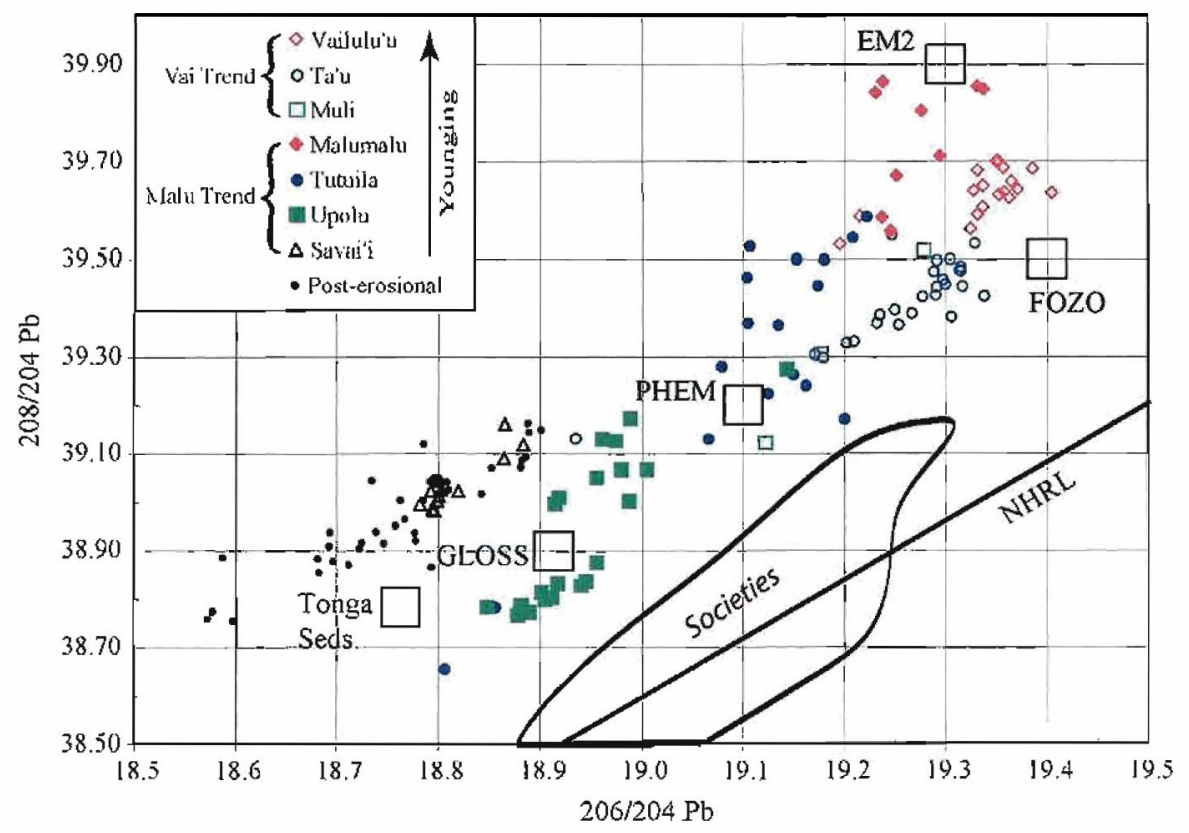

Figure 2-8. Plot of ${ }^{206} \mathrm{~Pb} /{ }^{204} \mathrm{~Pb}$ and ${ }^{208} \mathrm{~Pb} /{ }^{204} \mathrm{~Pb}$ of Samoan lavas. Again, the Vai and Malu Trends are separated into two isotopic arrays. Along each trend, the age of volcanoes increases in the direction of lower ${ }^{206} \mathrm{~Pb} /{ }^{204} \mathrm{~Pb}$ and ${ }^{208} \mathrm{~Pb} /{ }^{204} \mathrm{~Pb}$. See Figure 6 for references. 


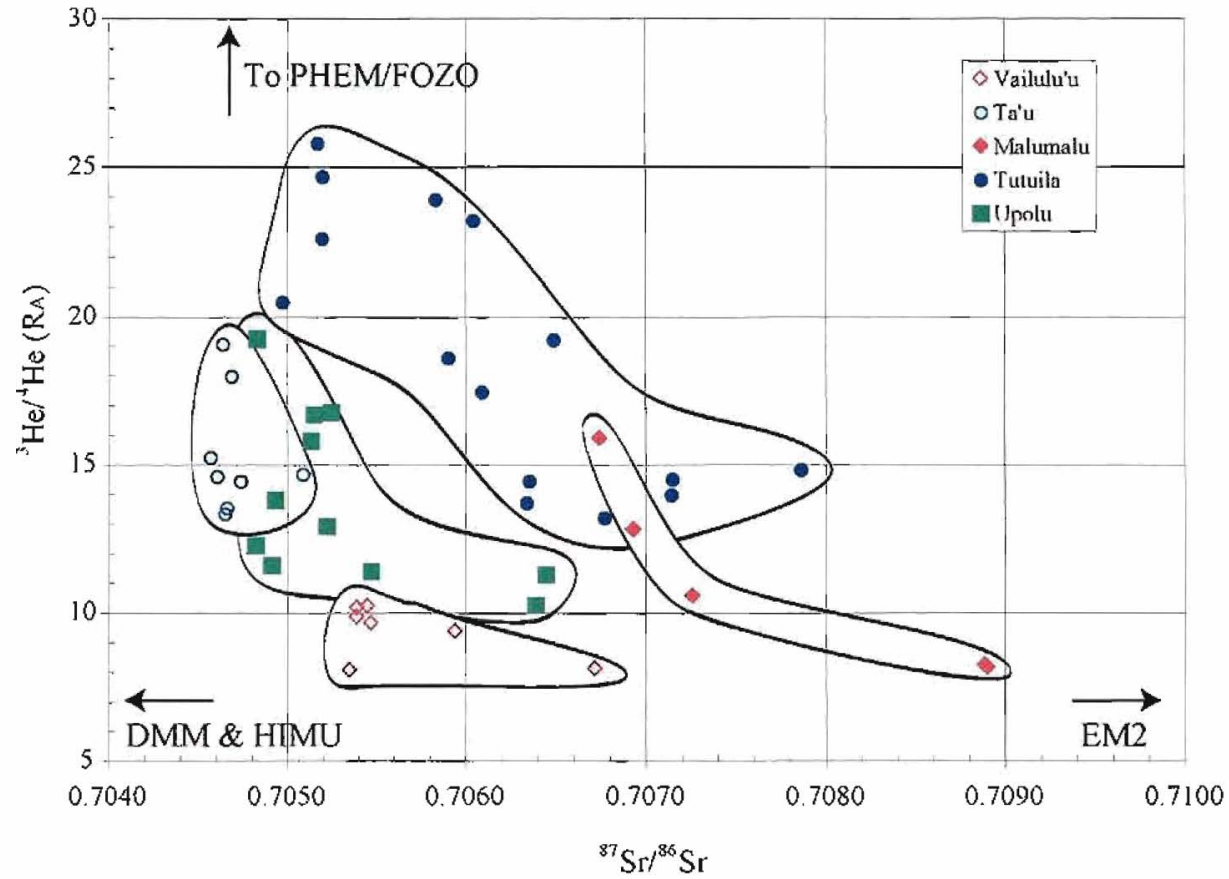

Figure 2-9. Plot of ${ }^{87} \mathrm{St} /{ }^{86} \mathrm{Sr}$ compositions of Samoan basalts with ${ }^{3} \mathrm{He} /{ }^{4} \mathrm{He}\left(\mathrm{R}_{\mathrm{A}}\right)$ of olivine phenocrysts and submarine glasses obtained from the same basalts. Some Tutuila samples are fran Farley et al. (1992). EM2 is shown here to approach the DMM ${ }^{3} \mathrm{He} /{ }^{4} \mathrm{He}$ value of $-8 \mathrm{R}_{\mathrm{A}}$ at $\mathrm{high}^{87} \mathrm{Sr} r^{86} \mathrm{Sr}$. 

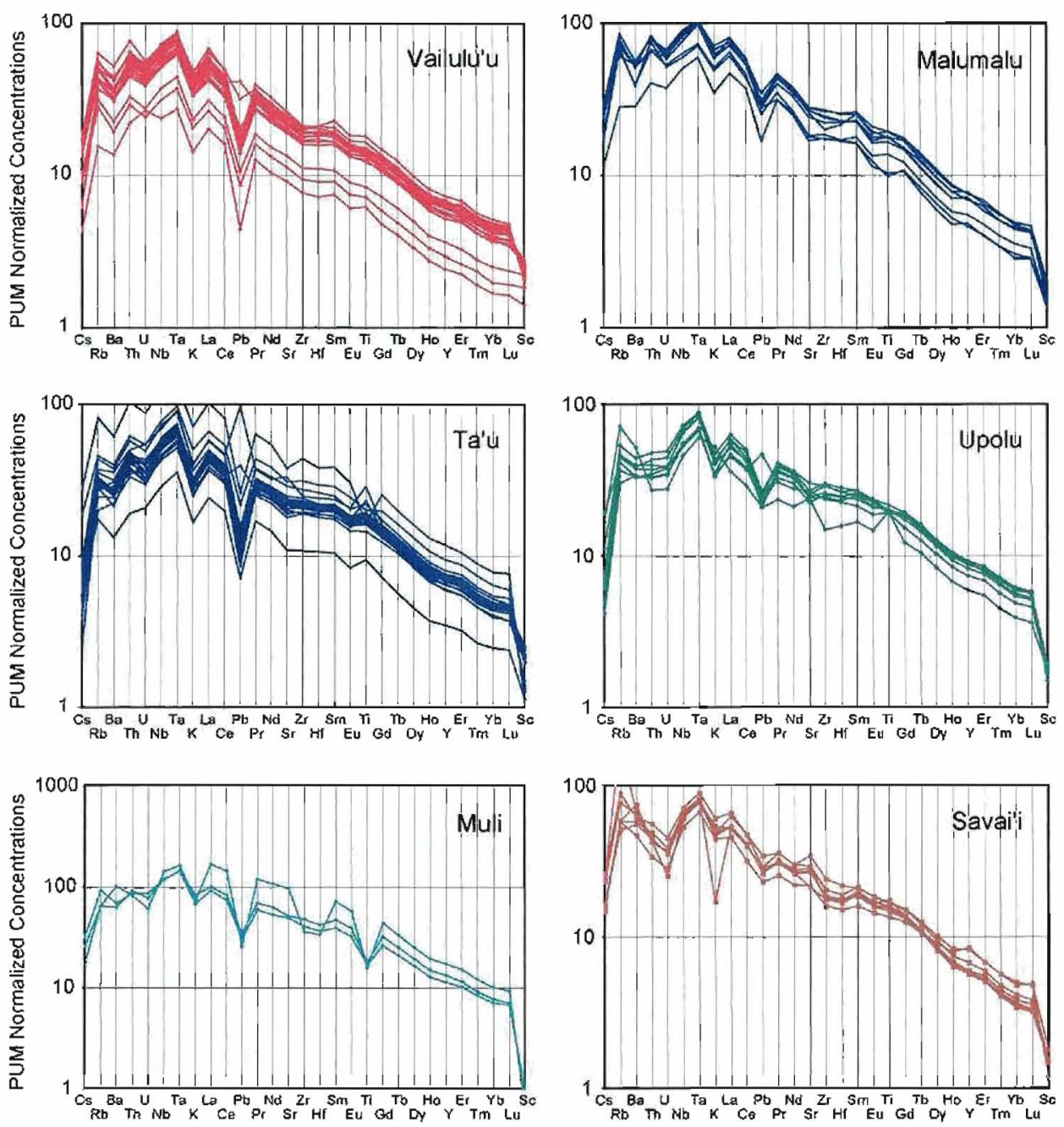

Figure 2-10. Trace element concentrations of Samoan lavas normalized to primitive upper mantle (PUM) of McDonough and Sun (1995). Note the difference in scale for the Muli lavas. Low concentration patterns are typically picrites (for example, the lowest three samples from Vailulu'u and lowest one from Ta'u). The highest concentration sample from Ta'u is T21, with $50 \%$ plagioclase phenocrysts. 


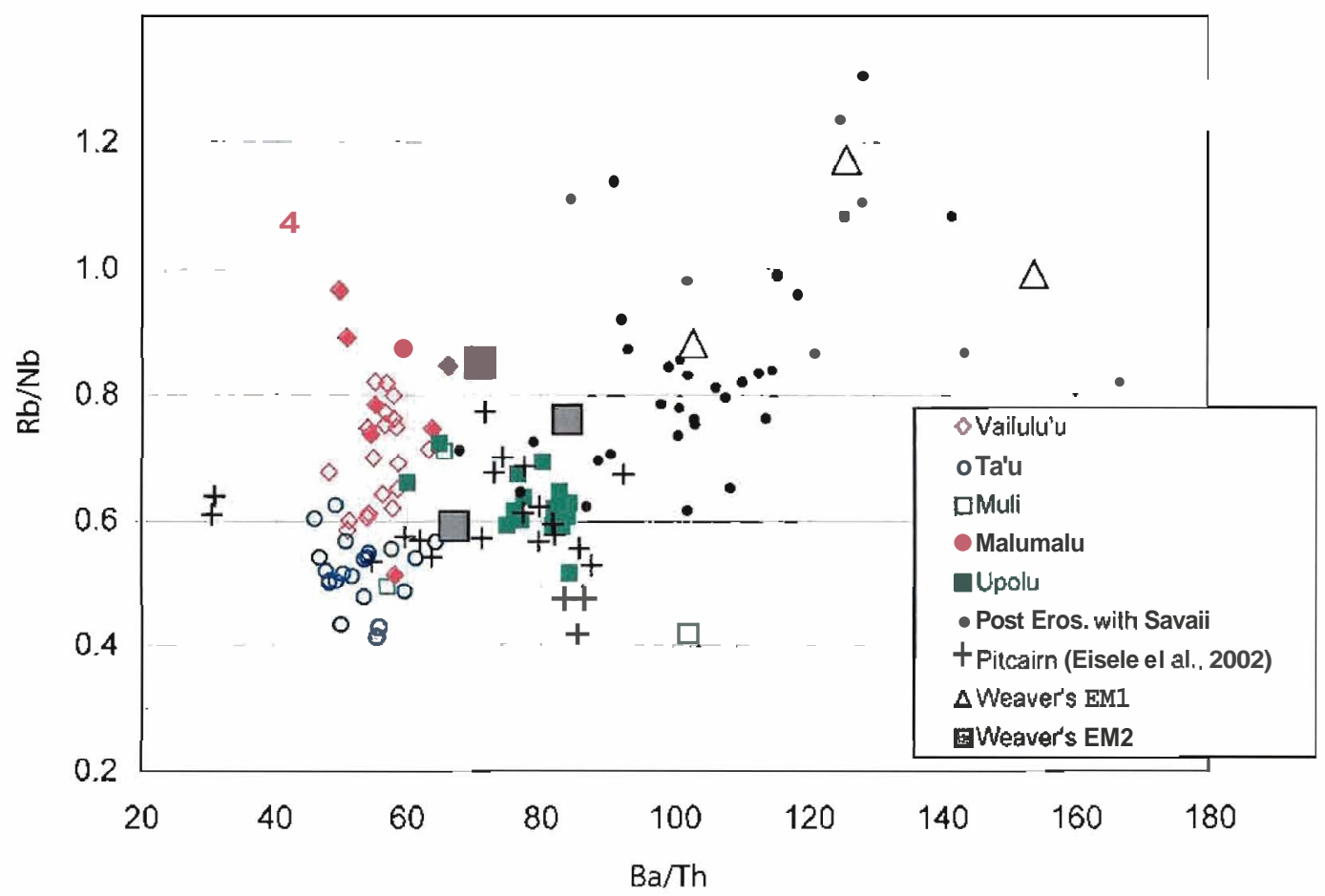

Figure 2-11. Ba/Th vs. Rb/Nb for lavas from Samoa (this study; Regelous et al., unpubl.; Hauri and Hart, 1997) and Pitcairn (Eisele et al., 2003) showing that Weaver's (1991) distinction between EM1 and EM2 trace element characteristics do not hold up to comparisons of lavas from endmember defining island chains (see Fig. 5). Pitcairn and Samoa show complete overlap in $\mathrm{Ba} / \mathrm{Th}$ and $\mathrm{Rb} / \mathrm{Nb}$, whereas Weaver (1991) showed separate fields for EM1 and EMM2 lavas. Plank and Langmuir (1998) report that terrigenous and pelagic sediments have indistinguishable $\mathrm{Ba} / \mathrm{Th}$ ratios, each with a range of $10-220$, with exceptions being rare hydrothermal clays and hemipelagic clays that are heavily-enriched in Ba. Therefore, the reason for initially identifying EM1 and EM2 as having recycled "pelagic" and "terrigenous" sediment, respectively, proves unfounded with further data collection. 


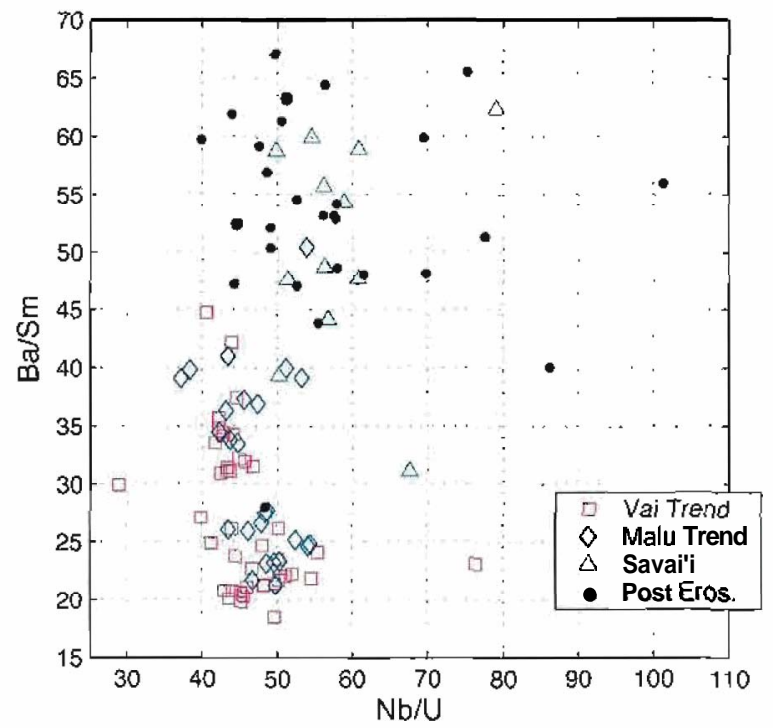

Figure 2-12. Plot of $\mathrm{Nb} / \mathrm{U}$ vs. $\mathrm{Ba} / \mathrm{Sm}$ used to highlight the trace element differences between shield and post-erosional lavas in Samoa. The new Savai'i lavas, sampled from the oldest mapped volcanic series on the island (Fagaloa Series; Kear and Wood, 1959), plot in the same field as post erosional lavas from all dong the Samoan chain. This leads to the conclusion that either post-erosional lavas and shield lavas are the same on Savai'i, or post-erosional volcanism has been unusually extensive. 


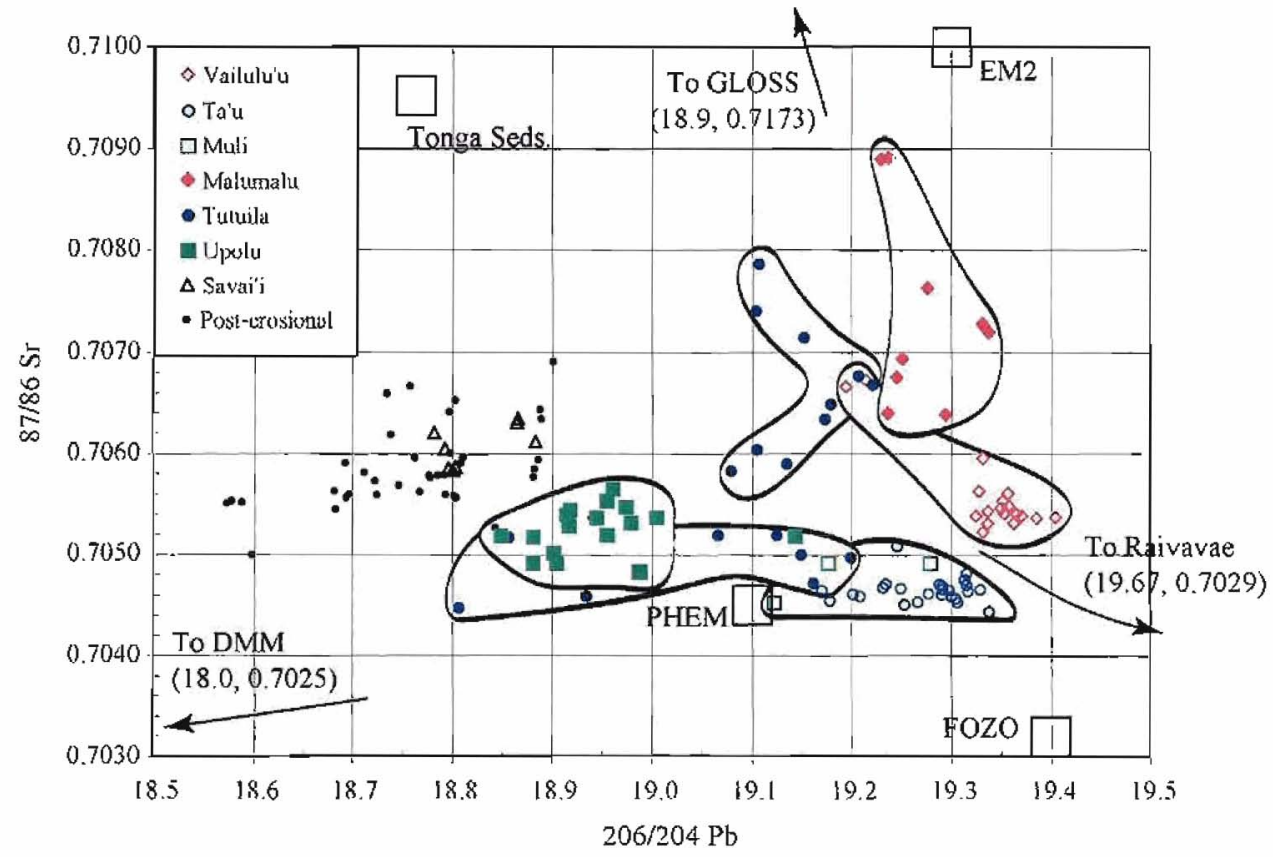

Figure 2-13. $\mathrm{Sr}$ and $\mathrm{Pb}$ isotope plot showing two classes of volcanoes - those which are elongate on the ${ }^{206}{ }^{20 b}{ }^{204} \mathrm{~Pb}$ axis (Upolu, Tutuila Pago shield, Muli, and $\mathrm{Ta}^{3} \mathrm{u}$ ) and those elongate on the ${ }^{87} \mathrm{St} /{ }^{86} \mathrm{Sr}$ axis. Mixing components are identified as DMM, HTMU, EM2 and the high ${ }^{3} \mathrm{He} /{ }^{4} \mathrm{He}$ reservoir, PHEM/FOZO. See Figure 6 for references. 


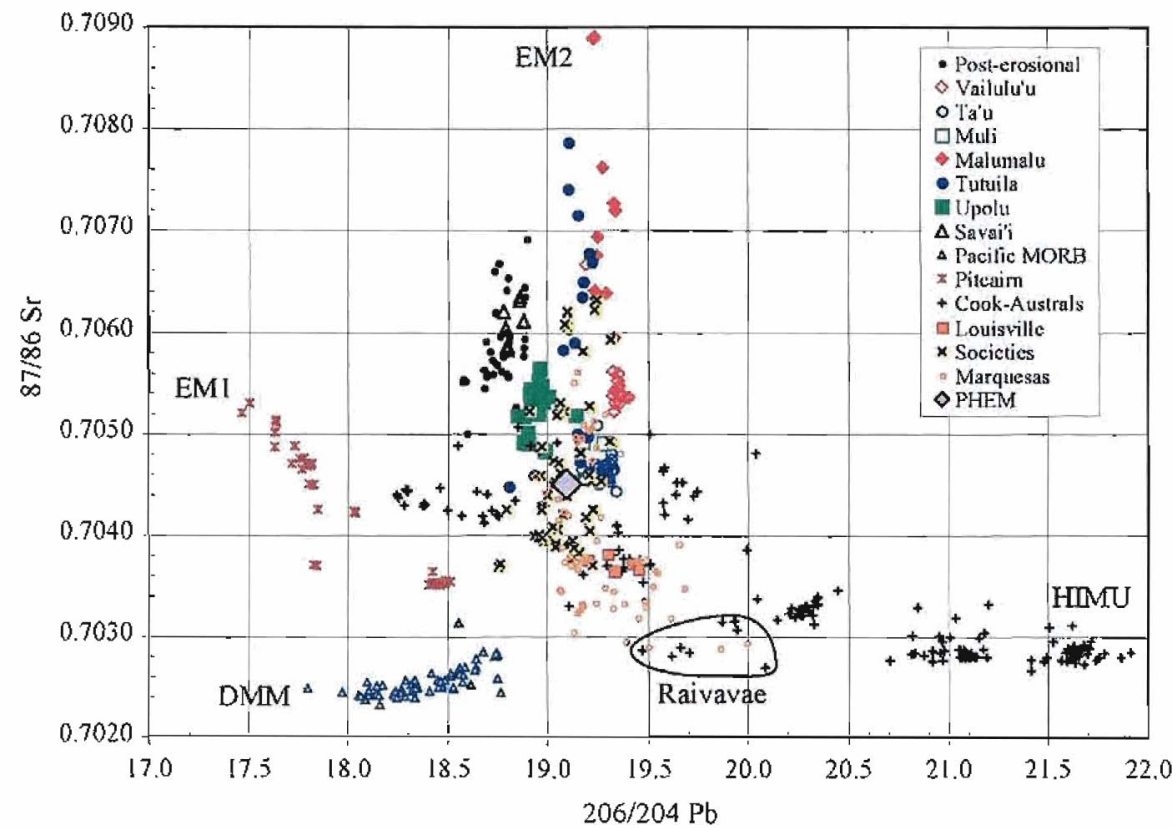

Figure 2-14. Plot showing $\mathrm{Sr}$ and $\mathrm{Pb}$ isotopic compositions for ocean islands of the Pacific Ocean. Data has been compiled from this study and the GEOROC database. EM2 dominates the spread in composition for the volcanoes Malumalu and Tutuila. Upolu volcano has a significant DMM component and Vailulu'u and Ta'u have been contaminated by HIMU from the Cook-Austral under-plated Pacific lithosphere. 


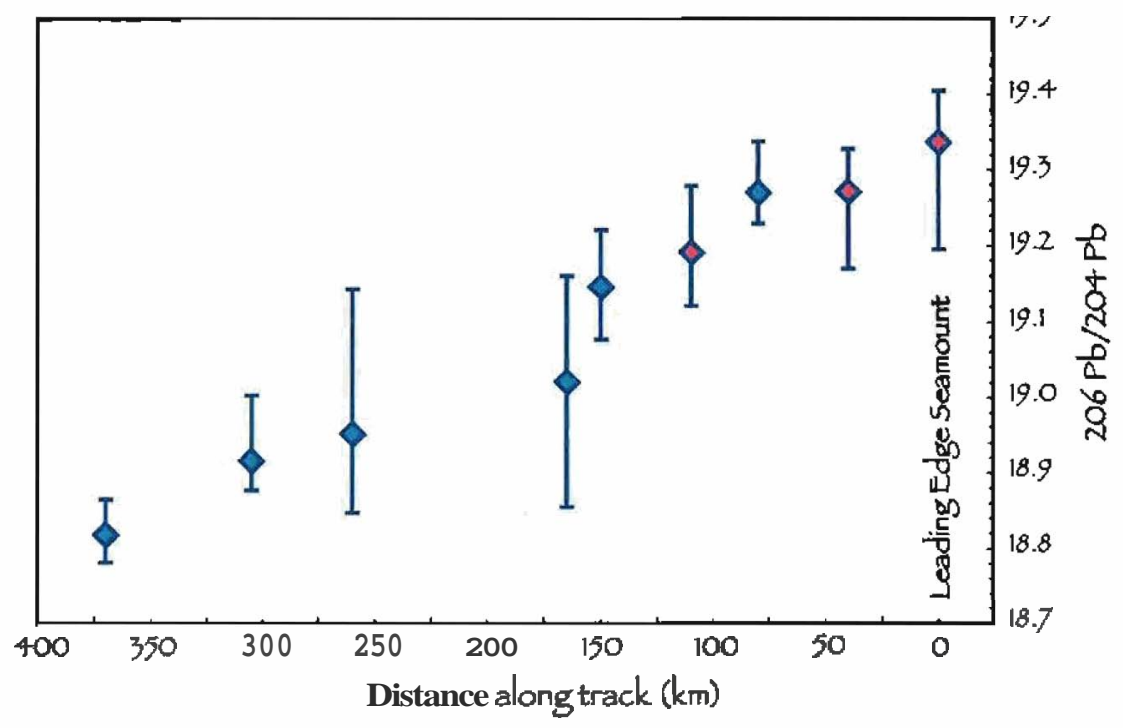

Figure 2-15. Plot showing a systematic increase in ${ }^{206} \mathrm{~Pb} /{ }^{204} \mathrm{~Pb}$ with eastward younging of volcanoes. Distance is measured from the zero-aged leading edge seamount, Vailulu'u. The "oldesr" volcano (at a distance of $370 \mathrm{~km}$ from Vailulu'u) is Savai'i, though no lavas have been shown to be as old as the theoretical $5 \mathrm{Myr}$ age of the island as suggested fram age progression models. High ${ }^{206} \mathrm{~Pb} /{ }^{204} \mathrm{~Pb}$ values are found in EM2 and HLMU; low ${ }^{206} \mathrm{~Pb} /{ }^{204} \mathrm{~Pb}$ values are found in $\mathrm{DMM}$. The increase in ${ }^{206} \mathrm{~Pb} /{ }^{204} \mathrm{~Pb}$ with time is therefore a waning of the DMM component in Samoan lavas. 


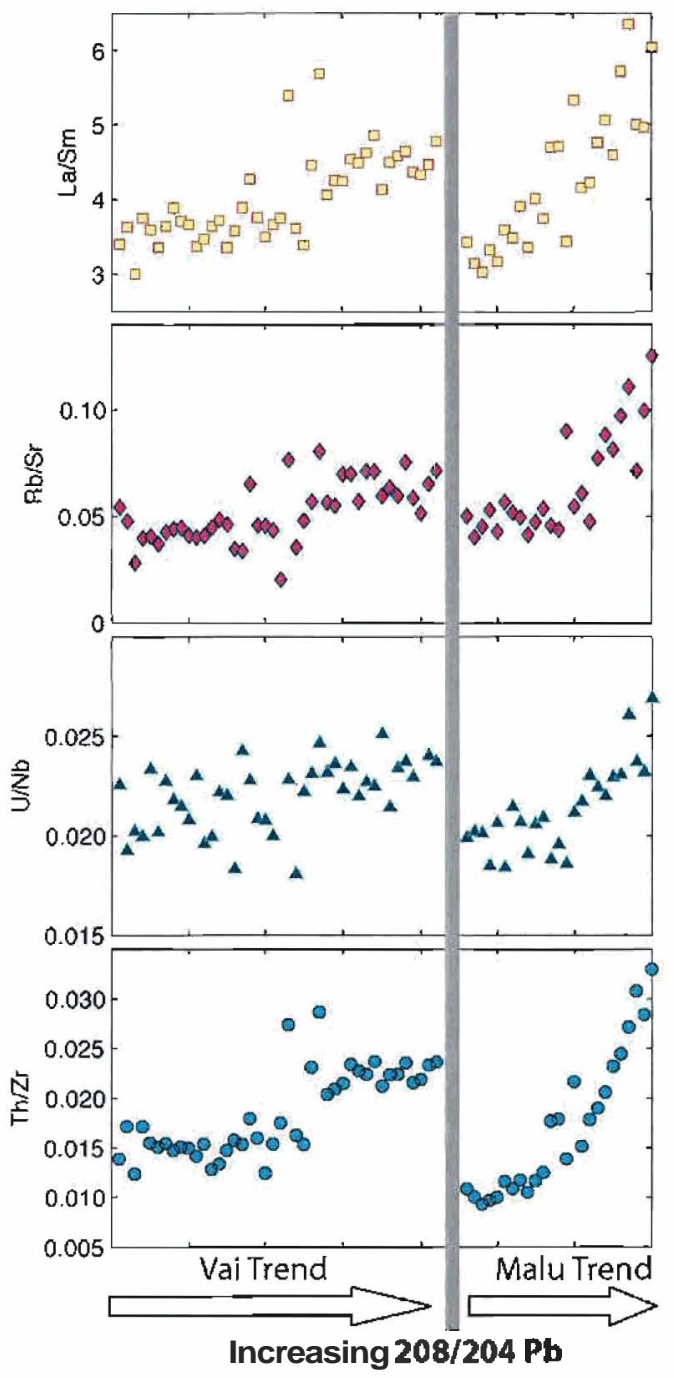

Figure 2-16. Trace element ratios of Samoan lavas, with the more incompatible element in the numerator, showing correlation with ${ }^{208} \mathrm{~Pb} /{ }^{204} \mathrm{~Pb}$ isotopic compositions. The Vai and Malu Trends have been separated into two groups, each sorted by increasing ${ }^{208} \mathrm{~Pb} /{ }^{204} \mathrm{~Pb}$, and plotted with trace element ratios. 

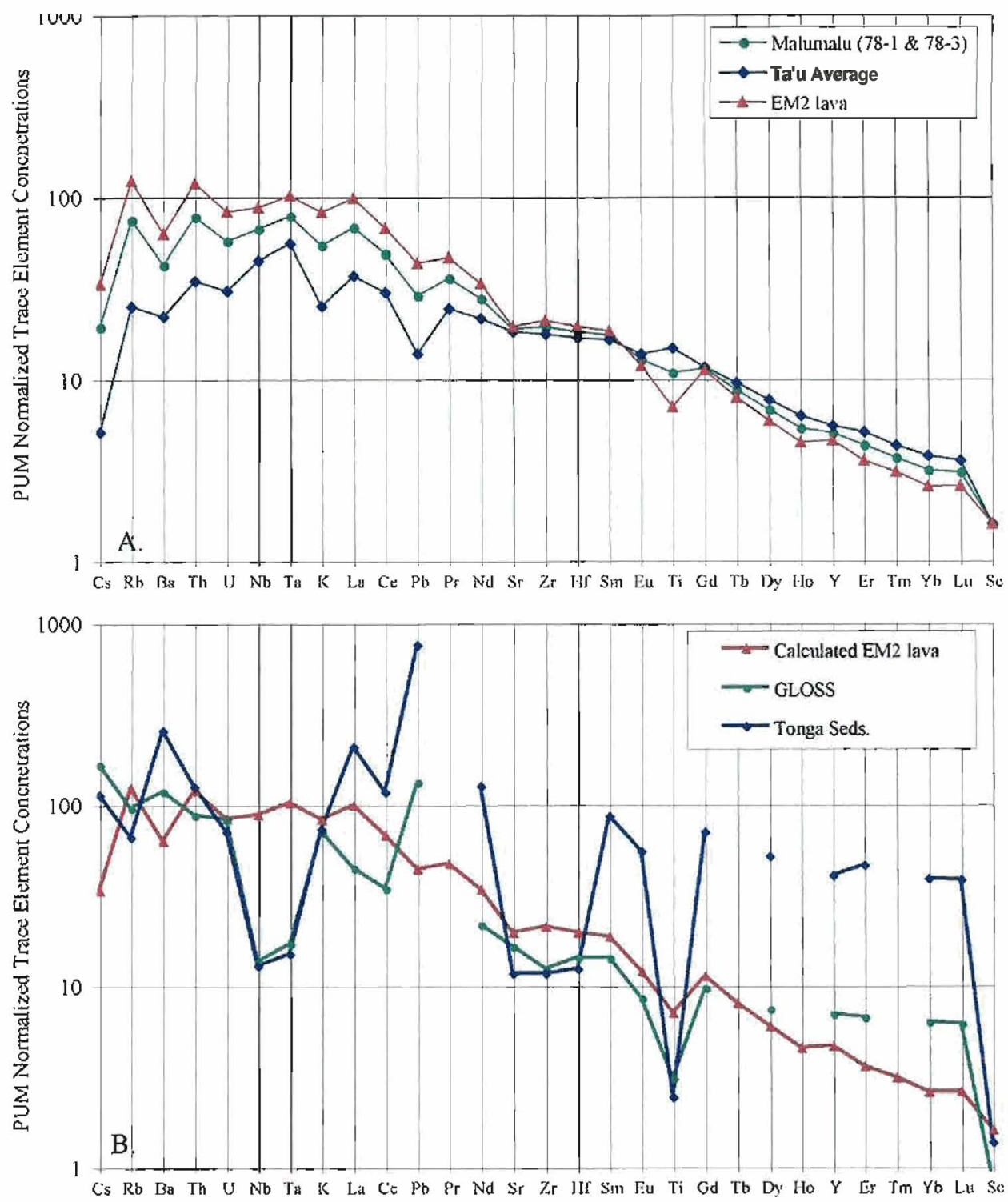

Figure 2-17. Spidergrams in a) show the average of Ta'u favas, the average of the two most enriched Maluraalu lavas, and a calculated EM2 lavas based on extrapolation between Ta'u and Malumalu trace element patterns shown here. All lavas have been corrected for olivine fractionation. In b), the calculated EM2 lava is compared to trace element patterns for globally subducting sediment (GLOSS) and a local Tongan sediment (both from Plank and Langmiur, 1998). Clearly, the trace element patterns between the EM2 lava and sediment are a near-zero match. 

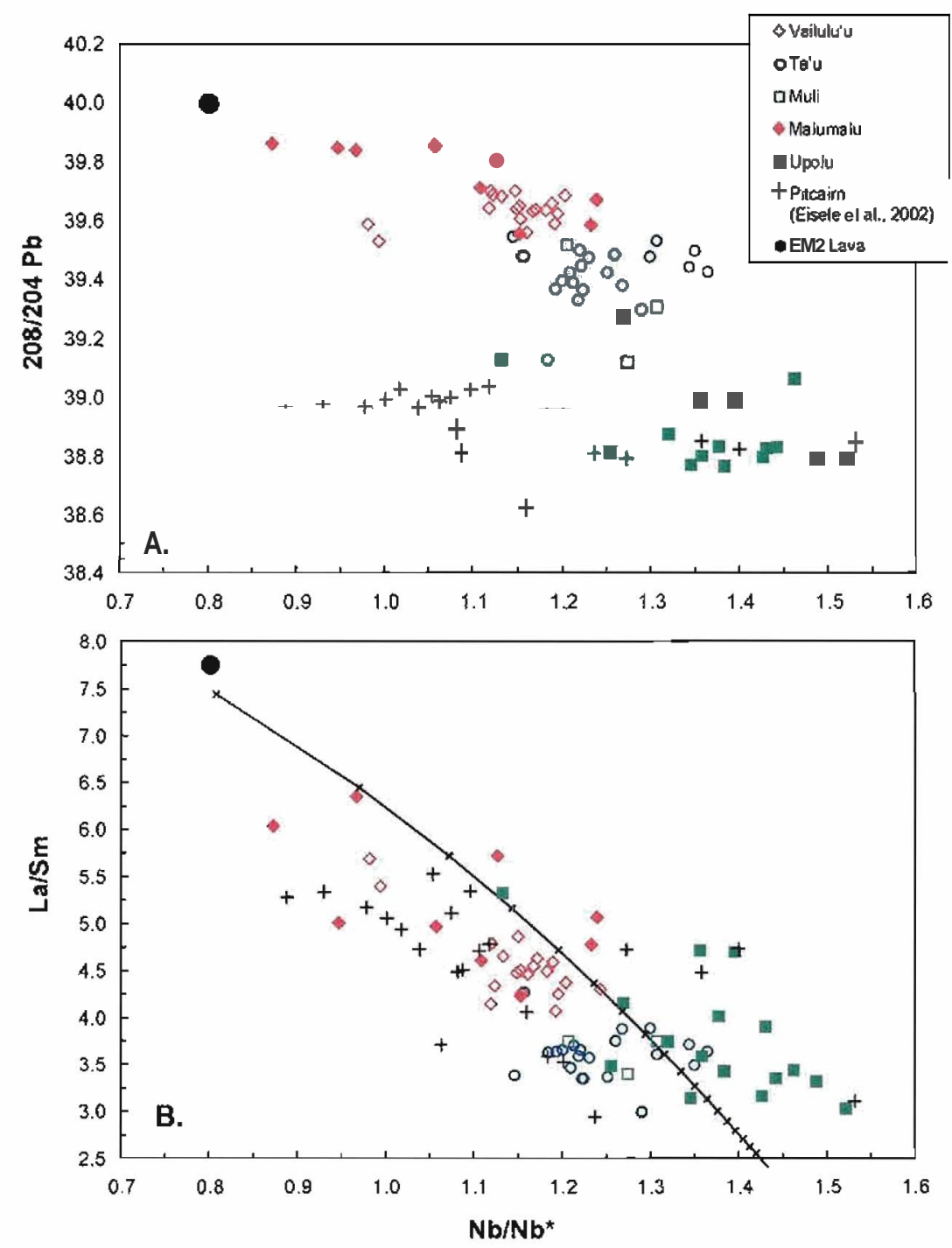

Figure 2-18. $\mathrm{Nb} / \mathrm{Nb}^{*}$ (calculated as $\mathrm{Nb} \mathrm{N}_{\mathrm{N}} / \mathrm{N}\left(\mathrm{Th}_{\mathrm{N}} \times \mathrm{La}_{\mathrm{N}}\right)$, as in Eisele et al. [2002]) plotted with a) ${ }^{208} \mathrm{~Pb} /{ }^{204} \mathrm{~Pb}$ and b) La/Sm, of Samoan Iavas and Pitcairn lavas (from Eisele et al., 2002). Pitcairn lavas have little source variation, as seen by a narrow range in ${ }^{208} \mathrm{~Pb} /{ }^{204} \mathrm{~Pb}$, but they have a range in $\mathrm{Nb} / \mathrm{Nb}^{*}$ and $\mathrm{La} / \mathrm{S}$ s that is nearly identical to Samoa. This indicates that varying degrees of melting of the same source can provide a wide range of trace element ratios otherwise interpreted to be source variations. The negative correlation in Samoa shows that at small degrees of melting (i.e. high La/Sm and low Nb/Nb*), the enriched component may be preferentially sampled from the mantle. The melting curve is for bacth melting of a mantle with the following concentrations in $\mathrm{ppm}$ : $\mathrm{Tb}=0.032, \mathrm{Nb}=0.457, \mathrm{La}=0.32, \mathrm{Sm}=0.326$. D values for these elements are respectively $0.00038,0.0043,0.0045,0.04$. Tick marks are every $0.1 \%$ melting, increasing toward low $\mathrm{La} / \mathrm{Sm}$. 


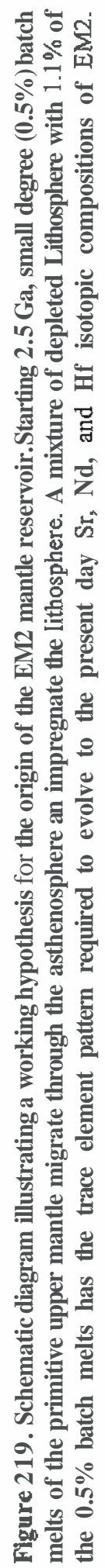




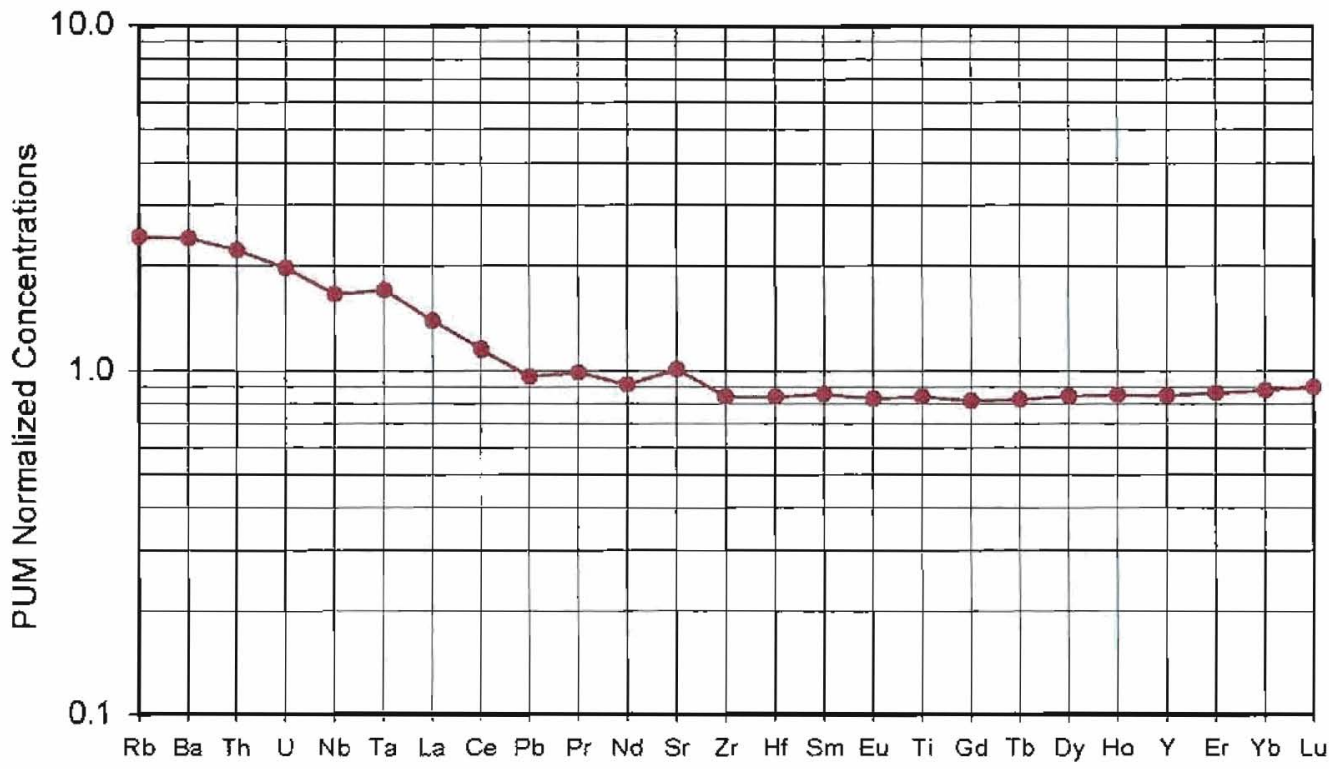

Figure 2-20. Calculated trace element pattern for the EM2 source. a theoretical $2.5 \mathrm{Ga}$, a $0.5 \%$ batch melt from a primitive upper mantle source has been calculated with a combination of garnet peridotite D values (weighted $72 \%$ ) and spinel peridotite D values (weighted 28\%) from a compilation by Kelemen et al. (2003). Exceptions to Kelemen's $D$ values are as follows: $D^{R b}=0.0001$, and $D^{0}=0.0016$ for both garnet and spinel field melting; for garnet melting, $\mathrm{D}^{\mathrm{Th}}=0.00038, \mathrm{D}^{\mathrm{Zs}}=0.05$, and $\mathrm{D}^{\mathrm{HS}}=0.08$; for spinel melting, $D^{T h}=0.0011$. Mixing of $1.1 \%$ of this melt into a semi-depleted lithosphere results in the trace element pattern shown. 


\section{Tables}

Table 2-1. 40/39 Argon Ages from Upolu and Savai'i, Western Samoa

\begin{tabular}{|c|c|c|c|c|c|}
\hline $\begin{array}{c}\text { Sample } \\
\text { Number }\end{array}$ & Location & $\begin{array}{l}\text { Steps Used/ } \\
\text { Total Steps }\end{array}$ & $\begin{array}{c}{ }^{39} \mathrm{Ar} \\
\text { Fraction } \\
\text { Used }\end{array}$ & $\begin{array}{l}40139 \text { Total } \\
\text { Fusion (my) }\end{array}$ & $\begin{array}{l}\text { Weighted } \\
\text { Plateau } \\
\text { (my) }\end{array}$ \\
\hline U10 & $\begin{array}{l}\text { Upolu, A'ana } \\
\text { Shield } \\
\text { Upolu, A'ana }\end{array}$ & $5 / 7$ & $3.1-98.8 \%$ & $0.972 \pm 0.020$ & $0.933 \pm 0.011$ \\
\hline U12 & Shield & $5 / 6$ & $0-92.8 \%$ & $2.68 \pm 0.03$ & $2.65 \pm 0.02$ \\
\hline S11 & $\begin{array}{c}\text { Savai'i, Manase } \\
\text { Shield } \\
\text { Savai'i, Manase }\end{array}$ & $3 / 6$ & $4.4-64.7 \%$ & $0.900 \pm 0.122$ & $0.236 \pm 0.052$ \\
\hline S23 & $\begin{array}{c}\text { Shield } \\
\text { Savai'i, Vanu }\end{array}$ & $5 / 6$ & $0-91.3 \%$ & $0.590 \pm 0.024$ & $0.386 \pm 0.014$ \\
\hline 91SVK-7 & River Shield & - & - & $2.05 \pm 0 . ?$ & - \\
\hline
\end{tabular}

- Step-release heating from $600^{\circ}-1400^{\circ} \mathrm{C}$

- 2-sigma errors include measurement uncertainties, and uncertainty in J-value (flux gradient from FCT3 biotite monitor), but nor uncertainty in monitor age.

- $9 ! \mathrm{SVK} \cdot 7$ is a trachyte cobble from the lower Vanu River, analyzed by K. A. Farley 
Table 2-2. Sample information and chemical data for Samoan basalts

\begin{tabular}{|c|c|c|c|c|c|c|c|}
\hline $\begin{array}{l}\text { Volcano } \\
\text { Sainple }\end{array}$ & $\begin{array}{c}\text { Vailulu'u } \\
\text { 63-3 }\end{array}$ & $\begin{array}{c}\text { Vailulu'u } \\
63-5\end{array}$ & $\begin{array}{c}\text { Vailulu'u } \\
63-13 \\
\end{array}$ & $\begin{array}{c}\text { Vailulu'u } \\
64-1\end{array}$ & $\begin{array}{c}\text { Vajlulu'u } \\
68-3\end{array}$ & $\begin{array}{c}\text { Vailulu'u } \\
68-10 \\
\end{array}$ & $\begin{array}{c}\text { Vailulu'u } \\
68-11 \\
\end{array}$ \\
\hline Latirude ( $\left.{ }^{\circ} \mathrm{S}\right)$ & 14.218 & 14.218 & 14.218 & 14.260 & 14.217 & 14.217 & 14.217 \\
\hline Longitude $\left({ }^{\circ} \mathrm{W}\right)$ & 169.059 & 169.059 & 169.059 & 169.056 & 169.064 & 169.064 & 169.064 \\
\hline Water Depth (m) & 920 & 920 & 920 & 2630 & 780 & 780 & 780 \\
\hline Phenocrysts & $10 \% 01$ & $\begin{array}{l}5 \% \mathbf{O} \\
\operatorname{Tr} \mathrm{Cpx}\end{array}$ & Aphyric & $\begin{array}{c}3 \% \text { Ol } \\
2 \% \text { Cpx }\end{array}$ & $10 \% \mathrm{O}$ & Aphytic & $60 \% \mathrm{OI}$ \\
\hline Major elements & $(w t \%)$ & & & & & & \\
\hline $\mathrm{SiO}_{2}$ & 48.29 & 48.07 & 47.16 & 47.71 & 47.84 & 48.18 & 45.61 \\
\hline $\mathrm{Al}_{2} \mathrm{O}_{3}$ & 11.88 & 13.42 & 14.76 & 13.38 & 11.86 & 14.90 & 5.64 \\
\hline $\mathrm{TiO}_{2}$ & 2.52 & 2.67 & 3.01 & 2.80 & 2.55 & 3.00 & 1.24 \\
\hline $\mathrm{FeO}^{*}$ & 10.03 & 10.19 & 11.59 & 10.60 & 10.51 & 11.34 & 11.21 \\
\hline $\mathrm{MnO}$ & 0.17 & 0.17 & 0.18 & 0.17 & 0.17 & 0.19 & 0.17 \\
\hline $\mathrm{CaO}$ & 12.78 & 13.70 & 12.37 & L3.48 & 12.75 & 12.09 & 6.23 \\
\hline $\mathrm{MgO}$ & 10.94 & 8.26 & 6.57 & 8.15 & 10.68 & 6.06 & 28.34 \\
\hline $\mathrm{K}_{2} \mathrm{O}$ & 0.96 & 0.96 & 1.28 & 1.07 & 0.99 & 1.13 & 0.41 \\
\hline $\mathrm{Na}_{2} \mathrm{O}$ & 2.13 & 2.24 & 2.72 & 2.31 & 2.36 & 2.76 & 1.00 \\
\hline $\mathrm{P}_{2} \mathrm{O}_{5}$ & 0.29 & 0.32 & 0.37 & 0.33 & 0.29 & 0.36 & 0.14 \\
\hline $\mathrm{Mg} \#$ & 69.58 & 62.96 & 54.31 & 61.72 & 68.07 & 52.85 & 84.13 \\
\hline Trace Elements & (ppm) & & & & & & \\
\hline $\mathrm{Ni}$ & 285 & 110 & 59 & 104 & 285 & 47 & 1067 \\
\hline $\mathrm{Cr}$ & 879 & 498 & 110 & 455 & 822 & 66 & 2771 \\
\hline $\mathrm{V}$ & 299 & 335 & 339 & 329 & 300 & 351 & 154 \\
\hline $\mathrm{Ga}$ & 16 & 20 & 20 & 19 & 20 & 18 & 6 \\
\hline $\mathrm{Cu}$ & 86 & 59 & 58 & 85 & 82 & 68 & 103 \\
\hline $\mathrm{Zn}$ & 84 & 85 & 95 & 82 & 89 & 94 & 86 \\
\hline Cs & 0.29 & 0.13 & 0.28 & 0.33 & 0.30 & 0.38 & 0.09 \\
\hline $\mathrm{Rb}$ & 24.7 & 22.2 & 33.6 & 29.6 & 26.6 & 24.7 & 9.3 \\
\hline $\mathrm{Ba}$ & 216 & 210 & 279 & 236 & · 218 & 239 & 90 \\
\hline Th & 3.92 & 3.72 & 5.15 & 4.06 & 4.04 & 4.67 & 1.75 \\
\hline $\mathrm{U}$ & 0.85 & 0.82 & 1.07 & 0.87 & 0.87 & 0.98 & 0.54 \\
\hline $\mathrm{Nb}$ & 35.41 & 34.74 & 45.14 & 38.97 & 36.44 & 42.41 & 15.57 \\
\hline $\mathrm{Ta}$ & 2.41 & 2.32 & 3.08 & 2.59 & 2.50 & 2.90 & 1.01 \\
\hline $\mathrm{La}$ & 28.82 & 28.95 & 37.44 & 31.12 & 29.29 & 33.97 & 13.04 \\
\hline $\mathrm{Ce}$ & 58.36 & 58.29 & 74.35 & 63.12 & 58.67 & 67.35 & 26.90 \\
\hline $\mathrm{Pb}$ & 2.41 & 2.08 & 2.76 & 3.04 & 2.50 & 2.96 & 0.66 \\
\hline $\operatorname{Pr}$ & 6.84 & 7.00 & 8.74 & 7.58 & 6.86 & 8.07 & 3.19 \\
\hline $\mathrm{Nd}$ & 27.84 & 29.05 & 35.38 & 3129 & 29 & 32.91 & 12.96 \\
\hline $\mathrm{Sr}$ & 378 & 404 & 470 & 424 & 387 & 434 & 181 \\
\hline $\mathrm{Zr}$ & 168 & 178 & 218 & 189 & 168 & 202 & 80 \\
\hline $\mathrm{Hf}$ & 4.46 & 4.69 & 5.76 & 5.13 & 4.43 & 5.45 & 2.03 \\
\hline $\mathrm{Sm}$ & 6.45 & 6.80 & 7.83 & 7.33 & 6.46 & 7.62 & 3.01 \\
\hline $\mathrm{Eu}$ & 2.03 & 2.13 & 2.45 & 2.26 & 1.99 & 2.39 & 0.93 \\
\hline $\mathrm{Gd}$ & 5.75 & 6.16 & 7.09 & 6.72 & 5.81 & 6.83 & 2.58 \\
\hline $\mathrm{Tb}$ & 0.88 & 0.92 & 1.08 & 1.02 & 0.86 & 1.06 & 0.40 \\
\hline Dy & 4.90 & 5.17 & 5.88 & 5.68 & 4.83 & 5.95 & 2.24 \\
\hline Ho & 0.87 & 0.94 & 1.10 & 1.01 & 0.88 & 1.11 & 0.41 \\
\hline $\mathrm{Y}$ & 22.08 & 24.09 & 27.50 & 26.43 & 22.46 & 27.93 & 10.47 \\
\hline Er & 2.14 & 2.32 & 2.70 & 2.53 & 2.13 & 2.77 & 0.99 \\
\hline $\mathrm{Tm}$ & 0.28 & 0.30 & 0.35 & 0.33 & 0.28 & 0.36 & 0.13 \\
\hline $\mathrm{Yb}$ & 1.60 & 1.75 & 2.02 & 1.91 & 1.63 & 2.12 & 0.74 \\
\hline $\mathrm{Lu}$ & 0.24 & 0.25 & 0.30 & 0.27 & 0.24 & 0.31 & 0.11 \\
\hline $\mathrm{Sc}$ & 40.4 & 42.6 & 33.4 & 42.2 & 40.9 & 34.0 & 22.8 \\
\hline
\end{tabular}


Table 2-2, page 2.

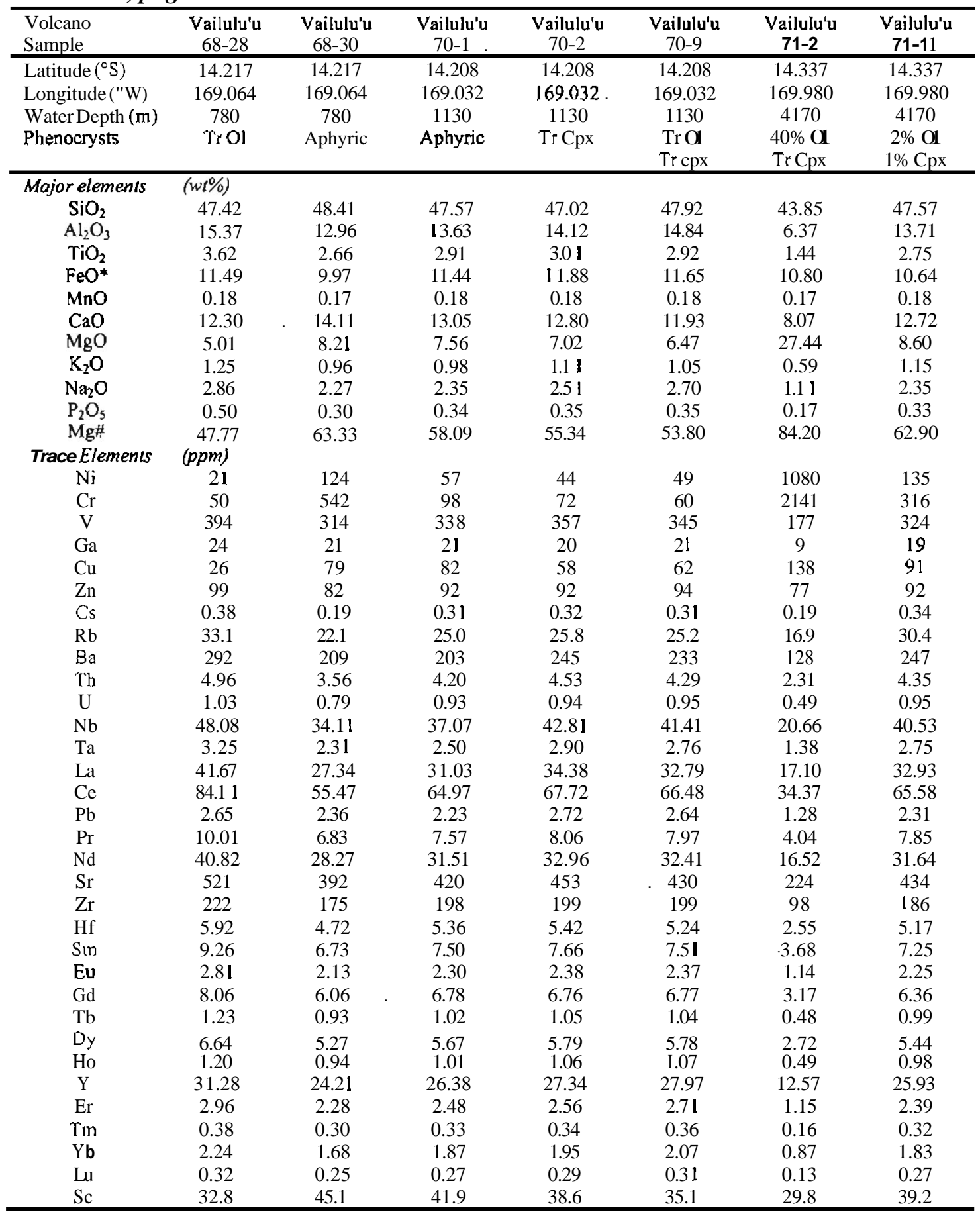


Table 2-2, page 3.

\begin{tabular}{|c|c|c|c|c|c|c|c|}
\hline $\begin{array}{l}\text { Volcano } \\
\text { Sample } \\
\end{array}$ & $\begin{array}{c}\text { Vailulu'u } \\
71-22 \\
\end{array}$ & $\begin{array}{c}\text { Vailulu'u } \\
72-2 \\
\end{array}$ & $\begin{array}{c}\text { Vailulu'u } \\
73-1 \\
\end{array}$ & $\begin{array}{c}\text { Vailulu'u } \\
73-2 \\
\end{array}$ & $\begin{array}{c}\text { Vailulu'u } \\
\mathbf{7 3 - 3} \\
\end{array}$ & $\begin{array}{c}\text { Vailulu'u } \\
73-12 \\
\end{array}$ & $\begin{array}{l}\text { Ta'u } \\
\text { r10 } \\
\end{array}$ \\
\hline Latitude ("S) & 14.337 & 14.184 & 14.214 & 14.214 & 14.214 & 14.214 & 14.218 \\
\hline Longitude $\left({ }^{\circ} \mathrm{W}\right)$ & 169.980 & 169.894 & 169.059 & 169.059 & 169.059 & 169.059 & 169.509 \\
\hline Water Depth(m) & 4170 & 3835 & 960 & 960 & 960 & 960 & \\
\hline Phenocrysts & $40 \% \mathrm{Ol}$ & Aphync & $\operatorname{Tr} C p x$ & $15 \% \mathrm{O}$ & $\begin{array}{r}1 \% \mathrm{Ol} \\
\operatorname{Tr} \mathrm{Cpx} \\
\end{array}$ & $15 \% \mathrm{OI}$ & $\operatorname{Tr} \mathrm{OI}$ \\
\hline Major elements & $(w t \%)$ & & & & & & \\
\hline $\mathrm{SiO}_{2}$ & 45.21 & 45.53 & 47.14 & 47.42 & 46.90 & 47.10 & 46.60 \\
\hline $\mathrm{Al}_{2} \mathrm{O}_{3}$ & 8.13 & 14.10 & 13.97 & 11.29 & 14.12 & 12.07 & 12.41 \\
\hline $\mathrm{TiO}_{2}$ & 1.68 & 3.31 & 2.80 & 2.34 & 2.87 & 2.46 & 3.54 \\
\hline $\mathrm{FeO} *$ & 10.77 & 12.13 & $\mathbf{l} 1.26$ & 10.66 & 11.49 & 10.25 & 12.35 \\
\hline $\mathrm{MnO}$ & 0.17 & 0.19 & 0.18 & 0.17 & 0.18 & 0.18 & 0.19 \\
\hline $\mathrm{CaO}$ & 9.99 & 11.88 & 12.93 & 13.18 & 12.58 & 12.80 & 10.98 \\
\hline $\mathrm{MgO}$ & 21.79 & 8.56 & 7.52 & 11.43 & 7.71 & 11.70 & 10.13 \\
\hline $\mathrm{K}_{2} \mathrm{O}$ & 0.67 & 1.40 & 1.37 & 0.95 & 1.23 & 1.15 & 0.92 \\
\hline $\mathrm{Na}_{2} \mathrm{O}$ & 1.39 & 2.54 & 2.50 & 2.30 & 2.56 & 2.02 & 2.43 \\
\hline $\mathrm{P}_{2} \mathrm{O}_{5}$ & 0.20 & 0.37 & 0.34 & 0.26 & 0.35 & 0.28 & 0.45 \\
\hline $\mathrm{Mg} \#$ & 80.93 & 59.68 & 58.34 & 69.23 & 58.46 & 70.53 & 63.24 \\
\hline Trace Elements & (ppm) & & & & & & \\
\hline $\mathrm{Ni}$ & 778 & 110 & 79 & 303 & 101 & 220 & 214 \\
\hline $\mathrm{Cr}$ & 1687 & 227 & 202 & 840 & 241 & 768 & 579 \\
\hline V & 212 & 367. & 325 & 292 & 328 & 295 & 336 \\
\hline $\mathrm{Ga}$ & 14 & 23 & 14 & 17 & 22 & 17 & 19 \\
\hline $\mathrm{Cu}$ & 156 & 79 & 70 & 109 & 66 & 59 & 72 \\
\hline $2 n$ & 78 & 102 & 86 & 84 & 89 & 77 & 111 \\
\hline Cs & 0.21 & 0.39 & 0.38 & 0.11 & 0.32 & 0.31 & 0.12 \\
\hline $\mathrm{Rb}$ & 19.0 & 29.3 & 38.1 & 24.5 & 33.2 & 30.4 & 19.9 \\
\hline $\mathrm{Ba}$ & 149 & 287 & 347 & 203 & 283 & . 282 & 178 \\
\hline Th & 2.62 & 4.95 & 6.08 & 3.90 & 4.83 & 4.85 & 2.77 \\
\hline $\mathrm{U}$ & 0.56 & $1.1 \mathrm{l}$ & 1.15 & 0.83 & 1.00 & 0.87 & 0.73 \\
\hline $\mathrm{Nb}$ & 24.69 & 47.47 & 46.68 & 34.41 & 44.50 & 38.17 & 35.18 \\
\hline $\mathrm{Ta}$ & 1.64 & 3.18 & 3.09 & 2.31 & 2.93 & 2.53 & 2.52 \\
\hline $\mathrm{La}$ & 20.16 & 38.26 & 44.17 & 27.56 & 36.83 & 36.11 & 29.20 \\
\hline $\mathrm{Ce}$ & 40.44 & 76.30 & 83.63 & 54.86 & 72.25 & 68.75 & 62.19 \\
\hline $\mathrm{Pb}$ & I. .59 & 2.53 & 4.79 & 1.78 & 2.62 & 6.23 & 2.02 \\
\hline $\operatorname{Pr}$ & 4.73 & 9.08 & 9.36 & 6.38 & 8.48 & 7.78 & 8.14 \\
\hline $\mathrm{Nd}$ & 19.03 & 37.20 & 35.97 & 26.50 & 33.93 & 30.18 & 34.70 \\
\hline$S_{r}$ & 267 & 492 & 473 & 360 & 467 & 398 & 437 \\
\hline $\mathrm{Zr}$ & 117 & 221 & 212 & 159 & 204 & 177 & 223 \\
\hline $\mathrm{Hf}$ & $3.1 \mathrm{l}$ & 5.89 & 5.77 & 4.21 & 5.33 & 4.89 & 5.97 \\
\hline $\mathrm{Sm}$ & 4.36 & 8.35 & 7.77 & 6.15 & 7.58 & 6.70 & 8.35 \\
\hline $\mathrm{Eu}$ & 1.38 & 2.60 & 2.36 & 1.92 & 2.36 & 2.07 & 2.55 \\
\hline $\mathrm{Gd}$ & 3.92 & 7.32 & 6.77 & 5.51 & 6.67 & 5.95 & 7.92 \\
\hline $\mathrm{Tb}$ & 0.60 & 1.11 & 1.05 & 0.84 & 1.03 & 0.90 & 1.14 \\
\hline Dy & 3.34 & 6.03 & 5.64 & 4.59 & 5.57 & 4.96 & 6.14 \\
\hline Ho & 0.59 & 1.10 & 1.04 & 0.86 & I.02 & 0.90 & 1.11 \\
\hline $\mathbf{Y}$ & 15.55 & 29.25 & 27.27 & 21.99 & 27.61 & 23.49 & $29.4 \mathrm{I}$ \\
\hline $\mathrm{Er}$ & 1.42 & 2.66 & 2.50 & 2.02 & 2.50 & 2.19 & 2.78 \\
\hline $\mathrm{Tm}$ & 0.19 & 0.35 & 0.33 & 028 & 0.33 & 0.28 & 0.37 \\
\hline $\mathrm{Yb}$ & '1.1 ا l & 2.02 & 1.90 & 1.54 & I. .88 & 1.64 & 2.14 \\
\hline $\mathrm{Lu}$ & 0.16 & 029 & 0.28 & 0.23 & 0.28 & 0.23 & 0.32 \\
\hline $\mathrm{Sc}$ & 36.0 & 38.0 & 39.1 & 43.1 & 37.3 & 42.7 & 21.5 \\
\hline
\end{tabular}


Table 2-2, page 4.

\begin{tabular}{|c|c|c|c|c|c|c|c|}
\hline $\begin{array}{l}\text { Volcano } \\
\text { Sample } \\
\end{array}$ & $\begin{array}{l}\text { Ta'u } \\
\text { T14 }\end{array}$ & $\begin{array}{l}\text { Ta'u } \\
\text { T16 }\end{array}$ & $\begin{array}{l}\text { Ta'u } \\
\text { T19 } \\
\end{array}$ & $\begin{array}{l}\text { Ta'u } \\
\text { T21 }\end{array}$ & $\begin{array}{l}\text { Ta'u } \\
\text { T22 } \\
\end{array}$ & $\begin{array}{l}\text { Ta'u } \\
\mathbf{T 2 3} \\
\end{array}$ & $\begin{array}{l}\text { Ta'u } \\
\text { T25 }\end{array}$ \\
\hline Latitude $\left({ }^{\circ} \mathrm{S}\right)$ & 14.2163 & 14.2164 & 14.2192 & 14.2160 & 14.2160 & 14.2174 & 14.2163 \\
\hline $\begin{array}{l}\text { Longitude }\left({ }^{\circ} \mathrm{W}\right) \\
\text { Water Depth }(\mathbf{m})\end{array}$ & 169.5079 & 169.5094 & 169.5037 & 169.4762 & 169.4726 & 169.4648 & 169.4652 \\
\hline Phenocrysts & $\begin{array}{l}2 \% \mathrm{OI} \\
\operatorname{Tr} C p x \\
\end{array}$ & $8 \%$ Ol & $2 \% \mathrm{OI}$ & $\begin{array}{l}50 \% \text { Plag } \\
\text { Tr O1, Cpx } \\
\end{array}$ & Aphyric & Aphyric & $25 \% \mathrm{OI}$ \\
\hline Major elements & $(w t \%)$ & & & & & & \\
\hline $\mathrm{SiO}_{2}$ & 46.25 & 46.71 & 47.14 & 48.61 & 46.51 & 47.49 & 45.23 \\
\hline $\mathrm{Al}_{2} \mathrm{O}_{3}$ & 10.84 & I 1.27 & 12.12 & 17.66 & 14.47 & 13.44 & 8.37 \\
\hline $\mathrm{TiO}_{2}$ & 3.24 & 3.38 & 3.52 & 3.31 & 4.40 & 3.85 & 2.42 \\
\hline $\mathrm{FeO} *$ & 12.48 & 11.63 & 12.07 & 11.34 & 12.15 & 12.39 & 12.80 \\
\hline $\mathrm{MnO}$ & 0.19 & 0.18 & 0.18 & 0.19 & 0.18 & 0.18 & 0.19 \\
\hline $\mathrm{CaO}$ & 10.33 & 10.91 & 11.43 & 8.65 & 10.51 & 11.84 & 8.41 \\
\hline $\mathrm{MgO}$ & 13.26 & 12.42 & 9.73 & 3.18 & 7.20 & 6.77 & 19.87 \\
\hline $\mathrm{K}_{2} \mathrm{O}$ & 0.82 & 0.86 & 0.86 & 2.07 & 1.15 & 0.92 & 0.66 \\
\hline $\mathrm{Na}_{2} \mathrm{O}$ & 2.23 & 2.23 & 2.55 & 4.07 & 2.93 & 2.71 & 1.78 \\
\hline $\mathrm{P}_{2} \mathrm{O}_{5}$ & 0.37 & 0.39 & 0.39 & 0.93 & 0.52 & 0.42 & 0.28 \\
\hline Mg\# & 69.02 & 69.13 & 62.83 & 37.03 & 55.41 & 53.40 & 76.50 \\
\hline Trace Elements & (ppm) & & & & & & \\
\hline $\mathrm{Ni}$ & 396 & 360 & 194 & 9 & 83 & 79 & 723 \\
\hline $\mathrm{Cr}$ & 943 & 729 & 542 & 5 & 185 & 112 & 1406 \\
\hline V & 333 & 340 & 345 & 182 & 369 & 373 & 254 \\
\hline $\mathrm{Ga}$ & 20 & 20 & 20 & 27 & 22 & 22 & 13 \\
\hline $\mathrm{Cu}$ & 116 & 32 & 110 & 101 & 70 & 105 & 69 \\
\hline $\mathrm{Zn}$ & 126 & 102 & 127 & 150 & 124 & 123 & 111 \\
\hline Cs & 0.12 & 0.09 & 0.09 & 0.58 & 0.19 & 0.05 & 0.16 \\
\hline $\mathrm{Rb}$ & 18.0 & 19.8 & 18.8 & 49.1 & 26.3 & 16.4 & 15.9 \\
\hline $\mathrm{Ba}$ & 164 & 177 & 164 & 406 & 248 & 190 & 126 \\
\hline Th & 3.51 & 2.89 & 3.24 & 8.26 & 4.58 & 3.80 & 2.59 \\
\hline $\mathrm{U}$ & 0.64 & 0.73 & 0.73 & 1.79 & 1.00 & 0.71 & 0.57 \\
\hline $\mathrm{Nb}$ & 33.26 & 36.62 & 33.16 & 78.63 & 47.97 & 38.73 & 24.03 \\
\hline $\mathrm{Ta}$ & 2.27 & 2.60 & 2.30 & 5.09 & 3.29 & 2.64 & 1.66 \\
\hline La & 26.79 & 29.68 & 27.08 & 66.60 & 37.70 & 31.06 & 19.90 \\
\hline $\mathrm{Ce}$ & 55.65 & 63.08 & 56.61 & 136.19 & 79.07 & 65.26 & 41.81 \\
\hline $\mathrm{Pb}$ & 5.95 & 1.82 & 1.47 & 3.89 & 2.25 & I. 46 & 1.40 \\
\hline $\mathrm{Pr}$ & 6.80 & 8.24 & 7.06 & 16.23 & 9.62 & 7.98 & 5.20 \\
\hline $\mathrm{Nd}$ & 29.62 & 35.06 & 31.01 & 67.87 & 41.52 & 35.00 & 22.45 \\
\hline $\mathrm{Sr}$ & 377 & 442 & 407 & 754 & 575 & 472 & 294 \\
\hline $\mathrm{Zr}$ & 205 & 225 & 220 & 460 & 287 & 241 & 154 \\
\hline $\mathrm{Hf}$ & 5.34 & 5.83 & 5.52 & 10.79 & 7.40 & 6.14 & 3.92 \\
\hline חוS & 7.37 & 8.15 & 8.07 & 15.59 & 10.04 & 8.68 & 5.61 \\
\hline $\mathrm{Eu}$ & 2.41 & 2.47 & 2.53 & 4.69 & 3.13 & 2.75 & 1.78 \\
\hline $\mathrm{Gd}$ & 7.20 & 7.64 & 7.70 & 13.74 & 9.38 & 8.25 & 5.22 \\
\hline To & 1.08 & 1.08 & 1.15 & 1.96 & 1.37 & I.21 & 0.79 \\
\hline Dy & 5.61 & 5.77 & 6.41 & 10.77 & 7.46 & 6.82 & 4.27 \\
\hline Ho & 1.00 & 1.03 & 1.17 & 1.94 & 1.34 & 1.21 & 0.79 \\
\hline $\mathrm{Y}$ & 25.74 & 27.91 & 28.94 & 50.43 & 34.20 & 30.48 & 20.21 \\
\hline $\mathrm{ET}_{\mathrm{T}}$ & 2.39 & 2.55 & 2.72 & 4.58 & 3.27 & 2.94 & 1.85 \\
\hline $\mathrm{Tm}$ & 0.31 & 0.33 & 0.36 & 0.60 & 0.42 & 0.38 & 0.24 \\
\hline $\mathrm{Yb}$ & 1.78 & 1.97 & 2.04 & 3.43 & 2.38 & 2.10 & 1.37 \\
\hline $\mathrm{Lu}$ & 0.25 & 0.29 & 0.30 & 0.51 & 0.35 & 0.30 & 0.19 \\
\hline $\mathrm{Sc}$ & 32.4 & 24.2 & 35.7 & 17.0 & 32.7 & 34.9 & 26.8 \\
\hline
\end{tabular}


Table 2-2, page 5.

\begin{tabular}{|c|c|c|c|c|c|c|c|}
\hline $\begin{array}{l}\text { Volcano } \\
\text { Sample }\end{array}$ & $\begin{array}{l}\text { Ta'u } \\
\text { T27 }\end{array}$ & $\begin{array}{l}\text { Ta'u } \\
\text { T30 }\end{array}$ & $\begin{array}{l}\text { Ta'u } \\
\text { T32 }\end{array}$ & $\begin{array}{l}\text { Ta'u } \\
\text { T33 }\end{array}$ & $\begin{array}{l}\text { Ta'u } \\
\text { T38 }\end{array}$ & $\begin{array}{l}\text { Ta'u } \\
\text { T44 }\end{array}$ & $\begin{array}{l}\text { Ta'u } \\
\text { T45 }\end{array}$ \\
\hline Latitude $\left({ }^{\circ} \mathrm{S}\right)$ & 14.2161 & 14.2161 & 14.2163 & 14.2163 & 14.2161 & 14.2564 & 14.2556 \\
\hline $\begin{array}{l}\text { Longitude }\left({ }^{\circ} \mathrm{W}\right) \\
\text { Water Depth }(\mathrm{m})\end{array}$ & 169.4774 & 169.4774 & 169.4390 & 169.4421 & 169.4774 & 169.4312 & 169.4319 \\
\hline Phenocrysts & $\begin{array}{l}3 \% \mathrm{OI} \\
\mathrm{Tr} \operatorname{cp} x\end{array}$ & $\begin{array}{c}3 \% \mathrm{O} \\
\mathrm{j} \% \mathrm{Cpx} \\
\end{array}$ & Aphyric & $\begin{array}{l}10 \% \mathrm{Ol} \\
2 \% \mathrm{Cpx} \\
\end{array}$ & Aphyric & $\begin{array}{c}15 \% \text { Ol } \\
10 \% \mathrm{Cpx} \\
\end{array}$ & $3 \% \mathrm{O}$ \\
\hline Major elements & $(w t \%)$ & & & & & & \\
\hline $\mathrm{SiO}_{2}$ & 48.12 & 46.41 & 48.02 & 47.32 & 45.34 & 46.84 & 47.93 \\
\hline $\mathrm{Al}_{2} \mathrm{O}_{3}$ & 14.17 & 11.80 & 13.50 & 10.61 & 13.93 & 10.63 & 12.81 \\
\hline $\mathrm{TiO}_{2}$ & 3.86 & 3.57 & 3.68 & 3.09 & 4.64 & 2.90 & 3.80 \\
\hline $\mathrm{FeO}^{*}$ & 11.42 & 12.07 & 12.10 & 11.61 & 14.00 & 11.92 & 11.30 \\
\hline $\mathrm{MnO}$ & 0.17 & 0.18 & 0.18 & 0.17 & 0.20 & 0.18 & 0.17 \\
\hline $\mathrm{CaO}$ & I 1.54 & 10.86 & 11.71 & 11.54 & 1.1 .97 & 10.11 & 11.67 \\
\hline $\mathrm{MgO}$ & 6.36 & 11.52 & 6.67 & 12.40 & 6.11 & 14.15 & 8.36 \\
\hline $\mathrm{K}_{2} \mathrm{O}$ & 1.06 & 0.83 & 0.93 & 0.75 & 0.93 & 0.79 & 0.87 \\
\hline $\mathrm{Na}_{2} \mathrm{O}$ & 2.85 & 2.36 & 2.78 & 2.19 & 2.51 & 2.15 & 2.67 \\
\hline $\mathrm{P}_{2} \mathrm{O}_{5}$ & 0.46 & 0.41 & 0.42 & 0.33 & 0.39 & 0.33 & 0.43 \\
\hline Mg\# & 53.87 & 66.68 & 53.62 & 69.15 & 47.79 & 71.34 & 60.81 \\
\hline Trace Elements & $(p p m)$ & & & & & & \\
\hline $\mathrm{Ni}$ & 95 & 298 & 86 & 288 & 63 & 439 & 162 \\
\hline $\mathrm{Cr}$ & 290 & 682 & 100 & 988 & 59 & 764 & 549 \\
\hline $\mathrm{V}$ & 334 & 313 & 356 & 308 & 489 & 283 & 353 \\
\hline $\mathrm{Ga}$ & 25 & 19 & 22 & 18 & 24 & 17 & 25 \\
\hline $\mathrm{Cu}$ & 131 & 102 & 133 & 61 & 120 & 92 & 99 \\
\hline $\mathrm{Zn}$ & 122 & 121 & 121 & 103 & 121 & 115 & 113 \\
\hline Cs & 0.09 & 0.17 & 0.10 & $0.1 \mathrm{I}$ & 0.08 & 0.09 & 0.14 \\
\hline $\mathrm{Rb}$ & 21.4 & 19.0 & 19.0 & 15.7 & 16.7 & 17.1 & 18.4 \\
\hline $\mathrm{Ba}$ & 208 & 166 & 180 & 140 & 203 & 140 & 170 \\
\hline Th & 3.86 & 3.44 & 3.66 & 2.83 & 3.64 & 3.05 & 3.38 \\
\hline $\mathrm{U}$ & 0.79 & 0.82 & .0 .88 & 0.58 & 0.72 & 0.63 & 0.82 \\
\hline $\mathrm{Nb}$ & 39.56 & 37.63 & 37.74 & 28.68 & 39.88 & 28.37 & 35.66 \\
\hline $\mathrm{Ta}$ & 2.68 & 2.55 & 2.56 & 1.98 & 2.76 & 1.91 & 2.43 \\
\hline $\mathrm{La}$ & 32.43 & 30.50 & 31.24 & 23.65 & 30.45 & 23.94 & 28.63 \\
\hline $\mathrm{Ce}$ & 67.26 & 62.61 & 64.88 & 50.60 & 63.59 & 50.56 & 60.31 \\
\hline $\mathrm{Pb}$ & 1.86 & 1.43 & 2.32 & 1.94 & 1.45 & 1.90 & 1.36 \\
\hline $\operatorname{Pr}$ & 8.24 & 7.45 & 7.94 & 6.38 & 7.78 & 6.32 & 7.44 \\
\hline $\mathrm{Nd}$ & 35.65 & 32.06 & 34.68 & 27.80 & 33.84 & 27.82 & 32.80 \\
\hline $\mathrm{Sr}$ & 492 & 431 & 469 & 366 & 471 & 356 & 458 \\
\hline$Z_{T}$ & 251 & 233 & 236 & 190 & 224 & 199 & 239 \\
\hline $\mathrm{Hf}$ & 6.22 & 5.66 & 6.11 & 4.96 & 5.98 & 5.08 & 6.07 \\
\hline $\mathrm{Sm}$ & 8.85 & 7.85 & 8.69 & 7.09 & 8.43 & 7.07 & 8.49 \\
\hline $\mathrm{Eu}$ & 2.82 & 2.50 & 2.77 & 2.25 & 2.69 & 2.24 & 2.74 \\
\hline $\mathrm{Gd}$ & 8.54 & 7.39 & 8.30 & 6.69 & 8.06 & 6.70 & 8.21 \\
\hline $\mathrm{Tb}$ & 1.29 & 1.11 & 1.24 & 1.02 & 1.19 & 1.03 & 1.23 \\
\hline Dy & 7.01 & 6.03 & 6.78 & 5.62 & 6.48 & 5.66 & 6.87 \\
\hline Ho & 1.28 & 1.07 & 1.21 & 1.01 & 1.18 & 1.01 & 1.24 \\
\hline$Y$ & 32.55 & 27.50 & 31.25 & 26.16 & 29.69 & 25.28 & 31.49 \\
\hline Er & 3.10 & 2.62 & 2.93 & 2.39 & 2.78 & 2.40 & 2.88 \\
\hline Tin & 0.40 & 0.33 & 0.38 & 0.31 & 0.36 & 0.31 & 0.38 \\
\hline $\mathrm{Yb}$ & 2.28 & 1.91 & 2.13 & 1.74 & 2.05 & I.72 & 2.16 \\
\hline $\mathrm{Lu}$ & 0.32 & 0.28 & 0.31 & 0.25 & 0.29 & 0.25 & 0.31 \\
\hline $\mathrm{Sc}$ & 31.5 & 32.5 & 34.6 & 36.9 & 40.0 & 32.4 & 36.5 \\
\hline
\end{tabular}


Table 2-2, page 6.

\begin{tabular}{|c|c|c|c|c|c|c|c|}
\hline $\begin{array}{l}\text { Volcano } \\
\text { Sample }\end{array}$ & $\begin{array}{l}\text { Ta'u } \\
\text { T46 }\end{array}$ & $\begin{array}{l}\text { Ta'u } \\
\text { T47 }\end{array}$ & $\begin{array}{l}\text { Ta'u } \\
\text { T48 }\end{array}$ & $\begin{array}{l}\text { Ta'u } \\
\text { T51 }\end{array}$ & $\begin{array}{l}\text { Ta'u } \\
\text { T55 }\end{array}$ & $\begin{array}{l}\text { Ta'u } \\
74-1\end{array}$ & $\begin{array}{l}\text { Ta'u } \\
\mathbf{7 4 - 4}\end{array}$ \\
\hline Latitude $\left({ }^{\circ} \mathrm{S}\right)$ & 14.2312 & 14.2131 & 14.2176 & 14.2179 & 14.2650 & 14.363 & 14.363 \\
\hline $\begin{array}{l}\left.\text { Longitude ( }{ }^{\circ} \mathrm{W}\right) \\
\text { Water Depth }(\mathrm{m})\end{array}$ & 169.4200 & 169.4361 & 169.4202 & 169.4846. & 169.4968 & $\begin{array}{c}169.386 \\
2544\end{array}$ & $\begin{array}{c}169.386 \\
2544\end{array}$ \\
\hline Phenocrysts & $\begin{array}{c}3 \% \mathrm{O} \\
2 \% \mathrm{Cpx} \\
\end{array}$ & $\begin{array}{c}2 \% \mathrm{OI} \\
1 \% \mathrm{Cpx}\end{array}$ & $1 \% \mathrm{OI}$ & $2 \% 01$ & $\begin{array}{r}3 \% \mathrm{OI} \\
2 \% \mathrm{Cpx} \\
\end{array}$ & $25 \%$ O & Aphyric \\
\hline Major elements & $\left(w t^{0}\right)$ & & & & & & \\
\hline $\mathrm{SiO}_{2}$ & 46.56 & 48.31 & 46.13 & 46.95 & 48.25 & 44.09 & 45.52 \\
\hline $\mathrm{Al}_{2} \mathrm{O}_{3}$ & 12.19 & 11.51 & 11.75 & 12.26 & 12.56 & 6.67 & 15.33 \\
\hline $\mathrm{TiO}_{2}$ & 3.51 & 3.33 & 3.33 & 3.55 & 3.71 & 1.89 & 5.76 \\
\hline $\mathrm{FeO}^{*}$ & 12.46 & 11.34 & 12.52 & 12.02 & 11.70 & 12.79 & 13.92 \\
\hline $\mathrm{MnO}$ & 0.19 & 0.17 & 0.18 & 0.18 & 0.18 & 0.19 & 0.19 \\
\hline $\mathrm{CaO}$ & 10.78 & 12.68 & 10.17 & I 1.42 & 12.15 & 6.98 & 9.48 \\
\hline $\mathrm{MgO}$ & 10.38 & 9.33 & 12.19 & 9.82 & 7.85 & 25.45 & 4.83 \\
\hline $\mathrm{K}_{2} \mathrm{O}$ & 0.85 & 0.71 & 0.87 & 0.87 & 0.73 & 0.48 & 1.17 \\
\hline $\mathrm{Na}_{2} \mathrm{O}$ & 2.66 & 2.26 & 2.44 & 2.53 & 2.48 & 1.25 & 3.31 \\
\hline $\mathrm{P}_{2} \mathrm{O}_{5}$ & 0.43 & 0.36 & 0.41 & 0.40 & 0.38 & 0.22 & 0.51 \\
\hline $\mathrm{Mg} \not$ & 63.60 & 63.31 & 67.13 & 63.14 & 58.46 & 80.67 & 42.12 \\
\hline Truce Elements & $(p p m)$ & & & & & & \\
\hline $\mathrm{Ni}$ & 230 & 171 & 351 & 194 & 112 & 1019 & 36 \\
\hline $\mathrm{Cr}$ & 515 & 654 & 687 & 540 & $33 I$ & 1655 & 32 \\
\hline $\mathrm{V}$ & 323 & 346 & 308 & 341 & 355 & 187 & 472 \\
\hline $\mathrm{Ga}$ & 20 & 21 & 22 & 22 & 22 & 13 & 24 \\
\hline $\mathrm{Cu}$ & 115 & 106 & 85 & 110 & 104 & 69 & 145 \\
\hline $\mathrm{Zn}$ & 130 & 112 & 120 & 126 & 124 & 103 & 142 \\
\hline Cs & 0.20 & 0.16 & 0.05 & 0.10 & 0.10 & 0.13 & 0.15 \\
\hline $\mathrm{Rb}$ & 19.2 & 14.7 & 17.8 & 17.5 & 12.0 & 10.5 & 22.3 \\
\hline $\mathrm{Ba}$ & 176 & 160 & 171 & 177 & 147 & 87 & 237 \\
\hline Th & 3.69 & 3.00 & 3.55 & 3.43 & 2.65 & 1.51 & 3.98 \\
\hline $\mathrm{U}$ & 0.84 & 0.62 & 0.74 & 0.67 & 0.60 & 0.42 & 1.11 \\
\hline $\mathrm{Nb}$ & 36.94 & 30.76 & 35.58 & 34.21 & 29.72 & 18.94 & 45.78 \\
\hline $\mathrm{Ta}$ & 2.54 & 2.14 & 2.43 & 2.34 & 2.04 & 1.32 & 3.38 \\
\hline La & 30.96 & 25.08 & 29.49 & 27.81 & 23.86 & 15.66 & 37.13 \\
\hline $\mathrm{Ce}$ & 63.70 & 53.29 & 60.93 & 58.49 & 51.28 & 33.14 & 77.39 \\
\hline $\mathrm{Pb}$ & 1.66 & 1.28 & 1.58 & 2.05 & 1.95 & 1.06 & 14.60 \\
\hline $\operatorname{Pr}$ & 7.76 & 6.62 & 7.39 & 7.28 & 6.52 & 4.30 & 9.44 \\
\hline $\mathrm{Nd}$ & 33.77 & 29.37 & 32.39 & 31.76 & 29.68 & 18.16 & 40.30 \\
\hline $\mathrm{Sr}$ & 451 & 396 & 434 & 427 & 427 & 217 & 660 \\
\hline $\mathrm{Zr}$ & 239 & 199 & 237 & 223 & 214 & 113 & 259 \\
\hline $\mathrm{Hf}$ & 6.18 & 5.28 & 5.94 & 5.72 & 5.60 & 3.01 & 6.79 \\
\hline $\mathrm{Sm}$ & 8.50 & 7.47 & 8.05 & 8.02 & 7.95 & 4.21 & 9.55 \\
\hline $\mathrm{Eu}$ & 2.72 & 2.40 & 2.57 & 2.56 & 2.64 & 1.28 & 3.20 \\
\hline $\mathrm{Gd}$ & 8.17 & 7.29 & 7.53 & 7.72 & 7.89 & 3.92 & 8.68 \\
\hline $\mathrm{Tb}$ & 1.24 & 1.09 & 1.14 & 1.16 & 1.20 & 0.56 & 1.29 \\
\hline Dy & 6.76 & 6.09 & 6.28 & 6.36 & 6.64 & 3.04 & 7.11 \\
\hline Ho & 1.21 & 1.09 & 1.14 & 1.17 & 1.21 & 0.55 & 1.27 \\
\hline $\mathrm{Y}$ & 31.09 & 27.53 & 28.85 & 28.91 & 30.30 & 14.91 & 32.34 \\
\hline $\mathrm{Er}$ & 2.90 & 2.61 & 2.74 & 2.74 & 2.88 & 1.40 & 3.00 \\
\hline $\mathrm{Tm}$ & 0.37 & 0.34 & 0.35 & 0.36 & 0.38 & 0.18 & 0.40 \\
\hline$Y b$ & 2.13 & 1.91 & 2.00 & 1.97 & 2.10 & .1 .08 & 2.27 \\
\hline $\mathrm{Lu}$ & 0.30 & 0.28 & 0.29 & 0.29 & 0.30 & 0.16 & 0.32 \\
\hline $\mathrm{Sc}$ & 34.0 & 41.1 & 31.5 & 35.8 & 38.5 & 18.3 & 22.5 \\
\hline
\end{tabular}


Table 2-2, page 7.

\begin{tabular}{|c|c|c|c|c|c|c|c|}
\hline $\begin{array}{l}\text { Volcano } \\
\text { Sample }\end{array}$ & $\begin{array}{c}\text { Ta'u } \\
75-10\end{array}$ & $\begin{array}{l}\text { Muli } \\
79-4\end{array}$ & $\begin{array}{l}\text { Muli } \\
79-7\end{array}$ & $\begin{array}{c}\text { Muli } \\
80-23 \\
\end{array}$ & $\begin{array}{c}\text { Malumalu } \\
76-1\end{array}$ & $\begin{array}{c}\text { Malumalu } \\
76-8\end{array}$ & $\begin{array}{c}\text { Malumalu } \\
76-9\end{array}$ \\
\hline Latitude $\left({ }^{\circ} \mathrm{S}\right)$ & 14.181 & 13.916 & 13.916 & 14.129 & 14.569 & 14.569 & 14.569 \\
\hline Longitude ("W) & 169.304 & 169.993 & 169.993 & 170.062 & 169.718 & 169.718 & 169.718 \\
\hline Water Depth (m) & 2675 & 3484 & 3484 & 2368 & 2785 & 2785 & 2785 \\
\hline Phenocrysts & Aphyric & $\begin{array}{c}\text { 1\% Plag } \\
\text { Tr Ol, Cpx }\end{array}$ & Tr Cpx & Aphyric & Aphyric & $2 \% \mathrm{Ol}$ & $\begin{array}{l}10 \% \text { O } \\
3 \% \mathrm{Cpx}\end{array}$ \\
\hline Major elements & $(w t \%)$ & & & & & & \\
\hline $\mathrm{SiO}_{2}$ & 47.10 & 47.23 & 45.88 & 48.27 & 47.62 & 47.04 & 45.91 \\
\hline $\mathrm{Al}_{2} \mathrm{O}_{3}$ & 16.29 & 17.06 & 15.99 & 17.23 & 14.30 & 13.69 & 9.77 \\
\hline $\mathrm{TiO}_{2}$ & 4.02 & 3.13 & 3.58 & 3.36 & 3.54 & 3.88 & 2.74 \\
\hline $\mathrm{FeO}^{*}$ & 12.56 & 11.55 & 12.78 & 11.05 & 11.41 & 11.93 & 12.20 \\
\hline $\mathrm{MnO}$ & 0.20 & 0.22 & 0.22 & 0.20 & 0.16 & 0.18 & 0.17 \\
\hline $\mathrm{CaO}$ & 9.11 & 8.39 & 8.93 & 8.70 & 12.34 & 11.86 & 10.19 \\
\hline $\mathrm{MgO}$ & 5.16 & 3.27 & 4.38 & 4.21 & 5.81 & 6.27 & 15.84 \\
\hline $\mathrm{K}_{2} \mathrm{O}$ & 1.46 & 2.09 & 2.37 & 1.94 & 1.69 & 1.92 & 100 \\
\hline $\mathrm{Na}_{2} \mathrm{O}$ & 3.47 & 4.70 & 4.46 & 4.17 & 2.75 & 2.75 & 1.88 \\
\hline $\mathrm{P}_{2} \mathrm{O}_{5}$ & 0.63 & 2.37 & 1.40 & 0.87 & 0.38 & 0.49 & 0.32 \\
\hline $\mathrm{Mg} \#$ & 46.28 & 37.25 & 41.82 & 44.41 & 51.64 & 52.43 & 73.14 \\
\hline Trace Elements & (ppm) & & & & & & \\
\hline $\mathrm{Ni}$ & 5 & 4 & 0 & 0 & 46 & 65 & 458 \\
\hline $\mathrm{Cr}$ & 15 & 1 & 6 & 7 & 94 & 137 & 889 \\
\hline V & 282 & 144 & 168 & 205 & 370 & 356 & 276 \\
\hline $\mathrm{Ga}$ & 26 & 23 & 27 & 28 & 23 & 22 & 19 \\
\hline $\mathrm{Cu}$ & 21 & 10 & 6 & 13 & 138 & 72 & 56 \\
\hline $\mathrm{Zn}$ & 140 & 188 & 191 & 163 & 109 & 121 & 107 \\
\hline $\mathrm{Cs}$ & 0.39 & 0.54 & 0.68 & 0.37 & 0.64 & 0.51 & 0.24 \\
\hline $\mathrm{Rb}$ & 27.6 & 38.6 & 54.8 & 38.4 & 36.6 & 44.3 & 16.9 \\
\hline $\mathrm{Ba}$ & 264 & 662 & 447 & 409 & 351 & 355 & 187 \\
\hline Th & 4.94 & 6.48 & 6.82 & 7.18 & 6.43 & 6.41 & 3.21 \\
\hline $\mathrm{U}$ & 1.10 & 1.21 & 1.74 & 1.55 & 1.18 & 1.30 & 0.76 \\
\hline $\mathrm{Nb}$ & 51.26 & 92.26 & 77.19 & 77.72 & 49.78 & 56.67 & 33.01 \\
\hline $\mathrm{Ta}$ & 3.59 & 5.95 & 5.28 & 524 & 3.64 & 3.93 & 2.20 \\
\hline $\mathrm{La}$ & 43.08 & 107.50 & 64.09 & 58.62 & 51.07 & 48.43 & 30.37 \\
\hline $\mathrm{Ce}$ & 90.50 & 238.81 & 137.70 & 122.09 & 97.08 & 95.90 & 62.55 \\
\hline $\mathrm{Pb}$ & 3.26 & 3.80 & 5.06 & 4.52 & 4.32 & 4.24 & 2.50 \\
\hline$P_{T}$ & 11.08 & 29.95 & 17.2 I & 14.81 & 11.13 & 11.17 & 7.94 \\
\hline $\mathrm{Nd}$ & 47.98 & $132.4 \mathrm{I}$ & 77.37 & 65.12 & 45.11 & 46.27 & 32.42 \\
\hline $\mathrm{Sr}$ & 617 & 1901 & 1010 & 967 & 512 & 544 & 356 \\
\hline $\mathrm{ZT}$ & 327 & 371 & 492 & 419 & 209 & 276 & 180 \\
\hline $\mathrm{Hf}$ & 8.31 & 9.45 & 11.73 & 10.18 & 6.01 & 7.23 & 4.79 \\
\hline $\mathrm{Sm}$ & I 1.62 & 28.68 & 18.84 & 15.63 & 10.20 & 10.52 & 7.19 \\
\hline Eu & 3.75 & 8.77 & 5.94 & 4.94 & 2.98 & 3.19 & 2.05 \\
\hline $\mathrm{Gd}$ & 10.74 & 23.57 & 17.17 & 14.04 & 9.17 & 9.49 & 6.56 \\
\hline$T b$ & 1.60 & 3.22 & 2.46 & 2.04 & 1.33 & 1.38 & 0.91 \\
\hline Dy & 8.83 & 16.70 & 12.86 & 10.92 & 7.08 & 7.42 & 4.81 \\
\hline Ho & 1.59 & 2.85 & 2.19 & 1.88 & 1.25 & 1.28 & 0.85 \\
\hline$Y$ & 40.24 & 73.39 & 56.38 & 48.07 & 32.32 & 32.16 & 23.37 \\
\hline$E_{r}$ & 3.81 & 6.52 & 4.97 & 4.39 & 2.97 & 2.97 & 2.06 \\
\hline $\operatorname{Tin}$ & 0.50 & 0.81 & 0.61 & 0.56 & 0.38 & 0.38 & 0.27 \\
\hline $\mathrm{Yb}$ & 2.80 & 4.39 & 3.34 & 3.07 & 2.09 & 2.05 & 1.54 \\
\hline $\mathrm{Lu}$ & 0.40 & 0.62 & 0.47 & 0.45 & 0.31 & 0.29 & 0.22 \\
\hline Sc & 20.5 & 10.4 & 14.1 & 15.7 & 32.8 & 31.0 & 24.0 \\
\hline
\end{tabular}


Table 2-2, page 8.

\begin{tabular}{|c|c|c|c|c|c|c|c|}
\hline $\begin{array}{l}\text { Volcano } \\
\text { Sample }\end{array}$ & $\begin{array}{c}\text { Malumalu } \\
76-13\end{array}$ & $\begin{array}{c}\text { Malumalu } \\
77-1\end{array}$ & $\begin{array}{c}\text { Malumalu } \\
\mathbf{7 7 - 9}\end{array}$ & $\begin{array}{c}\text { Máamalu } \\
78-1\end{array}$ & $\begin{array}{c}\text { Malumalu } \\
78-3\end{array}$ & $\begin{array}{c}\text { Malumalu } \\
78-8\end{array}$ & $\begin{array}{c}\text { Upolu } \\
\text { U10 }\end{array}$ \\
\hline Latitude $\left({ }^{\circ} \mathrm{S}\right)$ & 14.569 & 14.701 & 14.701 & 14.623 & 14.623 & 14.623 & 13.9283 \\
\hline Longitude $\left({ }^{\circ} \mathrm{W}\right)$ & 169.718 & 169.767 & 169.767 & 169.726 & 169.726 & 169.726 & 171.9813 \\
\hline Water Depth (m) & 2785 & 3605 & 3605 & 2264 & 2264 & 2264 & \\
\hline Phenocrysts & Aphyric & $\begin{array}{c}3 \% \mathrm{Ol} \\
2 \% \mathrm{Cpx}\end{array}$ & $3 \% \mathrm{O}$ & $\begin{array}{l}25 \% \text { O } \\
5 \% \mathrm{Cpx}\end{array}$ & $\begin{array}{l}30 \% \text { O1 } \\
5 \% \text { Cpx }\end{array}$ & $\begin{array}{l}2 \% \mathrm{Ol} \\
\operatorname{Tr} \mathrm{Cpx}\end{array}$ & Aphyric \\
\hline Major elements & $(w t \%)$ & & & & & & \\
\hline $\mathrm{SiO}_{2}$ & 46.35 & 46.55 & 46.83 & 45.54 & 45.44 & 47.33 & 45.46 \\
\hline $\mathrm{Al}_{2} \mathrm{O}_{3}$ & 13.55 & 13.22 & 13.80 & 8.94 & 9.49 & 14.19 & 13.21 \\
\hline $\mathrm{TiO}_{2}$ & 3.86 & 3.55 & 3.58 & 1.96 & 2.06 & 3.29 & 3.91 \\
\hline $\mathrm{FeO}{ }^{*}$ & 12.78 & 12.17 & 11.08 & 11.89 & 11.91 & 11.45 & 13.09 \\
\hline $\mathrm{MnO}$ & 0.20 & 0.17 & 0.17 & 0.17 & 0.17 & 0.17 & 0.19 \\
\hline $\mathrm{CaO}$ & 11.80 & 11.90 & 11.34 & 8.23 & 8.41 & 11.47 & 11.27 \\
\hline $\mathrm{MgO}$ & 6.42 & 7.62 & 8.45 & 19.68 & 18.81 & 6.93 & 8.97 \\
\hline $\mathrm{K}_{2} \mathrm{O}$ & 1.94 & 1.70 & 1.81 & 1.41 & 1.47 & 2.05 & 1.52 \\
\hline $\mathrm{Na}_{2} \mathrm{O}$ & 2.61 & 2.70 & 2.59 & 1.92 & 1.96 & 2.74 & 2.05 \\
\hline $\mathrm{P}_{2} \mathrm{O}_{5}$ & 0.49 & 0.42 & 0.36 & 0.27 & 0.28 & 0.40 & 0.34 \\
\hline $\mathrm{Mg} \#$ & 51.30 & 56.77 & 61.53 & 77.63 & 76.81 & 55.93 & 58.97 \\
\hline Trace Elements & $(p p m)$ & & & & & & \\
\hline $\mathrm{Ni}$ & 71 & 116 & 154 & 616 & 578 & 97 & 142 \\
\hline $\mathrm{Cr}$ & 130 & 252 & 391 & 1289 & 1175 & 106 & 433 \\
\hline V & 384 & 356 & 370 & 194 & 213 & 342 & 346 \\
\hline $\mathrm{Ga}$ & 26 & 24 & 21 & 14 & 16 & 21 & 21 \\
\hline $\mathrm{Cu}$ & 95 & 97 & 62 & 49 & 53 & 79 & 51 \\
\hline $\mathrm{Zn}$ & 125 & 109 & 108 & 102 & 101 & 104 & 106 \\
\hline $\mathrm{Cs}$ & 0.50 & 0.51 & 0.55 & 0.39 & 0.36 & 0.60 & 0.35 \\
\hline $\mathrm{Rb}$ & 42.8 & 46.8 & 47.5 & 41.8 & 40.0 & 51.4 & 42.8 \\
\hline $\mathrm{Ba}$ & 341 & 341 & 336 & 255 & 261 & 372 & 341 \\
\hline Th & 5.33 & 5.14 & 6.59 & 6.03 & 5.24 & 6.26 & 2.16 \\
\hline $\mathrm{U}$ & 1.29 & 1.22 & 1.24 & 1.05 & 1.08 & 1.36 & 0.56 \\
\hline $\mathrm{Nb}$ & 57.53 & 55.47 & 53.44 & 39.02 & 41.45 & 58.97 & 30.02 \\
\hline $\mathrm{Ta}$ & 3.84 & 3.70 & 3.64 & 2.63 & 2.71 & 3.84 & 2.22 \\
\hline $\mathrm{La}$ & 48.57 & 46.34 & 46.05 & 39.44 & 41.66 & 51.99 & 23.29 \\
\hline $\mathrm{CE}$ & 96.33 & 90.88 & 89.34 & 73.02 & 77.38 & 98.76 & 48.32 \\
\hline $\mathrm{Pb}$ & 5.18 & 4.14 & 4.18 & 4.19 & 3.77 & 4.58 & 3.11 \\
\hline $\operatorname{Pr}$ & 11.80 & 11.05 & 10.13 & 7.93 & 8.85 & 11.52 & 5.93 \\
\hline $\mathrm{Nd}$ & 47.24 & 43.33 & 41.30 & 31.00 & 32.86 & 44.15 & 26.24 \\
\hline $\mathrm{Sr}$ & 554 & 530 & 477 & 333 & 361 & 529 & 475 \\
\hline $\mathrm{Zr}$ & 281 & 250 & 232 & 183 & 193 & 256 & 155 \\
\hline $\mathrm{Hf}$ & 7.11 & 6.38 & 6.23 & 4.71 & 4.80 & 6.42 & 4.41 \\
\hline $\mathrm{Sm}$ & 10.18 & 9.15 & 9.27 & 6.53 & 6.56 & 9.09 & 6.77 \\
\hline Eu & 2.87 & 2.59 & 2.72 & 1.89 & 1.75 & 2.51 & 2.25 \\
\hline$G d$ & 9.10 & 8.09 & 8.16 & 5.81 & 5.67 & 7.96 & 6.60 \\
\hline $\mathrm{Tb}$ & 1.26 & 1.12 & 1.22 & 0.82 & 0.77 & 1.11 & 1.03 \\
\hline Dy & 6.57 & 5.96 & 6.52 & 4.40 & 4.00 & 5.84 & 5.59 \\
\hline Ho & 1.15 & 1.04 & 1.15 & 0.77 & 0.70 & 1.04 & 1.00 \\
\hline $\mathrm{Y}$ & 33.12 & 29.97 & 29.31 & 19.57 & 20.49 & 30.47 & 25.19 \\
\hline $\mathrm{Er}$ & 2.82 & 2.55 & 2.72 & 1.76 & 1.73 & 2.53 & 2.38 \\
\hline $\mathrm{Tm}$ & 0.37 & 0.34 & 0.34 & 0.23 & 0.23 & 0.34 & 0.30 \\
\hline $\mathrm{Yb}$ & 2.13 & 1.92 & 1.92 & 1.24 & 1.32 & 1.97 & 1.70 \\
\hline $\mathrm{Lu}$ & 0.31 & 0.29 & 0.28 & 0.19 & 0.19 & 0.29 & 0.24 \\
\hline $\mathrm{Sc}$ & 25.0 & 27.4 & 31.2 & 25.2 & 21.9 & 28.5 & 28.0 \\
\hline
\end{tabular}


Table 2-2, page 9.

\begin{tabular}{|c|c|c|c|c|c|c|c|}
\hline $\begin{array}{l}\text { Volcano } \\
\text { Sample }\end{array}$ & $\begin{array}{c}\text { Upolu } \\
\text { U12 } \\
\end{array}$ & $\begin{array}{c}\text { Upolu } \\
\text { U14 }\end{array}$ & $\begin{array}{l}\text { Upolu } \\
\text { U16 }\end{array}$ & $\begin{array}{c}\text { Upolu } \\
\text { U19 }\end{array}$ & $\begin{array}{l}\text { Upolu } \\
\text { U21 }\end{array}$ & $\begin{array}{l}\text { Upolu } \\
\text { U22 }\end{array}$ & $\begin{array}{l}\text { Upolu } \\
\text { U24 }\end{array}$ \\
\hline Latitude $\left({ }^{\circ} \mathrm{S}\right)$ & 13.9456 & 13.9383 & 13.9355 & 13.9392 & 13.8926 & 13.8922 & 13.9314 \\
\hline Longitude $\left({ }^{\circ} \mathrm{W}\right)$ & 171.9766 & 171.9805 & 171.9991 & 171.9938 & 171.9640 & 171.9630 & 171.9661 \\
\hline $\begin{array}{l}\text { water Depth (m) } \\
\text { Phenocrysts }\end{array}$ & $\begin{array}{c}\text { Tr OI,Plag } \\
\text { Tr Cpx }\end{array}$ & $2 \%$ Plag & $\begin{array}{c}3 \% \text { Plag, } \\
\text { O } \\
\text { Tr Cpx }\end{array}$ & $\begin{array}{l}8 \% \text { Plag } \\
2 \% \text { Cpx }\end{array}$ & $\begin{array}{c}2 \% \text { Cpx } \\
\text { Tr O1, Plag }\end{array}$ & $\begin{array}{c}4 \% \mathrm{Cpx} \\
2 \% \mathrm{O} \\
\end{array}$ & $\begin{array}{c}\text { 5\% Plag } \\
\operatorname{Tr} 01, \text { Cpx }\end{array}$ \\
\hline Major elements & $(w t \%)$ & & & & & & \\
\hline $\mathrm{SiO}_{2}$ & 48.08 & 47.51 & 47.65 & 47.36 & 48.24 & 47.24 & 49.01 \\
\hline $\mathrm{Al}_{2} \mathrm{O}_{3}$ & 14.32 & 14.53 & 14.49 & 15.63 & 13.88 & 14.32 & 15.85 \\
\hline $\mathrm{TiO}_{2}$ & 4.04 & 4.34 & 4.03 & 3.83 & 3.79 & 4.00 & 3.92 \\
\hline $\mathrm{FeO}^{*}$ & 12.91 & 13.41 & 12.20 & 11.94 & 12.04 & 12.84 & 11.71 \\
\hline $\mathrm{MnO}$ & 0.19 & 0.20 & 0.18 & 0.17 & 0.17 & 0.18 & 0.18 \\
\hline $\mathrm{CaO}$ & 10.14 & 9.94 & 10.47 & 11.17 & 10.64 & 9.95 & 9.56 \\
\hline $\mathrm{MgO}$ & 5.95 & 5.13 & 6.30 & 5.72 & 7.15 & 6.98 & 4.61 \\
\hline $\mathrm{K}_{2} \mathrm{O}$ & 0.96 & 1.22 & 1.16 & 0.99 & 1.00 & 1.19 & 1.35 \\
\hline $\mathrm{Na}_{2} \mathrm{O}$ & 2.90 & 3.12 & 2.99 & 2.74 & 2.59 & 2.77 & 3.19 \\
\hline $\mathrm{P}_{2} \mathrm{O}_{5}$ & 0.51 & 0.60 & 0.54 & 0.46 & 0.49 & 0.54 & 0.63 \\
\hline $\mathrm{Mg \#}$ & 49.15 & 44.51 & 51.99 & 50.12 & 55.46 & 53.27 & 45.22 \\
\hline Trace Elements & $(p p m)$ & & & & & & \\
\hline $\mathrm{Ni}$ & 72 & 43 & 95 & 73 & 122 & 131 & 43 \\
\hline $\mathrm{Cr}$ & 137 & 59 & 191 & 162 & 246 & 211 & 64 \\
\hline V & 360 & 361 & 353 & 338 & 354 & 368 & 341 \\
\hline $\mathrm{Ga}$ & 24 & 24 & 24 & 22 & 23 & 22 & 22 \\
\hline $\mathrm{Cu}$ & $3 \mathrm{l}$ & 38 & 75 & 61 & 48 & 92 & 35 \\
\hline $\mathrm{Zn}$ & 122 & 130 & 112 & 105 & 116 & 125 & 117 \\
\hline Cs & 0.09 & 0.13 & 0.15 & 0.10 & 0.40 & 0.23 & 0.15 \\
\hline $\mathrm{Rb}$ & 18.0 & 26.8 & 26.7 & 21.9 & 24.8 & 27.7 & 32.1 \\
\hline $\mathrm{Ba}$ & 223 & 255 & 247 & 218 & 220 & 260 & 290 \\
\hline Th & 2.64 & 3.40 & 2.93 & 2.59 & 2.74 & 3.14 & 3.79 \\
\hline $\mathrm{U}$ & 0.70 & 0.90 & 0.79 & 0.69 & 0.77 & 0.79 & 0.99 \\
\hline $\mathrm{Nb}$ & 34.81 & 45.28 & 42.59 & 36.23 & 35.77 & 42.88 & 47.60 \\
\hline Ta & 2.47 & 3.21 & 3.02 & 2.59 & 2.54 & 3.02 & 3.26 \\
\hline $\mathrm{La}$ & 30.14 & 37.48 & 33.30 & 29.03 & 35.27 & 37.73 & 40.81 \\
\hline $\mathrm{Ce}$ & 63.91 & 80.50 & 71.31 & 61.80 & 70.00 & 73.99 & 83.91 \\
\hline $\mathrm{Pb}$ & 3.32 & 3.70 & 3.54 & 6.98 & 3.14 & 3.79 & 3.93 \\
\hline $\mathrm{Pr}$ & 8.24 & 10.11 & 8.98 & 7.73 & 9.26 & 9.78 & 10.37 \\
\hline $\mathrm{Nd}$ & 37.45 & 44.40 & 40.23 & 34.51 & 41.25 & 43.19 & 45.31 \\
\hline $\mathrm{Sr}$ & 447 & 535 & 505 & 530 & 479 & 488 & 597 \\
\hline $\mathrm{Zr}$ & 263 & 313 & 302 & 247 & 253 & 271 & 303 \\
\hline $\mathrm{Hf}$ & 6.85 & 7.91 & 7.42 & 6.35 & 6.49 & 6.92 & 7.51 \\
\hline $\mathrm{Sm}$ & 9.59 & 10.93 & 10.03 & 8.65 & 10.12 & 10.50 & 10.90 \\
\hline $\mathrm{Eu}$ & 3.21 & 3.60 & 3.28 & 2.86 & 3.50 & 3.55 & 3.60 \\
\hline $\mathrm{Gd}$ & 9.35 & 10.47 & 9.45 & 8.27 & 9.96 & 10.12 & 10.35 \\
\hline $\mathrm{Tb}$ & 1.46 & 1.59 & 1.42 & 1.25 & 1.48 & 1.51 & 1.56 \\
\hline Dy & 8.06 & 8.51 & 7.76 & 6.87 & 7.99 & 8.34 & 8.44 \\
\hline Ho & 1.47 & 1.56 & 1.38 & 1.25 & 1.45 & 1.50 & 1.53 \\
\hline Y & 37.16 & 39.30 & 35.14 & 31.35 & 37.88 & 38.35 & 39.08 \\
\hline Er & 3.53 & 3.68 & 3.29 & 2.99 & 3.43 & 3.54 & 3.70 \\
\hline $\mathrm{Tm}$ & 0.46 & 0.49 & 0.43 & 0.38 & 0.44 & 0.47 & 0.47 \\
\hline $\mathrm{Yb}$ & 2.62 & 2.68 & 2.36 & 2.12 & 2.46 & 2.59 & 2.65 \\
\hline $\mathrm{Lu}$ & 0.37 & 0.39 & 0.34 & 0.31 & 0.35 & 0.38 & 0.38 \\
\hline $\mathrm{Sc}$ & 31.1 & 26.8 & 29.4 & 29.4 & 30.1 & 28.5 & 23.9 \\
\hline
\end{tabular}


Table 2-2, page 10.

\begin{tabular}{|c|c|c|c|c|c|c|c|}
\hline $\begin{array}{l}\text { Volcano } \\
\text { Sample }\end{array}$ & $\begin{array}{l}\text { Savai'i } \\
\text { S1I }\end{array}$ & $\begin{array}{l}\text { Savai'i } \\
\text { S12 }\end{array}$ & $\begin{array}{l}\text { Savai'i } \\
\text { S15 }\end{array}$ & $\begin{array}{l}\text { Savai'i } \\
\text { S16 }\end{array}$ & $\begin{array}{c}\text { Savai'i } \\
\text { S18 }\end{array}$ & $\begin{array}{l}\text { Savai'i } \\
\text { S23 }\end{array}$ & $\begin{array}{l}\text { Savai'i } \\
\text { S25 }\end{array}$ \\
\hline Latitude("S) & 13.4840 & 13.4614 & 13.4561 & 13.4767 & 13.4751 & 13.4469 & 13.4469 \\
\hline $\begin{array}{l}\text { Longitude }\left({ }^{\circ} \mathrm{W}\right) \\
\text { Water Depth }(\mathrm{m})\end{array}$ & 172.3787 & 172.3654 & 172.3939 & 172.3950 . & 172.3929 & 172.3900 & 172.3864 \\
\hline Phenocrysts & $\begin{array}{c}3 \% \mathrm{OI} \\
2 \% \mathrm{Cpx}\end{array}$ & $2 \% \mathrm{Ol}$ & $\begin{array}{l}2 \% \mathrm{O} \\
\text { Tr Cpx }\end{array}$ & Aphync & Aphyric & $2 \% \mathrm{Ol}$ & $1 \% 01$ \\
\hline Major elements & $(w t \%)$ & & & & & & \\
\hline $\mathrm{SiO}_{2}$ & 45.95 & 46.30 & 45.45 & 47.16 & 47.95 & 45.46 & 45.57 \\
\hline $\mathrm{Al}_{2} \mathrm{O}_{3}$ & 13.27 & 12.84 & 12.80 & 16.43 & 14.92 & 11.80 & 12.00 \\
\hline $\mathrm{TiO}_{2}$ & 3.31 & 2.96 & 3.49 & 3.35 & 2.70 & 3.09 & 3.16 \\
\hline $\mathrm{FeO}^{*}$ & 12.08 & 11.91 & 13.06 & 11.78 & 10.66 & 11.60 & 11.79 \\
\hline $\mathrm{MnO}$ & 0.17 & 0.17 & 0.18 & 0.17 & 0.17 & 0.17 & 0.17 \\
\hline $\mathrm{CaO}$ & 10.54 & 9.91 & 7.81 & .8 .45 & 10.87 & 9.81 & 10.07 \\
\hline $\mathrm{MgO}$ & 9.86 & 11.86 & 13.94 & 6.62 & 8.23 & 13.54 & 13.09 \\
\hline $\mathrm{K}_{2} \mathrm{O}$ & 1.39 & 1.35 & 1.42 & 1.75 & 1.28 & 1.55 & 0.49 \\
\hline $\mathrm{Na}_{2} \mathrm{O}$ & 2.91 & 2.24 & 1.41 & 3.78 & 2.87 & 2.54 & 3.21 \\
\hline $\mathrm{P}_{2} \mathrm{O}_{5}$ & 0.53 & 0.46 & 0.44 & 0.52 & 0.36 & 0.44 & 0.46 \\
\hline $\mathrm{MgH}$ & 63.12 & 67.62 & 69.12 & 54.10 & 61.82 & 71.00 & 69.96 \\
\hline Trace Elements & $(p p m)$ & & & & & & \\
\hline $\mathrm{Ni}$ & 193 & 286 & 451 & 86 & 137 & 406 & 383 \\
\hline $\mathrm{Cr}$ & 415 & 502 & 612 & 77 & 298 & 555 & 568 \\
\hline V & 294 & 271 & 243 & 258 & 271 & 250 & 258 \\
\hline $\mathrm{Ga}$ & 20 & 18 & 23 & 25 & 22 & 19 & 17 \\
\hline $\mathrm{Cu}$ & 39 & 44 & 55 & 22 & 57 & 51 & 50 \\
\hline $\mathrm{Zn}$ & 109 & 106 & 112 & 111 & 85 & 99 & 101 \\
\hline Cs & 0.31 & 0.34 & 0.33 & 0.54 & 0.31 & 0.49 & 0.52 \\
\hline $\mathrm{Rb}$ & 34.7 & 30.4 & 34.8 & 53.1 & 34.4 & 45.8 & 116.3 \\
\hline $\mathrm{Ba}$ & 379 & 363 & 489 & 404 & 308 & 430 & 435 \\
\hline $\mathrm{Th}$ & 3.87 & 3.53 & 3.41 & 4.43 & 2.67 & 3.35 & 3.46 \\
\hline $\mathrm{U}$ & 0.78 & 0.71 & 0.51 & 0.91 & 0.57 & 0.74 & 0.72 \\
\hline $\mathrm{Nb}$ & 44.21 & 40.01 & 40.20 & 46.64 & 34.71 & 41.43 & 42.42 \\
\hline $\mathrm{Ta}$ & 2.99 & 2.87 & 2.89 & 3.28 & 2.46 & 2.85 & 2.97 \\
\hline $\mathrm{La}$ & 40.18 & 34.41 & 33.75 & 42.60 & 29.28 & 33.20 & 34.48 \\
\hline $\mathrm{Ce}$ & 78.56 & 67.10 & 66.36 & 78.71 & 52.74 & 66.01 & 68.38 \\
\hline $\mathrm{Pb}$ & 4.30 & 4.06 & 4.05 & $5.1 \mathrm{~J}$ & 3.44 & 4.29 & 3.92 \\
\hline Pr & 9.02 & 7.76 & 7.76 & 9.03 & 6.43 & 7.75 & 8.08 \\
\hline $\mathrm{Nd}$ & 37.22 & 32.31 & 33.13 & 37.01 & 27.41 & 32.74 & 34.15 \\
\hline $\mathrm{Sr}$ & 581 & 532 & 420 & 680 & 429 & 544 & 564 \\
\hline $2 r$ & 213 & 194 & 185 & 251 & 167 & 186 & 189 \\
\hline $\mathrm{Hf}$ & 5.34 & 4.97 & 4.90 & 6.14 & 4.27 & 4.70 & 4.91 \\
\hline $\mathrm{Sm}$ & 8.58 & 7.46 & 7.84 & 8.49 & 6.46 & 7.72 & 8.02 \\
\hline $\mathrm{Eu}$ & 2.81 & 2.43 & 2.54 & 2.84 & 2.21 & 2.47 & 2.60 \\
\hline $\mathrm{Gd}$ & 8.14 & 7.09 & 7.32 & 8.22 & 6.74 & 7.14 & 7.42 \\
\hline $\mathrm{Tb}$ & 1.19 & 1.05 & 1.06 & 1.23 & 1.04 & 1.05 & 1.08 \\
\hline Dy & 6.37 & 5.74 & 5.56 & 6.76 & 6.03 & 5.45 & 5.73 \\
\hline Ho & 1.11 & $1 . \mathrm{O} 1$ & 0.96 & 124 & 1.17 & 0.94 & 0.98 \\
\hline Y & 28.79 & 25.35 & 24.13 & 35.14 & 36.39 & 24.49 & 24.90 \\
\hline $\mathrm{Er}$ & 2.59 & 2.39 & 2.22 & 2.96 & 2.97 & 2.20 & 2.26 \\
\hline $\mathrm{Tm}$ & 0.33 & 0.30 & 0.28 & 0.39 & 0.38 & 0.27 & 0.29 \\
\hline $\mathrm{Yb}$ & 1.82 & 1.68 & 1.54 & 2.19 & 2.09 & 1.50 & 1.60 \\
\hline $\mathrm{Lu}$ & 0.26 & 0.24 & 0.22 & 0.32 & 0.33 & 0.21 & 0.22 \\
\hline $\mathrm{Sc}$ & 24.9 & 23.8 & 25.2 & 19.0 & 29.1 & 24.4 & 24.7 \\
\hline
\end{tabular}




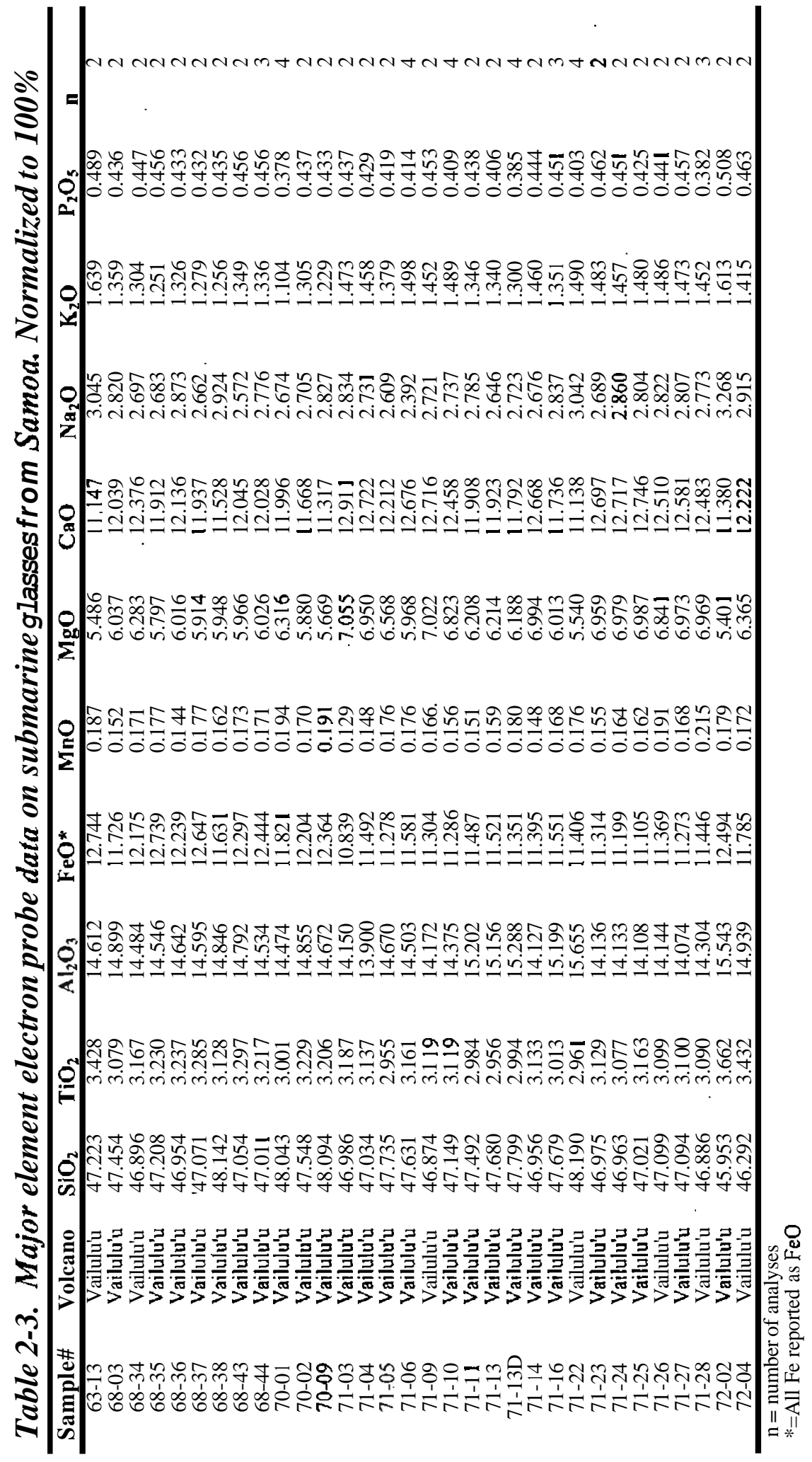




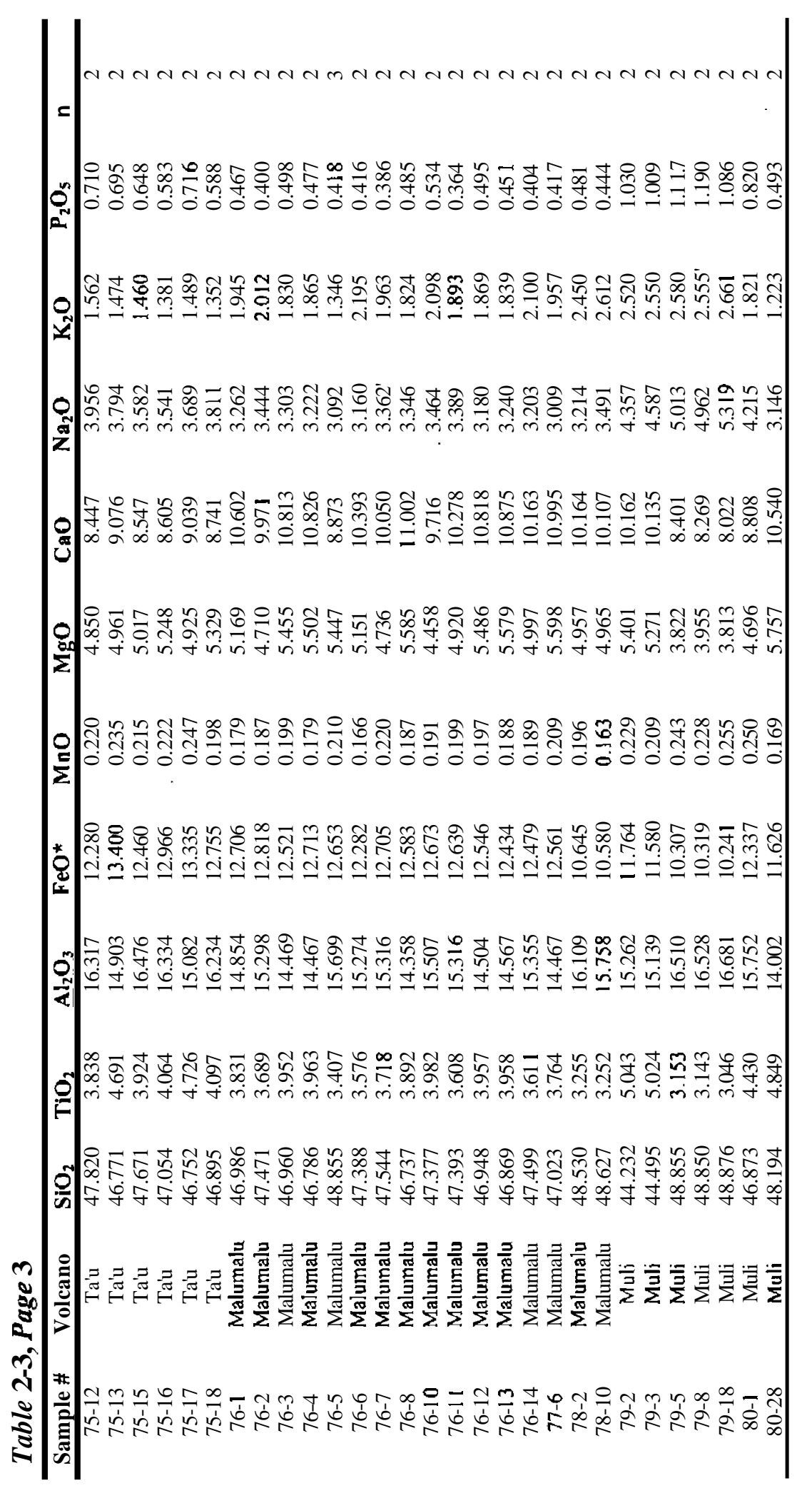




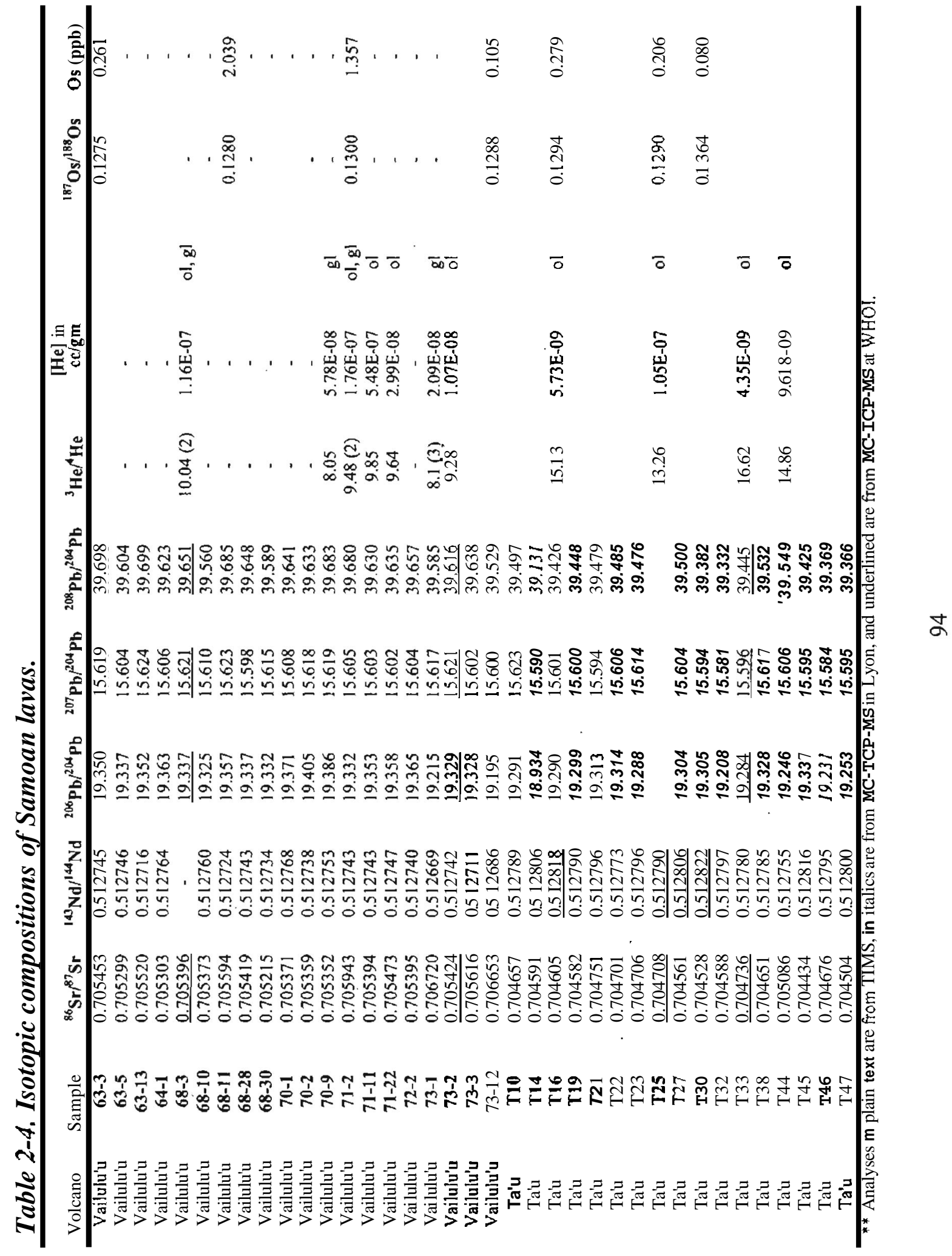




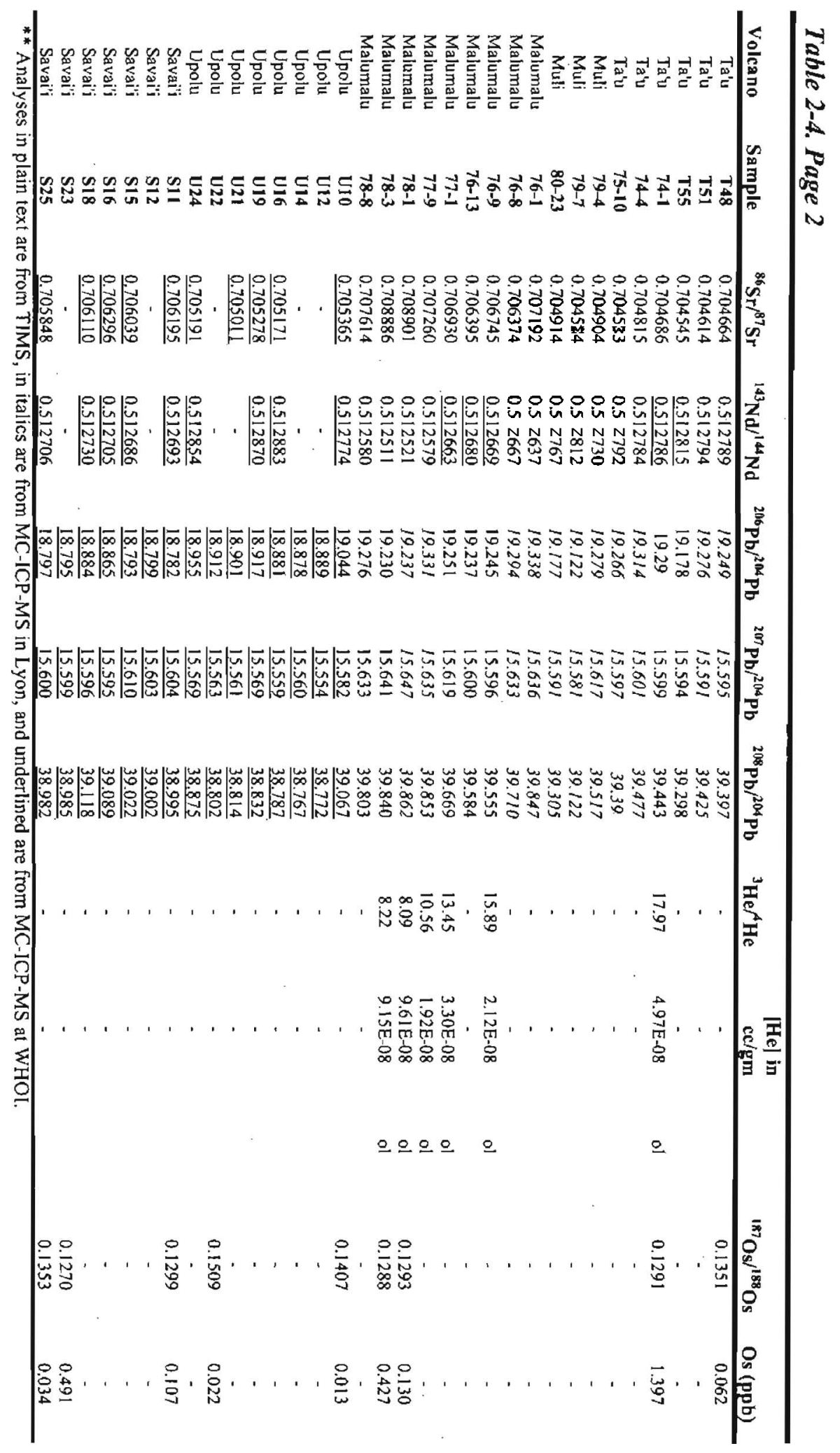


Table 2-5. Sample information and chemical data for Samoan basalts collected by M. Regelous*

\begin{tabular}{|c|c|c|c|c|c|c|c|}
\hline $\begin{array}{l}\text { Volcano } \\
\text { Sample } \\
\end{array}$ & $\begin{array}{l}\text { Upolu } \\
\text { U11 F } \\
\end{array}$ & $\begin{array}{l}\text { Upolu } \\
\text { U } 13 \mathrm{~F} \\
\end{array}$ & $\begin{array}{l}\text { Upolu } \\
\text { U 14F }\end{array}$ & $\begin{array}{l}\text { Upolu } \\
\text { U } 38 \text { F } \\
\end{array}$ & $\begin{array}{l}\text { Upolu } \\
\text { U } 39 \text { F } \\
\end{array}$ & $\begin{array}{l}\text { Upolu } \\
\text { U } 40 \mathrm{~F} \\
\end{array}$ & $\begin{array}{l}\text { Upolu } \\
\text { U } 41 \text { F }\end{array}$ \\
\hline Volcanic Series & Fagaloa & Fagaloa & Fagaloa & Fagaloa & Fagaloa & Fagaloa & Fagaloa \\
\hline Lat. $\left({ }^{\circ} \mathrm{S}\right)$ & 13.8537 & 13.8533 & 13.9422 & 13.8453 & 13.8512 & 13.8597 & 13.8648 \\
\hline Long. $\left({ }^{\circ} \mathrm{W}\right)$ & 171.6886 & 171.6582 & 171.5848 & 171.7093 & 171.7033 & 171.6523 & 171.6436 \\
\hline \multicolumn{8}{|c|}{ Major elements (w1\%) } \\
\hline $\mathrm{SiO}_{2}$ & 48.06 & 45.65 & 45.78 & 48.28 & 47.33 & 47.53 & 46.01 \\
\hline $\mathrm{Al}_{2} \mathrm{O}_{3}$ & 15.20 & 13.98 & 15.79 & 15.32 & 13.86 & 14.00 & 13.87 \\
\hline $\mathrm{TiO}_{2}$ & 4.24 & 2.92 & 3.65 & 4.28 & 5.09 & 3.88 & 2.96 \\
\hline $\mathrm{FeO}^{*}$ & 12.01 & 12.82 & 12.84 & 12.05 & 12.25 & 12.50 & 12.67 \\
\hline $\mathrm{MnO}$ & 0.16 & 0.18 & 0.19 & 0.17 & 0.16 & 0.17 & 0.18 \\
\hline $\mathrm{CaO}$ & 9.73 & 10.27 & 9.82 & 9.37 & 10.47 & 10.26 & 10.77 \\
\hline $\mathrm{MgO}$ & 5.38 & 10.24 & 6.72 & 5.27 & 5.80 & 7.45 & 10.00 \\
\hline $\mathrm{K}_{2} \mathrm{O}$ & 1.37 & 0.91 & 0.56 & 1.41 & 1.44 & 0.97 & 0.94 \\
\hline $\mathrm{Na}_{2} \mathrm{O}$ & 3.22 & 2.59 & 4.00 & 3.22 & 2.92 & 2.75 & 2.16 \\
\hline$P_{2} \bar{O}_{5}$ & 0.63 & 0.44 & 0.65 & 0.63 & 0.68 & 0.48 & 0.45 \\
\hline $\mathrm{Mg} \#$ & 48.44 & 62.63 & 52.31 & 47.85 & 49.82 & 55.54 & 62.35 \\
\hline \multicolumn{8}{|c|}{ Trace Elements (ppm) } \\
\hline $\mathrm{Ni}$ & 72 & 249 & 72 & 73 & 79 & 140 & 248 \\
\hline $\mathrm{Cr}$ & 105 & 389 & 75 & 98 & 73 & 220 & 411 \\
\hline $\mathrm{V}$ & 312 & 272 & 293 & 311 & 341 & 316 & 280 \\
\hline $\mathrm{Ga}$ & 25 & 20 & 23 & 25 & 25 & 22 & 21 \\
\hline $\mathrm{Cu}$ & 71 & 92 & 38 & 69 & 120 & 101 & 98 \\
\hline $\mathrm{Zn}$ & 144 & 123 & 134 & 150 & 154 & 130 & 124 \\
\hline $\mathrm{Cs}$ & 0.20 & 0.40 & 0.54 & 0.32 & 0.47 & 0.14 & 0.23 \\
\hline $\mathrm{Rb}$ & 32.3 & 23.8 & 38.2 & 33.0 & 38.2 & 21.2 & 23.8 \\
\hline $\mathrm{Ba}$ & $31 \mathbf{l}$ & 259 & 341 & 292 & 305 & 203 & 272 \\
\hline Th & 3.79 & 3.17 & 5.27 & 3.77 & 5.08 & 2.64 & 3.27 \\
\hline $\mathrm{U}$ & 1.07 & 0.76 & 1.12 & 1.07 & 1.26 & 0.73 & 0.79 \\
\hline $\mathrm{Nb}$ & 52.18 & 40.16 & 52.88 & 51.82 & 58.00 & 35.35 & 40.33 \\
\hline $\mathrm{Ta}$ & 3.26 & 2.48 & 3.07 & 3.19 & 3.60 & 2.23 & 2.50 \\
\hline $\mathrm{La}$ & 45.10 & 31.13 & 49.32 & 41.43 & 48.93 & 27.74 & 32.16 \\
\hline $\mathrm{Ce}$ & 96.38 & 66.54 & 102.63 & 93.74 & 105.67 & 65.00 & 67.97 \\
\hline $\mathrm{Pb}$ & 2.82 & 2.40 & 3.72 & 2.98 & 3.48 & 1.70 & 2.27 \\
\hline $\mathrm{Pr}$ & 13.21 & 8.21 & 12.34 & 12.49 & 13.99 & 9.03 & 8.43 \\
\hline $\mathrm{Nd}$ & 53.08 & 31.72 & 46.48 & 50.08 & 55.92 & 38.14 & 32.80 \\
\hline Sr & 683 & 521 & 699 & 664 & 631 & 494 & 543 \\
\hline $\mathrm{Zr}$ & 324 & 179 & 243 & 322 & 335 & 264 & 183 \\
\hline $\mathrm{Hr}$ & 7.79 & 4.35 & 5.71 & 7.71 & 8.13 & 6.46 & 4.51 \\
\hline Sm & 11.24 & 6.62 & 9.25 & 10.61 & 11.76 & 8.76 & 6.82 \\
\hline Eu & 3.60 & 2.11 & 2.89 & 3.36 & 3.66 & 2.79 & 2.18 \\
\hline $\mathrm{Gd}$ & 10.52 & 6.11 & 8.19 & 9.57 & 10.63 & 8.18 & 6.33 \\
\hline $\mathrm{Tb}$ & 1.46 & 0.87 & 1.14 & 1.34 & 1.46 & 1.17 & 0.89 \\
\hline Dy & 8.11 . & 4.82 & 6.25 & 7.37 & 7.97 & 6.56 & 4.95 \\
\hline Ho & 1.49 & 0.88 & 1.13 & 1.33 & 1.42 & 1.21 & 0.90 \\
\hline$Y$ & 39.25 & 21.40 & 27.44 & 31.82 & 34.83 & 28.89 & 21.98 \\
\hline $\mathrm{Er}$ & 3.69 & 2.17 & 2.75 & 3.21 & 3.44 & 2.94 & 2.23 \\
\hline $\mathrm{Tm}$ & 0.47 & 0.29 & 0.36 & 0.42 & 0.44 & 0.39 & 0.29 \\
\hline $\mathrm{Yb}$ & 2.69 & 1.69 & 2.10 & 2.42 & 2.53 & 2.25 & 1.71 \\
\hline $\mathrm{Lu}$ & 0.38 & 0.24 & 0.30 & 0.34 & 0.35 & 0.32 & 0.24 \\
\hline $\mathrm{Sc}$ & 22.2 & 22.7 & 19.0 & 21.9 & 25.3 & 25.9 & 24.0 \\
\hline${ }^{86} \mathrm{Sr} /{ }^{87} \mathrm{Sr}$ & 0.705361 & 0.705391 & 0.705644 & & 0.705180 & 0.704904 & 0.705439 \\
\hline${ }^{143} \mathrm{Nd} /{ }^{144} \mathrm{Nd}$ & 0.512874 & 0.512783 & 0.512773 & & & 0.512907 & 0.512777 \\
\hline${ }^{2016} \mathrm{~Pb} /{ }^{204} \mathrm{~Pb}$ & 18.944 & 18.914 & 18.961 & 18.940 & 19.143 & 18.905 & 18.918 \\
\hline${ }^{207} \mathrm{~Pb} /{ }^{204} \mathrm{~Pb}$ & 15.580 & 15.582 & 15.603 & 15.576 & 15.606 & 15.568 & 15.584 \\
\hline${ }^{208} \mathrm{~Pb} /{ }^{204} \mathrm{~Pb}$ & 38.835 . & 38.996 & 39.130 & 38.827 & 39.273 & 38.798 & 39.009 \\
\hline
\end{tabular}

* See Appendix 1 for analytical techniques.

** $\mathrm{Mg} \#=$ molar ratio of $\mathrm{MgO} /(\mathrm{MgO}+0.85 * \mathrm{FeO})$ 
Table 2-5, Page 2

\begin{tabular}{|c|c|c|c|c|c|c|c|}
\hline $\begin{array}{l}\text { Volcano } \\
\text { Sample }\end{array}$ & $\begin{array}{l}\text { Upolu } \\
\text { U } 43 \mathrm{~F}\end{array}$ & $\begin{array}{l}\text { Savai'i } \\
\text { S 36 F } \\
\end{array}$ & $\begin{array}{l}\text { Savai'i } \\
S 44 \text { F } \\
\end{array}$ & $\begin{array}{l}\text { Savai'i } \\
\text { S } 45 \text { F }\end{array}$ & $\begin{array}{l}\text { Savai'i } \\
\text { S 46 F } \\
\end{array}$ & $\begin{array}{l}\text { Savai'i } \\
\text { S 47 F }\end{array}$ & $\begin{array}{c}\text { Savai'i PE } \\
\text { S10 M }\end{array}$ \\
\hline Volcanic & & & & & & & \\
\hline Series . & Fagaloa & Fagaloa & Fagaloa & Fagaloa & Fagaloa & Fagaloa & Mulifanua \\
\hline Lat. $\left({ }^{\circ} \mathrm{S}\right)$ & 13.8895 & 13.2642 & 13.2662 & 13.2662 & 13.2642 & 13.2637 & 13.3058 \\
\hline Long. ( $\left.{ }^{\circ} \mathrm{W}\right)$ & 171.5614 & 172.3815 & 172.3677 & 172.3674 & 172.3813 & 172.3841 & 172.6411 \\
\hline \multicolumn{8}{|c|}{ Mujor elements (wt\%) } \\
\hline $\mathrm{SiO}_{2}$ & 46.66 & 45.93 & 47.24 & 11.94 & 13.93 & 14.70 & 12.70 \\
\hline $\mathrm{Al}_{2} \mathrm{O}_{3}$ & 13.69 & 11.92 & 14.48 & 3.04 & 2.72 & 3.11 & 3.37 \\
\hline $\mathrm{TiO}_{2}$ & 5.16 & 3.12 & 2.57 & I 1.34 & 11.29 & 11.86 & 11.25 \\
\hline $\mathrm{FeO} *$ & 14.15 & 11.59 & 11.86 & 0.16 & 0.16 & 0.16 & 0.15 \\
\hline $\mathrm{MnO}$ & 0.18 & 0.16 & 0.16 & 9.70 & 10.35 & 9.18 & 9.26 \\
\hline $\mathrm{CaO}$ & 9.76 & 10.05 & 10.19 & 13.24 & 9.34 & 10.16 & 11.01 \\
\hline $\mathrm{MgO}$ & 5.46 & 13.21 & 9.62 & 1.61 & 0.94 & 1.08 & 2.10 \\
\hline $\mathrm{K}_{2} \mathrm{O}$ & 1.07 & 0.48 & 0.96 & 2.69 & 2.73 & 2.62 & 3.28 \\
\hline $\mathrm{Na}_{2} \mathrm{O}$ & 3.35 & 3.10 & 2.64 & 0.44 & 0.29 & 0.31 & 0.56 \\
\hline $\mathrm{P}_{2} \mathrm{O}_{5}$ & 0.50 & 0.44 & 0.27 & 71.01 & 63.44 & 64.24 & 67.25 \\
\hline Mg\# & 44.72 & 70.51 & 62.98 & 11.94 & 13.93 & 14.70 & 12.70 \\
\hline \multicolumn{8}{|c|}{ Trace Elements (ppm) } \\
\hline $\mathrm{Ni}$ & 35 & 386 & 214 & 385 & 174 & 202 & 281 \\
\hline $\mathrm{Cr}$ & 4 & 603 & 339 & 600 & 423 & 526 & 440 \\
\hline V & 389 & 238 & 252 & 233 & 251 & 265 & 224 \\
\hline $\mathrm{Ga}$ & 25 & 19 & 21 & 19 & 20 & 22 & 21 \\
\hline $\mathrm{Cu}$ & 84 & 76 & 73 & 77 & 81 & 54 & 63 \\
\hline $\mathrm{Zn}$ & 160 & 120 & 121 & 115 & 110 & 122 & 132 \\
\hline Cs & 0.28 & 0.40 & 0.14 & 0.43 & 0.14 & 0.13 & 0.62 \\
\hline $\mathbf{R b}$ & 25.0 & 55.9 & 23.2 & 48.0 & 25.1 & 16.8 & 55.2 \\
\hline $\mathrm{Ba}$ & 213 & 431 & 235 & 437 & 224 & 323 & 543 \\
\hline Th & 2.80 & 3.36 & 2.18 & 3.48 & 2.41 & 2.23 & 4.93 \\
\hline U & 0.82 & 0.70 & 0.43 & 0.81 & 0.57 & 0.73 & 1.19 \\
\hline $\mathrm{Nb}$ & 40.56 & 42.85 & 29.16 & 44.36 & 28.81 & 36.51 & 67.26 \\
\hline$T a$ & 2.59 & 2.65 & 3.80 & 2.70 & 1.76 & 2.58 & 4.15 \\
\hline $\mathrm{La}$ & 30.24 & 31.95 & 41.87 & 31.95 & 22.82 & 20.37 & 41.90 \\
\hline $\mathrm{Ce}$ & 72.09 & 69.29 & 47.58 & 69.49 & 49.31 & 44.97 & 87.77 \\
\hline $\mathrm{Pb}$ & 3.15 & 2.79 & 2.01 & 2.87 & 2.07 & 2.06 & 4.22 \\
\hline $\operatorname{Pr}$ & 9.91 & 8.76 & 8.94 & 8.80 & 6.36 & 5.94 & 10.91 \\
\hline Nd & 42.30 & 34.84 & 36.05 & 34.74 & 25.53 & 24.21 & 41.94 \\
\hline $\mathrm{Sr}$ & 552 & 585 & 436 & 821 & 419 & 394 & 679 \\
\hline $\mathrm{Zr}$ & 301 & 188 & 161 & 191 & 156 & 189 & 267 \\
\hline $\mathrm{Hf}$ & 7.55 & 4.7 I & 4.00 & 4.69 & 3.90 & 4.74 & 6.35 \\
\hline $\mathrm{Sm}$ & 9.98 & 7.32 & 7.55 & 7.29 & 5.70 & 5.50 & 8.42 \\
\hline Eu & 3.23 & 2.35 & 2.67 & 2.33 & 1.92 & 1.83 & 2.62 \\
\hline Gd & $9: 57$ & 6.67 & 9.17 & 6.60 & 5.62 & 5.38 & 7.48 \\
\hline $\mathrm{Tb}$ & 1.37 & 0.92 & 1.32 & 0.92 & 0.83 & 0.81 & 1.03 \\
\hline Dy & 7.65 & 4.99 & 7.93 & 4.93 & 4.74 & 4.64 & 5.47 \\
\hline Ho & 1.38 & 0.87 & 1.59 & 0.86 & 0.87 & 0.86 & 0.95 \\
\hline$Y$ & 33.23 & 20.89 & 46.87 & 20.84 & 21.40 & 21.05 & 23.34 \\
\hline EI & 3.36 & 2.06 & 4.10 & 2.07 & 2.20 & 2.19 & 2.24 \\
\hline $\mathrm{Tm}$ & 0.44 & 0.27 & 0.54 & 0.26 & 0.29 & 0.30 & 0.28 \\
\hline $\mathrm{Yb}$ & 2.50 & 1.49 & 3.09 & I. 49 & 1.71 & 1.72 & 1.59 \\
\hline $\mathrm{Lu}$ & 0.35 & 0.21 & 0.49 & 0.21 & 0.25 & 0.25 & 0.22 \\
\hline $\mathrm{Sc}$ & 26.0 & 22.2 & 24.4 & 21.4 & 25.2 & 21.5 & 18.7 \\
\hline${ }^{86} \mathrm{Sr} /{ }^{87} \mathrm{Sr}$ & 0.705179 & 0.705823 & 0.706670 & 0.705856 & 0.706338 & & 0.706528 \\
\hline${ }^{143} \mathrm{Nd} /{ }^{144} \mathrm{Nd}$ & 0.512883 & 0.512702 & & 0.512695 & 0.512678 & 0.512725 & 0.512682 \\
\hline${ }^{206} \mathrm{~Pb} /{ }^{204} \mathrm{~Pb}$ & 18.848 & 18.801 & & 18.804 & 18.866 & 18.821 & 18.803 \\
\hline${ }^{207} \mathrm{~Pb} /{ }^{204} \mathrm{~Pb}$ & 15.564 & 15.609 & & 15.612 & 15.613 & 15.604 & 15.615 \\
\hline${ }^{208} \mathrm{~Pb} /{ }^{204} \mathrm{~Pb}$ & 38.783 & 39.012 & & 39.024 & 39.159 & 39.022 & 39.019 \\
\hline
\end{tabular}


Table 2-5, Page 3

\begin{tabular}{|c|c|c|c|c|c|c|c|}
\hline $\begin{array}{l}\text { Volcano } \\
\text { Sample }\end{array}$ & $\begin{array}{c}\text { Savai'i PE } \\
\text { S } 15 \mathrm{Ma}\end{array}$ & $\begin{array}{c}\text { Savai'i PE } \\
\text { S 26 S }\end{array}$ & $\begin{array}{c}\text { Savai'i PE } \\
\mathrm{S} 28 \mathrm{~Pb}\end{array}$ & $\begin{array}{c}\text { Savai'i PE } \\
\text { s31 P }\end{array}$ & $\begin{array}{c}\text { Savai'i PE } \\
\text { s } 32 \text { M }\end{array}$ & $\begin{array}{c}\text { Savaili PE } \\
\text { s33 P }\end{array}$ & $\begin{array}{c}\text { Savai'i PE } \\
\text { s } 34 \text { A }\end{array}$ \\
\hline \multicolumn{8}{|l|}{ Volcanic } \\
\hline Series & Mulifanua & Salani & Puapua & Puapua & Mulifanua & Puapua & Aopo \\
\hline Lat. $\left({ }^{\circ} \mathrm{S}\right)$ & 13.3094 & 134327 & 13.4611 & 13.4753 & 13.3799 & 13.3099 & 13.318 \\
\hline Long $\left({ }^{\circ} \mathrm{W}\right)$ & 172.7021 & 172.314 & 172.3728 & 172.513 & 172.6655 & 172.7404 & 172.5523 \\
\hline \multicolumn{8}{|c|}{ Major elements (wt\%) } \\
\hline $\mathrm{SiO}_{2}$ & 44.62 & 45.51 & 48.64 & 48.76 & 45.39 & 48.05 & 45.89 \\
\hline $\mathrm{Al}_{2} \mathrm{O}_{3}$ & 12.40 & 12.64 & 14.20 & 14.18 & 11.84 & 14.25 & 12.38 \\
\hline $\mathrm{TiO}_{2}$ & 3.30 & . $3: 24$ & 3.01 & 2.96 & 3.83 & 2.73 & 3.13 \\
\hline $\mathrm{FeO}^{*}$ & 11.46 & 11.80 & 10.58 & 10.48 & 12.11 & 10.91 & 11.23 \\
\hline $\mathrm{MnO}$ & 0.16 & 0.15 & 0.14 & 0.14 & 0.15 & 0.15 & 0.16 \\
\hline $\mathrm{CaO}$ & 10.48 & 9.07 & 8.07 & 8.05 & 9.07 & 8.57 & $9.5 \mathrm{I}$ \\
\hline $\mathrm{MgO}$ & 11.92 & 12.04 & 8.98 & 9.08 & 12.75 & 9.76 & 12.31 \\
\hline $\mathrm{K}_{2} \mathrm{O}$ & 1.91 & 1.80 & 2.09 & 2.06 & 1.88 & 1.68 & 1.78 \\
\hline $\mathrm{Na}_{2} \mathrm{O}$ & 3.04 & 3.25 & 3.73 & 3.72 & 2.62 & 3.28 & 3.15 \\
\hline $\mathrm{P}_{2} \mathrm{O}_{5}$ & 0.71 & 0.52 & 0.56 & 0.56 & 0.36 & 0.61 & 0.47 \\
\hline $\mathrm{M}_{g \#} \#$ & 68.57 & 68.14 & 64.03 & 64.50 & 68.82 & 65.24 & 69.68 \\
\hline \multicolumn{8}{|c|}{ Trace Elements (ppm) } \\
\hline $\mathrm{Ni}$ & 275 & 329 & & 233 & 361 & 236 & 340 \\
\hline$C_{T}$ & 500 & 405 & & 315 & 520 & 350 & 535 \\
\hline V & 244 & 238 & & 196 & 268 & 201 & 240 \\
\hline $\mathrm{Ga}$ & 21 & 22 & & 23 & 22 & 22 & 20 \\
\hline $\mathrm{Cu}$ & 69 & 59 & & 55 & 75 & 50 & 60 \\
\hline $\mathrm{Zn}$ & 128 & 139 & & 133 & 134 & 129 & 118 \\
\hline Cs & 0.58 & 0.52 & & 0.75 & 0.65 & 0.48 & 0.50 \\
\hline $\mathrm{Rb}$ & 51.0 & 46.1 & & 61.4 & 55.2 & 44.9 & 49.3 \\
\hline $\mathrm{Ba}$ & 500 & 388 & & 451 & 399 & 503 & 401 \\
\hline Th & 6.34 & 3.39 & & 5.33 & 2.82 & 4.75 & 3.94 \\
\hline $\mathrm{U}$ & 1.43 & 0.89 & & 1.39 & 0.73 & 1.11 & 0.87 \\
\hline $\mathrm{Nb}$ & 70.27 & 54.93 & & 55.33 & 50.96 & 55.28 & 50.26 \\
\hline $\mathrm{Ta}$ & 4.27 & 3.42 & & 3.55 & 3.63 & 3.43 & 3.28 \\
\hline $\mathrm{La}$ & 54.90 & 32.20 & & 36.37 & 24.26 & 39.62 & 36.60 \\
\hline $\mathrm{Ce}$ & 12.66 & 71.92 & & 75.05 & 54.51 & 81.56 & 77.21 \\
\hline $\mathrm{Pb}$ & 5.24 & 3.06 & & 4.21 & 2.32 & 3.94 & 3.08 \\
\hline $\operatorname{Pr}$ & 13.50 & 9.34 & & 9.26 & 7.17 & 9.82 & 9.48 \\
\hline $\mathrm{Nd}$ & 50.24 & 37.53 & & 35.63 & 29.73 & 37.02 & 36.57 \\
\hline $\mathrm{Sr}$ & 748 & 670 & & 610 & 491 & 606 & 556 \\
\hline $\mathrm{Zr}$ & 272 & 251 & & 284 & 250 & 253 & 225 \\
\hline $\mathrm{Hf}$ & 6.39 & 6.00 & & 6.64 & 6.40 & 5.93 & 5.57 \\
\hline Sm & 9.59 & 8.09 & & 7.55 & 6.66 & 7.50 & 7.58 \\
\hline $\mathrm{Eu}$ & 2.92 & 2.57 & & 2.43 & 2.15 & 2.37 & 2.30 \\
\hline$G d$ & 8.11 & 7.31 & & 7.00 & 6.18 & 6.83 & 6.88 \\
\hline $\mathrm{Tb}$ & $1.1 \mathrm{I}$ & 1.02 & & 0.99 & 0.86 & 0.98 & 0.95 \\
\hline Dy & 5.78 & 5.35 & & 5.31 & 4.60 & 5.46 & 5.15 \\
\hline Ho & 0.99 & 0.91 & & 0.91 & 0.79 & 0.98 & 0.90 \\
\hline $\mathbf{Y}$ & 24.41. & 21.99 & & 22.24 & 19.21 & 24.02 & 21.52 \\
\hline Er & 2.39 & 2.10 & & 2.14 & 1.87 & 2.39 & 2.11 \\
\hline $\mathrm{Tm}$ & 0.30 & 0.26 & & 0.28 & 0.24 & 0.31 & 0.27 \\
\hline $\mathrm{Yb}$ & 1.67 & 1.43 & & 1.54 & 1.31 & 1.84 & 1.53 \\
\hline $\mathrm{Lu}$ & 0.24 & 0.20 & & 0.22 & 0.18 & 0.26 & 0.22 \\
\hline $\mathrm{Sc}$ & 21.3 & 18.4 & & .15 .8 & 20.4 & 17.2 & 20.3 \\
\hline${ }^{80} \mathrm{Sr} /{ }^{5 /} \overline{\mathrm{S}} \mathrm{r}$ & 0.706435 & 0.705597 & 0.705784 & 0.705765 & 0.705267 & 0.705451 & 0.706409 \\
\hline${ }^{143} \mathrm{Nd} / 144 \mathrm{Nd}$ & & & 0.512747 & 0.512751 & 0.512795 & 0.512776 & \\
\hline${ }^{206} \mathrm{~Pb} /{ }^{204} \mathrm{~Pb}$ & 18.888 & 18.793 & 18.776 & 18.777 & 18.842 & 18.682 & 18.796 \\
\hline${ }^{207} \mathrm{~Pb} /{ }^{204} \mathrm{~Pb}$ & 15.623 & 15.580 & 15.602 & 15.598 & 15.589 & 15.603 & 15.607 \\
\hline${ }^{208} \mathrm{~Pb} /{ }^{204} \mathrm{~Pb}$ & 39.163 & 38.866 & 38.938 & 38.921 & 39.017 & 38.856 & 39.051 \\
\hline
\end{tabular}


Table 2-5, Page 4

\begin{tabular}{|c|c|c|c|c|c|c|c|}
\hline $\begin{array}{l}\text { Volcano } \\
\text { Sample }\end{array}$ & $\begin{array}{c}\text { Savai'i PE } \\
\text { S35 P }\end{array}$ & $\begin{array}{c}\text { Savai'i PE } \\
\mathbf{S 3 9} \mathbf{A}\end{array}$ & $\begin{array}{c}\text { Savai'i PE } \\
\text { S 42 A }\end{array}$ & $\begin{array}{c}\text { Savai'' PE } \\
\text { S 43 P }\end{array}$ & $\begin{array}{c}\text { Savai'i PE } \\
\text { S } 50 \mathrm{~S}\end{array}$ & $\begin{array}{c}\text { Savai'i PE } \\
\text { S } 52 \mathbf{M}\end{array}$ & $\begin{array}{c}\text { Upolu PE } \\
\text { U } 10 \mathrm{~S}\end{array}$ \\
\hline \multicolumn{8}{|l|}{ Volcanic } \\
\hline Series & Puapua & Aopo & Aopo & Puapua & Salani & Mulifanua & Salani \\
\hline Lat. $\left({ }^{\circ} \mathrm{S}\right)$ & 13.2957 & 13.2703 & 13.2673 & 13.32 & 13.3596 & 13.42 & 13.8368 \\
\hline Long. $\left({ }^{\circ} \mathrm{W}\right)$ & 172.4654 & 172.3123 & 172.3106 & 172.2362 & 172.2673 & 172.2024 & 171.7362 \\
\hline \multicolumn{8}{|c|}{ Major elements (wr\%) } \\
\hline $\mathrm{SiO}_{2}$ & 48.30 & 47.33 & 46.05 & 44.72 & 45.94 & 45.83 & 48.41 \\
\hline $\mathrm{Al}_{2} \mathrm{O}_{3}$ & 13.32 & 12.47 & 11.76 & 11.45 & 12.59 & 11.98 & 15.15 \\
\hline $\mathrm{TiO}_{2}$ & 2.94 & 2.70 & 2.83 & 3.67 & 3.27 & 3.04 & 4.23 \\
\hline $\mathrm{FeO}^{*}$ & 11.29 & 11.71 & 11.98 & 12.42 & 12.37 & 11.45 & 11.88 \\
\hline $\mathrm{MnO}$ & 0.15 & 0.16 & 0.16 & 0.16 & 0.17 & 0.15 & 0.16 \\
\hline $\mathrm{CaO}$ & 9.44 & 9.45 & 9.28 & 9.13 & 9.79 & 9.24 & 9.64 \\
\hline $\mathrm{MgO}$ & 10.16 & 12.04 & 13.75 & 14.06 & 11.95 & 13.33 & 5.21 \\
\hline $\mathrm{K}_{2} \mathrm{O}$ & 1.23 & 0.96 & 1.19 & 1.56 & 1.32 & 1.59 & 1.40 \\
\hline $\mathrm{Na}_{2} \mathrm{O}$ & 2.84 & 2.88 & 2.66 & 2.45 & 2.32 & 2.86 & 3.26 \\
\hline $\mathrm{P}_{2} \mathrm{O}_{5}$ & 0.33 & 0.31 & 0.35 & 0.39 & 0.27 & 0.52 & 0.65 \\
\hline $\mathrm{Mg \#}$ & 65.38 & 68.32 & 70.64 & 70.37 & 66.94 & 70.93 & 47.92 \\
\hline \multicolumn{8}{|c|}{ Trace Elements (ppm) } \\
\hline $\mathrm{Ni}$ & 255 & 340 & 412 & & 302 & 402 & 62 \\
\hline $\mathrm{Cr}$ & 456 & 570 & 594 & & 552 & 491 & 86 \\
\hline V & 236 & 231 & 231 & & 266 & 223 & 309 \\
\hline Ga & 21 & 20 & 19 & & 21 & 20 & 25 \\
\hline $\mathrm{Cu}$ & 55 & 72 & 66 & & 83 & 65 & 78 \\
\hline $\mathrm{Zn}$ & 114 & 121 & 124 & & 123 & 126 & 146 \\
\hline Cs & 0.15 & 0.30 & 0.36 & & 0.51 & 0.66 & 0.31 \\
\hline $\mathrm{Rb}$ & 29.5 & 24.8 & 31.0 & & 38.6 & 44.0 & 33.7 \\
\hline $\mathrm{Ba}$ & 277 & 245 & 288 & & 334 & 438 & 298 \\
\hline Th & 2.44 & 2.44 & $2.9 !$ & & 1.88 & 4.35 & 3.87 \\
\hline $\mathrm{U}$ & 0.55 & 0.57 & 0.70 & & 0.46 & 1.06 & 1.08 \\
\hline $\mathrm{Nb}$ & 38.69 & 31.82 & 36.65 & & 47.12 & 51.33 & 52.29 \\
\hline $\mathrm{Ta}$ & 2.73 & 2.12 & 2.40 & & 3.45 & 3.13 & 3.27 \\
\hline $\mathrm{La}$ & 21.29 & 22.02 & 26.43 & & 19.08 & 37.49 & 42.54 \\
\hline $\mathrm{Ce}$ & 47.10 & 47.50 & 56.59 & & 44.93 & 78.41 & 97.06 \\
\hline $\mathrm{Pb}$ & 3.18 & 1.98 & 2.38 & & 1.72 & 3.78 & 3.03 \\
\hline $\operatorname{Pr}$ & 6.10 & 6.08 & 7.15 & & 6.04 & 9.67 & 12.72 \\
\hline $\mathrm{Nd}$ & 25.00 & 24.42 & 28.34 & & 25.09 & 37.30 & 51.10 \\
\hline$S r^{*}$ & 402 & 398 & 437 & & 409 & 794 & 676 \\
\hline $\mathrm{Zr}$ & 187 & 159 & 175 & & 211 & 225 & 326 \\
\hline $\mathrm{Hf}$ & 4.95 & 4.16 & 4.47 & & 5.53 & 5.39 & 7.96 \\
\hline $\mathrm{Sm}$ & 5.76 & 5.60 & 6.13 & & 5.62 & 7.70 & 10.63 \\
\hline $\mathrm{Eu}$ & 1.90 & 1.81 & 1.92 & & 1.85 & 2.44 & 3.33 \\
\hline $\mathrm{Gd}$ & 5.70 & 5.57 & 5.84 & & 5.38 & 6.94 & 9.68 \\
\hline$T b$ & 0.84 & 0.83 & 0.85 & & 0.77 & 0.97 & 1.37 \\
\hline Dy & 4.75 & 4.74 & 4.73 & & 4.29 & 5.20 & 7.50 \\
\hline Ho & 0.86 & 0.87 & 0.85 & & 0.77 & 0.90 & 1.35 \\
\hline Y & 20.55 & 20.92 & 20.49 & & 18.63 & 21.87 & 32.62 \\
\hline Er & 2.12 & 2.16 & 2.09 & & 1.90 & 2.15 & 3.32 \\
\hline $\mathrm{Tm}$ & 0.28 & 0.28 & 0.27 & & 0.25 & 0.27 & 0.44 \\
\hline $\mathbf{Y b}$ & 1.60 & 1.61 & 1.54 & & 1.43 & 1.53 & 2.50 \\
\hline $\mathrm{Lu}$ & 0.23 & 0.23 & 0.22 & & 0.20 & 0.21 & 0.35 \\
\hline Sc & 21.5 & 22.1 & 20.8 & & 22.5 & 19.0 & 21.6 \\
\hline${ }^{86} \mathrm{~S}_{\Gamma} /^{87} \mathrm{Sr}$ & & 0.705564 & 0.705793 & 0.706018 & 0.706907 & 0.705686 & 0.705363 \\
\hline${ }^{143} \mathrm{Nd} /{ }^{144} \mathrm{Nd}$ & & 0.512705 & & 0.512712 & 0.512711 & 0.512736 & 0.512870 \\
\hline${ }^{206} \mathrm{~Pb} /{ }^{204} \mathrm{~Pb}$ & 18.853 & 18.803 & 18.792 & & 18.901 & 18.746 & 18.940 \\
\hline${ }^{207} \mathrm{~Pb} /{ }^{204} \mathrm{~Pb}$ & 15.602 & 15.607 & 15.607 & & 15.611 & 15.602 & 15.577 \\
\hline${ }^{208} \mathrm{~Pb} /{ }^{204} \mathrm{~Pb}$ & 39.071 & 39.039 & 39.044 & & 39.150 & 38.916 & 38.826 \\
\hline
\end{tabular}


Table 2-5, Page 5

\begin{tabular}{|c|c|c|c|c|c|c|c|}
\hline $\begin{array}{l}\text { Volcano } \\
\text { Sample }\end{array}$ & $\begin{array}{c}\text { Upolu PE } \\
\text { U } 15 \text { S }\end{array}$ & $\begin{array}{c}\text { Upolu PE } \\
\text { U } 16 \mathrm{~S}\end{array}$ & $\begin{array}{c}\text { Upolu PE } \\
\text { U } 17 \text { S (1) }\end{array}$ & $\begin{array}{l}\text { Upolu PE } \\
\text { U } 17 \text { S (2) }\end{array}$ & $\begin{array}{c}\text { Upolu PE } \\
\text { U21 S }\end{array}$ & $\begin{array}{c}\text { Upolu PE } \\
\text { U } 23 \mathbf{~ P ~}\end{array}$ & $\begin{array}{c}\text { Upolu PE } \\
\text { U } 24 \text { L }\end{array}$ \\
\hline Volcanic & & & & & & & \\
\hline Series & Salani & Salani & Salani & Salani & Salani & Pцарuа & Lefaga \\
\hline Lat. ( $\left.{ }^{\circ} \mathrm{S}\right)$ & 13.9983 & 14.0306 & 14.0357 & Same Flow & 13.9541 & 14.0221 & 13.9668 \\
\hline Long. $\left({ }^{\circ} \mathrm{W}\right)$ & 171.4222 & 171.4325 & 171.4619 & Few meters & 171.7674 & 171.731 & 171.9434 \\
\hline \multicolumn{8}{|c|}{ Major elements (wr\%) } \\
\hline $\mathrm{SiO}_{2}$ & 44.68 & 47.20 & 45.13 & & 45.29 & 41.85 & 44.11 \\
\hline $\mathrm{Al}_{2} \mathrm{O}_{3}$ & 12.02 & 12.21 & 11.67 & & 12.26 & 11.79 & 12.63 \\
\hline $\mathrm{TiO}_{2}$ & 4.53 & 3.99 & 3.96 & & 3.45 & 4.52 & 3.62 \\
\hline $\mathrm{FeO}$ & 12.55 & 12.32 & 12.33 & & 12.61 & 13.48 & 12.32 \\
\hline $\mathrm{MnO}$ & 0.16 & 0.15 & 0.16 & & 0.17 & 0.17 & 0.17 \\
\hline $\mathrm{CaO}$ & 9.96 & 8.99 & 9.87 & & 10.45 & 10.91 & 10.83 \\
\hline $\mathrm{MgO}$ & 11.63 & 10.57 & 11.94 & & 11.51 & 11.14 & 11.04 \\
\hline $\mathrm{K}_{2} \mathrm{O}$ & 1.66 & 1.54 & 1.51 & & 1.19 & 1.85 & 1.40 \\
\hline $\mathrm{Na}_{2} \mathrm{O}$ & $2.2 \mathrm{I}$ & 2.67 & 2.88 & & 2.52 & 3.56 & 3.15 \\
\hline $\mathrm{P}_{2} \mathrm{O}_{3}$ & 0.59 & 0.36 & 0.56 & & 0.55 & 0.72 & 0.72 \\
\hline$M g \#$ & 66.02 & 64.28 & 67.00 & & 65.68 & 63.42 & 65.27 \\
\hline \multicolumn{8}{|c|}{ Trace Elements (ppm) } \\
\hline $\mathrm{Ni}$ & 315 & & 327 & & 284 & 248 & 240 \\
\hline $\mathrm{Cr}$ & 427 & & 430 & & 441 & 325 & 419 \\
\hline V & 275 & & 257 & & 245 & 288 & 270 \\
\hline $\mathrm{Ga}$ & 22 & & 20 & & 21 & 21 & 21 \\
\hline $\mathrm{Cu}$ & 21 & & 81 & & 67 & 66 & 69 \\
\hline $2 \pi$ & 151 & & 134 & & 131 & 145 & 128 \\
\hline $\mathrm{Cs}$ & 0.19 & & 0.47 & & 0.43 & 0.63 & 0.19 \\
\hline $\mathrm{Rb}$ & 43.7 & & 56.8 & & 31.9 & 53.3 & 38.4 \\
\hline $\mathrm{Ba}$ & 533 & & 466 & & 403 & 677 & 486 \\
\hline Th & 4.41 & & 3.73 & & 4.54 & 6.73 & 7.17 \\
\hline $\mathrm{U}$ & 1.06 & & 0.87 & & 1.03 & 1.43 & 0.93 \\
\hline $\mathrm{Nb}$ & 50.54 & & 45.98 & & 45.85 & 72.56 & 54.02 \\
\hline Ta & 3.09 & & 2.85 & & 2.80 & 4.09 & 3.03 \\
\hline $\mathrm{La}$ & 41.63 & & 36.96 & & 42.94 & 63.55 & 65.36 \\
\hline $\mathrm{Ce}$ & 88.37 & & 79.28 & & 89.24 & 129.64 & 130.00 \\
\hline $\mathbf{P b}$ & 2.26 & & 2.99 & & 3.68 & 4.95 & 4.48 \\
\hline $\mathrm{Pr}_{5}$ & 11.01 & & 9.96 & & 11.00 & 15.49 & 14.99 \\
\hline Nd & 43.34 & & 39.79 & & 42.36 & 57.75 & 53.99 \\
\hline $\mathrm{Sr}$ & 643 & & 613 & & 623 & 892 & 823 \\
\hline $\mathrm{Zr}$ & 219 & & 203 & & 225 & 264 & 231 \\
\hline $\mathrm{Hf}$ & 5.49 & & 5.24 & & 5.70 & 6.36 & 5.40 \\
\hline $\mathrm{Sm}$ & 9.01 & & 8.54 & & 8.54 & 11.03 & 10.00 \\
\hline $\mathrm{Eu}$ & 2.76 & & 2.61 & & 2.60 & 3.37 & 300 \\
\hline Gd & 8.27 & & 7.84 & & 7.52 & 9.40 & 8.39 \\
\hline Tb & 1.13 & & 1.09 & & 1.04 & 1.28 & 1.16 \\
\hline Dy & 6.06 & & 5.89 & & 5.69 & 6.70 & 6.23 \\
\hline Ho & 1.04 & & 1.02 & & 0.99 & 1.15 & 1.09 \\
\hline $\mathbf{Y}$ & 24.89 & & 24.32 & & 23.80 & 27.84 & 27.05 \\
\hline Er & 2.41 & & 2.38 & & 2.35 & 2.64 & 2.63 \\
\hline $\mathrm{Tm}$ & 0.30 & & 0.30 & & 0.30 & 0.32 & 0.33 \\
\hline $\mathrm{Yb}$ & 1.67 & & 1.66 & & 1.67 & 1.78 & 1.94 \\
\hline $\mathrm{Lu}$ & 0.23 & & 0.23 & & 0.23 & 0.24 & 0.27 \\
\hline $\mathrm{Sc}$ & 21.3 & & 21.2 & & 21.4 & 21.5 & 22.3 \\
\hline${ }^{86} \mathrm{Sr} r^{87} \mathrm{Sr}$ & & 0.706088 & 0.705813 & 0.705750 & 0.705393 & 0.705536 & 0.705670 \\
\hline${ }^{143} \mathrm{Nd} /{ }^{144} \mathrm{Nd}$ & & & 0.5127 .11 & 0.512713 & 0.512662 & 0.512671 & 0.512666 \\
\hline${ }^{206} \mathrm{~Pb} /{ }^{204} \mathrm{~Pb}$ & 18.785 & & 18.711 & & & 18.577 & \\
\hline${ }^{207} \mathrm{~Pb} /{ }^{204} \mathrm{~Pb}$ & 15.623 & & 15.607 & & & 15.611 & \\
\hline${ }^{208} \mathrm{~Pb} /{ }^{204} \mathrm{~Pb}$ & 39.004 & & 38.871 & & & 38.775 & \\
\hline
\end{tabular}


Table 2-5, Page 6

\begin{tabular}{|c|c|c|c|c|c|c|c|}
\hline $\begin{array}{l}\text { Volcano } \\
\text { Sainple } \\
\end{array}$ & $\begin{array}{c}\text { Upolu PE } \\
\text { U 26 L }\end{array}$ & $\begin{array}{c}\text { Upolu PE } \\
\text { U 28 I }\end{array}$ & $\begin{array}{c}\text { Upolu PE } \\
\text { U 30 L }\end{array}$ & $\begin{array}{l}\text { Upolu PE } \\
\text { U 32 M }\end{array}$ & $\begin{array}{l}\text { Upolu PE } \\
\text { U } 33 \mathbf{~ M}\end{array}$ & $\begin{array}{c}\text { Upolu PE } \\
\text { U 35 M(1) } \\
\end{array}$ & $\begin{array}{c}\text { Upolu PE } \\
\text { U } 35 \mathrm{M}(2)\end{array}$ \\
\hline Volcanic & & & & & & & \\
\hline Series & Lefaga & Lefaga & Lefaga & Mulifanua & Mulifanua & Mulifanua & Mulifanua \\
\hline Lat. $\left({ }^{\circ} \mathrm{S}\right)$. & 13.9728 & 13.9677 & 13.9804 & 13.7917 & 13.8265 & 13.8359 & Same Flow \\
\hline Long $\left({ }^{\circ} \mathrm{W}\right)$ & 171.9399 & 171.9416 & 171.9329 & 171.9007 & 171.9974 & 171.9469 & Few meters \\
\hline \multicolumn{8}{|c|}{ Mojor elements (wt\%) } \\
\hline $\mathrm{SiO}_{2}$ & 41.64 & 42.25 & 42.10 & 44.65 & 48.37 & 41.58 & \\
\hline $\mathrm{Al}_{2} \mathrm{O}_{3}$ & 11.95 & 11.58 & 11.74 & 12.14 & 13.63 & 11.14 & \\
\hline $\mathrm{TiO}_{2}$ & 5.82 & 5.63 & 5.67 & 4.31 & 3.34 & 6.58 & \\
\hline $\mathrm{FeO}^{*}$ & 14.39 & 13.92 & 14.02 & 13.14 & 11.30 & 14.55 & \\
\hline $\mathrm{MnO}$ & 0.18 & 0.16 & 0.17 & 0.16 & 0.14 & 0.17 & \\
\hline $\mathrm{CaO}$ & 10.26 & 9.90 & 10.03 & 9.67 & 9.01 & 9.97 & \\
\hline $\mathrm{MgO}$ & 11.67 & 11.44 & 11.45 & 12.35 & 8.12 & 11.77 & \\
\hline $\mathrm{K}_{2} \mathrm{O}$ & 1.20 & 1.65 & 1.54 & 1.27 & 1.92 & 1.39 & \\
\hline $\mathrm{Na}_{2} \mathrm{O}$ & 2.29 & 2.87 & 2.69 & 1.99 & 3.50 & 2.42 & \\
\hline $\mathrm{P}_{2} \mathrm{O}_{3}$ & 0.61 & 0.59 & 0.58 & 0.34 & 0.68 & 0.42 & \\
\hline $\mathrm{Mg} \#$ & 62.99 & 63.29 & 63.14 & 66.35 & 60.11 & 62.92 & \\
\hline \multicolumn{8}{|c|}{ Trace Elements (ppm) } \\
\hline $\mathrm{Ni}$ & 299 & 301 & & 357 & 171 & 328 & \\
\hline $\mathrm{Cr}$ & 376 & 375 & & 489 & 204 & 460 & \\
\hline V & 322 & 320 & & 292 & 189 & 379 & \\
\hline $\mathrm{Oa}$ & 22 & 22 & & 20 & 23 & 20 & \\
\hline $\mathrm{Cu}$ & 67 & 69 & & 68 & 29 & 87 & \\
\hline $\mathrm{Zn}$ & 145 & 145 & & 129 & 142 & 140 & \\
\hline Cs & 0.54 & 0.54 & & 0.29 & 0.51 & 0.41 & \\
\hline $\mathrm{Rb}$ & 37.8 & 50.2 & & 32.3 & 47.9 & 40.4 & \\
\hline $\mathrm{Ba}$ & 509 & 499 & & 425 & 576 & 429 & \\
\hline Th & 5.00 & 4.90 & & 2.26 & 4.86 & 3.81 & \\
\hline $\mathrm{U}$ & 1.07 & 1.08 & & 0.47 & 1.14 & 0.84 & \\
\hline $\mathrm{Nb}$ & 61.34 & 60.31 & & 35.56 & 49.91 & 48.46 & \\
\hline $\mathrm{Ta}$ & 3.73 & 3.66 & & 2.40 & 2.84 & 3.08 & \\
\hline $\mathrm{La}$ & 47.75 & 47.09 & & 24.93 & 44.65 & 36.18 & \\
\hline $\mathrm{Ce}$ & 100.15 & 98.79 & & 52.55 & 91.89 & 77.47 & \\
\hline $\mathrm{Pb}$ & $3.5 !$ & 3.37 & & 1.94 & 4.03 & 2.74 & \\
\hline Pt & 12.26 & 12.15 & & 7.00 & 11.32 & 9.72 & \\
\hline $\mathrm{Nd}$ & 46.86 & 46.38 & & 28.67 & 44.05 & 37.78 & \\
\hline $\mathrm{Sr}$ & 704 & 689 & & 641 & 766 & 524 & \\
\hline $\mathrm{Zr}$ & 260 & 256 & & 186 & 235 & 226 & \\
\hline $\mathrm{Hi}$ & 6.51 & 6.33 & & 4.99 & 5.72 & 6.02 & \\
\hline $\mathrm{Sm}$ & 9.58 & 9.39 & & 6.48 & 9.30 & 7.92 & \\
\hline Eu & 2.95 & 2.88 & & 2.08 & 2.98 & 2.46 & \\
\hline $\mathrm{Gd}$ & 8.50 & 8.32 & & 6.25 & 8.54 & 7.21 & \\
\hline$T b$ & 1.18 & 1.15 & & 0.89 & 1.19 & 1.01 & \\
\hline Dy & 6.19 & 6.08 & & 4.83 & 6.27 & 5.56 & \\
\hline Ho & 1.08 & 1.06 & & 0.87 & 1.07 & 0.99 & \\
\hline Y & 25.96 & 25.48 & & 21.69 & 26.33 & 23.61 & \\
\hline $\mathrm{Er}$ & 2.49 & 2.44 & & 2.09 & 2.46 & 2.35 & \\
\hline $\mathrm{Tm}$ & 0.31 & 0.30 & & 0.27 & 0.30 & 0.30 & \\
\hline Yb & 1.73 & 1.68 & & 1.53 & 1.64 & 1.74 & \\
\hline Lu & 0.24 & 0.23 & & 0.21 & 0.22 & 0.23 & \\
\hline $\mathrm{Sc}$ & 22.8 & 22.6 & & 23.8 & 16.1 & 27.4 & \\
\hline${ }^{86} \mathrm{Sr} /{ }^{87} \mathrm{Sr}$ & 0.705620 & 0.705594 & 0.705379 & 0.706113 & 0.705664 & 0.705631 & 0.705607 \\
\hline${ }^{193} \mathrm{Nd} / /^{144} \mathrm{Nd}$ & 0.512728 & 0.512684 & 0.512881 & 0.512734 & 0.512690 & 0.512668 & 0.512656 \\
\hline${ }^{206} \mathrm{~Pb} /{ }^{204} \mathrm{~Pb}$ & & 18.696 & & & & 18.681 & \\
\hline${ }^{207} \mathrm{~Pb} /{ }^{204} \mathrm{~Pb}$ & & 15.610 & & & & 15.606 & \\
\hline${ }^{208} \mathrm{~Pb} /{ }^{204} \mathrm{~Pb}$ & & 38.878 & & & & 38.883 & \\
\hline
\end{tabular}


Table 2-5, Page 7

\begin{tabular}{|c|c|c|c|c|}
\hline $\begin{array}{l}\text { Volcano } \\
\text { Sample }\end{array}$ & $\begin{array}{c}\text { Upolu PE } \\
\text { U } 37 \mathbf{P}\end{array}$ & \multicolumn{3}{|c|}{ BHVO-I Standard } \\
\hline Volcanic & & & & \\
\hline Series & Puapua & & & \\
\hline Lat. $\left({ }^{\circ} \mathrm{S}\right)$ & 14.0068 & & & \\
\hline Long. ("W) & 171.7292 & \multicolumn{3}{|c|}{ Long-term average, U. Queensland } \\
\hline \multicolumn{2}{|c|}{ Major elements (wi\%) } & & & \\
\hline $\mathrm{SiO}_{2}$ & 41.75 & & & \\
\hline $\mathrm{Al}_{2} \mathrm{O}_{3}$ & 11.84 & & & \\
\hline $\mathrm{TiO}_{2}$ & 4.45 & Ti 49 & 16376 & 1.02 \\
\hline $\mathrm{FeO}^{*}$ & 13.34 & & & \\
\hline $\mathrm{MnO}$ & 0.18 & & & \\
\hline $\mathrm{CaO}$ & 10.92 & & & \\
\hline $\mathrm{MgO}$ & 11.06 & & & \\
\hline $\mathrm{K}_{2} \mathrm{O}$ & 1.86 & & & \\
\hline $\mathrm{Na}_{2} \mathrm{O}$ & 3.92 & & & \\
\hline $\mathrm{P}_{2} \mathrm{O}_{5}$ & 0.69 & & & \\
\hline $\mathrm{MgH}$ & 63.49 & & & \\
\hline \multicolumn{5}{|c|}{ Trace Elements (ppm) } \\
\hline $\mathrm{Ni}$ & 241 & Ni 60 & 116 & 2.57 \\
\hline $\mathrm{Cr}$ & 312 & Cr 52 & 295 & 2.37 \\
\hline $\mathrm{V}$ & 290 & V 51 & 286 & 1.39 \\
\hline $\mathrm{Ga}$ & 21 & Ga 71 & 21.2 & 1.18 \\
\hline $\mathrm{Cu}$ & 67 & $\mathrm{Cu} 65$ & 137 & 0.94 \\
\hline $\mathrm{Zn}$ & 142 & Zn 66 & 106 & 1.81 \\
\hline $\mathrm{Cs}$ & 0.63 & Cs 133 & 0.0967 & 1.21 \\
\hline $\mathrm{Rb}$ & 53.6 & $\mathrm{Rb} 85$ & 9.27 & 0.83 \\
\hline $\mathrm{Ba}$ & 678 & Ва 137 & 132 & 0.75 \\
\hline Th & 6.58 & Th 232 & 1.19 & 1.09 \\
\hline $\mathbf{U}$ & 1.39 & U 238 & 0.433 & 1.09 \\
\hline $\mathrm{Nb}$ & 71.19 & $\mathrm{Nb} 93$ & 18.4 & 0.86 \\
\hline $\mathrm{Ta}$ & 4.04 & Та 181 & 1.15 & 1.31 \\
\hline $\mathrm{La}$ & 61.31 & La 139 & 15.1 & 0.74 \\
\hline $\mathrm{Ce}$ & 125.23 & Ce 140 & 37.7 & 0.65 \\
\hline $\mathrm{Pb}$ & 95.09 & $\mathrm{~Pb} 208$ & 1.97 & 3.87 \\
\hline $\operatorname{Pr}$ & 15.00 & Pr 141 & 5.45 & 0.55 \\
\hline $\mathrm{Nd}$ & 55.86 & Nd 146 & 24.1 & 0.52 \\
\hline $\mathrm{Sr}$ & 861 & Sr 86 & 394 & 0.52 \\
\hline $\mathrm{Zr}$ & 256 & Zr 90 & 165 & 0.94 \\
\hline $\mathrm{Hf}$ & 6.20 & Hf 178 & 4.37 & 1.28 \\
\hline Sin & 10.69 & Sm 149 & 5.95 & 0.79 \\
\hline $\mathrm{Eu}$ & 3.27 & Eu 151 & 2.04 & 0.98 \\
\hline $\mathrm{Gd}$ & 9.10 & Gd 160 & 5.97 & 0.68 \\
\hline $\mathrm{Tb}$ & 125 & Tb 159 & 0.886 & 0.97 \\
\hline Dy & 6.59 & Dy 161 & 5.11 & 0.85 \\
\hline Ho & 1.13 & Но 165 & 0.953 & 0.84 \\
\hline$Y$ & 27.60 & Y 89 & 22.9 & 0.76 \\
\hline Er & 2.63 & Er 167 & 2.42 & 1.32 \\
\hline$T$ In & 0.32 & Tm 169 & 0.324 & 1.28 \\
\hline $\mathrm{Yb}$ & I.79 & Yb 172 & 1.90 & 1.05 \\
\hline $\mathrm{Lu}$ & 0.24 & Lu 175 & 0.268 & 1.36 \\
\hline $\mathrm{Sc}$ & 22.2 & Sc 45 & 29.9 & 1.68 \\
\hline${ }^{86} \mathrm{Sr} r^{87} \mathrm{Sr}$ & 0.705492 & & & \\
\hline${ }^{143} \mathrm{Nd} /{ }^{144} \mathrm{Nd}$ & 0.512618 & & & \\
\hline${ }^{206} \mathrm{~Pb} /{ }^{204} \mathrm{~Pb}$ & & & & \\
\hline${ }^{207} \mathrm{~Pb} /{ }^{204} \mathrm{~Pb}$ & & & & \\
\hline${ }^{2018} \mathrm{~Pb} /{ }^{204} \mathrm{~Pb}$ & & & & \\
\hline
\end{tabular}




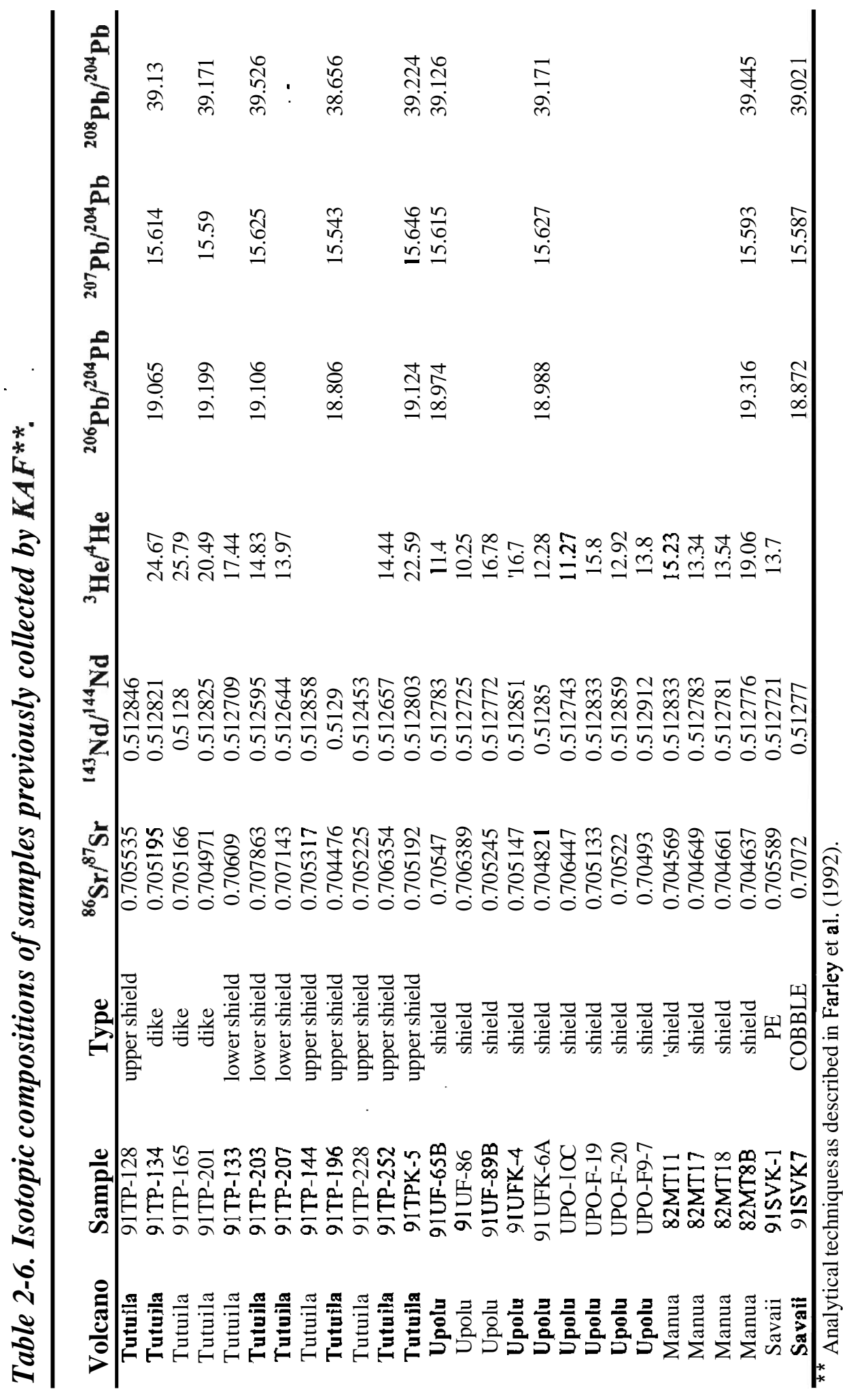

8 
Table 2-7. Calculated trace element composition of a "pure" EM2 melt.

\begin{tabular}{|c|c|c|c|}
\hline & $\begin{array}{c}\text { Average } \\
\text { Ta'u }\end{array}$ & $\begin{array}{c}\text { Average } \\
\text { Malumalu }\end{array}$ & $\begin{array}{l}\text { EM2 } \\
\text { Melt }\end{array}$ \\
\hline${ }^{87} \mathrm{Sr} /{ }^{86} \mathrm{Sr}$ & 0.7046 & 0.70889 & 0.7128 \\
\hline Cs & 0.11 & 0.41 & 0.70 \\
\hline $\mathbf{R b}$ & 15.17 & 44.73 & 73.47 \\
\hline $\mathbf{B a}$ & 146.96 & 281.99 & 413.29 \\
\hline Th & 2.78 & 6.17 & 9.46 \\
\hline $\mathbf{U}$ & 0.62 & 1.16 & 1.69 \\
\hline $\mathbf{N b}$ & 29.71 & 43.96 & 57.83 \\
\hline $\mathbf{T a}$ & 2.06 & 2.92 & 3.76 \\
\hline $\mathbf{K}$ & 0.73 & 1.57 & 2.39 \\
\hline La & 24.16 & 44.31 & 63.90 \\
\hline $\mathrm{Ce}$ & 50.61 & 82.17 & 112.85 \\
\hline $\mathbf{P b}$ & 2.09 & 4.35 & 6.56 \\
\hline Pr & 6.27 & 9.16 & 11.98 \\
\hline Nd & 27.24 & 34.89 & 42.33 \\
\hline $\mathrm{Sr}$ & 367.00 & 379.09 & 390.83 \\
\hline $\mathbf{Z r}$ & 187.15 & 205.43 & 223.20 \\
\hline Hf & 4.82 & 5.20 & 5.57 \\
\hline $\mathrm{Sm}$ & 6.74 & 7.15 & 7.56 \\
\hline Eu & 2.15 & 1.99 & 1.84 \\
\hline $\mathrm{Ti}$ & 2.99 & 2.20 & 1.42 \\
\hline Gd & 6.41 & 6.28 & 6.15 \\
\hline Tb & 0.95 & 0.87 & 0.79 \\
\hline Dy & 5.21 & 4.59 & 4.00 \\
\hline Ho & 0.94 & 0.80 & 0.67 \\
\hline $\mathbf{Y}$ & 24.00 & 21.89 & 19.84 \\
\hline Er & 2.26 & 1.91 & 1.57 \\
\hline $\mathrm{Tm}$ & 0.29 & 0.25 & 0.21 \\
\hline $\mathbf{Y b}$ & 1.67 & ] 40 & 1.13 \\
\hline Lu & 0.24 & 0.21 & 0.17 \\
\hline Sc & 25.76 & 25.77 & 25.79 \\
\hline
\end{tabular}

**All reported as ppm except $\mathrm{K}$ and $\mathrm{Ti}$ in $w t \%$.

**All samples in averages are olivine corrected to $\mathrm{Mg} \# 73$. 


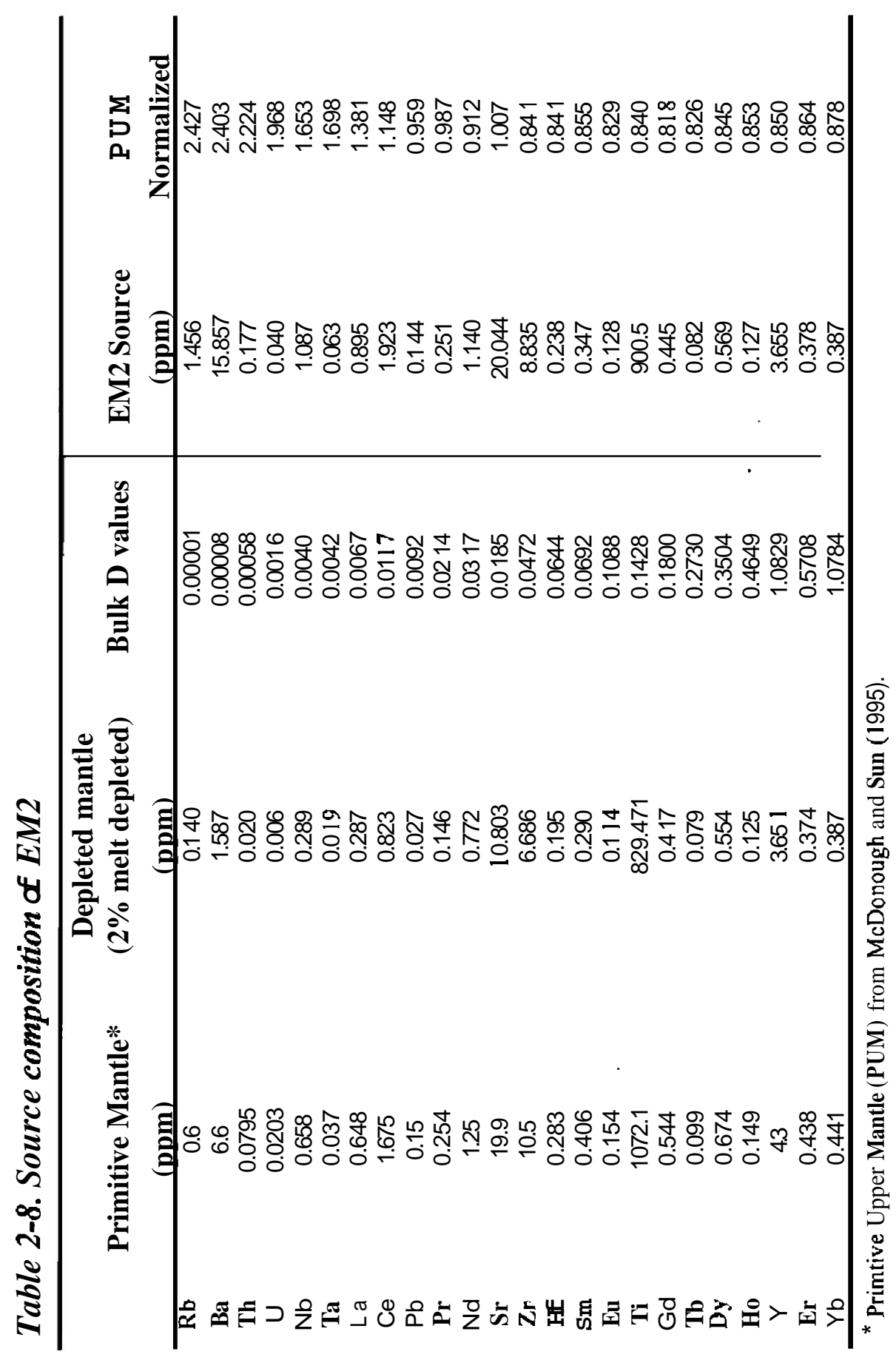




\title{
Chapter 3:
}

\section{Major and Trace Element Composition of the Depleted MORB Mantle (DMM)*}

\begin{abstract}
We derive an estimate for the chemical composition of the depleted MORB mantle (DMM), the source reservoir to mid-ocean ridge basalts (MORBs), which represents at least $30 \%$ the mass of the whole silicate Earth. A database for the chemical and physical properties of abyssal peridotites has become robust and complete enough to truly access a reference DMM. Using trace element depletion trends from the abyssal peridotites, it is possible to construct a large part of DMM's trace element pattern.'Splicing this information with isotopic constraints ( $\mathrm{Sr}-\mathrm{Nd}-\mathrm{Pb}-\mathrm{Hf}$ ) and canonical ratios $(\mathrm{Ce} / \mathrm{Pb}, \mathrm{Nb} / \mathrm{Ta}, \mathrm{Nb} / \mathrm{U}, \mathrm{Ba} / \mathrm{Rb}$, $\mathrm{H}_{2} \mathrm{O} / \mathrm{Ce}, \mathrm{CO}_{2} / \mathrm{Nb}$ and $\mathrm{Cl} / \mathrm{K}$ ), we can extend abundance estimates to all the incompatible elements including volatile content. The resulting trace element pattern for average DMM constrains parental MORB to be generated by $6 \%$ aggregated fractional melting consistent with recent models for hydrous melting of the mantle (Asimow et al., 2004). We show that DMM is roughly balanced by the continental crust and better balanced upon inclusion of ocean island basalt source and oceanic crust components. Compared to the primitive mantle, DMM has been depleted by $2-3 \%$ melt extraction and has only $15 \%$ the radiogenic heat production.
\end{abstract}

${ }^{\text {* }}$ Published in EPSL Volume 231, Feb. 2005 


\section{Introduction}

The trace element composition of the depleted upper mantle (DMM) is a fundamental parameter in modeling the generation of mid-ocean ridge basalts (MORBs), calculating the crust-mantle mass balance, and establishing the chemical and thermal evolution of the Earth. To date, all attempts to establish an average composition for the upper mantle, whether by parent/daughter derivations from isotopic systems (Allègre et al., 1983; Galer and O'Nions; 1985; Albarede and Brouxel, 1987; Shimizu, 1998; Elliot et al., 1999; Salters and Stracke, 2004) or by MORB trace element inversions (Salters and Stracke, 2004; McKenzie and O'Nions, 1991, Hofmann, 1988, Sun and McDonough, 1989), have centered on MORB liquids and include major assumptions about melt generation, melt transport and differentiation processes that have affected these upper mantle melts. Unfortunately, it is just these processes that we are trying to understand,rather than assume a priori.

The most compelling evidence for upper mantle depletion comes from the heavyelement isotopic composition of MORBs. Although MORBs and their residues, abyssal peridotites, have some degree of heterogeneity in radiogenic isotope ratios ( $\mathrm{Sr}-\mathrm{Nd}-\mathrm{Pb}-\mathrm{Hf}$ ), they are focused within a small range of values relative to ocean island basalts and are, with very few exceptions, depleted from bulk earth values in ${ }^{87} \mathrm{Sr} /{ }^{86} \mathrm{Sr},{ }^{143} \mathrm{Nd} /{ }^{144} \mathrm{Nd}$ and ${ }^{176} \mathrm{Hf} /{ }^{177} \mathrm{Hf}$, thus requiring a long-term history of low $\mathrm{Rb} / \mathrm{Sr}, \mathrm{Hf} / \mathrm{Lu}$ and $\mathrm{Nd} / \mathrm{Sm}$ (i.e. incompatible element depletion). Direct evidence for upper mantle depletion came with the classic trace element studies of Johnson et al. (1990) and Johnson and Dick (1992) on abyssal peridotites, but most of the observed depletion in these peridotites is due to melt extraction during the latest spreading events, so that the composition of the general ambient upper mantle has been severely overprinted by this latest melting episode.

Ultimately, we know that this mantle, which has been estimated to comprise $30-70 \%$ by mass of the bulk silicate earth, has been depleted over time in the highly incompatible (lithophile) elements (Allègre et al., 1983; Hofmann, 1988, refs. therein). Most models ascribe the depletion of the upper mantle to the extraction of the enriched continental crust, a process that has removed up to $90 \%$ of the most incompatible elements, and $80-85 \%$ of the heat-producing elements (e.g. Hofmann, 1988). Some part of the depletion may also be created by the preservation of recycled oceanic crust that is currently sequestered in unknown regions of the mantle. It is possible the lower mantle (below $670 \mathrm{~km}$ ) has also been depleted by such processes, but this question is highly controversial at present. 
In place of assuming a set of bulk partition coefficients or a degree of melt extraction, we use in this paper the following constraints in deriving an average trace element composition of DMM: 1) trace element content of clinopyroxenes from abyssal peridotites, 2) isotopic evolution from primitive upper mantle (PUM) and 3) canonical trace element ratios in MORBs. Abyssal peridotite data from the literature, the backbone of this study, are treated in a way reminiscent of studies such as Loubet et al. (1975), Hart and Zindler (1986) and McDonough and Sun (1995). Abyssal peridotites, unlike basalts, are not modified by secondary processes such as fractional crystallization, magma mixing and crustal assimilation (Dick et al., 1984), but may be subject to melt impregnation (Dick, 1989) and melt/rock reaction (Kelemen et al., 1992). We show that melt impregnation can be recognized and therefore filtered from the abyssal peridotite dataset and suggest that melt/rock reaction in the dataset we have used has had more effect on major element chemistry than trace element chemistry. Overall, it seems that, for the moderately incompatible elements, abyssal peridotites more accurately record the trend of upper mantle depletion than do MORBs.

The average trace element content of DMM, as deduced here, generally shows a very smooth pattern with increasing trace element compatibility, which to first order massbalances with the continental crust. The degree of depletion indicated in DMM represents 23\% melt removal from the primitive upper mantle (PUM) of McDonough and Sun (I 995); this means that DMM has only $15 \%$ the radiogenic heat production of PUM (from $K, U$ and Th). Present-day ocean crust (i.e. MORBs) can be modeled with $6 \%$ aggregated fractional melting of the deduced DMM.

\section{Trace Element Composition of DMM}

\subsection{Abyssal Peridotites}

Abyssal peridotites have been shown to be residues of fractional or near-fractional melting that produces MORB (e.g. Johnson et al., 1990). Although bulk trace element compositions of these peridotites are heavily modified by alteration on the seafloor, many workers have analyzed the trace element compositions ( $\mathrm{Sr}, \mathrm{Zr}, \mathrm{Ti}, \mathrm{Ce}, \mathrm{Nd}, \mathrm{Sm}, \mathrm{Eu}, \mathrm{Gd}$, Dy, $\mathrm{Er}, \mathrm{Yb}$, and $\mathrm{Y}$ ) of relict, unaltered clinopyroxene grains as a means of chemical characterization (Johnson et al., 1990; Johnson and Dick, 1992; Dick and Natland, 1996; Hellebrand et al., 2002; Salters and Dick, 2002; Tartarotti et al., 2002). Using such 
clinopyroxene compositions, bulk compositions $\left(\mathrm{C}_{\text {wholeRock }}\right)$ of the peridotites can be calculated for each trace element with the following equation:

$$
C_{\text {WholeRuck }}=C_{c p x}\left(\frac{D_{b u l k}}{D_{c p x}}\right)
$$

where the bulk partition coefficient $\left(\mathrm{D}_{\text {bulk }}\right)$ is determined from modal abundances ( $\mathrm{x}_{\text {mineral }}$ ) of olivine (ol), orthopyroxene (opx), clinopyroxene (cpx) and spinel (sp), and mineral/melt partition coefficients $\left(\mathrm{D}_{\text {mineral }}\right)$ as follows:

$$
D_{b u l k}=x_{o l} D_{o l}+x_{o p x} D_{o p x}+x_{c p x} D_{c p x}+x_{s p} D_{s p}
$$

This method of calculating bulk peridotite compositions is a substitute for a more accurate method, which would be to sum the concentrations of trace elements in minerals according to their modal proportions. Converting to whole rock compositions from clinopyroxene alone is done simply due to the fact that almost no trace element data exists for other minerals in the peridotite samples.

We have compiled a data set from the literature that includes abyssal peridotites having both cpx trace element analyses and modal abundances (data sources are Johnson et al, 1990; Johnson and Dick, 1992; Dick et al., 1984; Dick and Natland, 1996; Hellebrand et al., 2002; Salters and Dick, 2002; Tartarotti et al., 2002). All samples containing more than $1 \%$ modal plagioclase are excluded on the basis that most plagioclase in abyssal peridotites has been interpreted as a secondary phase representative of melt impregnation (Dick, 1989; Tartarotti et al., 2002); as a result, only 5 out of almost 90 samples included have any reported modal plagioclase at all. Anomalously high $\mathrm{Ce}$ and $\mathrm{Sr}$ values have also been excluded for some samples. For Sr, some anomalous values are suspected seawater alteration; such $\mathrm{Sr}$ anomalies are not accompanied by Eu anomalies and therefore are not suspected to be plagioclase reaction products. For both $\mathrm{Sr}$ and $\mathrm{Ce}$, the most incompatible elements of the sample suite and therefore the most depleted in abyssal peridotites, elevated concentrations are probably due to small amounts of melt impregnation (see discussion below).

The final trace element data set for the abyssal peridotites, corrected to whole rock compositions using mineral/melt partition coefficients from Kelemen et al. (2003), 
published modal abundances and the above equations, is shown in Figure 1 and the Supp. Data Table 1. It is important to note that the geographical distribution of the sample suite is highly focused on the Southern Ocean; $90 \%$ of the samples originate from the AmericanAntarctic, Southwest Indian and Central Indian Mid-Ocean Ridges, with the remaining 10\% obtained from the Mid-Atlantic Ridge and East Pacific Rise. The question of whether or not this geographical bias manifests as a chemical bias will not be answered until larger datasets from other localities are established.

The purpose of compiling bulk rock information is to derive the inter-relationships between different trace elements (i.e. to what degree the various incompatible trace elements are depleted relative to each other over the entire history of mantle depletion). A formulation of the trace element "system" begins by interpreting the trace element compositions of peridotites using the equation for a residue of fractional melting (see Zou, 1998, for review of melting models). Calculations show that modal fractional melting used to interpret residues of melting is a fine approximation for any number of more complicated melting models (see Appendix 1). The ratio of the concentration of a given element in a solid, $\mathrm{C}_{s}$, to its original concentration, $\mathrm{C}$, after some fraction of melting, $\mathrm{F}$, is as follows:

$$
\frac{C_{s}}{C_{o}}=(1-F)^{\left(\frac{1}{D}-1\right)}
$$

where $\mathrm{D}$ is the bulk solid/melt partition coefficient for modal melting.

The relationship between the concentrations of two elements in the residue, $[\mathrm{A}]$ and $[\mathrm{B}]$, can be linearized upon equating two equations solved for $\mathrm{F}$ :

$\ln \left(C_{s}^{A}\right)=R \ln \left(C_{s}^{B}\right)+\ln \left(\frac{C_{o}^{A}}{\left(C_{o}^{B}\right)^{R}}\right)$

where the slope, $R$, on the linear $\ln ([A])$ versus $\ln ([B])$ array is a function of the bulk partition coefficients for elements A and B:

$R=\frac{D_{B}\left(1-D_{A}\right)}{D_{A}\left(1-D_{B}\right)}$

Given that we have information for 12 different elements (see fig. 1), there are 132 of the $\ln ([\mathrm{A}])$ vs. $\ln ([\mathrm{B}])$ relationships to consider in the overall reduction of this dataset; 
Figure 2 shows a sampling of these linear arrays, with the more incompatible of a given 'element pair plotted on the x-axis. The peridotites show an extremely wide range in degree of depletion and form well-correlated depletion trends for upper mantle melting. Correlations are best for those element pairs having similar bulk D values (see the $\mathrm{Sm}-\mathrm{Nd}$, Sm-Eu and Dy-Er panels in fig. 2), and fall off slightly for elements with increasingly dissimilar bulk D's (see Zr-Ti and Sm-Yb). Some of the scatter in correlations may have been produced by melt impregnation. For instance, impregnation of low degree melts into highly depleted residues would cause points to fall off the depletion trends toward the more incompatible element, as shown in Figure 2. Melt impregnation trajectories for relationships among the HREE (e.g. Dy-Er) very closely overlap their well-correlated arrays (not shown for clarity), thereby indicating that melt impregnation has none to very little effect on the slopes or positions of these depletion trends.

The $\ln ([\mathrm{A}])$ vs. $\ln ([\mathrm{B}])$ depletion trends have been fit by a York (1996) two-error regression (fig. 2), assuming a blanket error of $10 \%$ for all points. The regressions have also been forced through the primitive upper mantle (PUM) coordinate of McDonough and Sun (1995); most regressions intersect the PUM coordinate without forcing, but this treatment becomes appropriate for some regressions with poor correlations (for example, see the Ce-Nd panel in fig. 2) and we find it necessary for obtaining robust output from the regression scheme.

The upper mantle is certainly not a unique composition (isotopic or otherwise), but rather a range of compositions reflecting variable amounts of depletion and/or reenrichment. A given peridotite's bulk trace element composition represents the culmination of melt depletion and enrichment over the entire history of that peridotite. Also, integrated within the trace element trends (fig. 2) is the net transfer of material out of the mantle by oceanic and continental crust generation as well as crustal recycling, in so far as the recycled material is well-mixed within the upper mantle. In this sense, some of the more complicated processes affecting upper mantle composition are incorporated into the abyssal peridotite trends, but are not required to explain the trace element data.

Knowing that much of the depletion observed in abyssal peridotites is caused by the most recent melting event, we need to define where today's average, unmelted upper mantle lies on the depletion trends. For this we need another constraint, the most obvious being the isotopic evolution of DMM: calculating the present-day $\mathrm{Sm} / \mathrm{Nd}$ ratio from ${ }^{143} \mathrm{Nd} /{ }^{144} \mathrm{Nd}$ signatures in MORBs defines a unique position on the abyssal peridotite depletion trends. 


\subsection{Isotope Constraints}

Although there has been much written on the homogeneity of MORBs relative to OIBs (Zindler and Hart, 1986; (fig. 3) that the MORB mantle is not one sole isotopic composition and by inference not one sole trace element composition. The variation in $\mathrm{MORB}{ }^{87} \mathrm{Sr} /{ }^{86} \mathrm{Sr},{ }^{143} \mathrm{Nd} /{ }^{144} \mathrm{Nd}$, and ${ }^{206} \mathrm{~Pb} /{ }^{204} \mathrm{~Pb}$ compared to all oceanic basalts is $18 \%, 35 \%$ and $47 \%$, respectively. To address this issue of compositional heterogeneity in the upper mantle we derive three different trace element compositions for the MORB source by calculating present-day parent/daughter ratios from isotopic signatures and relating those ratios to the abyssal peridotite depletion trends. A study by Su and Langmuir (2003), who have filtered global MORB data for proximity to subduction zones and known plumes/hot spots (fig. 3; Table 1), provides an average MORB isotopic composition ( $\mathrm{Sr}-\mathrm{Nd}-\mathrm{Pb}$ ) as well as a standard deviation of the isotope data. We use the Su and Langmuir (2003) data analysis to define the following: 1) the average DMM composition, 2) an E-DMM based on isotopes that are 20 enriched over the average, and 3) a D-DMM based on isotopes that are $2 \sigma$ depleted from the average. The ${ }^{176} \mathrm{Hf} /{ }^{177} \mathrm{Hf}$ value of DMM is selected by averaging MORB values from Nowell et al. (1998), Chauvel and Blichert-Toft (2001) and Andres et al. (2002); ${ }^{176} \mathrm{Hf} /{ }^{177} \mathrm{Hf}$ values for E-DMM and D-DMM are based on correlations with ${ }^{143} \mathrm{Nd} /{ }^{144} \mathrm{Nd}$ (e.g. Chauvel and Blichert-Toft, 2001).

To derive present-day parent/daughter ratios, a depletion model must be assumed. It is common to use a two-stage evolution model with a single, instantaneous depletion event at a time $(\mathrm{t})$ equal to the average age of the continental crust. An example from the $\mathbf{R b}-\mathbf{S r}$ system, where $\mathrm{T}$ is the age of the Earth and parent/daughter ratios are for present-day is the following:

$$
\left(\frac{{ }^{87} S r}{{ }^{86} S r}\right)_{D M M}=\left(\frac{{ }^{87} S r}{{ }^{86} S r}\right)_{0}+\left(\frac{{ }^{87} R b}{{ }^{86} S r}\right)_{B S E}\left(e^{\lambda r}-e^{\lambda t}\right)+\left(\frac{{ }^{87} R b}{{ }^{86} S r}\right)_{D M M}\left(e^{\lambda t}-1\right)
$$

However, because mantle depletion is largely the result of continental crust extraction, it is important to consider continental growth through time and the fact that it is not a single depletion event as modeled in the above equation. Although there is debate about continuous growth (Hurley and Rand, 1969) or constant volume with crustal recycling (Armstrong, 1968; Armstrong, 1981; Fyfe, 1978), somewhere in between (such as episodic growth) is probably the reality (McColloch and Bennett, 1994; Taylor and McLennan, 1995; Condie, 
2000). Models suggesting continuous growth generally agree that the real increase in continental mass was at about $3 \mathrm{Ga}$ (Taylor and McLennan, 1995). Models in favor of constant crustal volume suggest rapid (or at least effective) recycling of crust greater than $\mathbf{3}$ billion years old (e.g. Armstrong, 1981; Bowring and Housh, 1995). For our purpose, it is really preservation that is of issue; even though these are isotopic arguments for a $4.0 \mathrm{Ga}$ depleted mantle of similar size and degree of depletion as the modern depleted mantle (e.g. Bowring and Housh, 1995; Vervoort et al., 1996), it is more important here that the abundance of that old crust is low compared to crust younger than $3.0 \mathrm{Ga}$. Isotopically, the recycling of old crust would make depletion appear to be younger on average and smear out (or even negate) the signal of ancient depletion.

Here we have improved on the classical methods by using a continuous transport, melt depletion model starting at $3 \mathrm{Ga}$. The equation for the $\mathrm{Sr}$ isotopic composition of DMM at time, t, as derived by Allègre (1969) and and Brooks (1970) is:

$\left(\frac{{ }^{87} S r}{{ }^{86} S r}\right)_{t}=\left(\frac{{ }^{87} S r}{{ }^{86} S r}\right)_{0}+\frac{\lambda\left({ }^{87} R b /^{86} S r\right)_{0}\left[1-e^{-(\lambda+k) t}\right]}{\lambda+k}$

where $\lambda$ is the decay constant for ${ }^{87} \mathrm{Rb}$ and $\mathrm{k}$ is the difference in transport coefficients between $\mathrm{Rb}$ and $\mathrm{Sr}$ and essentially relates to the difference between bulk partitioning of the two elements. The initial conditions are values for bulk silicate Earth at the time when depletion begins $(3.0 \mathrm{Ga})$. The parameter, $k$, is solved for by knowing the isotopic composition of bulk Earth at $3 \mathrm{Ga}$ and DMM at time zero (i.e. present-day), as shown in Table 1. The parent/daughter variation through time is then:

$$
\left({ }^{87} R b /^{86} S r\right)_{1}=\left({ }^{87} R b /^{86} S r\right)_{0} e^{-(\lambda+k) r}
$$

Figure 4 shows how this model, as used for the $\mathrm{Rb} / \mathrm{Sr}$ system, gives a factor of -2 lower estimate for the present-day $\mathrm{Rb} / \mathrm{Sr}$ ratio of DMM, compared to the usual two-stage model. Decreasing the age of depletion requires' lower $\mathrm{Rb} / \mathrm{Sr}$ ratios for the same present-day ${ }^{87} \mathrm{Sr} /{ }^{86} \mathrm{Sr}$ ratio. In the same way that the $\mathrm{Sr}$ isotopes are used to constrain the $\mathrm{Rb} / \mathrm{Sr}$ ratio of DMM, similar constraints result in determinations for $\mathrm{Sm} / \mathrm{Nd}$, Lu/Hf, and U/Pb (Table 1). The choice of depletion model does not greatly affect the Sm-Nd system, but is important for the whole suite of parent/daughter ratios. 
Most important to the abyssal peridotite inversion is the present-day $\mathrm{Sm} / \mathrm{Nd}$ ratio for DMM, since this identifies the present-day position of DMM on the mantle depletion arrays. Figure 5 shows how the $\mathrm{Sm} / \mathrm{Nd}$ ratio of 0.411 in average DMM has a unique intersection with the Sm-Nd abyssal peridotite regression line, defining unique $\mathrm{Sm}$ and $\mathrm{Nd}$ concentrations of $0.239 \mathrm{ppm}$ and $0.581 \mathrm{ppm}$, respectively. Given the absolute concentrations of $\mathrm{Sm}$ and $\mathbf{N d}$, we can derive the absolute concentrations of all the other trace elements that have been analyzed in abyssal peridotites (REE, Sr, Zr, Ti, Y; Table 2). Ultimately, estimates for every element concentration are obtained based on relationships with every other element. Standard deviations of various estimates for a given element are on the order of $1-2 \%$ for REE's and $\mathrm{Ti}$ and $5-6 \%$ for $\mathrm{Sr}, \mathrm{Zr}$ and $\mathrm{Ce}$, indicating that the depletion trends are internally very consistent; note that these standard deviations do not testify to the accuracy of the model. With other parent/daughter ratios, other pieces of the trace element pattern for DMM are estimated: $\mathrm{Rb}$ derives directly from the $\mathrm{Sr}$; Hf derives. from extrapolation to $\mathrm{Lu}$ from the REE's; $\mathrm{Pb}$ derives from the $\mathrm{Ce} / \mathrm{Pb}$ canonical ratio (see below) and $U$ follows (Table 2). The same procedure is applied with the E-DMM and DDMM isotopic compositions.

It is possible to derive Th concentrations from $\mathrm{Th} / \mathrm{U}$ ratios inferred from ${ }^{208} \mathrm{~Pb} /{ }^{204} \mathrm{~Pb}$ and ${ }^{206} \mathrm{~Pb} /{ }^{204} \mathrm{~Pb}$ isotopic evolution. However, it has been widely recognized that inferred Th/U ratios are generally much higher than observed Th/U ratios in MORBs; this has been termed the 'kappa conundrum' (Galer and O'Nions, 1985; Elliot et al., 1999; Tatsumoto, 1996). Since Th and U are both highly incompatible during mantle melting, with Th being slightly more incompatible, the Th/U ratios of MORBs should provide an upper limit to the source Th/U. Due to the extremely long half-life of ${ }^{232} \mathrm{Th}$ (14 Byr), we interpret the kappa conundrum to be a problem where the Th-Pb system has not "caught-up" with the U-Pb system. For a more accurate representation of present-day upper mantle, we use Th/U ratios measured by careful U-Series studies on MORBs (Lundstrom et al., 1999; Sims et al., 2002; Sims et al., 2003) over the range in isotopic composition used to define ow D-DMM through to E-DMM (Table 1).

\subsection{Canonical Ratios and Volatile Contents}

There are a few trace element ratios in MORBs (as well as many OIBs) that remain constant over variable degree of melting and variable isotopic composition. These ratios $(\mathrm{Ce} / \mathrm{Pb}, \mathrm{Nb} / \mathrm{Ta}, \mathrm{Nb} / \mathrm{U}$, and $\mathrm{Ba} / \mathrm{Rb}$ ) are termed "canonical" and their constancy is interpreted to be due to bulk partition coefficients being very nearly the same for the element pairs 
during upper mantle melting, preventing significant fractionation (Hofmann and White, 1983; Hofmann et al., 1986; Jochum et al., 1997; Sims and DePaolo, 1997; Pfander et al, 2002; Weyer et al., 2002). Hence, ratios in the melts are presumed to be identical to ratios of these elements in the source.

We employ these canonical ratios in order to complete the trace element pattern of DMM. It is clear though, from Figure 6, that some canonical ratios are better behaved than others; $\mathrm{Nb} / \mathrm{Ta}, \mathrm{Nb} / \mathrm{U}$ and $\mathrm{Ba} / \mathrm{Rb}$ all hover about their published values of $15.5,47$ and 11.3 respectively (Hofmann and White, 1983; Hofmann et al., 1986; Jochum et al., 1997; Wander et al,, 2002; Weyer et al., 2002), whereas $\mathrm{Ce} / \mathrm{Pb}$ ratios display much more scatter with a significant distribution of data higher than either published canonical values of 25 and 20 (Hofmann et al., 1986; Sims and DePaolo, 1997). As a mid-value of the MORB cata, we use a $\mathrm{Ce} / \mathrm{Pb}$ ratio of 30 ; if, in studies to come, it is determined that $\mathrm{Ce} / \mathrm{Pb}$ should be lower, we recommend changing only the $\mathrm{Pb}$ concentration in $\mathrm{DMM}$, as the $\mathrm{U}-\mathrm{Nb}-\mathrm{Ta}-\mathrm{La}-\mathrm{Ce}$ segment of the trace element patterns derived is consistent with MORB trace element characteristics (see section 3.2). This would imply that the derived $\mathrm{U} / \mathrm{Pb}$ ratios from $\mathrm{Pb}$ isotopic inversions are not accurate - i.e. that $\mathrm{U}$ and $\mathrm{Pb}$ cycling in the upper mantle is more complicated than is assumed to be here. All other canonical ratios used are as previously published.

There is also a suite of canonical ratios involving the volatile elements $\mathrm{H}, \mathbf{C}$ and $\mathbf{C l}$ that are useful for estimating the budget of these elements in the upper mantle. Volatile elements play an important role in melt generation and transport, so the following estimates are crucial input parameters for modeling such processes. The compatibility of water has been shown to be similar to that of $\mathrm{Ce}$, and MORBs have on average an $\mathrm{H}_{2} \mathrm{O} / \mathrm{Ce}$ ratio of -200 (Michael, 1995). Using $\mathrm{Ce}=0.550 \mathrm{ppm}$ (Table 2), $\mathrm{H}_{2} \mathrm{O}$ is calculated to be $110 \mathrm{ppm}$ in DMM. Using a lower limit of 150 and upper limit of 250 for $\mathrm{H}_{2} \mathrm{O} / \mathrm{Ce}$ (Michael, 1995) along with our lower and upper estimates for Ce (Table 2), respectively, the range of water content in DMM is 70-160 ppm.

In a recent study on volatile undersaturated basaltic melt inclusions from the Siqueiros transform fault, Saal et al. (2002) have established two new working canonical ratios: CO${ }_{2} / \mathrm{Nb}$ at $239 \pm 46$ and $\mathrm{Cl} / \mathrm{K}$ at $0.0075 \pm 0.0025$. Using our $\mathrm{Nb} \mathrm{min} / \mathrm{max}$ estimates from Table 2 and our K estimate from Table 3 (see section 3.1 below), average DMM has a $\mathrm{CO}_{2}$ content of $36 \pm 12 \mathrm{ppm}$ and a $\mathrm{Cl}$ content of $0.38 \pm 0.25 \mathrm{ppm}$. These estimates are about 2 times lower than those reported by Saal et al. (2002) due to their use of different trace 
element abundances in DMM, but within error of recent estimates by Salters and Stracke (2004).

\subsection{Final product}

Combining the mantle depletion trends from the abyssal peridotites, parent/daughter ratios from the isotopic evolution of DMM, and a handful of canonical ratios, trace element patterns ("spidergrams") of average DMM, E-DMM (enriched from the average) and DDMM (depleted from the average) have been derived (fig. 7a; Table 1 for isotope values; Table 2 for trace element compositions). Overall, the spidergrams are very smooth except for a dip in $\mathrm{Sr}$ along with an expected $\mathrm{Pb}$ anomaly (see Hofmann, 1988). The greatest difference between the three compositions is in the highly incompatible elements; for example, $\mathrm{Rb}$ and $\mathrm{Ba}$ vary by a factor of -5 , but $\mathrm{Sm}$ varies by only $30 \%$.

Because it is difficult to assign errors to the estimated compositions, we have provided minimum and maximum estimates for trace element concentrations in the average DMM by using starting ages for the continuous depletion model at 2.5 and $3.5 \mathbf{G a}$, respectively (see the grey lines on Figure $\mathbf{7 b}$; Table 2). By changing the initial assumption of depletion age, we are effectively saying DMM is more or less depleted and all elements together move up or down the depletion arrays in proportion to their compatibilities during melting. Each of these patterns is internally consistent, and therefore not a true range for each element but rather a coherent solution for the assumptions made. It is not advisable to "mix and match" values from different patterns, since the elements behave as a system, not independently, and should be regarded as such. However, the $\mathrm{Ba} / \mathrm{Th}$ ratios for the 2.5 and $3.5 \mathrm{Ga}$ patterns are, respectively, too high and too low to generate realistic MORB compositions (see section 3.2) and support the idea that $3.0 \mathrm{Ga}$ is an appropriate assumption for initiation of mantle depletion. As an aside, using a classical $1.8 \mathrm{Ga}$ instantaneous depletion model results in a

spidergram (not shown) very similar to that of the $3.5 \mathrm{Ga}$ pattern but with $\mathrm{Rb}$ and $\mathrm{Ba}$ close to values for the $3.0 \mathrm{Ga}$ (preferred) pattern.

The Salters and Stracke (2004) spidergram (fig. 7b) for average DMM, based on depleted MORB elemental ratios and isotopic evolution, is generally less depleted than the average DMM of this study. In particular, they show significantly higher estimates for the whole left side of the spidergram ( $\mathrm{Rb}$ to $\mathrm{Ce}$ ), as well as higher $\mathrm{Zr}$, $\mathrm{Hf}$ and $\mathrm{Y}$, than predicted even for our maximum estimate; this is most likely due to their use of an instantaneous (two-stage) depletion model for isotopic evolution instead of the gradual depletion model described in this paper. 
Please note that in the following sections, only average DMM is discussed.

\section{Physical and Chemical Properties of DMM}

\subsection{Modal abundances \& major elements}

Abyssal peridotites from all over the world show depletion trends not only in trace element content, but also in major element content in the form of modal abundances and mineral compositions (Dick et al., 1984; Dick and Natland, 1996; Hellebrand et al., 2002; Michael and Bonatti, 1985; Niu et al., 1997; Baker and Beckett, 1999). In general, these observations are supported by experimental and theoretical studies of peridotite melting (Kinzler and Grove, 1992a; Walter et al., 1995; Gaetani and Grove, 1998; Hirschmann et al., 1998). With increasing degree of melt depletion, olivine increases in modal proportion while orthopyroxene, clinopyroxene and spinel decrease. Al, $\mathrm{Ca}, \mathrm{Na}, \mathrm{K}$ and $\mathrm{Ti}$ are more incompatible during melting than $\mathrm{Mg}, \mathrm{Cr}$ and $\mathrm{Ni}$, so have the highest mineral and whole. rock concentrations in the least depleted peridotites (e.g. Baker and Beckett, 1999).

Since we have established the systematics of incompatible trace elements in abyssal peridotites (see above), we use their relationship to modes to estimate the proportion of minerals in today's average DMM, then challenge the results with considerations of melt extraction and a comparison to the primitive mantle. Using the same data set as employed earlier (Suppl. Data Table 1), we have plotted bulk trace element concentrations.against modal abundances in individual abyssal peridotites (see examples in fig. 8); note that these are not completely independent parameters since modes in part determine bulk trace element contents. By extrapolating the trends like those in Figure 8 to the DMM trace element concentrations (Table 2), we find DMM to be composed of $57 \%$ ol, $28 \% \mathrm{opx}, 13 \% \mathrm{cpx}$ and $2 \%$ sp (Table 3); orthopyroxene does not correlate with any trace elements and has been solved for by summation to $100 \%$. These modes are very close to those found by extrapolating the modal abundance correlations for the South-West Indian Ridge abyssal peridotites (Dick, 1989) for which, without spinel, yields $60 \%$ ol, $30 \%$ opx and $10 \%$ cpx.

Constructing the bulk depleted mantle composition from mineral modes requires fairly precise knowledge of oxide abundances in the mantle minerals. Baker and Beckett (1999) have reduced mineral data for abyssal peridotites and provided algorithms for-estimating major element compositions of minerals according to the modal abundance of olivine. Using the Baker and Beckett (1999) mineral compositions at 57\% olivine and combining 
the minerals in the given proportions, results in a bulk DMM having an $\mathrm{Al}_{2} \mathrm{O}_{3}$ content nearly that of the primitive upper mantle (PUM; McDonough and Sun, 1995), along with a very low $\mathrm{Ca} / \mathrm{Al}$ ratio compared to PUM. Since $\mathrm{Al}$ is depleted during melt extraction and $\mathrm{Al}$ is more enriched than $\mathrm{Ca}$ in mantle melts (see Table 3), it is reasonable to expect the depleted mantle to have lower $\mathrm{Ca}$ and $\mathrm{Al}$ concentrations and a equal or higher $\mathrm{Ca} / \mathrm{Al}$ ratio than that of PUM. This seems to be a problem only with $\mathrm{Al}$ abundance and is interpreted to be due to extrapolating mineral compositions beyond the limit of data used by Baker and Beckett (1999). For this reason, we find it more appropriate to use mineral compositions at $60 \%$ olivine, the lowermost (i.e. fertile) limit of their regressed data In doing so, we calculate the major element composition of DMM as reported in Table 3.

Compared to PUM, estimated DMM has, as expected, lower $\mathrm{SiO}_{2}, \mathrm{TiO}_{2}, \mathrm{Al}_{2} \mathrm{O}_{3}, \mathrm{CaO}$, $\mathrm{Na}_{2} \mathrm{O}$, and $\mathrm{K}_{2} \mathrm{O}$ with higher $\mathrm{MgO}$ and $\mathrm{Cr}_{2} \mathrm{O}_{3}$ (Table 3). The $\mathrm{TiO}_{2}$ content of 0.13 wt\% is very close to the 0.12 wt\% calculated from the trace element derivation (Table 2). The $\mathrm{CaO} / \mathrm{Al}_{2} \mathrm{O}_{3}$ ratio is equal to that of PUM $(0.80)$, and would increase to 0.86 by lowering the spinel abundance by only $0.5 \%$. As previously mentioned, much of the trace element depletion in the upper mantle can be attributed to the continental crust. The question now is: can the newly estimated major element depletion also be attributed to the continental crust? The continental crust budget (see mass-balance section below and bulk continental crust of Rudnick and Fountain, 1997) does largely account for the low $\mathrm{TiO}_{2}$ and $\mathrm{K}_{2} \mathrm{O}$, the most incompatible of the major elements, and partially accounts for the $\mathrm{Na}_{2} \mathrm{O}$. However, owing to the small mass of continental crust, major elements with less contrast between the crust and mantle cannot be balanced solely by the continents. As a possible solution, Table 3 shows a rudimentary mass balance of the DMM major elements in which $3 \%$ of primary MORB is subtracted from PUM (note that this is not a melting model). The major elements calculated in this way show striking similarity to the estimated DMM composition, implying that there is a isolated reservoir of oceanic crust somewhere within in the silicate Fath as also suggested by Hauri and Hart (1997). A second estimate for $\mathrm{Na}_{2} \mathrm{O}$ based on mass balance with both the continental crust and a MORB reservoir is also provided in Table 3 and is most likely more accurate than the original sum of mineral compositions.

To convert mineral modes into practical information for those who study abyssal peridotites, we have calculated the trace element composition of the constituent minerals in unmelted, average DMM by using Eqns. (1) and (2) with mineral/melt partition coefficients compiled by Kelemen et al. (2003). This effectively distributes the DMM trace element 
budget among the minerals according to their relative affinity for incompatible elements. The resulting mineral compositions are reported as Suppl. Data Table $\mathbf{2}$

As a cautionary note, the reported modes and mineral compositions will only apply to the very shallow mantle, owing to variable mineral compositions and phases with pressure and temperature, 'but the average bulk composition of unmelted, upper mantle should be similar at any depth in this reservoir.

\subsection{MORB generation}

Here we present the average DMM trace element composition; so should be able to produce an average parental N-MORB. To model MORB generation, we first calculate bulk partition coefficients (D) from Eqn. (5) applied to the abyssal peridotite depletion trends. Because the slopes of the depletion trends (fig. 2) only supply information about ratios of $\mathrm{D}$ values, we initially have to assume a $\mathrm{D}$ for one element and then calculate the remainder in relation to that one. We have chosen a bulk $D_{\mathrm{Nd}}$ of 0.031 , according to a compilation from Kelemen et al. (2003) for upper mantle melting, since the bulk compatibility of $\mathrm{Nd}$ is almost identical in both the spinet and garnet facies.

The set of partition coefficients resulting from the inversion of all abyssal peridotite depletion trends is reported in Table 2. Figure 9 shows the calculated D values compared to both garnet and spinel facies bulk D's from Kelemen et al. (2003); clearly the slope of the calculated $D$ values very closely matches that of spinel facies melting and is far off the slope of garnet facies melting. Note that choosing a different $D_{N d}$ will change the absolute position but not the slope of the $\mathrm{D}$ values shown in Figure 9 (meaning the ratios of D's will not change). The above observation does not exclude a contribution of trace elements from small degree melts in the garnet facies, especially for elements with low D values; this may be why $\mathrm{Sr}$ and $\mathrm{Ce}$ are a little lower than the spinel facies prediction. For elements with higher bulk D's in the garnet facies, the majority of depletion will happen in the spinel facies, thus is reflected in the depletion arrays. If depletion for the middle to heavy REE's was significant in garnet melting, the trace element pattern across the REE would be steeper, even if the last $\mathrm{D}$ values to act on the peridotites were those of spinel melting. This is a straightforward effect of fractional melting on residues.

As an average MORB trace element pattern to be fit by our modeling, we use the parental (fractionation-corrected) N-MORB reported by Su and Langmuir (2003). A point generally agreed upon, and hence applied here, is that MORBs are aggregated fractional or near-fractional melts over a range of pressures, as initially confirmed by Sobolev and 
Shimizu (1993). The highly incompatible elements are enriched $~ 16$-fold over DMM, thus requiring $6 \%$ aggregated fractional melting of DMM. Figure 10 shows the excellent fit to $\mathrm{N}-\mathrm{MORB}$ using the $\mathrm{D}$ values derived here and reported in Table 2.

The $6 \%$ degree of melting to generate MORB is on the low side of previous estimates ranging from 6-20\% (Langmuir et al., 1992; Kinzler and Grove, 1992b). A higher F could be obtained if a greater fractionation correction is applied to the already-corrected parental N-MORB of Su and Langmuir (2003) since F is mainly 'limited by the concentration of highly incompatible elements (i.e. $\mathrm{Rb}, \mathrm{Ba}, \mathrm{U}, \mathrm{Th}, \mathrm{Nb}, \mathrm{Ta}$ ) in the modeled MORB; however, this requires generally higher $D$ 's to maintain the proper slope for M- to HREE. To get to F $=10 \%$, at least another $30 \%$ fractionation is necessary and this seems unlikely. This low value for F, as compared to previous models, may be due to the fact that older estimates are based on anhydrous melting. Water content in the upper mantle is increasingly recognized as a very important aspect of mantle viscosity and convection (Hirth and Kohlstedt, 1996) as well and mantle melting (Hirth and Kohlstedt, 1996; Asimow and Langmuir, 2003; Asimow et al., 2004; Parman and Grove, 2004). To test the validity of $\mathbf{6 \%}$ mean F, we apply our estimated concentration of $\mathrm{H}_{2} \mathrm{O}$ to the recent model by Asimow et al. (2004) for hydrous mantle melting (the pHMELTS model).

A pHMELTS model run, using 110 ppm water, the major element compositions in Table 3 , a potential temperature of $1360^{\circ} \mathrm{C}$, a 2-D passive triangle melting regime and nearfractional melting, results in $7.0 \%$ mean melting to produce MORB and a crustal thickness of $6.3 \mathrm{~km}$ (P. Asimow, pers. comm., 2004). This confirms that the mean degree of melting (as defined by Plank et al., 1995) for hydrous models is generally on the low side of previous estimates from anhydrous models.

For average DMM, the derived D values (Table 2) translate into 2-3\% melt depletion from primitive mantle using either non-modal or modal fractional melting models. Because average DMM is only 2-3\% melt depleted, but average MORB is generated by $6 \%$ melting, one or all of the following is implied: 1) the degree of melting was lower in the past, 2) the mantle is a cannibal, recycling some crust and lithosphere back into itself, 3) depleted mantle has exchanged with the less depleted mantle, or 4) MORB generation is not the process that depletes the mantle. 


\section{Crust-Mantle Mass Balance}

Classic works based on continental crust and the depleted mantle being sole complementaries calculate that from $30 \%$ to $70 \%$ of the mantle is depleted according to isotope and parent/daughter constraints [Allègre et al., 1983, refs. therein]. In the following paragraphs, we provide three different scenarios for the balance of chemical reservoirs in the silicate earth, with each scenario progressively involving additional reservoirs. We believe that using the entire trace element suite to assess the extent to which the silicate earth does or does not mass-balance is a robust way to calculate relative proportions of reservoirs. The mass of the continental crust is fixed to be $0.6 \%$ the mass of the silicate Earth. For each scenario, the best estimates of reservoir masses along with uncertainty in the estimates are derived from a Monte Carlo simulation with $10^{5}$ trials in which element concentrations for each reservoir are considered as normal random variables with means given as PUM normalized concentrations and la equal to $10 \%$; in each trial, the relative reservoir masses are determined by a linear least-squares fit to the input parameters. Uncertainties are quoted as $2 \sigma$.

Scenario 1 is our own mass-balance involving only DMM and the continental crust, meaning in what proportion do DMM and the continental crust have to be added in order to sum back to primitive mantle? Our calculations indicate that $\mathbf{3 3 2 3} \%$ the mass of the silicate' Earth has to be DMM, with the remainder being primitive mantle, to best balance the bulk continental crust composition as estimated by Rudnick and Fountain (1997). For this particular 'reconstituted' mantle, all elements sum to within $15 \%$ of the primitive mantle except $\mathrm{Rb}$ and $\mathrm{Pb}$ which are in excess by $28 \%$ and $21 \%$, respectively. This scenario is no doubt overly simplistic. For one, there is no real evidence for the existence of a primitive mantle reservoir (see review by van Keken et al., 2002). However, there is evidence for a lower mantle that is less depleted than DMM, but depleted nonetheless; this reservoir is implied from many OIB isotopic arrays and termed FOZO by Hart et al. (1992). If a depleted lower mantle were accounted for here, the DMM reservoir would be significantly smaller than $33 \%$ in order to allow for the moderate depletion of the lower mantle.

Scenario 2 is the mass-balance of DMM, continental crust, and recycled oceanic crust. The idea of a recycled MORB component in the mantle is corroborated by the observation that the major element composition of DMM cannot be balanced by continental crust alone (see Table 3). At $43 \pm 6 \%$ DMM and $2.0 \pm 0.6 \%$ parental N-MORB of Su and Langmuir (2003), this scenario provides a better fit for most elements than does the first scenario; all 
elements here are fit to within $8 \%$ except $\mathrm{Rb}$ and $\mathrm{Pb}$ with $20 \%$ and $15 \%$ excesses and $\mathrm{Nb}$ with a $17 \%$ deficit. The abundance of MORB cannot be increased greatly without having elevated M- to HREE that cannot be compensated by adding more DMM. However, we have not considered subduction zone alteration of oceanic crust, which almost certainly affects this mass' balance.

Scenario 3 is the mass-balance of DMM, continental crust, recycled oceanic crust and an OIB source component (from Workman et al., 2004). To show upper limits on the sizes of enriched mantle components, the mass balance calculation has been made assuming $0 \%$ primitive mantle. The resulting balance is $74 \pm 5 \%$ DMM, $4.7 \pm 1.0 \%$ MORB and $21 \pm 5 \%$ OIB source; all elements are fit to within $15 \%$ except $\mathrm{Rb}$ and $\mathrm{Nb}$ with $\mathbf{2 3 \%}$ excess and $21 \%$ deficit, respectively.

In each scenario 2 and 3, the fraction of MORB in the mass-balance is less than the mass of oceanic crust generated throughout Eath history $(67 \%$ of the mantle mass, assuming constant rates for $4.55 \mathrm{Ga}$ ). As such, it is suggestive of the mantle being partially cannibalistic with respect to subducted oceanic crust. However, these mass balances do not include a depleted lithosphere, and could therefore be misrepresentative if oceanic crust and lithosphere are shown to be absolutely mechanically and thermally coupled.

\section{Conclusions}

Through abyssal peridotite trends, the isotopic composition of N-MORB and a few canonical ratios, we have constructed a major and trace element reference model for average, unmelted, depleted MORB mantle (DMM). From this DMM, parental MORB is generated by about $6 \%$ aggregated fractional melting as constrained primarily from the enrichment factor for the highly incompatible elements in parental MORB. Melting occurs mainly in the spinel facies mantle, but is most likely initiated within the uppermost garnet facies, as suggested by pHMELTS model runs. The water content inferred by the derived trace element composition is between 70 and 160 ppm, and is an integral ingredient in modeling mantle melting (Asimow et al., 2004) and mantle viscosity (Hirth and Kohlstedt, 1996; 2004). We have provided trace element compositions for minerals in the uppermost mantle which can be better estimated in the future with increasingly accurate information on mineral/mineral partitioning of trace elements and compositional variations of minerals with temperature and pressure. 
The radiogenic heat production of DMM (from $\mathrm{U}, \mathrm{Th}$, and $\mathrm{K}$ ) is only $15 \%$ that of the bulk silicate Earth at $2.43 \times 10^{-9}$ Watts $/ \mathrm{m}^{3}$, using a density of $3.20 \mathrm{~g} / \mathrm{cm}^{3}$ and radiogenic heat production values from Durrance (1986). It takes $\mathbf{- 3 3 \%}$ of the mantle mass to be composed of DMM, the remaining being primitive mantle, to balance the continental crust alone, and $\mathbf{- 4 3 \%}$ if including an oceanic crust component. If there is no primitive mantle, the maximum masses of the oceanic crust and OIB reservoirs are $5 \%$ and $21 \%$, respectively, if these enriched reservoirs are balanced purely by DMM.

Overall, the composition constructed here is a robust estimate for average upper mantle and can be used as an input parameter for a variety of models concerning mantle processes.

\section{Acknowledgements}

We are endlessly grateful to Henry Dick, whose decades of toils over mid-ocean ridges and abyssal peridotites have made possible the work presented here; in jest we question his sanity for counting over half a million points on abyssal peridotite modal abundances. Many stimulating conversations have been had with Nobu Shimizu, Jessica Warren, Glenn Gaetani, Peter Kelemen and Greg Hirth on the nature of the depleted mantle. We especially thank Paul Asimow for a sneak-preview application of his new pHMELTS model, as well as E. Hauri and W. McDonough for their helpful reviews. 


\section{Appendix 3-1.}

Calculations for other melting models show that the fractional melting model used here to interpret residues of melting is a fine approximation for any number of more complicated (and maybe more realistic) melting models. Figure Al plots melt depletion trends for Sm and $\mathrm{Nd}$ in residues of melting, starting with PUM of McDonough and Sun [14], and using equations for modal fractional, non-modal fractional, dynamic and non-modal dynamic melting as derived or summarized in Zou [23]. Residual porosity is chosen to be $0.5 \%$ for dynamic melting. Mineral/melt partition coefficients have been borrowed from Kelemen et al. [22] and the empirical coefficients of melting are from Niu [79] as follows: olivine = 0.17 , orthopyroxene $=0.65$, clinopyroxene $=0.47$, spinel $=0.05$. Bulk D values for $\mathrm{Sm}$ and $\mathrm{Nd}$ are taken from Table 2 in main text.

By definition, the two modal melting models are linear in Figure Al, with dynamic melting resulting in slightly less depletion for a given degree of melting (both curves end at $25 \%$ melting). Non-modal melting results in much greater depletion for a given degree of melting than modal melting and in slightly curved trajectories of melt depletion, but not severely enough to make a linear approximation (i.e. modal melting) invalid. For the upper few decades of melt depletion, the melting models are all nearly identical (fig. Al). Even at the point where they are clearly distinguishablefrom each other, the models all are contained within the scatter of the abyssal peridotite data (not shown on fig. A1 for clarity, but see figs. 2 and 5 above), Using modal fractional melting as an approximation for any of the other melting models will primarily lead to different $\mathrm{D}$ values than may be truly "Bulk D's", but will not change the ultimate estimate of DMM. For example, if the real melting style beneath ridges is non-modal dynamic melting, a linear fit by modal fractional melting will lead to estimates of 'effective' partition coefficients, meaning the 'non-modal' part of melting will be incorporated into the $\mathrm{D}$ outputs. Because we solve for relative partition coefficients (and do not assume them a priori), it is almost inconsequential which model is used given the resolution of the peridotite dataset. However, the estimate for the degree of melt depletion in DMM could be over-estimated if assuming an initial absolute D that is too high. 


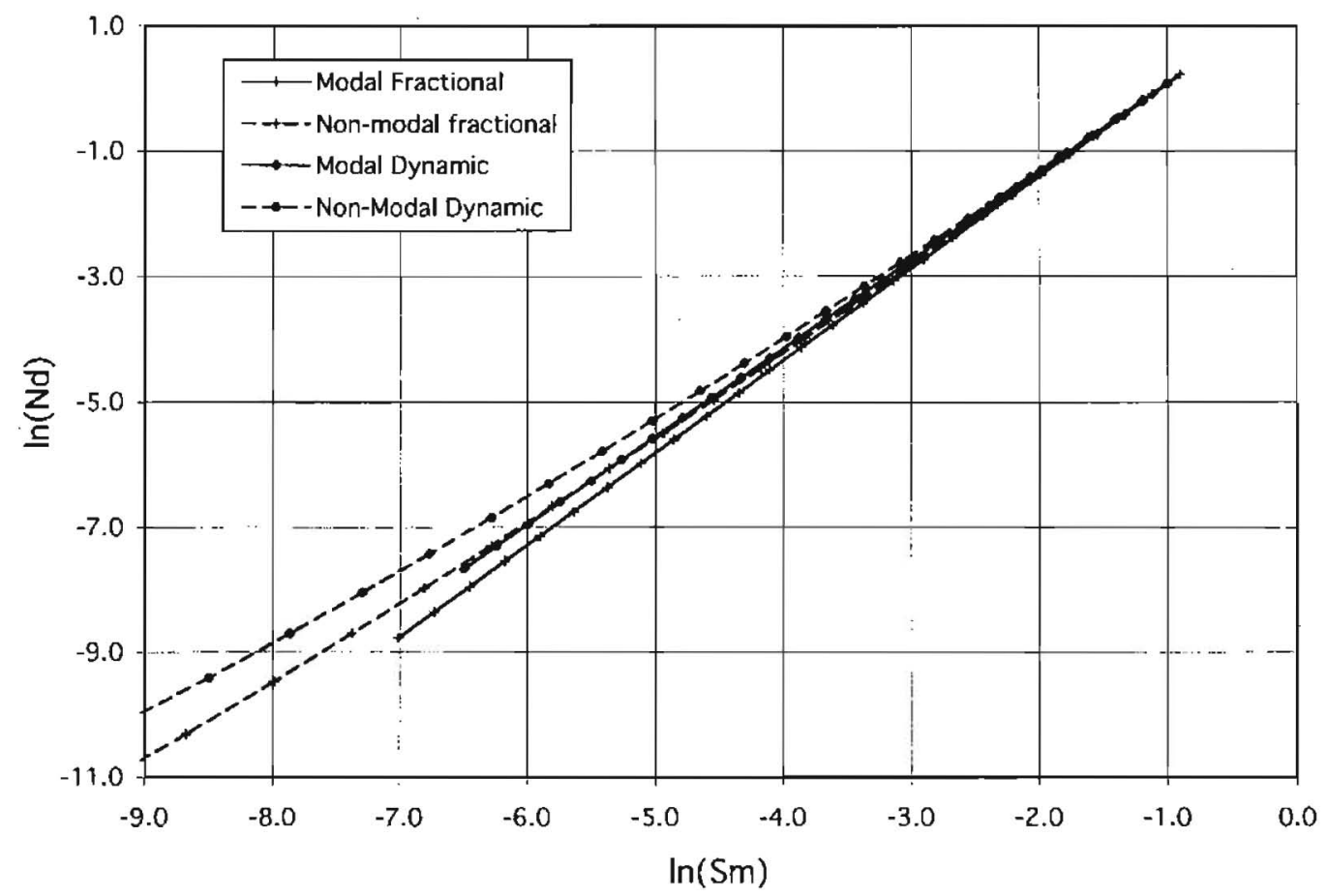

\section{Figure A1.}

Melting models showing depletion trends for $\mathrm{Sm}$ and $\mathrm{Nd}$ in residues of melt extraction. See text for details. Curves for modal melting models (fractional and dynamic) both end at $25 \%$ melt extraction. Non-modal fractional and dynamic curves are fall off the plot at $21 \%$ and $22 \%$ melting, respectively. Although not shown, the scatter in the abyssal peridotite data brackets all the melting model curves. 


\section{References}

Albarede, F. and M. Brouxel, The $\mathrm{Sm} / \mathrm{Nd}$ secular evolution of the continental crust and depleted mantle, Earth and Planet. Sci. Letters 82 (1987) 25-35.

Allègre, C. J., Comportement des systemes U-Th-Pb dans le manteau superieur et modele d'evolution de ce dernier au cours des temps geologiques, Earth and Planet. Sci. Letters 5 (1969) 261-269.

Allègre, C. J., S: R. Hart, and J. F. Minster, Chemical structure and evolution of the mantle and the continents determined by inversion of $\mathrm{Nd}$ and $\mathrm{Sr}$ isotopic data, Il. Numerical experiments and discussion, Earth Planet. Sci. Le t 66 (1983) 191-213.

Andres, M., J. Blichert-Toft, J. Schilling, Hafnium isotopes in basalts from the southern Mid-Atlantic Ridge from $40^{\circ} \mathrm{S}$ to $55^{\circ} \mathrm{S}$ : Discovery and Shona plume-ridge interactions and the role of recycled sediments, Geochem., Geophys., Geosyst. 3 (2002) doi:10.1029/2002GC000324.

Armstrong, R. L., A Model for the Evolution of Strontium and Lead Isotopes in a Dynamic Earth, Rev. of Geophysics 6 (1968) 175-199.

Armstrong, R. L., Radiogenic isotopes: the case for crustal recycling on a near-steady-state no-continental-growthEarth, Phil. Trans. R. Sœ. London 301 (1981) 443-472.

Asimow, P. D. and C. H. Langmuir, The importance of water to oceanic mantle melting regimes, Nature 421 (2003) 815-820.

Asimow, P. D., J. E. Dixon and C. H. Langmuir, A hydrous melting and fractionation model for mid-ocean ridge basalts: Application to the Mid-Atlantic Ridge near the Azores, Geochem.,Geophys., Geosyst. 5 (2004) doi:10.1029/2003GC000568.

Baker, M.B. and J.R. Beckett, The origin of abyssal peridotites: a reinterpretation of constraints based on primary bulk compositions, Earth and Planet. Sci. Lett. 171 (1999) 49-61.

Bowring, S. A. and T. Housh, The Earth's Early Evolution, Science 269 (1995) 1535-1540.

Chauvel, C. and J. Blichert-Toft, A hafnium isotope and trace element perspective on melting of the depleted mantle, Earth and Planet. Sci. Letters 190 (2001) 137-151.

Condie, K. C.,Episodic continental growth models: afterthoughts and extensions, Tectonophysics 322 (2000) 153-162.

Dick, H. J. B., Abyssal-peridotites, very slow spreading ridges and oceanic ridge magmatism, in: A.D. Saunders, M.J. Norry (Eds.), Magmatism in the Ocean Basins, 
Geological Society, London, 1989, pp. 71-105.

Dick, H. J. B. and J. H. Natland, Late-stage melt evolution and transport in the shallow mantle beneath the East Pacific Rise, in: C. Mevel, K. M. Gillis, J. F. Allan, P. S. Meyer (Eds.), Proceedings of the Ocean Drilling Program, Scientific Results 147, 1996, pp.103-134.

Dick, H. J. B., R. L. Fisher, and W. B. Bryan, Mineralogical variability of the uppermost mantle along mid-ocean ridges, Earth and Planet. Sci. Letters 69 (1984) 88-106.

Dickin, A.P., Radiogenic Isotope Geology, Cambridge University Press, Cambridge, UK, 1995,490 pp.

Durrance, E. M., Radioactivity on Geology: Principles and Applications, Ellis Horwood Limited, Chichester, 1986.

Elliott, T., A. Zindler, and B. Bourdon, Exploring the kappa conundrum: the role of recycling in the lead isotope evolution of the mantle, Earth and Planet. Sci. Letters 169 (1999) 129-145.

Fyfe, W. S., The evolution of the Earth's crust; modern plate tectonics to ancient hot spot tectonics, Chemical Geology 23 (1978) 89-114.

Gaetani, G. A. and T. L. Grove, The influence of water on melting of mantle peridotite, Contrib. Mineral. Petrol. 131 (1998) 323-346.

Galer, J.J.G. and R.K.O'Nions, Residence time of thorium, uranium and lead in the mantle and implications for mantle convection, Nature 316 (1985) 778-782.

Hart, S. R., Heterogeneous mantle domains: signatures, genesis and mixing chronologies, Earth Planet. Sci. Lett. 90 (1988) 273-296.

Hart, S. R. and C. Brooks, Rb-Sr Mantle Evolution Models, Carnegie Institution Yearbook 68 (1970) 426-429.

Hart, S. R., and A. Zindler, In search of a bulk-earth composition, Chem. Geol. 57 (1986) 247-267.

Fat, S. R., Hauri, E.H., Oschmann, L.A., and Whitehead, J.A., Mantle Plumes and Entrainment: Isotopic Evidence, Science 256 (1992) 517-520.

Hauri, E. and $S$. R. Hart, Rhenium abundances and systematics in oceanic basalts, Chem. Geology 139 (1997) 185-205.

Hellebrand, E., J. E. Snow, P. Hoppe and A. W. Hofmann, Garnet-field Melting and Latestage Refertilization in 'Residual' Abyssal Peridotites from the Central Indian Ridge, J. of Petrology 43 (2002) 2305-2338.

Hirschmann, M. M., M. S. Ghiorso, L. E. Wasylenki, P. D. Asimow and E. M. Stolper 
Calculation of peridotite partial melting from thermodynamic models of minerals and melts. I. Review of methods and comparison with experiments, J. Petrol. 39 (1998)

1091-1115.

Hirth, G. and D. L. Kohlstedt, Water in the oceanic upper mantle: implications for rheology, melt extraction, and the evolution of the lithosphere, Earth and Planet. Sci. 344 (1996) 93-108.

Hirth, $\boldsymbol{G}$. and D. L. Kohlstedt, Rheology of the Upper Mantle and the Mantle Wedge: A View from the Experimentalists, in: J. Eiler (Ed.), Inside the Subduction Factory, AGU Monograph 138, AGU, Washington D.C.,2004, pp. 83-105.

Nofmann, A.W., K. P. Jochum, H. M. Seufert, and W. M. White, $\mathrm{Nb}$ and $\mathrm{Pb}$ in oceanic basalts: new constraints on mantle evolution, Earth Planet. Sci. Lett. 79 (1986) 33-45.

Hofmann, A. W., Chemical differentiation of the Earth: the relationship between mantle, continental crust, and oceanic crust, Earth and Planet. Sci. Letters 90 (1988) 297-314.

Hofmann, A. W., Mantle geochemistry: the message from oceanic volcanism, Nature 385 (1997) 219-229.

Hofmann, A. W., and W. M. White, Ba, Rb and Cs in the Earth's Mantle, Z. Naturforsch 38 (1983) 256-266.

Hurley, P. M. and J. R. Rand, Pre-drift continental nuclei, Science 164 (1969) 1229-1242.

Jochum, K. P., J. A. Pfander, J. E. Snow and A. W. Hofmann, Nb/Ta in Mantle and Crust, EOS 78 (1997) F805.

Johnson, K. T. M. and H. J. B. Dick, Open system melting and temporal and spatial variation of peridotite and basalt at the Atlantis II fracture zone, J. Geophys. Res. 97 (I 992) 9219-9241.

Johnson, K. T. M., H. J. B. Dick, and N. Shimizu, Melting in the oceanic upper mantle; an ion microprobe study of diopsides in abyssal peridotites, J. of Geophys. Res. 95 (1990) 2661-2678.

Kelemen, P. B., H. J.B. Dick and J. E. Quick, Formation of harzburgite by pervasive melt/rock reaction in the upper mantle, Nature 358 (1992) 635-641.

Kelemen, P.B., G.M. Yogodzinski and D.W. Scholl, Along-strike variation in lavas of the Aleutian island arc: Implications for the genesis of high $\mathrm{Mg \#}$ andesite and the continental crust, in: J. Eiler (Ed.), Inside the Subduction Factory, AGU Monograph 138, AGU, Washington D.C., 2003, pp. 223-276.

Kinzler, R. J. and T. L. Grove, Primary magmas of Mid-Ocean Ridge Basalts 1. Experiments and Methods, J. Geophys. Res. 97 (1992a) 6885-6906. 
Kinzler, R. J. and T. L. Grove, Primary magmas of Mid-Ocean Ridge Basalts 2.

Applications, J. Geophys. Res. 97 (1992b) 6907-6926.

Langmuir, C.H., E.M. Klein and T. Plank, Petrological systematics of mid-ocean ridge basalts: Constraints on melt generation beneath ocean ridges, in: J.P Morgan, D.K. Blackman, J.M. Sinton, (Eds.), Mantle Flow and Melt Generation at Mid-Ocean Ridges, Geophys. Monogr. Ser. 71, AGU, Washington, D.C., 1992, pp. 183-180.

Loubet, M., N. Shimizu and C. J. Allegre, Rare Earth Elements in Alpine Peridotites, Contrib. Mineral. Petrol. 53 (1975) 1-12.

Lundstrom, C.C., D.E. Sarnpson, M.R. Perfit, J. Gill, Q. Williams, Insights into mid-ocean ridge basalt petrogenesis: U-series disequilibriafrom the Siqueiros Transform, Larnont Seamounts, and the Pacific Rise, J. Geophys. Res. 104 (1999) 13,035-13,048.

McCulloch, M.T., V.C. Bennett, Progressive growth of the Earth'scontinental crust and depleted mantle; geochemical constraints, Geochimica et Cosmochimica Acta 58 (1994) 4717-4738.

McDonough, W.F., and S.-s. Sun, The composition of the Earth, Chem. Geol. 120 (1995) 223-253.

McKenzie, D. and R.K. O'Nions, Partial Melt Distributions from Inversion of Rare Eath Element Concentrations, J. Pet. 32 (1991) 1021-1091.

Michael, P., Regionally distinctive sources of depleted MORB: Evidence from trace elements and $\mathrm{H}_{2} \mathrm{O}$, Earth and Planet. Sci. Letters, 131 (1995) 301-320.

Michael, P. J., and E. Bonatti, Peridotite compositions from the North Atlantic: regional and tectonic variations and implications for partial melting, Earth and Planet. Sci. Letters 73 (1985) 91-104.

Niu, Y., Mantle Melting and Melt Extraction Processes beneath Ocean Ridges: Evidence from Abyssal Peridotites, J. Pet. 38 (1997) 1047-1074.

Niu, Y., C. H. Langmuir and R. J. Kinzler, The origin of abyssal peridotites: a new perspective, Earth and Planet. Sci. Letters, 152, 251-265, 1997.

Nowell, G.M., P.D. Kernpton, S.R. Noble, J.G.Fitton, A.D. Saunders, J.J. Mahoney and R.N. Taylor, High precision Hf isotope measurements of MORB and OIB by thermal ionization mass spectrometry: insights into the depleted mantle, Chemical Geology 149 (1998) 211-233.

Parman, S.W., T.L. Grove, Harzburgite melting with and without $\mathrm{H}_{2} \mathrm{O}$ : Experimental data and predictive modeling, J. Geophys. Res. 109 (2004) doi:10.1029/2003JB002566.

Pfänder, J. A., C. Miinker, K. Mezger and A. W. Hofmann, In search of a superchondritic 
$\mathrm{Nb}$ /Ta reservoir: High-precision $\mathrm{Nb} / \mathrm{Ta}$ and $\mathrm{Zr} / \mathrm{Hf}$ ratios in ocean island and interplate basalts, Goldschmidt Conference Abstracts 66 (2002) A597.

Plank, T., M. Spiegelman, C.H. Langmuir, D.W. Forsyth, The meaning of "mean F": Clarifying the mean extent of melting at ocean ridges, J. Geophys. Res. 100 (1995) $15,045-15,052$.

Presnall, D.C, and J.D.Hoover, High pressure phase equlibrium constraints on the origin of mid-ocean ridge basalts, in: B.O. Mysen (Ed.), Magmatic Processes: Physicochemical Principles, The Geochemical Society Special Publication No. 1, 1987, 75-89.

Rudnick, R. L. and D. M. Fountain, Nature and composition of the continental crust: a lower crustal perspective. Rev. Geophysics 33, (1995) 267-309.

Saal., A., E. H. Hauri, C. H. Langmuir and M. R. Perfit, Vapor undersaturation in primitive mid-ocean-ridge basalt and the volatile content of Earth's upper mantle, Nature, 419 (2002) 451-455.

Salters, V. J. M., and H. J. B. Dick, Mineralogy of the mid-ocean ridge basalt source from neodymium isotopic composition in abyssal peridotites, Nature 418 (2002) 68-72.

Salters, V. J. M, and A. Stracke, The composition of the depleted mantle, Geochem., Geophys., Geosyst. 5 ( 5 )(2004).doi: 10.1029/2003GC00097.

Shimizu, N., The geochemistry of olivine-hosted melt inclusions in a FAMOUS basalt ALV519-4-1, Phys. of the Earth and Planet. Int. 107 (1998) 183-201.

Sims, K. W. W. and D. J. DePaolo, Inferences about mantle magma sources from incompatible trace element concentration ratios in oceanic basalts, Geochimica et Cosrnochimica Acta 61 (1997) 765-784.

Sims, K.W.W., S.J. Goldstein, J. Blichert-Toft, M.R. Perfit, P. Kelemen, D.J. Fornari, P. Michael, M.T. Murrell, S.R. Zut, D.J. DePaolo, G.D. Layne, L.A. Ball, M. Jull, J. Bender, Chemical and isotopic constraints on the generation and transport of magma beneath the East Pacific Rise, Geochimica et Cosmochimica Acta 66 (2002) 3481-3504.

Sims, K.W.W., J. Blichert-Toft, D.J. .Fornari, M.R. Perfit, S.J. Goldstein, P. Johnson, D.J. DePaolo, S.R. Hart, M.T. Murrell, P.J. Michael, G.D. Layne, L.A. Ball, Aberrant Youth: Chemical and isotopic constraints on the origin of off-axis lavas from the East Pacific Rise, $9^{\circ}-10^{\circ} \mathrm{N}$, Cheochem. Geophys., Geosyst. 4 (2003) doi:10.1029/2002GC000443.

Sobolev, A. V. and Shimizu, N., Ultra-depleted primary melt included in an olivine from the Mid-Atlantic Ridge, Nature 363 (1993) 151-154,

$\mathrm{Su}, \mathrm{Y}$. and C.H. Langmuir, Global MORB chemistry compilation at the segment scale, Ph.D. Thesis, Department of Earth and Environmental Sciences, Columbia University 
(2003) Available at: http://petdb.ldeo.columbia.edu/documentation/morbcompilation/.

Sun, S.-s., and W.F. McDonough, Chemical and isotopic systematics of oceanic basalts: implications for mantle composition and processes, in: A.D. Saunders, M.J. Norry (Eds.), Magmatism in the Ocean Basins, Geological Society, London, 1989, pp. 313345.

Tartarotti, P., S. Susini, P. Nimis and L. Ottolini, Melt migration in the upper mantle along the Romanche Fracture Zone (Equatorial Atlantic), Lithos 63 (2002) 125-149.

Tatsumoto, M., Genetic relations of oceanic basalts as indicated by lead isotopes, Science 153 (1996) 1094-1101.

Taylor, S. R. and S. M. McLennan, The geochemical evolution of the continental crust, Rev. of Geophysics 33 (1995) 241-265.

Van Keken, P. E., E. H. Hauri, C. J. Ballentine, Mantle Mixing: The Generation, Preservation, and Destruction of Chemical Heterogeneity, Ann. Rev. Earth and Planet. Sci 30 (2002) 493-525.

Vervoort, J. D., P. J. Patchett, G. E. Gehrels, A. P. Nutman, Constraints on early Earth differentiation from hafnium and neodymium isotopes, Nature 379 (1996) 624-627.

Walter, M. J., T. W. Sisson and D. C. Presnall, A mass proportion method for calculating melting reactions and application to melting of model upper mantle lherzolite, Earth and Planet. Sci. Letters 135 (1995) 77-90.

Weyer, S., C. Munker, M. Rehkamper, and K. Mezger, Determination of ultra-low Nb, Ta, $\mathrm{Zr}$ and $\mathrm{Hf}$ concentrations and the chondritic $\mathrm{Zr} / \mathrm{Hf}$ and $\mathrm{Nb} / \mathrm{Ta}$ ratios by isotope dilution analyses with multiple collector ICP-MS, Chemical Geology 187 (2002) 295-313.

Workman, R.K.S. R. Jut, M. Jackson, M. Regelous, K. A. Farley, J. Blusztajn, M. Kurz and H. Staudigel, Recycled metasomatized lithosphere as the origin of the Enriched Mantle II (EM2) Endmember: Evidence from the Samoan Volcanic Chain, Geochem., Geophys., Geosyst. 5 (2004) doi:10.1029/2003GC000623.

York, D., Least-squares fitting of a straight line, Can. J. Phys. 44 (1966) 1079-1086.

Zindler, A., S.R. Hart, Chemical Geodynamics, Ann. Rev. Earth Planet. Sci. 14 (1986) 493571.

Zou, H., Trace element Fractionation during modal and nonmodal dynamic melting and open-system melting: A mathematical treatment, Geochimica et Cosmochimica Acta 62 (I 998 ) 1937-1945. 


\section{Figures}

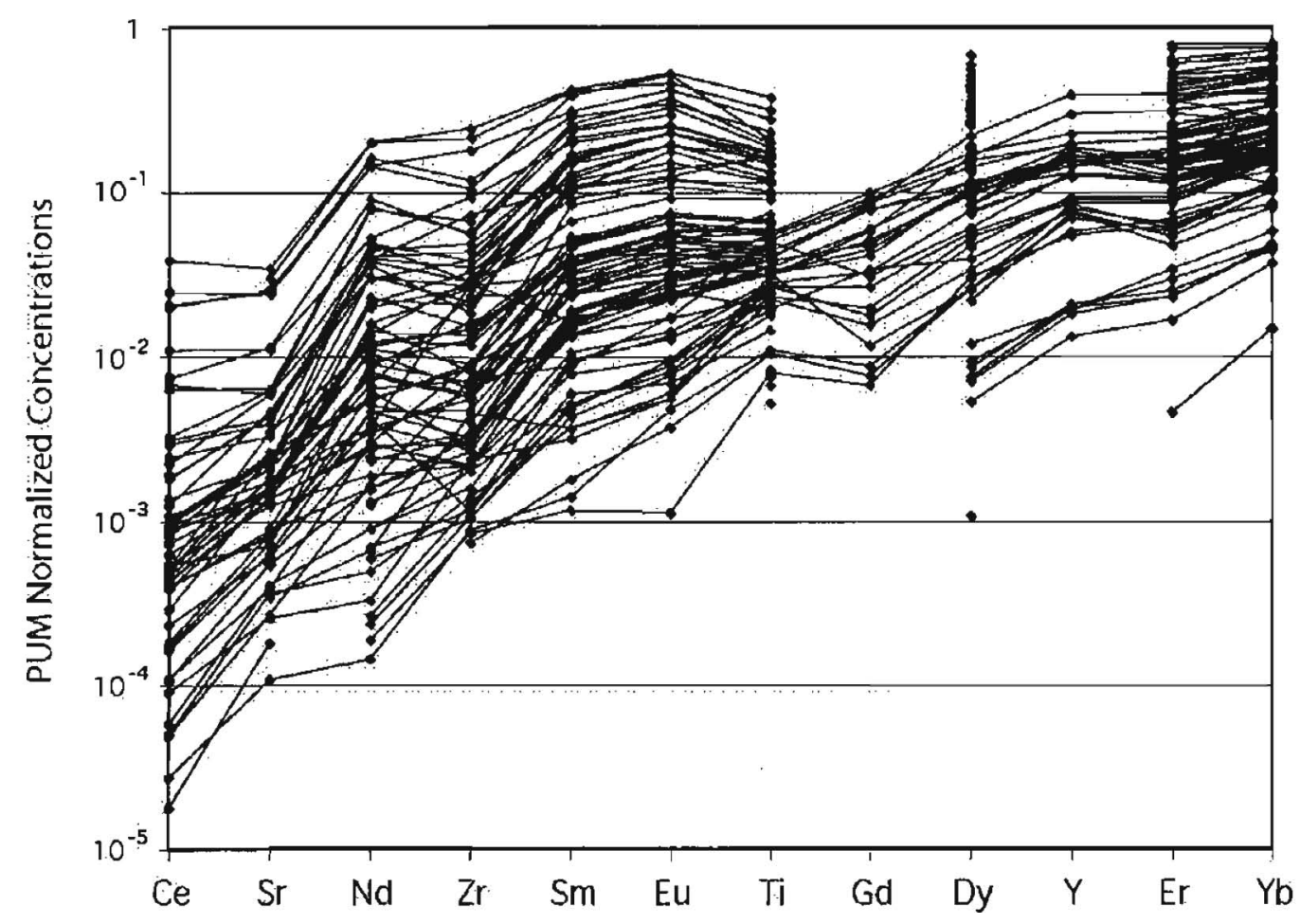

Figure 3-1. Calculated whole rock trace element compositions of abyssal peridotites. Data can be found in Suppl. Data Table 1; data sources as quoted in the text. 

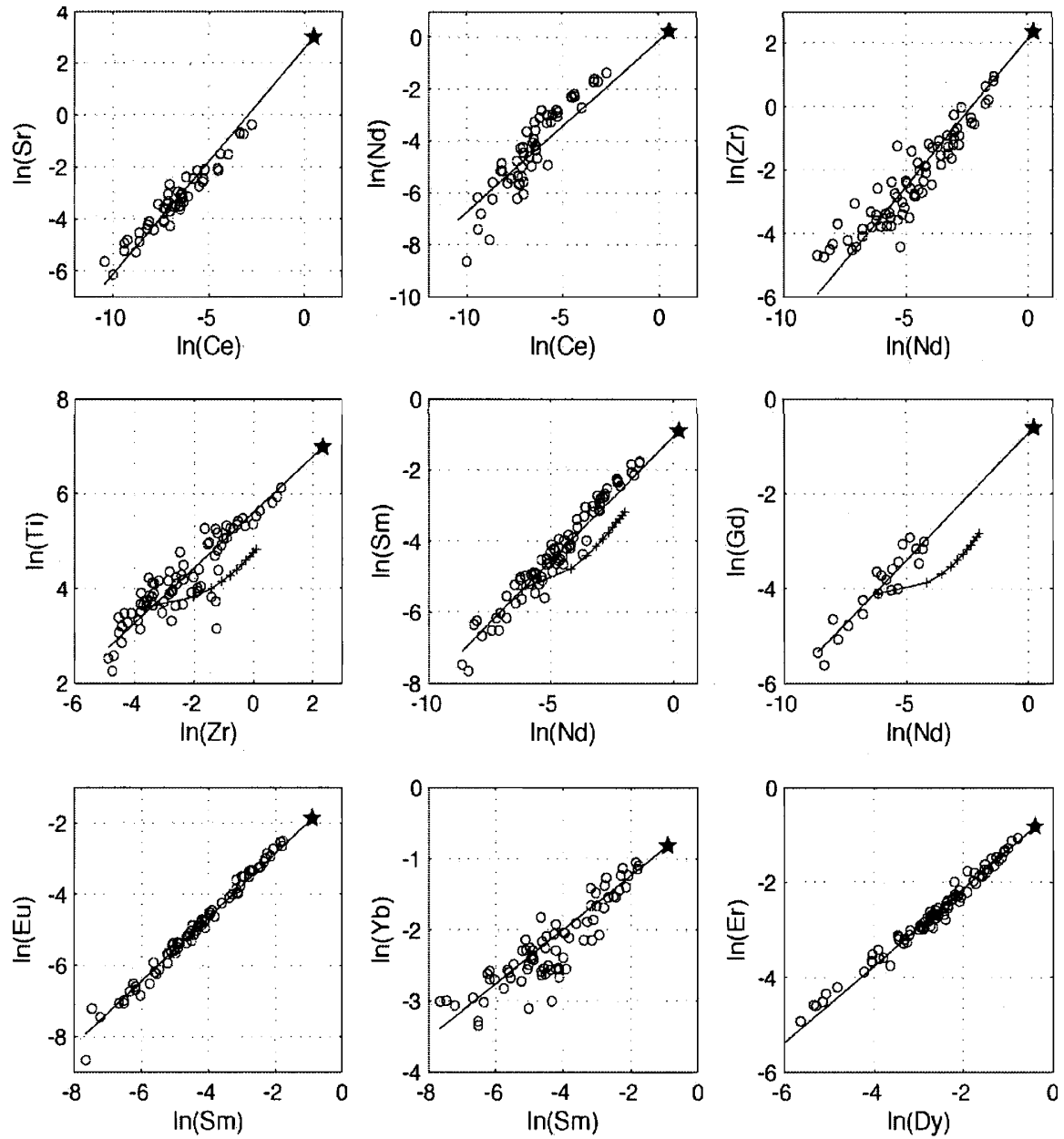

Figure 3-2. Co-variation diagrams for trace elements in abyssal peridotites, plotted as $\ln ([\mathrm{A}])$ against $\ln ([\mathrm{B}])$ in accordance with Eq. 4; the more incompatible element is on the $\mathrm{x}$-axis for each plot. Star symbol is Primitive Upper Mantle (PUM; also Bulk Silicate Earth, BSE) of McDonough and Sun (1995). Solid line is the best-fit regression, forced through the PUM coordinate and with assigned errors of $10 \%$ for each point. The curved lines with crosses (in the middle three panels) are trajectories for impregnation of a $1 \%$ melt of DMM (see Fig. 7; D values from Kelemen et al., 2004) into a depleted mantle of composition indicated by the points of origin on the regression lines; ticks are in increments of $0.1 \%$ up to a total of $1 \%$ melt impregnation. 

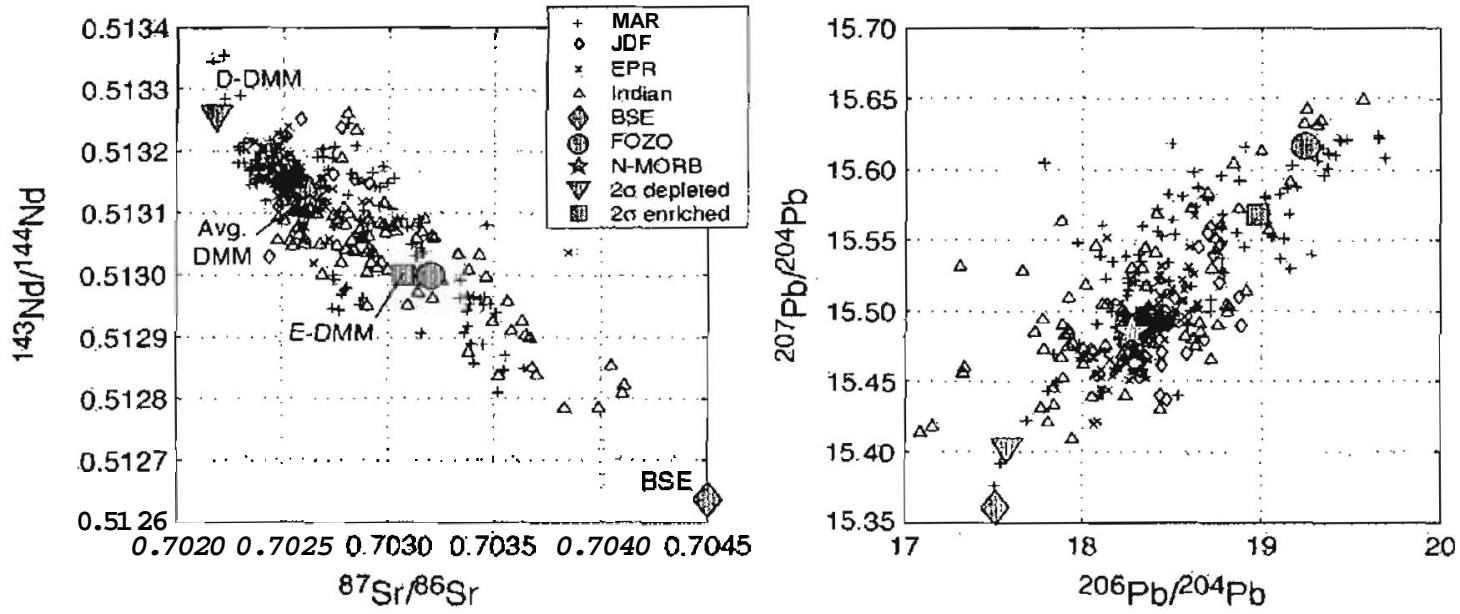

Figure 3-3. T w o panels showing the Sr-Nd-Pb isotopic compositions of global MORB data obtained from the PETDB database (http://petdb.ldeo.columbia edu/petdb/) MAR = Mid-Atlantic Ridge; JDF = Juan de Fuca Ridge; EPR = East Pacific Rise; Indian = Indian Ocean ridge systems; BSE = Bulk Silicate Earth; FOZO = Focus Zone (Hart et al., 1992); N-MORB and All-MORB are, respectively, the average composition for normal MORBs and unfiltered (all) MORBs according to Su and Langmuir (2003). The variation in $\mathrm{N}-\mathrm{MORB}{ }^{87} \mathrm{Sr} /{ }^{86} \mathrm{Sr},{ }^{143} \mathrm{Nd} /{ }^{144} \mathrm{Nd}$, and ${ }^{206} \mathrm{~Pb} /{ }^{204} \mathrm{~Pb}$ compared to all of oceanic basalts is $18 \%$, $35 \%$ and $47 \%$, respectively. 


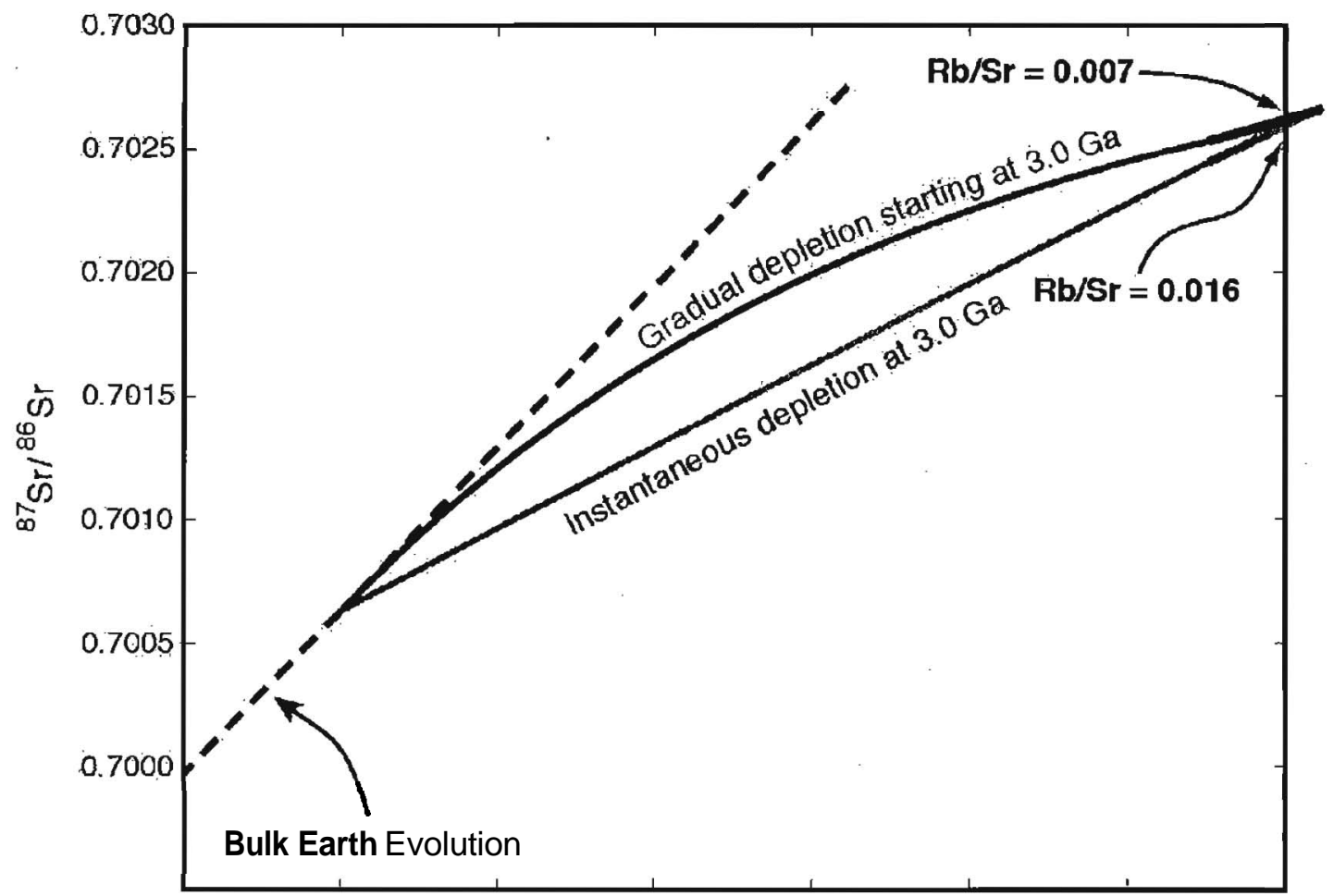

Figure 3-4. Plot showing examples of instantaneous depletion and continuous depletion models for the isotopic evolution of $\mathrm{Sr}$ in $\mathrm{DMM}$. Note that the derived $\mathrm{Rb} / \mathrm{Sr}$ ratio of today's upper mantle varies by a factor of about two between the models - the $\mathrm{Rb} / \mathrm{Sr}$ ratio is defined by the slope of the evolution curves. $\mathrm{Nd}$ isotopic evolution by continuous depletion is not shown since it is essentially linear through time. See Table 1 for isotope evolution parameters and Eqs. 7 and 8 for continuous depletion model. 


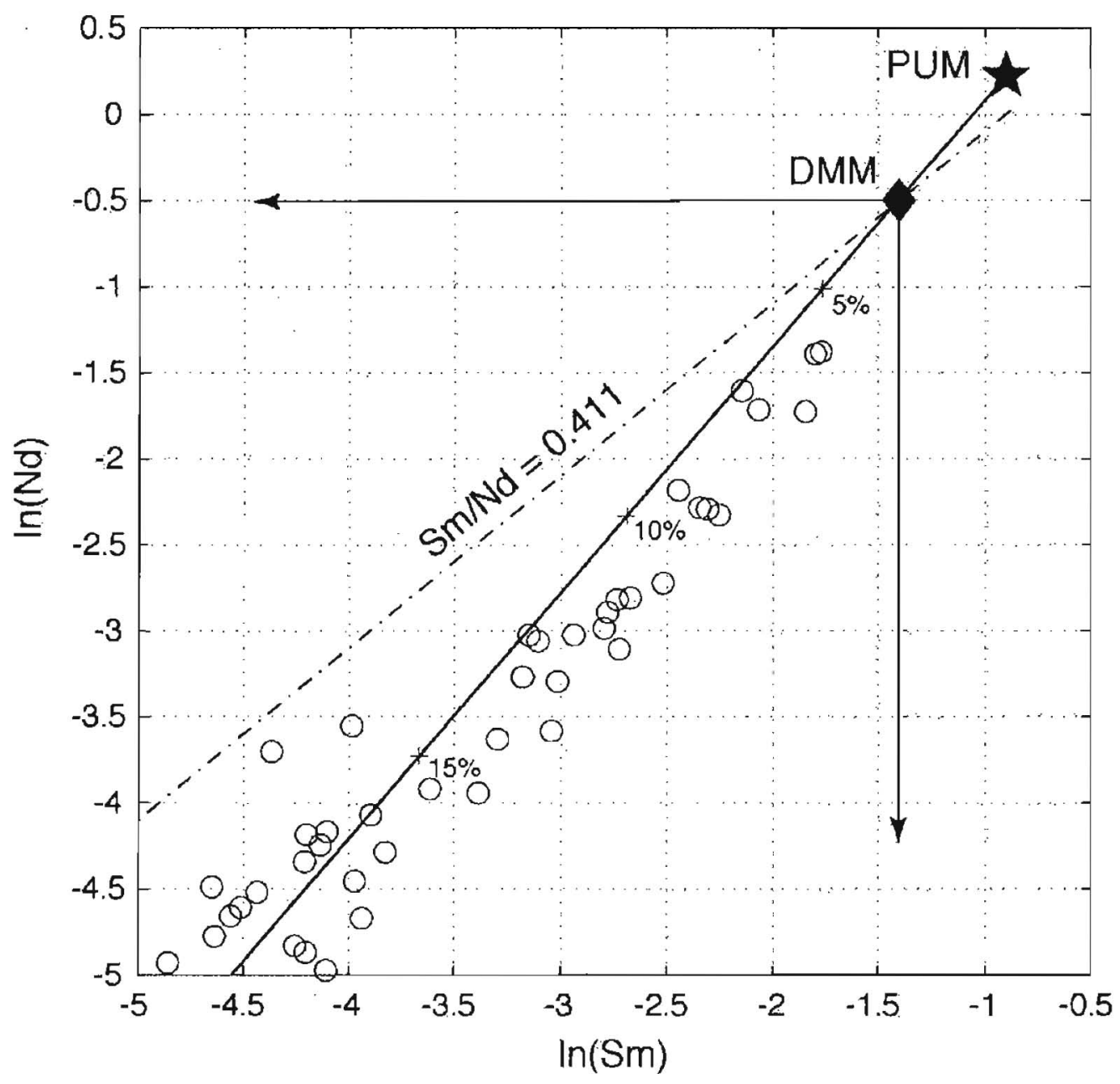

Figure 3-5. Plot of $\ln ([\mathrm{Sm}])$ versus $\ln ([\mathrm{Nd}])$ of abyssal peridotites showing the upper half of the mantle depletion array (see fig. 2 for full scale). Star symbol marks the PUM coordinate (i.e. BSE) of McDonough and Sun (1995). Crosses on the mantle depletion line mark percent melt extraction for fractional melting using bulk D values as reported in Table 2. Line of constant $\mathrm{Sm} / \mathrm{Nd}$ of 0.411 is derived from the $\mathrm{Nd}$ isotopic evolution of DMM; the intersection of this line with the mantle depletion line marks today's average composition of DMM. From Sm and Nd concentrations, concentrations of all other elements reported for abyssal peridotites (see fig. 1) can be derived from the system of mantle depletion arrays like those shown in fig. 2. 

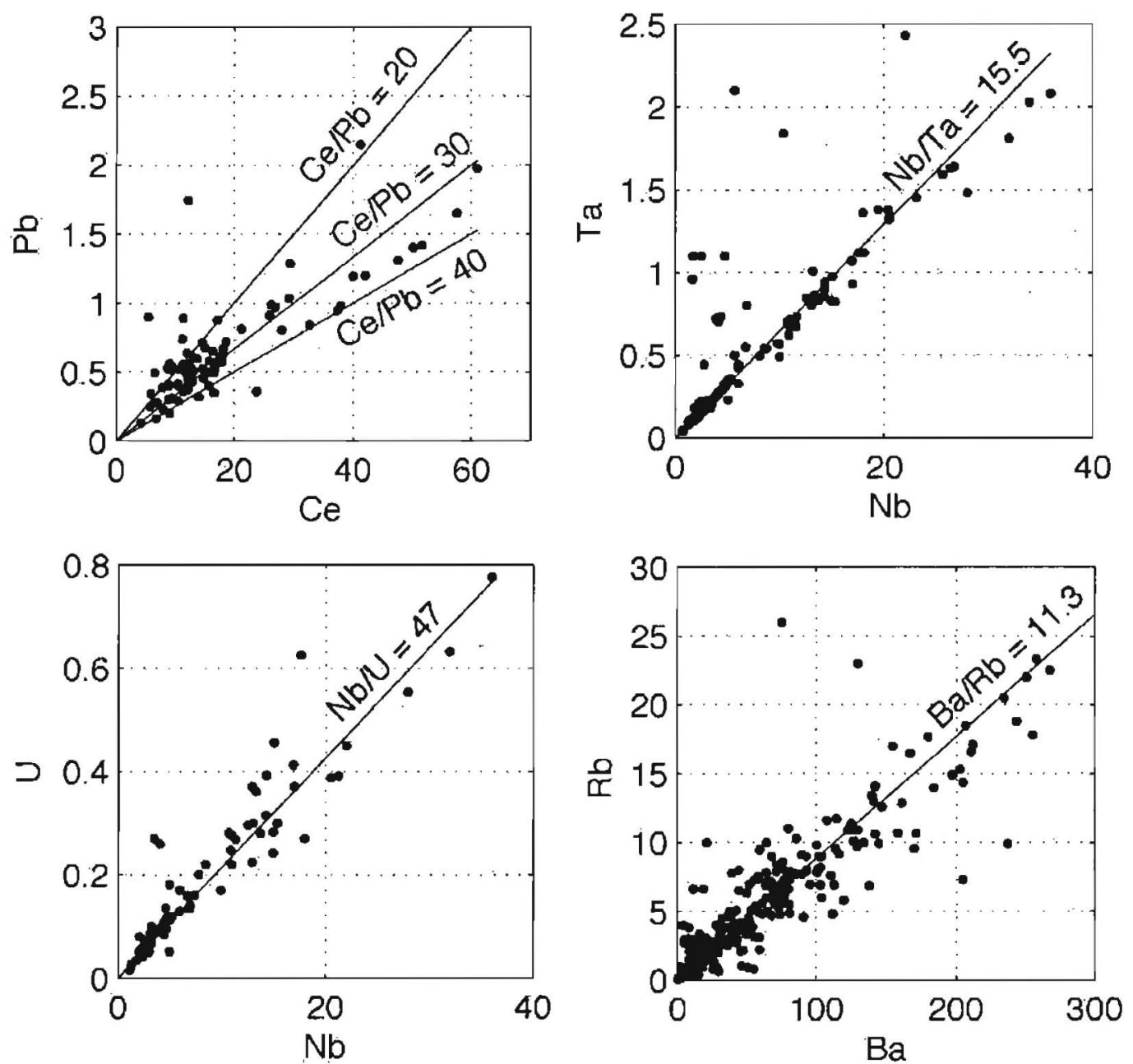

Figure 3-6. Four panels showing co-variation plots for elements in MORBs having canonical ratios. Data acquired from the PETDB database (http://petdb.ldeo.columbia.edu/petdb/) and reported as ppm. Literature values for canonical ratios (see text for references) are plotted for all panels except $\mathrm{Ce}-\mathrm{Pb}$, for which bounding and median values are shown. 

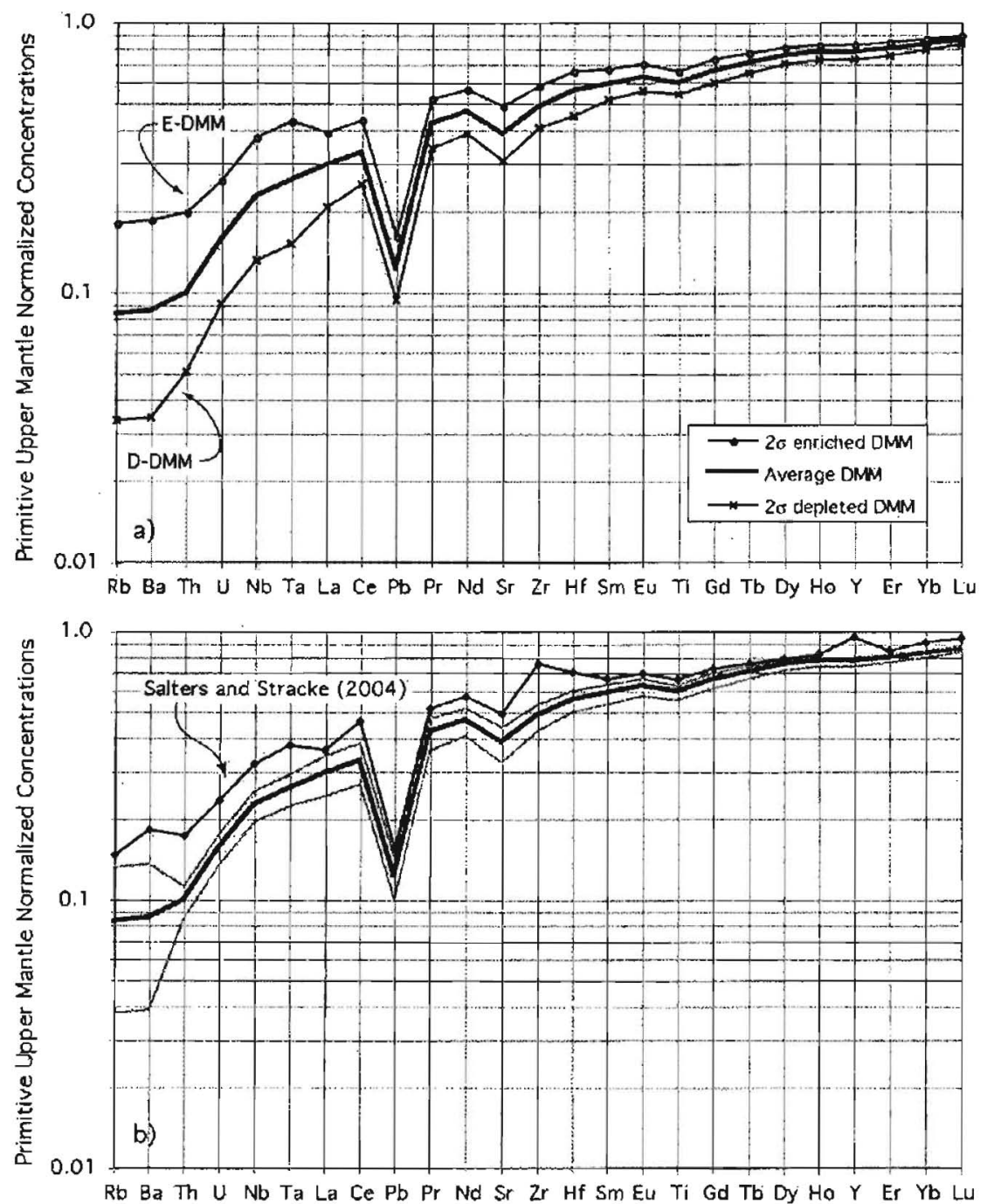

Figure 3-7. Panel a) shows trace element patterns for average Depleted MORB Mantle (DMM), E-DMM and D-DMM (E- and D- are, respectively, enriched and depleted over the average DMM, as based on a isotopic compositions reported in Table 1). Trace element compositions have been derived from abyssal peridotite depletion trends (see fig. 2), isotopic evolution based on the average $\mathrm{N}-\mathrm{MORB}$ Sr-Nd-Pb-Hf isotopic compositions with a gradual depletion model starting at $3 \mathrm{Ga}$ (Table 1; Fig. 3), and canonical ratios (fig. 6). In panel b) the upper and lower grey lines result from using gradual depletion models starting at 3.5 $\mathrm{Ga}$ and $2.5 \mathrm{Ga}$, respectively, for the average DMM isotopic composition. The Salters and Stracke (2004) trace element pattern for average DMM is shown for comparison. 

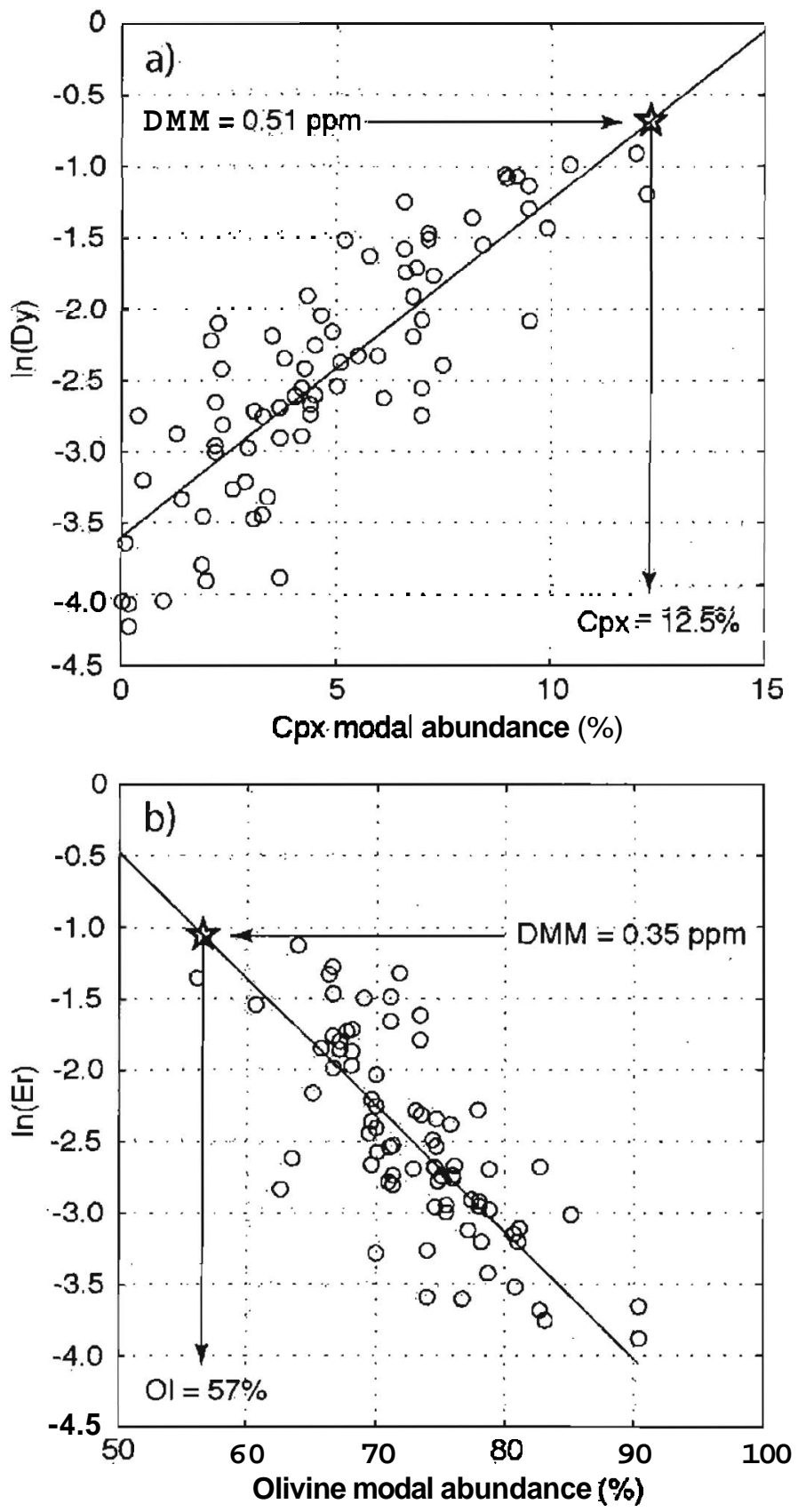

Figure 3-8. Modal abundances of a) clinopyroxene and b) olivine plotted with calculated (in the same way as for Figures I and 2) bulk trace element compositions of individual peridotites. Determination of the modal composition of DMM results from extrapolating the two-error regressions here to our best estimate for DMM's trace element concentrations (from Table 2). 


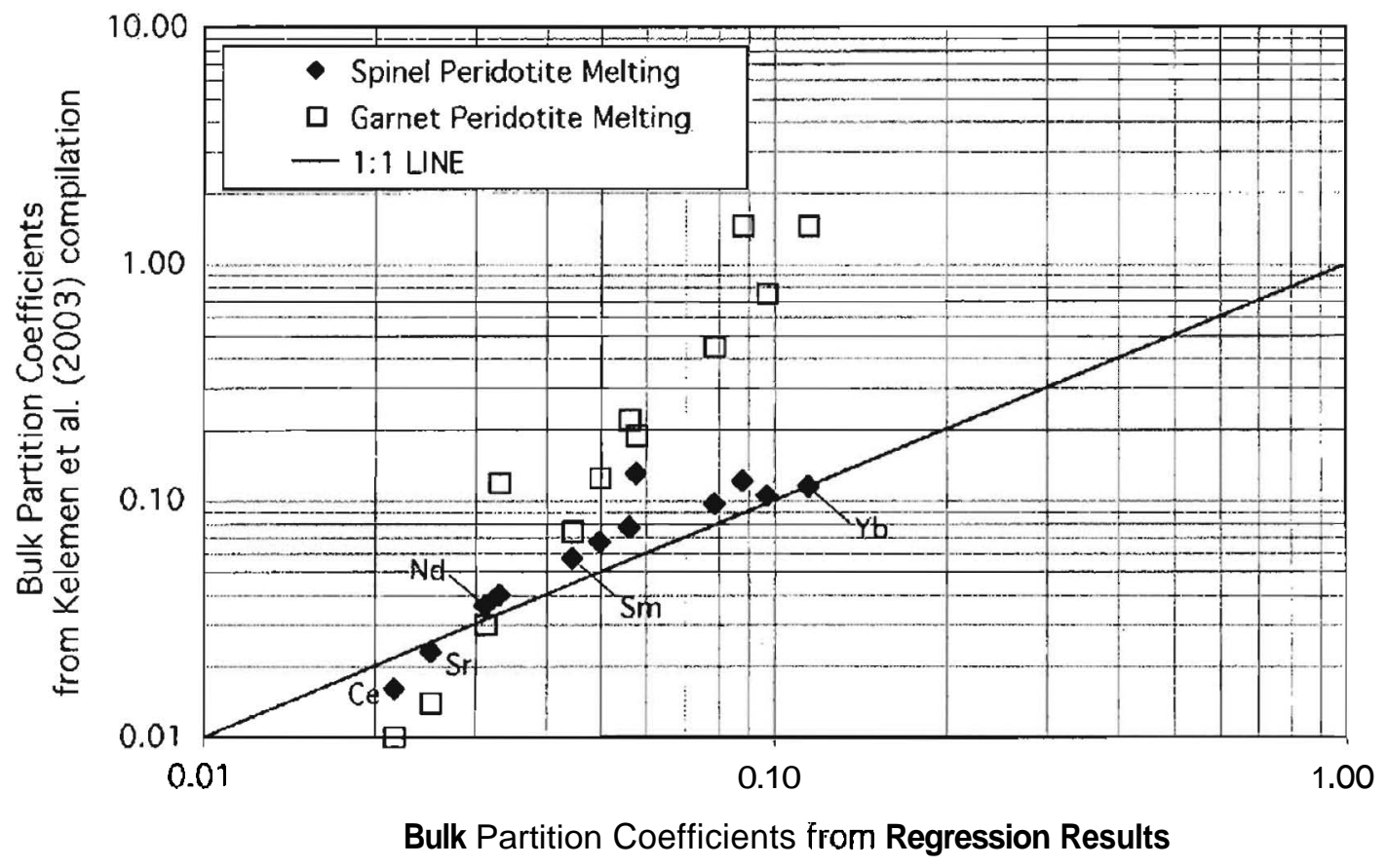

Figure 3-9. Bulk partition coefficients (D's) as obtained from abyssal peridotite trends (fig. 2, Table 2) plotted against both spinel and garnet facies bulk D values from Kelemen et al. (2003). Regression-based D values are calculated with Eqn. $S$ and assuming $D_{N d}=0.031$. It is clear that the slope of the $D$ values obtained reflect melting more in the spinel facies than the garnet facies, as the garnet facies is much steeper. Another, choice for $D_{N d}$ will change the absolute concentrations, but not the slope, of the points plotted here. 


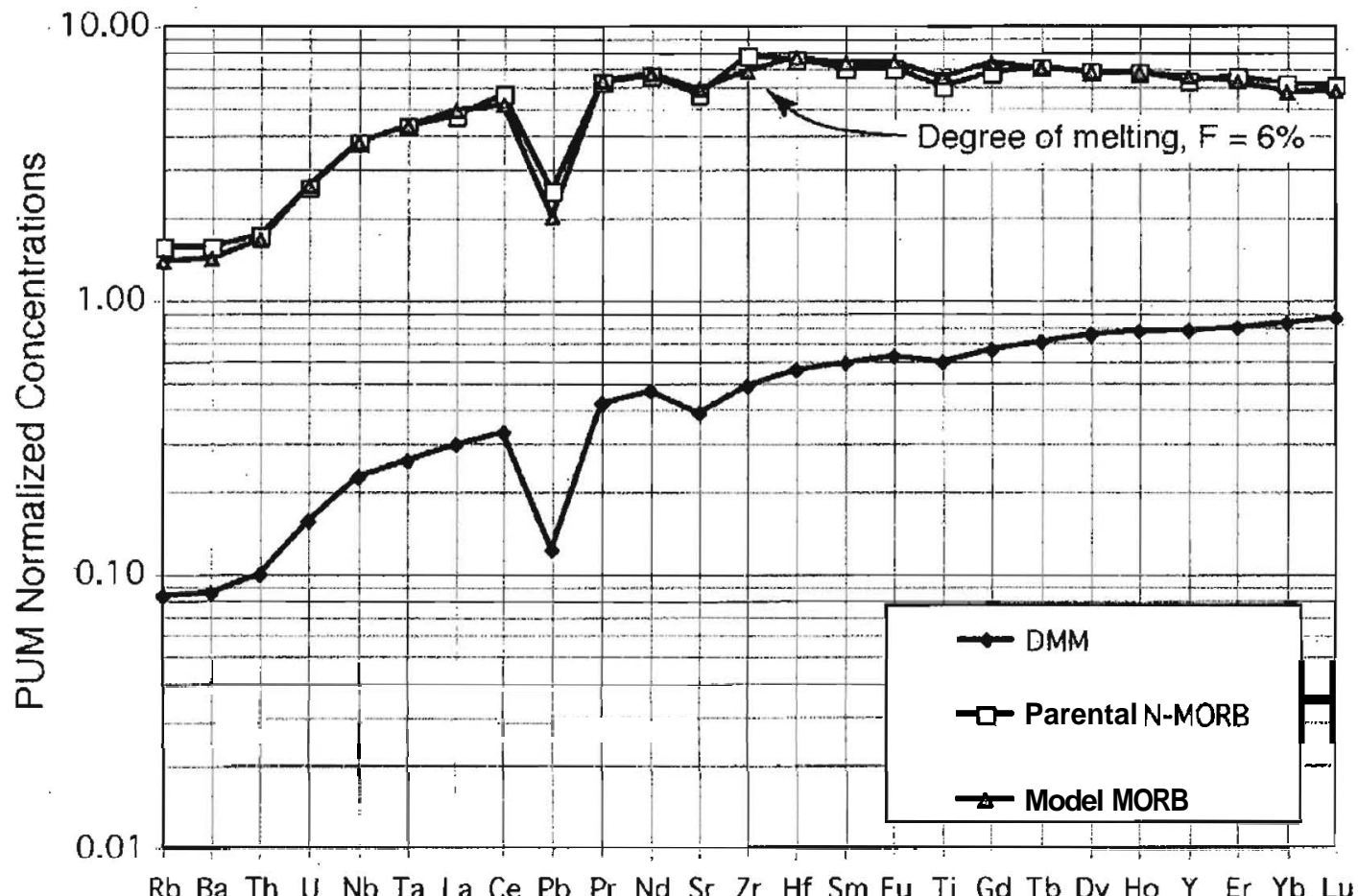

Figure 3-10. Plot showing the spectacular fit of parental N-MORB (from Su and Langmuir (2003) by $6 \%$ aggregated fractional melting of DMM (from this study) using Bulk $\mathrm{D}$ values in Table 2. The $\mathrm{Rb}, \mathrm{Ba}, \mathrm{Th}$, $\mathrm{U}$, and $\mathrm{Pb}$ for the parental MORB are taken from the $\mathrm{N}$-MORB average of Hofmann (1988) and adjusted according to fractionation corrections provided by Su and Langmuir (2003). 


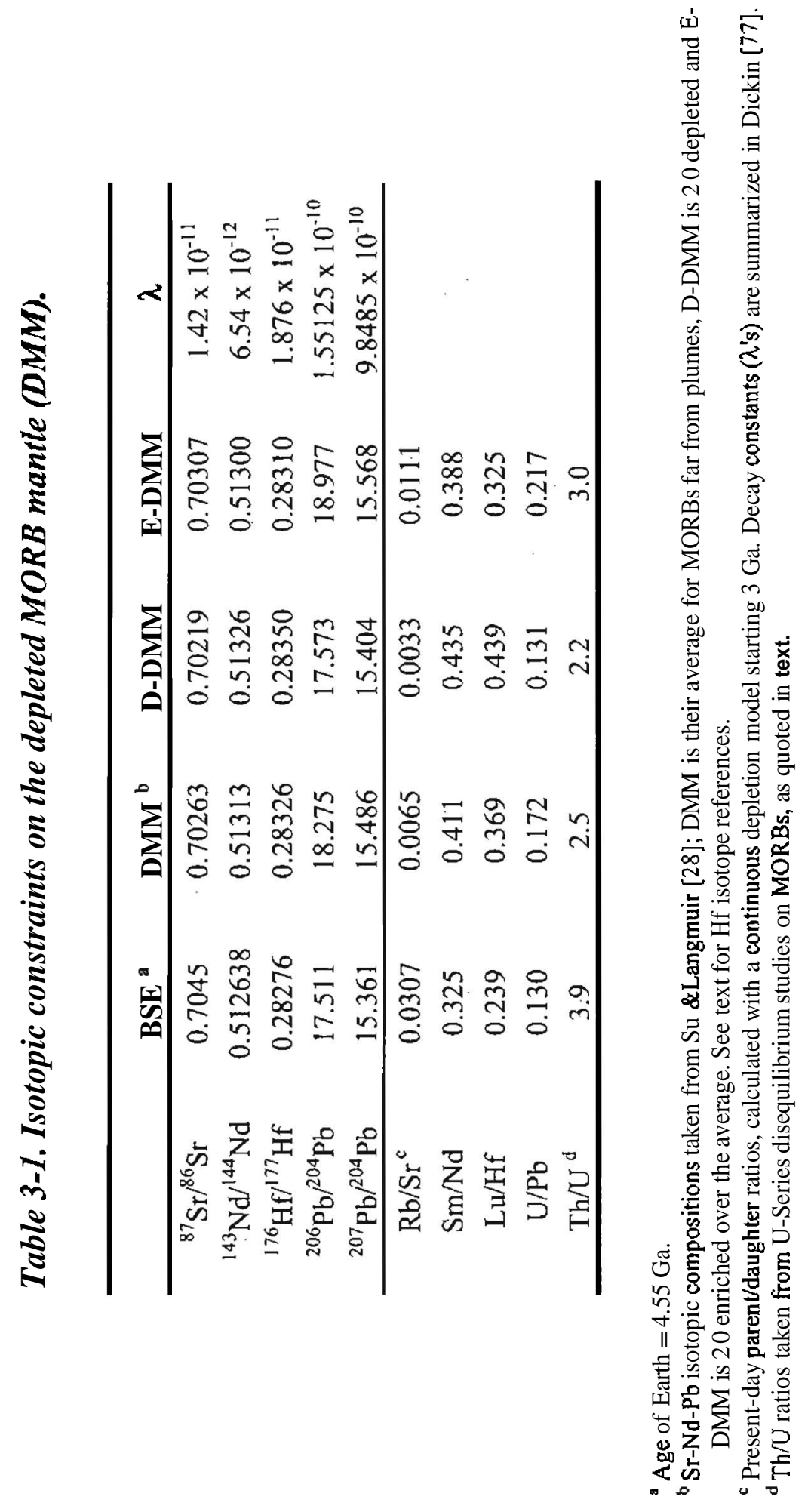




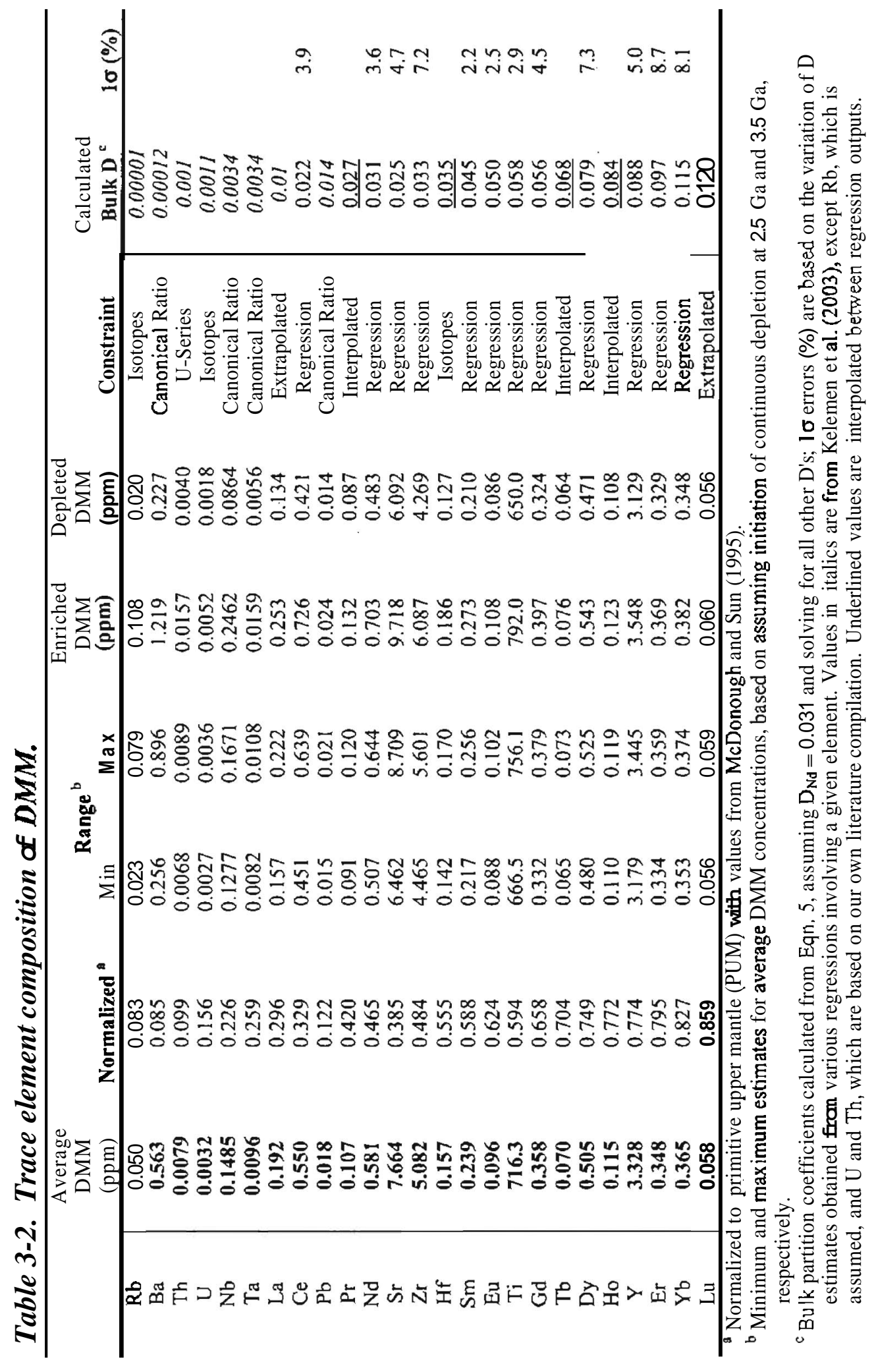


Table 3-3. Modal abundances and major element composition of DMM.

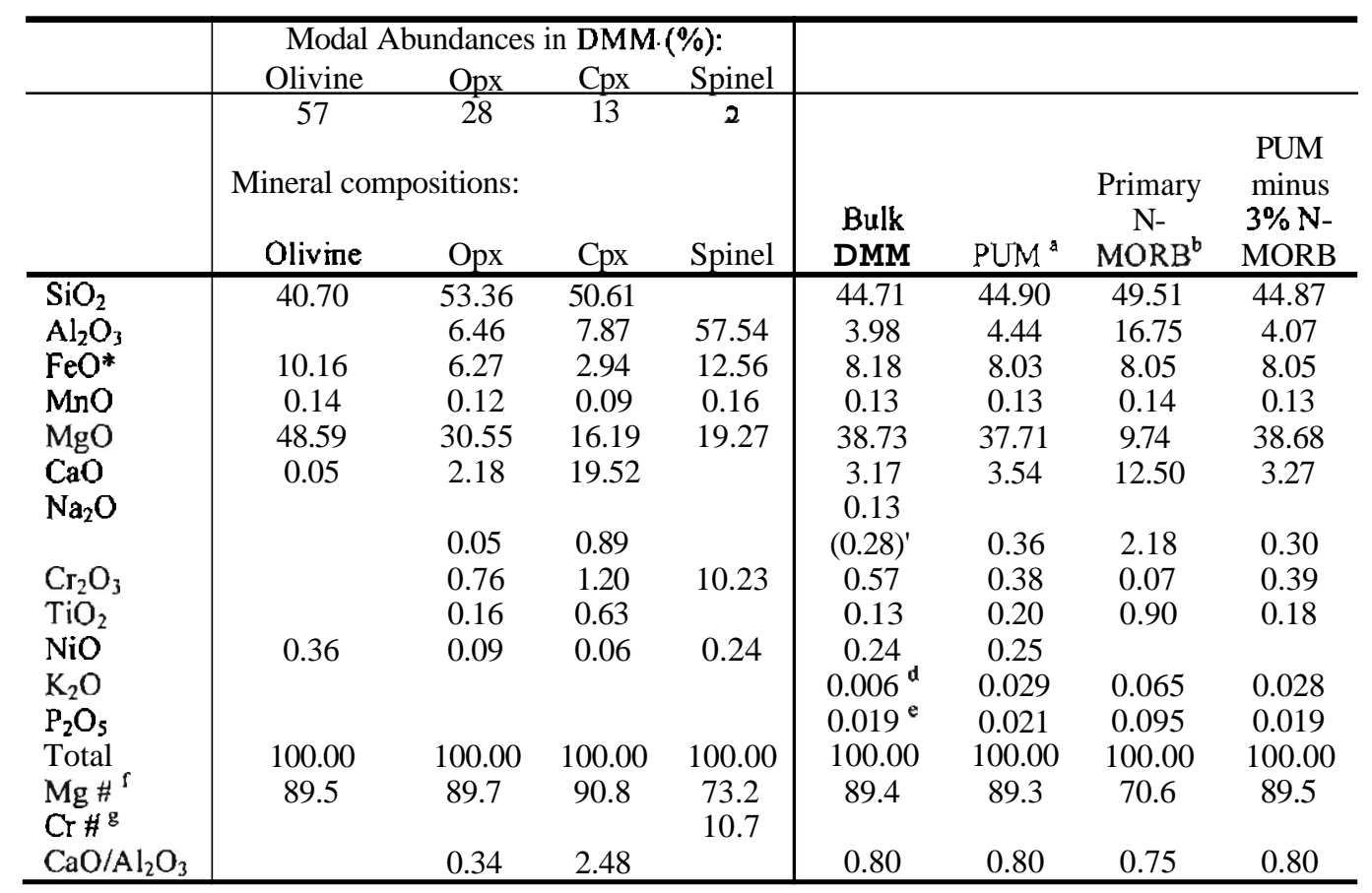

* Total Fe as FeO.

" Primitive Upper Mantle (PUM) from McDonough and Sun (1995).

${ }^{b}$ Primary N-MORB from averaged glass compositions in Presnall and Hoover (1987).

${ }^{\mathrm{c}}$ Value in parentheses is $\mathrm{Na}_{2} \mathrm{O}$ estimated from the mass balance with continental crust (see text).

${ }^{\mathrm{d}}$ Calculated by inverting parental N-MORB at $0.1 \mathrm{wt} \% \mathrm{~K}_{2} \mathrm{O}$ for $6 \%$ melting and assuming $\mathrm{D}_{\mathrm{K}}=0.0013$.

¿ Calculated by extracting 3\% primary N-MORB (shown here) from PUM.

${ }^{\mathrm{r}} \mathrm{Mg} \#=$ molar ratio of $\mathrm{Mg} /\left(\mathrm{Mg}+\mathrm{Fe}^{2+}\right) ; \mathrm{Mg} \nRightarrow$ of $\mathrm{N}-\mathrm{MORB}$ uses $90 \%$ total $\mathrm{FeO}$ as $\mathrm{Fe}^{2+}$.

${ }^{8} \mathrm{Cr} \#=$ molar ratio of $\mathrm{Cr} /(\mathrm{Cr}+\mathrm{A})$ ). 


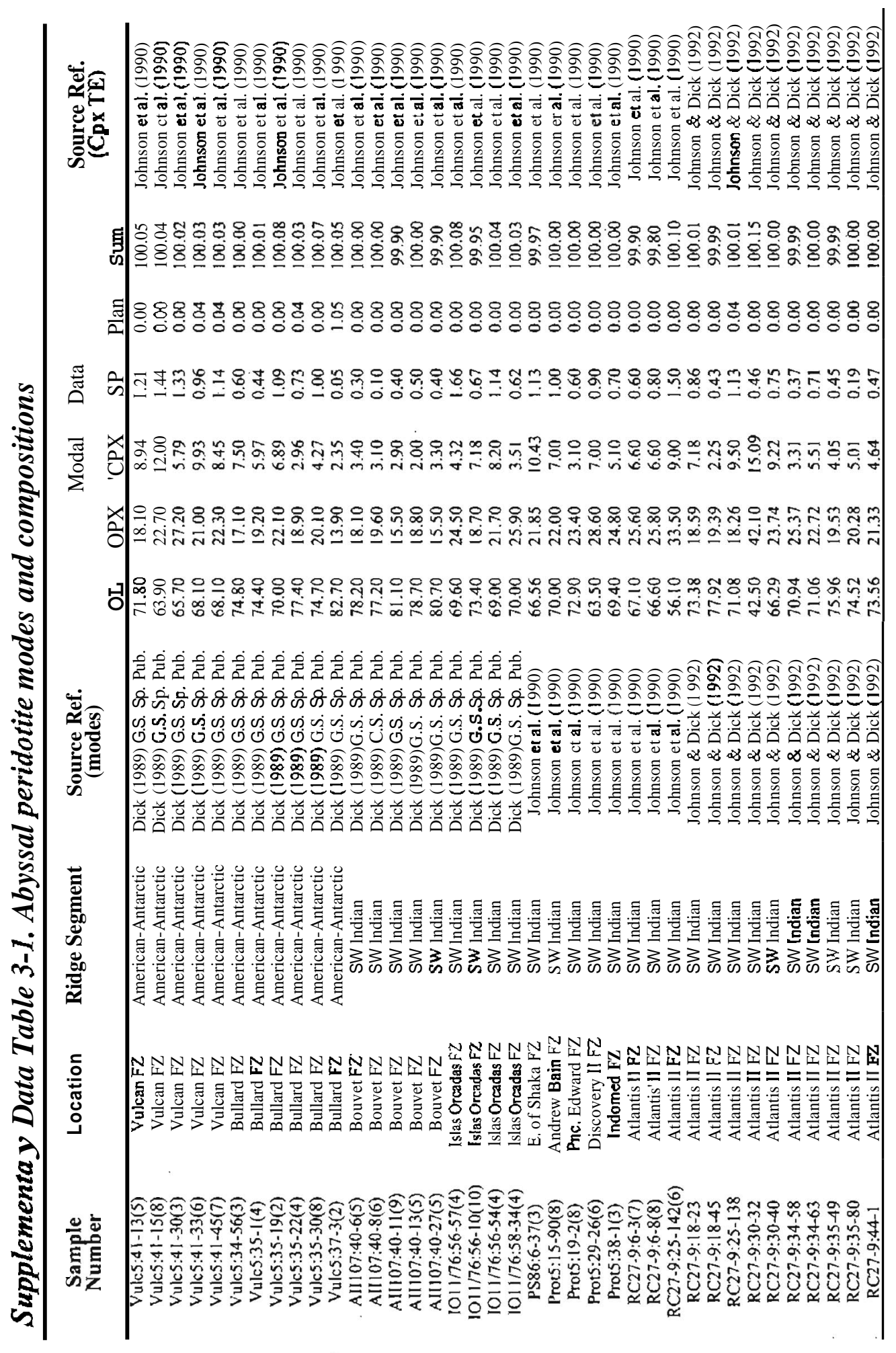




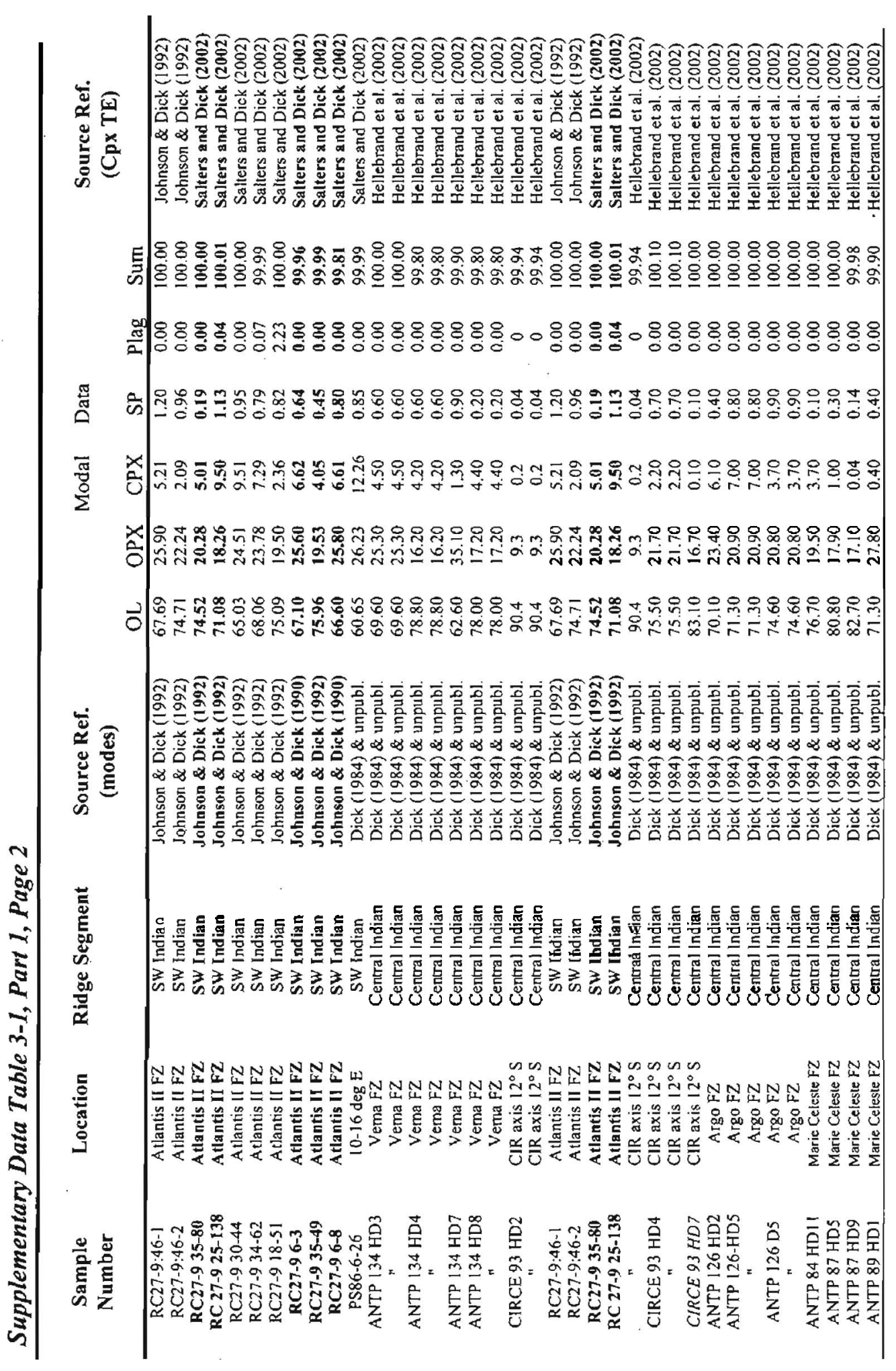


Supplementary Data Table 3-1, Part 1, Page 3

\begin{tabular}{|c|c|c|c|c|c|c|c|c|c|c|}
\hline \multirow{2}{*}{$\begin{array}{l}\text { Sample } \\
\text { Number }\end{array}$} & \multirow[t]{2}{*}{ Location } & \multirow[t]{2}{*}{ Ridge Segment } & \multirow{2}{*}{$\begin{array}{c}\text { Source Ref. } \\
\text { (modes) }\end{array}$} & \multicolumn{3}{|c|}{ Modal } & \multicolumn{2}{|l|}{ Data } & \multicolumn{2}{|r|}{ Source Ref. } \\
\hline & & & & $\mathrm{OL}$ & OPX & CPX & SP & Plag & Sum & \\
\hline ANTP 89 HD2 & Marie Celeste FZ & Central Indian & Dick (1984) \& unpubl. & 76.10 & 21.20 & 2.20 & 0.30 & 0.00 & 99.80 & Hellebrand et al. (2002) \\
\hline ANTP 89 HDS & Marie Celeste FZ & Central Indian & Dick (1984) \& unpubl. & 73.10 & 20.50 & 4.90 & 0.50 & 1.00 & 100.00 & Hellebrand et al. (2002) \\
\hline ANTP 89 HD8 & Marie Celeste FZ & Central Indian & Dick (1984) \& unpubl. & 75.80 & 19.90 & 3.80 & 0.30 & 0.00 & 9980 & Hellebrand et al. $(2002)$ \\
\hline ANTP89 HDI 5 & Marie Celeste FZ & Central Indian & Dick (1984) \& unpubl. & 85.10 & 14.40 & 0.50 & 0.04 & 0.00 & 100.04 & Hellebrand et al. (2002) \\
\hline ANTP 89 HDI7 & Marie Celesie FZ & Central Indian & Dick (1984) \& unpubl. & 81.00 & 16.90 & 1.90 & 0.10 & 0.00 & 99.90 & Hellebrand et al. (2002) \\
\hline ME33/2-3IGTV & Green Rock Hill & Central Indian & Hellebrand et al. (2002) & 70.00 & 28.00 & 1.40 & 0.60 & NA & 100.00 & Hellebrand et al. (2002) \\
\hline SO92-60GTV & Green Rock Hill & Central Indian & Hcllebrand et al. (2002) & 74.00 & 22.80 & 2.60 & 0.60 & NA & 100.00 & Hellebrand et al. (2002) \\
\hline SO92-74GTV & Green Rock Hill & Central Indian & Heftebrand et al. (2002) & 74.00 & 23.50 & 1.90 & 0.60 & NA & 100.00 & Hellebrand et al. (2002) \\
\hline G96-39/36 & Romanche FZ & Mid-Atlantic & Tanorotti et al (2002) & 66.60 & 25.00 & 6.80 & 1.10 & 0.50 & 100.00 & Tartorotti et al. (2002) \\
\hline G96-39/36 & Romanche FZ & Mid-Atlantic & Tartorotti et al. (2002) & 66.60 & 25.00 & 6.80 & 1.10 & 0.50 & 100.00 & Tartorotti el al. (2002) \\
\hline 895B IR-1, 71.76 & Site 895 & East Pacific Rise & Dick and Natlland (1996) & 87.70 & 11.30 & 0.31 & 0.62 & 0.12 & 100.05 & Dick and Natlland (1996) \\
\hline $895 \mathrm{C}$ IR-I, 28-32 & Site 895 & East Pacific Rise & Dick and Natlland (1996) & 82.60 & 14.90 & 1.22 & 1.24 & 0.00 & 99.96 & Dick and Natlland (19\%) \\
\hline $895 \mathrm{C}$ IR-1, 28-32 & Site 895 & East Pacific Rise & Dick and Natlland (1996) & 82.60 & 14.90 & 1.22 & 1.24 & 0.00 & 99.96 & Dick and Natlland (1996) \\
\hline $895 \mathrm{C} 3 \mathrm{R}-1,35-39$ & Site 895 & East Pacific Rise & Dick and Natlland (19\%) & 81.30 & 16.20 & 1.43 & 1.04 & 0.00 & 99.97 & Dick and Natlland (1996) \\
\hline 895D 3R-I 116-120 & Site 895 & East Pacific Rise & Dick and Natlland (19\%) & 82.20 & 15.90 & 1.16 & 0.79 & 0.00 & 100.05 & Dick and Natlland (1996) \\
\hline 895D 4R-3 97-101 & Site 895 & East Pacific Rise & Dick and Nattland (19\%) & 78.0 & 18.70 & 2.41 & 0.87 & 0.00 & 99.98 & Dick and Netllarsd (1996) \\
\hline 895D 7R-2, 129-133 & Site 895 & East Pacific Rise & Dick and Natlland (1996) & 82.20 & 15.60 & 1.71 & 0.48 & 0.00 & 99.99 & Dick and Natlland (1996) \\
\hline
\end{tabular}




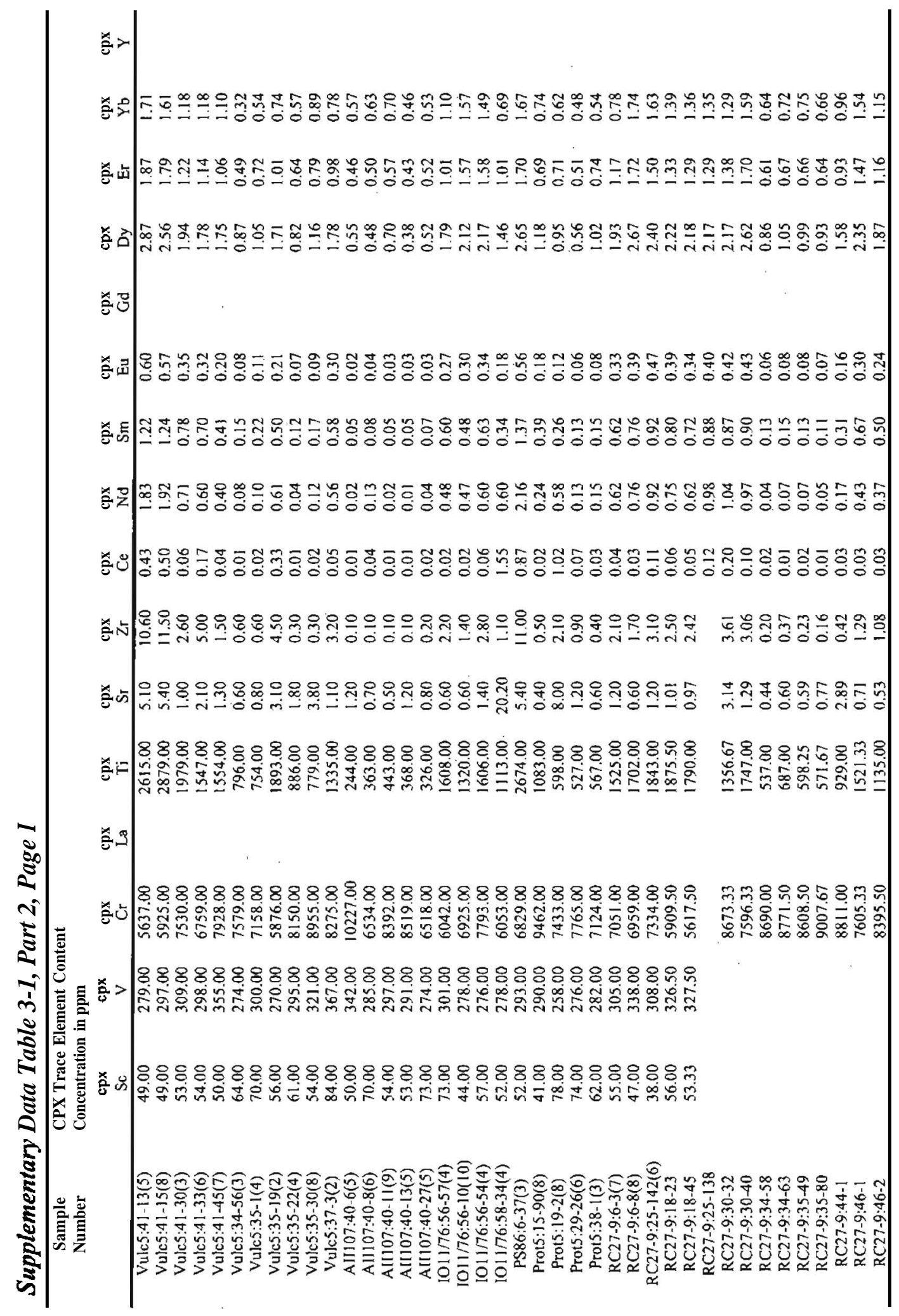




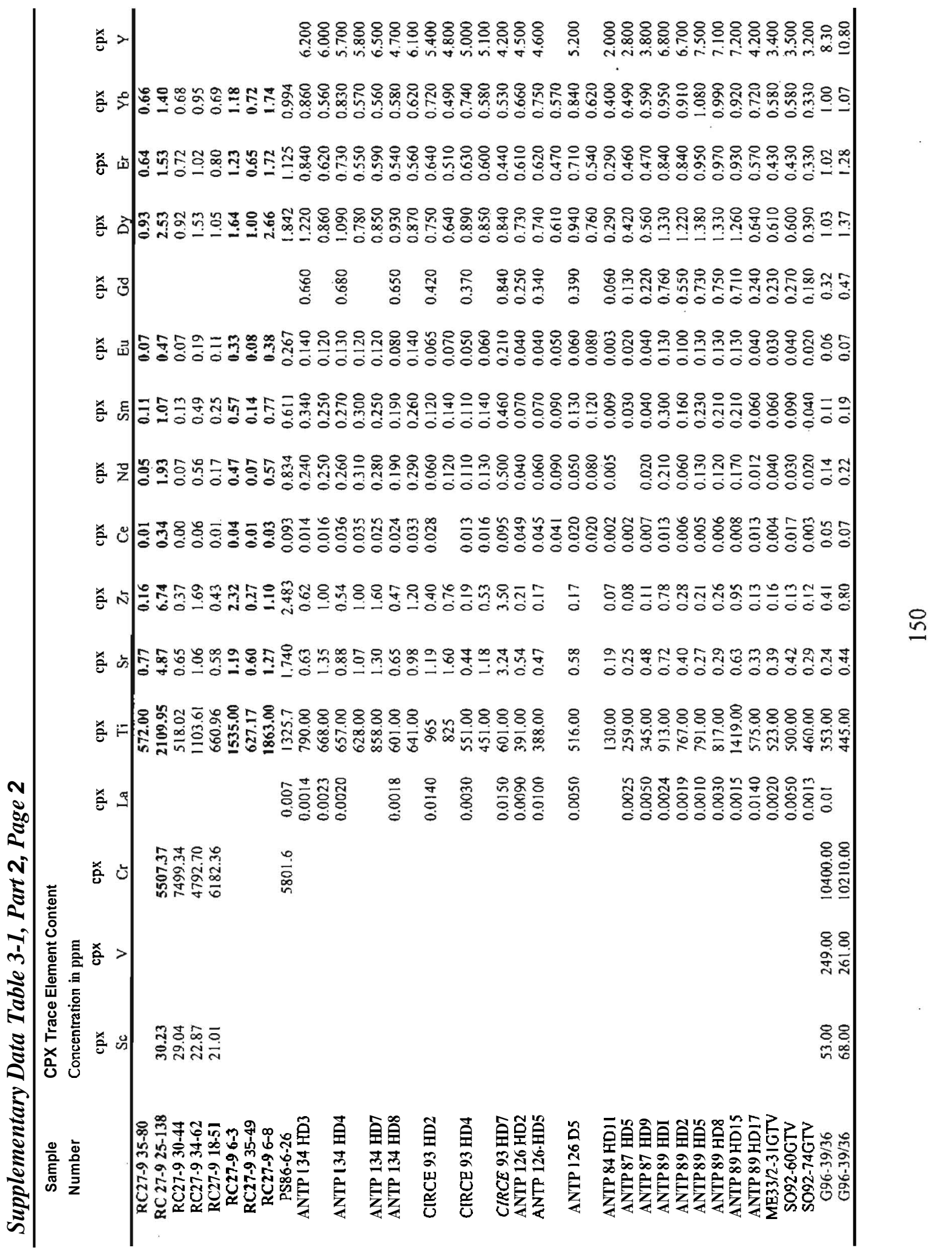




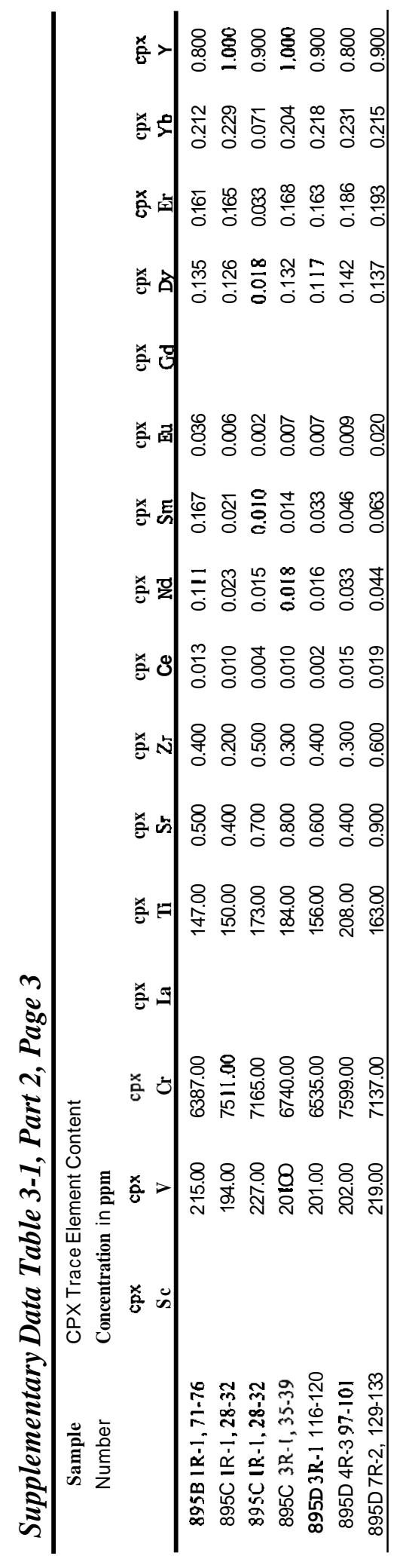

$n$ 


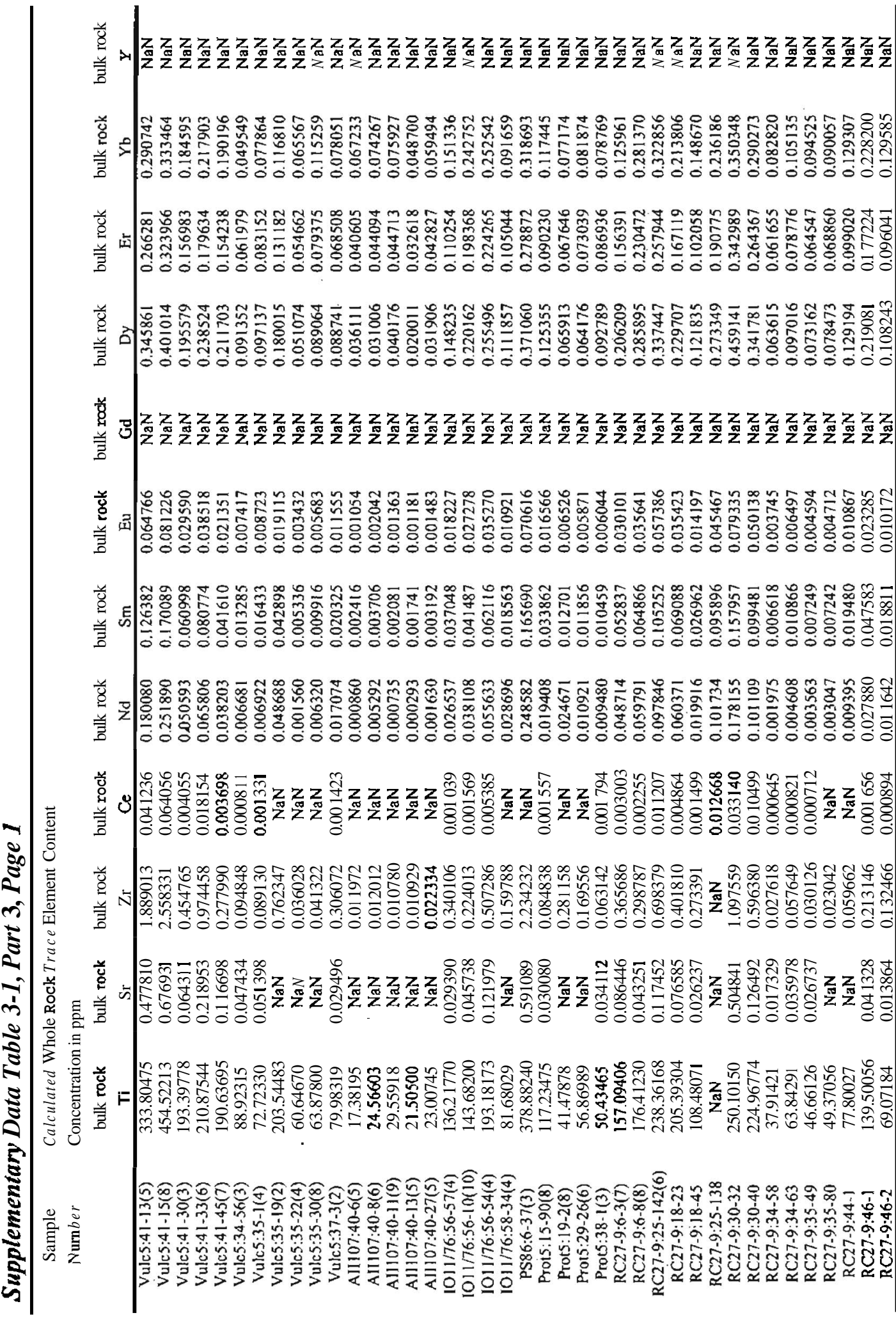




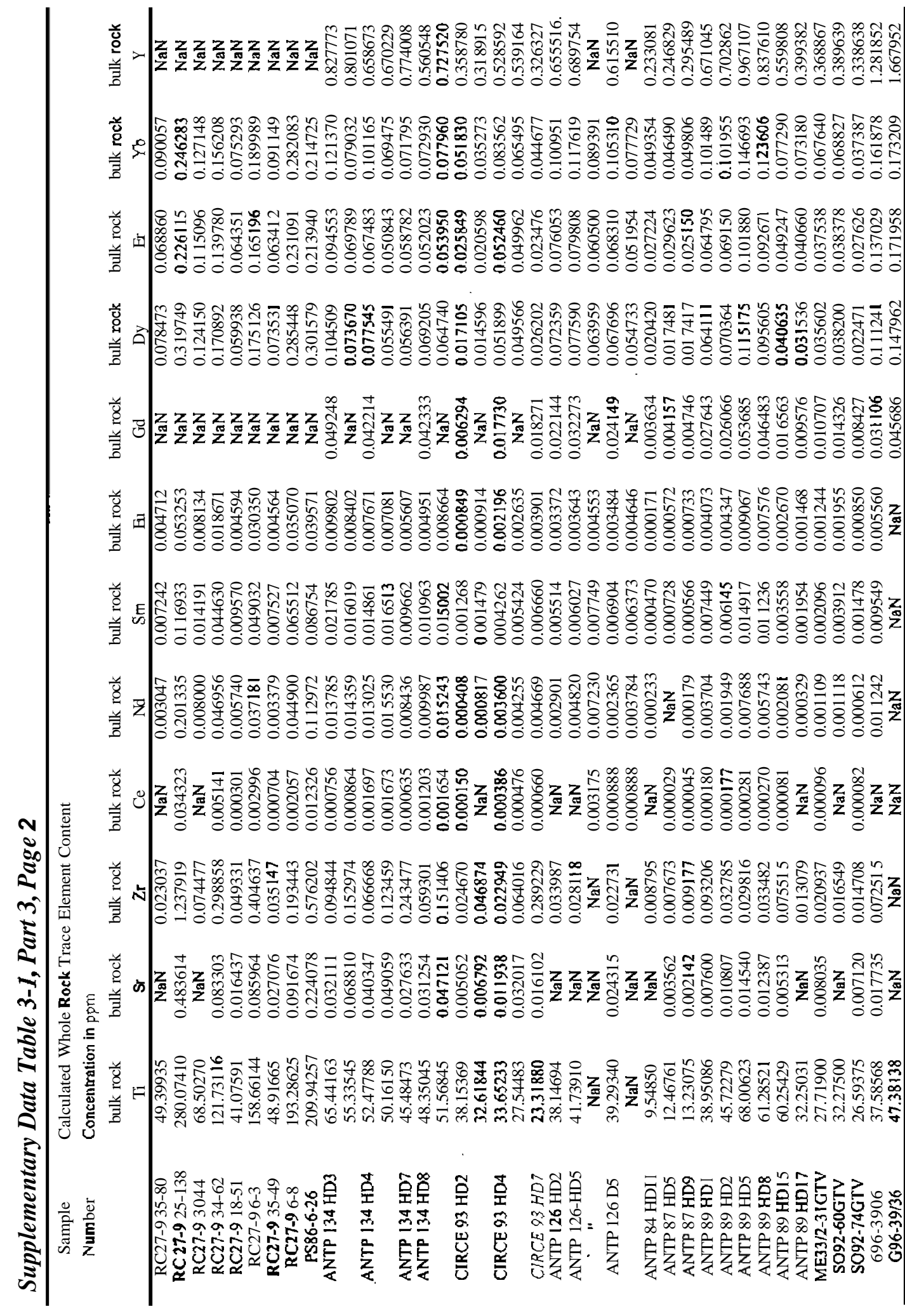




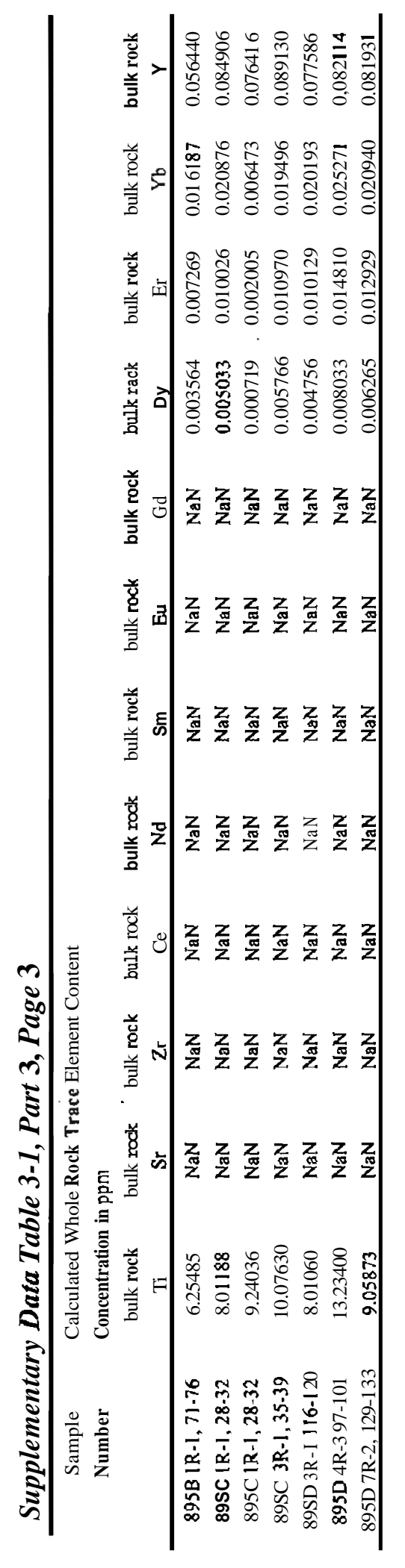


Supplementary Data Table 3-2. Mineral compositions in average DMM.

\begin{tabular}{|c|c|c|c|c|c|}
\hline \multicolumn{6}{|c|}{ Mineral Modes } \\
\hline & ol & opx & $\operatorname{cpx}$ & sp & sum \\
\hline & 0.57 & 0.28 & $0.13^{\prime}$ & 0.02 & 1 \\
\hline \multicolumn{6}{|c|}{ Mineral Trace element compositions (ppm) } \\
\hline & ol & opx & $\operatorname{cpx}$ & sp & $\operatorname{sum}^{\mathrm{a}}$ \\
\hline $\mathrm{Rb}$ & & 0.005 & 0.371 & & 0.050 \\
\hline $\mathrm{Ba}$ & & 0.062 & 4.197 & & 0.563 . \\
\hline Th & & 0.0001 & 0.061 & & 0.008 \\
\hline $\mathrm{U}$ & & 0.0002 & 0.024 & & 0.003 \\
\hline $\mathrm{K}$ & & 0.541 & 389.6 & & 50.800 \\
\hline $\mathrm{Nb}$ & 0.058 & 0.167 & 0.443 & 0.575 & 0.149 \\
\hline $\mathrm{Ta}$ & 0.004 & 0.011 & 0.029 & 0.037 & 0.010 \\
\hline $\mathrm{La}$ & 0.0002 & 0.026 & 1.414 & 0.016 & 0.192 \\
\hline $\mathrm{Ce}$ & 0.0005 & 0.137 & 3.930 & 0.027 & 0.550 \\
\hline $\mathrm{Pb}$ & 0.00002 & 0.005 & 0.129 & 0.001 & 0.018 \\
\hline $\operatorname{Pr}$ & 0.0002 & 0.034 & 0.744 & 0.003 & 0.107 \\
\hline $\mathrm{Nd}$ & 0.002 & 0.194 & 4.044 & 0.013 & 0.581 \\
\hline $\mathrm{Sr}$ & 0.004 & 1.312 & 56.11 & & 7.664 \\
\hline $\mathrm{Zr}$ & 0.657 & 6.574 & 20.28 & 11.50 & 5.082 \\
\hline $\mathrm{Hf}$ & 0.013 & 0.131 & 0.836 & 0.228 & 0.157 \\
\hline $\mathrm{Sm}$ & 0.004 & 0.109 & 1.585 & 0.003 & 0.239 \\
\hline Eu & 0.002 & 0.056 & 0.611 & 0.001 & 0.096 \\
\hline $\mathrm{Ti}$ & 101.8 & 1018 & 2715 & 10.18 & 716.3 \\
\hline $\mathrm{Gd}$ & 0.007 & 0.239 & 2.209 & 0.004 & 0.358 \\
\hline $\mathrm{Tb}$ & 0.003 & 0.051 & 0.415 & 0.001 & 0.070 \\
\hline Dy & 0.026 & 0.396 & 2.916 & 0.010 & 0.505 \\
\hline Но & 0.010 & 0.096 & 0.633 & 0.003 & 0.115 \\
\hline $\mathrm{Y}$ & 0.751 & 3.266 & 15.25 & 0.147 & 3.328 \\
\hline Er & 0.036 & 0.363 & 1.735 & 0.012 & 0.348 \\
\hline $\mathrm{Yb}$ & 0.086 & 0.376 & 1.615 & 0.017 & 0.365 \\
\hline $\mathrm{Lu}$ & 0.016 & 0.065 & 0.235 & 0.003 & 0.058 \\
\hline
\end{tabular}




\title{
Chapter 4:
}

\section{Volatile and Trace Elements in Basaltic Glasses}

\section{from Samoa: Implications for Water Distribution in the Mantle}

\begin{abstract}
We report volatile $\left(\mathrm{H}_{2} \mathrm{O}, \mathrm{CO}, \mathrm{F}, \mathrm{S}, \mathrm{Cl}\right)$ and trace element data for submarine alkalic basalt glasses from the three youngest Samoan volcanoes, Ta'u, Malumalu and Vailulu'u. Most samples are.visibly sulfide saturated, so have likely lost some $\mathrm{S}$ during fractionation. $\mathrm{Cl} / \mathrm{K}$ ratios $(0.04-0.15)$ extend 'to higher values than pristine MORBs, but are suspected to be partly due to source differences since $\mathrm{Cl} / \mathrm{K}$ roughly varies as a function of ${ }^{87} \mathrm{Sr} /{ }^{86} \mathrm{Sr}$. There are no resolvable differences in the relative enrichment of $\mathrm{F}$ among sources, and compatibility of $\mathrm{F}$ during mantle melting is established to be nearly identical to $\mathrm{Nd}$. Shallow degassing has affected $\mathrm{CO}$, in all samples, and $\mathrm{H}_{2} \mathrm{O}$ only in the most shallowly erupted samples from Vailulu'u. Absolute water contents are high for Samoa (0.63-1.50 wt\%), but relative enrichment of water compared to trace element enrichment is low. $\mathrm{H}_{2} \mathrm{O} / \mathrm{Ce}(58$ 157) and $\mathrm{H}_{2} \mathrm{O} / \mathrm{La}\left(120\right.$ - 350) correlate inversely with ${ }^{87} \mathrm{Sr} /{ }^{86} \mathrm{Sr}$ compositions $(0.7045$ 0.7089). This leads us to believe that, because of very fast diffusion of hydrogen in olivine, recycled lithospheric material with high initial water content will lose water to the drier ambient mantle during storage within the inner Earth. The net result is the counter-intuitive appearance of greater dehydration with greater mantle enrichment.
\end{abstract}




\section{Introduction}

Volatile elements such as hydrogen, carbon, fluorine, sulfur and chlorine track not only the melt phase in magmatic systems, but also the gas and fluid phases. Because of their ability to decouple from lithophile elements, especially at or near the Earth's surface, these elements provide a possible fingerprint of processes that are not actively recorded by the standard suite of incompatible trace elements (e.g. Sr, Rb, U, Th, and the rare earth elements). They have been used extensively to study volatile-driven arc magmatism, but have not been as widely applied to ocean island volcanism. It is now well established that the distribution of water in the mantle (primarily in nominally anhydrous minerals) strongly determines the locations and extents of mantle melting (Asimow and Langmuir, 2003) along with mantle rheology (Hirth and Kohlstedt, 1996; 2003), so it is important to understand the abundance of water in all rnantle materials.

Lavas from the Samoan islands and seamounts have unique geochemical characteristics compared to other ocean island basalts (OIBs) as well as mid-ocean ridge basalts (MORBs), including extreme ${ }^{87} \mathrm{Sr} /{ }^{86} \mathrm{Sr}$ (up to 0.7089), low ${ }^{143} \mathrm{Nd} /{ }^{144} \mathrm{Nd}$ (down to 0.5125 ), and highly trace element enriched lavas (Wright and White, 1986; Fariey et al., 1992; Workman et al., 2004). These characteristics define the Enriched Mantle 2 reservoir (EM2; Zindler and Hart, 1986). EM2 has classically been interpreted as oceanic crust and terrigeneous sediment that had been recycled back to the mantle through subduction zones (e.g. Weaver, 1991). Upon closer inspection, the standard recycling model of ocean crust/sediment fails as an explanation for producing EM2, due to smooth trace element patterns, low ${ }^{187} \mathrm{Os} /{ }^{188} \mathrm{Os}$ ratios, incorrect $\mathrm{Pb}$ isotope compositions, and high ${ }^{3} \mathrm{He} /{ }^{4} \mathrm{He}(>8 \mathrm{R}$ ${ }_{\text {A }}$ ) in Samoan lavas (Workman et al., 2004). Instead, the origin of EM2 has been modeled with the ancient formation of metasomatised oceanic lithosphere, followed by storage in the deep mantle and return to the surface in the Samoan plume. Although Samoa is strongly EM2 in character, other mantle reservoirs, such as HIMU (high ${ }^{238} \mathrm{U} /{ }^{204} \mathrm{~Pb}$ mantle; Zindler and Hart, 1986) and PHEM (Primitive Helium Mantle; Farley et al., 1992), are thought to contribute to the Samoan lavas, and hence in one location there is extreme compositional heterogeneity.

Here we report a study of volatile element concentrations in Samoan lavas in order to assess their relative enrichment compared to other trace element and isotope signatures, and to use them as potential clues to the origin of compositional variations in the mantle. We 
find that water enrichment (identified by $\mathrm{H}_{2} \mathrm{O} / \mathrm{Ce}$ and $\mathrm{H}_{2} \mathrm{O} / \mathrm{La}$ ratios) in EM2 lavas has an inverse relationship to lithophile element enrichment (e.g. high $\mathrm{Rb} / \mathrm{Sr}$ and ${ }^{87} \mathrm{Sr}{ }^{86} \mathrm{Sr}$ ratios). The model for the formation of EM2 (Workman et al., 2004) would not result in fractionation of water from the lithophile elements. However, the fast diffusion of water through mantle minerals (Mackwell and Kohlstedt, 1990) provides a very effective means of losing water from EM2 to a water-poor ambient mantle during the long-term $(-2.5 \mathrm{Ga})$ storage of EM2 - to the point of there being very similar bulk water contents ( $<100 \mathrm{ppm}$ ) in EM2 and the Depleted MORB Mantle (DMM). This finding leads credence to the idea that enriched mantle plumes are indeed "hot-spots" (Morgan, 1971; Sleep, 1990; Campbell and Griffiths, 1990) and not "wet-spots" (Schilling, et al., 1980; Green and Falloon, 1998).

\section{Background}

\subsection{Geological and Geochemical Setting}

The Samoan islands and seamounts are centered on $14^{\circ} \mathrm{S}$ latitude, stretch from 169$177.5^{\circ} \mathrm{W}$ longitude (fig. 1), and rest on the outer rim of the geophysical "superplume" of the South Pacific (Su et al., 1994). Seismic tomography images from beneath Samoa show a slow velocity anomaly extending into the lowermost mantle (Montelli et al., 2003), supporting a deep origin for upwelling mantle material feeding the Samoa hotspot. The tectonic setting of Samoa is complicated by having the northern termination of the Tonga Trench only $100 \mathrm{~km}$ to the south of the island chain. Hart et al. (2004a) have given a synthesis of the regional tectonic history and how plume-trench interaction has influenced the distribution of Samoan volcanism, specifically the en-echelon topographic ridges seen in Figure 1. Hart et al. (2004a) also established, from K-Ar dating and isotope geochemistry of seamounts extending to the west of Savai' $i$, that the Samoan plume has been active for at least 25 million years, producing a $1700 \mathrm{~km}$ long volcanic chain.

The easternmost, leading-edge Samoan volcano is the seamount, Vailulu'u (fig. 1); it rises from a $5000 \mathrm{~m}$ deep seafloor to a summit depth of $590 \mathrm{~m}$ and rests $45 \mathrm{~km}$ east of its nearest neighbor, Ta'u Island ant et al., 2000). Vailulu'u has been shown to be both volcanically and hydrothermally very active (Hart et al., 2000; Hart et al., 2003; Staudigel et al., 2004; Konter et al., 2004). The power output from Vailulu'u's summit crater is estimated to be 610-760 MW, the equivalent of 20-100 Mid-Ocean Ridge black smokers; 
Mn export is estimated at $240-300 \mathrm{~kg} /$ day, or the equivalent of about 10 black smokers (Staudigel et al., 2004; Fat et al., 2003). The presence of ${ }^{3} \mathrm{He}$ anomalies in the water column show that at least this volatileelement is actively degassing from upwelling magmas beneath Vailulu'u (Staudigel et al., 2004). We suspect that the hydrothermal circulation of seawater and degassing of magmas observed at Vailulu'u is representative of all the Samoan volcanoes at this stage of growth.

One goal of this study is to understand volatile enrichments/depletions as a function of mantle source composition. Each of these Samoan volcanoes has a distinct and wellcharacterized geochemical signature, discussed in detail by Workman et al. (2004). In summary, Malumalu displays the most extreme EM2 signature yet documented from ocean island basalts, with ${ }^{87} \mathrm{Sr} /{ }^{86} \mathrm{Sr}$ up to 0.7089 and extreme trace element enrichment. Ta'u shows some of the least enriched lavas from Samoa, with $\mathrm{Sr}-\mathrm{Nd}-\mathrm{Pb}$ isotopic values that are close to the mantle component PHEM (Primitive Helium Mantle of Farley et al. [1992];

$\left.{ }^{87} \mathrm{Sr} /{ }^{86} \mathrm{Sr}=0.7045\right)$; for $\mathrm{Ta}$ 'u this corresponds to ${ }^{3} \mathrm{He} /{ }^{4} \mathrm{He}$ up to $18 \mathrm{R}_{\mathrm{A}}$ and a lesser degree of trace element enrichment. Vailulu'u lavas are of intermediate enrichment and are thought to contain a small component of HIMU mantle, giving Vailulu'u the highest ${ }^{206} \mathrm{~Pb} /{ }^{204} \mathrm{~Pb}$ (19.4) in Samoa.

\subsection{Samples and Volcano ages}

Glass samples from the three youngest Samoan volcanoes, Vailulu'u, Malumalu, and Ta'u, have been taken from glassy rims of pillow basalts dredged during the 1999 AVON2/3 cruise aboard the R/V Melville. In this paper, we report data on samples obtained from 1.1 dredges ranging from 780 to 4170 meters deep - 6 from Vailulu'u, 2 from Ta'u and 3 from Malumalu (see Table I). All Ta'u and Malurnalu dredges are from a similar depth of 2300 - 3600 meters, whereas the shallowest and deepest dredges are from Vailulu'u.

All samples have some vesicles, most with less than $10 \%$ by volume and none over about $30 \%$, indicating that these samples have experienced volatile exsolution during eruption. All dredges except 72 (Vailulu'u) and 75 (Ta'u) have sulfides present in nearly every sample (see Table 1); these occur as $10-50 \mu \mathrm{m}$ spheres and are visible under reflected light in the glass chips that were analyzed. Micro-phenocryts of olivine, spinel, and clinopyroxene are common within the glasses. In a few of the olivine phenocrysts, melt inclusions have been fortuitously exposed, so these were analyzed for their volatilecontents 
to compare with volatile abundances in the matrix glass, but they have not been properly studied for major elements and mineral-melt equilibration.

U-series data have been collected for samples from each Vailulu'u and Malumalu dredge (Sims and Hart, 2004), including the following samples studied here: 63-13, 70-01, 71-02, 71-09, 72-02, 73-01, 73-03, 73-12, 76-01, 78-01. All show ${ }^{230} \mathrm{Th} /{ }^{238} \mathrm{U}$ excesses and are interpreted to be less than 300 thousand years old. The ${ }^{230} \mathrm{Th} /{ }^{238} \mathrm{U}$ excesses shown from Malumalu are similar to those on Vailulu'u, suggesting that Malumalu is not significantly older than Vailulu'u. Two samples from Vailulu'u (63-13 and 70-09) show ${ }^{210} \mathrm{~Pb}$ disequilibria are interpreted to be less than 100 years old (Hart et al., 2000).

The oldest K-Ar age from Tau Island is $0.3 \mathrm{Ma}$ (McDougall, 1985). The youngest volcanic series on Tau (Faleasao) is probably younger than 37,000 years, based on ${ }^{14} \mathrm{C}$ ages of coral inclusions in these volcanics (Hart, unpublished). Additionally, there was an underwater eruption just west of Tau in 1866 (see description in Keating, 1992).

\section{Analytical Techniques}

Multiple glass chips from the quenched rims of dredged pillow basalts were handpicked and mounted with epoxy for ion microprobe analyses. Volatile abundances $\left(\mathrm{H}_{2} \mathrm{O}\right.$, $\mathrm{CO}_{2}, \mathrm{~F}, \mathrm{~S}$ and $\mathrm{Cl}$ ) were determined by triplicate analyses on the Cameca IMS of ion microprobe at the Department of Terrestrial Magmatism with a 5-10 nA Cs ${ }^{+}$primary beam. See Hauri et al. (2002) for a full description of the mircobeam method. Trace elements were determined on the same area of glass using the same instrument, but with an $\mathrm{O}^{-}$primary beam. Analytical uncertainties are $\pm 10 \%$ for $\mathrm{H}_{2} \mathrm{O}$ and $\pm 5 \%$ for all other elements. All calibrations were made against mafic glass standards.

For $\mathrm{Sr}$ isotope analyses, glass chips were hand-picked and leached for 1 hour in $6 \mathrm{~N}$ $\mathrm{HCl}$. Sr was separated by a standard cation exchange procedure described in Taras and Hart (1987). Isotopic analyses were carried out on the NEPTUNE multi-collector ICP/MS at W.H.O.I.; ${ }^{87} \mathrm{Sr} /{ }^{86} \mathrm{Sr}$ values are corrected to 0.71024 for NBS 987 and carry a $2 \sigma$ precision equal to $\pm 25 \mathrm{ppm}$ (Hartet al., 2004b).

\section{Results}

Volatile and other trace element concentrations for Samoan glasses are listed in Table 1. Major element abundances of the glasses were analyzed by electron microprobe at MIT and 
have been previously published (Workman et al., 2004). $\mathrm{Sr}, \mathrm{Nd}$ and $\mathrm{Pb}$ isotope measurements have been made on a few whole rock samples (for which we now report glass data) and are also published in Workman et al. (2004). New ${ }^{87} \mathrm{Sr} /{ }^{86} \mathrm{Sr}$ measurements on glass samples are reported in Table 1 , and range from 0.70452 to 0.70841 , within the previously established range for whole rock analyses of Samoan lavas (Workman et al., 2004). The ${ }^{87} \mathrm{Sr} /{ }^{86} \mathrm{Sr}$ compositions of glass and whole rock pairs for individual samples

have been found to be within analytical error (Jackson et al., unpubl.), so using ${ }^{87} \mathrm{Sr} /{ }^{86} \mathrm{Sr}$ values from "mixed material" is inconsequential to our data analysis.

\subsection{Trace elements and fractionation correction}

All the glasses presented here are evolved beyond clinopyroxene saturation, as identified by: 1) low $\mathrm{Mg \# 's} \mathrm{(molar} \mathrm{percent} \mathrm{of} \mathrm{Mg} /\left[\mathrm{Mg}+\mathrm{Fe}^{+2}\right]$ ), ranging from 39 to $61 ; 2$ ) positive correlations between $\mathrm{Mg} \#$ and $\mathrm{CaO} ; 3)$ presence of clinopyroxene phenocrysts in whole rock samples; and 4) liquid lines of descent predicted by 'the pMELTS model (see fig. 2). They are all alkali basalts, with $\mathrm{SiO}_{2}$ from 45.5 to 48.9 wt \% and total alkalis $\left(\mathrm{K}_{2} \mathrm{O}+\mathrm{Na}_{2} \mathrm{O}\right)$ from 3.2 to $6.1 \mathrm{wt} \%$. The glasses are generally further along on fractionation trends than their whole rocks (fig. 2) due to the exclusion of phenocrysts in the glasses. Mg\#'s of aphyric whole rocks are equal, to or slightly higher than their glasses, but some glasses come from picritic samples with Mg\#'s up to 81-84.

Trace element patterns of the glasses closely parallel whole rock trace element patterns (from Workman et al., 2004) of each volcano. La/Sm and $\mathrm{Sm} / \mathrm{Yb}$ for glass and whole rock pairs are usually within analytical error, showing that the fractionation of olivine and clinopyroxene has had little effect on incompatible element ratios. Hence, using the data in this way (as elemental ratios) would be the most reliable in assessing primary melt characteristics.

$\mathrm{La} / \mathrm{Sm}$ values of the glasses range from 3.3 to 7.5 and correlate positively with ${ }^{87} \mathrm{Sr} /{ }^{86} \mathrm{Sr}$, a proxy for source enrichment (i.e. Ta'u has the lowest and Malumalu has the highest $\mathrm{La} / \mathrm{Sm}$; not shown). $\mathrm{Sm} / \mathrm{Yb}$, on the other hand, does not correlate with enrichment, and the three volcanoes overlap in values from 2.9 - 5.6. For comparison, N-MORB La/Sm and $\mathrm{Sm} / \mathrm{Yb}$ ratios are each -1.0 (Hofmann, 1988). The steepness of Samoan rare-earth element slopes is a strong indication of melting within the stability field of garnet lherzolite (Hauri et al., 1994; Salters et al., 2002), as to be expected with melting beneath an old tectonic plate where the bottom of the lithosphere (e.g. Li et al., 2004) is near the garnet to spinel transition (Kogiso et al., 1998; Robinson and Wood, 1998; Klemme and O'Neill, 2000). 
In order to estimate the compositions of primitive Samoan magmas, we have corrected the raw glass data for crystal fractionation by using the pMELTS trends (Ghiorso et al., 2002) to calculate the remaining liquid mass as a function of $\mathrm{MgH}$. The degree of fractionation ranges from $17 \%$ to $66 \%$, with the majority of lavas falling within the range of $30-46 \%$ fractionated. Figure 2 shows that Malumalu and Ta'u lavas lie along very similar fractionation lines. Vailulu'u lavas are on a separate trend at higher $\mathrm{CaO}$, with shallow dredges $(63,68,70$ and 73$)$ being more fractionated on average than deep dredges (70 and $71)$.

The same fractionation corrections have been applied to the volatile contents, assuming that crystal fractionation happened at vapor under-saturated conditions. Figure 3 shows the fractionation-corrected abundances of volatile elements and a select group of trace elements, listed in the order of increasing compatibility during mantle melting. Concentrations are normalized to primitive upper mantle (PUM); most values for PUM are taken from McDonough and Sun (1995) except for $\mathrm{CO}$, and $\mathrm{H}_{2} \mathrm{O}$, which are calculated assuming that PUM has a $\mathrm{CO}_{2} / \mathrm{Nb}$ ratio of 239 (Saal et al., 2002) and an $\mathrm{H}_{2} \mathrm{O} / \mathrm{Ce}$ ratio of 200 (the value for FOZO observed by Dixon et al., 2002). This plot allows for a brief overview of the relative enrichments of volatile elements compared to the trace elements, suspending (for the moment) any interpretation about loss of volatiles by degassing. For all volcanoes, the negative anomalies for $\mathrm{CO}, \mathrm{H}_{2} \mathrm{O}$, and $\mathrm{S}$ indicate that these volatiles are less enriched in the lavas than lithophile elements of similar compatibility; the opposite is true for the positive anomaly at $\mathrm{Cl}$ for most of the Vailulu'u lavas. $\mathrm{F}$ is the only volatile element that is consistently "conformable" with the lithophile elements in all samples. In the following sections, we attempt to discern which of these signals are primary and how they can be used to understand the composition and evolution of the mantle.

\subsection{Water and carbon dioxide in glasses}

The Samoan lavas show a large range in raw $\mathrm{H}_{2} \mathrm{O}(0.63-1.50 \mathrm{wt} \%)$ and $\mathrm{CO},(6-233$ ppm) contents (fig. 4a; Table 1). Such water contents are highly elevated over MORBs (fig. 4b), but are very similar to Hawaii's submarine lavas from Loihi Seamount (Dixon and Clague, 2001) and the North Arch lava field (Dixon et al., 1997), and to melt inclusion data from the Austral Islands (Lassiter et al., 2002). Water in OIB lavas is generally lower than in arc lavas (up to $\sim 6 \mathrm{wt} \%$ ) but in the same range as back-arc basin lavas (e.g. Newman et al., 2000, for the Marianas system). 
The presence of vesicles (1-30 vol\%; Table 1) in every sample indicates that these lavas were all vapor saturated during eruption onto the seafloor. Some vapor loss can be accounted for by correcting for vesicle gases (i.e. the manifestation of closed system degassing). As a test for the severity of water loss, vesicle abundances.were determined in 3 of the most vesicle-rich samples, 73-01, 73-03, and 78-03, by point-counting standard-sized thin sections. By volume, these contain $31 \%, 20 \%$ and $24 \%$ vesicles, respectively. Adding equilibrium vapor compositions back into the glasses, following the procedure described in Dixon et al. (2002), results in increases in bulk water content on the order of 0.03 to 0.05 wt\%; yet these samples still have the lowest water abundances. Because this level of correction is within error of the analyses, we chose not to make vesicle corrections for all samples in the Samoan suite. It is likely that the volume of vesicles present in the glasses at eruption does not represent the total amount of degassing experienced by these lavas; in other words, we think it is likely that these lavas have lost gas via open-system degassing with bubble loss, prior to their final eruption and emplacement on the seafloor.

$\mathrm{H}_{2} \mathrm{O}-\mathrm{CO}_{2}$ solubility models (Stolper and Holloway, 1988; Dixon et al., 1995; Dixon, 1997) show that $\mathrm{CO}_{2}$ is much more insoluble than $\mathrm{H}_{2} \mathrm{O}$ in basaltic magmas. As a result, with Samoan water contents, vapor compositions during open-system degassing are almost entirely $\mathrm{CO}$, until pressures drop below -100 bars (ocean depth of 1000 meters) (Newman and Lowenstern, 2002). In Figure 4a, the arrow at the end of the degassing trend marks the sharp change from $\mathrm{CO}_{2}$-dominated to $\mathrm{H}_{2} \mathrm{O}$-dominated vapor compositions; above this point, open-system degassing results in nearly negligible water loss.

In Figure 4c, calculated equilibrium saturation pressures (using the Dixon [1997] model for $\mathrm{H}_{2} \mathrm{O}-\mathrm{CO}_{2}$ saturation in alkali basalts) are plotted with collection depth. Lavas that lie very close to the 1:1 line erupted close to their dredge depth. Lavas below the 1:1 line are interpreted to have erupted more shallowly and flowed down slope; lavas above the line experienced incomplete degassing (i.e. rapid quenching). Note that some scatter is because dredges are along flanks of the volcanoes and hence may traverse 100's of meter of depth contours (see fig.1); the quoted dredge depth is the average for each dredge and may not represent every sample accurately.

As indicated by carbon dioxide concentrations and pressures of equilibration, both the most and the least degassed samples are from Vailulu'u: the deep dredges (71 and 72 from $4200 \mathrm{~m}$ and $3800 \mathrm{~m}$ deep, respectively) show water contents up to $1.50 \mathrm{wt} \%$, and the shallowest dredges $(63,68,70$, and 73 at or near $1000 \mathrm{~m})$ have water contents down to 0.63 wt $\%$. The low water in the shallow dredges is the result of degassing a water-rich vapor (fig. 
4a). Ta'u and Malumalu lavas all have high enough pressures of equilibration (fig. 4c) to precludeloss of significant water by open system degassing.

In summary, degassing has affected $\mathrm{CO}_{2}$ in all samples, and $\mathrm{H}_{2} \mathrm{O}$ only in the most shallowly-erupted samples from Vailulu'u. Additional support for minimal water loss is that fact that the most melt inclusions have water contents that are identical (within error) to their host matrix glasses, but with equal or higher $\mathrm{CO}_{2}$ (Tables 1 and 2; the one exception is a melt inclusion from sample 71-03, which has lower $\mathrm{CO}_{2}$ and $\mathrm{H}_{2} \mathrm{O}$ than its matrix glass). One melt inclusion from sample 72-12 shows the highest pressure of vapor saturation at 818 bars, indicating a minimum crystal fractionation depth of $1.6 \mathrm{~km}$ within the oceanic crust (3840 meters dredge depth plus 1600 meters igneous crust at a rock density of 2800 $\left.\mathrm{kg} / \mathrm{m}^{3}\right)$.

\subsection{Water and carbon dioxide in primary magmas}

After fractionation-correction (see section 4.1), we estimate primary magmas to have $\mathrm{H}_{2} \mathrm{O}$ in the range of $0.4-1.1 \mathrm{wt} \%$. Shallowly erupted Vailulu' u lavas are once again at the lower limit of this range, representing the greatest losses of water by both open- and closedsystem degassing.

Original $\mathrm{CO}$, concentrations in the primary magmas can be estimated using the observation that $\mathrm{CO}_{2} / \mathrm{Nb}$ ratios are roughly constant in volatile under-saturated MORB melt inclusions from the Siquieros Transform (Saal et al., 2002) - it is still highly uncertain whether or not this ratio applies to OIBs. Using fractionation-corrected $\mathrm{Nb}$ concentrations and $\mathrm{CO}_{2} / \mathrm{Nb}$ equal to 239 (Saal et al., 2002), $95 \%$ of the data suggest primary $\mathrm{CO}$, contents in the narrow range of 0.8 to $1.2 \mathrm{wt} \%$.

We have used the $\mathrm{H}_{2} \mathrm{O}-\mathrm{CO}_{2}$ degassing program by Newman and Lowenstern (2002) to estimate the maximum water loss from deep, open-system degassing, and find that a primary magma with $47 \mathrm{wt} \% \mathrm{SiO}_{2}$ and initial volatile content of $1.2 \mathrm{wt} \% \mathrm{H}_{2} \mathrm{O}$ and $1.0 \mathrm{wt} \%$ $\mathrm{CO}_{2}$ will still have $1.15 \mathrm{wt} \% \mathrm{H}_{2} \mathrm{O}$ after $\mathrm{CO}$, has degassed to $-10 \mathrm{ppm}$. This difference is within the analytical error for water and evidence that the observed water contents for all lavas except those from the shallow Vailulu'u dredges $(63,68,70$ and 73) are robust estimates of original abundances of water.

At the pMELTS-modeled fractionation pressures of 3-4 kbar, the data indicate that CO, is the only strongly oversaturated volatile component, as it is very insoluble in basaltic magmas (Stolper and Holloway, 1988; Dixon et al., 1995; Dixon, 1997). Carbonitite 
metasomatism has been documented in Samoan xenoliths (Hauri et al., 1993), and is further evidence for deep $\mathrm{CO}$, degassing.

\subsection{Fluorine}

Raw F contents range from 800 to 1890 ppm and are well correlated with incompatible trace elements including $\mathrm{P}, \mathrm{Na}, \mathrm{K}$ and Ti (fig. 5; Table 1). Fractionation-corrected values for $\mathrm{F}$ are 480 to $880 \mathrm{ppm}$ and closely overlap primitive Hawaiian melt inclusions that have $\mathbf{3 0 0}$ to $1000 \mathrm{ppm}$ F (Hauri, 2002). These values are similar to other plume related lavas, but are significantly higher than in MORBs (e.g. Schilling et al., 1980; fig. 5).

There are no resolvable differences in the relative enrichment of $\mathrm{F}$ between the different volcanoes or the different dredges; instead there is a constant F/Nd ratio of $21.7 \pm 2.6$ $(2 \sigma)$ across the whole sample suite, indicating F compatibility equal to that of Nd. Figure 5 shows that Samoa glasses, together with normal MORBs (PETBD database: http://beta.www.petdib.org), very 'depleted MORBs (from the Siquieros Transform; Saal et al., 2002; Saal et al., unpubl.) and Primitive Upper Mantle (McDonough and Sun, 1995), all fall along a F/Nd line of 21. 'Siquieros samples alone (Saal et al., 2002) show a mean F/Nd of $19.4 \mathrm{f} 2.6$ (lo), whereas all MORBs show $\mathrm{F} / \mathrm{Nd}=20.1 \pm 5.8$ (1o). Continental crust is also estimated to have a F/Nd ratio within this range (at 20.7; Wanke et al, 1984). To our knowledge, the only basalts that fall dramatically off this line are melt inclusions from the Austral Islands showing F/Nd ratios that are generally 60-70 (Lassiter et al., 2002). Elevated F may be a characteristic of the HIMU mantle end-member that is represented by lavas from the Austral island chain (Hauri and 1993). However, Vailulu'u glasses, which are thought to contain a small HIMU component (Workman et al., 2004), show no systematic elevation of $\mathrm{F}$.

\subsection{Sulfur}

Sulfur in the Samoan glasses ranges from 781 - 2651 ppm, consistent with other oceanic basalts (Wallace and Carmichael, 1992). As discussed above, most glasses are saturated with a sulfide phase, so have likely lost some $S$ by sulfide fractionation. Figure 6 shows the rough positive correlation between S/Dy and Mg\# of the whole suite of Samoan glasses (note that $S$ and Dy have been suggested to have similar compatibilities during mantle melting [Saal et al., 2002], so S/Dy should not change as a function of melting or olivine/clinopyroxene crystallization, but will decrease if sulfides are fractionated from a 


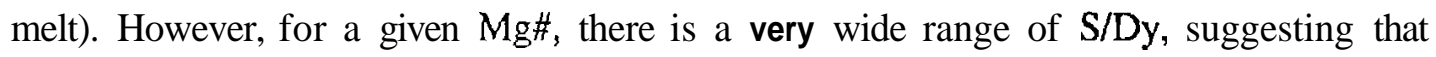
fractionation of sulfides may not be the only factor in controlling relative $S$ depletions.

At the FeO contents of Samoan glasses (10.5 - 14.2 wt\%), S concentrations are higher than they are in sulfide-saturated MORBs, possibly because Samoan lavas have higher oxygen fugacities (see Dixon, 1997; Dixon and Clague, 2001). Sulfide saturation is a complicated function of $\mathrm{fO}_{2}$, temperature, pressure and melt composition (e.g. Wallace and Carmichae], 1992), making further analysis of $S$ beyond the scope of this paper.

\subsection{Chorine}

Raw Cl contents of the Samoan glasses fall within the range of 451-1815 ppm (Table 1); fractionation-corrected values are 269-1412 ppm, similar to other plume related magmas (e.g. Dixon and Clague, 2001; Simons et al., 2002), but much greater than estimated parental MORBs (<100; Michael and Cornell, 1998). Glasses from Vailulu'u and dredge 76 from Malumalu have the highest $\mathrm{Cl}$, while Ta'u glasses fill the lower half of the whole range. $\mathrm{Cl}$ saturation in basaltic melts is greater than $\mathbf{2} \mathrm{wt} \%$ at these water contents (Webster et al., 1999), so we expect that there was no $\mathrm{Cl}$ degassing at any point in the evolution of the magmas. Curiously, of all the volatile and trace elements, $\mathbf{C l}$ is best correlated with $\mathbf{S}$ across the whole Samoan suite (fig. 7). There is no reason to expect these two elements to have either similar compatibilities or similar behavior in magmatic systems.

$\mathrm{Cl}$ concentrations are roughly correlated with other incompatible' elements for certain groups of dredges. Figure 8 shows one example of this with the relationship between $\mathrm{Cl}$ and $\mathbf{K}$ (the element most often used in assessing relative $\mathrm{Cl}$ enrichments; see below). The lowest $\mathrm{Cl} / \mathrm{K}$ ratios (-0.04) are found primarily in glasses from Ta'u and Malumalu (dredge 78), and the highest ratios are from a collection of Vailulu' $\mathrm{u}$ dredges that define a $\mathrm{Cl} / \mathrm{K}$ line of approximately 0.12. Two dredges, 73 and 76, fall "across-trend" in between these two groups of $\mathrm{Cl} / \mathrm{K}$. It is important to note that this layout is not unique to $\mathrm{Cl}$ and $\mathrm{K}$ concentration space, and instead looks very similar for $\mathrm{Cl}$ with almost all trace elements.

There is much precedent for interpreting high $\mathrm{Cl}$ concentrations in oceanic basalts as being the product of seawater assimilation (Michael and Cornell, 1998; Kent et al., 1999; Lassiter et al., 2002; Simons et al., 2002; Stroncik and Haase, 2004) due to very high concentrations of $\mathbf{C l}$ in seawater and especially in brines (Kent et al., 1999). A study by Michael and Cornell (1998) found that $\mathrm{Cl} / \mathrm{K}$ ratios in MORBs that are unaffected by seawater contamination range from $0.01-0.07$, with depleted MORBs at the low end and enriched MORBs at the high end of this range. Samoan glasses overlap with the MORB 
range and extend to higher $\mathrm{Cl} / \mathrm{K}$ (up to 0.15 ; fig. 8). The question is: how much of this Samoan signal is primary and how much is caused by assimilation? We address this question in the paragraphs below;

By omitting samples that fall along brine assimilation trends, Stroncik and Haase (2004) recently found $\mathrm{Cl} / \mathrm{K}$ ratios in OIBs to be a function of source signatures, as recognized by their correlation with $\mathrm{Sr}$ and $\mathrm{Pb}$ isotopic values. Enriched mantle (EM1 and EM2) lavas have low $\mathrm{Cl} / \mathrm{K}$ ratios (down to 0.02 ) and $\mathrm{HIMU}$ lavas have $\mathrm{Cl} / \mathrm{K}$ ratios up to 0.08 (Stroncik and Haase, 2004). Also, plume-influenced glasses from the Easter Seamount Chain, having $\mathrm{Cl}$ concentrations interpreted as primary based on good correlations between $\mathrm{CI}$ and La, show $\mathrm{Cl} / \mathrm{K}$ ratios from 0.05 up to 0.12 (Simons et al., 2002), similar to our Samoan glasses.

The relationship between $\mathrm{Cl} / \mathrm{K}$ and ${ }^{87} \mathrm{Sr} /{ }^{86} \mathrm{Sr}$ for Samoa is displayed in Figure 8. The most extreme EM2 lavas (Malumalu, dredge 78) at high ${ }^{87} \mathrm{Sr} /{ }^{86} \mathrm{Sr}$ have some of the lowest $\mathrm{Cl} / \mathrm{K}$. With decreasing ${ }^{87} \mathrm{Sr} /{ }^{86} \mathrm{Sr}, \mathrm{Cl} / \mathrm{K}$ ratios increase up to a maximum value of 0.15 in the Vailulu'u lavas (that have a small HIMU component; see background section above) and then drop to MORB-type values in Ta'u. This result is in general agreement with Stroncik and Haase (2004), despite our absolute $\mathrm{Cl} / \mathrm{K}$ and ${ }^{87} \mathrm{Sr} /{ }^{86} \mathrm{Sr}$ ranging to significantly higher values.

The minimum $\mathrm{Cl} / \mathrm{K}$ ratio from each volcano is -0.04 and could be taken as the primary composition for all of Samoan magmas before Cl contamination. However, enumerated below are reasons to believe that the $\mathrm{Cl}$ signal in Samoa is largely primary, with scatter caused by minimal assimilation:

1. There are correlations between high $\mathrm{Cl}$ and other trace elements that are not enriched in brines (for example, $\mathrm{Cl}$ and $\mathrm{Nb}$ show a similar relationship as do $\mathrm{Cl}$ and $\mathrm{K}$ in fig. 7). $\mathrm{A}$ $15 \%$ brine derived from seawater contains about 10 wt\% $\mathrm{Cl}$ (Kent et al., 1999), and it would take only $1 \%$ of this brine to elevate a magma's $\mathrm{Cl}$ content from 500 to $1500 \mathrm{ppm}$ (almost the full range in Samoa). With the same amount of brine, there would be a negligible effect on most other trace elements (including $\mathrm{K}$ ), yet we observe increased trace element concentrations with increased Cl. Also, Kent et al. (1999) claim that assimilated material is high in $\mathrm{B}$ as well as $\mathrm{Cl}$, but $\mathrm{B}$ is not elevated in high $\mathrm{Cl}$ Samoan glasses; in fact the highest $\mathrm{B}$ concentrations occur is glasses from dredge 78, which have some of the lowest $\mathrm{Cl}$ and lowest $\mathrm{Cl} / \mathrm{K}$ ratios.

2. Michael and Cornell (1998) clearly demonstrate that high levels of assimilation occur in lavas that are highly evolved. The opposite is observed for the Samoan glasses: the least evolved Vailulu'u samples (see fig. 2) show the highest $\mathrm{Cl}$ and $\mathrm{Cl} / \mathrm{K}$ ratios (fig. 8). 
3. The few melt inclusions we have analyzed (Table 2) have $\mathrm{Cl}$ contents usually within error of their host matrix glasses. However, this evidence alone may not prove the $\mathrm{Cl}$ is primary, since it is possible that $\mathrm{Cl}$ in the inclusions was assimilated at the depth of crystal fractionation.

4. There is a correlation between $\mathrm{Cl} / \mathrm{K}$ and ${ }^{87} \mathrm{Sr} /{ }^{86} \mathrm{Sr}$ (fig. 8), which in general mimics the observation of Stroncik and Haase (2004) that EM sources and depleted mantle have low $\mathrm{Cl} / \mathrm{K}$ while HIMU has higher $\mathrm{Cl} / \mathrm{K}$. However, Vailulu'u is in no way end-member HIMU, but instead is EM2 with a small component of HIMU.

5. Figure 7 indicates that high $\mathrm{Cl}$ magmas also have high $\mathrm{S}$, and no known assimilant contains $\mathrm{Cl}$ and $S$ in the required 1:1 ratio. Either high $\mathrm{Cl}$ is a primary feature of the lavas, or the correlation between $\mathrm{C}$ ] and $\mathrm{S}$ is coincidental.

A study on chlorine isotopes (e.g. Magenheim et al., 1995) might provide compelling evidence against an assimilation origin for the high $\mathrm{Cl}$, and ultimately may be the only way to define the proportion of igneous- to seawater-derived $\mathrm{Cl}$.

\section{Source Variations In Water Enrichment}

Since $\mathrm{CO}_{2}$ is severely degassed, $\mathrm{S}$ is subject to sulfide fractionation, $\mathrm{Cl}$ is sensitive to seawater contamination, and $\mathrm{F}$ abundances do not vary relative to trace element abundances, we focus our attention here on the source variations of water.

During mantle melting, the compatibility of water is similar to $\mathrm{Ce}$ and $\mathrm{La}$, as determined both observationally (e.g. Michael, 1995; Danyushevsky et al., 2000) and experimentally (Hauri et al., in revision). As such, ratios of $\mathrm{H}_{2} \mathrm{O} / \mathrm{Ce}$ and/or $\mathrm{H}_{2} \mathrm{O} / \mathrm{La}$ have been used as direct indicators of source compositions and the extent to which water is enriched or depleted. For example, low $\mathrm{H}_{2} \mathrm{O} / \mathrm{Ce}$ ratios in Loihi magmas (Dixon and Clague, 2001) and plumeinfluenced MORBs (Dixon et al., 2002) have been used to argue for the presence of recycled oceanic crust and sediment that had been efficiently dehydrated during subduction.

The relationship between $\mathrm{H}_{2} \mathrm{O} / \mathrm{La}$ and ${ }^{87} \mathrm{Sr} /{ }^{86} \mathrm{Sr}$ in Samoan basalts (fig. 9) extends the observation by Dixon et al. (2002) that enriched mantle sources have relative depletion of water (note that $\mathrm{H}_{2} \mathrm{O} / \mathrm{La}$ is used rather than $\mathrm{H}_{2} \mathrm{O} / \mathrm{Ce}$ since $\mathrm{H}_{2} \mathrm{O}$ and $\mathrm{La}$ are most similar in compatibility during melting of garnet lherzolite [Hauri et al., in revision]). The Samoan glasses have a wide range in ${ }^{87} \mathrm{Sr} /{ }^{86} \mathrm{Sr}(0.7045-0.7089)$ that is inversely correlated with $\mathrm{H}_{2} \mathrm{O} / \mathrm{La}$ (ranging from 120 to 316). Thehighest $\mathrm{H}_{2} \mathrm{O} / \mathrm{La}$ ratios in Samoa overlap with the low $\mathrm{H}_{2} \mathrm{O} / \mathrm{La}$ end of the plume-influenced Discovery lavas from the S. Atlantic (Dixon et al., 
2002). Otherwise, all Samoa glasses have much lower $\mathrm{H}_{2} \mathrm{O} / \mathrm{La}$ ratios than do average MORBs or average Loihi lavas (Dixon and Clague, 2001; Dixon et al., 2002). Ultimately, it seems that the greater the "enrichment" of the mantle (in terms of heavy isotopes and trace elements), the greater the apparent dehydration.

We do not believe that this relationship is an artifact of secondary processes in Samoan glasses. There is no coincidental correlation between ${ }^{87} \mathrm{Sr} /{ }^{86} \mathrm{Sr}$ and dredge depth (i.e. possible degassing). In the above section on water and carbon dioxide, we have shown that degassing has not resulted in significant water loss for any of the samples plotted in Figure 9. As supporting evidence, water contents in melt inclusions are equal to or less than the water contents in the glasses at equal or higher $\mathrm{CO}_{2}$ (Tables 1 and 2): The slightly higher water in some glasses may reflect a greater degree of fractionation of these melts - this is not confirmed since we lack major element compositions for the melt inclusions. For the sake of argument, if the water content in samples from dredge 78 was the same as the highest water in Samoa, then the $\mathrm{H}_{2} \mathrm{O} / \mathrm{La}$ ratio would be -200 (instead of 120) - still well below values for MORB, Loihi and Discovery. Finally, if water has been assimilated from seawater or brine, then the $\mathrm{H}_{2} \mathrm{O} / \mathrm{L}$ a ratios plotted in Figure 9 would be maximum values, and the signal we observe would be a dampened one; however, $\mathrm{H}_{2} \mathrm{O} / \mathrm{La}$ does not correlate with any potential "assimilation" proxies such as CUK.

\section{Origin Of EM2's "Dehydration"}

The origin of the EM2 mantle end-member is classically explained as the recycling of oceanic crust plus terrigeneous sediment through subduction zones (e.g. Weaver, 1991). However, our recent work on extreme EM2 lavas from Samoa (found at Malumalu, in particular) argues against simple mixing of a sedimentary component into depleted mantle based on trace element and isotopic trends in the Samoan lavas (see Workman et al. [2004] for detail). Instead, the origin of EM2 is explained as ancient $(2.5 \mathrm{Ga})$, recycled, metasomatized lower oceanic lithosphere; a small degree, upper mantle melt (like those imagined to be formed at depth beneath mid-ocean ridges or island arcs) impregnated a depleted lithosphere, then the material was subducted and stored in the mantle (Workman et al., 2004). This is simply one scenario that works to explain the observations in Samoa that the EM2 source has a trace element pattern more reflective of upper mantle magmatic fractionation processes than sedimentary compositions, but does not completely rule out a 
subduction-related origin for EM2 (in other words, we do not necessarily know where the metasomatism has taken place).

The above model for the formation of EM2 cannot account for the low $\mathrm{H}_{2} \mathrm{O} / \mathrm{La}$ ratios observed in the Samoan glasses since (non-arc) mantle melting cannot produce large fractionations of water from La owing to their similar compatibilities. In addition, since the model EM2 reservoir is created in the lower oceanic lithosphere, it will be isolated from the subduction zone dehydration processes affecting the crust/sediment package in the upper part of the subducted slab. However, the aging of EM2 can account for our observations. This is how: very fast diffusion of hydrogen in olivine (Mackwell and Kohlstedt, 1990) will cause recycled material with high initial water content to lose water to the drier ambient mantle during storage within the deep Earth.

Mackwell and Kohlstedt (1990) provide an Arrhenius equation for the temperature dependence of hydrogen diffusion in olivine; this leads to a diffusion coefficient of $8.9 \times 10^{-}$ ${ }^{9} \mathrm{~m}^{2} / \mathrm{s}$ at $1500^{\circ} \mathrm{C}$, for the fast [100] direction. Using a constant temperature of $1500^{\circ} \mathrm{C}$, in $2.5 \mathrm{Ga}$ (the estimated age of EM2), a $26 \mathrm{~km}$ thick slab can be fully equilibrated with the ambient mantle using the approximation that equilibrated distance, $x=\sqrt{\text { (diffusion }}$ coefficient $\times$ time). At an assumed upwelling rate of $1 \mathrm{~cm} / \mathrm{yr}$, water abundance can be fully equilibrated over $4 \mathrm{krn}$ with the surrounding mantle during convective transport through the upper mantle $(660 \mathrm{~km})$ alone. Since much of the mantle is at temperatures higher than $1500^{\circ} \mathrm{C}$, these are conservative estimates; the effects of enhanced diffusion through grain boundaries will also serve to aid equilibration. It is unknown whether or not similar diffusion rates for hydrogen apply to other major mantle minerals. If helium can be used as an analogue for $\mathrm{H}$, at $1500^{\circ} \mathrm{C}$, He diffusion in clinopyroxene and garnet is equal or faster than that in olivine (Trull et al., 1991; Dunai and Roselieb, 1996). In contrast to moter, most other elements will have much smaller equilibration distances; for example, rare-earthelement diffusion rates at the same temperature results in the full equilibration of less than 10 meters in 4 billion years (Hofrnann and 1978; Van Orman et al., 2001). As a result, the enhanced solid-state mobility of hydrogen in the mantle can potentially shift the $\mathrm{H}_{2} \mathrm{O} / \mathrm{La}$ ratio in the absence of any melting or mantle-fluid interactions.

Figure 10 is a conceptual diagram for the diffusive equilibration of water during the recycling and storage of EM2. Workman et al. (2004) give an estimate for the trace element composition of EM2: $\mathrm{La}=0.895, \mathrm{Ce}=1.923$, and if $\mathrm{H}_{2} \mathrm{O} / \mathrm{Ce}$ was initially like the common mantle, FOZO (i.e. 200; Dixon et al., 2002), then the starting $\mathrm{H}_{2} \mathrm{O}$ content of EM2 would be $385 \mathrm{ppm}$. The Depleted MORB Mantle (DMM) is estimated to contain 0.19 ppm La and 
0.55 ppm Ce (Workman and Hart, 2005). At an $\mathrm{H}_{2} \mathrm{O} / \mathrm{Ce}$ ratio of 150 (Dixon et al., 2002), $\mathrm{H}_{2} \mathrm{O}$ in DMM $=82.5 \mathrm{ppm}$, less than $25 \%$ that of EM2. Assuming all reservoirs here are peridotite lithologies, when "wet" EM2 is introduced to "dry" depleted mantle, water will diffuse out of EM2 and into the "infinite sink" of ambient depleted mantle until their water activites are equal (at DMM $=82.5 \mathrm{ppm}$ ). When EM2 equilibrates with the depleted mantle and the two components have the same water content, the resulting $\mathrm{H}_{2} \mathrm{O} / \mathrm{Ce}$ 'is 43 and $\mathrm{H}_{2} \mathrm{O} / \mathrm{La}$ is 92 in the EM2 component; these values are nearly identical to the values seen in the high ${ }^{87} \mathrm{Sr} /{ }^{86} \mathrm{Sr}$ glasses from Malumalu (see fig. 9 for $\mathrm{H}_{2} \mathrm{O} / \mathrm{La}$ ). Less-enriched sources, lying initially between EM2 and DMM along a $\mathrm{H}_{2} \mathrm{O} / \mathrm{La}=500$ line, will lose water when recycled to the mantle until they reach the $82.5 \mathrm{ppm}$ water line. Thus, in aged sources, $\mathrm{H}_{2} \mathrm{O} / \mathrm{La}$ increases as the degree of enrichment decreases. This analysis shows that the observed differences in $\mathrm{H}_{2} \mathrm{O} / \mathrm{La}$ ratios in these mantle sources are not the result of different water contents, but instead are due to differences in REE enrichment at similar water contents.

The above discussion is focused on dehydration of enriched reservoirs, but the same thinking will apply to re-hydration of dry mantle reservoirs. If subducted material becomes extensively dehydrated (e.g. as called upon by Dixon et al. [2002]), storage within the mantle will result in a re-hydration of the slab until the slab and mantle are in chemical equilibrium in terms of water content. This is a nearly unavoidable consequence of recycling, unless slab temperatures stay very cold (much less than $1500^{\circ} \mathrm{C}$ ) or recycling times are very rapid ( $<50$ million years).

\section{Discussion}

Volatile and trace element abundances for nearly 100 submarine basaltic glasses from the three youngest Samoan volcanoes have been presented here. We have found that water abundance relative to trace element abundance correlates inversely with source enrichment. This leads us to believe that, because of very fast diffusion of hydrogen in olivine (Mackwell and Kohlstedt, 1990), recycled material with high initial water content will lose water to the drier ambient mantle during storage within the Earth. However, this is a somewhat incomplete picture since 1) the greatest budget of water in an upper mantle peridotite is not contained in olivine, but in clinopyroxene and orthopyroxene (Hirth and Kohlstedt, 1996; Hauri et al., in revision) and 2) other lithologies (especially pyroxenites, 
with little olivine) may be present in the mantle as subducted oceanic crust (e.g. Hirschmann and Stolper, 1996).

The water content of EM2 is estimated to be close to that of the upper mante $(-100$ ppm), and differences in the $\mathrm{H}_{2} \mathrm{O} / \mathrm{La}$ ratio of Samoan mantle components are due to local diffusive homogenization of their water contents during long-term storage in the mantle. Therefore, the differences in water concentrations between Samoan lavas and MORBs are more a difference in degree of melting than source composition. $\mathrm{La}, \mathrm{H}_{2} \mathrm{O}$ and $\mathrm{Ce}$ are enriched in Samoan lavas about 60-fold over their estimated EM2 source concentrations, requiring a degree of melting on the order of $1 \%$ (with $D_{\mathcal{C}_{c} \text {, waier }}=0.01$ and aggregated fractional melting). This contrasts with an estimated degree of melting at 6-7\% to generate MORB liquids from the upper mantle (Workman and lat, 2005).

If the diffusion rates of hydrogen in other mantle minerals are similar to olivine, water may be one of the only elements whose abundance is nearly constant over great distances in the mantle, assuming similar source lithologies. This "diffusive dehydration" model has important implications for the interpretation of mantle $\mathrm{H}_{2} \mathrm{O} / \mathrm{La}$ and $\mathrm{H}_{2} \mathrm{O} / \mathrm{Ce}$ ratios. Whether or not subducted materials have higher or lower $\mathrm{H}_{2} \mathrm{O} / \mathrm{La}$ than the upper mantle, slabs and mantle wedge material stored in the deep Earth for significant periods of time will experience temperature-dependent diffusive mobility of hydrogen and will likely lose hydrogen to the ambient mantle.

The direction of diffusive hydrogen transport will depend not on the $\mathrm{H}_{2} \mathrm{O} / \mathrm{La}$ ratio but on the bulk $\mathrm{H}_{2} \mathrm{O}$ contents of juxtaposed mantle sources. Indeed, subducted oceanic crust and sediment could enter the deep mantle with a low $\mathrm{H}_{2} \mathrm{O} / \mathrm{La}$ atio but a bulk $\mathrm{H}_{2} \mathrm{O}$ content that is still higher than the surrounding mantle, and thereby lose even more water via "diffusive dehydration". Alternatively, if dehydration and melting are extremely efficient in subduction zones, then recycled material may enter the deep mantle extremely dry, and become re-hydrated via diffusive exchange with the surrounding mantle. Either way, an evaluation of the absolute abundance of water in mantle sources requires more than simply knowing the ratio of $\mathrm{H}_{2} \mathrm{O}$ to $\mathrm{REE}$ in derivative lavas. Robust estimates of lithophile element concentrations, from accurate inversion of complete major element, trace element and isotopic data, must be the starting point for investigating the variability of water in the mantle in any tectonic setting. 


\section{Acknowledgements}

Many thanks go to Mark Kurz for allowing us to raid his collection of glasses he diligently collected during the 1999 cruise of the R/ Melville. During the preparation of this manuscript, discussions with Jackie Dixon, Nobu Shimizu, Alberto Saal, Glenn Gaetani and Jeff Standish were very helpful and much appreciated. DTM's hospitality during their $100^{\text {th }}$ year anniversary made a two-week session of data collection an especially enjoyable experience. 


\section{References}

Asimow, P. D. and C. H. Langmuir, The importance of water to oceanic mantle melting regimes, Nature, 421, 815-820,2003.

Campbell, I.H. and R.W. Griffiths, Implications of mantle plume structure for the evolution of flood basalts, Earth Planet. Sci. Lett., 99, 79-83,1990.

Danyushevsky, L.V., S.M. Eggins, T.J. Faloon, and D.M. Christie, $\mathrm{H}_{2} \mathrm{O}$ Abundance in Depleted to Moderately Enriched Mid-ocean Ridge Magmas; Part I: Incompatible Behaviour, Implications for Mantle Storage, and Origin of Regional Variations, J. Petrology, 41 (8), 1329-1364, 2000.

Dixon, J.E., Degassing of alkalic basalts, Am. Minerologist, 82,368-378, 1997.

Dixon, J.E., E.M. Stolper, and J. Holloway, An Experimental Study of Water and Carbon Dioxide Solubilities in Mid-Ocean Ridge Basaltic Liquids. Part I: Calibration and Solubility models, J. Petrology, 36 (6), 1607-1631,1995.

Dixon, J.E., D.A. Clague, P. Wallace, and R. Poreda, Volatiles in Alkalic Basalts from the North Arch Volcanic Field, Hawaii: Extensive Degassing of Deep Submarine-erupted Alkalic Series Lavas, J. Petrology, 38 (7), 911-939,1997.

Dixon, J.E., and D.A. Clague, Volatiles in Basaltic Glasses from Loihi Seamount, Hawaii: Evidence for a relatively dry plume component, J. Petrology, 42 (3), 627-654, 2001.

Dixon, J.E., L. Leist, C. Langmuir, and J.-G. Schilling, Recycled dehydrated lithosphere observed in plume-influenced mid-ocean-ridge basalts, Nature, 420,385-389,2002.

Dunai, T.J. and K. Roselieb, Sorption and diffusion of helium in garnet: implications for volatile tracing and dating, Earth Planet. Sci. Lett., 139, 41 1-421, 1996.

Farley, K. A., Natland, J.H., and Craig, H., Binary mixing of enriched and undegassed (primitive?) mantle components (He, $\mathrm{Sr}, \mathrm{Nd}, \mathrm{Pb})$ in Samoan lavas, Earth Planet. Sci. Len., 111,183-199,1992.

Ghiorso, M. S., Hirschmann, M.M., Reiners, P.W., and Kress, V.C. II, The pMELTS: A revision of MELTS for improved calculation of phase relations and major element partitioning related to partial melting of the mantle to $3 \mathrm{GPa}$, Geochemistry, Geophysics, Geosystems, 3(5), 10.102912001GC000217, 2002.

Green, D.H. and T.J. Falloon, Pyrolite: A Ringwood concept and its current expression, in: The Earth's Mantle: Composition, Structure and Evolution, ed., I.N.S. Jackson, Cambridge University Press, Cambridge, 311-378,1998. 
Hart, S. R., Staudigel, H., Koppers, A.A.P.,Blusztajn, J., Baker, E.T., Workman, R., Jackson, M., Hauri, E., Kurz, M., Sims, K., Fornari, D., Saal, A., and Lyons, S., Vailulu'u undersea volcano: The New Samoa, Geochemistry, Geophysics, Geosystems, 1, 2000GC000108, 2000.

Hart, S. R., H. Staudigel, R. Workman, A.A.P. Koppers, A.P. Girard, A fluorescein tracer release experiment in the hydrothermally active crater of Vailulu'u Volcano, Samoa, $\mathbf{J}$. Geophysical Research, v. 108, n. B8, 2377, 2003.

Hart, S.R., M. Coetzee, R.K. Workman, J. Blusztajn, K.T.M. Johnson, J.M. Sinton, J.W. Hawkins, Genesis of the Western Samoa Seamount Province: Age, Geochemical Fingerprint and Tectonics, Earth and Planet. Sci. Letters, 227, 37-56, 2004a.

Hart, S. R., L. Ball and M. Jackson, Sr Isotopes by Laser Ablation PIMMS: Application to Cpx from Samoan Peridotite Xenoliths, WHOI Plasma Facility Open File Report 11, available at: http://wrww.whoi.edu/science/GG/people/shart/open file.htm, 2004b.

Hauri, E. H., and Hart, S.R., Re-Os isotope systematics of HIMU and EMII oceanic island basalts from the south Pacific Ocean, Earth Planet. Sci. Lett., 114, 353-371, 1993.

Hauri,E. H., Shimizu, N., Dieu, J.J., and Hart, S.R, Evidence for hotspot-related carbonatite metasomatism in the oceanic upper mantle, Nature, 365,221-227, 1993.

Hauri, E.H., T.P. Wagner, T.L. Grove, Experimental and natural partitioning of Th, U, Pb and other trace elements between garnet, clinopyroxene and basaltic melts, Chemical Geology, 117, 149-166, 1994.

Hauri, E.H., J. Wang, J.E. Dixon, P.L. King, C. Mandeville, and S. Newman, SIMS analysis of volatile in silicate glasses, 1: Calibration, matrix effect and comparisons with FTIR, Chemical Geology, 183, 99-114,2002.

Hauri, E.H., SIMS analysis of volatile in silicate glasses, 2: isotopes and abundances in Hawaiian melt inclusions, Chemical Geology, 183, 115-141,2002.

Hauri, E.H., G.A. Gaetani, and T.H. Green, Partitioning of water during melting of the upper sources of oceanic basalts, Nature, in revision, 2005.

Hirschmann, M.M. and E.M. Stolper, A possible role for garnet pyroxenite in the origin of the "garnet signature" in MORB, Contrib. Mineral. Pet., 124 (2), 185-208, 1996.

Hirth, G. and D.L. Kohlstedt, Water in the oceanic upper mantle: implications for rheology, melt extraction, and the evolution of the lithosphere, Earth and Planet. Sci. Len., 144, 93-108, 1996.

Hirth, $\boldsymbol{G}$. and D.L. Kohlstedt, Rheology of the Upper Mantle and the Mantle Wedge: A View from the Experimentalists, In: Inside the Subduction Factory, Ed. I. Eiler, AGU 
Monograph 138,2003.

Hofmann, A.W., Chemical differentiation of the Earth: the relationship between mantle, continental crust and oceanic crust, Earth Planet. Sci. Lett., 90,297-314, 1988.

Hofmann, A. and S. R. Hart, An assessment of local and regional isotopic equilibrium in the mantle, Earth Planet. Sci. Lett., 38, 44-62, 1978.

Keating, B. H., The geology of the Samoan Islands. In: Geology and offshore mineral resources of the Central Pacific basin, eds. B. H. Keating and B. R. Bolton, Circumpacific Council for Energy and Mineral Resources Earth Science Series, 14, 127-178, 1992.

Kenf A.J.R., M.C.Norman, I.D. Hutcheon, and E.M. Stolper, Assimilation of seawaterderived components in an oceanic volcano: evidence from matrix glasses and glass inclusions from Loihi seamount, Hawaii, Chemical Geology, 156,299-319,1999.

Klemme, S. and H. O'Neill, The near-solidus transition from garnet to spinel lherzolite, Contrib. Min. Pet., 138,237-248,2000.

Kogiso, T., K. Hirose and E. Takahashi, Melting experiments on homogeneous mixtures of peridotite and basalt: application to the genesis of ocean island basalts, Earth Planet. Sci. Lett., 162, 45-61, 1998.

Konter, J. G., H. Staudigel, S. R. Hart and P. M. Shearer, Seafloor seismic monitoring of an Active Submarine Volcano: Local Seismicity at Vailulu’u Seamount, Samoa, Geochem., Geophys., Geosyst., 5, 2004GC000702, 2004.

Lassiter, J.C., E.H. Hauri, I.K. Nikogosian, and H.G. Barsczus, Chlorine-potassium variations in mlet inclusions from Raivavae and Rapa, Austral Islands: constraints on chlorine recycling in the mantle and evidence for brine-induced melting of oceanic crust, Earth Planet. Sci. Len., 202,525-540,2002.

Li, X., R. Kind, X. Yuan, I. Wolbern, and W. Hanka, Rejuvenation of the lithosphere by the Hawaiian plume, Nature, 427,827-829,2004.

Mackwell,S.J., and Kohlstedt, Diffusion of Hydrogen in Olivine: Implication for Water in the Mantle, J. Geophys. Res., 95 (B4), 5079-5088,1990.

Magenheim, A.J., A.J. Spivack, P.J. Michael and J.M. Gieskes, Chlorine stable isotope composition of the oceanic crust: Implication for Earth's distribution of chlorine, Earth Planet. Sci. Len., 131,427-432, 1995.

McDonough, W. F. and S.-s. Sun, The composition of the Earth, Chemical Geology, 120, 223-253,1995.

McDougall, I., Age and Evolution of the Volcanoes of Tutuila, American Samoa, Pacific 
Science, 39, 311-320, 1985.

Michael, P., Regionally distinctive sources of depleted MORB: Evidence from trace elements and $\mathrm{H}_{2} \mathrm{O}$, Earth Planet. Sci. Lett., 131, 301-320, 1995.

Michael, P. and W.C. Cornell, Influence of spreading rate and magma supply on crystallization and assimilation beneath mid-ocean ridges: Evidence from chlorine and major element chemistry of mid-ocean ridge basalts, J. of Geophys. Res., 103 (B8), 18,325-18,356, 1998.'

Montelli, R., G. Nolet, F.A. Dahlen, G. Masters, E.R. Engdahl, S-H. Hung, FiniteFrequency Tomography Reveals a Variety of Plumes in the Mantle, Science, 10.1126/science.1092485,2003.

Morgan, W.J., Convection plumes in the lower mantle, Nature, 230, 42-43, 1971.

Newman, S., E. Stolper, and R. Stern, $\mathrm{H}_{2} \mathrm{O}$ and $\mathrm{CO}$, in magmas from the Mariana arc and back arc system, Geochem., Ceophys., Geosyst., 1, 30.102911999GC000027, 2000.

Newman, $S$. and J.B. Lowenstern, VolatileCalc: a silicate melt- $\mathrm{H}_{2} \mathrm{O}-\mathrm{CO}_{2}$ solution model written in visual basic for excel, Computers and Geosciences, 28, 597-604, 2002.

Robinson, J.A.C. and B.J. Wood, The depth of the spinel to garnet transition at the peridotite solidus, Earth Planet. Sci. Lett., 164,277-284, 1998.

Saal., AE., E.H. Hauri, C.H. Langmuir, and M.R. Perif, Vapor undersaturation in primitive mid-ocean-ridge basalt and the volatile content of Earth's upper mantle, Nature, 419, 451-455,2002.

Salters, V. J. M., Longhi, J.E., and Bizimis, M., Near mantle solidus trace element partitioning at pressures up to $3.4 \mathrm{GPa}$, Geochem., Geophys., Geosyst., 3(7), 10.1029/2001GC000148,2002.

Schilling, J.-G., M.B. Bergeron, and M.B. Evans, Halogens in the mantle beneath the North Atlantic, Philos. Trans. Royal Soc. London, Ser. A 297, 147-178, 1980.

Simons, K., J. Dixon, J.-G. Schilling, R. Kingsley, and R. Poreda, Volatile in basaltic glasses from the Easter-Salas y Gomez Seamount Chain and Easter Microplate: Implications for geochemical recycling of volatile elements, Geochem., Geophys.., Geosyst., 3(7), 10.1029/2001GC000173,2002.

Sims, K.W.W. and S.R. Th, Th, Nd, $\mathrm{Sr}$ and $\mathrm{Pb}$ isotopes in Samoan lavas: Implications for mantle heterogeneity,Eos. Trans. AGU, 85(47), Fall Meeting Suppl., Abstract V53A$0608,2004$.

Sleep, N.H., Hotspots and mantle plumes: Some phenomenology,J. Geophys, Res., 95, 6715-6736,1990. 
Staudigel, H., S.R. Hart, A.A.P. Koppers, C. Constable, R. Workman, M.D. Kurz, E.T. Baker, Hydrothermal Venting at Vailulu'u Seamount: The Smoking End of the Samoan Chain, Geochem. Geophys. Geosyst., 5, Q02003, 10.1029/2003GC000626, 2004.

Stolper, E.M., and J.R. Holloway, Experimental determination of the solubility of carbon dioxide in molten basalt at low pressure, Earth and Planet. Sci. Len., 87,397-408, 1988.

Stroncik, N.A. and K.M. Haase, Chlorine in oceanic intraplate basalts: Constraints on mantle sources and recycling processes, Geology, 32(11), 945-948,2004.

Su, W., R.L. Woodward and A.M. Dziewonski, Degree 12 model of shear velocity heterogeneity in the mantle, J. Geophys, Res., 99,6945-6980,1994.

Taras, B.D., and S.R. Hart, Geochemical evolution of the New England seamount chain: isotopic and trace-element constraints, Chemical Geology, 64, 35-54, 1987.

Trull, T.W., M.D. Kurz and W.J. Jenkins, diffusion of cosmogenic ${ }^{3} \mathrm{He}$ in olivine and quartz: implications for exposure age dating, Earth Planet. Sci. Lett., 103,241-256, 1991.

Van Orman J.A., T.L. Grove and N. Shimizu, Rare earth element diffusion in diopside: Influence of temperature, pressure and ionic radius, and an elastic model for diffusion in silicates, Contrib. Min. and Pel., 141, 687-703, 2001.

Wallace, P., and I.S.E. Carmichael, Sulfur in basaltic magmas, Geochim. et Cosmochim. Acta, 56, 1863-1874,1992.

Wänke, H., G. Dreibus, and E. Jagoutz, Mantle chemistry and accretion of the Earth, in Archean Geochemistry, eds. A. Kroner, G.N. Hanson, and A.M. Goodwin, SpringerVerlag, Berlin, pp. 1-24, 1984.

Webster, J.D., R.J. Kinzler, and E.A. Mathez, Chloride and water solubility in basalt and andesite melts and implications for magmatic degassing, Geochim. et Cosmochim. Acta, 63(5), 729-738, 1999.

Weaver, B. L., The origin of ocean island basalt end-member compositions: trace element and isotopic constraints, Earth Planet. Sci. Lett., 104, 381-397, 1991.

Workman, R.K., S.R. Hart, M. Jackson, M. Regelous, K. Farley, J. Blusztajn, M. Kurz, and H. Staudigel, Recycled Metasomatized Lithosphere as the Origin of the Enriched Mantle II (EM2) End-member: Evidence from the Samoan Volcanic Chain, Geochem. Geophys. Geosyst., 5, Q04008, doi:10.1029/2003GC000623, 2004.

Workman, R.K. and S.R. Hart, Major and Trace Element Composition of the Depleted MORB Mantle (DMM) , Earth and Planet. Sci. Letters, 231, 53-72, 2005.

Wright, E., and White, W.M., The origin of Samoa: new evidence from $\mathrm{Sr}, \mathrm{Nd}$, and $\mathrm{Pb}$ 
isotopes, Earth Planet. Sci. Len., 81, 151-162,1986187.

Zindler, A., and Hart, S.R.,Chemical Geodynamics, Annual Rev. Earth and Planet. Sci., 14, 493-571,1986. 


\section{Figures}

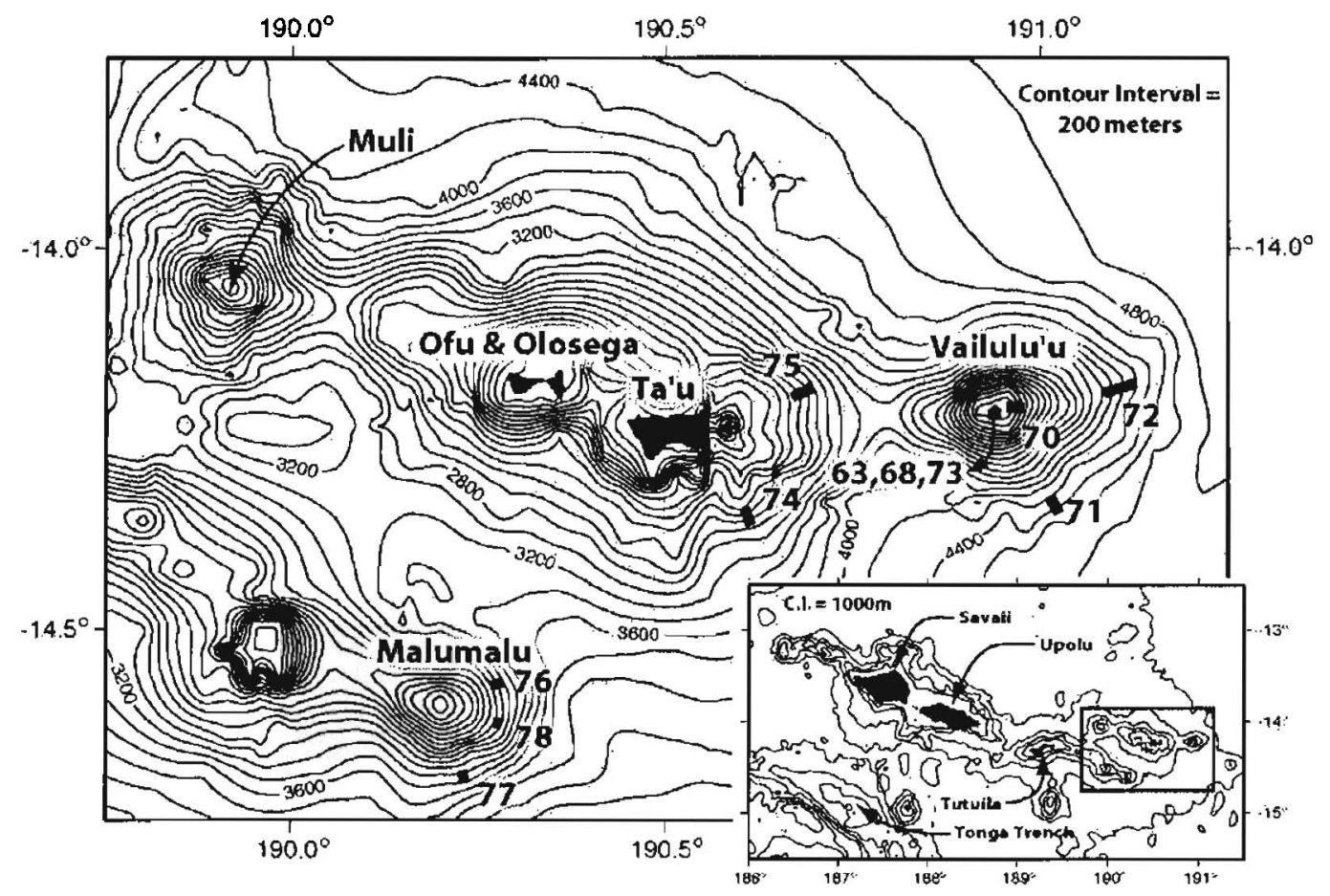

Figure 4-1. Location map for Samoan glasses. Thick lines with adjacent numbers mark individual dredges; note that some dredges traverse more contours than others. Depth contours are plotted using AVON 2/3 shipboard bathymetry data. Inset shows greater Samoan region, including the northernmost extent of the Tonga Trench. 


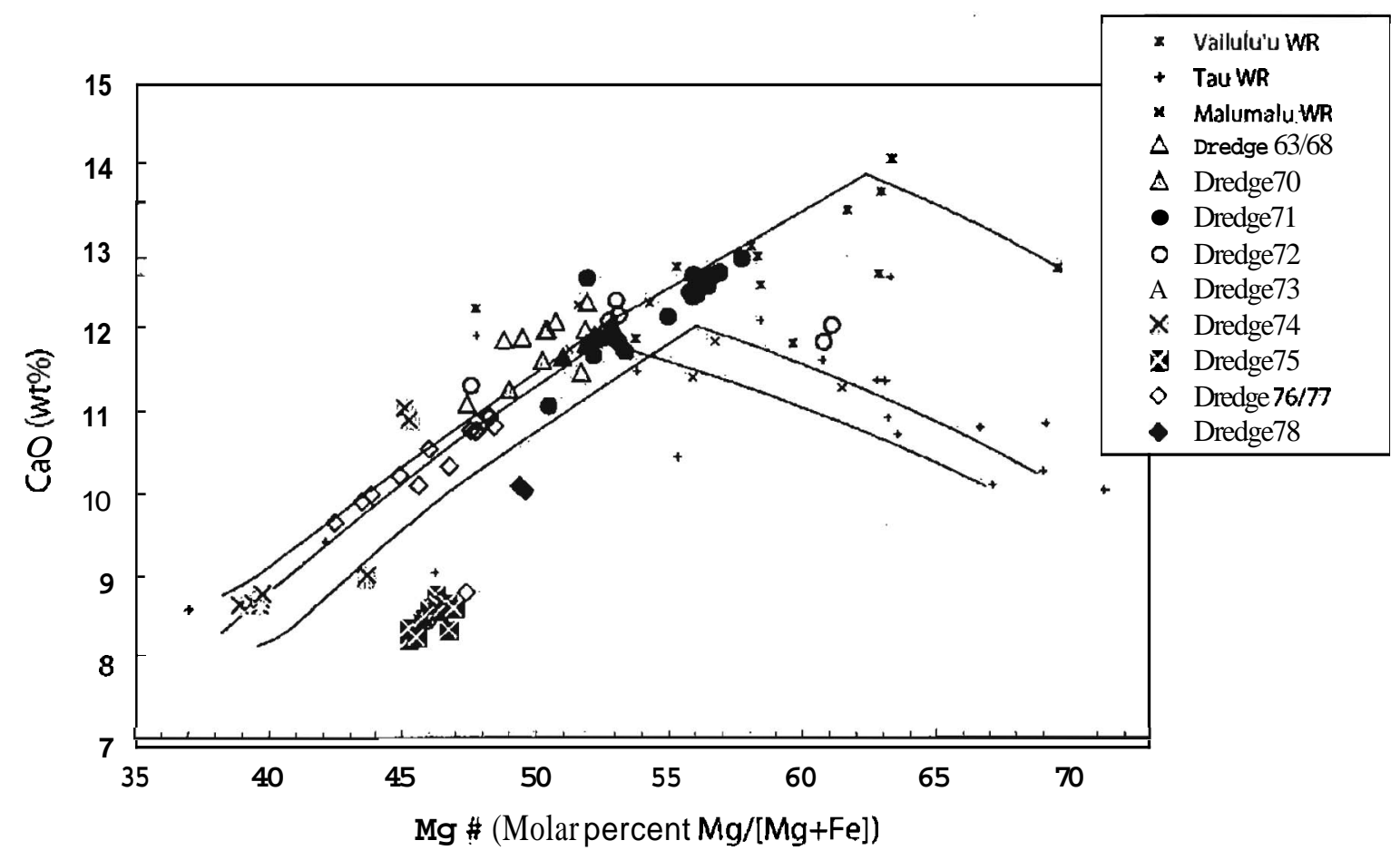

Figure 4-2. CaO plotted with Mg\# for Samoan whole rocks (Workman et al., 2004) and glasses (this study). Crystal fractionation trends plotted here have been calculated using pMELTS predicted liquid lines of decent (Ghiorso et al., 2002), starting with some of the most primitive whole rock compositions. Best fits to the observed glass compositional trends are from pMELTS anhydrous runs at pressures of 3-4 kbar. Runs with 1 wt \% water are nearly identical to those plotted here, but with 1 kbar higher pressure. 


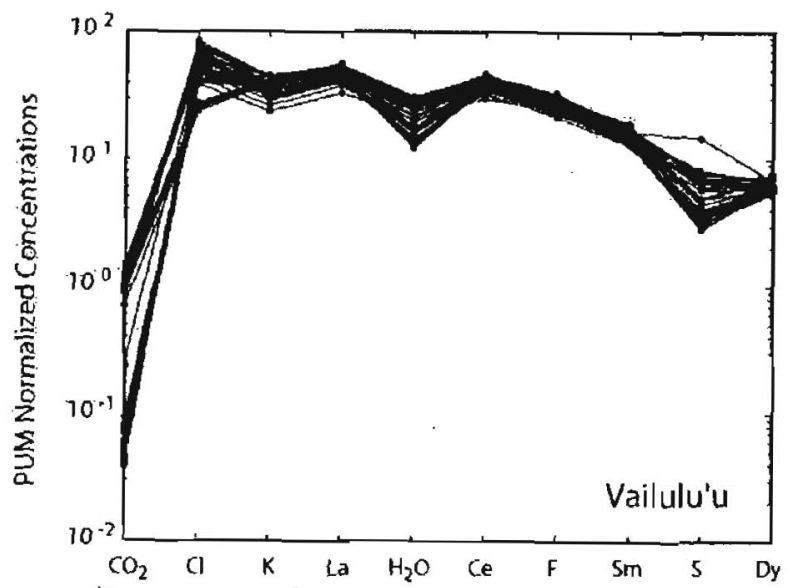

Figure 4-3. Fractionationcorrected trace and volatile element concentrations, listed in the order of increasing compatibility during mantle melting. Values are normalized to Primitive Upper Mantle (PUM) of McDonough and Sun (1995), except for water (at 335 ppm assuming $\mathrm{H}_{2} \mathrm{O} / \mathrm{Ce}=200$ ) and carbon dioxide (at $157 \mathrm{ppm}$ assuming $\mathrm{CO}_{2} / \mathrm{Nb}=\mathbf{2 3 9}$ [Saal et al., 20021).
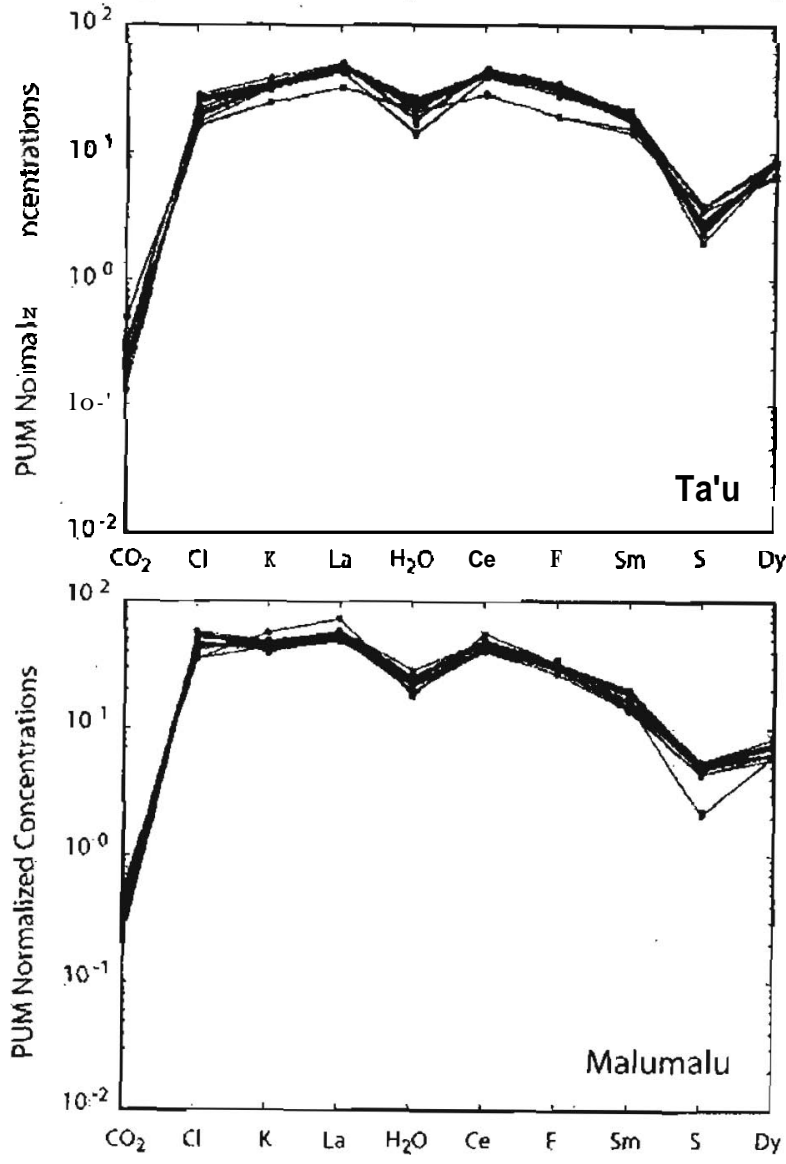

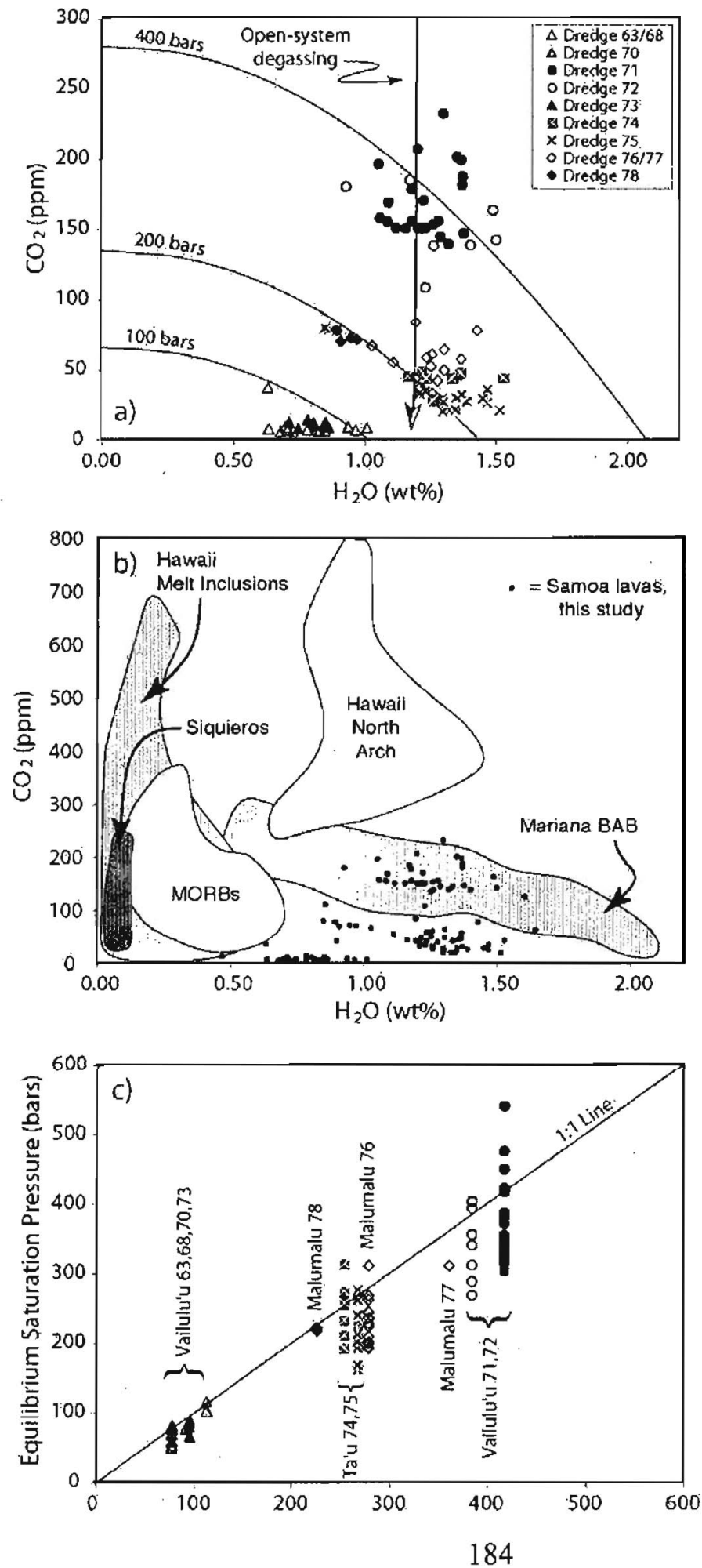

Figure 4-4. Panel a) shows water and carbon dioxide contents of Samoan glasses plotted with equilibrium vapor saturation curves and degassing trends of Dixon (1997); because opensystem degassing trends are nearly vertical on this diagram, we expect that water loss has been negligible for all glasses except those at pressures less than 100 bars. Panel b) compares $\mathrm{H}_{2} \mathrm{O}$ and $\mathrm{CO}_{2}$ contents of Samoan glasses from this study to magmas in other settings. Panel c) plots average dredge depths for individual dredges with calculated saturation pressures (Dixon, 1997) for each sample; most lavas lie near the $1: 1$ line, so 1) are saturated with an $\mathrm{H}_{2} \mathrm{O}-\mathrm{CO}_{2}$ vapor and 2) did not flow downhill from shallower extrusion depths. Each dredge traverses multiple deptb contours (up to 800 meters; see fig. 1), so there is some ambiguity about the exact collection depth. 


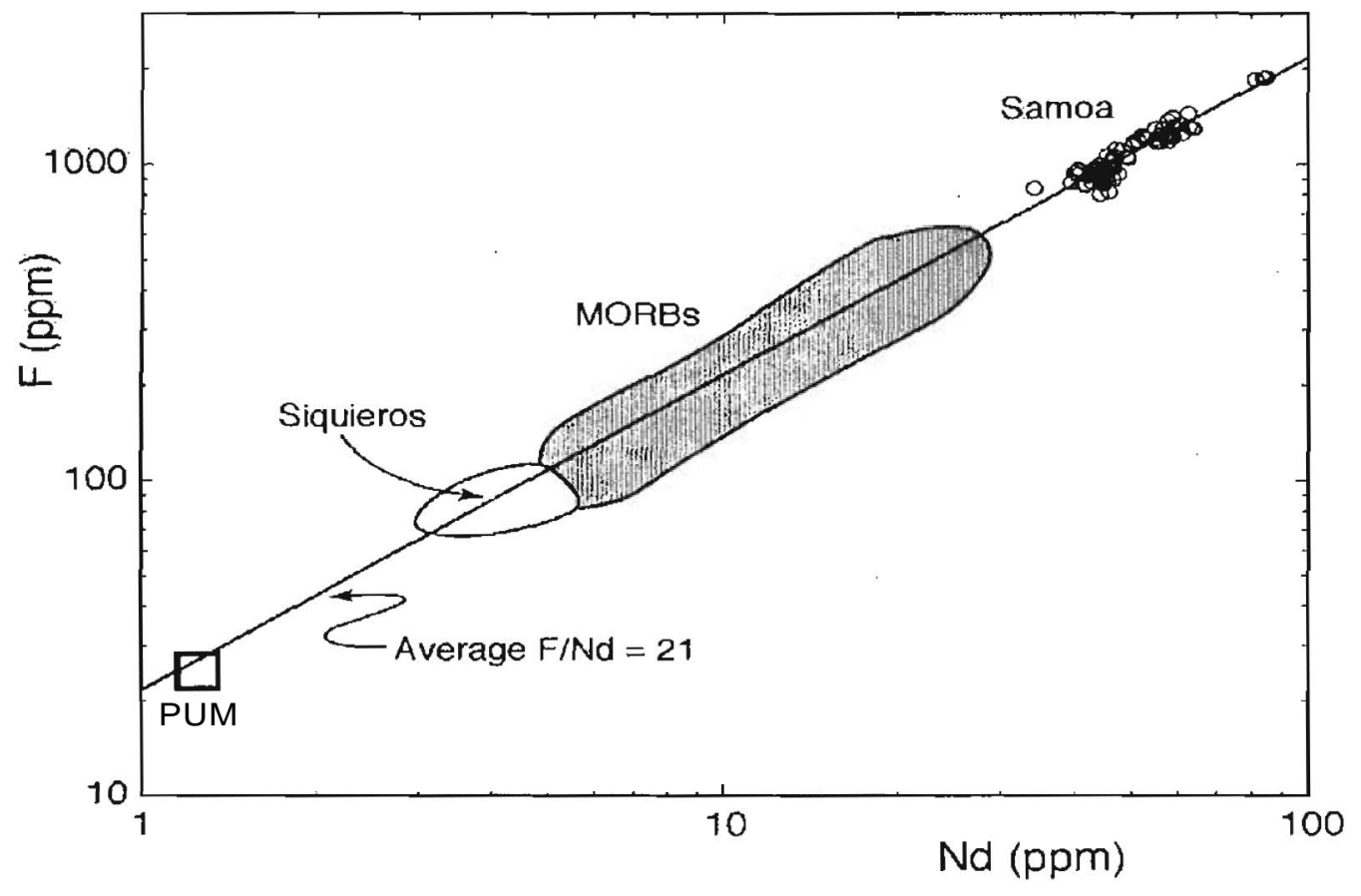

Figure 4-5. Plot of Nd and F concentrations in Samoan glasses from this study, normal MORBs (from the PETBD online database: http://beta.www.petdb.org/), very depleted MORBs (Saal et al., 2002; Saal et al., unpubl.) and Primitive Upper Mantle (McDonough and Sun, 1995). Collectively these oceanic lavas define a constant $F / N d$ ratio of 21 , showing that $F$ has a compatibility equal to $\mathrm{Nd}$ during upper mantle melting. 


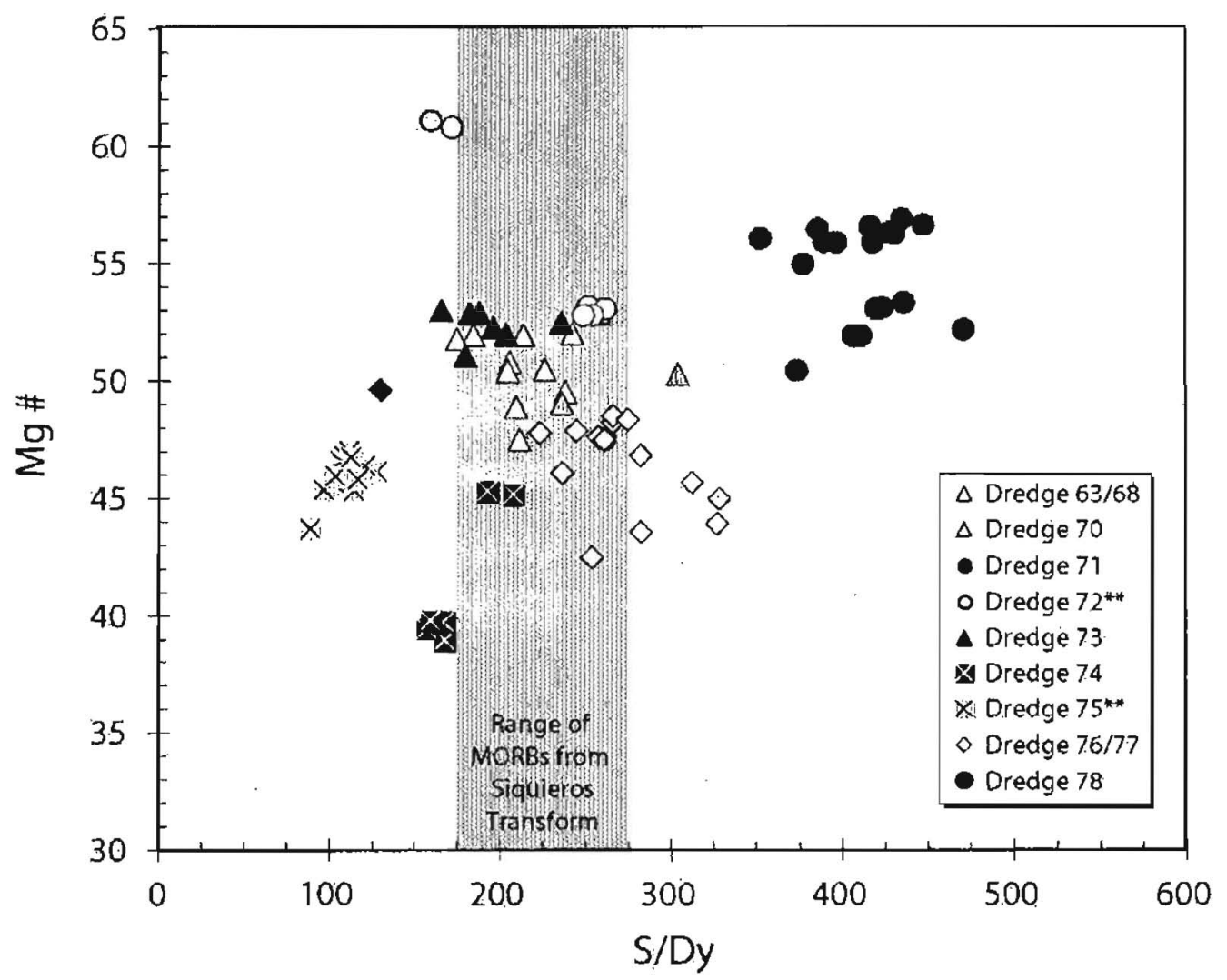

Figure 4-6. Plot of S/Dy with Mg\# of the Samoan glasses. $\mathrm{Mg \#}=$ molar percent $\mathrm{Mg} /(\mathrm{Mg}+0.85 \mathrm{Fe}) . \mathrm{S}$ has been suggested to have similar compatibility to Dy, so S/Dy ratios of melts should be similar to that of their source as long there has been no sulfide fractionation or $\mathrm{SO}_{2}$ degassing. Since sulfides were observed in all dredges except those marked with ${ }^{* *}$, and there is a rough positive correlation between S/Dy (as well any $\mathrm{S} / \mathrm{REE}$ ratio) and $\mathrm{MgH}$; we interpret these lavas to have lost some of their initial sulfur content by sulfide fractionation. 


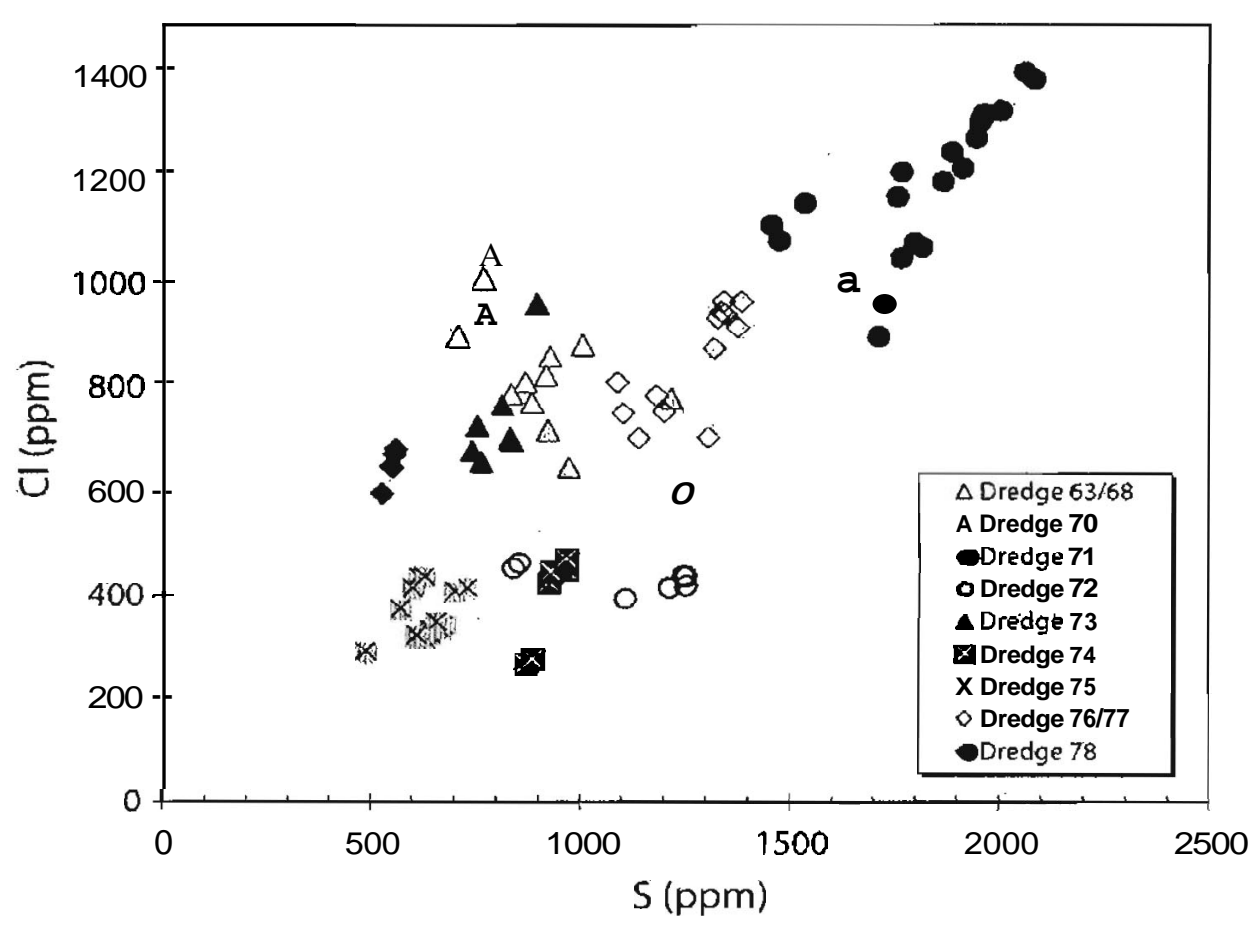

Figure 4-7. Fractionation-corrected $\mathrm{S}$ and $\mathrm{Cl}$ concentrations in Samoan basaltic glasses. Note from Figure 2 that the glasses with highest $\mathrm{S}$ and $\mathrm{Cl}$ are from the least evolved glasses of the Samoan suite. Although most glasses are saturated with sulfides, the correlation between $\mathrm{Cl}$ and $\mathrm{S}$ suggests that $\mathrm{S}$ loss by fractionation of a Fe-S liquid may be minimal. 

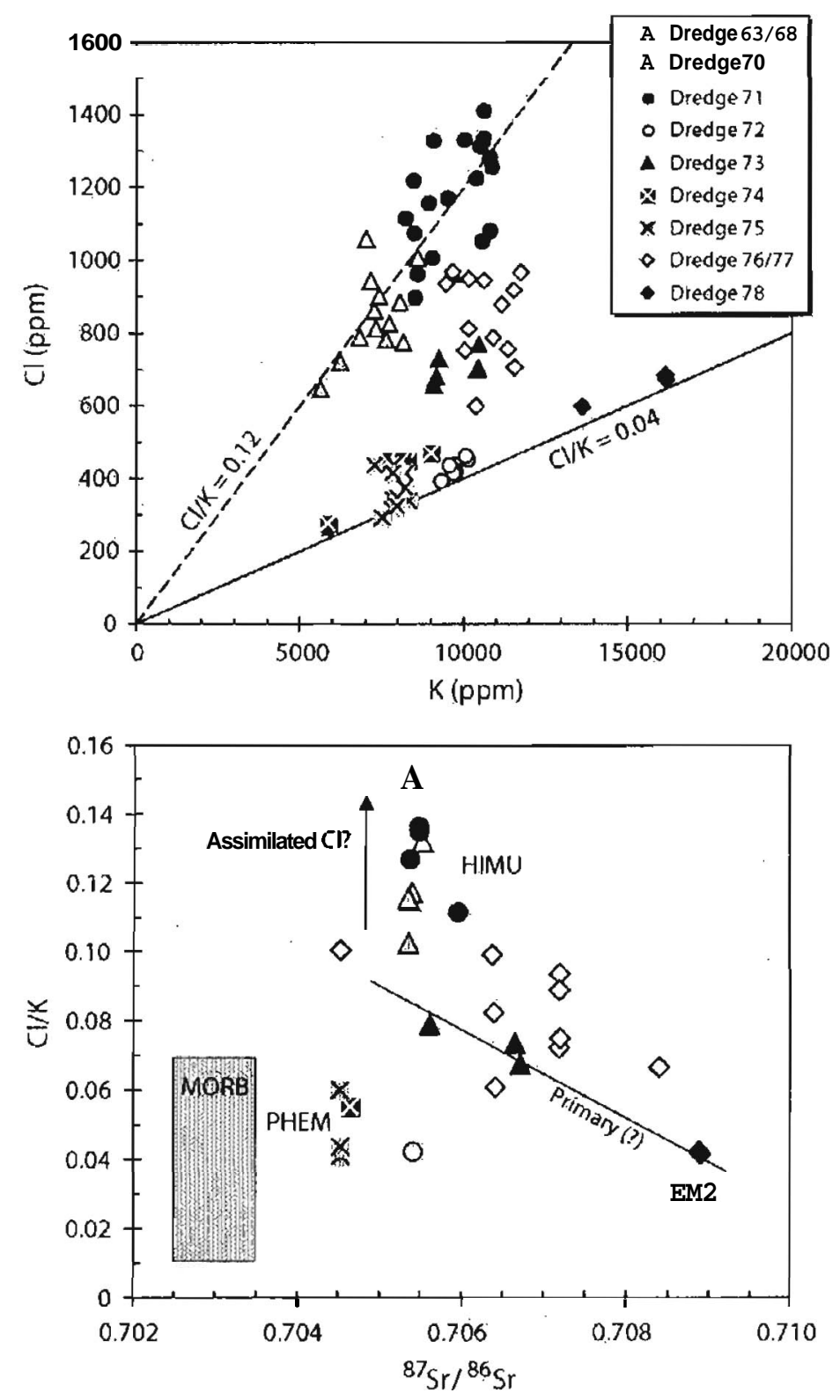

Figure 4-8. Two-panel diagram to show the systematics of $\mathrm{Cl}$ in Samoan glasses. Top panel shows fractionation-corrected concentrations of $\mathrm{K}$ and $\mathrm{Cl}$; Vailulu'u lavas define a high $\mathrm{Cl} / \mathrm{K}$ sub-suite, while Ta'u and dredge 78 from Malumalu define a low $\mathrm{C} / \mathrm{K}$ array. The lower panel shows that $\mathrm{C} / \mathrm{K}$ ratios vary with the ${ }^{87} \mathrm{Sr} /{ }^{86} \mathrm{Sr}$ source proxy. 


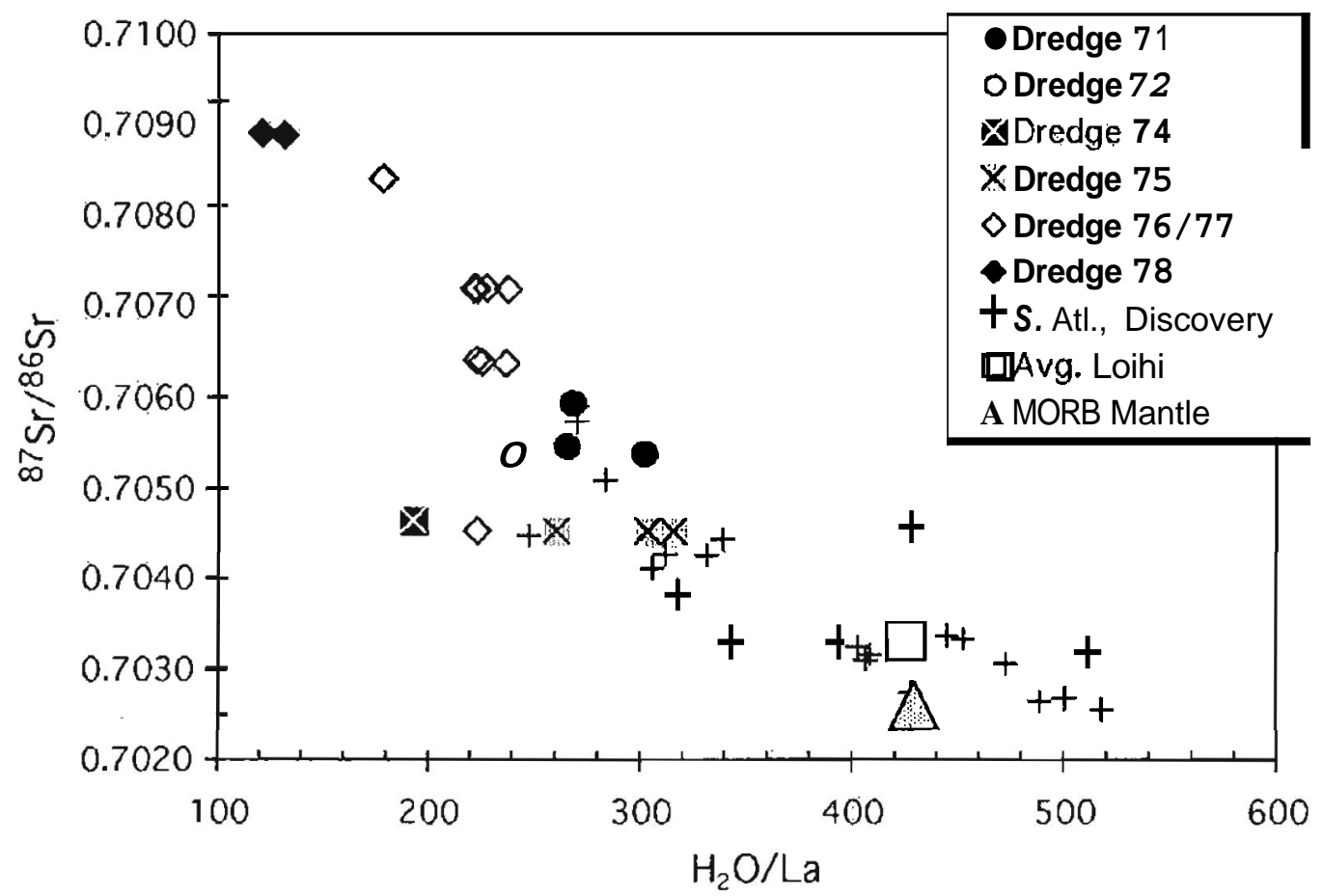

Figure 4-9. Plot of $\mathrm{H}_{2} \mathrm{O} / \mathrm{La}$ against ${ }^{87} \mathrm{Sr} /{ }^{86} \mathrm{Sr}$ in Samoan submarine glasses from this study along with plume-influenced glasses from the Discovery anomaly in the S. Atlantic (Dixon et al., 2002), average Loihi glasses (Dixon and Clague, 2001), and average normal MORB based on an $\mathrm{H}_{2} \mathrm{O} / \mathrm{Ce}$ ratio of 150 (Dixon et al., 2002). Note that the shallowly dredged, degassed Vailulu'u samples (from dredges 63, 68, 70 and 73) are not included on this plot (see fig. 4). The negative slope here indicates that increasingly enriched mantle has decreasing relative enrichment of water in its source. This water depletion in EM2 is interpreted to be the result of diffusive loss of water during storage of EM2 in a dry ambient mantle. The amount of water lost from EM2 is estimated to be $-75 \%$ its original (i.e. ')re-recycled") abundance. 


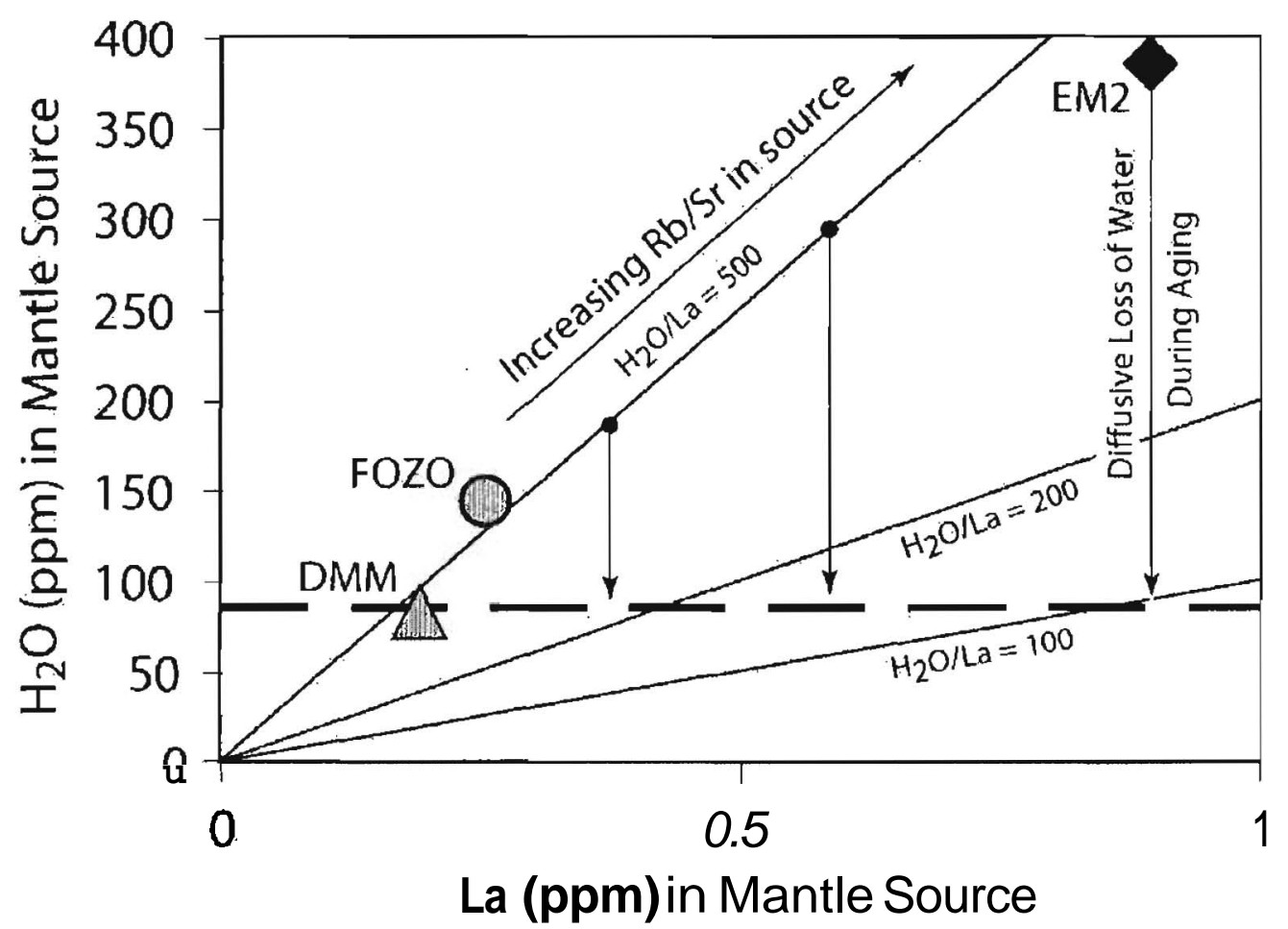

Figure 4-10. This plot is a conceptual diagram for the diffusive equilibration of water during the recycling and storage of EM2. At its formation, EM2 had "normal" enrichment of water, with $\mathrm{H}_{2} \mathrm{O} / \mathrm{Ce}$ of 200 and $\mathrm{H}_{2} \mathrm{O} / \mathrm{La}$ of 430 at $385 \mathrm{ppm} \mathrm{H}_{2} \mathrm{O}$. During storage of this material with high $\mathrm{H}_{2} \mathrm{O}$ in an ambient mantle with lower $\mathrm{H}_{2} \mathrm{O}$, water is diffusively lost from EM2 - but $\mathrm{La}$ is not due to their contrasting rates of diffusion. When EM2 has equilibrated with the upper mantle (82.5 ppm, heavy dashed line), this otherwise enriched reservoir has an $\mathrm{H}_{2} \mathrm{O} / \mathrm{La}$ ratio of 92 . Less enriched sources (that lay in-between EM2 and DMM), will likewise lose water while stored in a drier mantle, but, as a result of lower REE abundance, will equilibrate to higher $\mathrm{H}_{2} \mathrm{O} / \mathrm{La}$. This leads to the negative relationship between $\mathrm{H}_{2} \mathrm{O} / \mathrm{La}$ and ${ }^{87} \mathrm{Sr} /{ }^{86} \mathrm{Sr}$ seen in Figure 9. 


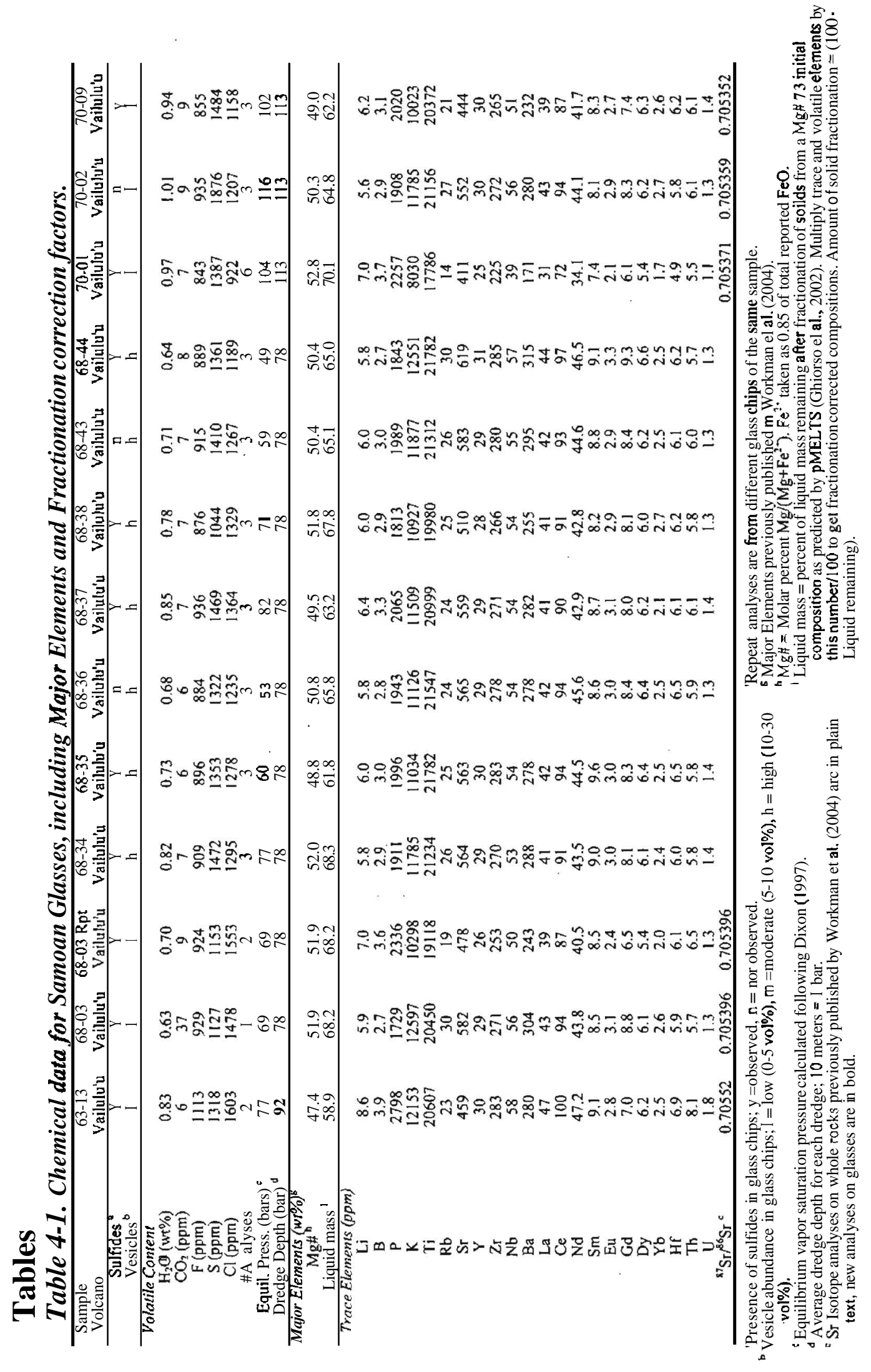




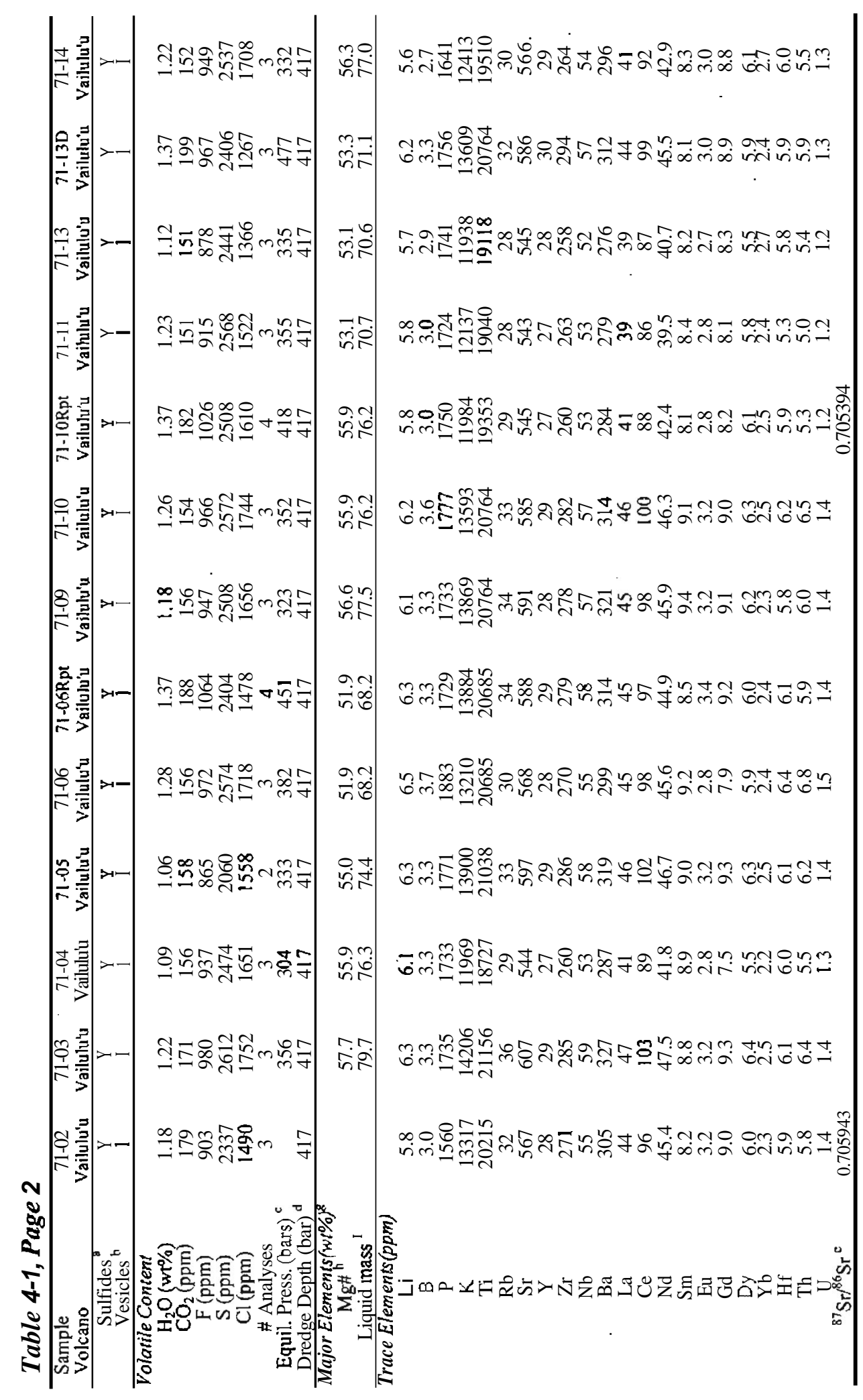




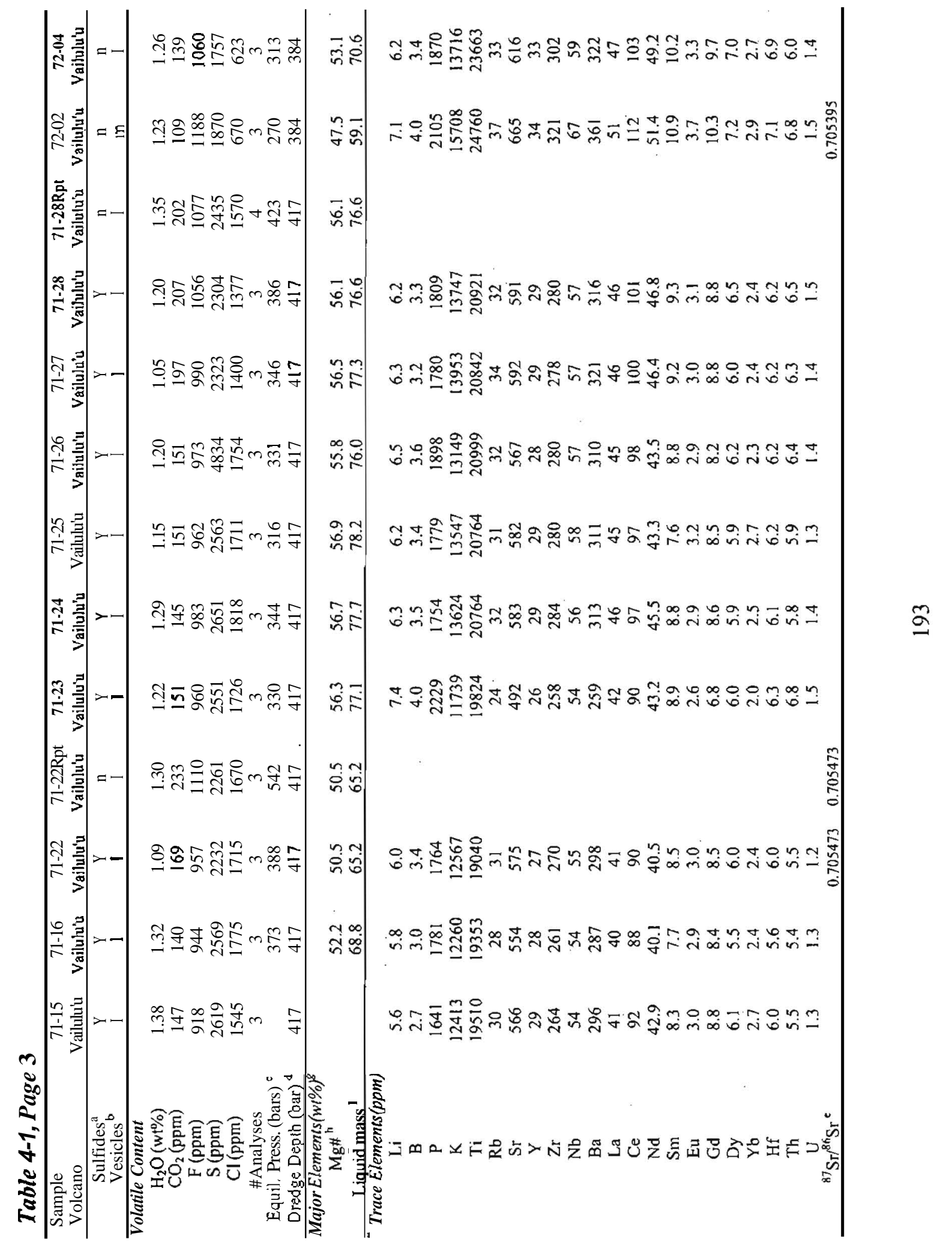




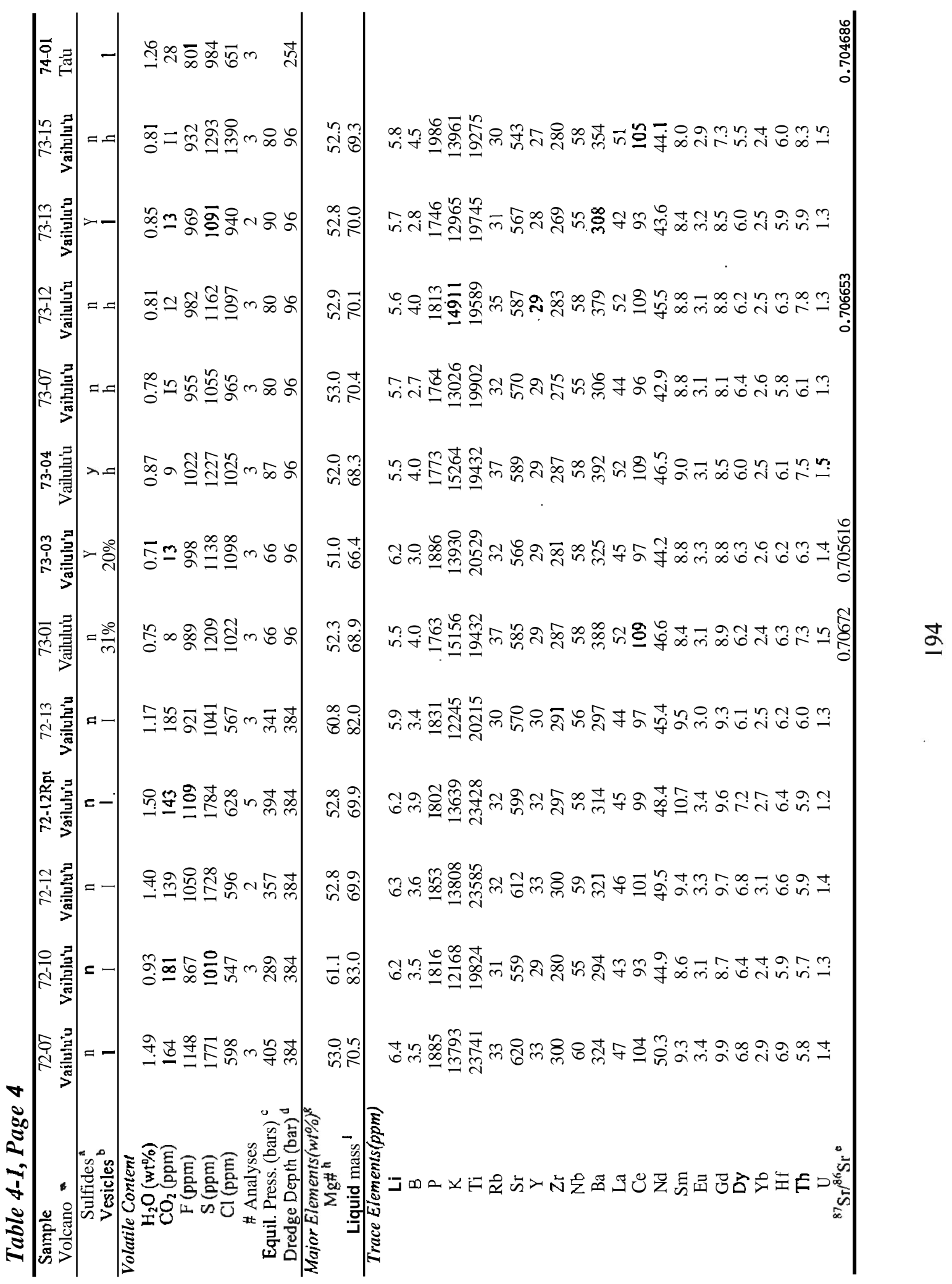




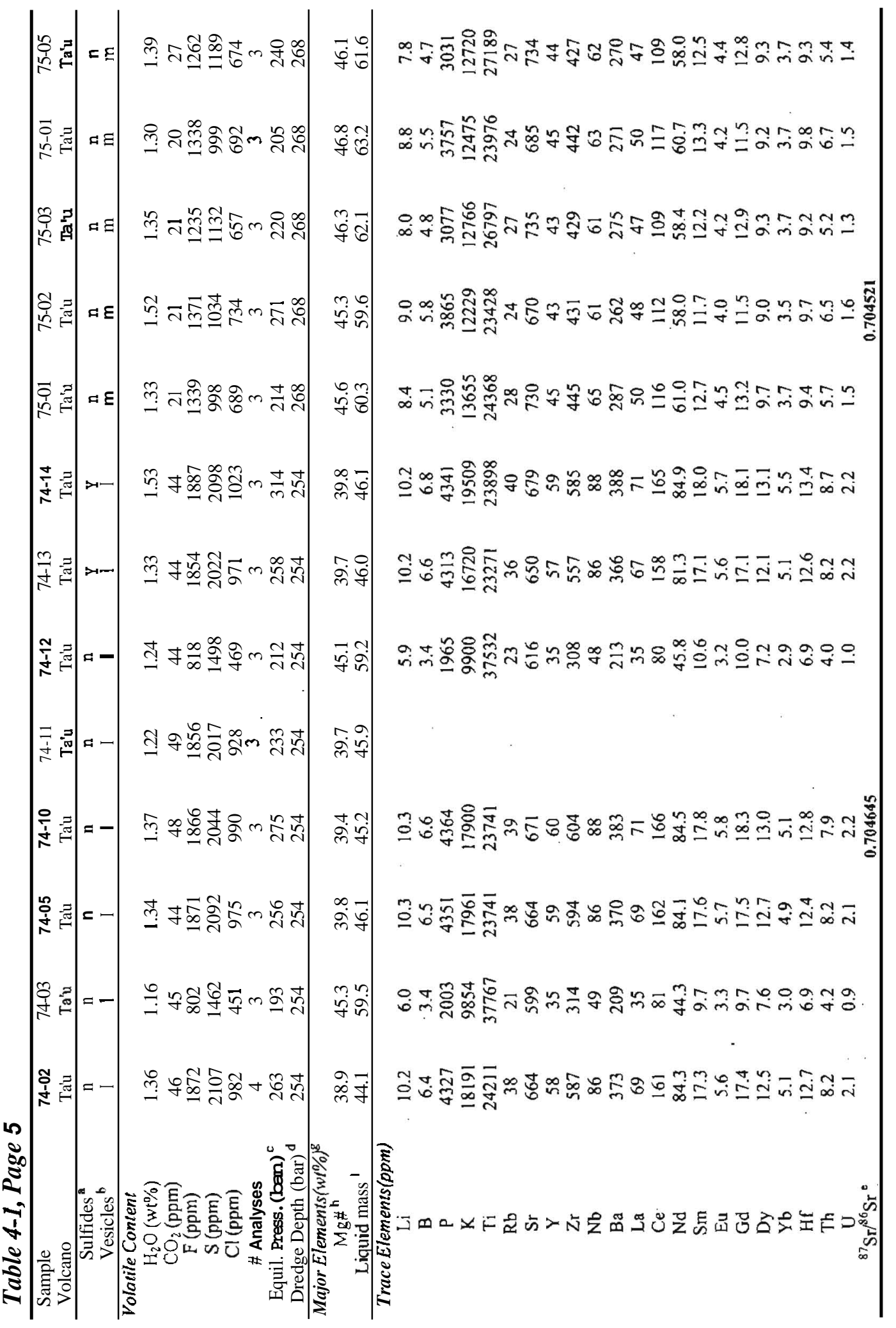




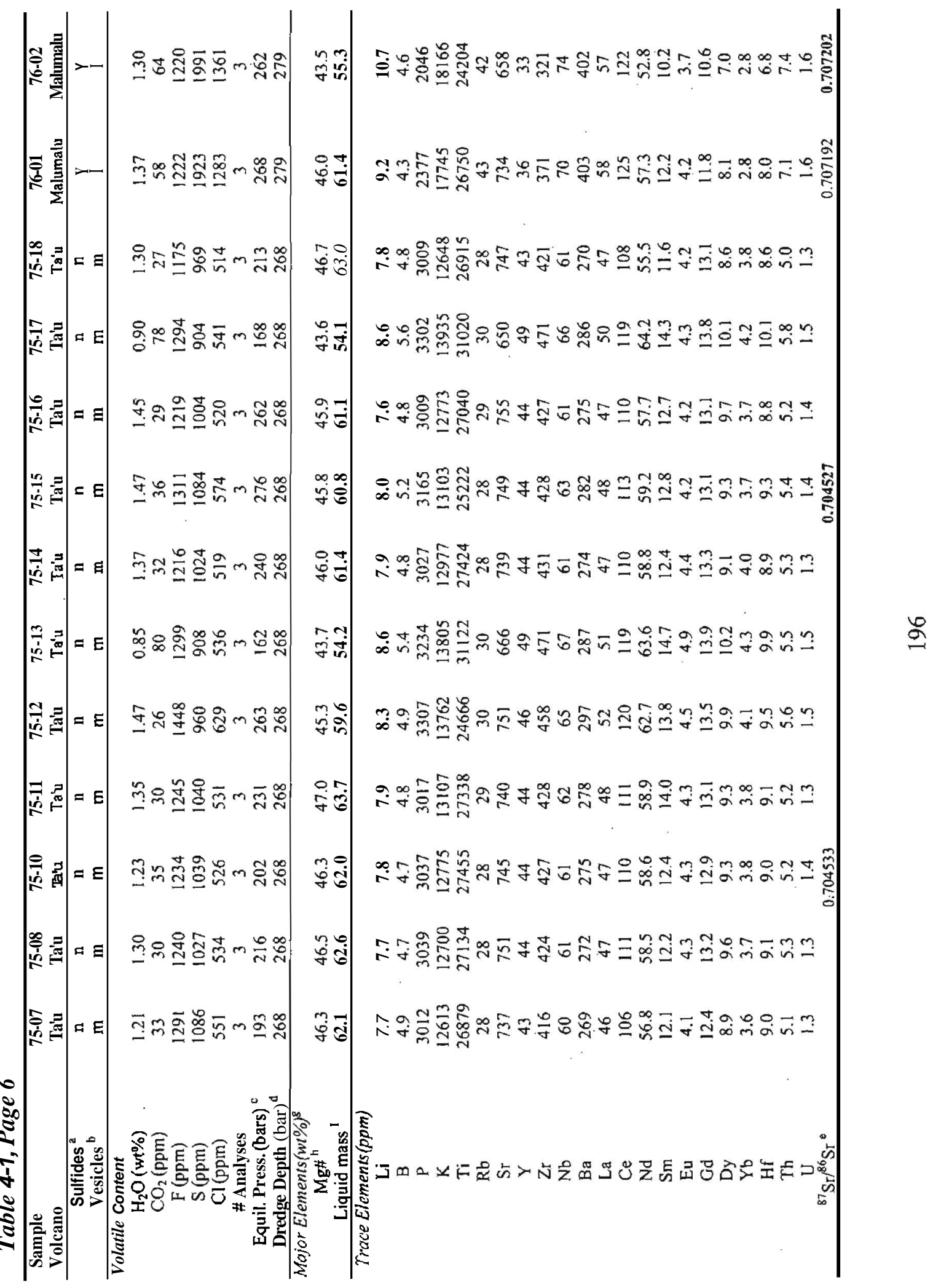




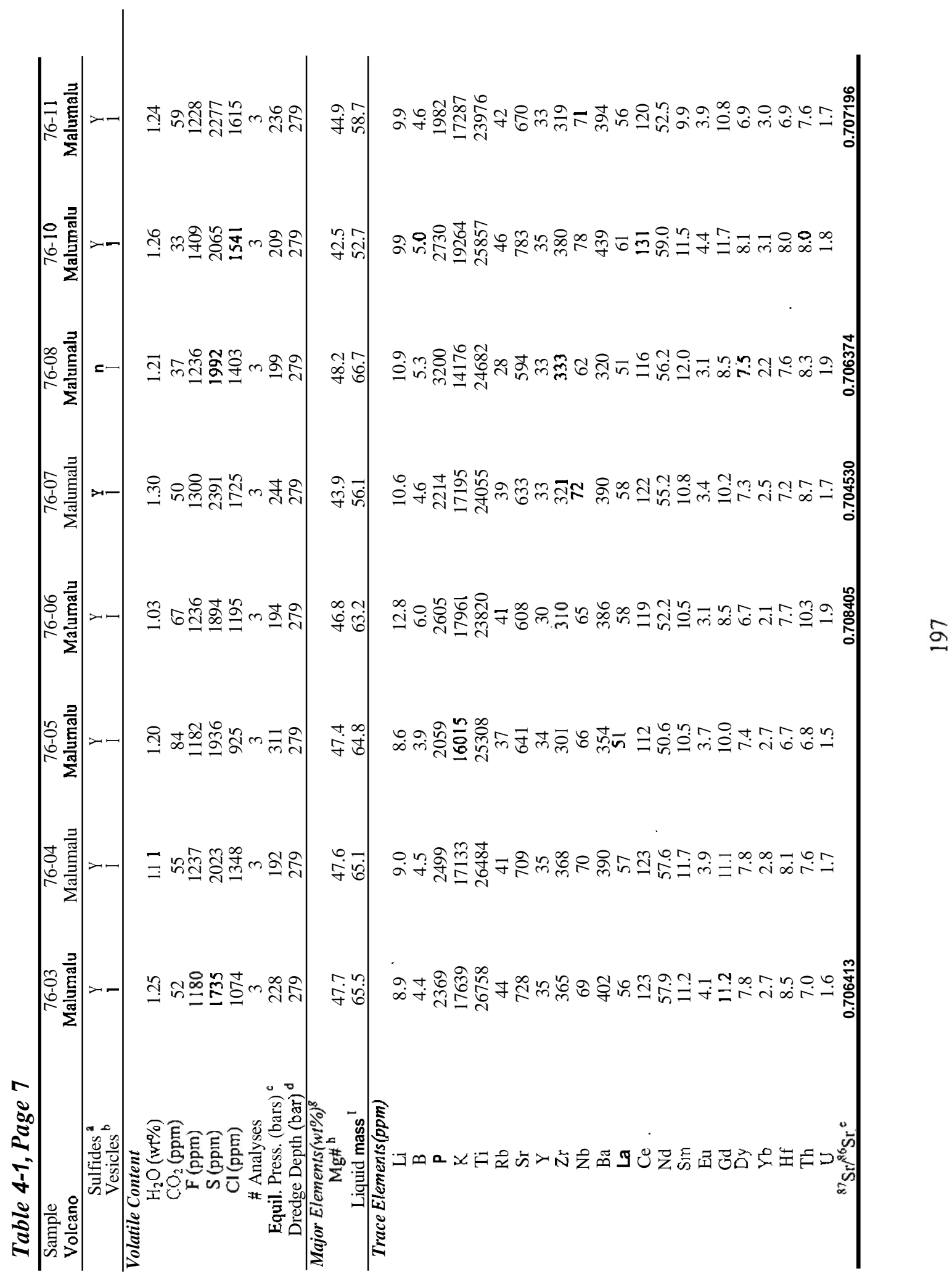




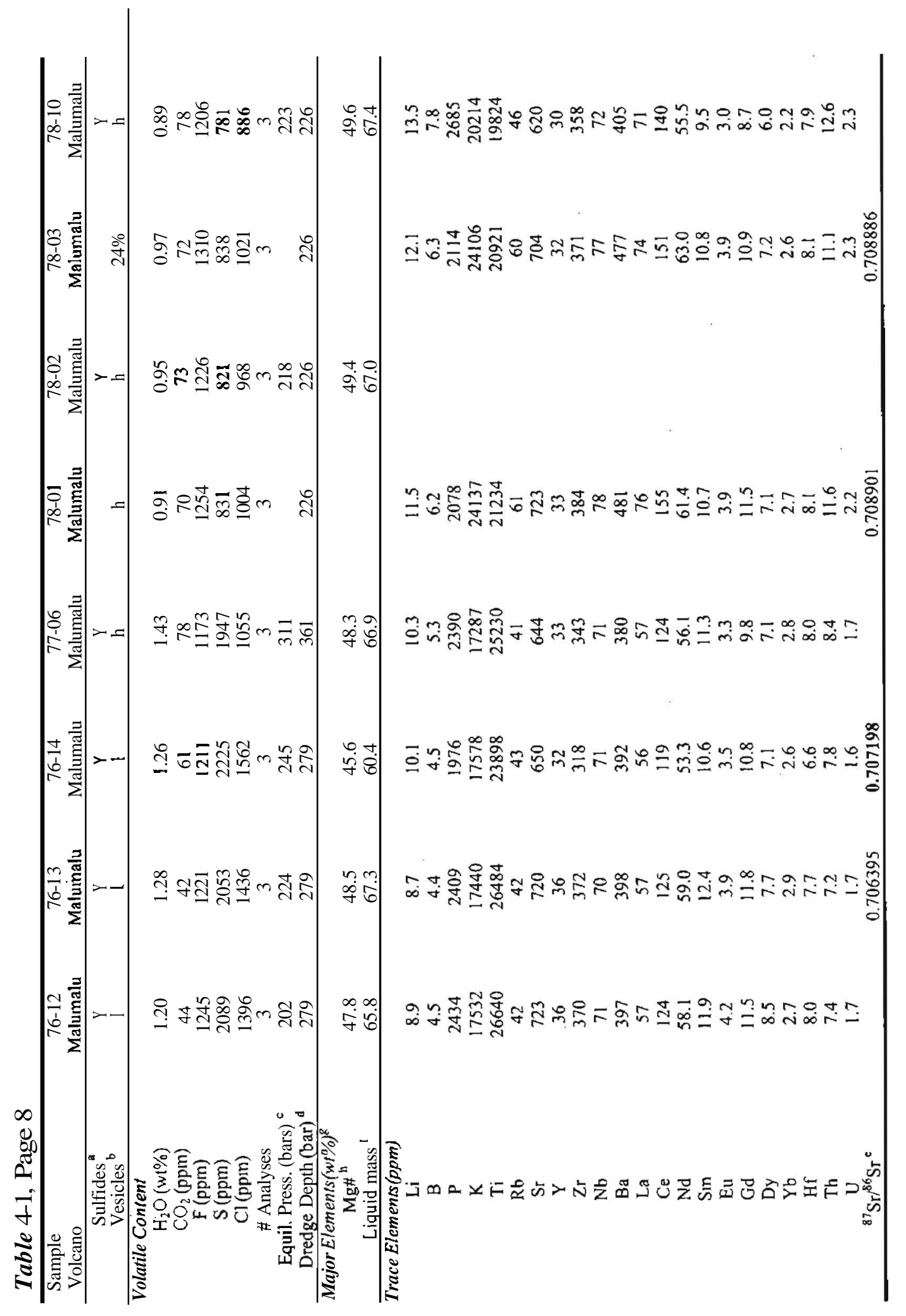




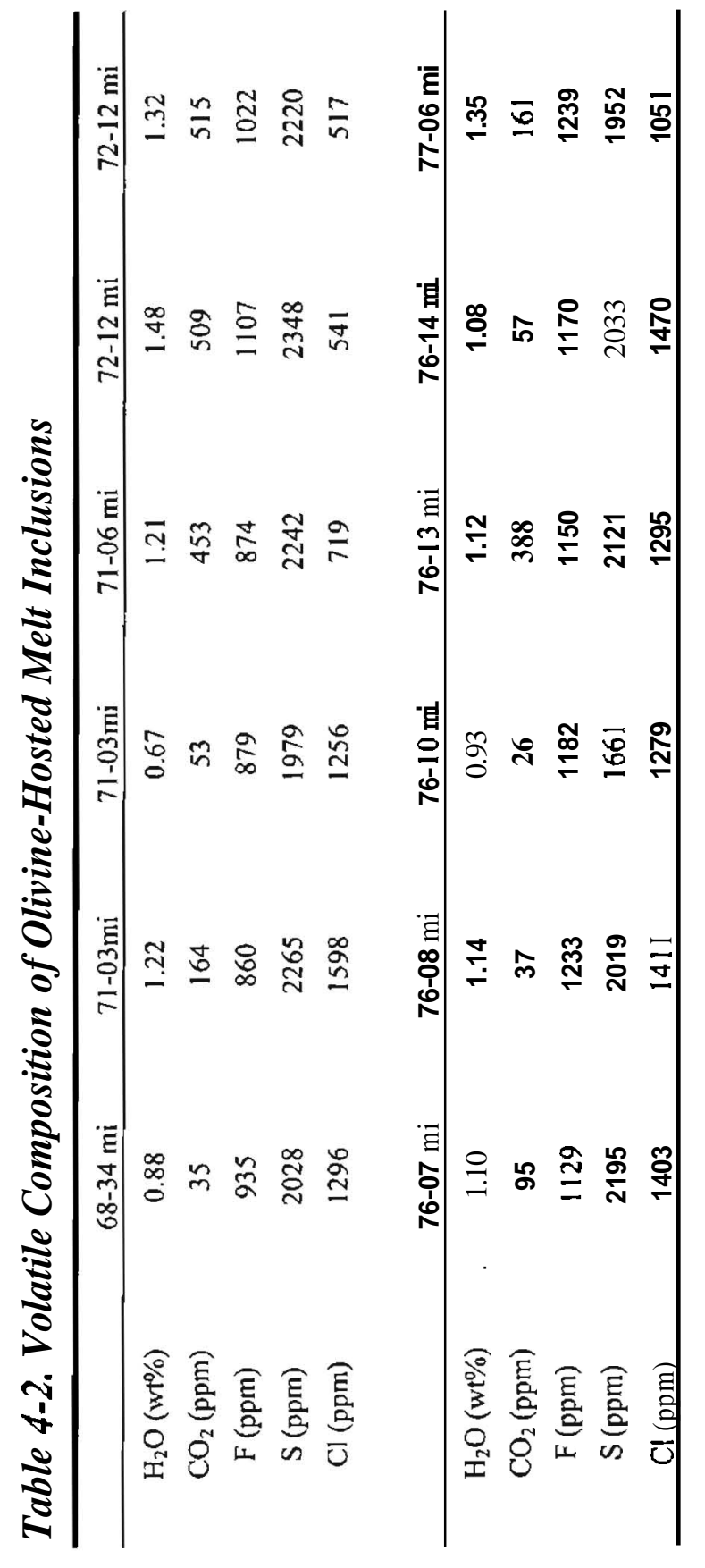




\title{
Chapter 5:
}

\section{Assessment of recycled, slab-derived material in enriched lavas from Samoa: evidence from oxygen}

\author{
isotopes
}

\begin{abstract}
Oxygen isotope compositions of olivine phenocrysts from Samoan lavas, ranging from $\delta^{18} \mathrm{O}$ of 5.1-5.6\%o, reconfirm that lavas from Enriched Mantle 2 (EM2) plumes display higher primary $\delta^{18} \mathrm{O}$ values than any other mid-ocean ridge or hotspot setting. We find that $\delta^{18} \mathrm{O}$ correlates well with ${ }^{87} \mathrm{Sr} /{ }^{86} \mathrm{Sr},{ }^{208} \mathrm{~Pb} /{ }^{204} \mathrm{~Pb}$ and incompatible element ratios such as $\mathrm{La} / \mathrm{Sm}$. There is no correlation between $\delta^{18} \mathrm{O}$ and $\mathrm{Mg \# 's}$ of whole-rocks or olivines, so we interpret the $\delta^{18} \mathrm{O}$ values to represent primary melt compositions. Clinopyroxene phenocrysts were also analyzed from a few samples and show a similar range in $\delta^{18} \mathrm{O}$ as the olivines; unlike a typical equilibrium fractionation of $\sim 0.4 \%$ for $\delta^{18} \mathrm{O}_{\mathrm{Cpx}}-\delta^{18} \mathrm{O}_{\mathrm{O}}$, most clinopyroxenes are lower in $\delta^{18} \mathrm{O}$ than their coexisting olivines. We test two models for the origin of EM2's enrichment in ${ }^{18} \mathrm{O}$, incompatible trace elements and $\mathrm{Sr}-\mathrm{Nd}-\mathrm{Pb}$ radiogenic isotopes; both are based almost entirely on comparisons of trace element patterns between a calculated source for the most EM2-rich lavas and our two model outputs. The first model is inspired by the classic interpretation that EM2 represents mantle that has been enriched by recycled marine sediments. The second model is one in which a subduction-zonedelineated mantle wedge is metasomatized by a melt from oceanic crust that has been subducted to eclogite facies pressure-temperature conditions. Each model has significant discrepancies with trace element patterns observed for Samoa, but the metasomatic model overall shows a better fit.
\end{abstract}




\section{Introduction}

Oxygen isotopes have become a commonly used proxy for the identification of ancient, recycled crustal components in arcs and mantle plumes and/or as a means to identify recent crustal contamination of mantle-derived igneous rocks (Eiler, 2001). The use of oxygen isotopes as a crustal tracer is made possible by the fact that only materials at or near the Earth's surface show great variability in $\delta^{18} \mathrm{O}$ as a result of low temperature equilibrium fractionation effects. However, $\delta^{18} \mathrm{O}$ variations in mantle-derived lavas and their phenocrysts are often small and care must be taken not to interpret secondary processes as mantle source signals.

The range in $\delta^{18} \mathrm{O}$ of olivines from MORBs and upper mantle peridotites is small (5.1 \pm 0.2\%o; Mattey, 1994; Chazot et al., 1997; Eiler et al., 1997; Eiler, 2001) and overlaps with values obtained from lunar rocks (Clayton et al., 1971; Clayton et al., 1972, Wiechert et al., 2000). Deviations from these 'primary' mantle values have been found in ocean island basalts (OIBs) and attributed to the addition of sediment/upper-crustal material (in the case of high $\delta^{18} \mathrm{O}$ ) or lower oceanic crust (in the case of low $\delta^{18} \mathrm{O}$ ), either as a present-day assimilant or as a component in the mantle plume (see the review by Eiler, 2001). Most detailed studies of $\delta^{18} \mathrm{O}$ compositions in OlBs have focused on locations where $\delta^{18} \mathrm{O}$ is either very similar to MORB (Pitcairn, Hawaii) or is lower than MORB (Hawaij, Iceland, Canaries) (Eiler, 2001). Here we expand on the observation by Eiler et al. (1997) that the EM2 mantle component (Enriched Mantle 2), found most extremely in the Samoan hotspot track and more weakly in the Society Islands, is the only one to consistently show $\delta^{18} \mathrm{O}$ values that are elevated over MORBs. The Samoan islands and seamounts are now very well characterized in terms of major and trace elements, water content and $\mathrm{Sr}-\mathrm{Nd}-\mathrm{Pb}-\mathrm{Hf}-\mathrm{Os}-\mathrm{He}$ isotopic composition, so there is abundant context in which to put the new oxygen isotope data that is presented in this paper.

Eiler et al. (1997) interpreted the high $\delta^{18} \mathrm{O}$ in Samoa as the occurrence of recycled marine sediment in the Samoan plume. Such an explanation for the origin of enrichment in EM2 followed previous suggestions for EM2's origin, but was subsequently refuted by Workman et al. (2004) based on a large suite of trace element and isotopic data. Instead, Workman et al. (2004) called upon metasomatism of the lithospheric mantle (by an upper mantle melt) to explain the formation of EM2; however, their model cannot directly account for elevated $\delta^{18} \mathrm{O}$ compositions. 
Here we present new $\delta^{18} \mathrm{O}$ analyses of olivine and clinopyroxene phenocrysts from 'Samoan lavas and test two models for the generation of EM2. The first is the standard sediment-recycling model. The second expands upon the metasomatic model of Workman et al. (2004) by identifying a location for the metasomatism (the mantle wedge), and more accurately defining what the metasomatising agent is (an eclogite melt). Each model shows some major misfits to characteristics of end-member Samoan lavas, although the metasomatic model requires less 'special pleading'.

\section{Samples and Methods}

The samples analyzed in this study have already been well characterized in terms of major and trace element abundances and isotopic ( $\mathrm{Sr}-\mathrm{Nd}-\mathrm{Pb}-\mathrm{He}-\mathrm{Os}$ ) compositions (Workman et al., 2004). Samples selected here are a subset of a much larger collection discussed by Workman et al. (2004) and are used as the result of their containing olivine phenocrysts plentiful enough for separation. Samples with names beginning with a letter ( $T$, $U$ or S) are subaerial samples from the Samoan Islands, and those beginning with numbers are dredged from Vailulu'u and Malumalu Seamounts as well as submarine portions of Ta'u Island.

Whole rock samples were crushed and sieved to obtain a 300-660 $\mu \mathrm{m}$ size fraction. The sieved fraction was then rinsed in acetone and deionized water. Olivine and clinopyroxene phenocrysts were hand-picked under binocular microscope either dry or from a water bath. The only mineral grains picked for $\delta^{18} \mathrm{O}$ analyses were those with the fewest visible melt inclusions, mineral inclusions or surface discolorations.

Oxygen isotope compositions $\left(\delta^{18} \mathrm{O}=1000 *\left({ }^{18} \mathrm{O} /{ }^{16} \mathrm{O}_{\text {sample }} /{ }^{18} \mathrm{O} /{ }^{16} \mathrm{O}_{\text {SMOw }}\right)-1\right)$, where $\mathrm{SMOW}=$ standard mean ocean water at an ${ }^{18} \mathrm{O} /{ }^{16} \mathrm{O}$ ratio of 0.0020052 ) were determined by laser fluorination (LF) at the Caltech laboratory based on methods described by Valley et al. (1995) and Eiler et al. (2000a). Over 3 days of LF analyses, 16 runs of the GMT-2 garnet show a la reproducibility of $0.07 \%$ about a mean of $5.83 \%$ - within error of the accepted, long-term average of 5.80\% (see Valley, 1995; Eiler et al., 2000a).

Sample runs contain 1-2 mg of multiple mineral grains, and each sample is ideally run in triplicate, although some samples presented here only have 1 or 2 analyses. During LF analyses, some (not all) sample runs showed a high value of the contaminant mass 47 (i.e. -100 times normal). This unknown contaminant was also enriched in mass 48 , resulting in highly elevated $\delta^{18} \mathrm{O}$ values (generally $10-20 \%$, but up to $37 \%$ ) that were all discarded. 
This was a problem that was never encountered on a standard run. Consequently, sample splits were heat-treated at $1000^{\circ} \mathrm{C}$ for 1 and 10 minutes in air, thereby greatly improving the frequency of good runs. Although the heat treatment causes visible oxidation of olivine grains, there is no systematic difference in $\delta^{18} \mathrm{O}$ between sample splits that were and were not pre-treated; in other words, heat-treated sample splits are both higher and lower than, but within 20 error of, their non-treated splits with successful LF runs (see Table 1).

The range in $\delta^{18} \mathrm{O}$ shown by replicate analyses of olivine from a given sample is slightly greater than the quoted reproducibility of the standard. For example, samples 71-2 $(n=4)$ and 78-3 $(n=3)$ both show variations on the order of $0.2 \%$. Although this is only barely beyond the limit of 20 reproducibility of the standard, it may be suggestive of minor sample heterogeneity, as shown strongly in a SIMS study of single olivine phenocrysts from Iceland (Gurenko and Chaussidon, 2000) as well as multiple olivine analyses from a single lava flow (also from Iceland; Eiler et al., 2000b).

\section{Results}

Olivine phenocrysts from 20 Samoan shield lavas have $\delta^{18} \mathrm{O}$ compositions of 5.11 . $5.55 \%$ (Table 1). The lower end of the Samoan range overlaps with olivines in MORBs and upper mantle peridotites $(5.1 \pm 0.2 \%$ ) that are either measured directly (Mattey, 1994; Eiler et al., 1997) or inferred from melt compositions (Eiler et al., 2000c). No lavas from any other mantle components, including another enriched mantle, EM1 (found at Pitcairn Island; Eiler et al., 1995), have $\delta^{18} \mathrm{O}$ extending to such high values (see Eiler et al., 1997; Eiler, 2001); exceptions are from lavas that have undergone extensive crystal fractionation (e.g. Muehlenbachs and Byerly, 1982; Geist et al., 1998; Harris et al., 2000) or recent assimilation of altered crustal components (Garcia et al., 1998).

Clinopyroxene (cpx) phenocrysts have been analyzed for $\delta^{18} \mathrm{O}$ from 5 samples and show a nearly equivalent range in $\delta^{18} \mathrm{O}(4.97-5.53 \%$ ) as the olivines. Figure 1 shows that for individual samples, the $\delta^{18} \mathrm{O}$ compositions of cpx's are similar to or lower than their coexisting olivines. This feature is directly opposite of measured and theoretical equilibrium $\delta^{18} \mathrm{O}$ partitioning between cpx and olivine, in which $\mathrm{cpx}$ is generally $0.4 \%$ higher than olivine (Chiba et al., 1989; Mattey et al., 1994; Chazot et al., 1997; Macpherson et al., 1998; Harris et al., 2000). From this perspective, if we only had cpx data, the $\delta^{18} \mathrm{O}$ values found in Samoa would not be an "0-enriched anomaly in the global database of oceanic basalts, as the implied $\delta^{18} \mathrm{O}$ of equilibrium melts would be fully below the upper limit of MORB melts 
(basaltic melts are assumed to be $0.5 \%$ heavier than olivines and hence $0.1 \%$ heavier than cpx; Anderson et al., 1971; Kyser et al., 1981; Eiler, 2001). Although precise knowledge of equilibrium $\delta^{18} \mathrm{O}$ fractionations as a function of mineral and melt major element compositions, temperature and volatile content are lacking, it is possible that olivine and cpx are seemingly out of equilibrium because they record $\delta^{18} \mathrm{O}$ at different stages in the evolution of the melts. Because olivine is the first mineral to become saturated in Samoan magmas (along with spinel), we henceforth use olivine as a proxy for $\delta^{18} \mathrm{O}$ compositions of primary liquids.

Increasing $\delta^{18} \mathrm{O}$ values of olivine strongly correlate with increasing incompatible element ratios and heavy isotope compositions (figs. 2-4). Figure 2 shows the relationship between $\delta^{18} \mathrm{O}$ and $\mathrm{La} / \mathrm{Sm}$, but there are similarly good correlations with other element ratios such as $\mathrm{K} / \mathrm{Na}$, $\mathrm{K} / \mathrm{Ti}$ and $\mathrm{Rb} / \mathrm{Sr}$, suggesting that high $\delta^{18} \mathrm{O}$ derives from sources that are enriched in the highly incompatible elements. The highest $\delta^{18} \mathrm{O}$ occurs in Malumalu lavas (samples 78-1 and 78-3), which also have the highest $\mathrm{La} / \mathrm{Sm}(6.4),{ }^{208} \mathrm{~Pb} /{ }^{204} \mathrm{~Pb}$ (39.86) and ${ }^{87} \mathrm{Sr} /{ }^{86} \mathrm{Sr}(0.7089)$. These Malumalu lavas define the most extreme EM2 basalts in the current global database and therefore equilibrium olivine from end-member EM2 is established to have $\delta^{18} \mathrm{O}$ equal to $5.5 \%$. Sources with the lowest ${ }^{87} \mathrm{Sr} /{ }^{86} \mathrm{Sr}$, marked primarily by lavas from Ta'u and Upolu, are almost entirely separate from Malumalu by having lower oxygen and Sr isotopic compositions along with lower La/Sm (figs. 2-4). Vailulu'u olivines show the greatest range in $\delta^{18} \mathrm{O}$ of any volcano $(\sim 0.4 \%$ ), but all other source proxies are nearly identical for the 6 Vailulu'u samples. On the other hand, Malumalu shows the greatest range in ${ }^{87} \mathrm{Sr} /{ }^{86} \mathrm{Sr}(0.7067-0.7089)$ of these volcanoes, but has $\delta^{18} \mathrm{O}$ values that vary by only $0.22 \%$ (fig. 4 ).

The differences in source characteristics between eastern and western Samoa are highlighted in Figure 3. Western Samoan, comprised of the islands Savai'i and Upolu, overlaps the eastern shield lavas in $\delta^{18} \mathrm{O}$ but is distinctly lower in ${ }^{208} \mathrm{~Pb} /{ }^{204} \mathrm{~Pb}$. Workman et al. (2004) claim that, of all the Samoan volcanoes, Savai'i and Upolu have the least abundant EM2 component and instead are strongly influenced by depleted mantle (for Upolu) and another, yet unidentified, source with low ${ }^{206} \mathrm{~Pb} /{ }^{204} \mathrm{~Pb}$ and ${ }^{208} \mathrm{~Pb} /{ }^{204} \mathrm{~Pb}$ but high ${ }^{207} \mathrm{~Pb} /{ }^{204} \mathrm{~Pb}$ (for Savai'i). The one Savaiian sample presented here is from the oldest volcanic series exposed on the island and yields a $\delta^{18} \mathrm{O}$ composition (5.38\%) that is mid-range of the whole Samoan suite. Olivine in two young, post-erosional lavas from Savai'i, analyzed by Eiler et al. (1996), have $\delta^{18} \mathrm{O}$ values $(5.48 \%$ and $5.67 \%$ ) extending higher than the endmember EM2 value (5.5\%o), but it is unclear-if this represents a source signal or is a product 
of shallow assimilation of older, altered Savaiian shield. Since all lavas from Savai'i have similar $\mathrm{Sr}-\mathrm{Nd}-\mathrm{Pb}$ isotopic signatures (Workman et al., 2004), we suggest that the lower $\delta^{18} \mathrm{O}$ value for Savai'i is primary and the elevated $\delta^{18} \mathrm{O}$ in post-erosional samples is from secondary processes. No further attempt is made to explain the characteristics of posterosional lavas, as the primary focus of this work is to determine the origin of high $\delta^{18} \mathrm{O}$ in the EM2 mantle component.

\section{Process Control}

The inference of small variations of $\delta^{18} \mathrm{O}$ in mantle sources based on small variations of $\delta^{18} \mathrm{O}$ in mantle-derived lavas must be validated with an assessment of melt generation and fractionation processes. Eiler (2001) shows that joint olivine and plagioclase fractionation, as appropriate for MORBs, results in a nearly negligible net change of $\delta^{18} \mathrm{O}(<0.1 \%$, over a large range of $\mathrm{MgO}$ ) since light olivine is 'buffered' by heavy plagioclase. However, the Samoan lavas from this study have liquid lines of descent that are saturated with olivine \pm clinopyroxene (Workman et al., 2004), minerals that. are both lighter than equilibrium melts (see discussion above). A simple calculation, assuming an olivine-melt $\delta^{18} \mathrm{O}$ fractionation of $0.5 \%$, indicates that $40 \%$ olivine fractionation (an upper limit for magmas presented here) will increase a melt's $\delta^{18} \mathrm{O}$ composition by $0.2 \%$. Greater increases in a melt's $\delta^{18} \mathrm{O}$ can only occur if minerals with greater mineral-melt $\delta^{18} \mathrm{O}$ differences are fractionated. Spinel and chromite are two such minerals (Eiler, 2001) that are present in Samoan lavas, but at a possible fractionated mass of $-2 \%$ and mineral-melt $\delta^{18} \mathrm{O}$ fractionation of $2 \%$, melt $\delta^{18} \mathrm{O}$ will increase by less than $0.1 \%$. Fractionation of titanomagnetite has been shown to cause increases in $\delta^{18} \mathrm{O}$ of silicic Galapagos lavas (Muehlenbachs and Byerly, 1982), but there is no evidence this phase has played a role in Samoan fractionation trends.

An assessment of crystal fractionation effects on melt $\delta^{18} \mathrm{O}$ values would benefit from more detailed modeling of an AFC-type process (Assimilation-Fractional-Crystallization; DePaolo, 1981) suggested to occur in some OIB lavas. However, an AFC process to create high $\delta^{18} \mathrm{O}$ may be more important in the formation of EM2 mantle than in the present-day generation of Samoan melts; there is no reason to think that EM2 hotspot chains are unique in the way they generate or process melts, and no other OIB's show elevated $\delta^{18} \mathrm{O}$ values.

Olivines with higher $\delta^{18} \mathrm{O}$ tend to come from whole rocks with lower $\mathrm{SiO}_{2}$ and $\mathrm{CaO}$ than do the lower $\delta^{18} \mathrm{O}$ olivines (fig. 5). This negative correlation is slightly deceptive because picritic samples (with low $\mathrm{SiO}_{2}$ and $\mathrm{CaO}$ ) are generally from Vailulu'u and 
Malumalu (with high $\delta^{18} \mathrm{O}$ ). This observed relationship is not the.result of crystal

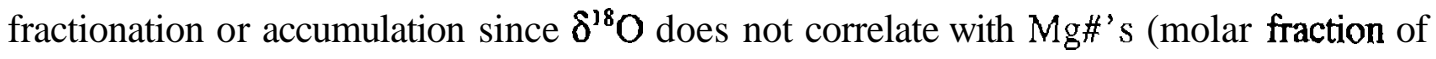
$\mathrm{Mg} /\left[\mathrm{Mg}+\mathrm{Fe}^{2+}\right]$ ) of whole rocks or of olivines (Jackson et al., unpubl.). Whole rock samples with the lowest Mg\#'s are from Upolu, and are the only obvious candidates for

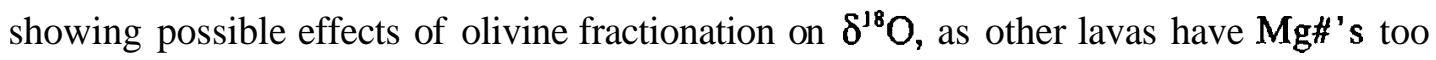
high to have fractionated enough olivine to significantly change a melt's $\delta^{18} \mathrm{O}$. It is, of course, possible that a melt has experienced crystal fractionation and then accumulated 'foreign' olivine.

The above factors may play in role in causing scatter in plots such as those in Figures 2 through 4 , but do not negate the fact that $\boldsymbol{\delta}^{18} \mathrm{O}$ values are enriched in olivines from EM2 end-member lavas. Fractionations of $\delta^{18} \mathrm{O}$ upon the generation of melt from a peridotite lithology will likewise not lead to the observed variation in Samoa's $\delta^{18} \mathrm{O}$ values; Eiler (2001) shows that, in theory, the $\delta^{18} \mathrm{O}$ composition of a melt is a function of $\mathrm{Na}_{2} \mathrm{O}$ content, but the Samoan lavas are within a relatively narrow range of $\mathrm{Na}_{2} \mathrm{O}(-1-3 \mathrm{wt} \%)$ where there is very little leverage on $\delta^{18} \mathrm{O}\left(0.1 \%\right.$ ). Also, there is no correlation between $\delta^{18} \mathrm{O}$ and $\mathrm{Na}_{2} \mathrm{O}$, even if lavas are fractionation-corrected to $\mathrm{Mg \#} 73$ by incremental addition or subtraction of equilibrium olivine.

\section{Source Control}

The correlations of $\boldsymbol{\delta}^{18} \mathrm{O}$ (olivine) with trace element and $\mathrm{Sr}-\mathrm{Pb}$ isotopic enrichment in. whole rocks (figs. 2-4) robustly indicate that ${ }^{18} \mathrm{O}$-enrichment exists in the EM2 source. Eiler et al. (1997) made the same observation with analyses from Savai'i (the post-erosional samples discussed above) and the Society Islands, another EM2 hotspot chain (although not as extreme in EM2 as Samoan lavas). Their interpretation was that EM2 represents a mixture of depleted mantle and $2-6 \%$ marine sediment having $\delta^{18} \mathrm{O}=15 \%$ and ${ }^{87} \mathrm{Sr} /{ }^{86} \mathrm{Sr}=$ 0.710 . They also suggest that extensive metasomatism could potentially elevate a source's $\delta^{18} \mathrm{O}$, as evidenced by high $\delta^{18} \mathrm{O}$ found in olivines (5.3-5.5\%o ) and pyroxenes (5.7-5.8\%o) from metasomatised Savaiian xenoliths. In an earlier study, Hauri et al. (1993) showed that cpx separates from these xenoliths have ${ }^{87} \mathrm{Sr} /{ }^{86} \mathrm{Sr}$ up to 0.7128 , higher than any values seen in the Samoan lavas; however, the genetic relationship of the xenoliths to the lavas is unclear since $\mathrm{Pb}$ isotopic compositions of cpx in the xenoliths do not lay on an extension of trends formed by the lavas (see Workman et al., 2004). 
With new light from data presented here and in Workman et al. (2004), it has become clear that the composition of end-member EM2 lavas is much lower in $\delta^{18} \mathrm{O}$ and higher in ${ }^{87} \mathrm{Sr} /{ }^{86} \mathrm{Sr}$ than reported by Eiler et al. (1997). To model the new $\delta^{18} \mathrm{O}-{ }^{87} \mathrm{Sr} /{ }^{86} \mathrm{Sr}$ trend, sediment having $\delta^{18} \mathrm{O}$ of $15-25 \%$ must have ${ }^{87} \mathrm{Sr} /{ }^{86} \mathrm{Sr}$ of 0.720 to 0.732 if mixing with primitive mantle and a more narrow range of 0.715 to 0.720 if mixing with depleted mantle; the mass of sediment added would be $2-4 \%$, with less sediment needed as the $\delta^{18} \mathrm{O}$ of the sediment increases (see fig. 4). Although the data is roughly fit in these two dimensions, a sediment origin for EM2 is not guaranteed by this calculation alone - there are many more parameters to be checked in order to assess the plausibility of this scenario. Accordingly, in the section below (5.1), we compare a sediment plus mantle mixture to the whole trace element pattern of end-member Samoan lavas.

Marine sediments are not the only material characterized by heavy oxygen. Altered upper oceanic crust (AOC) has been found to have $\mathbf{\delta 1 8 0}$ values up to $\mathbf{- 1 5 - 2 0 \% o ~ ( S t a u d i g e l ~}$ et al., 1981, Staudigel et al., 1995; Alt, 2003). When AOC is subducted at convergent margins, elements that are enriched in the ocean crust by low temperature alteration on the seafloor (Rb, Ba, U, K, Pb; Hart and Staudigel , 1989; Staudigel et al., 1996; Bach et al., 2003; Kelley et al., 2003) are also lost from the crust by dehydration and metamorphism, as seen in compositions of eclogites, the high temperature/pressure assemblage of oceanic crust (e.g. Becker et al., 2000). On the contrary, there is evidence from metabasalts and eclogites (Matthews et al., 1984; Neal et al., 1990; Nadeau et al., 1993; Putlitz et al., 2000) that deeply subducted materials do not lose the high 6180 compositions they acquired from seafloor alteration. Although bulk addition of subducted AOC (i.e. eclogite) would never result in enrichments of the highly-incompatible and light-rare-earth elements, it is possible that a melt derived from such material could have the required trace element enrichments as well as high $\delta 180^{\circ}$. Below we test a second model for the generation of EM2: metasomatism of the mantle wedge by an eclogite melt derived from a subducting slab. This model expands on the one put forth by Workman et al. (2004) by providing a location (the mantle wedge) and an agent (an eclogite melt) for their proposed mantle metasomatism; however, it is very different in the regard that this is potentially a much more complicated process, involving a greater variety of minerals as well as a greater numbers of 'steps' in the processing of materials.

There are a couple of fairly convincing arguments against a fluid being the enriching component in EM2 mantle: 1) Samoan lavas have slight negative anomalies in the fluidmobile elements - for example, even though the absolute abundances of $\mathrm{U}$ and $\mathrm{K}$ are high, 
$\mathrm{U} / \mathrm{Nb}$ and $\mathrm{K} / \mathrm{La}$ (ratios of 'neighboring' elements in the order of compatibility) are less than in the primitive mantle; and 2) end-member Malumalu lavas have low relative $\mathbf{C l}$ enrichment (see Chapter 4), whereas fluids in subduction zone systems are documented to have high $\mathrm{Cl}$ abundances (Kent et al, 2002; Scambelluri et al., 2004).

In summary, the following constraints for EM2, based on isotope and trace elements, must be satisfied in any plausible model for its origin: 1) high time-integrated $\mathrm{Rb} / \mathrm{Sr}$ and $\mathrm{Nd} / \mathrm{Sm}$; 2) elevated $\delta 180 ; 3$ ) lack of significant anomalies across the high-field-strength elements; 4) slight depletions in the fluid-mobile elements.

\subsection{Test for a sediment source of enrichment}

Present-day assimilation of local marine sediments with high $\delta^{18} \mathrm{O}$ cannot explain the origin of the Samoan lavas because $\mathrm{Pb}$ isotopic compositions of the sediments are too low in ${ }^{206} \mathrm{~Pb} /{ }^{204} \mathrm{~Pb}$ and ${ }^{208} \mathrm{~Pb} /{ }^{204} \mathrm{~Pb}$ to be the enriched component of the end-member Malumalu lavas (see Plank and Langmuir, 1998; Workman et al., 2004). Therefore, we must approach the problem as one of recycling ancient marine sediments back to the mantle at convergent margins, as melting and dehydration processes in the subduction zone have the potential to alter trace element compositions, hence parent/daughter ratios and, consequently over time, radiogenic isotopic compositions. However, difficulties in this problem arise since we have collectively little knowledge about past sediment compositions (that are, in part, a function of the redox state of the oceans), melting and dehydration processes in the subduction zone, and partitioning of trace elements between sediment/fluid and sediment/melt. There is some experimental evidence to suggest that subducted sediments will still look basically like unsubducted sediments (in term of the general sense of anomalies in their trace element patterns), even after dehydration and partial melting, due to sediment/fluid and sediment/melt partition coefficients being close to 1 and often higher (Johnson and Plank, 1999); this does not mean that trace element ratios will not change, but rather that generally enriched or depleted elements will stay generally enriched or depleted, respectively.

There is seemingly no foolproof way of 'selecting' a marine sediment composition to test as an enriching component in EM2, given the many unknowns listed above. Trace elements in sediments that are not thought to fractionate from each other during subduction zone alteration (i.e. Th/La; Plank, 2005) have the potential to fractionate during small-degree mantle melting to make the Samoan lavas. On the other hand, elements that may have similar compatibilities during mantle melting (i.e. $\mathrm{Th} / \mathrm{U}, \mathrm{Ba} / \mathrm{Th}, \mathrm{K} / \mathrm{C}, \mathrm{Ce} / \mathrm{Pb}, \mathrm{Sr} / \mathrm{Nd}$ ) are likely to 
fractionate from each other during dehydration of sediments in subduction zones because of slightly differing fluid mobilities (Johnson and Plank, 1999).

We have chosen to use $\mathrm{La} / \mathrm{Th}$ and $\mathrm{Nb} / \mathrm{Th}$ ratios in order to identify a 'test' sediment because these elements are thought to be immobile in sediment-derived fluids and therefore their ratios will not be fractionated by dehydration processes (Johnson and Plank, 1999; Plank, 2005). These ratios show a good correlation with each other for the Samoan lavas (fig: 6) and decent correlations with ${ }^{87} \mathrm{Sr} /{ }^{86} \mathrm{Sr}$ compositions, so must be largely reflective of source variations. We also use $\mathrm{Ba} / \mathrm{Th}$ as another 'filter' for choosing a sediment; $\mathrm{Ba}$ is more fluid-mobile than the other elements used (Johnson and Plank, 1999), but the enormous range of $\mathrm{Ba} / \mathrm{Th}$ in marine sediments (Plank and Langmuir, 1998) compensates for this possible fractionation in the subduction zone. Using compositions of individual marine sediments from the GLOSS study by Plank and Langmuir (1998), we have found 7 sediments (most of clay-dominated lithology) that lay on an extension of the Samoan trace element trends in $\mathrm{La} / \mathrm{Th}-\mathrm{Nb} / \mathrm{Th}-\mathrm{Ba} / \mathrm{Th}$ space (fig. 6). The average of these 7 selected sediments is reported in Table 2. These 7 out of the $\mathbf{4 3}$ sediment compositions reported by Plank and Langmuir (1998) are most distinct from GLOSS by having negative $\mathrm{Ba}$ and $\mathrm{Sr}$ anomalies.

Figure 7 shows a comparison between trace element patterns of a calculated Malumalu (i.e. EM2) source with mixtures of the selected sediment and depleted or primitive mantle. See Table 2 for details of calculating the Malumalu source composition. Each mixture contains $2 \%$ by mass of the sediment and will satisfy the observed $\delta^{18} \mathrm{O}$ of Malumalu if the sediment has a $\delta^{18} \mathrm{O}$ composition of $25 \%$. To the right of $\mathrm{La}$, the Malumalu source falls between the two sediment-mantle mixtures, except for $\mathrm{Pb}$. To the left of $\mathrm{La}$, the Malumalu source falls below either mixture, except for $\mathrm{Nb}$ and $\mathrm{Ta}$, which fall above. Sediment melting is thought to be common beneath arc volcanoes (Elliot et al., 1997; Hoogewerff et al., 1997; Plank and Langmuir, 1998; Johnson and Plank, 1999) and, if it occurred before mixing with the mantle, could potentially account for the excess abundance of $\mathrm{Rb}, \mathrm{Ba}, \mathrm{Th}, \mathrm{U}$ and $\mathrm{K}$, but will not be able to explain the low $\mathrm{Nb}$ and Ta (Johnson and Plank, 1999), unless a minor phase such as rutile (with high $\mathrm{Nb}$ and Ta compatibility;e.g. Rudnick et al., 2000) is present in the sediment during melting. Because of experimental challenges (e.g. Johnson and Plank, 1999), there is very little accurate information about $\mathrm{Pb}$ mobility during dehydration and melting. The great enrichment of $\mathrm{Pb}$ in the continental crust (42 ppm and 84 times the abundance in primitive upper mantle; Rudnick and Fountain, 1995) must be due to greatly enhanced mobility of $\mathrm{Pb}$ at some stage in its generation - whatever that process is could be 
the same to mobilize $\mathrm{Pb}$ from sediments and decrease the high positive anomaly in the sediment-mantle mixtures of Figure 7.

In summary, if sediment recycling to the mantle is the reason for trace element and hence isotopic enrichment in EM2, very specific changes must be made to the sediment before it is mixed and stored with the mantle. While these changes appear unlikely at present, future advancements in the understanding of subduction zone processes may either rule-out or rule-in a 'sediment scenario'.

\subsection{Test for an eclogite melt source of enrichment}

The trace element composition of eclogite, to be used in the calculation discussed below, is based on eclogite samples with MORB protoliths reported by Becker et al. (2000), and is listed in Table 2. As mentioned above, the addition of bulk eclogite to either primitive or depleted mantle will not result in the required LILE and LREE enrichment in the EM2 reservoir, since these elements are not preferentially enriched over MREE or HREE in eclogites (fig. 8). Even 2 to $\mathbf{3}$ billion years ago, oceanic crust was most likely not preferentially enriched in these elements, as there is evidence that a depleted upper mantle already existed at that time (Machado et al., 1986; Bowring and Housh, 1995; Vervoort et al., 1996).

Here we test a model in which the mantle wedge (the mantle in-between a subducted slab and the volcanic arc) is metasomatized by a melt from subducted oceanic crust. Recent thermal models for the mantle wedge and subducted slab (van Keken et al., 2002; Kelemen et al., 2003a) suggest that temperatures at the slab-wedge interface may exceed the watersaturated solidus of basaltic compositions beneath the volcanic front, and certainly will at more deeply subducted locations. Melting experiments on garnet pyroxenite show a very narrow temperature range between the solidus and liquidus (Kogiso et al.; 2003), meaning melt productivity (as a function of temperature; $\mathrm{dF} / \mathrm{dT}$ ), will be much greater than in peridotite melting.

The upper panel in Figure 8 shows the trace element pattern of our 'test' eclogite. A $30 \%$ melt of this eclogite (using partition coefficients in Table 2) is mixed with 1) primitive mantle and 2) depleted mantle. Adding 5\% of the melt to each melt-mantle mixture results in trace element patterns that show a fairly decent match to our calculated Malumalu source, especially given the potential errors in the chosen compositions and partition coefficients; to match the $\delta^{18} \mathrm{O}$ of Malumalu, the eclogite melt must have a $\delta^{18} \mathrm{O}$ composition of $15 \%$. The two mixtures bound the Malumalu source for most elements, with the only major misfit 
being at $U$. Since $U$ is a fluid-mobile element, it is possible that eclogites subducted to greater depths will lose additional $U$ by further dehydration reactions.

This scenario has promise in explaining the origin of enrichment in EM2. The caveat if this: the eclogite melt produced from the slab must not be extracted from the mantle wedge, but instead get 'stuck' in it. This may be possible if the melting takes place a subducted depths greater than occur beneath the volcanic arc and the enriched wedge is effectively 'swept away' into greater depths of the mantle.

\section{Discussion}

Each proposed option for elevated $\delta^{18} \mathrm{O}$ in enriched mantle lavas from Samoa requires some form of 'special pleading'. No single scenario can successfully explain the complete array of observation in the lavas, although many fewer discrepancies exist with the model involving metasomatism of the mantle wedge by eclogite melts. Likewise, no single scenario can be confidently ruled out as a possibility due to our limited knowledge base about ancient and present-day subduction zone processing of slabs, as well as compositions of ancient sediments and altered oceanic crust.

If ancient metasomatism by an eclogite melt is a plausible origin for the trace element enrichment in EM2, the reality must be a mixture of sediment and eclogite melts as the enriching component, since the solidus temperatures for these two materials can be very similar (Nichols et al., 1994; Johnson and Plank, 1999; Poli and Schmidt, 2000). This is' nearly unavoidable, given the close proximity of sediment overlaying the igneous crust, and the observation that metabasalts and metapelites are often severely intermingled (for example, see Hansteen and Troll, 2003). The exchange of $1 \%$ eclogite melt for $0.5 \%$ bulk sediment slightly improves the fit of $\mathrm{Rb}$ and the $\mathrm{Pr}-\mathrm{Nd}-\mathrm{Sr}$ sedment of the trace element pattern, but makes the negative anomaly in $\mathrm{Pb}$ turn positive.

It is possible that some of the second-order variations in the trace element pattern for the Samoan lavas are due to recent alterations to the EM2 source beneath Samoa. For example, recent carbonatite metasomatism has been documented in xenoliths from Savai'i (Hauri et al., 1993). If such a metasomatising material was extracted from the EM2 (Malumalu) source before Malumalu lavas were generated, then the trace element patterns of Malumalu lavas falsely represent their ancient composition. We will need to take great care in understanding the sequence of events in the history of a given source and its derivative melts from the time of their formation until the day of our sampling. 


\section{Acknowledgements}

We thank Erik Hauri for inspiring us to think of the mantle wedge as a possible place to generate EM2. We would also like to acknowledge Nami Kitchen for her talent and time spent with the LF analyses presented here. Nobu Shimizu has been a wonderful sounding board and resource for this work. 


\section{References}

Alt, J.C., Stable isotope composition of upper oceanic crust formed at a fast spreading ridge, ODP Site 801, Geochem. Geophys. Geosyst., 4 (5), doi: 10.1029/ 2002GC000400, 2003.

Anderson, A.T., R.N. Clayton and T.K. Mayeda, Oxygen isotope thermometry of mafic igneous rocks, J. Geology, 79,714-729.1971.

Bach, W., B. Peucker-Ehrenbrink, S.R. Hart and J.S. Blusztajn, Geochemistry of hydrothermally altered oceanic crust: DSDP/ODP Hole 504B - Implications for seawater-crustexchange budgets and $\mathrm{Sr}$ - and $\mathrm{Pb}$-isotopic evolution of the mantle, Geochem. Geophys. Geosyst., 4 (3), doi:10.1029/2002GC000419, 2003.

Becker, H., K.P Jochum and R.W. Carlson, Trace element fractionation during dehydration of eclogites from high-pressure terranes and the implications for element fluxes in subduction zones, Chemical Geology, 163, 65-99, 2000.

Bowring, S.A. and T. Housh, The Earth's Early Evolution, Science, 269, 1535-1540, 1995.

Chazot, G., D. Lowry, M. Menzies and D. Mattey, Oxygen isotopic composition of hydrous and anhydrous peridotites, Geochimica et Cosmochimica Acta, 61, 161-169, 1997.

Chiba, H., T. Chacko, R.N. Clayton and J.R. Goldsmith, Oxygen isotope fractionations involving diopside, forsterite, magnetite and calcite; application to geothermometry, Geochimica et Cosmochimica Acta, 53,2985-2995,1989.

Clayton, R.N. ,N. Onuma and T.K Mayeda, Oxygen isotope fractionation in Apollo 12 rocks and soils, Proc. $2^{\text {nd }}$ Lunar Sci. Conf., 1417-1420, 1971.

Clayton, R.N., J.M. Hurd and T.K. Mayeda, Oxygen isotope abundances in Apollo 14 and 15 rocks and minerals, Lunar Sci. Inst. Contrib.,88, 141-143,1972.

DePaolo, D.J., Trace element and isotopic effects of combined wallrock assimilation and fractional crystallization. Earth Planer. Sci. Lett., 53, 189-202, 1981.

Eiler, J.M., K.A. Farley, J.W. Valley, E.M. Stolper,E.H. Hauri and H. Craig, Oxygen isotope evidence against bulk recycled sediment in the mantle sources of Pitcairn island lavas, Nature, 377,138-141,1995.

Eiler, John M., K.A. Farley, J.W. Valley,E.H. Hauri, H. Craig, S.R.Hart and E.M. Stolper, Oxygen isotope variations in ocean island basalt phenocrysts, Geochimica et Cosrnochimica Acta, 61,2281-229,1997. 
Eiler, J.M., A.J. Crawford, T.R. Elliott, K.A. Farley, J.W. Valley, and E.M. Stolper, Oxygen isotope geochemistry of oceanic-arc lavas, Journal of Petrology, 41, 229-256, 2000a.

Eiler, J.M., K. Gronvold, and N. Kitchen, Oxygen isotope evidence for the origin of chemical variations in lavas from theistareykir volcano in iceland's northern volcanic zone, Earth and Planetary Science Letters, 184, 269-286, $2000 \mathrm{~b}$.

Eiler, John M., P. Schiano, N. Kitchen and E. M. Stolper, Oxygen-isotopeevidence for recycled crust in the sources of mid-ocean-ridge basalts, Nature, 403, 530-534, 2000c.

Eiler, J.M., Oxygen isotope variations of basaltic lavas and upper mantle rocks, in: Stable Isotope Geochemistry, Reviews in Mineralogy and Geochemistry, 43, eds. J.W. Valley and D.R. Cole, 319-364,2001.

Elliot, T., T. Plank, A. Zindler, W. White and B. Bourdon, Element transport from slab to volcanic front at the Mariana Arc, J. Geophys. Res., 102, 14,991-15,019, 1997.

Garcia, M.O., E. Ito, J.M. Eiler and A.J. Pietruszka, Crustal comtamination of Kilauea Volcano magmas revealed by oxygen isotope analyses of glass and olivine from Puu Oo eruption lavas, $J$. Petrology, 39,803-817, 1998.

Geist, D., T. Naumann and P. Larson, Evolution of the Galapagos Magmas: Mantle and crustal fractionation without assimilation, J. Petrology, 39,953-971, 1998.

Gurenko, A.A. and M. Chaussidon, Oxygen isotope variations in primitive tholeiites of iceland; evidence from a SIMS study of glass inclusions, olivine phenocrysts and pillow rim glasses, Earth and Planetary Science Letters, 205, 63-79, 2002.

Hansteen, T.H. and V.R. Troll, Oxygen isotope composition of xenoliths from the oceanic crust and volcanic edifice beneath Gran Canaria (Canary Islands); consequences for crustal contamination of ascending magmas, Chemical Geology, 193, 181-193, 2003.

Harris, C., H.S. Smith and A.P. le Roux, Oxygen isotope composition of phenocrysts from Tristan da Cunha and Gough Island lavas: variation with fractional crystallization and evidence for assimilation, Contrib. Mineral, Petrol., 138, 164-175,2000.

Fant, S. R., and H. Staudigel, Isotopic characterization and identification of recycled components, 15-28. In: Crust/Mantle Recycling at Convergence Zones, eds. S. R. Ft and L. Gulen, NATO ASI Series, Vol. 258, Series C, Kluwer Academic Publishers, Dordrecht, The Netherlands, 1989.

Hauri, E. H., N. Shimizu, J.J. Dieu, and S.R. Evidence for hotspot-related carbonatite metasomatism in the oceanic upper mantle, Nature, 365,221-227, 1993.

Hofmann, A.W., Chemical differentiation of the Earth: the relationship between mantle, continental crust, and oceanic crust, Earth and Planet. Sci. Letters, 90,297-314, 1988. 
Hoogewerff, J.A., M.J. van-Bergen, P.Z. Vroon, J. Hertogen, R. Wordel „ A. Sneyers, A. Nasution, J.C. Varekamp, H.L.E. Moens and D. Mouchel, U-series, Sr-Nd-Pbisotope and trace element systematics across an active island arc-continent collision zone: Implications for element transfer at the slab-wedge interface, Geachimica et Cosmochimica Acta, 61,1057-1072, 1997.

Johnson, M.C., and T. Plank, Dehydration and Melting Experiments Constrain the Fate of Subducted Sediments, Geochemistry, Geophysics, Geosystems, 1, 1999GC000014, 1999.

Kelemen, P.B., J. Rilling, E.M. Parmentier, L. Mehl and B.R. Hacker, Thermal structure due to solid-state flow in the mantle wedge beneath arcs, in: Inside the Subduction Factory, ed. J. Eiler, AGU Monogr. 138,293-311, 2003a.

Kelemen, P.B., G.M. Yogodzinski and D.W. Scholl, Along-strike variation in Iavas of the Aleutian island arc: Implications for the genesis of high $\mathbf{M g \#}$ andesite and the continental crust, In: Inside the Subduction Factory, Ed. J. Eiler, AGU Monograph 138, $2003 b$.

Kelley, K.A., T. Plank, J. Ludden and H. Staudigel, Composition of altered oceanic crust ¿ ODP Sites 801 and 1149, Geochem. Geophys. Geosyst., 4 (6), doi:10.1029/2002GC000435, 2003.

Kent, A.J.R., D.W. Peate, S. Newman, E.M. Stolper and J.A. Pearce, Chlorine in submarine glasses from the Lau Basin: seawater contamination and constraints on the composition of slab-derived fluids, Earth and Planet. Sci. Letters, 202, 361-377,2002.

Kogiso, T., M.M. Hirschmann and D.J. Frost, High-pressure partial melting of garnet pyroxenite: possible mafic lithologies in the sources of ocean island basalts, Earth and Planet. Sci. Letters, 216,603-617,2003.

Kyser, T.K., J.R. O'Neil and I.S.E. Carmichael, Oxygen isotope thermometry of basic lavas and mantle nodules, Contrib. Mineral, Petrol., 77, 11-23, 1981.

Machado, N., C. Brooks and S. R. Hart, Determination of initial ${ }^{87} \mathrm{Sr} /{ }^{86} \mathrm{Sr}$ and ${ }^{143} \mathrm{Nd} /{ }^{144} \mathrm{Nd}$ in primary minerals from mafic and ultramafic rocks: Experimental procedure and implications for the isotopic characteristics of the Archaean mantle under the Abitibi greenstone belt (Canada). Geochim. Cosmochim. Acta, 50,2335-2348,1986.

Mattey, D., D. Lowry and C. Macpherson, Oxygen isotope composition of mantle peridotite, Earth and Planet. Sci. Letters, 128,231-241, 1994.

Matthews, A. and M. Schliestedt, Evolution of the blueschist and greenschist facies rock of Sifnos, Cyclades Greece: a stable isotope study of subduction-related metamorphism, 
Contrib. Min. Petrol., 88, 150-163, 1984.

Macpherson, C.G., J.A. Gamble and D. Mattey, Oxygen isotope geochemistry of lavas from an oceanic to continental arc transition, Kermadec-Hikurangi margin, SW Pacific, Earth and Planet. Sci. Letters, 160,609-621, 1998.

McDonough, W.F., and S.-s. Sun, The composition of the Earth, Chemical Geology, 120, 223-253,1995.

Muehlenbachs, K. and $\boldsymbol{G}$. Byerly, ${ }^{18} \mathrm{O}$-enrichment of silicic magmas caused by crystal fractionation at the Galapagos Spreading Center, Contrib. Mineral, Petrol., 79, 76-79, 1982.

Nadeau, S., P. Philppot and F. Pineau, Fluid inclusion and mineral isotopic compositions (H-C-O) in eclogitic rocks as tracers of local fluid migration during high-pressure metamorphism, Earth and Planet. Sci. Letters, 114, 431-448, 1993.

Neal, C.R., L.A. Taylor, J.P. Davidson, P. Holden, A.N. Halliday, P.H. Nixon, J.B. Paces, R.N. Clayton and T.K. Mayeda, Eclogites with oceanic crustal and mantle signature from the Bellsbank kimberlite, South Africa, part 2: $\mathrm{Sr}, \mathrm{Nd}$, and $\mathrm{O}$ isotope geochemistry, Earth and Planet. Sci. Letters, 99,362-379, 1990.

Nichols, G.T., P.J. Wyllie and C.R. Stern, Subduction zone melting of pelagic sediments constrained by melting experiments, Nature, 371,785-788,1994.

Plank, T., Constraints from Thorium/Lanthanum on sediment recycling \& sunduction zones and the evolution of the continents, J. Petrology, in press, 2005.

Plank, T. and C.H. Langmuir, The chemical compositions of subducting sediments and its consequences for the crust and mantle, Chem. Geol., 145,325-394, 1998.

Poli, S. and M.W. Schmidt, Petrology of subducted slabs, Annu. Rev. Earth and Planet. Sci., 30,207-235,2002.

Putlitz, B., A. Matthews and J.W. Valley, Oxygen and hydrogen isotope study of highpressure rnetagabbros and metabasalts (Cyclades, Greece): implications for the subduction of oceanic crust, Contrib. Mineral, Petrol., 138, 114-126, 2000.

Rudnick, R.L., M. Barth, I. Horn, W.F. McDonough, Rutile-bearing Refractory Eclogites: Missing Link Between Continents and Depleted Mantle, Science, 287, 278-281,2000.

Rudnick, R.L. and D.M. Fountain, Nature and composition of the continental crust: a lower crustal perspective, Rev. Geophysics 33,267-309, 1995.

Scambelluri, M., J. Fiebig, N. Malaspina, O. Miintener and T. Pettke, Serpentinite Subduction: Implications for fluid processes and trace-element recycling, International Geology Rev. , 46,595-613, 2004. 
Staudigel, H., Davies, G., Hart, S. R., Marchant, K. M. and Smith, B. M., Large Scale Isotopic $\mathrm{Sr}, \mathrm{Nd}$ and $\mathrm{O}$ isotopic anatomy of altered oceanic crust at DSDP/ODP Sites 417/418, Earth Planetary Science Letters, 130,169-185, 1995.

Staudigel, H., K. Muehlenbachs, S. H. Richardson and S. R. Hart, Agents of low temperature ocean crust alteration, Contrib. Mineral Petrol., 77, 150-157, 1981.

Staudigel, H., T. Plank, B. White and H.-U. Schminke, Geochemical fluxes during seafloor alteration of the basaltic upper oceanic crust: DSDP Sites 417 and 418, in: Subduction: Top to Bottom, Geophys. Monogr. Ser., 96, ed. G.E. Bebout, pp. 19-38,1996.

Valley, J:W, N. Kitchen, M.J. Kohn, C.R. Niendorf and M.J. Spicuzza, UWG-2, a garnet standard for oxygen isotope ratios: Strategies for high precision and accuracy with laser heating, Geochim. et Cosmochim. Acta, 59,5223-5231, 1995.

van Keken, P.F., B. Kiefer and S.M. Peacock, High-resolutionmodels of subduction zones: Implications for mineral dehydration reactions and the transport of water into the deep mantle, Geochem. Geophys. Geosyst., 3, doi:10.1029/2001GC000256, 2002.

Vervoort, J.D., P.J. Patchett, G.E. Gehrels, A.P. Nutman, Constraints on early Earth differentiation from hafnium and neodymium isotopes, Nature, 379, 624-627, 1996.

Wiechert, U.H., A.N. Halliday, D.C. Ie, G.A. Snyder, L.A. Taylor and D. Rumble, Oxygen- and tungsten-isotopicconstraints on the early development of the moon, Meteoritics Planetary Sci., 35, A169, 2000.

Workman, R.K., S.R. Hart, M. Jackson, M. Regelous, K. Farley, J. Blusztajn, M. Kurz, and H. Staudigel, Recycled Metasomatized Lithosphere as the Origin of the Enriched Mantle II (EM2) End-member: Evidence from the Samoan Volcanic Chain, Geochem. Geophys. Geosyst., 5,404008, doi:10.1029/2003GC000623, 2004.

Workman, R.K. and S.R. Hart, Major and Trace Element Composition of the Depleted MORB Mantle (DMM), Earth and Planet. Sci. Letters, 231, 53-72, 2005. 


\section{Figures}

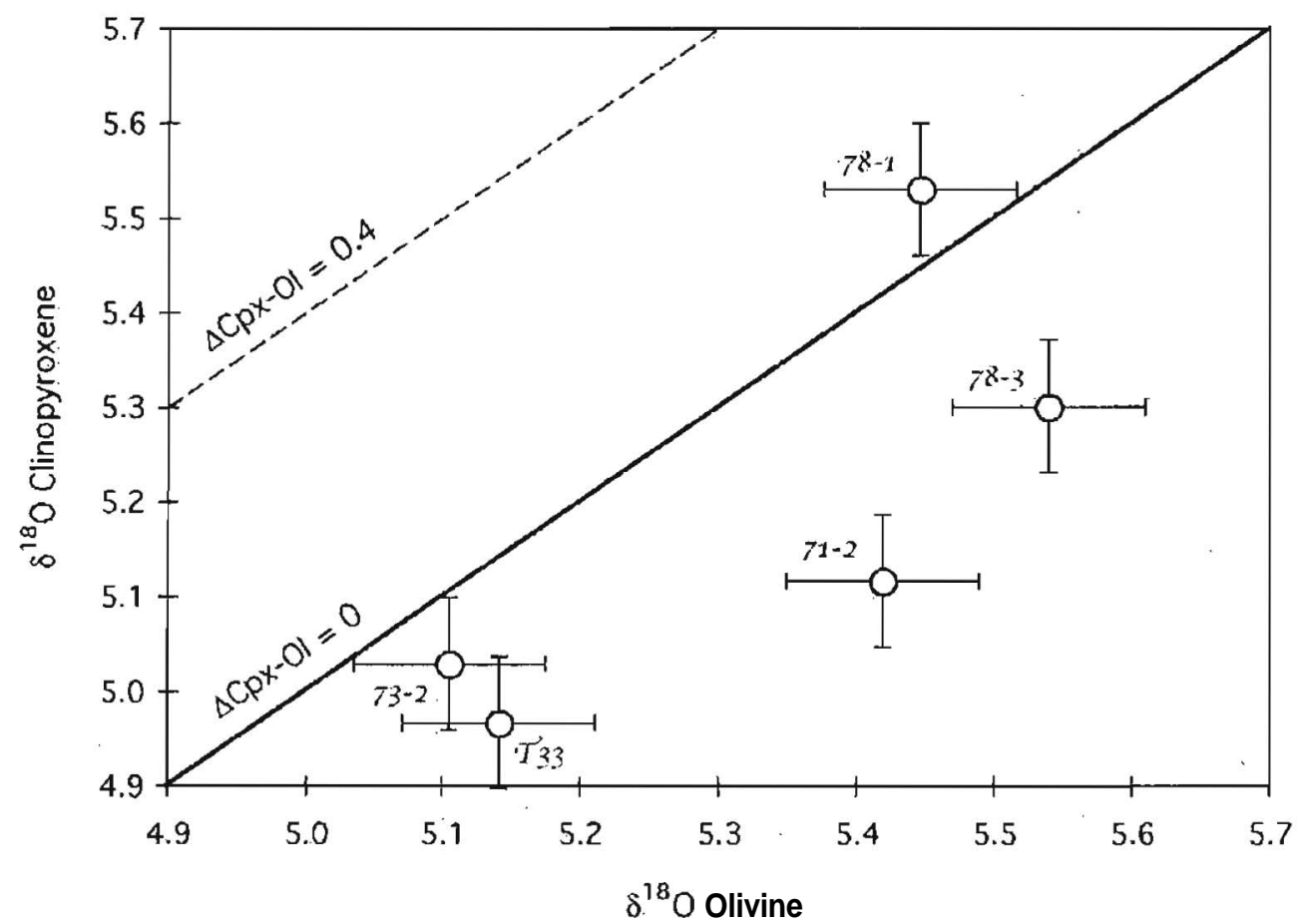

Figure 5-1. Oxygen isotope compositions of coexisting olivine and clinopyroxene from 5 Samoan lavas. $\Delta \mathrm{Cpx}-\mathrm{Ol}=\delta^{18} \mathrm{O}_{\mathrm{Cpx}}-\delta^{18} \mathrm{O}_{\text {Olivine. }}$. Equilibrium $\Delta \mathrm{Cpx}$-Ol fractionation is typically reported to be $0.4 \%$ (Chiba et al., 1989; Chazot et al., 1997; Macpherson et al., 1998; Harris et al., 2000), but the Samoan samples show near zero or negative values. The disequilibrium may be due to olivine and cpx recording magmatic $\delta^{18} \mathrm{O}$ compositions at different stages in the magmas' evolution. Since olivine is the first phase on the liquidus of Samoan melts, we interpret olivine to be the more reliable recorder of primary magmas. Error bars are plotted as $1 \sigma$ analytical error $(0.07 \%)$. 


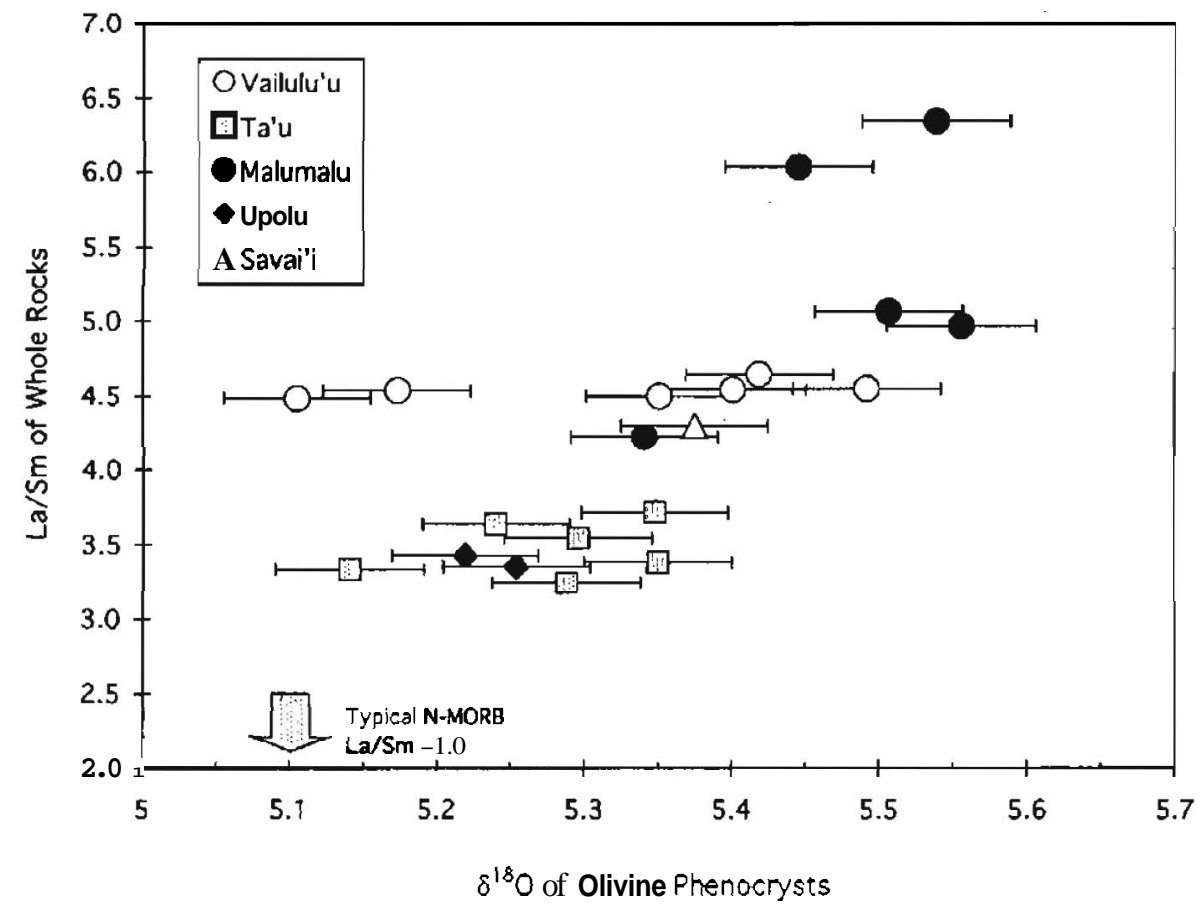

Figure 5-2. Correlation between $\mathrm{La} / \mathrm{Sm}(\mathrm{ppm} / \mathrm{ppm})$ and $\delta^{18} \mathrm{O}$ in Samoan lavas. $\mathrm{La} / \mathrm{Sm}$ ratios can vary as a function of degree of melting, but this is not suspected to control the correlation seen here since La/Sm also correlates well with ${ }^{87} \mathrm{Sr} /{ }^{86} \mathrm{Sr}$. There are similarly good correlations between $\delta^{18} \mathrm{O}$ and other element ratios such as $\mathrm{K} / \mathrm{Na}, \mathrm{K} / \mathrm{Ti}$ and $\mathrm{Rb} / \mathrm{Se}$, indicating general enrichment of incompatible elements in sources with elevated $\boldsymbol{\delta}^{18} \mathrm{O}$. Error bars are plotted as $1 \sigma$ standard error $(0.05 \%)$ for a sample run in duplicate. 


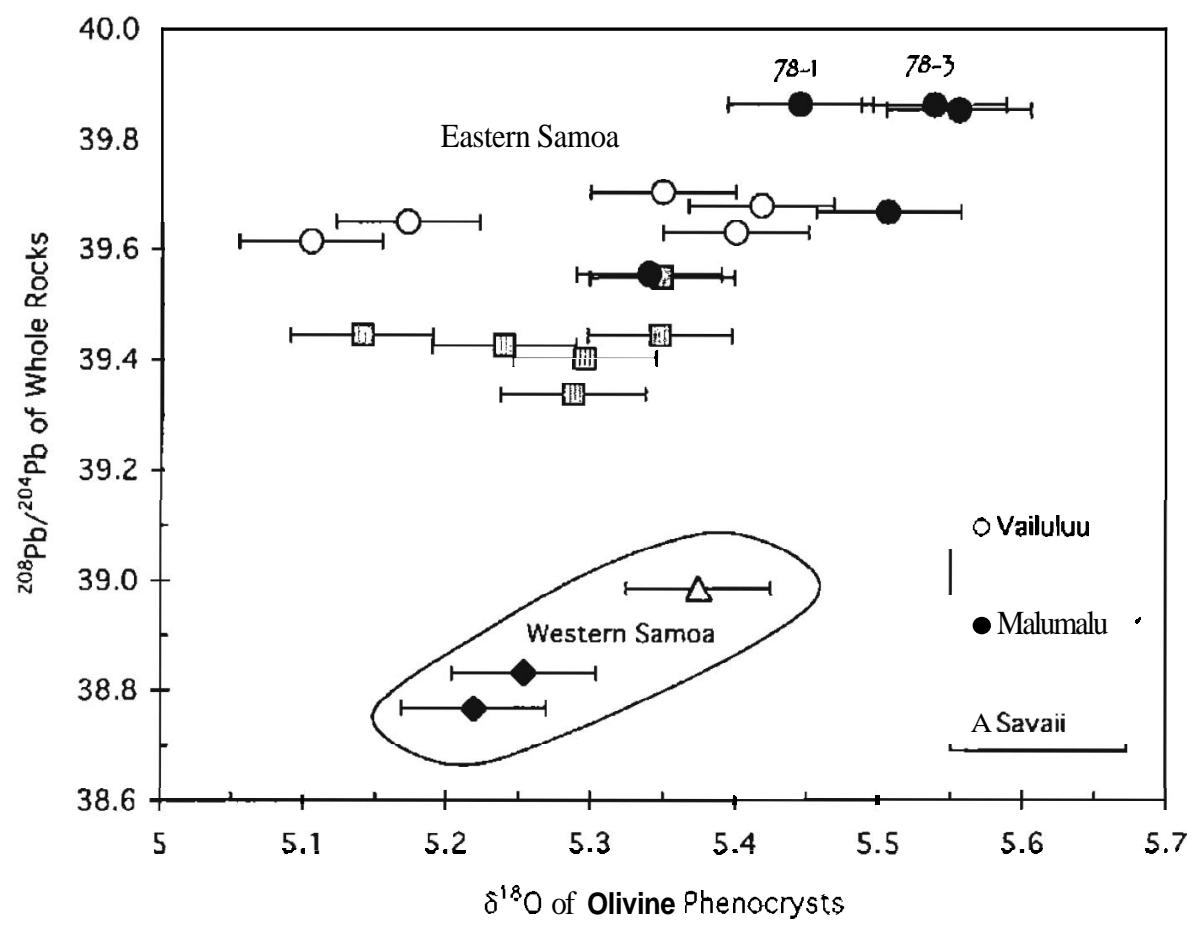

Figure 5-3. Relationship between oxygen and lead isotopes in Samoan lavas. Although the fields for Western Samoa (Savai'i and Upolu) and Eastern Samoa (Vailulu'u, Ta'u and Malumalu) overlap in $\delta^{18} \mathrm{O}$ values, they are distinct and entirely separate in ${ }^{208}{ }^{20}{ }^{204} \mathrm{~Pb}$. The source characteristics for Western Samoa lavas are discussed elsewhere (Workman et al., 2004), and the main topic of discussion in this paper is the origin for the extreme mantle enrichment displayed by Malumalu lavas (the two samples with the highest ${ }^{87} \mathrm{Sr}{ }^{86} \mathrm{Sr}$ in Samoa, 78-1 and 78-3, are identified for reference). Note that there is no $\mathrm{Pb}$ isotopic data for the highest $\delta^{18} \mathrm{O}$ sample from Vailulu'u. Error bars are plotted as lo standard exror $(0.05 \%)$ for a sample run in duplicate. 


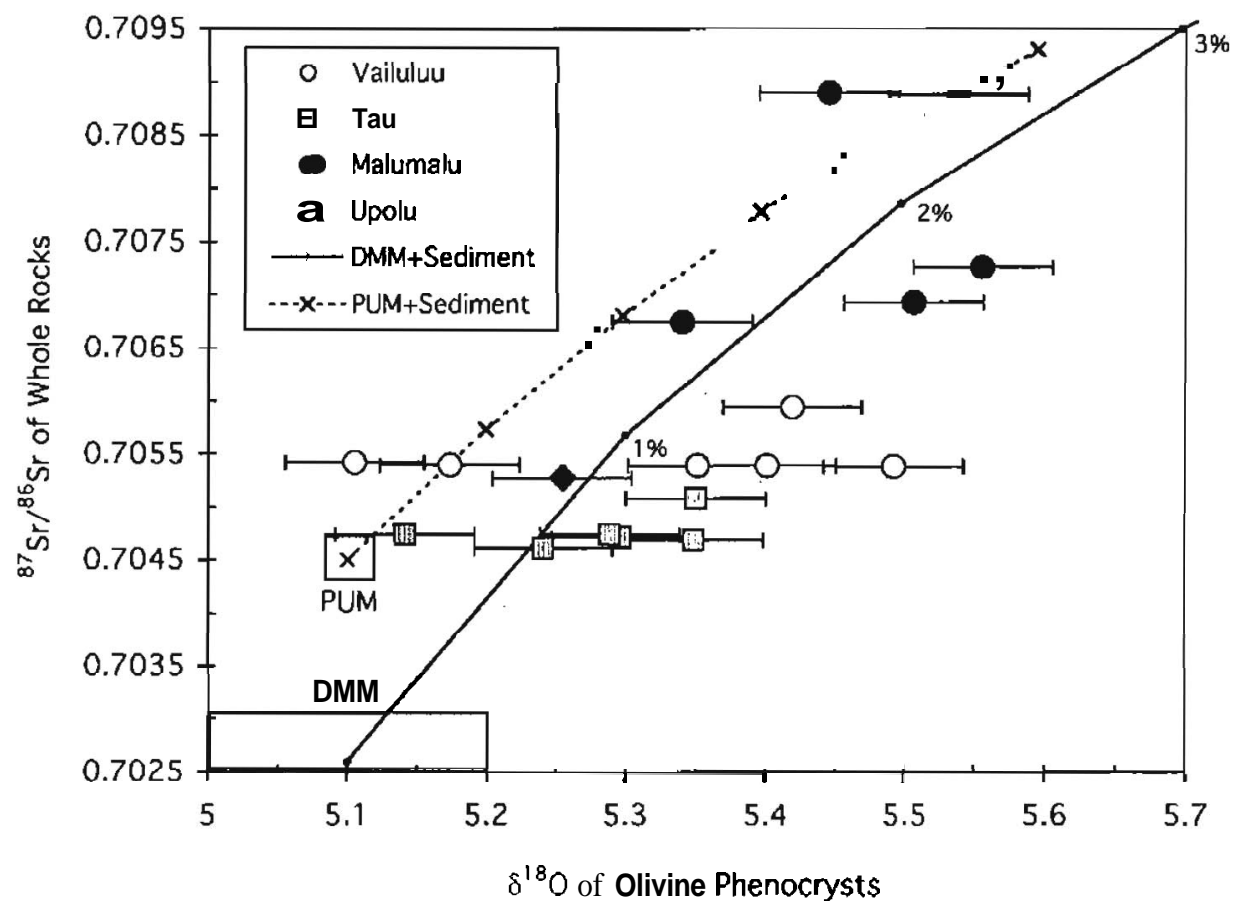

Figure 5-4. Relationship between oxygen and strontium isotopes for Samoan lavas. This positive correlation for enriched mantle lavas has previously been interpreted to represent recycling of sediments from subduction zones back to the mantle (Eiler et al., 1997). Two mixing calculations are shown for reference: Primitive Upper Mantle (PUM) contains $19.9 \mathrm{ppm}$ St (McDonough and Sun, 1995), and is mixed with a hypothetical sediment having $170 \mathrm{ppm} \mathrm{Sr},{ }^{87} \mathrm{Sr}{ }^{86} \mathrm{Sr}$ of 0.720 and $\delta^{18} \mathrm{O}$ of $15 \%$; Depleted MORB Mantle (DMM) contains 8 pprn Sr (Workman and Hart, 2005) and is mixed with the same sediment except with heavier $\delta^{18} \mathrm{O}(25 \%)$. Tick marks are in increments of $1 \%$ sediment addition. Error bars are plotted as $1 \sigma$ standard error $(0.05 \%$ ) for a sample run in duplicate. 


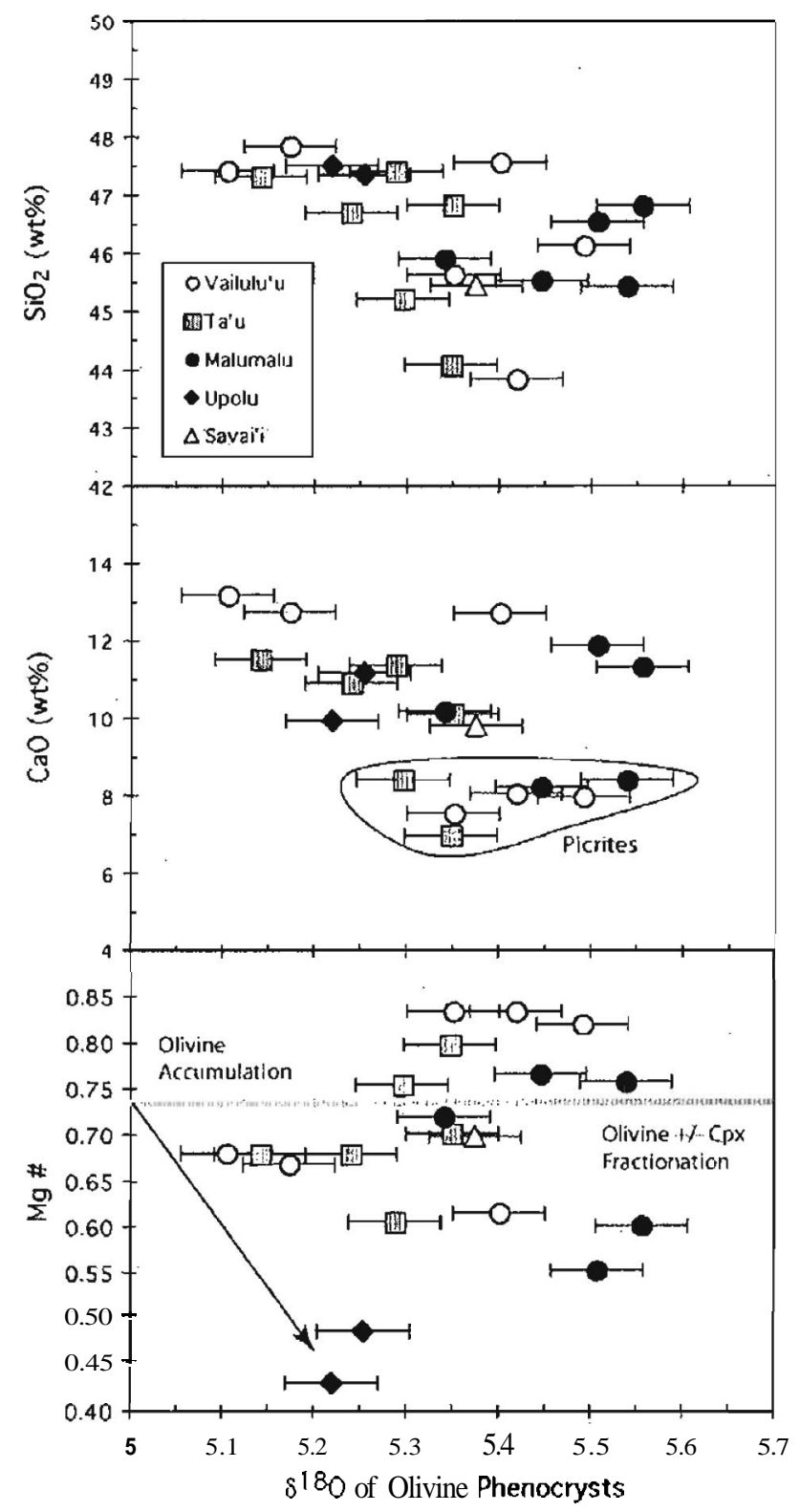

Figure 5-5. Relationships between $\delta^{18} \mathrm{O}$ compositions of olivine and whole-rock major element compositions of their host lavas. The line, drawn across the bottom plot at $\mathrm{Mg} \# \mathbf{7 3}$, marks the position of a melt in equilibrium with Fogo $_{90}$ mantle olivine. Lavas above this line are picrites that have accumulated olivine and below this line have fractionated olivine \pm clinopyroxene. The arrow shows the effect on $\delta^{18} \mathrm{O}$ from fractional crystallization of $40 \%$ olivine. Because there is no correlation between $\delta^{18} \mathrm{O}$ and $\mathrm{Mg} H, \delta^{18} \mathrm{O}$ values are not the result of crystal fractionation. 


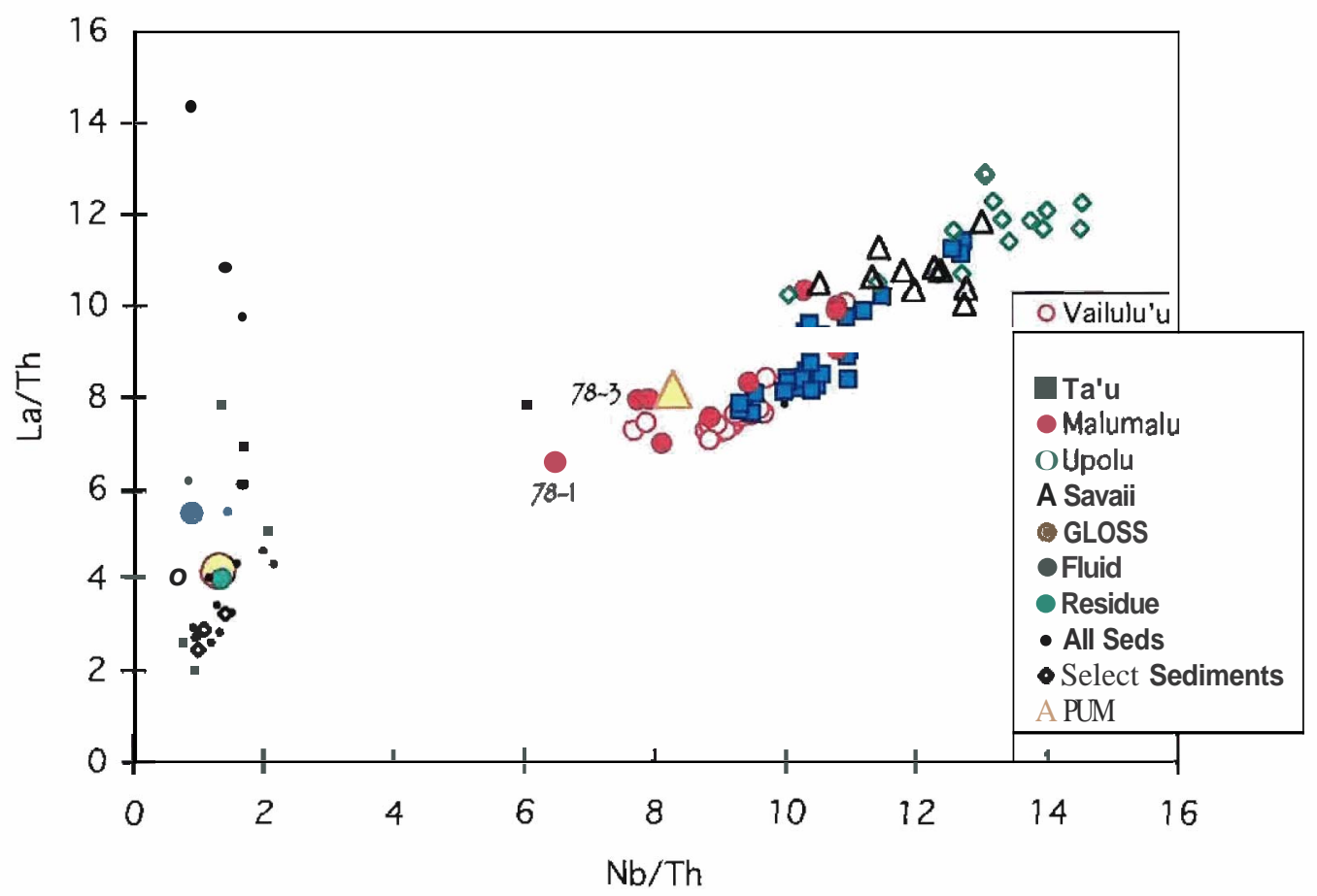

Figure 5-6. Plot of $\mathrm{Nb} / \mathrm{Tb}$ with $\mathrm{La} / \mathrm{Tb}$ ratios of whole rock Samoan basalts (Workman et al., 2004) compared to marine sediments from Plank and Langmuir (1998) used to identify sediment that would be a plausible component of EM2. These ratios were selected because they involve fluid-immobile elements (see Johnson and Plank, 1999; Plank, 2005), so will not be greatly altered by subduction-zone dehydration processes. Since Th is the denominator of each ratio, mixing lines will be linear on this diagram. For reference, $\mathrm{DMM}$ has $\mathrm{Nb} / \mathrm{Th}=18.8$ and $\mathrm{La} / \mathrm{Th}=24.3$ (Workman and Hart, 2005). PUM is Primitive Upper Mantle from McDonough and Sun (1995). GLOSS is an average of modern sediments being subducted in trenches today (Plank and Langmuir, 1998). 'All Seds' are individual sediments used to construct GLOSS. 'Select Sediments' are sediments chosen by us to be a plausible mixing component in EM2 based on their position on this plot as well as on a plot of La/Th-Ba/Th. 'Fluid' is a model for slab fluid from Eiler et al. (2000a), and 'Residue' is the residual composition after $7 \%$ of the 'Fluid' is removed from GLOSS, indicating insignificant compositional changes to sediment by dehydration (at least for the elements here). 


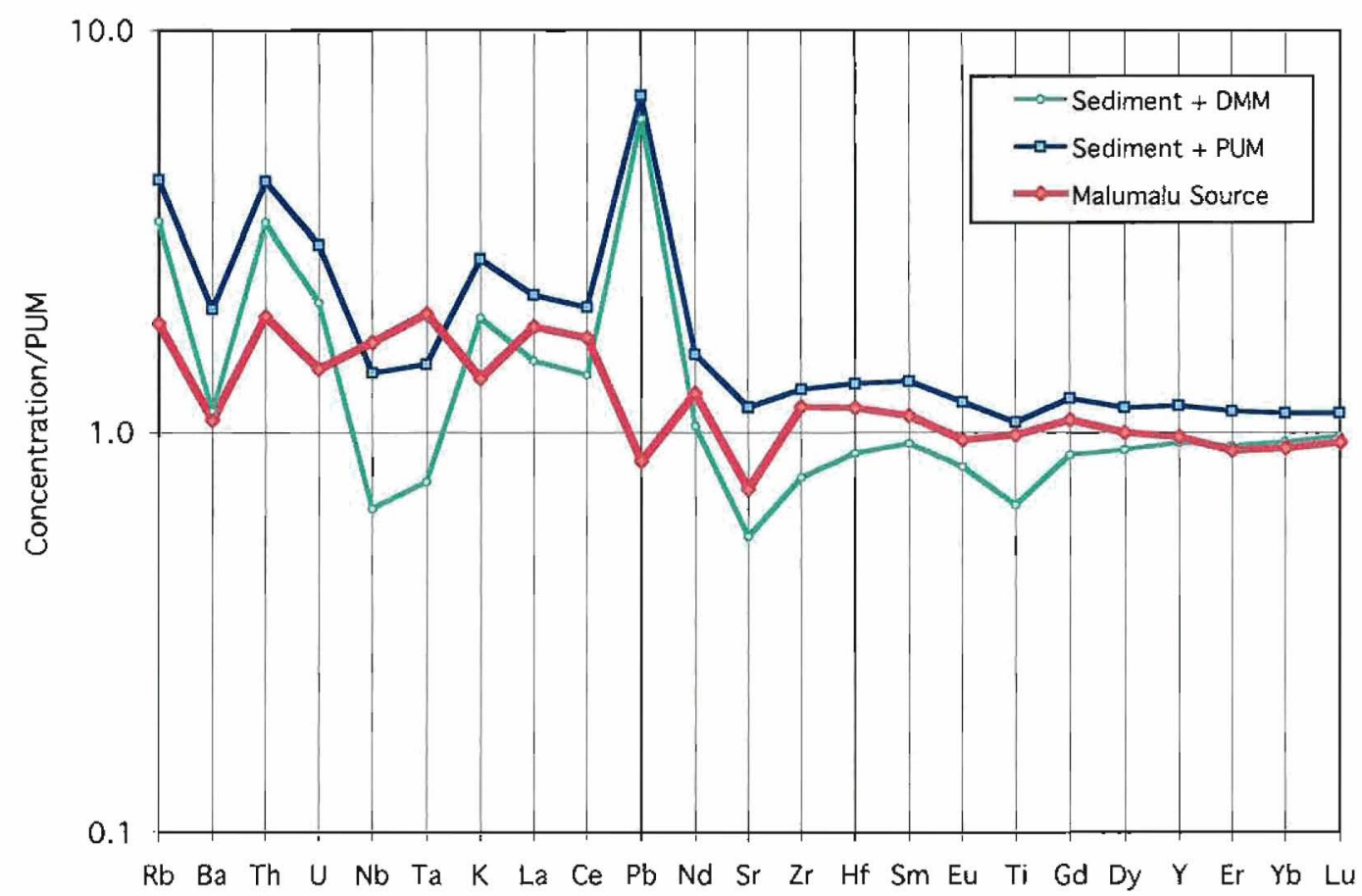

Figure 5-7. Test for mantle enrichment by marine sediments as the origin for EM2. Trace element concentrations are normalized to Primitive Upper Mantle (PUM; McDonough and Sun, 1995). Depleted MORB Mantle is from Workman and Hart (2005). See Figure $\mathbf{6}$ and Table $\mathbf{2}$ for sediment selection and derivation of Malumalu source. The Malumalu source is compared with mixtures of sediment with 1) PUM and 2) DMM . The mass fraction of sediment in each mixture is $2 \%$, requiring the sediment to have $\delta^{18} \mathrm{O}=$ $25 \%$ to match the $\delta^{18} \mathrm{O}$ composition of EM2. 

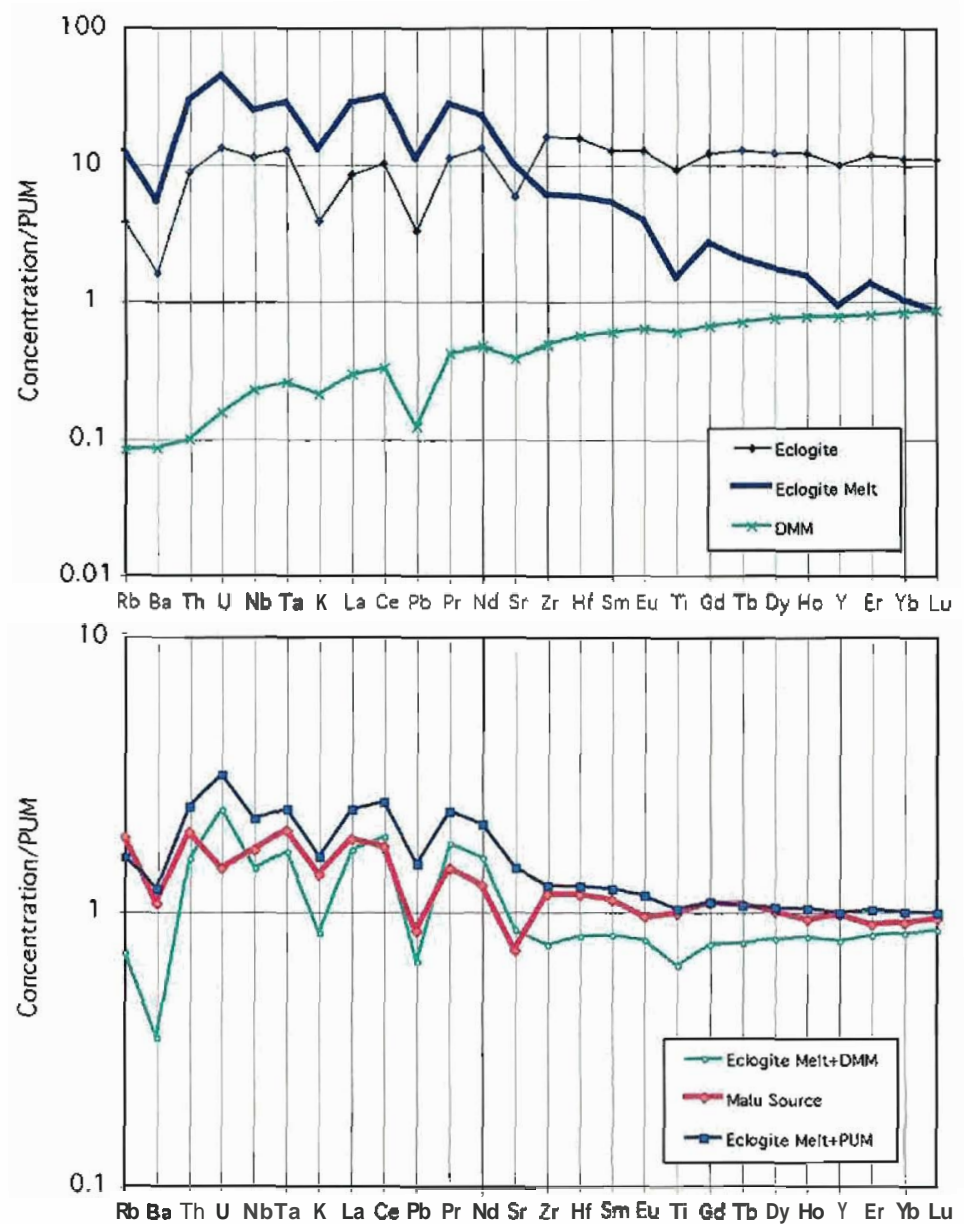

Figure 5-8. Test for metasomatism of depleted/primitive mantle by eclogitic melt as the origin for EM2. Trace element concentrations are normalized to Primitive Upper Mantle (PUM; McDonough and Sun, 1995). Top panel shows 1) the Depleted MORB Mantle (DMM; Workman and Hart, 2005); 2) an average of eclogites with MORB protoliths (Becker et al., 2000; weighted heavily to their sample W1); and 3) a $30 \%$ modal, aggregated fractional melt of the eclogite. Bottom panel shows 1) the source for Malumalu lavas assuming that the lavas represent $2.5 \%$ aggregated fractional melting; and 2) mixtures of DMM and PUM each with 5\% of the eclogitic melt showa in the top panel. The eclogite melt is required to have $\delta^{18} \mathrm{O}$ of $15 \%$ to match the $\delta^{38} \mathrm{O}$ composition of EM2. Trace element compositions, partition coefficients and additional details can be found in Table 2. Because the mantle-melt mixtures show the same general pattern as the calculated Malumalu source (with the only exception being $\mathrm{U}$ ), and the Malumalu source generally falls in-between the two mantle-melt mixtures (except for the Pr-Nd-Sr segment), we conclude that this scenario is aviable one for the formation of EM2. 


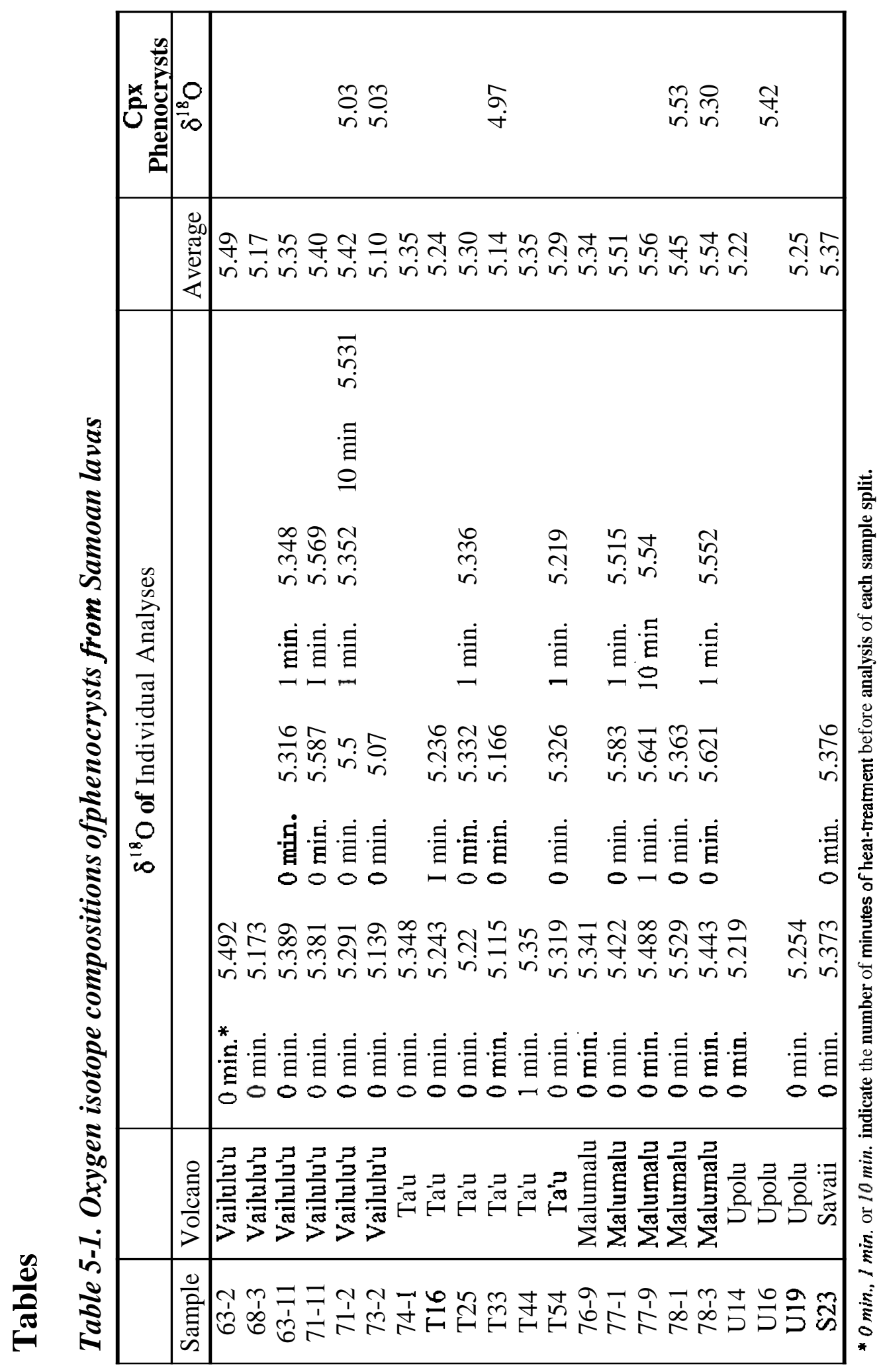

 


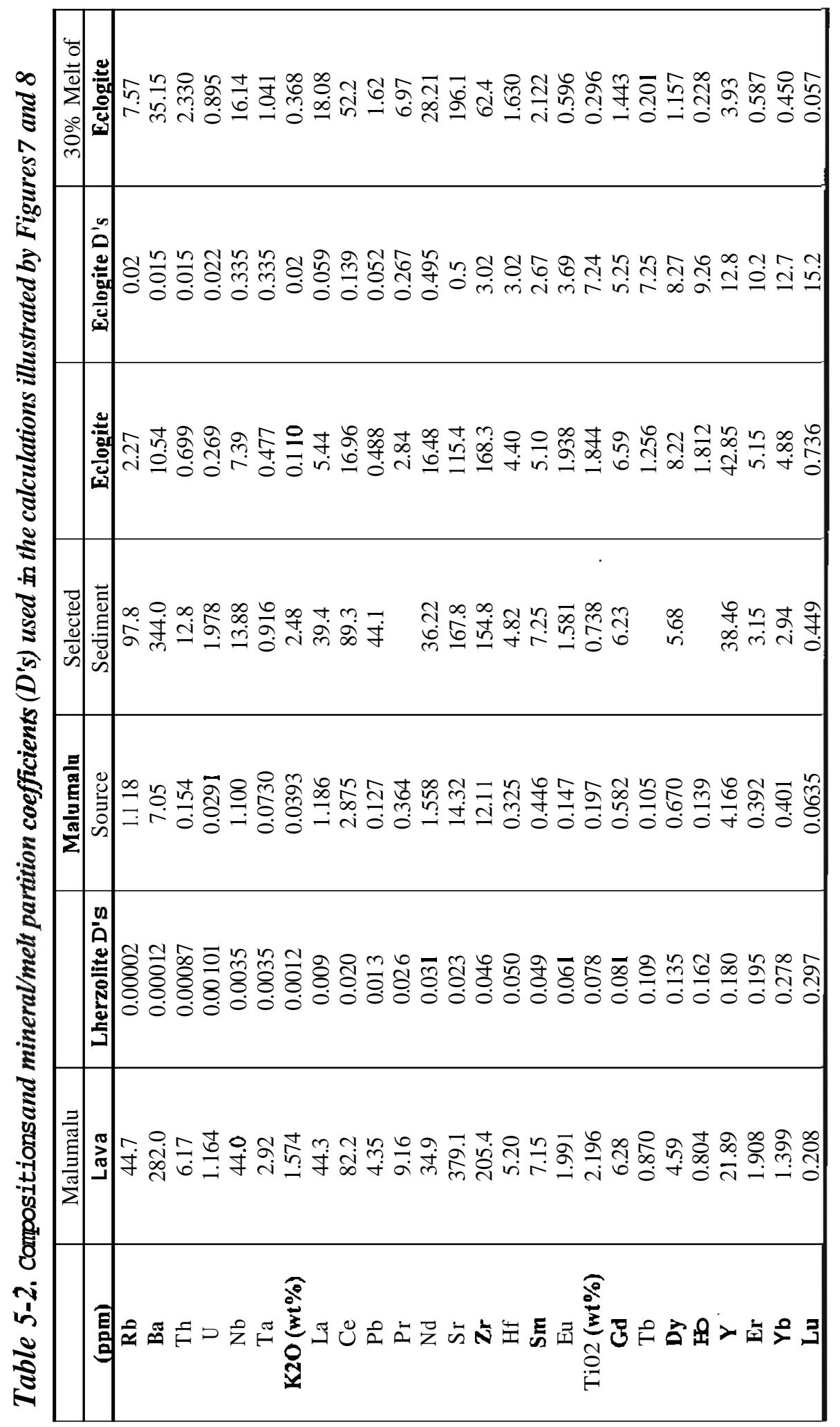




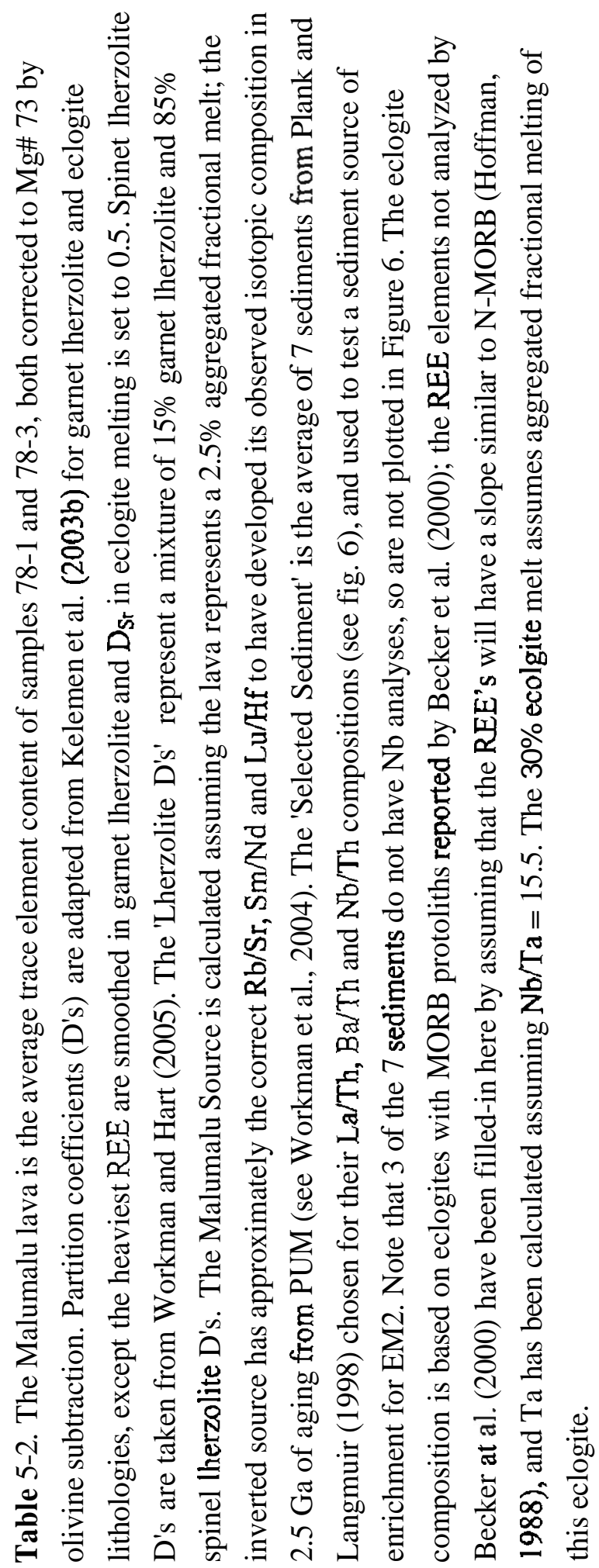


 


\title{
Chapter 6:
}

\section{Gravity-based calculation of crustal flux from the Samoan hotspot and its correlation with $\mathbf{P b}$ - isotopes: a brief overview}

\begin{abstract}
A Mantle Bouguer Anomaly (MBA) map has been calculated for Samoa from free air gravity and shipboard bathymetry, and then interpreted solely in terms of crustal thickness variations. We find that the western Samoan volcanoes have the greatest amount of excess igneous crust, and that integrated crustal flux decreases nearly monotonically approaching to Vailulu'u Seamount, the easternmost and youngest volcano. This trend shows excellent correspondence to increasing ${ }^{206} \mathrm{~Pb} /{ }^{204} \mathrm{~Pb}$ compositions of the lavas with decreasing age along the hotspot track. We speculate this correlation could be due to either a lithosphere thickening toward the east or decreasing potential temperature of the mantle plume.
\end{abstract}




\section{Introduction}

This chapter has been inspired by an age-old question about lavas that are sampled from ocean islands and mid-ocean ridges: are their compositions a product of their source, or a product of the way they are sampled and processed from a multi-component mantle? In other words, is there true spatial heterogeneity in the mantle or are the compositions of surface samples a function of how they are sampled from a 'homogeneously heterogeneous' mantle? The likely story is that both play an important role in magma compositions, but it is unclear how significant each factor could be. The issue of 'source vs. process' is difficult to address with geochemistry alone, as many of the needed physical constraints, such as lithospheric thickness, magma flux, thermal anomalies, and deep mantle structure are largely provided by geophysical observations.

With an extensive geochemical investigation of the Samoan Islands and Seamounts, we have documented systematic changes in lava composition with distance along the hotspot track; this is shown most strongly in the monotonically increasing ${ }^{206} \mathrm{~Pb} /{ }^{204} \mathrm{~Pb}$ compositions with distance from Savai'i toward Vailulu'u Seamount, the present-day hotspot center (see Chapter 2). The goal of this study is to determine whether or not geophysical parameters, specifically crustal flux, will also vary systematically along the volcanic chain.

Using a protocol similar to that of Van Ark and Lin (2004), we have calculated a mantle bouger anomaly map for the Samoan region and interpreted it as variations in total crustal thickness. Integrating excess crustal thickness (total crust minus $6 \mathrm{~km}$ of background ocean crust) in cross-sections along the Samoan lineament, we show that crustal flux is systematically decreasing with approach to Vailulu' $u$. Therefore, increasing ${ }^{206} \mathrm{~Pb} /{ }^{204} \mathrm{~Pb}$ compositions.occur as crustal flux wanes. We have not yet developed a detailed model to explain how the geochemical and geophysical properties are linked, but speculate that it may be due to decreasing potential temperature of the Samoan mantle plume or increasing lithospheric thickness over the last 5 million years.

\section{Calculations}

The calculations described below have been applied to a map region from $168^{\circ} \mathrm{E}$ to $195^{\circ} \mathrm{E}$ and $4^{\circ} \mathrm{S}$ to $16^{\circ} \mathrm{S}$ within the southern Pacific Ocean (Figure 1). Although we only interpret the results from a small sub-area of this large region, it is as easy to calculate a 
large region as it is a small region and we envision the regional scale maps to be used more fully in the future. For example, Hart et al. (2004) have shown that seamounts with a Samoan signature extend back as far as $\sim 175^{\circ} \mathrm{E}$, making the oldest known Samoan volcanism -23 million years old. It would be interesting to compare excess crust and geochemistry in this older section of the Samoan, as we do here for the youngest expression of the Samoan plume.

We employ two kinds of data for this study: free air gravity (FAA) and measured bathymetry. The free air gravity map of Sandwell and Smith (1997) is publicly available at litp://topex.ucsd.edu/WWW html/mar grav.html and was obtained from satellite altimetry measurements taken during the Geosat and ERS1 missions. It has I-minute by 1-minute resolution and determines the maximum resolution of our calculations since some of the bathymetry data is of higher resolution. The FAA map of our study region is shown in Figure 2. Bathymetry data is taken from two sources: 1) real bathymetry points from the Smith and Sandwell (1997) predicted bathyrnetry map (also available publicly at: http://topex..ucsd.edniWWW html/mar topo.html) and 2) SeaBeam bathymetry in the region of the Samoan Islands and Seamounts obtained during the 1999 AVON 2 and 3 cruises of the RN Melville (Hart et al., 2000). The coverage of real bathymetry is shown in Figure 3, with masking of grid nodes that have no data within a 1-minute radius. We have not considered the effect of sediment coverage in our calculations because sediment thicknesses are less than 1000 meters for the entire study region and less than 200 meters for the sub-region involved in our interpretations (fig. 4) (Divins, 2001).

The mantle Bouguer anomaly (MBA) map shown in Figure 5 is calculated, using the Parker (1972) algorithm, by subtracting the attraction of seafloor topography (fig. 3) and a reference model of $6 \mathrm{~km}$ thick ocean crust from the free air anomaly (fig. 2). We assume density values of $1.03,2.7$ and $3.3 \mathrm{~g} / \mathrm{cm}^{3}$ for seawater, the oceanic crust and the upper mantle, respectively (e.g., Kuo and Forsyth, 1988; Lin et al., 1990). The MBA map and all others to follow have been trimmed by $0.5^{\circ}$ on each side in order to edit out the 'edgeeffect' of our calculations. Negative values on the MBA map represent regions of excess lowdensity material (i.e., oceanic crust greater than $6 \mathrm{~km}$ ); the opposite is true for positive anomalies.

A map of depth to the Moho (base of the oceanic crust), shown in Figure 6, is calculated through a downward continuation of the MBA anomalies to a depth of $11 \mathrm{~km}$ (estimated combined depth of $5 \mathrm{~km}$ ocean depth plus $6 \mathrm{~km}$ reference oceanic crust thickness), as described in greater detail by Van Ark and Lin (2004). This assumes that the entire MBA 
signal is due to excesses or deficits in crustal thickness; if there are any mantle thermal effects contributing to the MBA signal, we will have over-estimated depth to the Moho at those locations. The Moho is offset by a constant $+3 \mathrm{~km}$ in order to force the 'background' Moho depth to be near $11 \mathrm{~km}$, which is the depth of the Moho if the oceanic crust is $6 \mathrm{~km}$ thick at locations away from islands or seamounts - for example at $190^{\circ} \mathrm{E}$ and $12.5^{\circ} \mathrm{S}$. Total crustal thickness, shown in Figure 7, is calculated by subtracting the seafloor topography from the calculated Moho depth. Excess crustal thickness is the remaining crust after removing a $6 \mathrm{~km}$ thick layer we assume to be 'original' oceanic crust produced at a spreading ridge (fig. 8).

\section{Results}

Figure 9 show a close-up of excess crustal thickness for the part of the Samoan volcanic chain that is the subject of Chapters 2, 4 and 5; the boundaries of this map are defined by the red box in Figure I, and coordinates are expressed in kilometers. Although the islands are not plotted here (so as not to obscure the thickness variations), the outlines of islands are clear from the contours of excess crustal thickness (i.e., compare to Figure 1). The calculated maximum excess crust for this area is $-25 \mathrm{~km}$; it occurs beneath Savai'i and is displayed in the cross-section of Savai'i in Figure 9. Moving southeast from Savaii, it is clear from Figure 9 alone that crustal thicknesses are waning. The last volcano of the Samoan chain, Vailulu' $u$, is shown in cross-section in Figure 9 and has a miximum crustal thickness of $-7 \mathrm{~km}$.

To estimate the crustal flux (i.e., erupted volume flux) from the Samoan plume through time, we have integrated excess crustal thicknesses for $200 \mathrm{~km}$-long cross-sections at every $1 \mathrm{~km}$ along the Samoan lineament. Crustal flux along the chain is shown in Figure 10 and is reported as $\mathrm{km}^{3}$ of crust for a $200 \mathrm{~km}$ by I km map area. Using a Pacific plate speed of 7 $\mathrm{cm} / \mathrm{yr}$ (Sella et al., 2002), the unit of crustal flux reported in Figure 10 translates to the number of $\mathrm{km}^{3}$ of crust erupted from the Samoan plume in a period of 14,300 years. From Savai'i to Vailulu'u, the calculated crustal flux decreases (almost monotonically except for over the Tutuila-Malumalu ridge) by $-75 \%$. The bottom panel of Figure 10 shows the strong inverse correlation of ${ }^{206} \mathrm{~Pb} /{ }^{204} \mathrm{~Pb}$ to crustal flux. Low ${ }^{206} \mathrm{~Pb} /{ }^{204} \mathrm{~Pb}$ indicates a contribution from trace-element-depleted mantle components to the lavas (i.e., FOZO and $\mathrm{DMM}$ ) and high ${ }^{206} \mathrm{~Pb} /{ }^{204} \mathrm{~Pb}$ indicates a contribution of trace-element-enriched mantle components to the lavas (i.e., EM2 and HIMU) (see Chapter 2, Figure 16 for correlations 
between trace element enrichment and $\mathrm{Pb}$ isotopes). Hence, periods of high crustal flux are 'accompanied by sampling of more depleted mantle components and periods of low crustal flux are accompanied by samples of more enriched mantle components. However, it may be slightly misleading to interpret the crustal thickness variations as if they directly represent temporal changes in magma production from the Samoan plume since recent eruptions have been documented for both Savaï and Vailulu'u (see Chapter 2). Not all the crustal volume from Savaii was produced 5 million years ago (its apparent age from plate motion), but it is unclear what proportion of the crust represents 'shield versus rejuvenated volcanism.

\section{Discussion}

The strong relationship between the geochemistry of Samoan lavas and our gravitybased estimate of crustal flux along the chain suggests there is a process-oriented mechanism for producing variations in lava compositions, meaning that lava compositions are a function of what materials are sampled from a multi-component mantle. Below we address two parameters that, if varied systematically, could potentially result in a systematic change in the composition of melts produced from the upwelling plume: lithospheric thickness and potential temperature of the plume.

A very interesting model for melting of a heterogeneous mantle has recently been developed by Ito and Mahoney (2005). They show that the same mantle (composed of multiple components) can produce magmas of varying composition (in trace elements and heavy isotopes) depending on lithospheric thickness at the location of magma genesis. This is due to fundamental differences in the solidus temperatures of the different components and the depth at which melting is 'shut-off' by the lithospheric cap. They assume that, at a given pressure, depleted mantle will melt at a higher temperature than enriched mantle, so melting that.is terminated deeply will result in magmas with strong enriched mantle signatures; on the other hand, if the melting column extends to' more shallow depths, the enriched melt will be diluted by depleted mantle melts.

Applying this concept to Samoa would suggest that the lithosphere beneath western Samoa is thinner than beneath eastern Samoa, resulting in the production of more melt from the depleted mantle component and, in summation, a greater total melt volume. We will need to explore the implication that western Samoan lavas reflect a greater degree of melting than eastern Samoa lavas; at the present state of investigation, it is not clear if this is the case (as a 
side-note, water concentrations in western Samoan lavas may be the key to this question, but such data has not yet been collected).

Changes in the potential temperature of the plume may also explain our observations by controlling the length of the melting column from the bottom instead of the top. At a constant lithospheric thickness, a cooling mantle plume will not be able to produce as much melt from its depleted mantle components, resulting in the geochemical and geophysical evolution from Savai'i to Vailulu'u. However, because of small melt productivity during deep melting (e.g., Asimow et al,, 2004), it is possible this scenario will not be able to account for the large differences in crustal volume western and eastern Samoa.

A changing composition of the Sarnoan plume (i.e., proportion of depleted to enriched material) would not easily account for coupled variation of calculated igneous flux and ${ }^{206} \mathrm{~Pb} /{ }^{204} \mathrm{~Pb}$. If the plume changes composition as it upwells beneath the Pacific Plate, but potential temperature and lithospheric thickness remain constant, we would expect the depleted material to produce less total melt volume because of a higher solidus temperature than the enriched material. Our observation is the opposite of this: depleted signatures occur with the greatest crustal volumes.

The last option is the one of coincidence. Consider that the average crustal volume $\left(-1200 \mathrm{~km}^{3}\right.$; Figure 10) over Upolu and Tutuila is the 'constant' crustal volume of a fullgrown Sarnoan shield volcano. Volcanoes to the east have not yet been fully developed, whereas Savai'i has entered a stage of extensive, post-shield, rejuvenated volcanism (as historically documented). From this perspective, geochemical variations would be independent of the igneous flux, unless the average $\mathrm{Pb}$ isotopic composition of a volcano changes with growth. 


\section{References}

Asimow, P.D., J.E. Dixon and C.H. Langmuir, A hydrous melting and fractionation model for mid-ocean ridge basalts: Application to the Mid-Atlantic Ridge near the Azores, Geochemistry, Geophysics, Geosystems, 5(1), 2003GC000568, 2004.

Divins, D., Total sediment thickness of the world's oceans and marginal seas, World Data Center Mar. Geol. And Geophys., Boulder, CO, 2001. Available publicly at: http://www.ngdc.noaa.gov/mgg/sedthick/sedthick.html

Hart, S. R., Staudigel, H., Koppers, A.A.P., Blusztajn, J., Baker, E.T., Workman, R., Jackson, M., Hauri, E., Kurz, M., Sims, K., Fornari, D., Saal, A., and Lyons, S., Vailulu'u undersea volcano: The New Samoa, Geochemistry, Geophysics, Geosystems, 1,2000GC000108,2000.

Hart, S.R., M. Coetzee, R.K. Workman, J. Blusztajn, K.T.MJohnson, J.M. Sinton, J.W. Hawkins, Genesis of the Western Samoa Seamount Province: Age, Geochemical Fingerprint and Tectonics, Earth and Planet. Sci. Letters, 227, 37-56, 2004a.

Ito, $\boldsymbol{G}$. and J.J. Mahoney, Flow and melting of a heterogeneous mantle: 1. Method and importance to the geochemistry of ocean island and mid-ocean ridge basalts, Earth Planet. Sci. Letters, 230, 29-46, 2005.

Kuo, B.Y. and D.W. Forsyth, Gravity anomalies of the ridge-transform system in the South Atlantic between 31 and $34.5^{\circ} \mathrm{S}$ : Upwelling centers and variations in crustal thickness, Mar. Geophys. Res., 10,205-232,1988.

Lin, J., G.M. Purdy, H. Schouten, J.-C. Sempere and C. Zervas, Evidence from gravity data for focused magmatic accretion along the Mid-Atlantic Ridge, Nature, 344,627-632, 1990.

Parker, R.L., The rapid calculation of potential anomalies, Geophys. J. Roy. Astro. Soc., 31, 447-455, 1972.

Sandwell, D.T. and W.H.F. Smith, Marine gravity anomaly from Geosat and ERSI satellite altimetry, J. Geophysical Research, 102 (B5), 10039-10054,1997.

Sella, G. F., Dixon, T.H., and Mao, A., REVEL: A model for recent plate velocities from space geodesy, J. Geophys. Res., 107, EGT 11-1 to 11-32,2002.

Smith, W.H.F. and D.T. Sandwell, Global seafloor topography from satellite altimetry and ship depth soundings, Science, 277,1957-1962,1997. 
Van Ark, E. and J. Lin, Time variation in igneous volume flux of the Hawaii-Emperor hot spot seamount chain, J. Geophys. Res., 109 (B11), doi:10.1029/2003JB002949, 2004. 


\section{Figures}

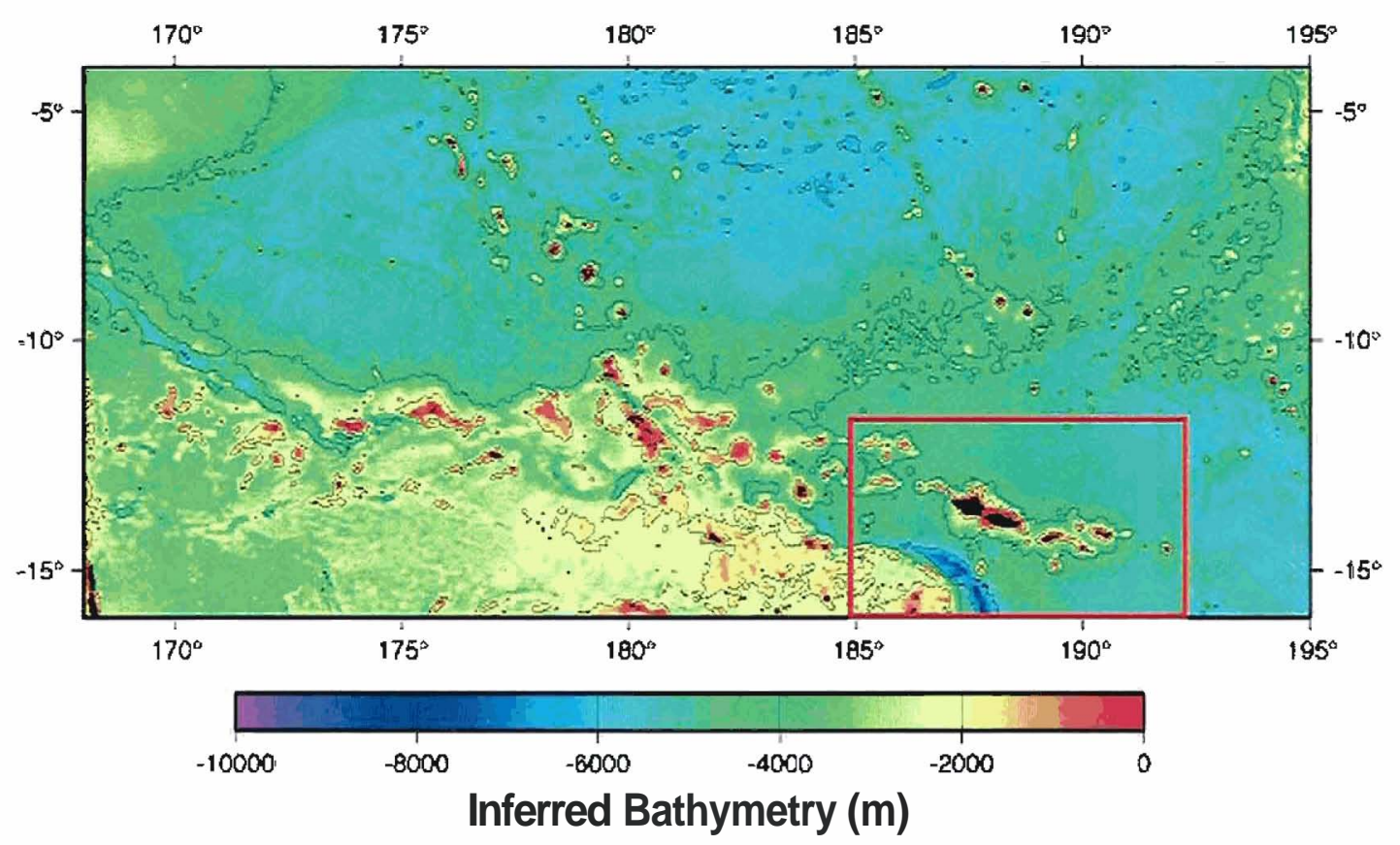

Figure 6-1. Sruith and Sandwell (1997) predicted bathymetry for the study region based on a combination of shipboard bathymetric measurements and bathymetry calculated from free air gravity measured by satellite altimetry. The Samoan Islands are shown in black in the southeastern corner of the map. The red box around them marks the boundaries of the map shown in Figure 9. 


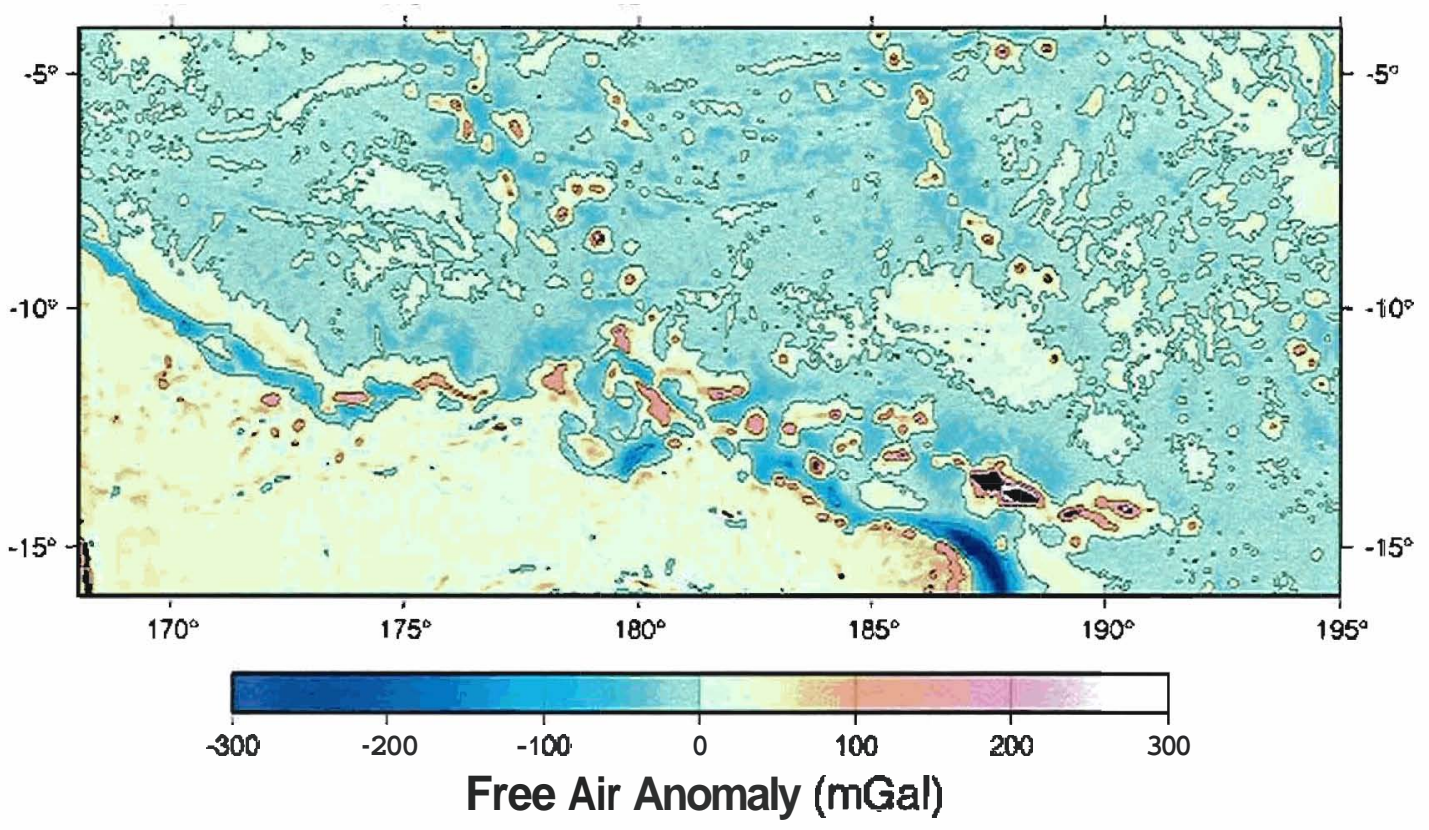

Figure 6-2. Free air anomaly map for the study region from Sandwell and Smith (1997). 


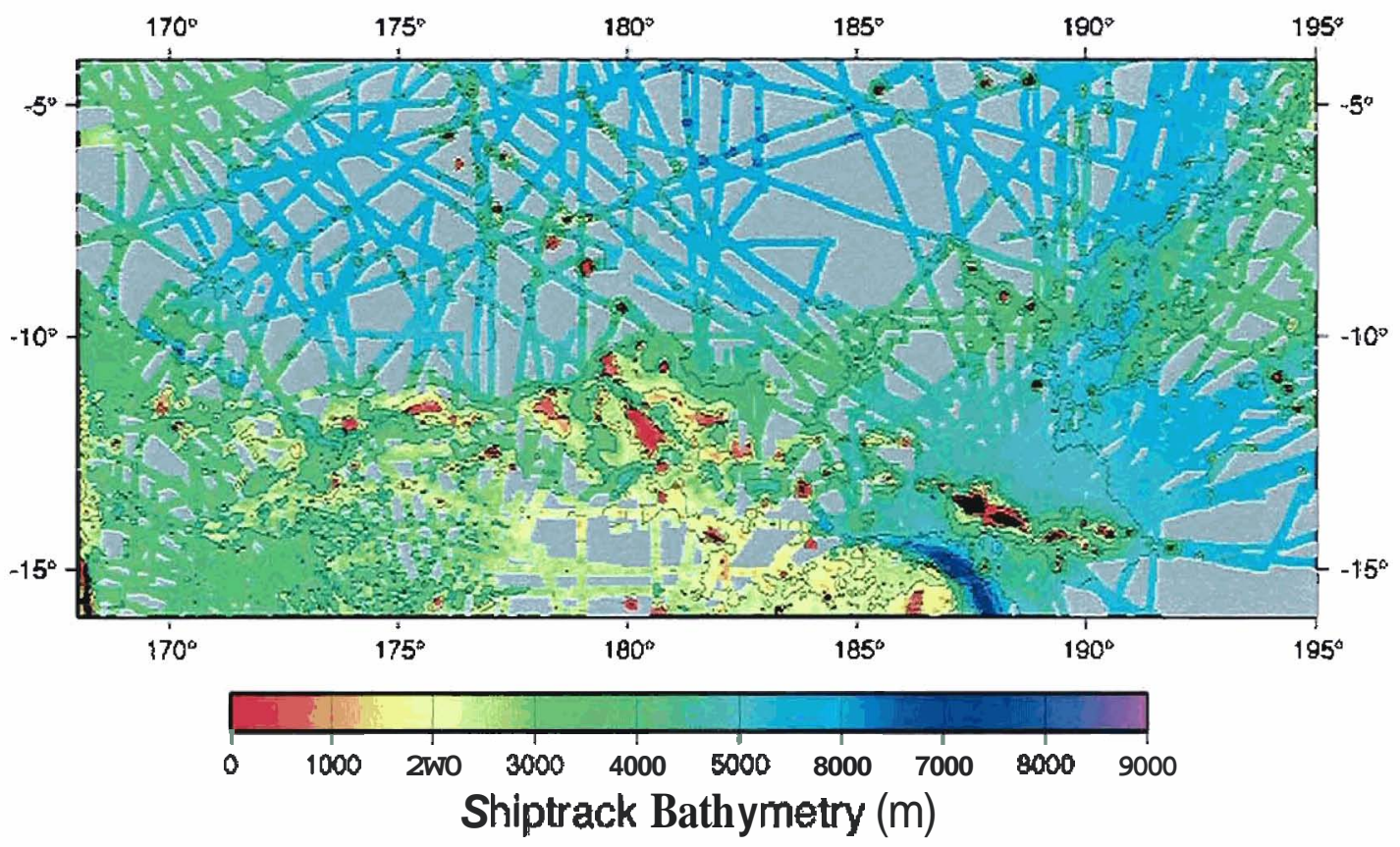

Figure 6-3. Real bathymetry measured by shiptrack. Data sources are Smith and Sandwell (1997) and SeaBeam data from the 1999 AVON 2 and 3 cruises of the R/V/ Melville. 


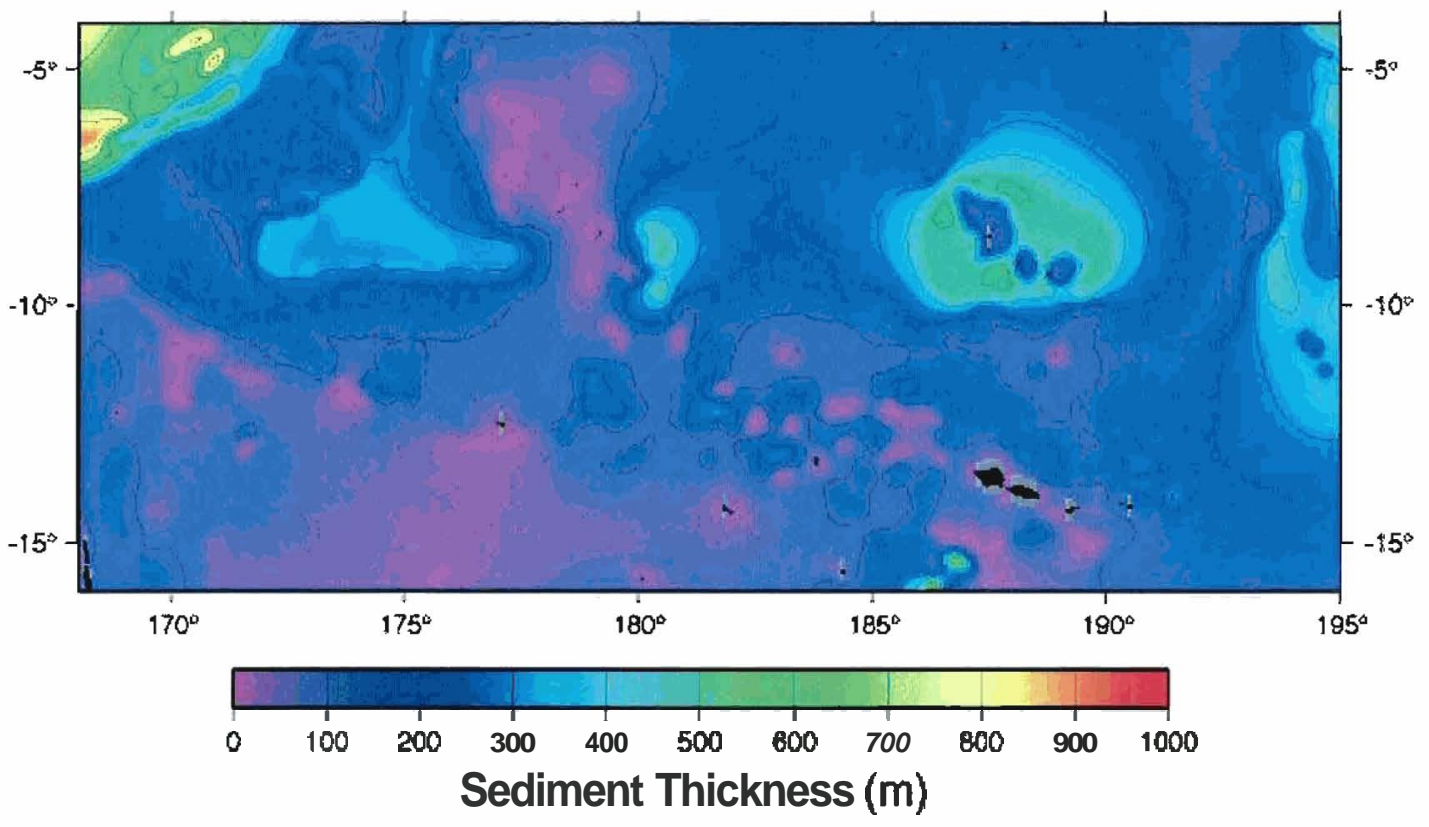

Figure 6-4. Regional sediment thickness map from Divins (2001). Since the sediment cover is generally very thin, we have not considered it in the calculation of MBA. 


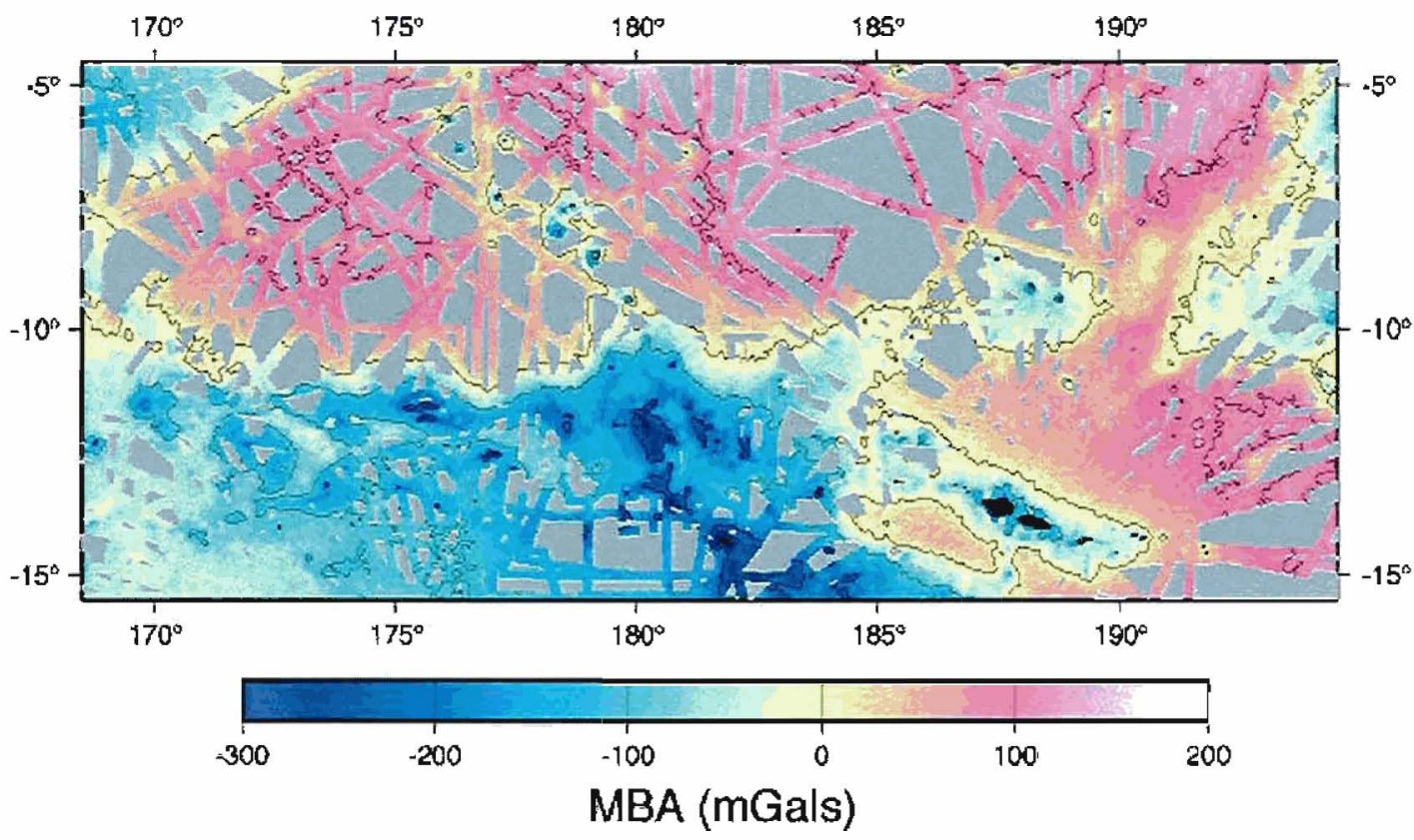

Figure 6-5. Mantle Bouguer anomaly map of the study region calculated according to the Parker (1972) algorithm as implemented by Kuo and Forsyth (1988) and Lin et al. (1990). Negative anomalies indicate excess low-density material, such as over the Samoan Islands and a large portion of the southwest quadrant of the map (some of which may be related to the Samoan plume). 


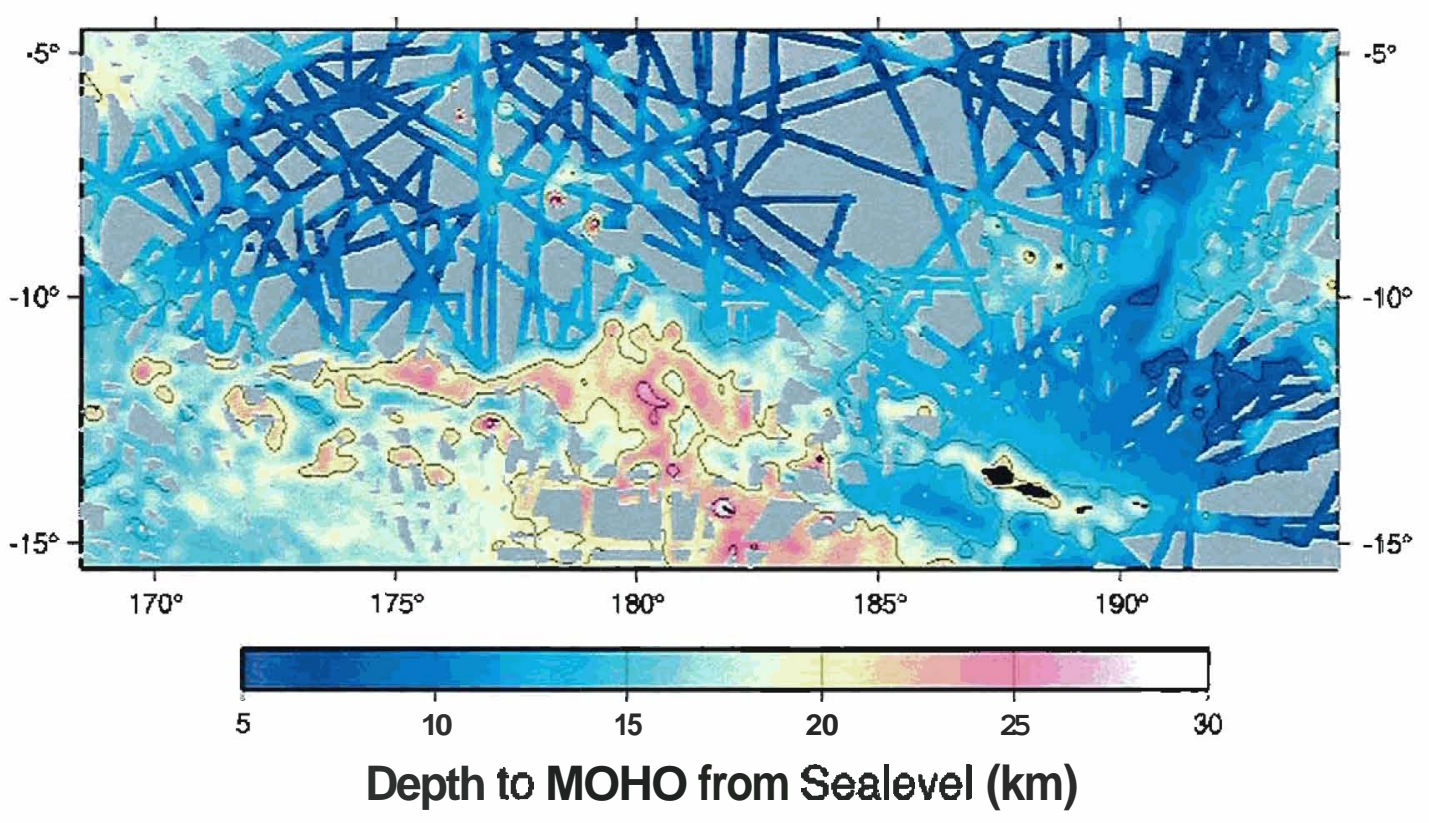

Figure 6-6. Depth to the Moho from sealevel calculated with a downward continuation of the MBA signal, assuming that all the MBA anomaly is due to crustal thickness variations. 


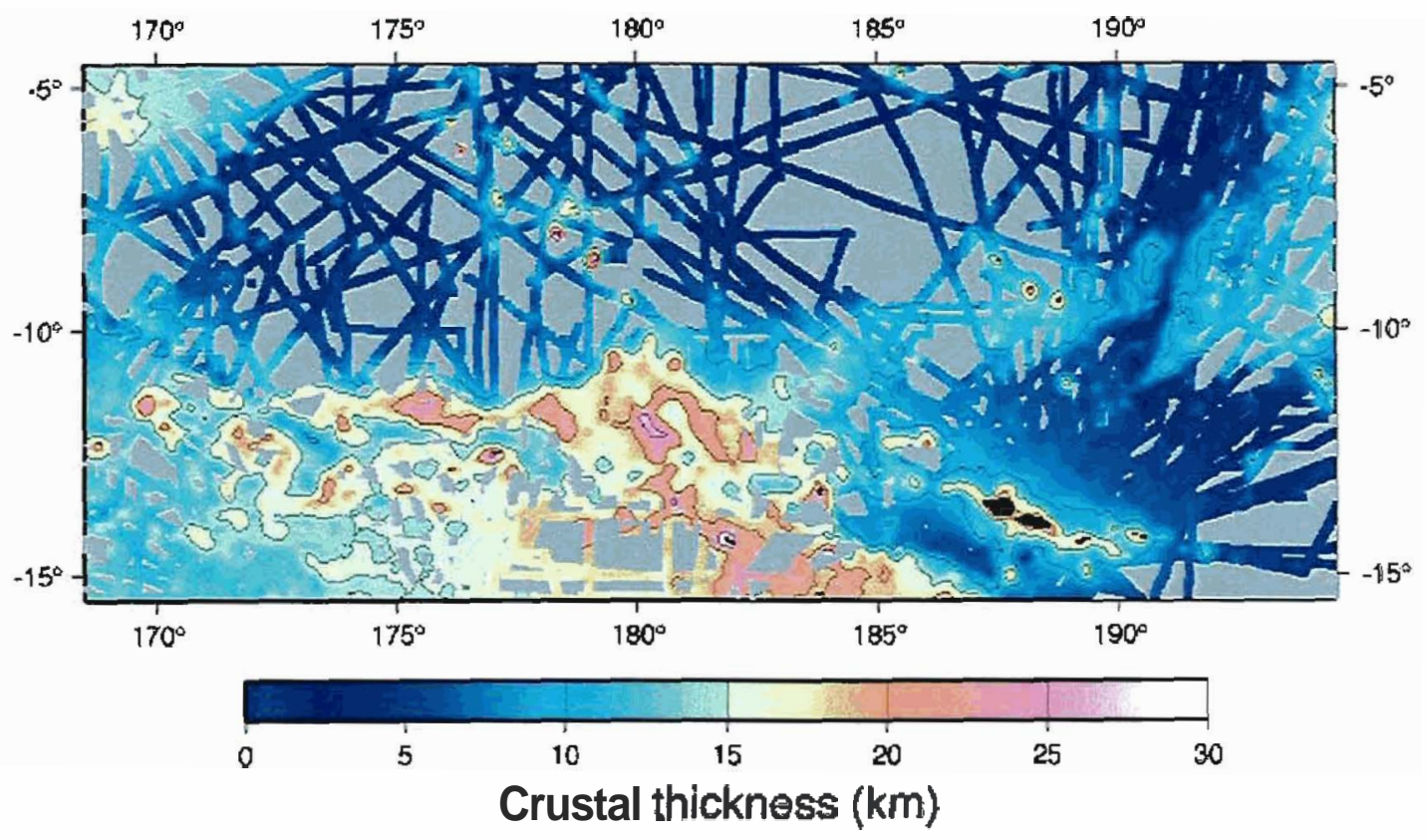

Figure 6-7. Crustal thickness map calculated by subtracting seafloor topography (fig. 3) from the Moho deptb (fig. 6). 


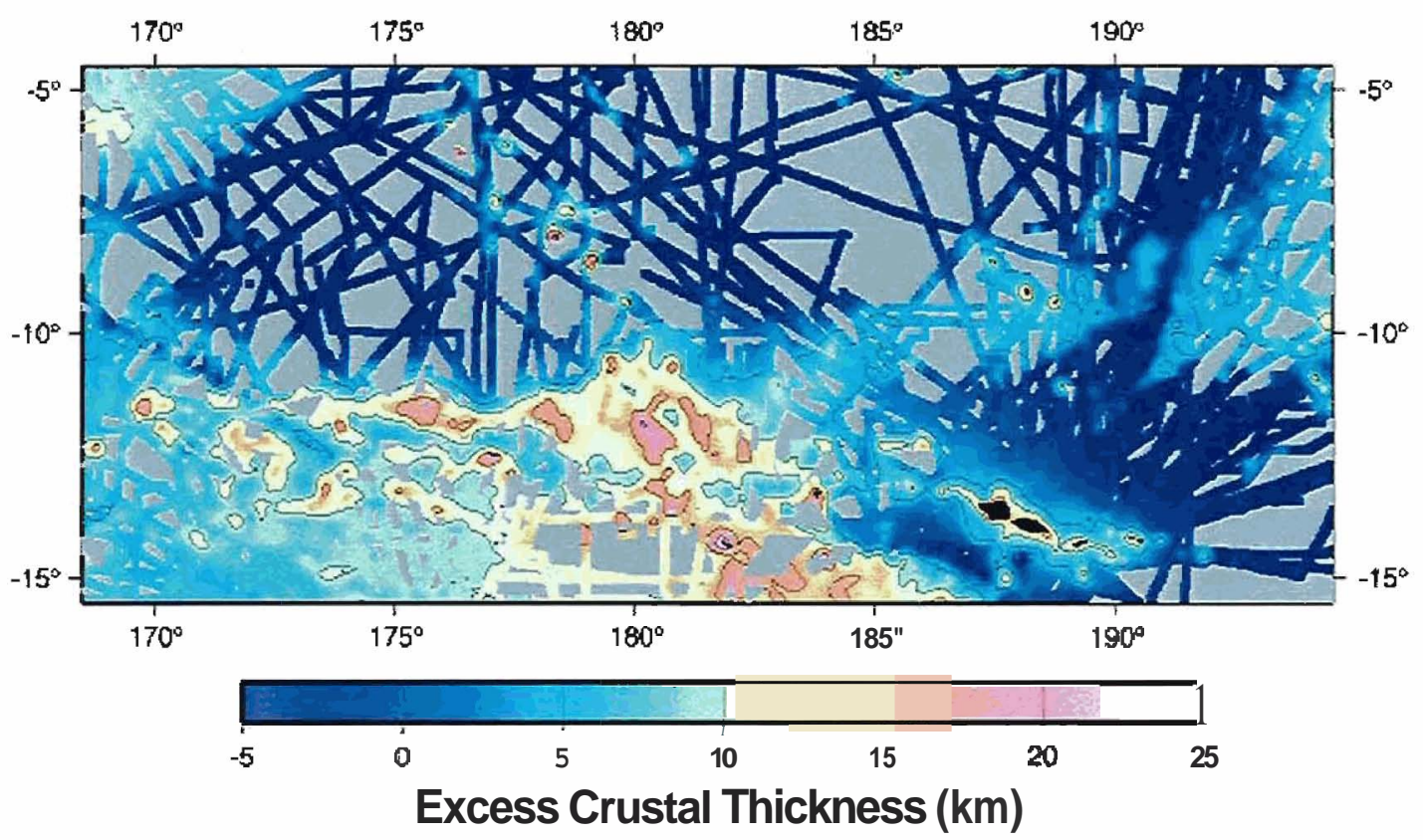

Figure 6-8. Excess crustal thickness calculated by subtracting 6 kilometers from the crustal thickness map in Figure 7. This provides an estimate of crustal flux associated with volcanism after formation of the plate at the East Pacific Rise. 

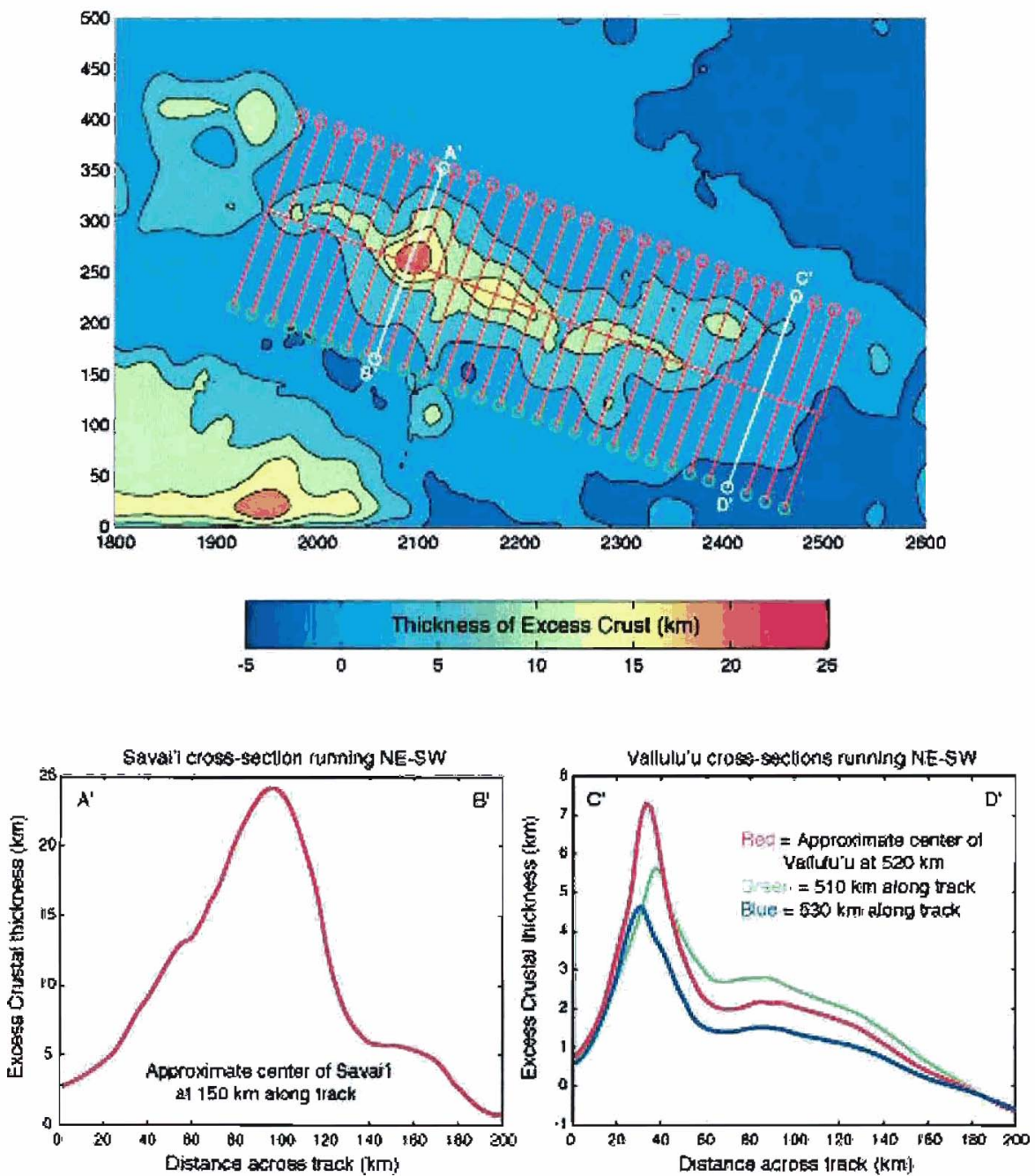

Figure 6-9. Top panel shows excess crustal thickness for the region around Samoa. The boundaries of this map are defined by the red box in Figure 1, but the coordiuates here are expressed as kilometers, with the origin being the southwest comer of Figure 1. The 'along-axis' line runs from Savaii at its northwest end to Vailulu'u Seamount at its southeast end. The total distance of the along-axis line is $585 \mathrm{kmn}$. 'Across-axis' lines are perpendicular to the along-axis line and are $200 \mathrm{~km}$ wide. Plotted here are examples of across-axis lines every $20 \mathrm{~km}$ along-axis. Also plotted are two white cross axis lmes that mark locations of the cross sections shown in the bottom two panels. Bottom left panel is a cross section of crustal thickness across the middle of Savaii, with a maximum of almost $25 \mathrm{~km}$ of crust. At the opposite end is Vailulu'u, shown in the bottom right panel. Maximum excess crustal thickness here is only $-7 \mathrm{~km}$; the two additional cross-sections of Vailulu'u are shown for a semi-3D perspective. For reference, the large mass of excess crust shown at the coordinate $(1950,20)$ is related to the Tonga Arc, but is not a completely reliable estimate of crustal thickness due to 'edge effects' at this map boundary. 


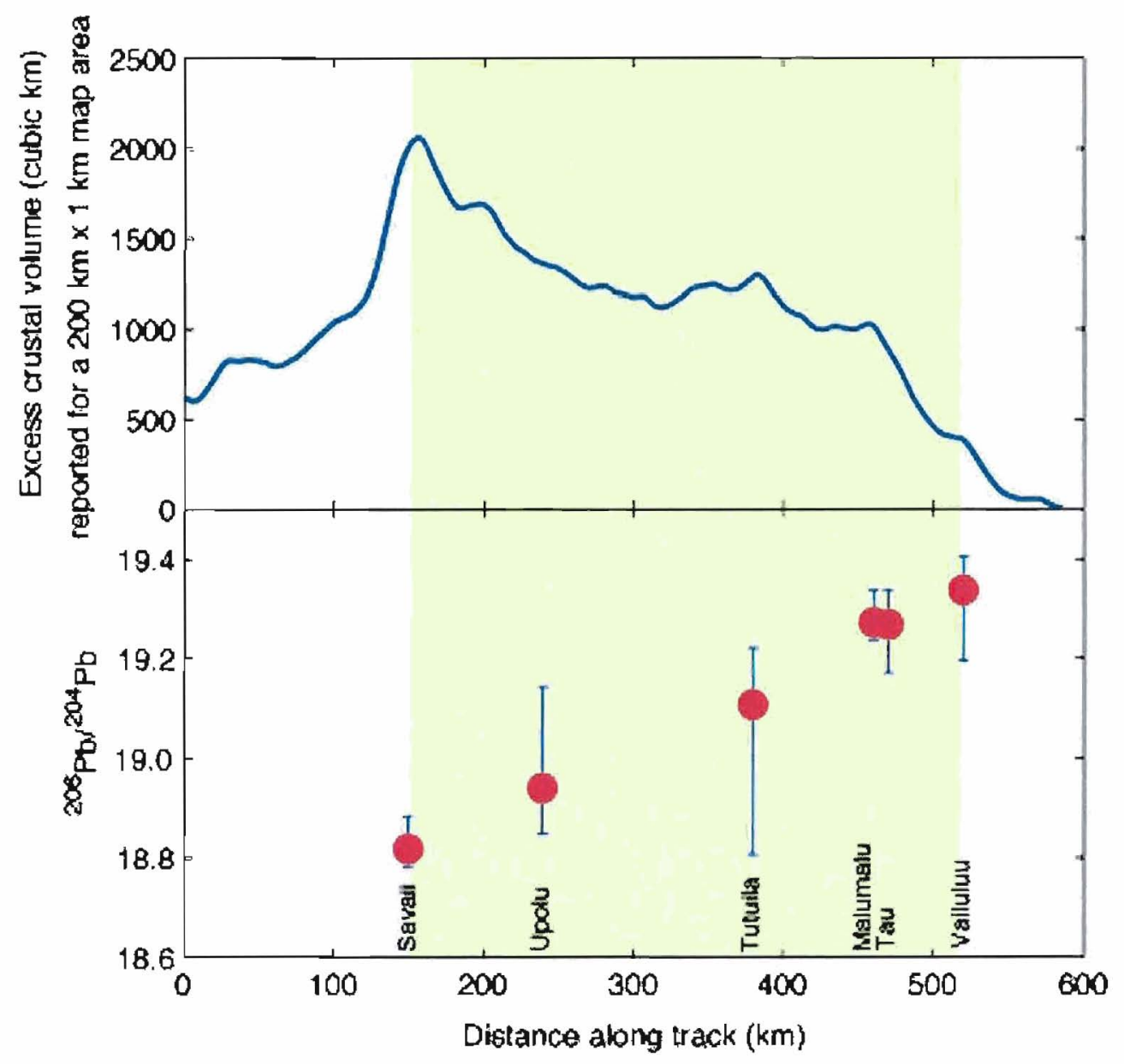

Figure 6-10. A two-panel plot illustrating crustal flux along the Samoan volcanic chain and its surprisingly good inverse correlation with ${ }^{206} \mathrm{~Pb} /{ }^{204} \mathrm{~Pb}$. Crustal flux is reported as the volume of crust in a $200 \mathrm{~km}$ by 1 kru area (map view) along the axis shown in Figure 9; i.e., each point is an integration of a cross-section such as those shown in the bottom two panels of Figure 9. Mean ${ }^{206} \mathrm{~Pb} /{ }^{204} \mathrm{~Pb}$ values for each island or seamount are plotted in red, with upper and lower bars indicating the full ranges (data is from Chapter 2). As crustal flux is monotonically decreasing from west to east, mean ${ }^{206} \mathrm{~Pb} /{ }^{204} \mathrm{~Pb}$ is monotonically increasing. We speculate this relationship is due to increasing lithospheric thickness or waning potential temperatures of the Samoan plume over time. 